LOURVAL DOS SANTOS SILVA

\title{
Estudo Numérico da Circulação e da Estrutura Termohalina no Canal de São Sebastião
}

Tese de Doutorado apresentada ao Instituto Oceanográfico da Universidade de São Paulo, como parte dos requisitos para obtenção do título de Doutor em Ciências, área de Oceanografia Física.

Orientador: Prof. Dr. Luiz Bruner de Miranda

Co-orientador: Prof. Dr. Belmiro Mendes de Castro Filho

São Paulo

2001 
UNIVERSIDADE DE SÃO PAULO

INSTITUTO OCEANOGRÁFICO

\section{Estudo Numérico da Circulação e da Estrutura Termohalina no Canal de São Sebastião}

\section{Lourval dos Santos Silva}

Tese de Doutorado apresentada ao Instituto Oceanográfico da Universidade de

São Paulo, como parte dos requisitos para obtenção do título de Doutor em Ciências, área de Oceanografia Física

Aprovada em _ _ $/ 2001$ por:

Prof. Dr. Luiz Bruner de Miranda - orientador

Prof. Dr. no Instituto Oceanográfico da Universidade de São Paulo

Prof. Dr. Edmo José Dias Campos

Prof. Dr. no Instituto Oceanográfico da Universidade de São Paulo

Prof. Dr. Ricardo de Camargo

Prof. Dr. no Instituto Astronômico da Universidade de São Paulo

Dr. José Luiz Stech

Pesquisador Sênior no Instituto Nacional de Pesquisas Espaciais

Prof. Dr. Osmar Olinto Moller Jr.

Prof. Dr. na Fundação Universidade Federal do Rio Grande 


\author{
À minha esposa Rosangela \\ Às minhas filhas \\ Wania e Walkiria
}

Aos meus pais, Walter e Lourdes

Aos meus irmãos

Walker e Waldenize 


\section{Conteúdo}

Agradecimentos $\quad$ i

Resumo ii

Abstract

Lista de Figura iv

\section{Introdução}

1.1 O Canal de São Sebastião.................................................................. 01

1.2 O Conhecimento Atual...................................................................... 04

1.3 Objetivos................................................................................ 10

\section{Metodologia}

2.1 Descrição do Modelo................................................................................. 11

2.2 Implementação do Modelo e Aspectos de Grade....................................... 14

2.3 Experimentos Realizados.................................................................... 29

\section{Resultados do Modo Barotrópico}

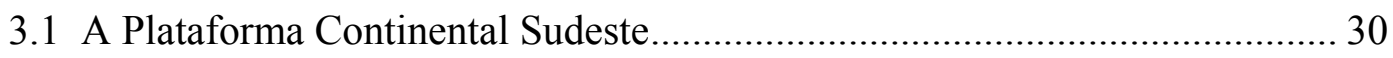

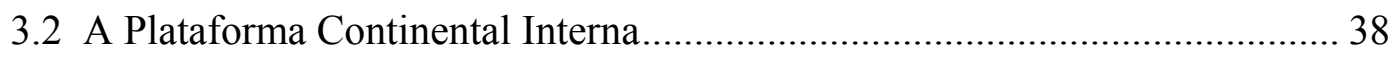

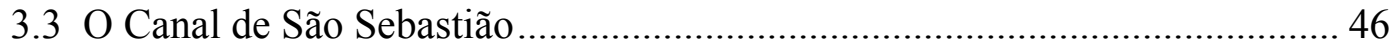

\section{Resultados do Modo Baroclínico}

4.1 A Primavera

4.1.1 A Plataforma Continental Sudeste.................................................... 54

4.1.2 A Plataforma Continental Interna........................................................ 64

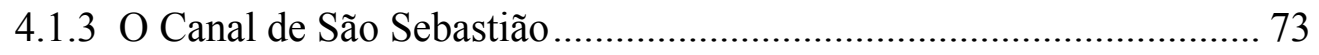

4.2 O Verão

4.2.1 A Plataforma Continental Sudeste................................................... 84

4.2.2 A Plataforma Continental Interna................................................... 93

4.2.3 O Canal de São Sebastião ............................................................ 102 
4.3.1 A Plataforma Continental Sudeste................................................... 116

4.3.2 A Plataforma Continental Interna.................................................. 125

4.3.3 O Canal de São Sebastião ............................................................... 133

4.4 O Inverno

4.4.1 A Plataforma Continental Sudeste.................................................... 146

4.4.2 A Plataforma Continental Interna................................................. 155

4.4.3 O Canal de São Sebastião.................................................................. 164

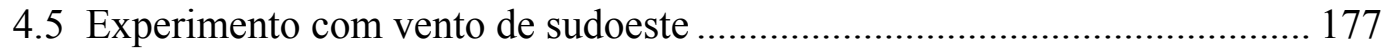

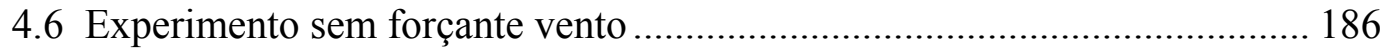

4.7 Experimento com forçante vento na PCSE

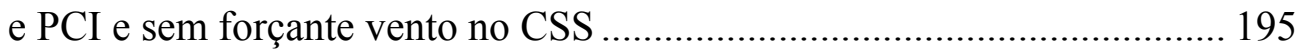

4.8 Simulação da estrutura térmica do CSS à passagem de uma frente fria ..... 203

\section{Discussão dos resultados}

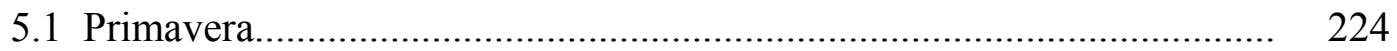

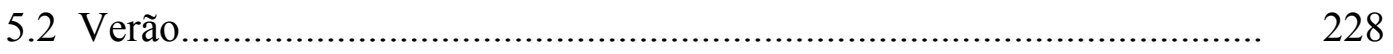

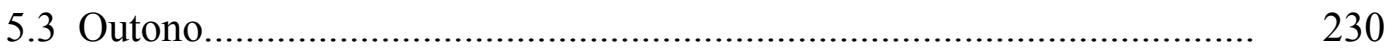

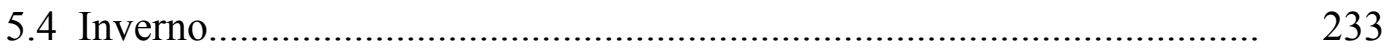

5.5 Outros experimentos..................................................................... 236

6 Conclusões 245

Bibliografia .................................................................................... 251 


\section{Agradecimentos}

Meus sinceros agradecimentos,

Ao Prof. Dr. Luiz Bruner de Miranda, pela orientação;

Ao Prof. Dr. Belmiro Mendes de Castro Filho, pela co-orientação;

Aos colegas José Helvécio Moraes de Rezende e Mauro Cirano pelas inúmeras sugestões feitas a este trabalho;

À Coordenação de Aperfeiçoamento de Pessoal de Nível Superior (CAPES), pelo suporte financeiro;

Aos colegas do LIO (Laboratório de Instrumentação Oceanográfica) e do LHICO (Laboratório de Hidrodinâmica Costeira) pelo suporte técnico;

Ao Prof. Dr. Edmo José Dias Campos, por ter gentilmente cedido os equipamentos do LABMON (Laboratório de Modelagem Numérica); 


\section{Resumo}

O Princeton Ocean Model foi adaptado ao Canal de São Sebastião (CSS) para estudar as variações sazonais de sua circulação e estrutura termohalina. Três grades numéricas foram aninhadas. A de menor resolução na Plataforma Continental Sudeste (PCSE) e a de maior resolução no Canal de São Sebastião (CSS) com uma grade de resolução intermediária na região adjacente ao canal (PCI). O modelo numérico partiu de condições termohalinas médias sazonais e teve como forçantes, ventos, fluxos de calor, de sal e de radiação de ondas curtas mensais. Nessas condições médias, o modelo representou razoavelmente bem as condições típicas de primavera, verão, outono e inverno, preenchendo o fundo do CSS com a Água Central do Atlântico Sul na primavera e no verão. No outono e no inverno esta massa de água não se encontra no canal, porém, seus sinais mais fracos são obtidos no outono sendo que nesta estação são encontrados os sinais mais fortes da Água Tropical. O modelo aponta o sul do canal, no fundo, ao lado da Ilha de São Sebastião como entrada preferencial de águas mais frias e a simulação numérica da passagem de uma frente fria pela Plataforma Continental Sudeste sugere a rápida resposta das águas do canal com o recuo para o largo da Água Central do Atlântico Sul e pronto retorno assim que a frente deixa a plataforma. Ventos de nordeste na grade da PCSE são imprescindíveis para que a Água Central do Atlântico Sul penetre o Canal de São Sebastião; todos os experimentos com ventos de outras direções nesta grade ou ventos de nordeste somente nas grades média e do CSS não colocaram esta massa de água no canal. A circulação de fundo obtida no CSS é basicamente para nordeste e associada à intrusão da ACAS forçada em primeira instância pelo vento de nordeste na PCSE e em um segundo momento pela força do gradiente de pressão (com destaque para a componente baroclínica), sempre maior na entrada sul do que na entrada norte e sempre maior no verão do que no inverno. A circulação superficial é para sudoeste com relaxamento no outono, intensificando-se em direção ao verão com máximo nesta estação.

Palavras-chaves: Modelagem numérica, estrutura termohalina, corrente, frente fria. 


\section{Abstract}

The Princeton Ocean Model was adapted to São Sebastião Channel (SSC) so as to study the seasonal changes of its circulation and thermohaline structure. Three numerical grids were nested. The coarse grid on Southeast Continental Shelf (SCS) and the fine grid on São Sebastião Channel with an intermediary grid on the region adjacent to the channel. The numerical model started from average seasonal thermohaline conditions and average monthly data forcing such as wind, heat flux, salt flux and short wave radiation flux. Within these average conditions, the numerical model simulated reasonably the typical conditions of spring, summer, autumn and winter, filling the bottom channel with South Atlantic Central Water (SACW) in spring and in summer. In autumn and in winter this mass of water is not found, nevertheless its weaker signs appear in autumn, which season one finds the stronger signs of Tropical Water (never more than 50\%). The model points out the bottom south entrance of the channel, next to the São Sebastião Island (SSI) as the natural gate of colder water and the numerical simulation of a cold front through SCS suggests the quick answer of the water channel with the falling back offshore of the SACW and immediate return when the cold front is gone. Northeasterly winds on the SCS grid are essential so that the SACW enters the SSC; all the experiments with another direction winds in this grid or northeasterly winds only in the intermediate and in the fine grid failed to get in the SACW in the channel. The bottom circulation obtained in SSC is essentially to northeast and associated to the intrusion of the SACW forced in first instance by the northeasterly winds in SCS and in second instance by the pressure force (with emphasis on the baroclinic component) always bigger at the south entrance than in the north entrance and always bigger in summer than in the winter. The superficial currents are southeastward with weakening in autumn and intensification towards summer with maximum in this season.

Descriptors: Numerical modeling, thermohaline structure, currents, cold front. 


\section{Lista de Figuras}

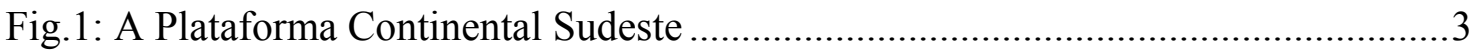

Fig.2: A Região Costeira ao Canal de São Sebastião ...........................................................

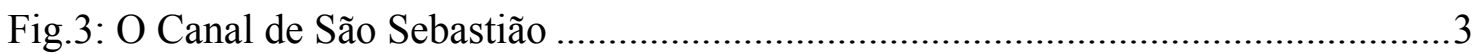

Fig.4: Distribuição vertical de temperatura junto à entrada sul do Canal de São Sebastião, nos cruzeiros realizados em 6/7/94 e 29/03/94. De acordo com Silva (1995a).

Fig.5: Localização geográfica dos pontos de grade na PCSE (A), na PCI (B) e no CSS (C).

Fig.6: Distribuição horizontal superficial do campo de temperatura inicial na Plataforma Continental Sudeste, representativo das estações da primavera (A), verão (B), outono (C) e inverno (D)

Fig.7: Distribuição horizontal superficial do campo de salinidade inicial na Plataforma Continental Sudeste, representativo das estações da primavera (A), verão (B), outono (C) e inverno (D)

Fig.8: Distribuição vertical do campo de temperatura inicial na Plataforma Continental Sudeste em uma seção ao sul do Canal de São Sebastião, representativo das estações da primavera (A), verão (B), outono (C) e inverno (D) .....21

Fig.9: Distribuição vertical do campo de salinidade inicial na Plataforma Continental Sudeste em uma seção ao sul do Canal de São Sebastião, representativo das estações da primavera (A), verão (B), outono (C) e inverno (D) .....22

Fig.10: Distribuição vertical do campo de temperatura inicial na Plataforma Continental Interna em uma seção ao sul do Canal de São Sebastião, representativo das estações da primavera (A), verão (B), outono (C) e inverno (D) .....23

Fig.11: Distribuição vertical do campo de salinidade inicial na Plataforma Continental Interna em uma seção ao sul do Canal de São Sebastião, representativo das estações da primavera (A), verão (B), outono (C) e inverno (D) .....24

Fig.12: Distribuição vertical do campo de temperatura inicial junto à seção $A$ do Canal de São Sebastião, representativo das estações da primavera (A), verão (B), outono (C) e inverno (D)

Fig.13: Distribuição vertical do campo de salinidade inicial junto à seção $\mathrm{A}$ do Canal de São Sebastião, representativo das estações da primavera (A), verão (B), outono (C) e inverno (D)...

Fig.14: Tensão de Cisalhamento do Vento Climatológico representativo dos meses de novembro (A), fevereiro (B), maio (C) e agosto (D) na Plataforma Continental Sudeste

Fig.15: Seções transversais (A) e seção longitudinal (B) no Canal de São Sebastião.

Fig.16: Curvas de energia mecânica (A), fluxos nos contornos (B) e nível do mar médio (C) na PCSE. Simulação de primavera - novembro 
Fig.17: Curvas de energia mecânica (A), fluxos nos contornos (B) e nível do mar médio (C) na PCSE. Simulação de verão - fevereiro

Fig.18: Curvas de energia mecânica (A), fluxos nos contornos (B) e nível do mar médio (C) na PCSE. Simulação de outono - maio

Fig.19: Curvas de energia mecânica (A), fluxos nos contornos (B) e nível do mar médio (C) na PCSE. Simulação de inverno - agosto .

Fig.20: Nível do mar na Plataforma Continental Sudeste obtido em modo barotrópico após 30 dias de integração nas simulações de primavera (A), verão (B), outono (C) e inverno (D)

Fig.21: Correntes na Plataforma Continental Sudeste obtidas em modo barotrópico após 30 dias de integração nas simulações de primavera (A), verão (B), outono (C) e inverno (D).

Fig.22: Curvas de energia mecânica (A), fluxos nos contornos (B) e nível do mar médio (C) na PCI. Simulação de primavera - novembro.

Fig.23: Curvas de energia mecânica (A), fluxos nos contornos (B) e nível do mar médio (C) na PCI. Simulação de verão - fevereiro

Fig.24: Curvas de energia mecânica (A), fluxos nos contornos (B) e nível do mar médio $(C)$ na PCI. Simulação de outono - maio

Fig.25: Curvas de energia mecânica (A), fluxos nos contornos (B) e nível do mar médio (C) na PCI. Simulação de inverno - agosto

Fig.26: Nível do mar na PCI obtidas em modo barotrópico após 30 dias de integração nas simulações de primavera (A), verão (B), outono (C) e inverno (D) ......44

Fig.27: Correntes na PCI obtidas em modo barotrópico após 30 dias de integração nas simulações de primavera (A), verão (B), outono (C) e inverno (D)

Fig.28: Curvas de energia mecânica (A), fluxos nos contornos (B) e nível do mar médio (C) no CSS. Simulação de primavera - novembro

Fig.29: Curvas de energia mecânica (A), fluxos nos contornos (B) e nível do mar médio (C) no CSS. Simulação de verão - fevereiro.

Fig.30: Curvas de energia mecânica (A), fluxos nos contornos (B) e nível do mar médio (C) no CSS. Simulação de outono - maio

Fig.31: Curvas de energia mecânica (A), fluxos nos contornos (B) e nível do mar médio (C) no CSS. Simulação de inverno - agosto

Fig.32: Nível do mar no Canal de São Sebastião obtido em modo barotrópico após 30 dias de integração nas simulações de primavera (A), verão (B), outono (C) e inverno (D)

Fig.33: Correntes no Canal de São Sebastião obtidas em modo barotrópico após 30 dias de integração nas simulações de primavera (A), verão (B), outono (C) e inverno (D)

Fig.34: Curvas de energia mecânica (A), fluxos nos contornos (B) e nível do mar médio (C) na PCSE. Modo Prognóstico. Simulação de primavera - novembro

Fig.35: Nível do mar (A) e Correntes superficiais (B) na Plataforma Continental Sudeste. Simulação de primavera - novembro. 
Fig.36: Distribuição horizontal superficial da temperatura (A), da salinidade (B) e da densidade convencional (C) na Plataforma Continental Sudeste. Simulação de primavera - novembro.

Fig.37: Distribuição horizontal superficial dos percentuais das massas de Água Costeira (A), Água Central do Atlântico Sul (B) e da Água Tropical (C) na Plataforma Continental Sudeste. Simulação de primavera - novembro

Fig.38: Distribuição vertical da temperatura (A), da salinidade (B) e da densidade convencional (C) na Plataforma Continental Sudeste ao sul do Canal de São Sebastião. Simulação de primavera - novembro

Fig.39: Distribuição vertical dos percentuais das massas de Água Costeira (A), da Água Central do Atlântico Sul (B) e da Água Tropical (C) na Plataforma Continental Sudeste ao sul do Canal de São Sebastião. Simulação de primavera novembro.....

Fig.40: Distribuição vertical das componentes de velocidade paralela (A) e perpendicular (B) à costa na Plataforma Continental Sudeste ao sul do Canal de São Sebastião. Simulação de primavera - novembro

Fig.41: Curvas de energia mecânica (A), fluxos nos contornos (B) e nível do mar médio (C) na PCI. Modo Prognóstico. Simulação de primavera - novembro

Fig.42: Nível do mar (A) e Correntes superficiais (B) na PCI. Simulação de primavera - novembro

Fig.43: Distribuição horizontal superficial da temperatura (A), da salinidade (B) e da densidade convencional (C) na PCI. Simulação de primavera - novembro.

Fig.44: Distribuição horizontal superficial dos percentuais das massas de Água Costeira (A), Água Central do Atlântico Sul (B) e da Água Tropical (C) na PCI. Simulação de primavera - novembro

Fig.45: Distribuição vertical da temperatura (A), da salinidade (B) e da densidade convencional (C) na PCI ao sul do Canal de São Sebastião. Simulação de primavera - novembro.

Fig.46: Distribuição vertical dos percentuais das massas de Água Costeira (A), da Água Central do Atlântico Sul (B) e da Água Tropical (C) na PCI ao sul do Canal de São Sebastião. Simulação de primavera - novembro

Fig.47: Distribuição vertical das componentes de velocidade paralela (A) e perpendicular (B) à costa na PCI ao sul do Canal de São Sebastião. Simulação de primavera - novembro.

Fig.48: Curvas de energia mecânica (A), fluxos nos contornos (B) e nível do mar médio (C) no CSS. Modo Prognóstico. Simulação de primavera - novembro.

Fig.49: Nível do mar (A) e Correntes superficiais (B) no Canal de São Sebastião. Simulação de primavera - novembro

Fig.50: Distribuição horizontal superficial da temperatura (A), da salinidade (B) e da densidade convencional (C) no Canal de São Sebastião. Simulação de primavera - novembro

Fig.51: Distribuição vertical da temperatura nas seções A, B, C e D, localizadas na região interna do Canal de São Sebastião. Simulação de primavera - novembro.....78 
Fig.52: Distribuição vertical da salinidade nas seções A, B, C e D, localizadas na região interna do Canal de São Sebastião. Simulação de primavera - novembro

Fig.53: Distribuição vertical da densidade convencional nas seções A, B, C e D, localizadas na região interna do Canal de São Sebastião. Simulação de primavera - novembro

Fig.54: Distribuição vertical ao longo do Canal de São Sebastião das propriedades temperatura (A), salinidade (B) e densidade convencional (C). Simulação de primavera - novembro

Fig.55: Distribuição vertical ao longo do Canal de São Sebastião dos percentuais das massas de Água Costeira (A), Água Central do Atlântico Sul (B) e Água Tropical (C). Simulação de primavera - novembro

Fig.56: Distribuição vertical das componentes de velocidade normal (A) e paralela (B) à seção A . Distribuição vertical ao longo do Canal de São Sebastião das componentes de velocidade normal (C) e paralela (D) às seções. Simulação de primavera - novembro....

Fig.57: Curvas de energia mecânica (A), fluxos nos contornos (B) e nível do mar médio (C) na PCSE. Modo Prognóstico. Simulação de verão - fevereiro

Fig.58: Nível do mar (A) e Correntes superficiais (B) na Plataforma Continental Sudeste. Simulação de verão - fevereiro.

Fig.59: Distribuição horizontal superficial da temperatura (A), da salinidade (B) e da densidade convencional (C) na Plataforma Continental Sudeste. Simulação de verão - fevereiro.

Fig.60: Distribuição horizontal superficial dos percentuais de massas de Água Costeira (A), Água Central do Atlântico Sul (B) e de Água Tropical (C) na Plataforma Continental Sudeste. Simulação de verão - fevereiro

Fig.61: Distribuição vertical da temperatura (A), da salinidade (B) e da densidade convencional (C) na Plataforma Continental Sudeste ao sul do Canal de São Sebastião. Simulação de verão - fevereiro

Fig.62: Distribuição vertical dos percentuais de massas de Água Costeira (A), Água Central do Atlântico Sul (B) e da Água Tropical (C) na Plataforma Continental Sudeste ao sul do Canal de São Sebastião. Simulação de verão fevereiro.

Fig.63: Distribuição vertical das componentes de velocidade paralela (A) e perpendicular (B) à costa na Plataforma Continental Sudeste ao sul do Canal de São Sebastião. Simulação de verão fevereiro

Fig.64: Curvas de energia mecânica (A), fluxos nos contornos (B) e nível do mar médio (C) na PCI. Modo Prognóstico. Simulação de verão - fevereiro

Fig.65: Nível do mar (A) e Correntes superficiais (B) na PCI. Simulação de verão - fevereiro.

Fig.66: Distribuição horizontal superficial da temperatura (A), da salinidade (B) e da densidade convencional (C) na PCI. Simulação de verão - fevereiro..... 
Fig.67: Distribuição horizontal superficial dos percentuais de massas de Água Costeira (A), Água Central do Atlântico Sul (B) e de Água Tropical (C) na PCI. Simulação de verão - fevereiro .

Fig.68: Distribuição vertical da temperatura (A), da salinidade (B) e da densidade convencional (C) na PCI ao sul do Canal de São Sebastião. Simulação de verão fevereiro.

Fig.69: Distribuição vertical dos percentuais de massas de Água Costeira (A), Água Central do Atlântico Sul (B) e da Água Tropical (C) na PCI ao sul do Canal de São Sebastião. Simulação de verão - fevereiro

Fig.70: Distribuição vertical das componentes de velocidade paralela (A) e perpendicular (B) à costa na PCI ao sul do Canal de São Sebastião. Simulação de verão fevereiro.

Fig.71: Curvas de energia mecânica (A), fluxos nos contornos (B) e nível do mar médio (C) no CSS. Modo Prognóstico. Simulação de verão - fevereiro

Fig.72: Nível do mar (A) e Correntes superficiais (B) no Canal de São Sebastião. Simulação de verão - fevereiro

Fig.73: Distribuição horizontal superficial da temperatura (A), da salinidade (B) e da densidade convencional (C) no Canal de São Sebastião. Simulação de verão fevereiro.

Fig.74: Distribuição horizontal superficial dos percentuais de massas de Água Costeira (A), Água Central do Atlântico Sul (B) e de Água Tropical (C) no Canal de São Sebastião. Simulação de verão - fevereiro

Fig.75: Distribuição vertical ao longo do Canal de São Sebastião das propriedades temperatura (A), salinidade (B) e densidade convencional (C). Simulação de verão - fevereiro.

Fig.76: Distribuição vertical ao longo do Canal de São Sebastião dos percentuais das massas de Água Costeira (A), Água Central do Atlântico Sul (B) e Água Tropical (C). Simulação de verão - fevereiro

Fig.77: Distribuição vertical das componentes de velocidade normal (A) e paralela (B) à seção A . Distribuição vertical ao longo do Canal de São Sebastião das componentes de velocidade normal (C) e paralela (D) às seções. Simulação de verão - fevereiro.

Fig.78: Distribuição vertical da temperatura nas seções A, B, C e D, localizadas na região interna do Canal de São Sebastião. Simulação de verão - fevereiro.

Fig.79: Distribuição vertical da salinidade nas seções A, B, C e D, localizadas na região interna do Canal de São Sebastião. Simulação de verão - fevereiro

Fig.80: Distribuição vertical da densidade convencional nas seções A, B, C e D, localizadas na região interna do Canal de São Sebastião. Simulação de verão fevereiro.

Fig.81: Distribuição vertical dos percentuais de massas de Água Costeira (A), Água Central do Atlântico Sul (B) e da Água Tropical (C) na seção A na região interna do Canal de São Sebastião. Simulação de verão - fevereiro. 
Fig.82: Curvas de energia mecânica (A), fluxos nos contornos (B) e nível do mar médio (C) na PCSE. Modo Prognóstico. Simulação de outono - maio .

Fig.83: Nível do mar (A) e Correntes superficiais (B) na Plataforma Continental Sudeste. Simulação de outono - maio.

Fig.84: Distribuição horizontal superficial da temperatura (A), da salinidade (B) e da densidade convencional (C) na Plataforma Continental Sudeste. Simulação de outono - maio

Fig.85: Distribuição horizontal superficial dos percentuais de massas de Água Costeira (A), Água Central do Atlântico Sul (B) e de Água Tropical (C) na Plataforma Continental Sudeste. Simulação de outono - maio.

Fig.86: Distribuição vertical da temperatura (A), da salinidade (B) e da densidade convencional (C) na Plataforma Continental Sudeste ao sul do Canal de São Sebastião. Simulação de outono - maio

Fig.87: Distribuição vertical dos percentuais de massas de Água Costeira (A), Água Central do Atlântico Sul (B) e da Água Tropical (C) na Plataforma Continental Sudeste ao sul do Canal de São Sebastião. Simulação de outono maio

Fig.88: Distribuição vertical das componentes de velocidade paralela (A) e perpendicular (B) à costa na Plataforma Continental Sudeste ao sul do Canal de São Sebastião. Simulação de outono - maio

Fig.89: Curvas de energia mecânica (A), fluxos nos contornos (B) e nível do mar médio (C) na PCI. Modo Prognóstico. Simulação de outono - maio

Fig.90: Nível do mar (A) e Correntes superficiais (B) na PCI. Simulação de outono - maio

Fig.91: Distribuição horizontal superficial da temperatura (A), da salinidade (B), da densidade convencional (C) e do percentual da massa de Água Costeira (D) na PCI. Simulação de outono - maio

Fig.92: Distribuição vertical da temperatura (A), da salinidade (B) e da densidade convencional (C) na PCI ao sul do Canal de São Sebastião. Simulação de outono - maio

Fig.93: Distribuição vertical dos percentuais de massas de Água Costeira (A), Água Central do Atlântico Sul (B) e da Água Tropical (C) na PCI ao sul do Canal de São Sebastião. Simulação de outono - maio

Fig.94: Distribuição vertical das componentes de velocidade paralela (A) e perpendicular (B) à costa na PCI ao sul do Canal de São Sebastião. Simulação de outono - maio

Fig.95: Curvas de energia mecânica (A), fluxos nos contornos (B) e nível do mar médio (C) no CSS. Modo Prognóstico. Simulação de outono - maio

Fig.96: Nível do mar (A) e Correntes superficiais (B) no Canal de São Sebastião.

Simulação de outono - maio

Fig.97: Distribuição horizontal superficial da temperatura (A), da salinidade (B) e da densidade convencional (C) no Canal de São Sebastião. Simulação de outono maio 
Fig.98: Distribuição vertical da temperatura nas seções A, B, C e D, localizadas na região interna do Canal de São Sebastião. Simulação de outono - maio

Fig.99: Distribuição vertical da salinidade nas seções A, B, C e D, localizadas na região interna do Canal de São Sebastião. Simulação de outono - maio

Fig.100: Distribuição vertical da densidade convencional nas seções A, B, C e D, localizadas na região interna do Canal de São Sebastião. Simulação de outono maio

Fig.101: Distribuição vertical do percentual da massa de Água Costeira nas seções A, B, C e D, localizadas na região interna do Canal de São Sebastião. Simulação de outono - maio

Fig.102: Distribuição vertical ao longo do Canal de São Sebastião das propriedades temperatura (A), salinidade (B) e densidade convencional (C). Simulação de outono - maio

Fig.103: Distribuição vertical ao longo do Canal de São Sebastião dos percentuais das massas de Água Costeira (A), Água Central do Atlântico Sul (B) e Água Tropical (C). Simulação de outono - maio

Fig.104: Distribuição vertical das componentes de velocidade normal (A) e paralela (B) à seção A . Distribuição vertical ao longo do Canal de São Sebastião das componentes de velocidade normal (C) e paralela (D) às seções. Simulação de outono - maio

Fig.105: Curvas de energia mecânica (A), fluxos nos contornos (B) e nível do mar médio (C) na PCSE. Modo Prognóstico. Simulação de inverno - agosto .

Fig.106: Nível do mar (A) e Correntes superficiais (B) na Plataforma Continental Sudeste. Simulação de inverno - agosto

Fig.107: Distribuição horizontal superficial da temperatura (A), da salinidade (B) e da densidade convencional (C) na Plataforma Continental Sudeste. Simulação de inverno - agosto.

Fig.108: Distribuição horizontal superficial dos percentuais de massas de Água Costeira (A), Água Central do Atlântico Sul (B) e de Água Tropical (C) na Plataforma Continental Sudeste. Simulação de inverno - agosto

Fig.109: Distribuição vertical da temperatura (A), da salinidade (B) e da densidade convencional (C) na Plataforma Continental Sudeste ao sul do Canal de São Sebastião. Simulação de inverno - agosto

Fig.110: Distribuição vertical dos percentuais de massas de Água Costeira (A), Água Central do Atlântico Sul (B) e da Água Tropical (C) na Plataforma Continental Sudeste ao sul do Canal de São Sebastião. Simulação de inverno agosto.

Fig.111: Distribuição vertical das componentes de velocidade paralela (A) e perpendicular (B) à costa na Plataforma Continental Sudeste ao sul do Canal de São Sebastião. Simulação de inverno - agosto

Fig.112: Curvas de energia mecânica (A), fluxos nos contornos (B) e nível do mar médio (C) na PCI. Modo Prognóstico. Simulação de inverno - agosto 
Fig.113: Nível do mar (A) e Correntes superficiais (B) na PCI. Simulação de inverno - agosto

Fig.114: Distribuição horizontal superficial da temperatura (A), da salinidade (B) e da densidade convencional (C) na PCI. Simulação de inverno - agosto.

Fig.115: Distribuição horizontal superficial dos percentuais das massas de Água Costeira (A), Água Central do Atlântico Sul (B) e da Água Tropical (C) na PCI. Simulação de inverno - agosto.

Fig.116: Distribuição vertical da temperatura (A), da salinidade (B) e da densidade convencional (C) na PCI ao sul do Canal de São Sebastião. Simulação de inverno - agosto

Fig.117: Distribuição vertical dos percentuais de massas de Água Costeira (A), Água Central do Atlântico Sul (B) e da Água Tropical (C) na PCI ao sul do Canal de São Sebastião. Simulação de inverno - agosto.

Fig.118: Distribuição vertical das componentes de velocidade paralela (A) e perpendicular (B) à costa na PCI ao sul do Canal de São Sebastião. Simulação de inverno - agosto

Fig.119: Curvas de energia mecânica (A), fluxos nos contornos (B) e nível do mar médio (C) no CSS. Modo Prognóstico. Simulação de inverno - agosto.

Fig.120: Nível do mar (A) e Correntes superficiais (B) no Canal de São Sebastião.

Simulação de inverno - agosto....

Fig.121: Distribuição horizontal superficial da temperatura (A), da salinidade (B) e da densidade convencional (C) no Canal de São Sebastião. Simulação de inverno - agosto

Fig.122: Distribuição horizontal superficial dos percentuais de massas de Água Costeira (A), Água Central do Atlântico Sul (B) e de Água Tropical (C) no Canal de São Sebastião. Simulação de inverno - agosto

Fig.123: Distribuição vertical da temperatura nas seções A, B, C e D, localizadas na região interna do Canal de São Sebastião. Simulação de inverno - agosto

Fig.124: Distribuição vertical da salinidade nas seções A, B, C e D, localizadas na região interna do Canal de São Sebastião. Simulação de inverno - agosto .

Fig.125: Distribuição vertical da densidade convencional nas seções A, B, C e D, localizadas na região interna do Canal de São Sebastião. Simulação de inverno agosto

Fig.126: Distribuição vertical dos percentuais das massas de Água Costeira (A), Água Central do Atlântico Sul (B) e da Água Tropical (C) junto à seção A, localizada no Canal de São Sebastião. Simulação de inverno - agosto .

Fig.127: Distribuição vertical ao longo do Canal de São Sebastião das propriedades temperatura (A), salinidade (B) e densidade convencional (C). Simulação de inverno - agosto.

Fig.128: Distribuição vertical ao longo do Canal de São Sebastião dos percentuais das massas de Água Costeira (A), Água Central do Atlântico Sul (B) e Água Tropical (C). Simulação de inverno - agosto 
Fig.129: Distribuição vertical das componentes de velocidade normal (A) e paralela (B) à seção A . Distribuição vertical ao longo do Canal de São Sebastião das componentes de velocidade normal (C) e paralela (D) às seções. Simulação de inverno - agosto

Fig.130: Nível do mar (A), Correntes superficiais (B), Distribuição horizontal superficial da temperatura (C) e da salinidade (D) na Plataforma Continental Sudeste após 10 dias de integração com vento de sudoeste e climatologia de verão - fevereiro.

Fig.131: Distribuição vertical da temperatura (A), da salinidade (B) e da densidade convencional (C) na Plataforma Continental Sudeste ao sul do Canal de São Sebastião após 10 dias de integração com vento de sudoeste e climatologia de verão - fevereiro.

Fig.132: Nível do mar (A), Correntes superficiais (B), Distribuição horizontal superficial dos percentuais das massas de Água Tropical (C) e da Água Costeira (D) na PCI, após 10 dias de integração com vento de sudoeste e climatologia de verão - fevereiro.

Fig.133: Distribuição vertical da temperatura (A), da salinidade (B) e da densidade convencional (C) na PCI ao sul do Canal de São Sebastião após 10 dias de integração com vento de sudoeste e climatologia de verão - fevereiro

Fig.134: Distribuição vertical dos percentuais das massas de Água Costeira (A), Água Central do Atlântico Sul (B) e Água Tropical (C) na PCI ao sul do Canal de São Sebastião. Distribuição vertical do percentual da massa de Água Tropical (D) na PCI ao norte do Canal de São Sebastião. Simulação com vento de sudoeste após 10 dias de integração e climatologia de verão - fevereiro

Fig.135: Nível do mar (A). Correntes superficiais (B). Distribuição vertical ao longo do Canal de São Sebastião, da temperatura (C) e da salinidade (D), após 10 dias de integração com vento de sudoeste e climatologia de verão - fevereiro

Fig.136: Distribuição vertical da temperatura (A), da salinidade (B), do percentual da massa de Água Costeira $(\mathrm{C})$ e da componente $\mathrm{v}$ da velocidade normal à seção A no Canal de São Sebastião após 10 dias de integração com vento de sudoeste e climatologia de verão - fevereiro .

Fig.137: Nível do mar (A), distribuição horizontal superficial da densidade convencional (B), dos percentuais das massas de Água Tropical (C) e da Água Costeira (D) na PCI após 10 dias de integração sem forçante vento e com climatologia de verão - fevereiro

Fig.138: Distribuição vertical dos percentuais das massas de Água Costeira (A), da Água Central do Atlântico Sul (B) e da Água Tropical (C) na PCI ao norte do Canal de São Sebastião após 10 dias de integração sem forçante vento e com climatologia de verão - fevereiro .

Fig.139: Distribuição vertical dos percentuais das massas de Água Costeira (A), da Água Central do Atlântico Sul (B) e da Água Tropical (C) na PCI ao sul do Canal de São Sebastião após 10 dias de integração sem forçante vento e com climatologia de verão - fevereiro 
Fig.140: Distribuição vertical ao longo do Canal de São Sebastião, da temperatura (A), da salinidade (B) e da densidade convencional (C) após 10 dias de integração, sem forçante vento e com climatologia de verão - fevereiro

Fig.141: Distribuição vertical ao longo do Canal de São Sebastião, dos percentuais das massas de Água Costeira (A), Água Central do Atlântico Sul (B) e da Água Tropical (C), após 10 dias de integração sem forçante vento e com climatologia de verão - fevereiro

Fig.142: Distribuição vertical da temperatura (A), da salinidade (B) e da densidade convencional (C) na seção A, ao sul do Canal de São Sebastião, após 10 dias de integração sem forçante vento e com climatologia de verão - fevereiro ....193

Fig.143: Distribuição vertical dos percentuais das massas de Água Costeira (A), Água Central do Atlântico Sul (B) e Água Tropical (C) na seção A, ao sul do Canal de São Sebastião, após 10 dias de integração, sem forçante vento e com climatologia de verão - fevereiro

Fig.144: Distribuição vertical de temperatura junto à seção A, no sul do Canal de São Sebastião, no $5^{\circ}$ dia (A), $10^{\circ}$ dia (B), $20^{\circ}$ dia (C) e $30^{\circ}$ dia (D) de simulação, com forçante vento na PCSE e PCI e sem forçante vento no CSS

Fig.145: Distribuição vertical da temperatura, ao longo do Canal de São Sebastião, no $5^{\circ}$ dia (A), $10^{\circ}$ dia (B), $20^{\circ}$ dia (C) e $30^{\circ}$ dia (D) de simulação, com forçante vento na PCSE e PCI e sem forçante vento no CSS

Fig.146: Distribuição vertical de salinidade junto à seção $\mathrm{A}$, no sul do Canal de São Sebastião, no $5^{\circ}$ dia (A), $10^{\circ}$ dia (B), $20^{\circ}$ dia (C) e $30^{\circ}$ dia (D) de simulação, com forçante vento na PCSE e PCI e sem forçante vento no CSS

Fig.147: Distribuição vertical da salinidade, ao longo do Canal de São Sebastião, no $5^{\circ}$ dia (A), $10^{\circ}$ dia (B), $20^{\circ}$ dia (C) e $30^{\circ}$ dia (D) de simulação, com forçante vento na PCSE e PCI e sem forçante vento no CSS

Fig.148: Distribuição vertical da componente de velocidade normal à seção $\mathrm{A}$, no sul do Canal de São Sebastião, no $5^{\circ}$ dia (A), $10^{\circ}$ dia (B), $20^{\circ}$ dia (C) e $30^{\circ}$ dia (D) de simulação, com forçante vento na PCSE e PCI e sem forçante vento no CSS

Fig.149: Distribuição vertical da componente de velocidade ao longo do Canal de São Sebastião, no $5^{\circ}$ dia (A), $10^{\circ}$ dia (B), $20^{\circ}$ dia (C) e $30^{\circ}$ dia (D) de simulação, com forçante vento na PCSE e PCI e sem forçante vento no CSS.....

Fig.150: Componente meridional do vento nos dias 21, 22, 23 e 24/02/1992, durante a passagem de uma frente fria na Plataforma Continental Sudeste. Dados extraídos de FNMOC

Fig.151: Componente meridional do vento nos dias 25, 26, 27 e 28/02/1992, durante a passagem de uma frente fria na Plataforma Continental Sudeste. Dados extraídos de FNMOC

Fig.152: Componente meridional do vento nos dias 29/02/1992 e 01, 02 e 03/03/92, durante a passagem de uma frente fria na Plataforma Continental Sudeste. Dados extraídos de FNMOC.

Fig.153: Componente meridional do vento nos dias 04 e 05/03/1992, durante a passagem de uma frente fria na Plataforma Continental Sudeste. Dados extraídos de FNMOC 
Fig.154: Distribuição vertical de temperatura junto à seção $\mathrm{A}$, no sul do Canal de São Sebastião, nos dias 20, 21, 22 e 23/02/1992, durante a simulação numérica da passagem de uma frente fria na Plataforma Continental Sudeste......

Fig.155: Distribuição vertical de temperatura junto à seção $\mathrm{A}$, no sul do Canal de São Sebastião, nos dias 24, 25, 26 e 27/02/1992, durante a simulação numérica da passagem de uma frente fria na Plataforma Continental Sudeste.

Fig.156: Distribuição vertical de temperatura junto à seção A, no sul do Canal de São Sebastião, nos dias 28 e 29/02/1992 e 01 e 02/03/1992, durante a simulação numérica da passagem de uma frente fria na Plataforma Continental Sudeste

Fig.157: Distribuição vertical de temperatura junto à seção $\mathrm{A}$, no sul do Canal de São Sebastião, nos dias 03, 04 e 05/03/1992, durante a simulação numérica da passagem de uma frente fria na Plataforma Continental Sudeste.....

Fig.158: Distribuição vertical de temperatura, ao longo do Canal de São Sebastião, nos dias 20, 21, 22 e 23/02/1992, durante a simulação numérica da passagem de uma frente fria na Plataforma Continental Sudeste.

Fig.159: Distribuição vertical de temperatura, ao longo do Canal de São Sebastião, nos dias 24, 25, 26 e 27/02/1992, durante a simulação numérica da passagem de uma frente fria na Plataforma Continental Sudeste.

Fig.160: Distribuição vertical de temperatura, ao longo do Canal de São Sebastião, nos dias 28 e 29/02/1992 e 01 e 02/03/1992, durante a simulação numérica da passagem de uma frente fria na Plataforma Continental Sudeste

Fig.161: Distribuição vertical de temperatura, ao longo do Canal de São Sebastião, nos dias 03, 04 e 05/03/1992, durante a simulação numérica da passagem de uma frente fria na Plataforma Continental Sudeste......

Fig.162: Séries temporais das componentes v e u de velocidade para um ponto localizado ao sul do Canal de São Sebastião.

Fig.163: Séries temporais das componentes v e u de velocidade para um ponto localizado na região central do Canal de São Sebastião

Fig.164: Séries temporais das componentes v e u de velocidade para um ponto localizado ao norte do Canal de São Sebastião

Fig.165: Séries temporais de temperatura (A, B), da componente v de tensão de cisalhamento do vento (C) e de nível do mar (D) para um ponto localizado ao sul do Canal de São Sebastião.

Fig.166: Séries temporais de temperatura (A, B) e de nível do mar (C) para um ponto localizado na região central do Canal de São Sebastião

Fig.167: Séries temporais de temperatura (A, B) e de nível do mar (C) para um ponto localizado ao norte do Canal de São Sebastião

Fig.168: Distribuição vertical do percentual de massas de água na seção A do CSS, em dez/93: AC (linha contínua em negrito) e ACAS (linha tracejada). De acordo com Coelho (1997)

Fig.169: Distribuição vertical de temperatura $\left({ }^{\circ} \mathrm{C}\right)$ na seção $\mathrm{A}$, no CSS, para o cruzeiro de fev/92. De acordo com Coelho (1997) 
Fig.170: Distribuição vertical do percentual de massas de água na seção A do CSS, em fev/92: AC (linha contínua) e ACAS (linha tracejada). De acordo com Coelho (1997)

Fig.171: Distribuição vertical das médias dos valores de temperatura no outono, na seção A. De acordo com Leandro (1999)

Fig.172: Variação da temperatura com a profundidade obtida em um cruzeiro oceanográfico de outono ao largo da Ilha de São Vicente, no Parque Estadual Marinho da Laje de Santos. De acordo com Silva (2000)

Fig.173: Distribuição vertical de temperatura $\left({ }^{\circ} \mathrm{C}\right)$ na seção A do CSS, em ago/92.

De acordo com Coelho (1997) .....

Fig.174: Distribuição vertical de salinidade na seção A do CSS, em ago/92. De acordo com Coelho (1997)

Fig.175: Distribuição vertical de salinidade na seção A do CSS, em jun/93. De acordo com Coelho (1997)

Fig.176: Balanço de forças em dois pontos na Plataforma Continental Sudeste; um em uma radial ao norte do Canal de São Sebastião (A, B) e outro ao sul do Canal de São Sebastião (C, D). Simulação de verão - fevereiro

Fig.177: Balanço de forças em dois pontos na PCI; um em uma radial ao norte do Canal de São Sebastião (A, B) e outro ao sul do Canal de São Sebastião (C, D). Simulação de verão - fevereiro

Fig.178: Balanço de forças em dois pontos no Canal de São Sebastião; um ao norte $(A, B)$ e outro ao sul $(C, D)$. Simulação de verão - fevereiro.

Fig.179: Balanço de forças em dois pontos na Plataforma Continental Sudeste; um em uma radial ao norte do Canal de São Sebastião (A, B) e outro ao sul do Canal de São Sebastião (C, D). Simulação de inverno - agosto

Fig.180: Balanço de forças em dois pontos na PCI; um em uma radial ao norte do Canal de São Sebastião (A, B) e outro ao sul do Canal de São Sebastião (C, D). Simulação de inverno - agosto....

Fig.181: Balanço de forças em dois pontos no Canal de São Sebastião; um ao norte (A, B) e outro ao sul (C, D). Simulação de inverno - agosto

Fig.182: Distribuição vertical longitudinal no Canal de São Sebastião do percentual da Água Central do Atlântico Sul com 6 horas, 12 horas, 18 horas e 24 horas de integração

Fig.183: Distribuição vertical longitudinal no Canal de São Sebastião do percentual da Água Central do Atlântico Sul com 30 horas, 36 horas, 42 horas e 2 dias de integração

Fig.184: Distribuição vertical longitudinal no Canal de São Sebastião do percentual da Água Central do Atlântico Sul com 3 dias, 4 dias, 5 dias e 6 dias de integração

Fig.185: Distribuição vertical longitudinal no Canal de São Sebastião do percentual da Água Central do Atlântico Sul com 7 dias, 8 dias e 10 dias de integração 


\section{Capítulo 1}

\section{Introdução}

\subsection{O Canal de São Sebastião}

A região sul-sudeste da costa brasileira, situa-se entre as latitudes de $19^{\circ}$ e $34^{\circ}$ S. A orientação predominante de sua costa é NE-SW, com exceção das regiões localizadas ao sul de Cabo Frio $\left(23^{\circ} \mathrm{S}\right)$, onde a orientação é E-W, e ao norte do Cabo de Santa Marta (28 40' S ), onde a orientação é N-S. Estes dois cabos, Cabo Frio e Cabo de Santa Marta, delimitam a chamada Plataforma Continental Sudeste (Fig. 1). Sua parte mais larga, cerca de $230 \mathrm{~km}$, está localizada em frente a Santos e sua parte mais estreita nas proximidades de Cabo Frio, com 50 km e Cabo de Santa Marta, com 70 km. O comprimento da Plataforma Continental Sudeste é aproximadamente de $1000 \mathrm{~km}$. A profundidade da quebra da plataforma varia entre $120 \mathrm{~m}$ e $180 \mathrm{~m}$ e a área total da PCSE está ao redor de $150000 \mathrm{~km}^{2}$ (Zembruscki, 1979).

O Canal de São Sebastião e região costeira adjacente (Figs. 2 e 3) estão localizados na parte central da plataforma continental sudeste brasileira, região esta denominada Embaiamento de São Paulo (Zembruscki, 1979). Ela se caracteriza pela proximidade da Corrente do Brasil, que flui ao longo do talude continental, transportando massas de água de origens distintas: a Massa de Água Tropical (AT) e a Massa de Água Central do Atlântico Sul (ACAS). A influência da AT é predominante na camada de superfície e, nas camadas mais profundas, a ACAS contribui com um volume superior a $50 \%$ do volume total da água da plataforma continental para a formação das massas de água a leste da Ilha de São Sebastião (Miranda, 1982).

O domínio interno da plataforma continental da região em estudo é de grande importância econômica e social não somente por seus recursos naturais, mas também pela localização de grandes centro urbanos, áreas de lazer, e por abrigar instalações portuárias e um dos mais importantes terminais marítimos da costa brasileira.

A plataforma continental interna, sendo uma região de transição entre o continente e o oceano adjacente, é a depositária das águas servidas dos centros urbanos e das indústrias através da drenagem continental e da descarga de pequenos rios e córregos. Como conseqüência, além dos impactos naturais, as águas dessa região também estão sujeitas às tensões associadas ao crescimento urbano e industrial. 
O Canal de São Sebastião (CSS) está localizado na parte nordeste do Estado de São Paulo (SP) entre a planície costeira e a Ilha de São Sebastião. Esse canal tem aproximadamente $22 \mathrm{~km}$ de comprimento, estendendo-se entre as latitudes $23^{\circ} 41^{\prime}$ e $23^{\circ}$ 54' S. Ele tem uma forma curva cuja orientação com o norte verdadeiro varia entre NE e $\mathrm{N}$ nas suas entradas sul e norte, respectivamente. Essas entradas, com a configuração afunilada, têm larguras aproximadas de 7,2 e $5,6 \mathrm{~km}$, e a parte mais estreita, com aproximadamente 1,9 km, está localizada na Ponta Araçá (Fig. 3). A região mais profunda do canal está localizada no lado insular, onde a profundidade varia aproximadamente entre $20 \mathrm{~m}$ nas entradas norte e sul, até uma profundidade máxima de aproximadamente $50 \mathrm{~m}$ na parte central do CSS. O lado insular, onde ocorrem as maiores profundidades, será referido como canal principal, caracterizando-se por uma topografia do fundo submarino com acentuadas inclinações laterais. Deve-se ressaltar a singularidade do CSS em costas brasileiras, não somente em relação às suas dimensões físicas, como também em relação ao fato de que trata-se de um canal não estuarino, o que torna sua oceanografia física bem particular. 


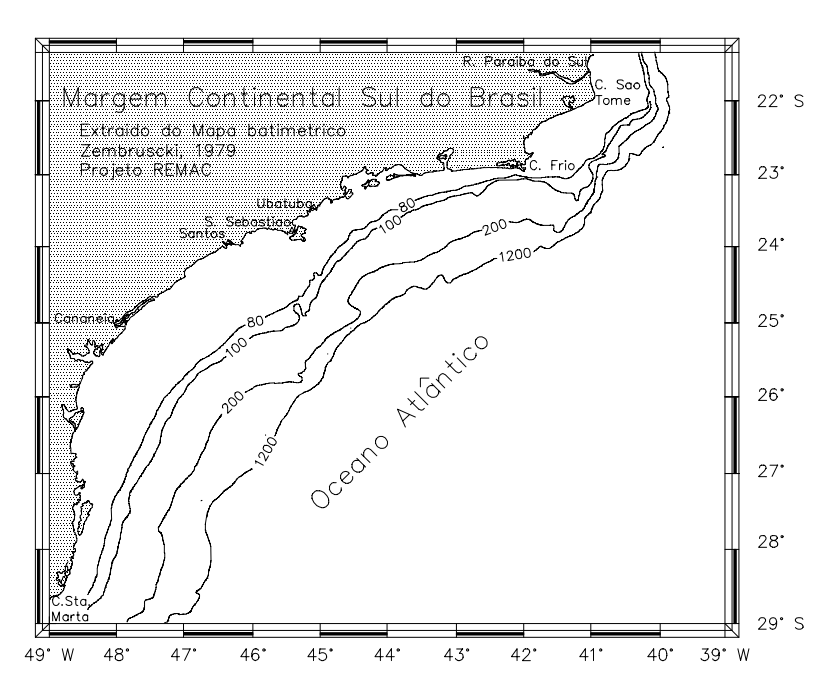

Figura 1: A Plataforma Continental Sudeste.

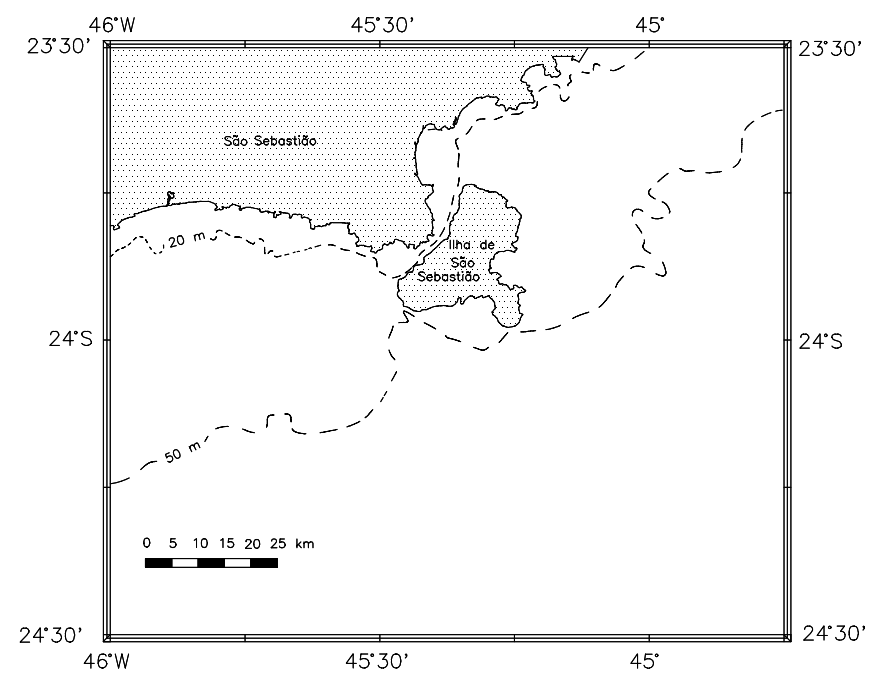

Figura 2: A Região Costeira Adjacente ao Canal de São Sebastião.

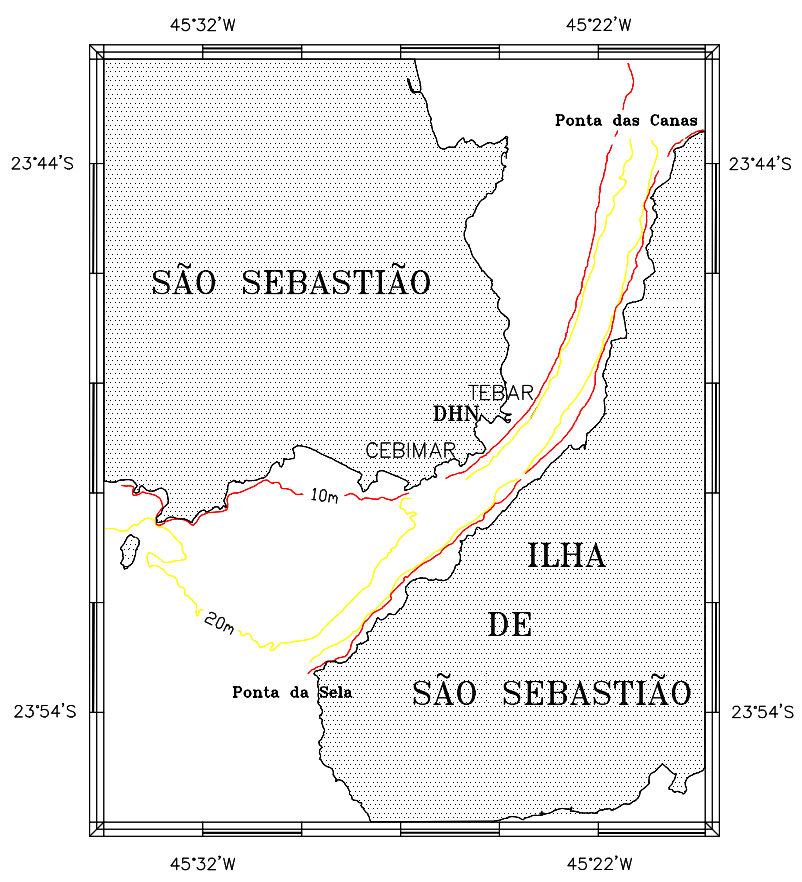

Figura 3: O Canal de São Sebastião. 


\subsection{Conhecimento atual}

A publicação pioneira contendo dados de propriedades físico-químicas das águas da plataforma continental do Estado de São Paulo (SP) foi apresentada por Emílsson (1956). A análise subseqüente desses dados (Emílsson, 1959; 1961), permitiu um conhecimento preliminar das estruturas térmica e halina em escala regional e a formulação de hipóteses sobre a origem e formação das massas de água da região sudeste da plataforma continental brasileira.

Um dos resultados de Emílsson (1961), obtido a partir de um conjunto de dados não sinóticos de março e novembro de 1956, foi a distribuição da salinidade na profundidade de $10 \mathrm{~m}$. Embora essa estrutura halina tenha sido obtida numa escala espacial, abrangendo a costa sudeste e sul, verifica-se que ao largo da Ilha de São Sebastião essa propriedade variava de um mínimo próximo a 34,5, ao longo da plataforma interna, a um extremo de 36,5 na região oceânica. Esse máximo foi interpretado por Emílsson (1961) como indicador da Massa de Água Tropical (AT) transportada para o sul pela Corrente do Brasil (CB).

A análise de características termohalinas das águas superficiais ao longo da plataforma continental entre a Ilha de São Sebastião (SP) e a Baía da Ilha Grande (RJ), com base em registros contínuos e quase-sinóticos de temperatura e salinidade, mostrou a ocorrência de frentes térmicas e halinas (Miranda \& Ikeda, 1976; Miranda et al. 1977). As frentes salinas, em geral visíveis e dinamicamente com melhor definição do que as frentes térmicas, foram interpretadas como resultantes da descarga de água doce na região costeira e da interação entre as águas da plataforma continental e a AT, transportada pela Corrente do Brasil na região oceânica adjacente.

Com relação aos movimentos periódicos que se sobrepõem às correntes da plataforma continental sudeste, devem-se mencionar os trabalhos experimentais e de modelagem numérica desenvolvidos por Mesquita \& Harari (1987, 1988). Esses trabalhos, demonstram uma predominância das componentes com freqüências diurnas e semi-diurnas geradas por forçantes astronômicas e meteorológicas, sendo que as maiores intensidades são geradas pelas constituintes da maré $\mathrm{M}_{2}, \mathrm{O}_{1}$ e $\mathrm{K}_{1}$.

Modelos numéricos da circulação gerada pelo vento no Embaiamento de São Paulo, foram desenvolvidos por Harari (1984) e Castro Filho (1985). Nesse último trabalho, o autor desenvolveu um modelo numérico hidrodinâmico barotrópico e 
hierarquizado na forma de ninhos e com três grades, sendo que a de maior resolução foi localizada no CSS. Ficou demonstrado que a circulação no Canal de São Sebastião resultante desse modelo no inverno, quando a coluna de água apresenta-se pouco estratificada, é uma manifestação local de movimento de escala espacial muito maior, predominantemente gerada pelo vento.

Stech \& Lorenzzetti (1992), utilizaram-se de um modelo de elementos finitos barotrópico, para estudar a resposta das águas da plataforma continental sudeste às passagens de frentes frias; um dos resultados deste trabalho mostra que a natureza dessa resposta é quase-geostrófica.

A região entre Ubatuba e a Ilha de São Sebastião foi pesquisada com amostragens quase-sinóticas em períodos de verão e de inverno, entre os anos de 1985 e 1988. Os resultados da análise dos dados para o verão de 1985 e o inverno de 1986 (Castro Filho, Miranda \& Miyao, 1987), mostraram padrões distintos de distribuição de massas de água em dois domínios (interior e costeiro, e exterior), separados por uma zona frontal térmica bem definida no inverno. Nesse trabalho, onde foram analisados dados hidrográficos de uma densa rede de estações oceanográficas, ficou reforçada a hipótese de que a ocorrência de vórtices e meandros, pode ocasionar variações anormais da estrutura termohalina da plataforma continental.

Durante o verão o domínio interior tem uma estratificação de massa em duas camadas, gerada pelo desenvolvimento da termoclina sazonal, que se intensifica devido ao efeito advectivo da ACAS nesta época do ano. No inverno a sua estrutura térmica tende a uma quase homogeneidade vertical. Com métodos de análise das curvas T-S, esses pesquisadores (Castro Filho, Miranda e Miyao, op. cit.) calcularam os percentuais de contribuição da AT e ACAS, para a formação da Massa de Água Costeira (AC).

As correntes de maré e inerciais da plataforma continental ao largo de Ubatuba foram temas de um estudo detalhado realizado por Alves (1992). Nesse trabalho, em que foram analisadas séries temporais de corrente cobrindo diferentes épocas do ano, os resultados da análise harmônica e espectral mostraram que o comportamento das constituintes semidiurnas $\mathrm{M}_{2}$ e $\mathrm{S}_{2}$ e diurnas $\mathrm{O}_{1}$ e $\mathrm{K}_{1}$, é predominantemente barotrópico e baroclínico, respectivamente. Por outro lado, variações sazonais periódicas importantes foram apenas observadas para as correntes geradas pelas constituintes diurnas $\mathrm{O}_{1}$ e $\mathrm{K}_{1}$. 
Campos, Gonçalves \& Ikeda (1995), analisando dados hidrográficos coletados entre Rio de Janeiro e Santos em janeiro de 1991, concluem que um forte meandramento da Corrente do Brasil parece ser responsável pela intrusão da ACAS sobre a plataforma continental e que a combinação de ressurgência costeira forçada pelo vento com a ressurgência de quebra de plataforma, constituem os mecanismos responsáveis pelo transporte de águas profundas, desde regiões abaixo de $200 \mathrm{~m}$ de profundidade para as camadas superficiais.

Cirano \& Campos (1996), utilizando-se de um modelo baroclínico de coordenadas sigma, realizaram um conjunto de experimentos diagnósticos, utilizando-se de estruturas de densidade baseadas em dados de verão e inverno de 1993, entre Ubatuba e Iguape, na plataforma continental sudeste. Os resultados sugerem, segundo os autores, uma intrusão da Água Tropical e da Água Central do Atlântico Sul sobre a plataforma continental na região entre Ubatuba e Santos, tanto durante o cruzeiro de verão quanto no de inverno.

Castro (1996), analisando dados de sete cruzeiros hidrográficos e de fundeios de correntógrafos, identifica na Plataforma Continental Norte de São Paulo, três regiões com características diferentes: plataforma continental interna (PCI), plataforma continental média (PCM) e plataforma continental externa (PCE). O autor destaca que essas três regiões são separadas por duas frentes: a frente halina superficial entre a PCM e a PCE e a frente térmica profunda que separa a PCI e a PCM. Segundo o autor, a intrusão da ACAS na PCM é sazonal e está presente durante todo o ano na PCE.

O CSS é uma região onde ocorrem complexos processos físicos e há poucos trabalhos publicados sobre a sua oceanografia física. O principal objetivo dos trabalhos anteriores foi estudar a sua circulação a qual não é gerada pela ação da maré e sim predominantemente forçada pelos ventos, que geram a circulação na plataforma interna adjacente que é canalizada para o seu interior graças à forma afunilada das suas entradas (Emílsson, 1962; Kvinge, 1967).

Para estimar a circulação geral de superfície e de fundo no CSS foram também utilizados corpos de deriva de superfície e de fundo nos trabalhos de Furtado (1978) e Furtado et al. (1987). Os resultados desses experimentos mostraram que a corrente residual de fundo orienta-se predominantemente para o norte. Esse resultado qualitativo é concordante com o valor médio da corrente resultante da análise de medidas obtidas na forma de séries temporais, amostradas por um correntógrafo localizado a $5 \mathrm{~m}$ de 
profundidade no inverno de 1979 (Castro Filho, 1990) e no outono de 1980 (Miranda \& Castro Filho, 1995).

Um modelo de dispersão desenvolvido por Soares (1995) calculou, com base nos resultados do modelo hidrodinâmico de Castro Filho (op.cit.), o espalhamento de uma mancha formada a partir do derrame de 250000 toneladas de uma substância no ponto central do Canal de São Sebastião. Os resultados mostraram que para uma situação hipotética de vento constante, quatro dias são suficientes para praticamente limpar o Canal de São Sebastião.

Castro Filho (1990), com o objetivo de investigar as características gerais da forçante atmosférica e a resposta subinercial das águas do CSS, analisou e comparou dados simultâneos de vento, corrente e nível do mar no CSS, e de pressão atmosférica e nível do mar na Plataforma Continental Sudeste (PCS), coletados durante o inverno de 1979. Uma das constatações do autor foi que a maior parte da variância nas séries de tempo (filtradas com um filtro passa-baixa com corte em 40 h) para o CSS, está concentrada em duas faixas de freqüência: 11-16 dias e 3 dias.

Um longo conjunto de dados correntográficos, coletados no CSS durante os anos de 1992 e 1993, foi analisado por Fontes (1995). Neste trabalho constatou-se um padrão sazonal para a circulação, com velocidades médias em torno de 0,40 a $0,60 \mathrm{~m} / \mathrm{s}$, circulação no interior do CSS essencialmente barotrópica, fluxo unidirecional predominantemente para NE em uma camada durante o outono, inverno e primavera. No verão, entretanto, podem ocorrer fluxos baroclínicos bidirecionais em duas camadas, predominantemente para SO e para NE nas camadas superficial e profunda, respectivamente. Ainda, segundo o autor, aqueles fluxos baroclínicos estariam associados à tensão de cisalhamento do vento e à penetração da ACAS pela extremidade sul do canal.

Os dados analisados por Silva (1995a), de seis cruzeiros hidrográficos coletados no período entre fevereiro de 1994 e março de 1995, confirmam a homogeneidade das águas do Canal de São Sebastião durante os meses de inverno e sugerem a influência da ACAS na entrada sul do canal em meses de verão (ventos preponderantes de nordeste) que podem, em circunstâncias ideais, levar à formação de duas camadas (Fig. 4).

Coelho (1997) analisou dados coletados de 16 cruzeiros oceanográficos no CSS e 4 cruzeiros na Plataforma Continental adjacente à ISS entre 1992 e 1993. O autor 
destaca o domínio da Água Costeira no CSS no outono, inverno e início de primavera e a intrusão da ACAS no fundo do CSS no verão e fim de primavera, sendo que esta massa de água flui para NE no fundo enquanto que a Água Costeira flui para SO, na superfície.

Valente (1998) com o objetivo de estudar a circulação da plataforma interna do litoral norte do estado de São Paulo, em escalas suprainercial e subinercial, analisou séries temporais de correntes coletadas entre novembro de 1991 e dezembro de $1992 \mathrm{em}$ três pontos: P1, ao sul do CSS; P2, ao norte do CSS e C2, no interior do CSS. Entre várias conclusões deste trabalho está a de que a circulação na Plataforma Continental Interna ao norte do estado de São Paulo é forçada pelo vento, local ou remoto e de que em P1 a corrente fluiu predominantemente para NE, com período de inversões para SO, no verão, tanto na superfície como no fundo. Já no ponto P2, a corrente manteve-se predominantemente para $\mathrm{SO}$, durante todo o período analisado, com inversões para $\mathrm{NE}$ no fundo, na estação do verão.

Leandro (1999) com dados hidrográficos e correntométricos coletados de 37 cruzeiros hidrográficos realizados entre janeiro de 1992 e março de 1997 em treze estações no Canal de São Sebastião, elaborou a climatologia da região. Neste trabalho o autor observa baixos valores das médias de temperatura no lado insular da entrada sul do canal durante a primavera e o verão e a homogeneidade das águas no inverno.

Mais recentemente, Assad (2000), utilizando-se de um modelo barotrópico, verticalmente integrado, bidimensional e não linear desenvolvido por Castro (1985), caracterizou a circulação de inverno no CSS. Em seus três experimentos o autor conclui que a circulação climatológica de julho é de nordeste para sudoeste no interior do CSS e que correntes para sudoeste estão associadas ao vento nordeste enquanto que correntes para nordeste estão associadas ao vento sudoeste. Um vórtice anticiclônico próximo à entrada sul do canal se apresenta quando o autor implementa o modelo analítico de uma frente fria conceitual desenvolvido por Stech e Lorenzzetti (1992).

Não obstante todos esses trabalhos prévios sobre características da estrutura termohalina e da circulação, a complexidade da interação entre as forçantes oceânicas e meteorológicas, fazem com que os processos físicos das águas da plataforma continental sudeste ainda sejam muito pouco conhecidos. 
RADIAL A - 06/07/94 - TEMPERATURA ( C)

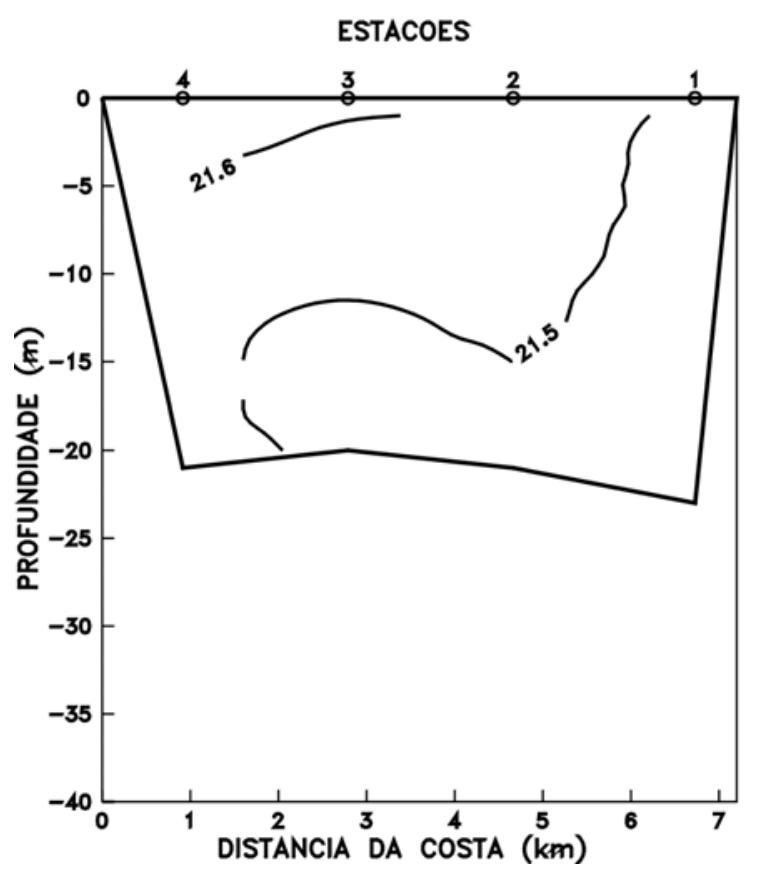

RADIAL A - 29/03/94 - TEMPERATURA ( C)

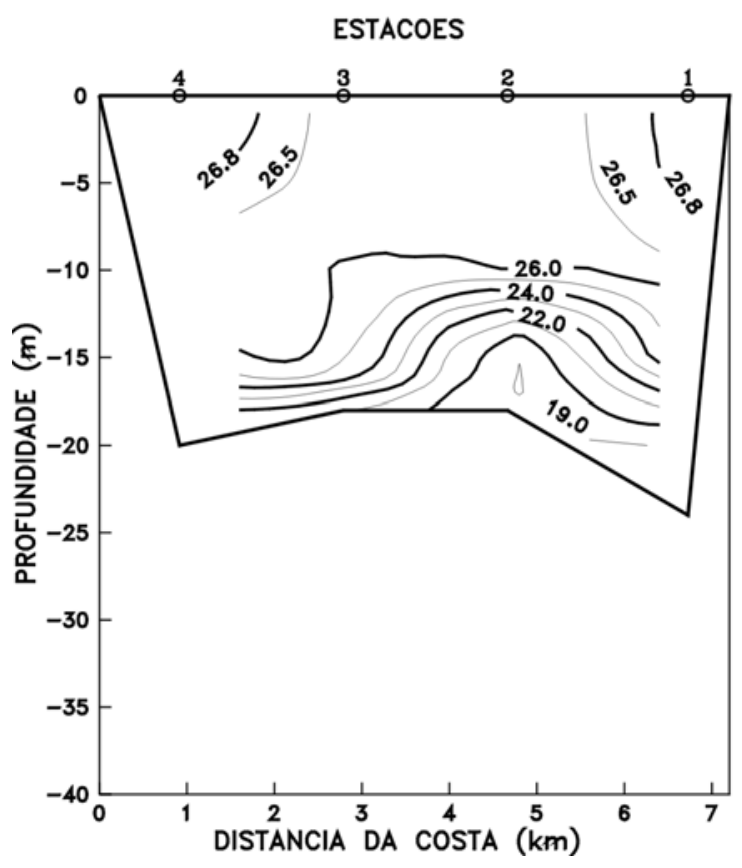

Figura 4: Distribuição vertical de temperatura junto à entrada sul do Canal de São Sebastião, nos cruzeiros realizados em 6/7/94 e 29/3/94. De acordo com Silva (1995a). 


\subsection{Objetivos}

A circulação do Canal de São Sebastião e sua estrutura termohalina têm sido estudadas em diversos trabalhos, entre artigos, dissertações de mestrado e teses de doutoramento. Estes trabalhos tiveram como ferramenta a análise de dados hidrográficos e correntográficos, sendo que somente dois trabalhos apresentaram modelos numéricos de sua circulação. Estes modelos apresentaram a circulação do CSS em meses de inverno, quando a coluna de água é bastante homogênea, sendo portanto modelos barotrópicos. A seqüência natural agora é apresentar um modelo que represente a circulação e a estrutura termohalina do CSS durante todo o ciclo anual, isto será possível através de um modelo baroclínico. Uma questão de interesse científico levantada freqüentemente na região de estudo é a penetração de águas frias pela entrada sul do canal, em muitos trabalhos já confirmada. Seriam essas águas parte da Água Central do Atlântico Sul ou sob sua influência? E a conhecida formação da estratificação vertical em duas camadas no CSS? Será decorrência da ACAS, ou possue outra causa desconhecida?

Em decorrência do acima exposto, este trabalho tem como principais objetivos:

- aplicar um modelo baroclínico ao Canal de São Sebastião, para estudar sua circulação e estrutura termohalina em escala sazonal;

- estudar a origem e os mecanismos da penetração de águas frias no Canal de São Sebastião, particularmente durante o verão;

- estudar a formação e o relaxamento da estratificação vertical em duas camadas na região em estudo. 


\section{Capítulo 2}

\section{Metodologia}

\subsection{Descrição do Modelo}

O modelo utilizado neste trabalho foi desenvolvido por George L. Mellor em 1975 e vem sendo constantemente refinado e atualizado de modo a incluir melhores representações físicas e maior robustez numérica. Uma descrição prévia desse modelo de circulação costeira e estuarina, tridimensional e dependente do tempo, pode ser vista em Blumberg e Mellor (1980) e Blumberg e Mellor (1987).

Esse modelo tem sido usado em numerosos estudos, em várias regiões costeiras, tais como: a South Atlantic Bight (Blumberg e Mellor, 1983); o estuário do Hudson-Raritan (Oey et al., 1985 a,b,c,d); o Golfo do México (Blumberg e Mellor, 1985); em Delaware Bay, incluindo a região estuarina e a plataforma continental adjacente (Galperin e Mellor, 1990 a,b); em Chesapeake Bay (Blumberg e Goodrich, 1990) e mais recentemente em Massachusetts Bay (Blumberg, Signell e Jenter, 1993). Em todos esses estudos, os resultados do modelo foram amplamente comparados com o dados disponíveis, sendo bem representada a realidade física de cada reprodução.

Algumas características do modelo são:

- Utilização de um sub-modelo, que utiliza-se de fechamento turbulento para determinar os coeficientes de mistura vertical;

- Uso da coordenada sigma;

- A grade horizontal utiliza coordenadas curvilíneas ortogonais e um esquema de diferenciação descrito pela grade $\mathrm{C}$ de Arakawa;

- O modelo utiliza um método semi-implícito onde os gradientes de pressão barotrópicos são tratados implicitamente. O algoritmo numérico implícito permite muito mais time steps do que aqueles baseados somente na condição de estabilidade computacional CFL ( Courant - Friedrichs - Levy );

- As equações associadas à circulação interna utilizam um método explícito no tempo, quando percorrem a grade horizontalmente, e implícito quando percorrem verticalmente (Roache, 1982). Essa última elimina as restrições temporais para a 
coordenada vertical e permite o uso de uma resolução vertical fina nas camadas limites superficiais e de fundo. É utilizado um esquema numérico semi-implícito na direção horizontal (Casulli, 1990);

- Completa resolução das variáveis termodinâmicas;

- Escolha de um esquema de advecção numérico para controle da dispersão numérica.

- Trata-se de um modelo oceânico-costeiro tridimensional, incorporando um esquema de fechamento turbulento para obtenção de uma parametrização realística dos processos de mistura vertical. As variáveis prognósticas são os três componentes da velocidade, a temperatura, a salinidade, a energia cinética turbulenta e as turbulências em macroescala. As equações do movimento são não lineares e incorporam um parâmetro de Coriolis variável (plano $\beta$ ). Elevações da superfície livre do mar também são calculadas prognosticamente, com algum sacrifício de tempo computacional. Eventos como marés e storm surges podem ser simulados. O modelo também acomoda de forma bastante realística a geometria da linha costeira e a topografia de fundo.

- Os processos físicos envolvidos na formação e manutenção de frentes são bem resolvidos pelo modelo pela suficiente resolução horizontal e vertical presentes; e os processos de mistura verticais são resolvidos por um sub-modelo de fechamento turbulento, onde os coeficientes de atrito e de difusão vertical são obtidos das equações de transporte de turbulência para a energia cinética e escalas de turbulência (Mellor e Yamada, 1982; Galperin et al., 1988).

- O tratamento da questão das condições de contorno abertas de um domínio limitado continua sendo uma área de pesquisa importante; os contornos devem ser prescritos com cuidados especiais, já que o meio exterior deve ser propriamente parametrizado e suas influências devem estar controladas, no que diz respeito aos efeitos na região modelada. As velocidades nos contornos são computadas usando os dados de elevação do nível do mar fornecidos pelo usuário. As entradas que ocorrem ao longo dos contornos devem ser providas pelo usuário, tal como dados de temperatura e salinidade, e as saídas são determinada pelas equações completas, usando um upstream scheme.

- Com relação às forçantes, o modelo responde à tensão de cisalhamento do vento, aos gradientes de pressão atmosféricos, aos fluxos de calor (calor sensível, calor latente, radiação de ondas longas e componentes da radiação solar líquida), fluxos de 
salinidade (precipitação menos evaporação), forçantes astronômicas (deslocamento do nível do mar), descargas estuarinas e condições de contorno laterais.

- Coeficientes de mistura horizontal, para a quantidade de movimento e para a conservação de sal e calor, são usados para parametrizar todos os processos que não são resolvidos na grade numérica. Esses coeficientes de mistura são escolhidos de modo a prover mínimo alisamento, sem excessiva dissipação dos processos físicos reais. Já que a grade numérica pode ser não uniforme, os coeficientes de mistura devem variar proporcionalmente, de modo a manter o número de Reynolds constante por toda a grade.

- As equações básicas são representadas a seguir, no senso do sistema de coordenadas sigma, o qual se baseia na transformação,

$$
x^{*}=x, y^{*}=y, \sigma=\frac{z-\eta}{H+\eta}, t^{*}=t
$$

onde $\mathrm{x}, \mathrm{y}, \mathrm{z}$ são as coordenadas cartesianas convencionais; $D=H+h$ onde $H(x, y)$ representa a espessura da coluna de água no repouso e $\eta(x, y)$ é a elevação da superfície livre. Desse modo, $\sigma$ varia de $\sigma=0$ em $z=\eta$, até $\sigma=-1$ em $z=-H$.

Desconsiderando os asteriscos, as equações básicas podem ser escritas como:

$$
\begin{aligned}
& \frac{\partial \eta}{\partial t}+\frac{\partial U D}{\partial x}+\frac{\partial V D}{\partial y}+\frac{\partial \omega}{\partial \sigma}=0 \\
& \frac{\partial U D}{\partial t}+\frac{\partial U^{2} D}{\partial x}+\frac{\partial U V D}{\partial y}+\frac{\partial U \omega}{\partial \sigma}-f V D+g D \frac{\partial \eta}{\partial x}= \\
& \frac{\partial}{\partial \sigma}\left(\frac{K_{M}}{D} \frac{\partial U}{\partial \sigma}\right)-\frac{g D^{2}}{\rho_{0}} \frac{\partial}{\partial x} \int_{\sigma}^{0} \rho d \sigma+\frac{g D}{\rho_{0}} \frac{\partial D}{\partial x} \int_{\sigma}^{0} \sigma \frac{\partial \rho}{\partial \sigma} d \sigma+F_{X} \\
& \frac{\partial V D}{\partial t}+\frac{\partial V^{2} D}{\partial y}+\frac{\partial U V D}{x}+\frac{\partial V \omega}{\partial \sigma}+f U D+g D \frac{\partial \eta}{\partial y}=
\end{aligned}
$$




$$
=\frac{\partial}{\partial \sigma}\left(\frac{K_{M}}{D} \frac{\partial V}{\partial \sigma}\right)-\frac{g D^{2}}{\rho_{0}} \frac{\partial}{\partial y} \int_{\sigma}^{0} \rho d \sigma+\frac{g D}{\rho_{0}} \frac{\partial D}{\partial y} \int_{\sigma}^{0} \sigma \frac{\partial \rho}{\partial \sigma} d \sigma+F_{Y}
$$

$$
\frac{\partial \theta D}{\partial t}+\frac{\partial \theta U D}{\partial x}+\frac{\partial \theta V D}{\partial y}+\frac{\partial \theta \omega}{\partial \sigma}=\frac{\partial}{\partial \sigma}\left(\frac{K_{H}}{D} \frac{\partial \theta}{\partial \sigma}\right)+F_{\theta}
$$

$$
\begin{aligned}
& \frac{\partial S D}{\partial t}+\frac{\partial S U D}{\partial x}+\frac{\partial S V D}{\partial y}+\frac{\partial S \omega}{\partial \sigma}=\frac{\partial}{\partial \sigma}\left(\frac{K_{H}}{D} \frac{\partial S}{\partial \sigma}\right)+F_{S} \\
& \frac{\partial q^{2} D}{\partial t}+\frac{\partial U q^{2} D}{\partial x}+\frac{\partial V q^{2} D}{\partial y}+\frac{\partial \omega q^{2}}{\partial \sigma}=\frac{\partial}{\partial \sigma}\left(\frac{K_{q}}{D} \frac{\partial q^{2}}{\partial \sigma}\right)+ \\
& +\frac{2 K_{M}}{D}\left[\left(\frac{\partial U}{\partial \sigma}\right)^{2}+\left(\frac{\partial V}{\partial \sigma}\right)^{2}\right]+\frac{2 g}{\rho_{0}} K_{H} \frac{\partial \rho}{\partial \sigma}-2 \frac{D q^{3}}{\Lambda_{1}}+F_{q} \\
& \frac{\partial q^{2} \lambda D}{\partial t}+\frac{\partial U q^{2} \lambda D}{\partial x}+\frac{\partial V q^{2} \lambda D}{\partial y}+\frac{\partial \omega q^{2} \lambda}{\partial \sigma}=\frac{\partial}{\partial \sigma}\left(\frac{K_{q}}{D} \frac{\partial q^{2} \lambda}{\partial \sigma}\right)+ \\
& +E_{1} \lambda\left\{\frac{K_{M}}{D}\left[\left(\frac{\partial U}{\partial \sigma}\right)^{2}+\left(\frac{\partial V}{\partial \sigma}\right)^{2}\right]+\frac{q D^{3}}{\rho_{0}} K_{H} \frac{\partial \rho}{\partial \sigma}\right\}-\frac{D q^{3}}{B_{1}} \frac{w^{+} D F_{\lambda}}{\partial{ }^{2}}+
\end{aligned}
$$

\subsection{Implementação do Modelo, Aspectos de Grade e Condições de Contorno}

A escolha do modelo, como justificada, permite resolver a topografia e a linha de costa de maneira bastante realística. Desse modo se procederá a escolha de uma grade e sub-grades que permitam resolução adequada aos fenômenos em estudo, em cada escala de interesse.

Para modelar o Canal de São Sebastião, a exemplo do trabalho de Castro (1985), a plataforma continental sudeste é forçada para obtermos as condições de 
contorno no canal. A grade tem três níveis: a grade maior com malhas quadradas de 13200 m estendendo-se de Cabo Frio ao Cabo de Santa Marta, uma grade intermediária com malhas quadradas de 2640 m envolvendo a região do Canal de São Sebastião desde Parati ao norte até Santos ao sul e finalmente uma grade de maior resolução com malhas de 528 m contendo o Canal de São Sebastião. O total de pontos da grade maior é de 2520, a grade intermediária com 2640 e a grade menor com 2064. Como pode ser visto na Fig. 5, estas grades possuem uma inclinação de $51^{\circ}$, sentido horário, em relação ao norte geográfico. Esta rotação, além de diminuir o tempo computacional (pois possui menor número de pontos de grade do que uma grade de orientação norte - sul, que envolva a mesma região), tem seu componente $\mathrm{v}$ de velocidade das correntes aproximadamente ao longo da costa e automaticamente a componente $\mathrm{u}$, perpendicular à costa.

Na plataforma, os dados termohalinos vêm do Programa de Avaliação do Potencial Sustentável de Recursos Vivos na Zona Econômica Exclusiva (REVIZEE) que conta com uma densa massa de dados coletada sistematicamente desde o Ano Geofísico Internacional (1957) ao longo da costa brasileira. Esses dados, após tratamento adequado, geraram a climatologia das águas da plataforma continental sudeste com resolução espacial de pelo menos $1^{\circ}$ de latitude e $1^{\circ}$ de longitude. $O$ tratamento desses dados foi efetuado pelo M.Sc. Lúcio de Rezende e consiste basicamente das seguintes fases: (a) identificação e eliminação de dados espúrios através da análise do diagrama T-S espalhado; (b) separação dos dados por faixas de níveis de observação (para obter seções horizontais representativas das diversas profundidades), por faixas de retas perpendiculares à costa e por faixa de isobatimétricas (que levam em consideração a profundidade local das estações); (c) obtenção das médias e desvios padrão dos dados para cada um desses subconjuntos.

Seqüencialmente e já neste trabalho, os dados foram interpolados horizontalmente em profundidades padronizadas através do método 'kriging' para os pontos de grade na PCSE e na PCI. Em seguida esses dados foram interpolados verticalmente através do método 'cubic spline' e descritos em um sistema de coordenadas sigma com 11 níveis. Estes níveis têm uma distribuição logarítmica na superfície e no fundo, permitindo maior resolução, e uma distribuição linear no restante da coluna d'água. As Figs. 6 e 7 mostram os perfis horizontais superficiais das propriedades temperatura e salinidade na PCSE enquanto que as Figs. 8 e 9 mostram os 
perfis verticais dessas propriedades, em uma seção ao sul do CSS. Analogamente, os perfis verticais em uma seção ao sul do CSS, na PCI, são mostrados nas Figs. 10 e 11.

Os dados termohalinos utilizados para a inicialização do modelo junto à grade menor (no CSS) tem origem na Climatologia do Canal de São Sebastião (Leandro, 1999) a partir dos dados dos projetos HIDROCASS e OPISS sistematicamente amostrados desde 1992 em intervalos aproximados de 40 dias e em 13 estações ao longo do CSS. Um perfil vertical desses dados, junto à entrada sul do canal, encontra-se nas Figs. 12 e 13.

Além dos dados termohalinos, o modelo também é forçado com dados que representam médias mensais de fluxos de calor e de sal, radiação de ondas curtas e tensão de cisalhamento do vento (TCV). Esses dados são obtidos de COADS (Comprehensive Ocean-Atmospheric Data Set). A distribuição horizontal da TCV na Plataforma Continental Sudeste, representativa dos meses de novembro, fevereiro, maio e agosto encontra-se na Fig. 14.

A condição de contorno escolhida para a grade maior foi a forma implícita da condição radiativa de Orlanski (1976), que é um esquema centrado no tempo e avançado no espaço, em conjunto com uma técnica de relaxação na região estendida da grade. Esta técnica de relaxação foi implementada originalmente por Martinsen e Engedhal (1987) como uma condição de contorno aberta utilizando-se um modelo linear de águas rasas. A avaliação da performance destas condições de contorno pode ser vista em Chapman (1985) e Palma \& Matano (1998). Estas condições de contorno foram usadas para as propriedades nível do mar e as componentes de velocidade paralelas aos contornos; para as componentes de velocidade perpendiculares ao contorno foi utilizada uma condição não gradiente. Os dados gerados pela grade maior são armazenados nos contornos da grade média, interpolados no tempo e no espaço e após o experimento, esta por sua vez armazena os dados nos contornos da grade menor; caracterizando desse modo condição de contorno ativa nas grades interiores. Neste modelo, os dados armazenados nos contornos das grades interiores foram: o nível do mar, as componentes de velocidade da corrente (tanto aquelas tomadas como média vertical, assim como aquelas dentro de cada camada sigma), a temperatura e a salinidade.

Os índices termohalinos da AT e da ACAS não apresentam variações sazonais significativas (Silva, 1995b) na borda da plataforma continental. Em decorrência deste fato, os índices termohalinos das massas de Água Central do Atlântico Sul e Água 
Tropical adotados neste trabalho para o cálculo de percentuais foram aqueles adotados por Coelho (1997) através da análise do diagrama T-S espalhado de 16 cruzeiros oceanográficos na PCI e no CSS; estes índices são $\left(13,2^{\circ} \mathrm{C} ; 35,27\right)$ para a ACAS e $\left(24,11^{\circ} \mathrm{C} ; 37,18\right)$ para a AT. Estes índices são muito próximos aos obtidos por Silva (1995b) e Castro (1996). O índice termohalino da Água Costeira foi obtido através do diagrama T-S espalhado após cada experimento, identificando na curva os pontos com maior temperatura associados às menores salinidades.

Para a melhor visualização dos dados, foram efetuados cortes transversais e longitudinais no CSS. Os cortes transversais no CSS são quatro: um ao sul (seção A), um ao norte (seção D) e dois intermediários (seções B e C). Estas seções foram colocadas tão próximas quanto possível das seções de coleta de dados realizadas no local com a intenção de melhor poder comparar os resultados do modelo com trabalhos experimentais anteriores. Os pontos superficiais destas seções transversais bem como os da seção longitudinal podem ser visualizados na Fig. 15.

Com o objetivo de avaliar a performance das condições de contorno, as seguintes integrais foram calculadas, como em Palma e Matano (1998):

Energia mecânica $=\left(1 / A_{T}\right) \cdot\left[\int_{A} \rho \cdot g \cdot \eta^{2} d A+\int_{A} 0,5 \cdot \rho \cdot\left(U^{2}+V^{2}\right) d A\right]$

Nível médio $=\left(1 / A_{T}\right) \cdot \int_{A} \eta d A$

Fluxo de energia $=(1 / W) \cdot \int_{0}^{W} D \cdot U \cdot\left(g \cdot \eta+\frac{1}{2} \cdot U^{2}+\frac{1}{2} \cdot V^{2}\right) d y$

A área do domínio é $A_{T}$, W é o comprimento do contorno aberto e D é a profundidade local. A energia mecânica e o nível do mar são valores médios sobre a área do domínio. A energia mecânica é usada para avaliar os níveis de energia das simulações ao passo que o nível do mar médio é utilizado para avaliar a condição de contorno com relação ao fluxo de massa através dos contornos abertos. O fluxo de energia é calculado tomando-se a média sobre o comprimento da bacia nos contornos abertos e é usada para detectar reflexões de ondas. 

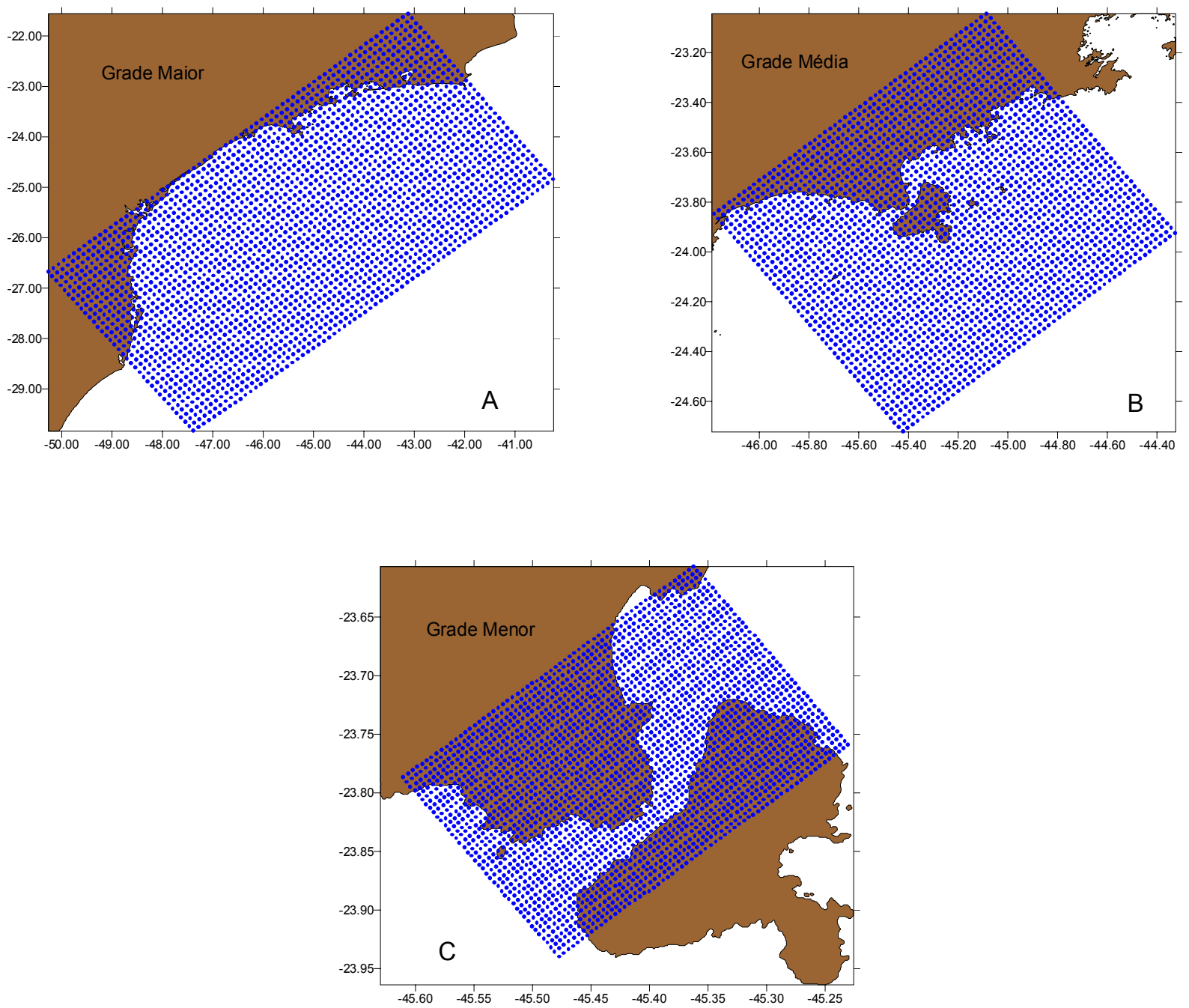

Figura 5: As Grades Maior (A), Média (B) e Menor (C). 

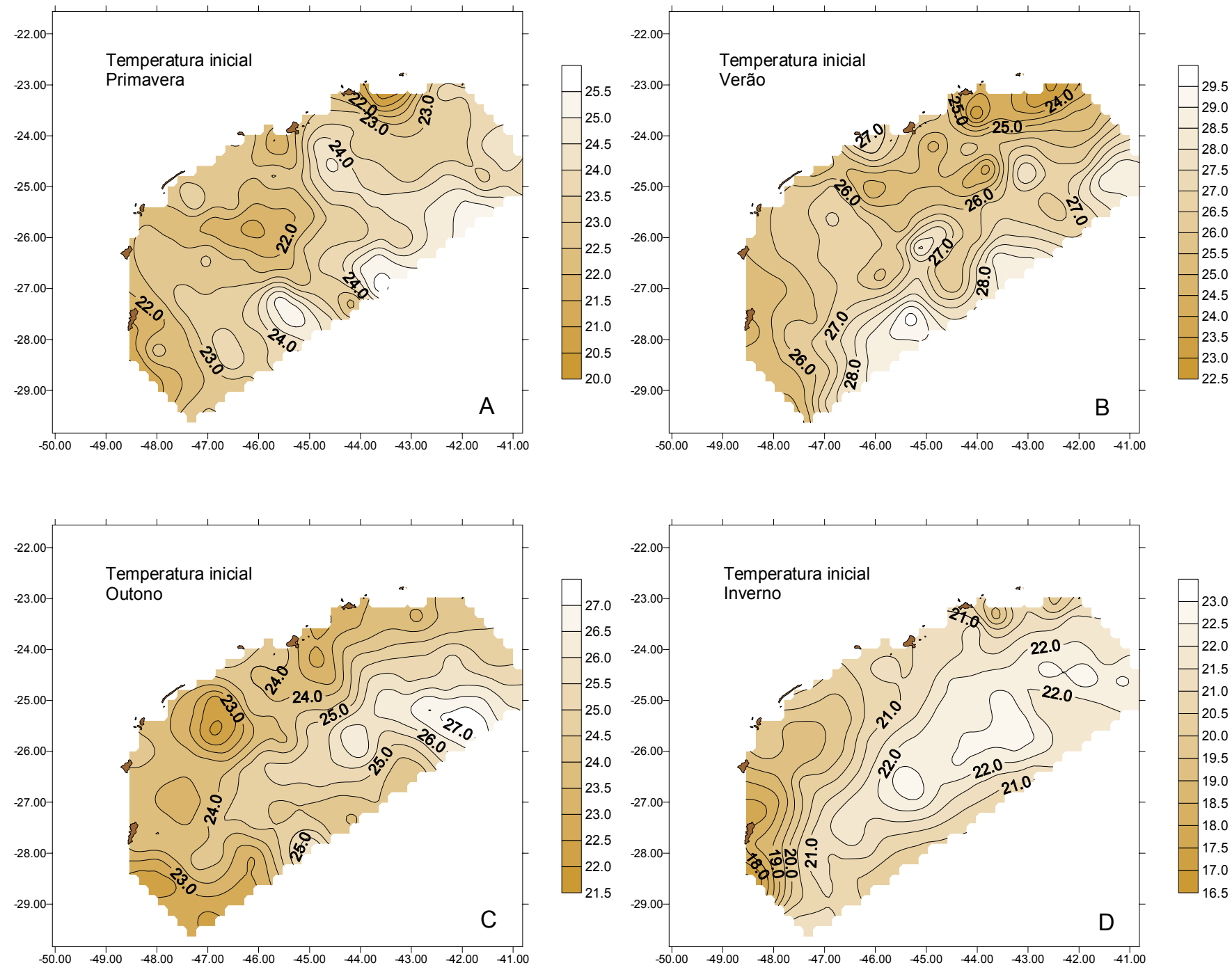

Figura 6: Distribuição horizontal superficial do campo de temperatura inicial na Plataforma Continental Sudeste, representativo das estações da primavera (A), verão (B), outono (C) e inverno (D). Fonte: REVIZEE. 

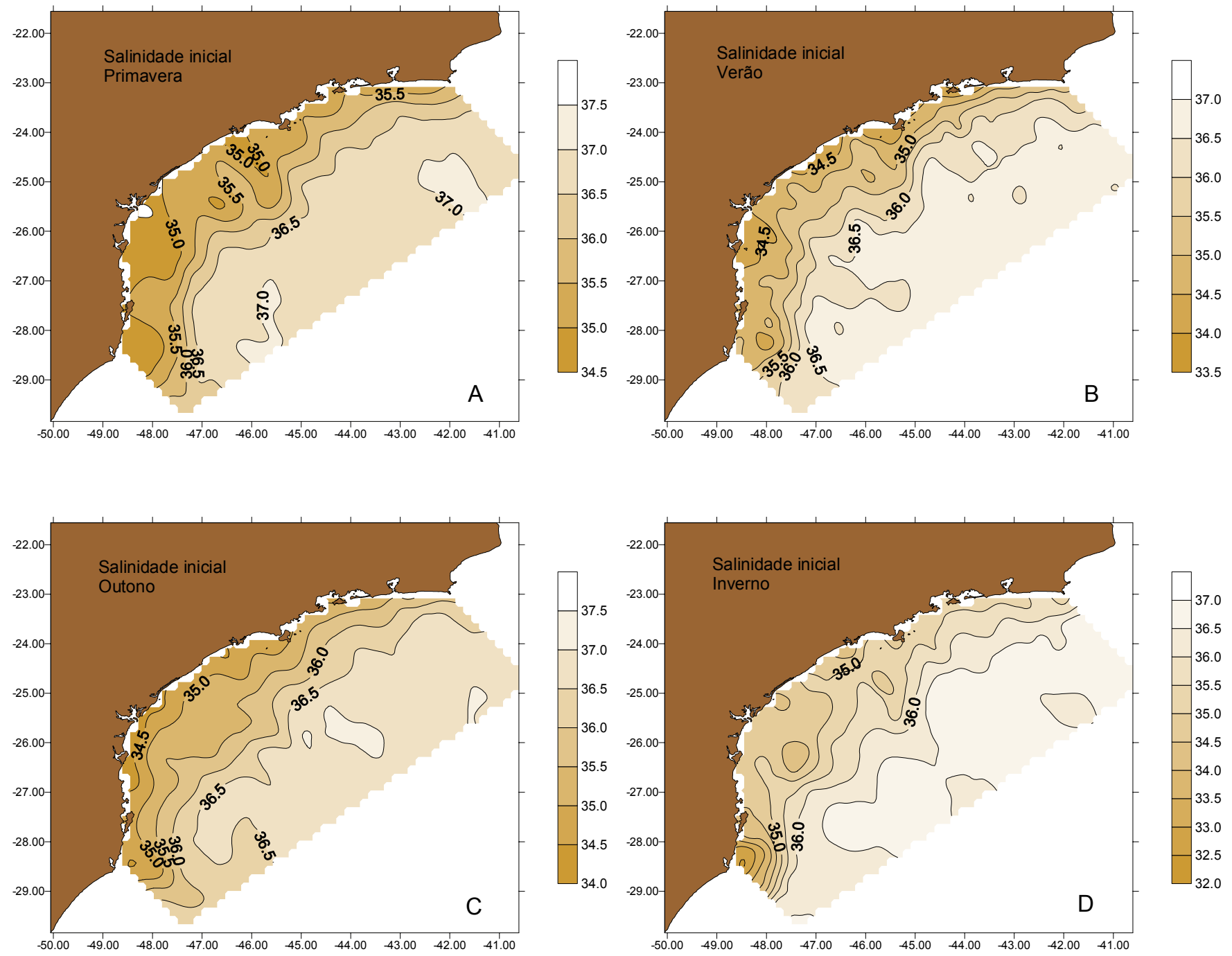

Figura 7: Distribuição horizontal superficial do campo de salinidade inicial na Plataforma Continental Sudeste, representativo das estações da primavera (A), verão (B), outono (C) e inverno (D). Fonte: REVIZEE. 

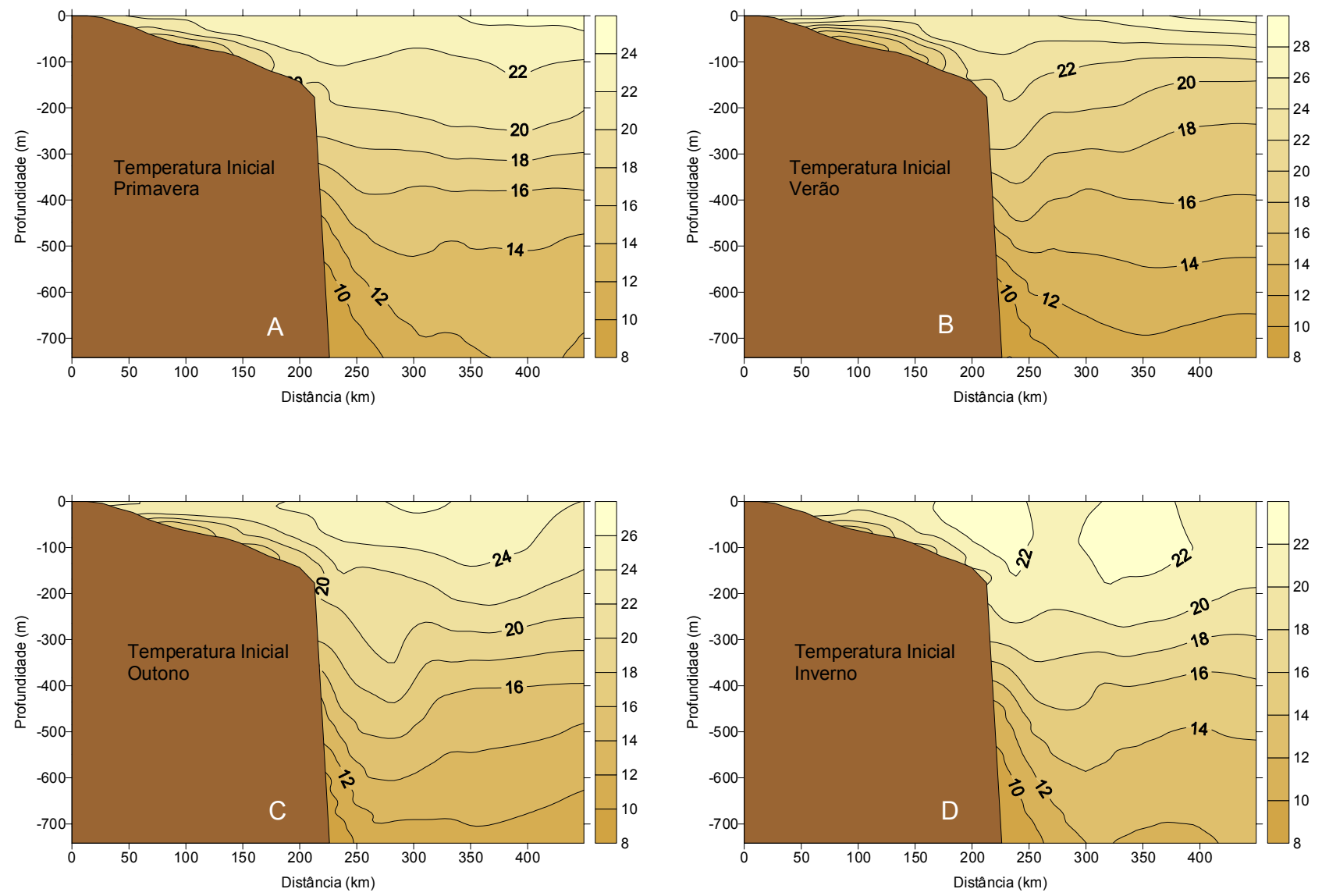

Figura 8: Distribuição vertical do campo de temperatura inicial na Plataforma Continental Sudeste em uma seção ao sul do Canal de São Sebastião, representativo das estações da primavera (A), verão (B), outono (C) e inverno (D). Fonte: REVIZEE. 

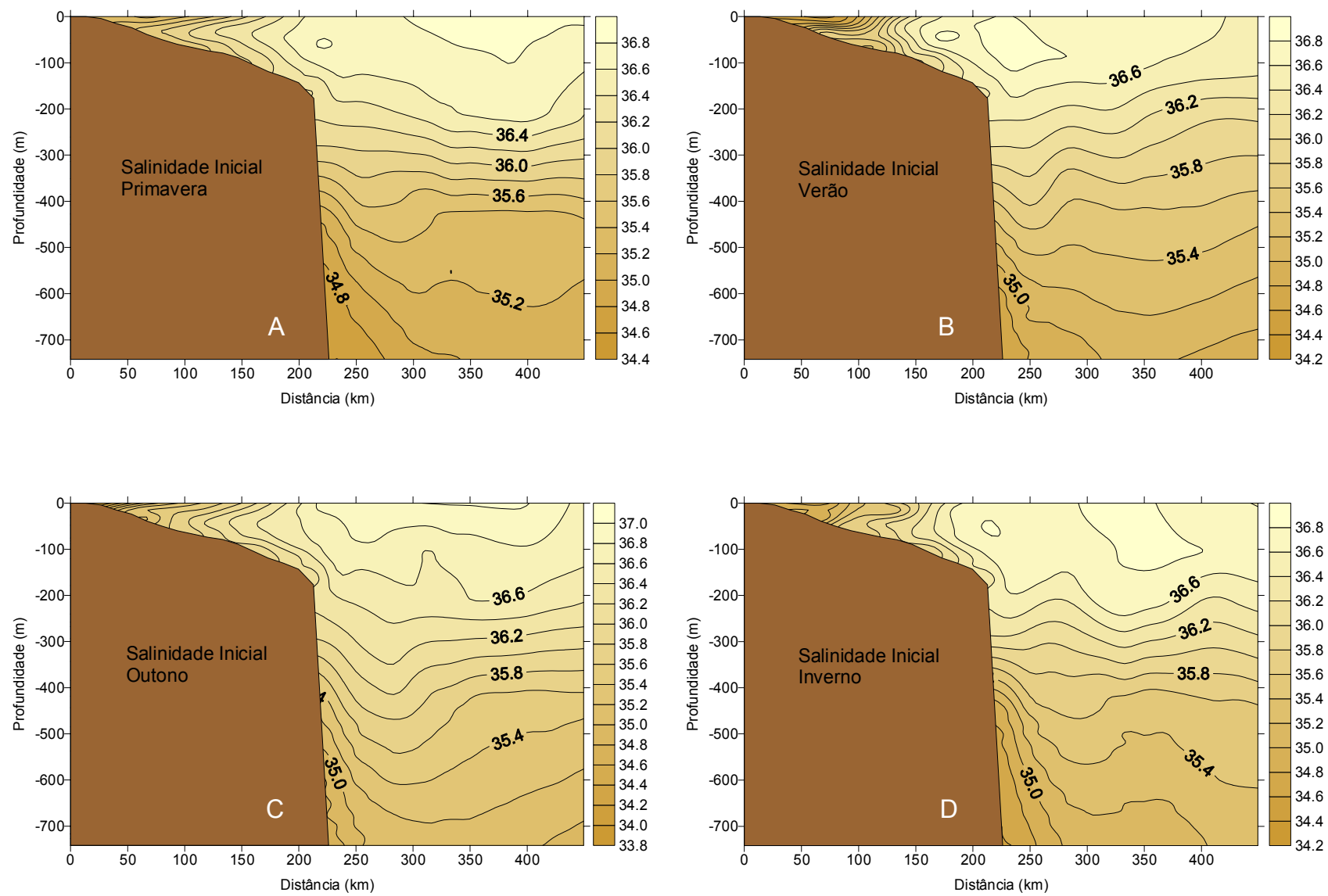

Figura 9: Distribuição vertical do campo de salinidade inicial na Plataforma Continental Sudeste em uma seção ao sul do Canal de São Sebastião, representativo das estações da primavera (A), verão (B), outono (C) e inverno (D). Fonte: REVIZEE. 

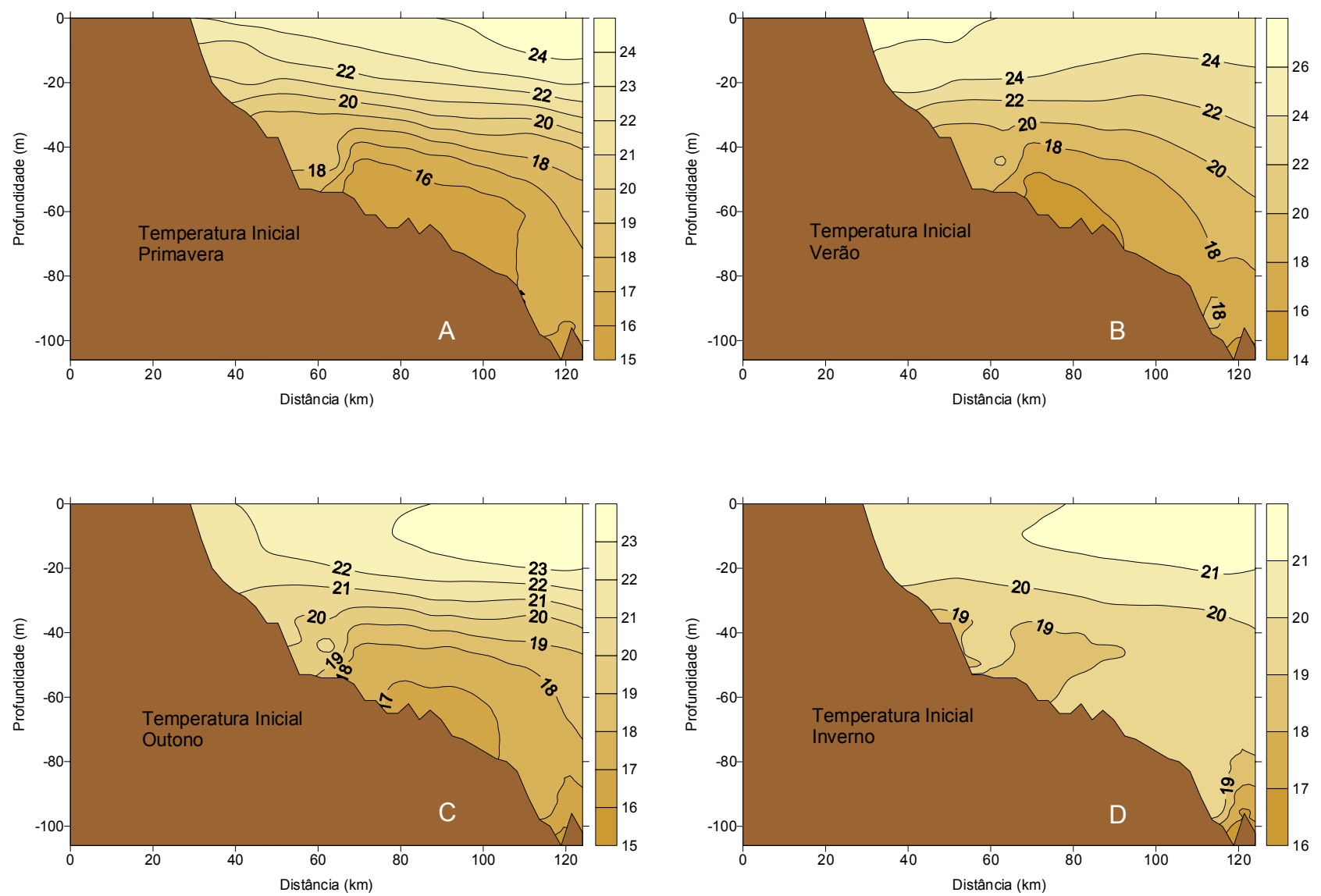

Figura 10: Distribuição vertical do campo de temperatura inicial na grade média em uma seção ao sul do Canal de São Sebastião, representativo das estações da primavera (A), verão (B), outono (C) e inverno (D). Fonte: REVIZEE. 

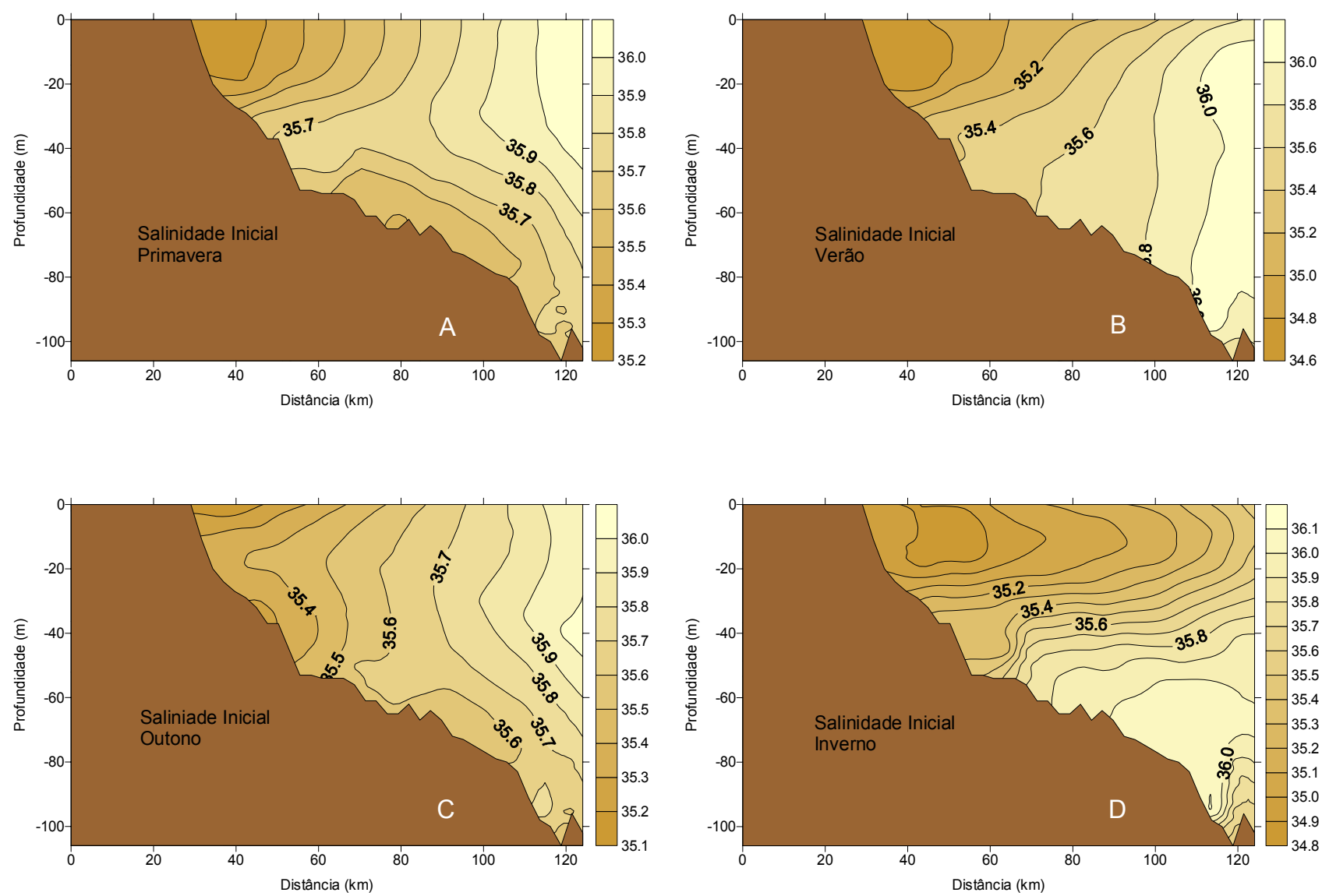

Figura 11: Distribuição vertical do campo de salinidade inicial na grade média em uma seção ao sul do Canal de São Sebastião, representativo das estações da primavera (A), verão (B), outono (C) e inverno (D). Fonte: REVIZEE. 

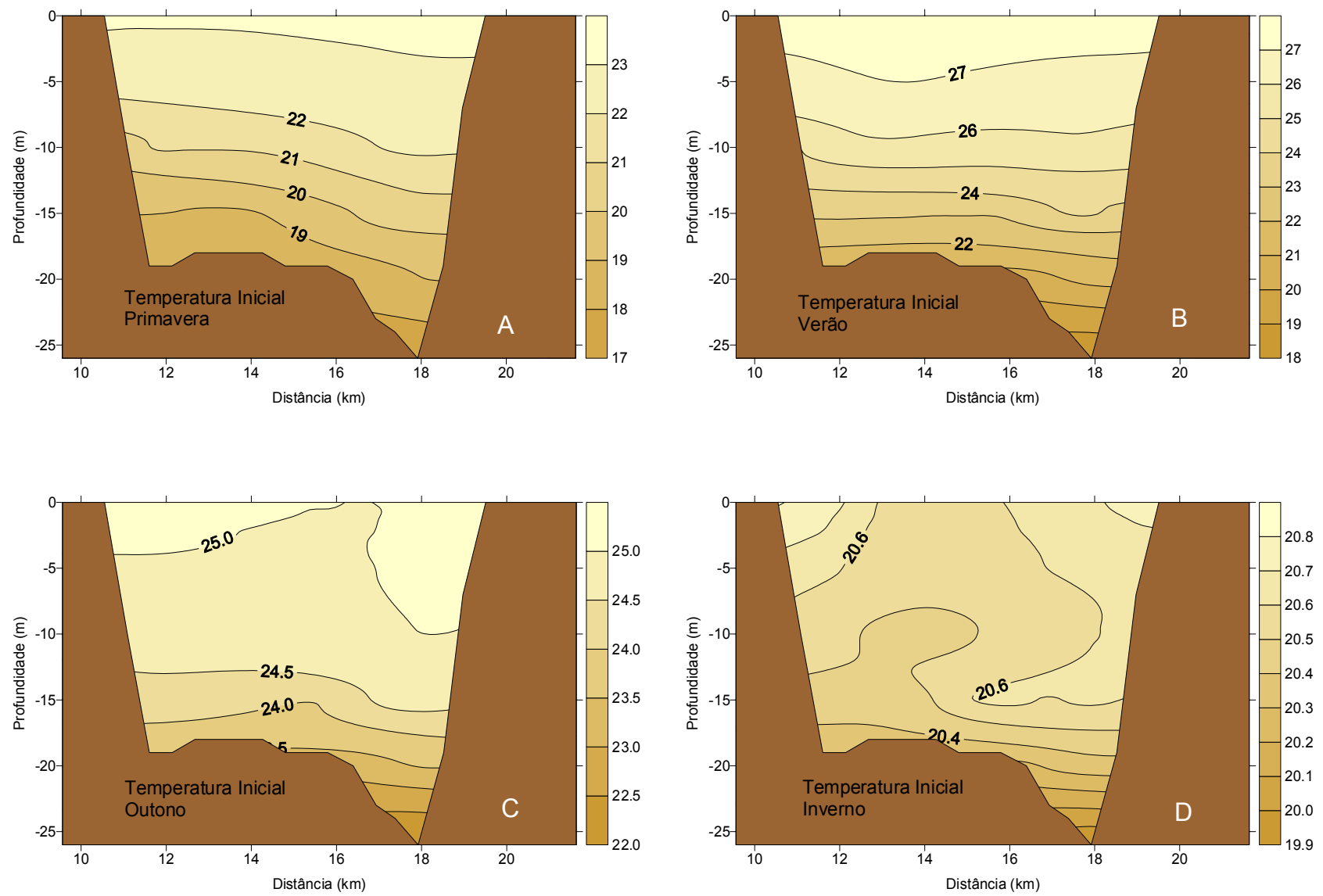

Figura 12: Distribuição vertical do campo de temperatura inicial junto à seção $A$ do Canal de São Sebastião, representativo das estações da primavera (A), verão (B), outono $(C)$ e inverno (D). De acordo com Leandro (1999). 

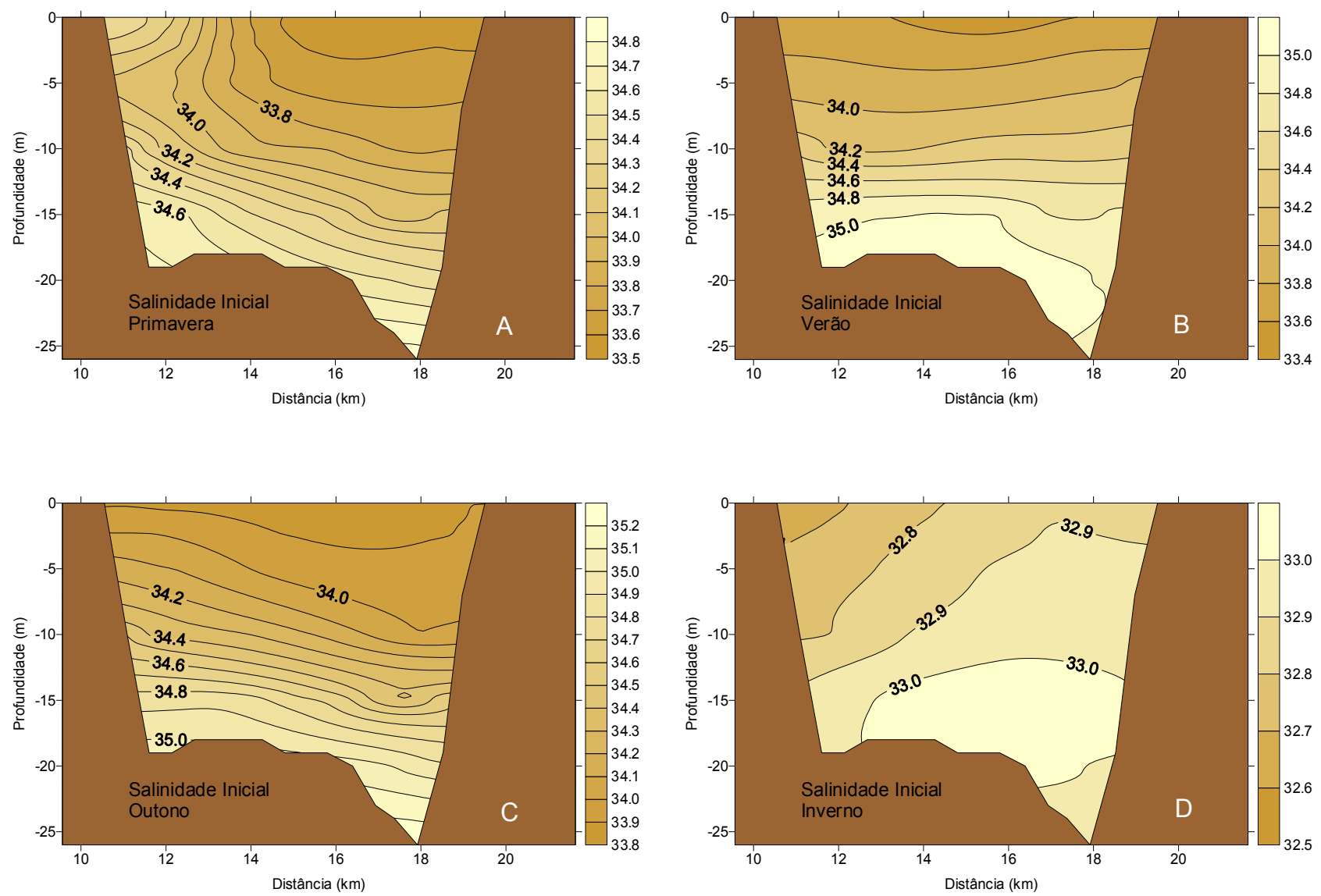

Figura 13: Distribuição vertical do campo de salinidade inicial junto à seção $A$ do Canal de São Sebastião, representativo das estações da primavera (A), verão (B), outono $(\mathrm{C})$ e inverno (D). De acordo com Leandro (1999). 


$$
r r
$$



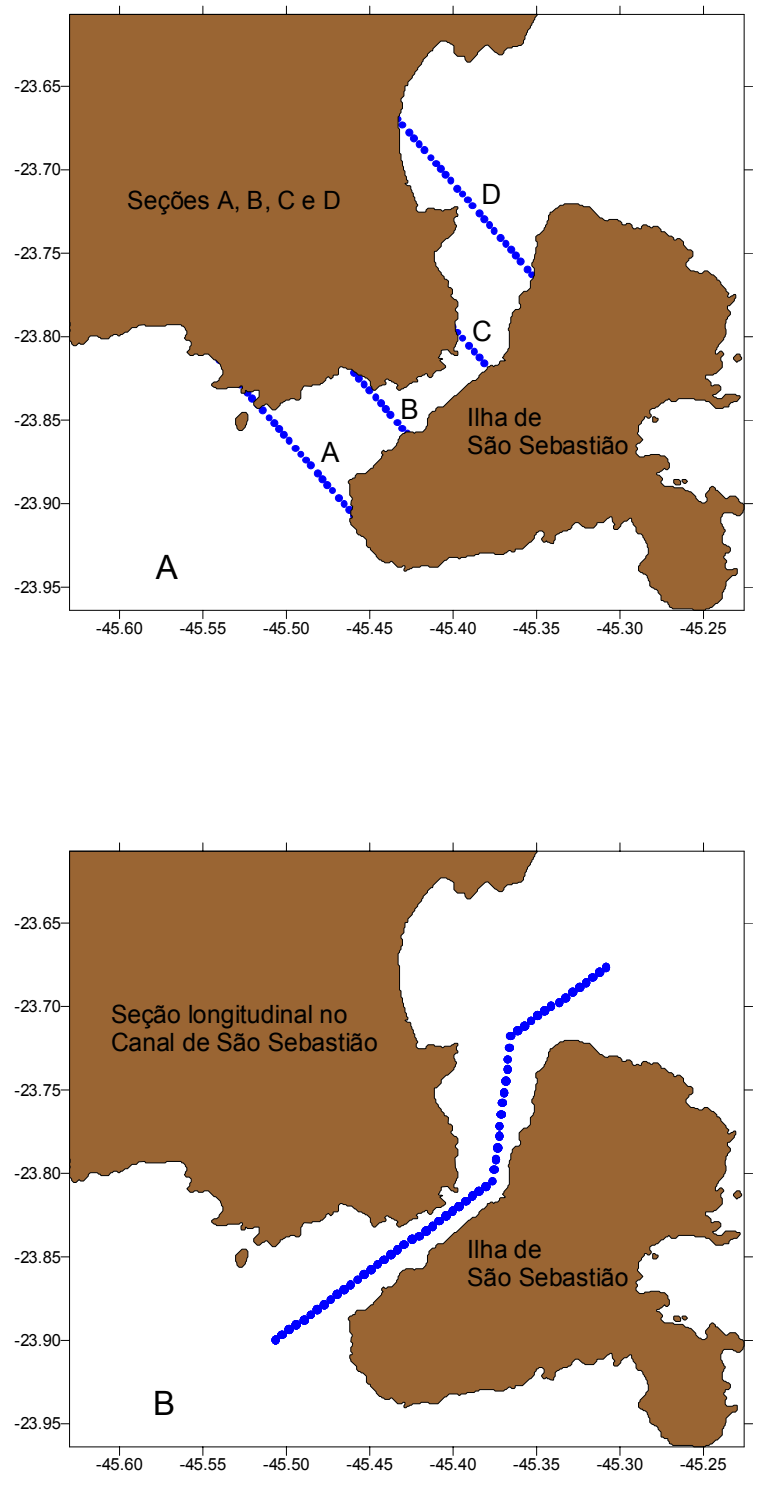

Figura 15: Seções transversais (A) e seção longitudinal (B) no Canal de São Sebastião. 


\subsection{Experimentos realizados}

Com dados médios de temperatura e salinidade para cada estação, dados médios mensais de fluxos de calor e de sal, radiação de ondas curtas e de tensão de cisalhamento do vento, foram realizadas simulações de primavera, verão, outono e inverno. Cada simulação com trinta dias. Foram escolhidos os meses de novembro, fevereiro, maio e agosto como representativos das estações de primavera, verão, outono e inverno respectivamente, quando a fonte dos dados é média mensal. Além destes, de caráter sazonal, foram implementados os seguintes experimentos: (a) vento proveniente de sul (10 dias de simulação com o vento climatológico invertido); (b) sem forçante vento (10 dias de simulação); (c) forçante vento nas grades maior e média mas não na grade do CSS (vento climatológico); (d) simulação dos efeitos sobre a estrutura termohalina e sobre a circulação à passagem de uma frente fria pela PCSE. As simulações foram realizadas em modo prognóstico. A seguir os experimentos são descritos. 


\section{Capítulo 3}

\section{Resultados do Modo Barotrópico}

\subsection{A Plataforma Continental Sudeste}

O nível do mar e a circulação na PCSE, foram simulados tendo por forçantes as tensões de cisalhamento do vento climatológico dos meses de novembro, fevereiro, maio e agosto (Fig. 14 A,B,C,D), representativas para as estações da primavera, verão, outono e inverno, respectivamente.

As Figs. 16, 17, 18 e 19 apresentam as curvas de energia mecânica, fluxos nos contornos e nível do mar médio para a PCSE nas quatro estações do ano, sendo que estas convergem assintoticamente para condições de estabilidade. Os níveis de energia aumentam do inverno em direção ao verão e desta estação em direção ao inverno, diminuem. Os níveis de fluxos de energia nos contornos têm a mesma orientação que os níveis de energia mecânica, isto é, aumentam do inverno para o verão, diminuindo em direção ao inverno. O fluxo de energia através do contorno sul é sempre maior do que o através dos outros contornos, com exceção feita para o inverno, onde o fluxo de energia através do contorno norte é maior. O fluxo através do contorno leste é sempre o menor, nas quatro estações. O nível do mar médio é negativo nas estações de inverno, primavera e verão (decrescente nesta ordem) e positivo no outono. A tensão de cisalhamento do vento paralela à costa nas estações de inverno, primavera e verão (sendo mais intensa nesta ordem), explica o comportamento do nível do mar médio (transporte de Ekman). No outono, a tensão de cisalhamento do vento, além de ser menos intensa, é basicamente contra a costa.

A Fig. 20 A,B,C,D apresenta o nível do mar na PCSE após 30 dias de integração, nas simulações de primavera, verão, outono e inverno respectivamente. $\mathrm{Na}$ primavera, o nível do mar é de cerca de $-0,05$ m na costa (Fig. 20A), com inclinação ascendente para o largo. As isolinhas de nível do mar não são paralelas ao longo de 
toda a costa em decorrência de que os ventos não são paralelos à costa em todo o domínio, sendo contra a costa na região onde há a quebra do paralelismo das isolinhas de nível do mar. No verão, o nível do mar é de $-0,07 \mathrm{~m}$ na costa (Fig. 20B), em decorrência da maior intensidade da tensão de cisalhamento do vento. O nível do mar no outono (Fig. 20C) é mais alto na costa $(0,03 \mathrm{~m})$, declinando para o largo e no inverno o nível do mar na costa, ao norte da PCSE (Fig. 20D) é de cerca de $-0,018 \mathrm{~m}$, com inclinação ascendente para o largo e para o sul. Assad (2000) chega a resultados bastante semelhantes para esta propriedade, no inverno, utilizando como forçante o vento climatológico de julho.

A Fig. 21 A,B,C,D apresenta as correntes na PCSE obtidas em modo barotrópico após 30 dias de integração nas simulações de primavera, verão, outono e inverno, respectivamente. Dentro de cada estação, as correntes tendem a ser mais intensas nas partes norte e sul do domínio com exceção feita ao inverno, onde no sul, as correntes são relativamente fracas. Na PCSE as correntes orientam-se ao longo das isóbatas (Fig.1), intensificando-se próximas à quebra da plataforma continental, sendo que fluem de nordeste para sudoeste nas estações de primavera, verão e inverno e de sudoeste para nordeste na estação do outono. Os campos de velocidade das correntes de verão e primavera são muito próximos em configuração, porém, no verão, as correntes são levemente mais intensas. As correntes nas estações de outono e inverno são bem menos intensas do que as de verão e primavera e observa-se que no inverno as correntes ao sul são relativamente bem menores do que as encontradas ao norte da PCSE. Os máximos de velocidade encontrados são $0,20 \mathrm{~m} / \mathrm{s}$ no verão, $0,15 \mathrm{~m} / \mathrm{s}$ na primavera, 0,06 $\mathrm{m} / \mathrm{s}$ no outono e no inverno. 

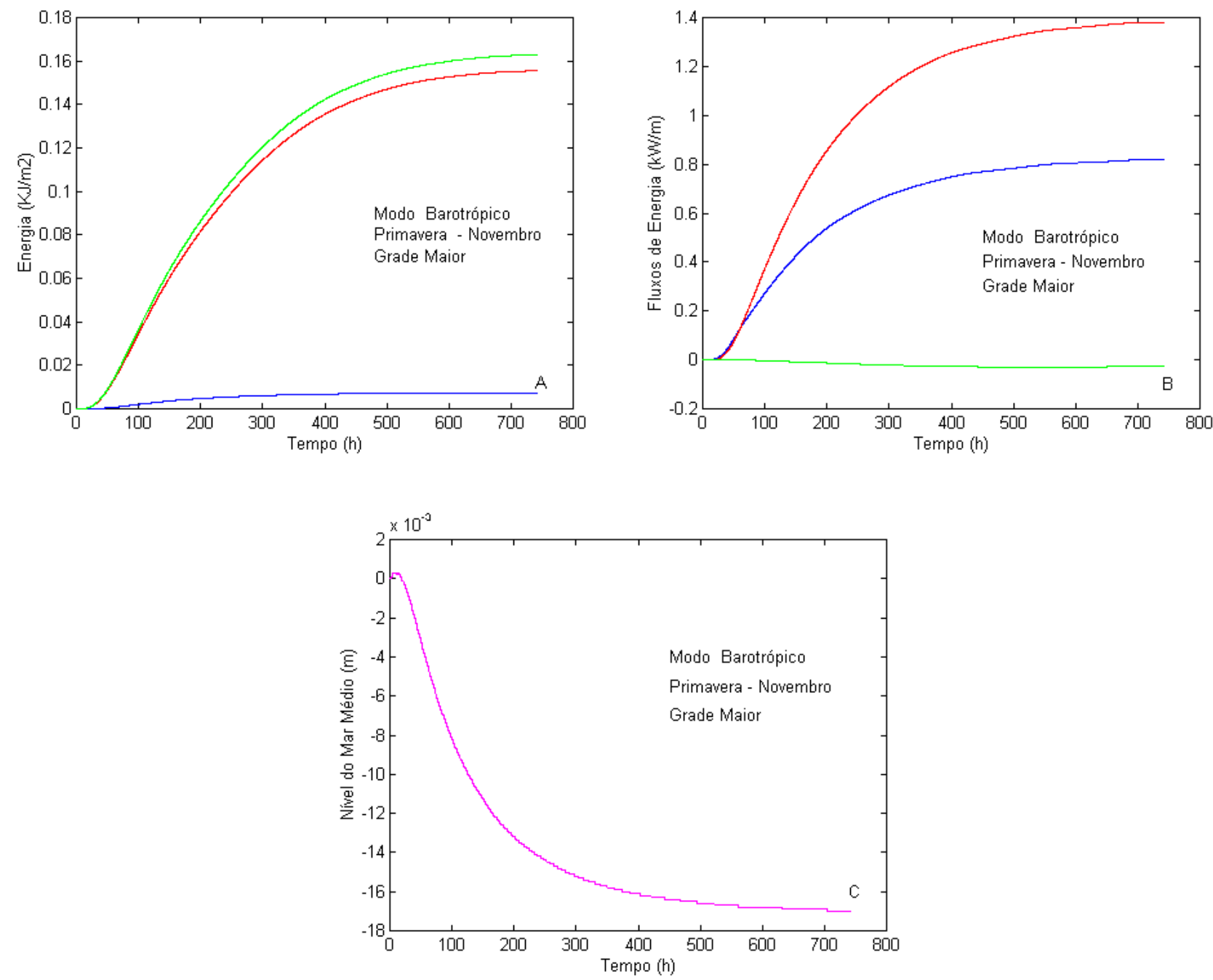

Figura 16: Curvas de energia mecânica (A), fluxos nos contornos (B) e nível do mar médio (C) na PCSE, sendo em (A), o verde, a energia mecânica, o vermelho, a energia cinética e o azul, a energia potencial. Em (B), o azul representa o fluxo através do contorno norte, o vermelho, o fluxo através do contorno sul e o verde, o fluxo através do contorno leste. Simulação de primavera - novembro. 

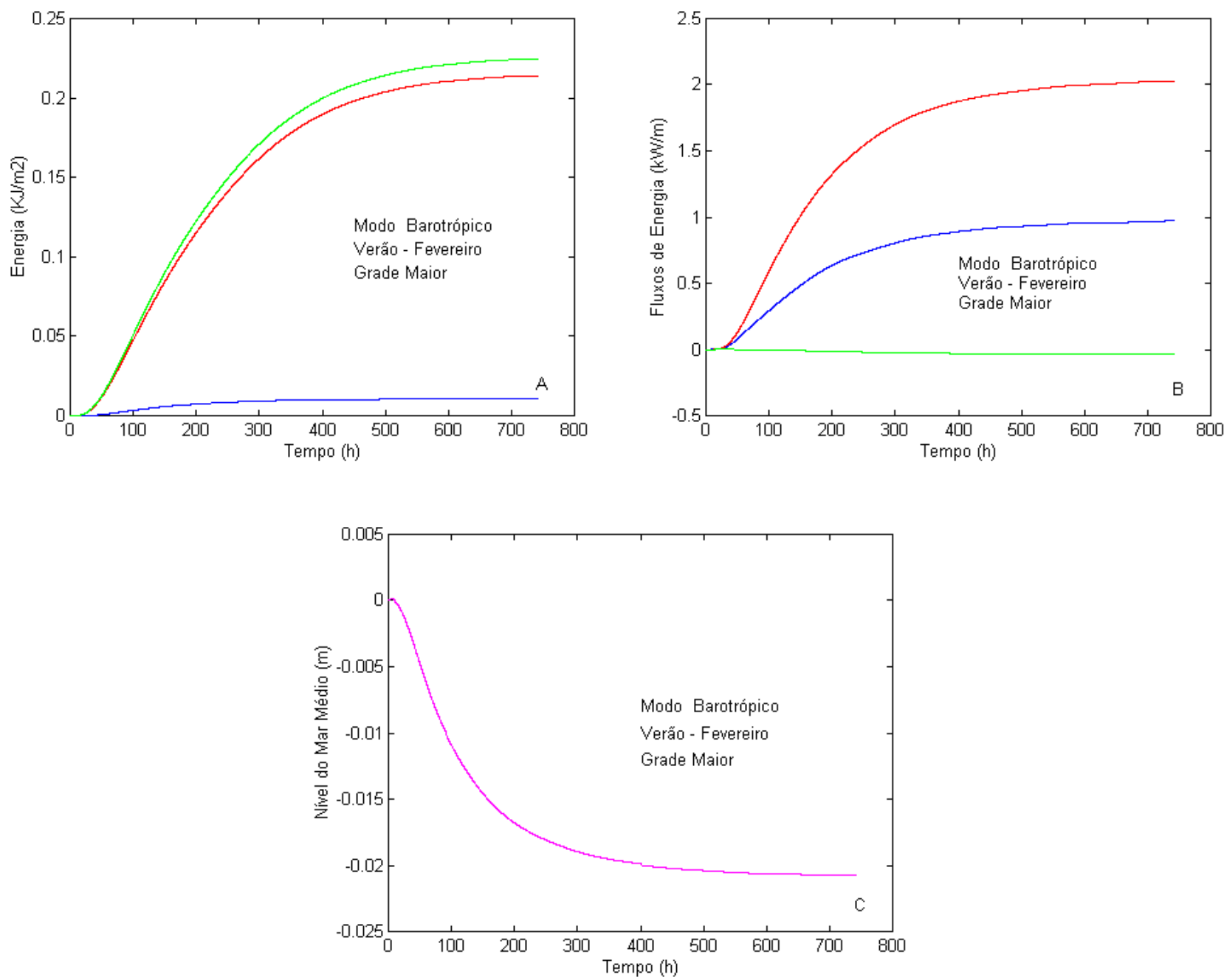

Figura 17: Curvas de energia mecânica (A), fluxos nos contornos (B) e nível do mar médio (C) na PCSE, sendo em (A), o verde, a energia mecânica, o vermelho, a energia cinética e o azul, a energia potencial. Em (B), o azul representa o fluxo através do contorno norte, o vermelho, o fluxo através do contorno sul e o verde, o fluxo através do contorno leste. Simulação de verão - fevereiro. 

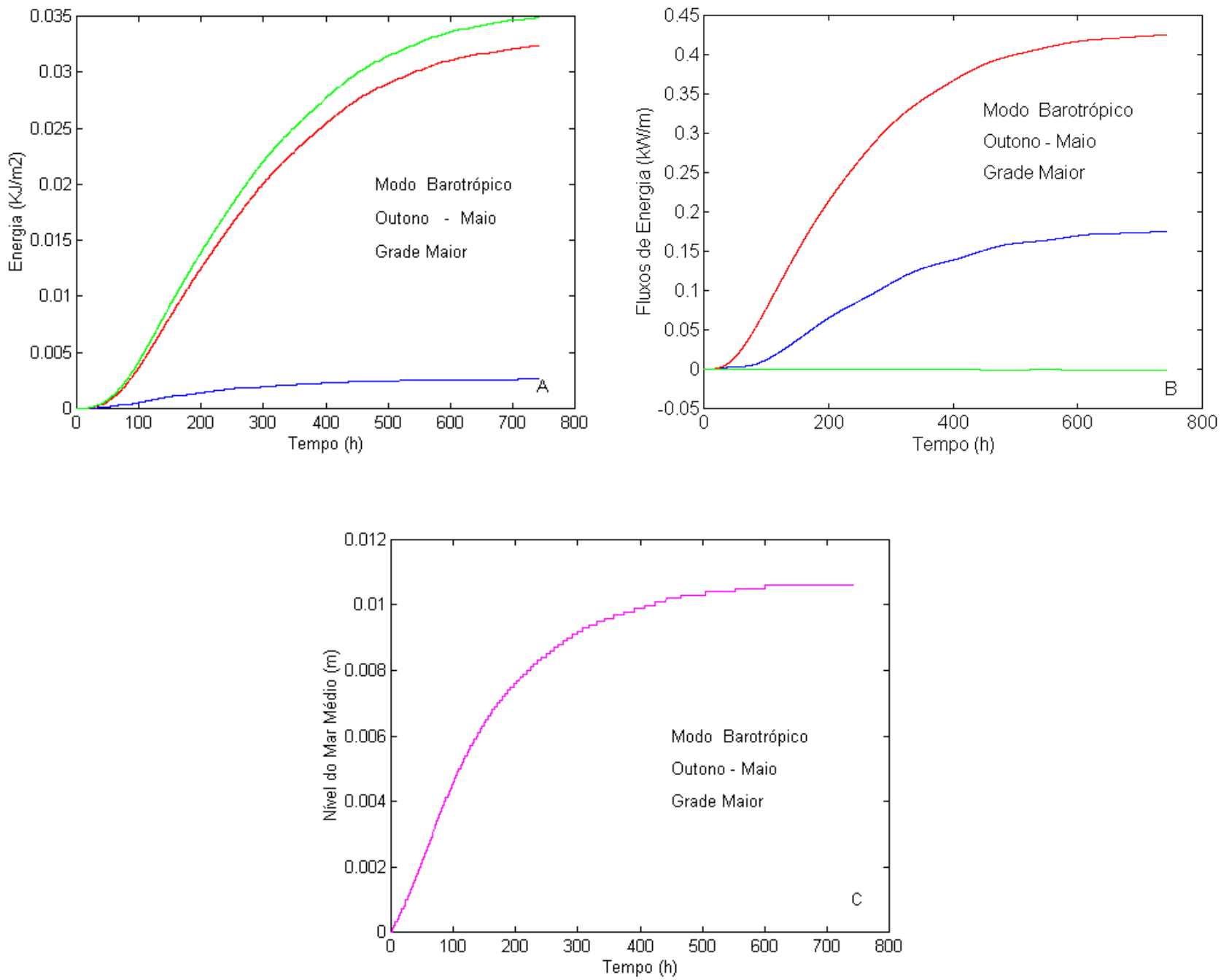

Figura 18: Curvas de energia mecânica (A), fluxos nos contornos (B) e nível do mar médio (C) na PCSE, sendo em (A), o verde, a energia mecânica, o vermelho, a energia cinética e o azul, a energia potencial. Em (B), o azul representa o fluxo através do contorno norte, o vermelho, o fluxo através do contorno sul e o verde, o fluxo através do contorno leste. Simulação de outono - maio. 

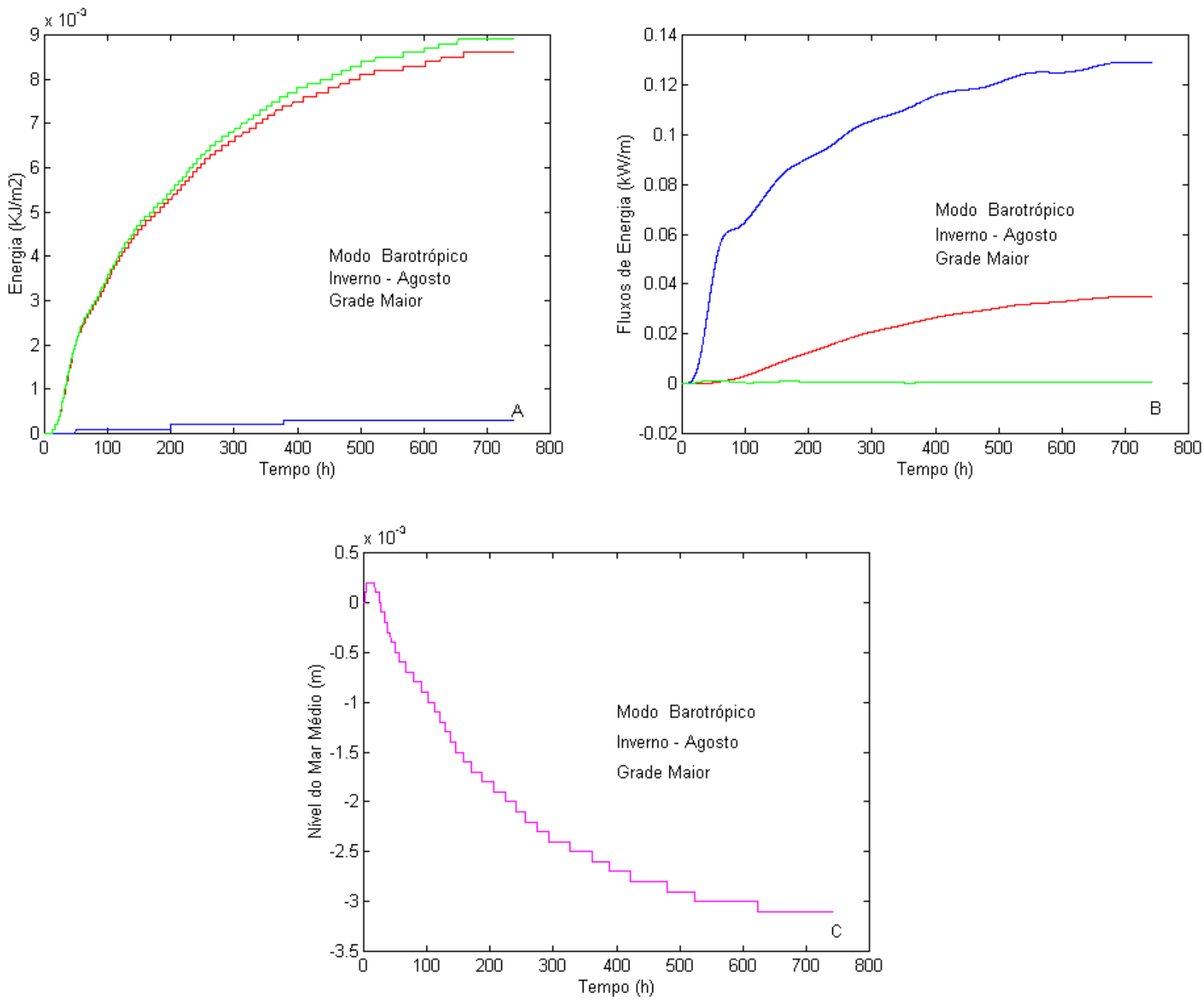

Figura 19: Curvas de energia mecânica (A), fluxos nos contornos (B) e nível do mar médio (C) na PCSE, sendo em (A), o verde, a energia mecânica, o vermelho, a energia cinética e o azul, a energia potencial. Em (B), o azul representa o fluxo através do contorno norte, o vermelho, o fluxo através do contorno sul e o verde, o fluxo através do contorno leste. Simulação de inverno - agosto. 

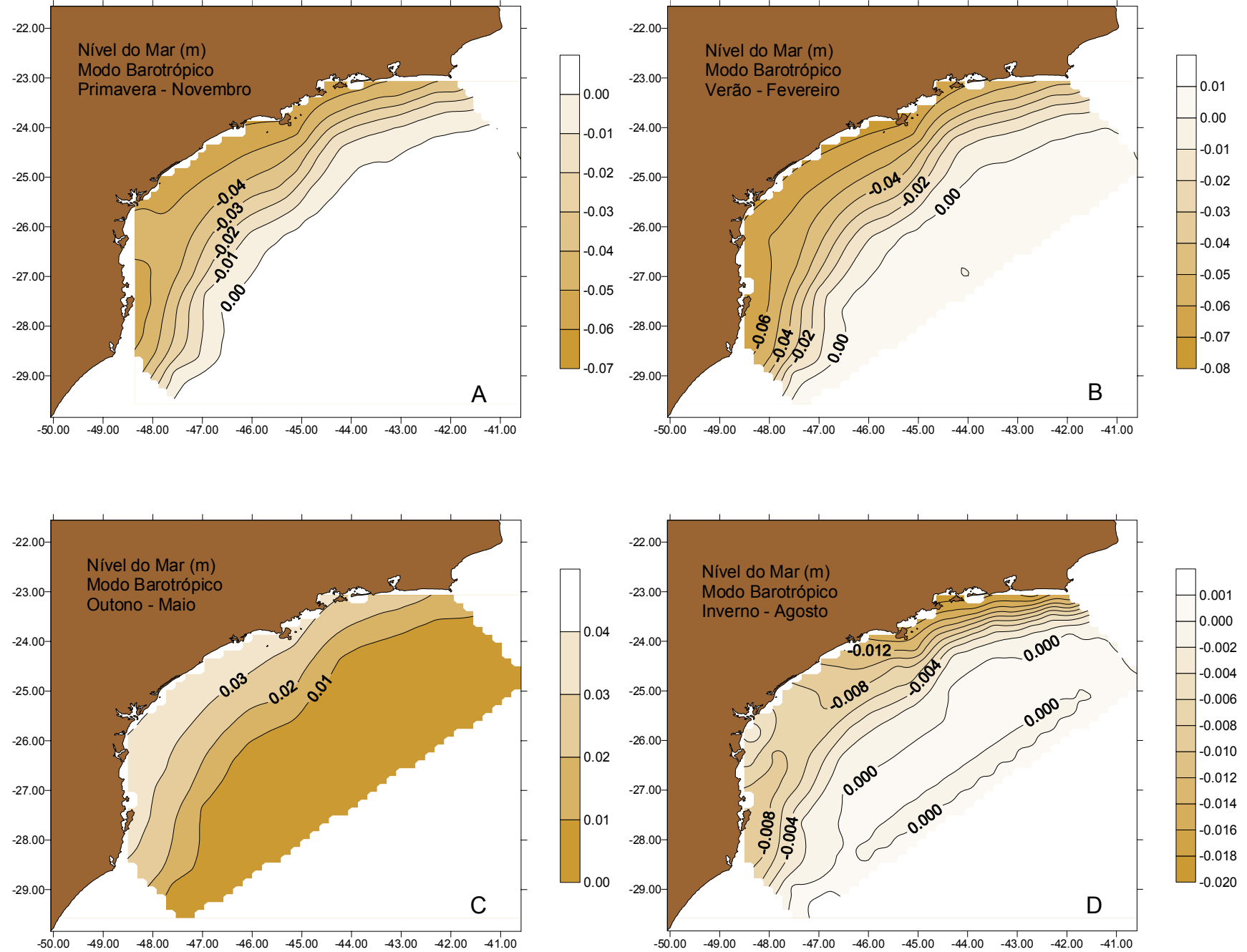

Figura 20: Nível do Mar na Plataforma Continental Sudeste obtido em modo barotrópico após 30 dias de integração nas simulações de primavera (A), verão $(B)$, outono $(C)$ e inverno (D). 

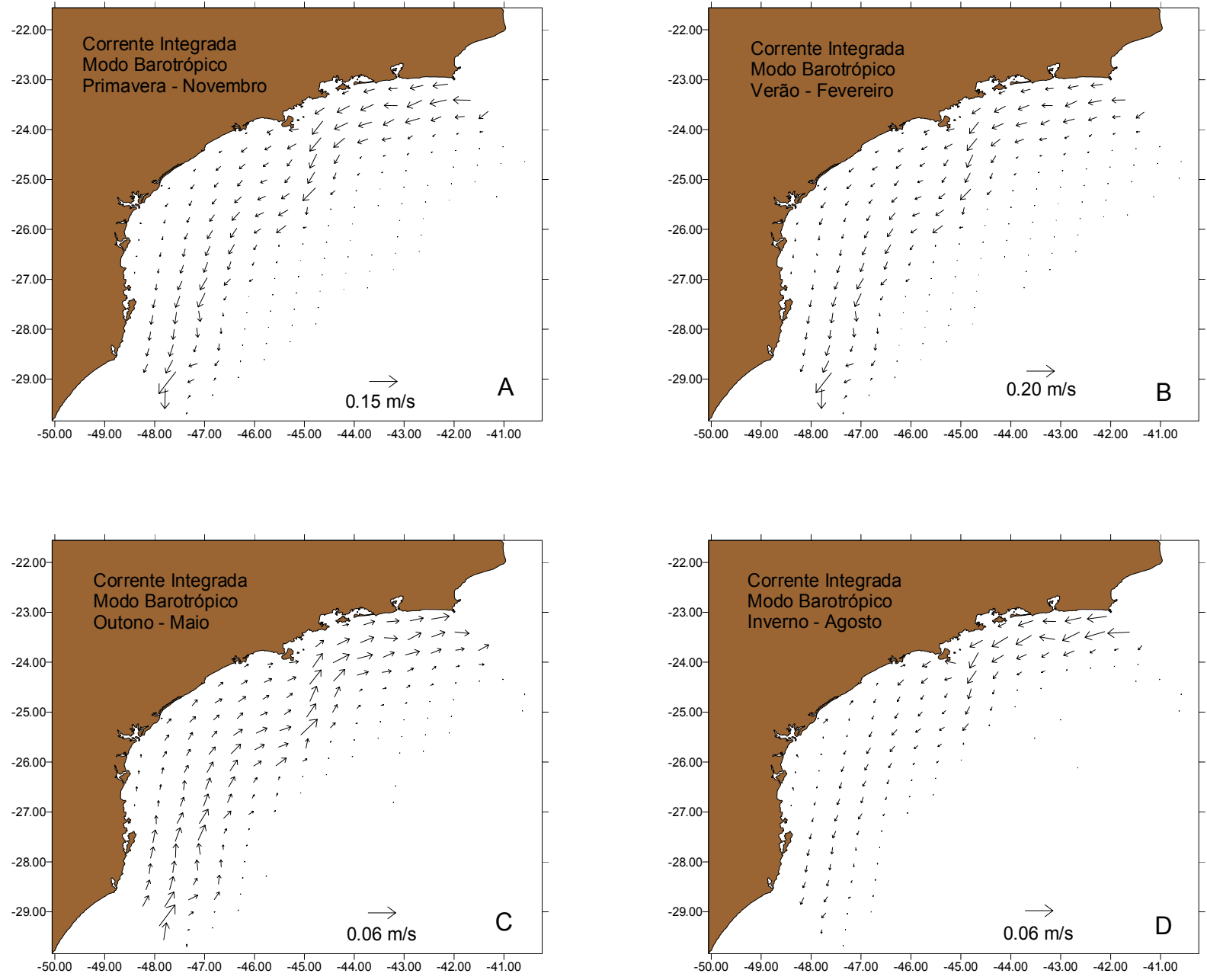

Figura 21: Correntes na Plataforma Continental Sudeste obtidas em modo barotrópico após 30 dias de integração nas simulações de primavera (A), verão (B), outono (C) e inverno (D). 


\subsection{A Plataforma Continental Interna}

As Figs. 22, 23, 24 e 25 apresentam as curvas de energia mecânica, fluxos nos contornos e nível do mar médio para a PCI nas quatro estações do ano. Estas curvas estabilizam ao redor de $400 \mathrm{~h}$ de integração.

$\mathrm{Na}$ grade de menor resolução (PCSE), a contribuição da energia potencial é relativamente pequena para a energia mecânica, cerca de $10 \%$; na PCI, porém, esta contribuição é bem maior, sendo maior do que $50 \%$ nas estações da primavera, verão e outono e maior do que $20 \%$ no inverno. A energia mecânica na grade da PCI é cerca de 1/3 daquela obtida para a grade da PCSE, isto nas estações de primavera, verão e outono, sendo exceção o inverno, onde o nível de energia obtido na PCI é o mesmo que o obtido na PCSE. Analogamente à grade da PCSE, a energia mecânica cresce do inverno para a primavera e desta para o verão, decrescendo do verão para o outono e deste para o inverno.

Os níveis de fluxos de energia através dos contornos têm o mesmo comportamento da energia mecânica durante as estações e o fluxo de energia através do contorno sul é sempre maior que o através dos outros contornos, sendo exceção o inverno onde o fluxo através do contorno norte é maior. O fluxo de energia através do contorno sul na PCI é cerca de 50\% menor do que aqueles encontrados para a PCSE sendo os fluxos nos contornos norte e leste relativamente maiores na PCI do que na PCSE quando comparados ao fluxo de energia através do contorno sul. O nível do mar médio na PCI, analogamente à PCSE, é negativo na primavera, verão e inverno e positivo no outono. Os valores encontrados nesta grade são sempre maiores do que aqueles encontrados para a PCSE, sendo cerca de 2 a 3 vezes maior na primavera, verão e outono e quatro vezes maior no inverno.

A Fig. 26 A,B,C,D apresenta o nível do mar na PCI após 30 dias de integração , nas simulações de primavera, verão, outono e inverno respectivamente. Na primavera, o nível do mar na costa é igual ao gerado na plataforma continental (-0,06 m) apresentando gradientes mais acentuados ao sul, onde a inclinação ascendente atinge 0,045 m (Fig. 26 A). A configuração das isolinhas de nível do mar no verão (Fig. 26 B) é muito semelhante à da primavera, sendo na costa encontrados níveis de $-0,07 \mathrm{~m}$ concordando com aqueles encontrados na PCSE. Os gradientes mais acentuados 
também estão no sul, onde o nível do mar é de $-0,05 \mathrm{~m}$. Em oposição às estações da primavera e verão, no outono (Fig. 26 C) os níveis mais baixos estão ao largo $(0,025 \mathrm{~m})$ com inclinação ascendente para a costa $(0,03 \mathrm{~m})$. A configuração das isolinhas de nível do mar no inverno também estão muito próximas às da primavera e verão, porém, com níveis maiores, sendo encontrado na costa níveis do mar variando entre $-0,014 \mathrm{~m}$ ao sul até $\quad-0,018 \mathrm{~m}$ ao norte. Ao largo e ao sul do domínio, o nível do mar chega a $-0,010$ m. Em todas as estações houve concordância com os valores encontrados na PCSE (Fig. 20).

A Fig. 27 A,B,C,D apresenta as correntes na PCI obtidas em modo barotrópico após 30 dias de integração nas simulações de primavera, verão, outono e inverno, respectivamente. Observa-se que nas quatro estações do ano os movimentos estão orientados basicamente ao longo das isóbatas (Fig.2) encontrando-se intensidades de até $0,07 \mathrm{~m} / \mathrm{s}$ no verão (Fig. $27 \mathrm{~A}$ ) e $0,06 \mathrm{~m} / \mathrm{s}$ na primavera (Fig. 27 B). As correntes fluem de nordeste para sudoeste no verão, primavera e inverno com menores intensidades no inverno e fluem de sudoeste para nordeste no outono; nesta estação encontram-se as menores intensidades $(0,03 \mathrm{~m} / \mathrm{s})$. As correntes ao sul da ISS são em quaisquer das quatro estações mais intensas do que as correntes ao norte da ISS, com intensificação quando contornam a ISS, principalmente ao sul da mesma, em direção da costa. Essa intensificação das correntes no contorno leste da ISS fluindo em seguida em direção à costa, foi obtida em vários outros trabalhos, entre eles, o de Assad (2000). 

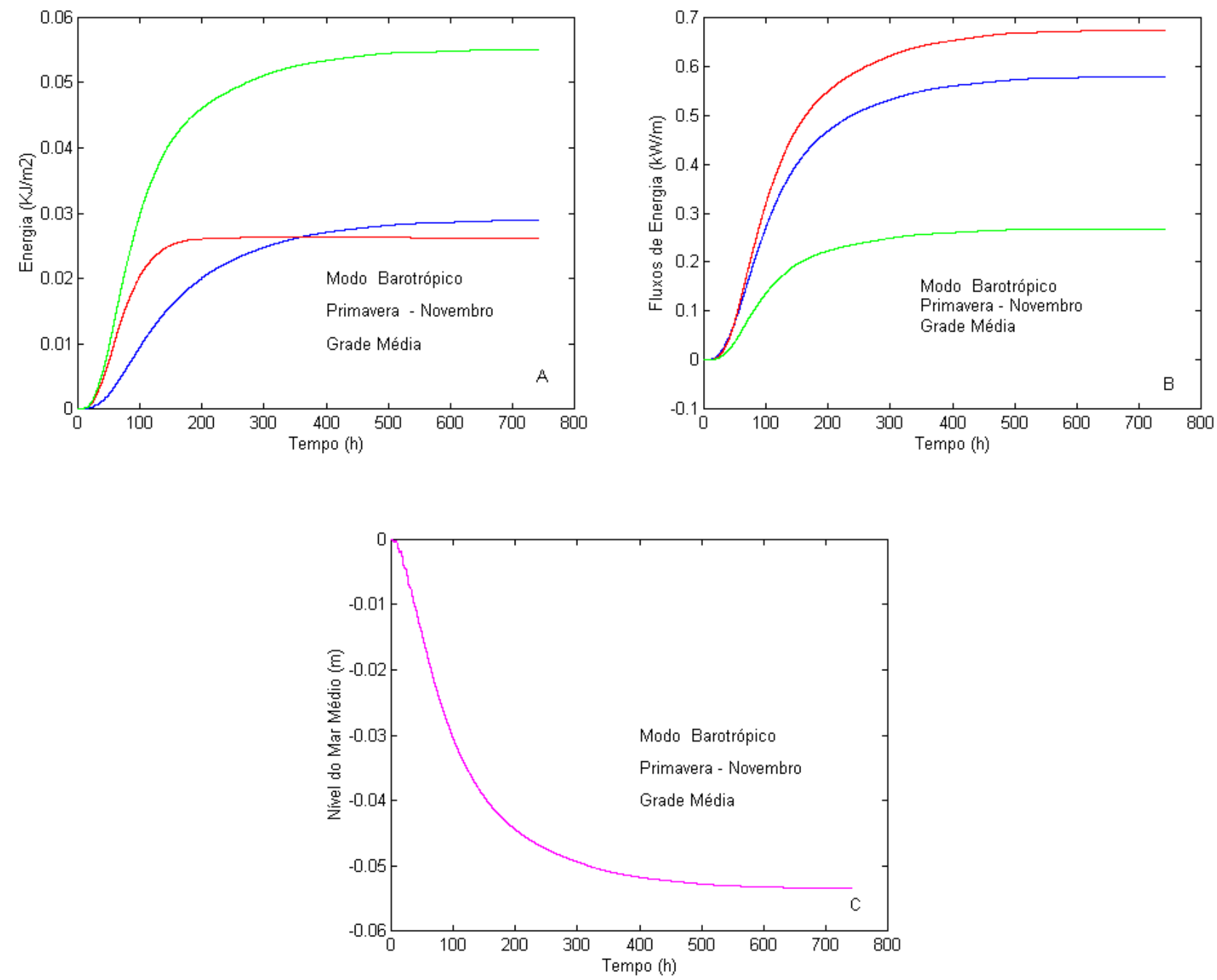

Figura 22: Curvas de energia mecânica (A), fluxos nos contornos (B) e nível do mar médio (C) na PCI, sendo em (A), o verde, a energia mecânica, o vermelho, a energia cinética e o azul, a energia potencial. Em (B), o azul representa o fluxo através do contorno norte, o vermelho, o fluxo através do contorno sul e o verde, o fluxo através do contorno leste. Simulação de primavera - novembro. 

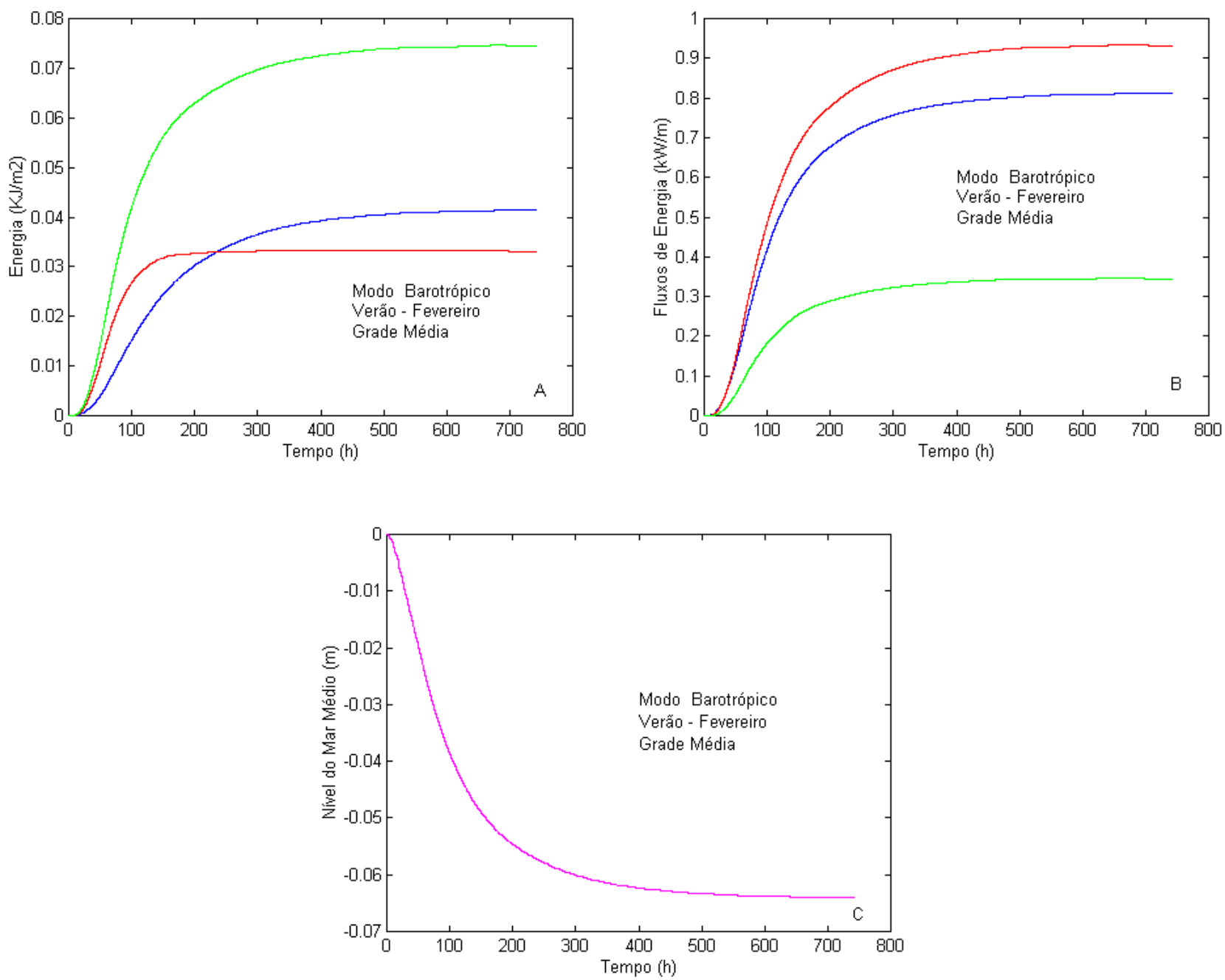

Figura 23: Curvas de energia mecânica (A), fluxos nos contornos (B) e nível do mar médio (C) na PCI, sendo em (A), o verde, a energia mecânica, o vermelho, a energia cinética e o azul, a energia potencial. Em (B), o azul representa o fluxo através do contorno norte, o vermelho, o fluxo através do contorno sul e o verde, o fluxo através do contorno leste. Simulação de verão - fevereiro. 

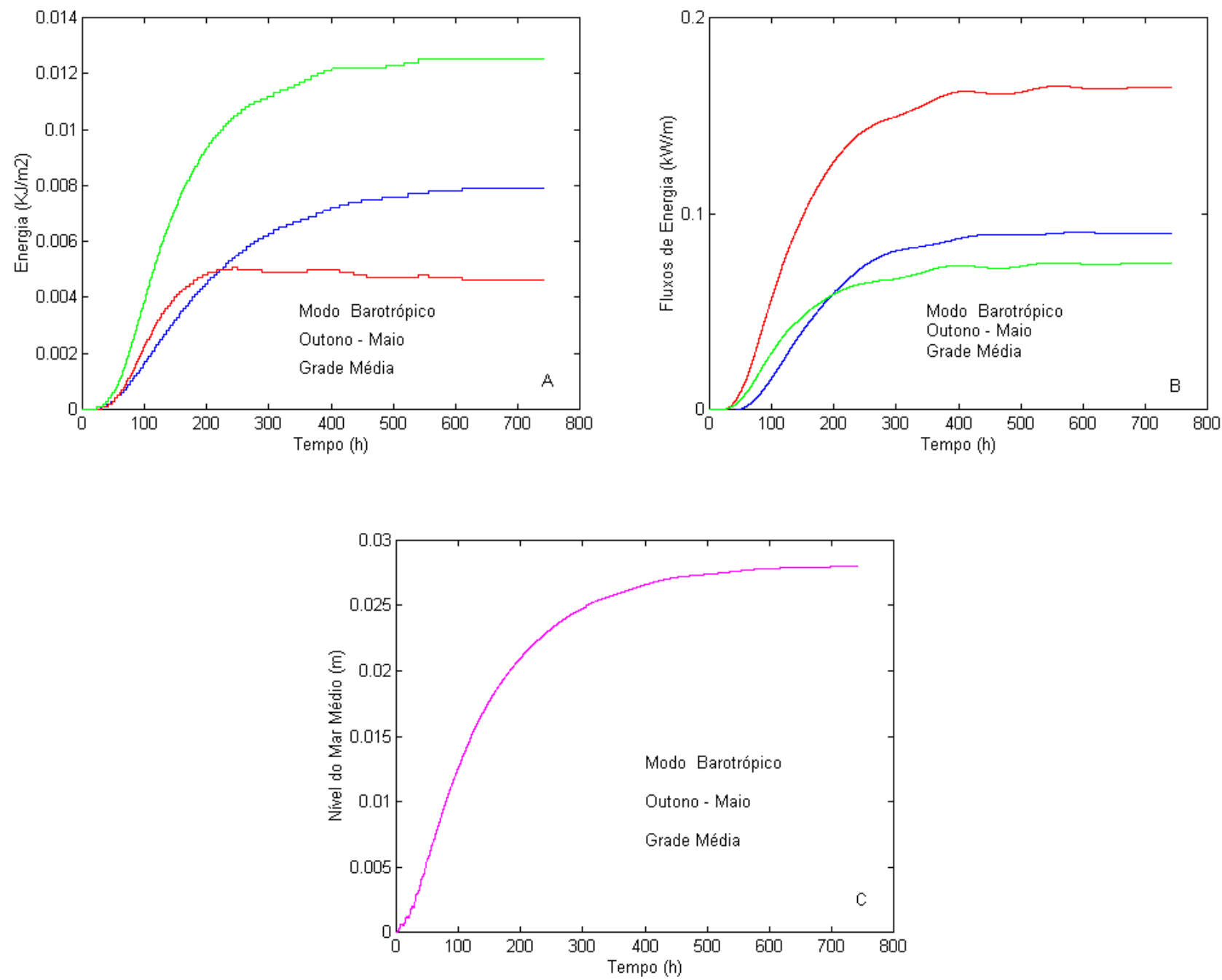

Figura 24: Curvas de energia mecânica (A), fluxos nos contornos (B) e nível do mar médio (C) na PCI, sendo em (A), o verde, a energia mecânica, o vermelho, a energia cinética e o azul, a energia potencial. Em (B), o azul representa o fluxo através do contorno norte, o vermelho, o fluxo através do contorno sul e o verde, o fluxo através do contorno leste. Simulação de outono - maio. 

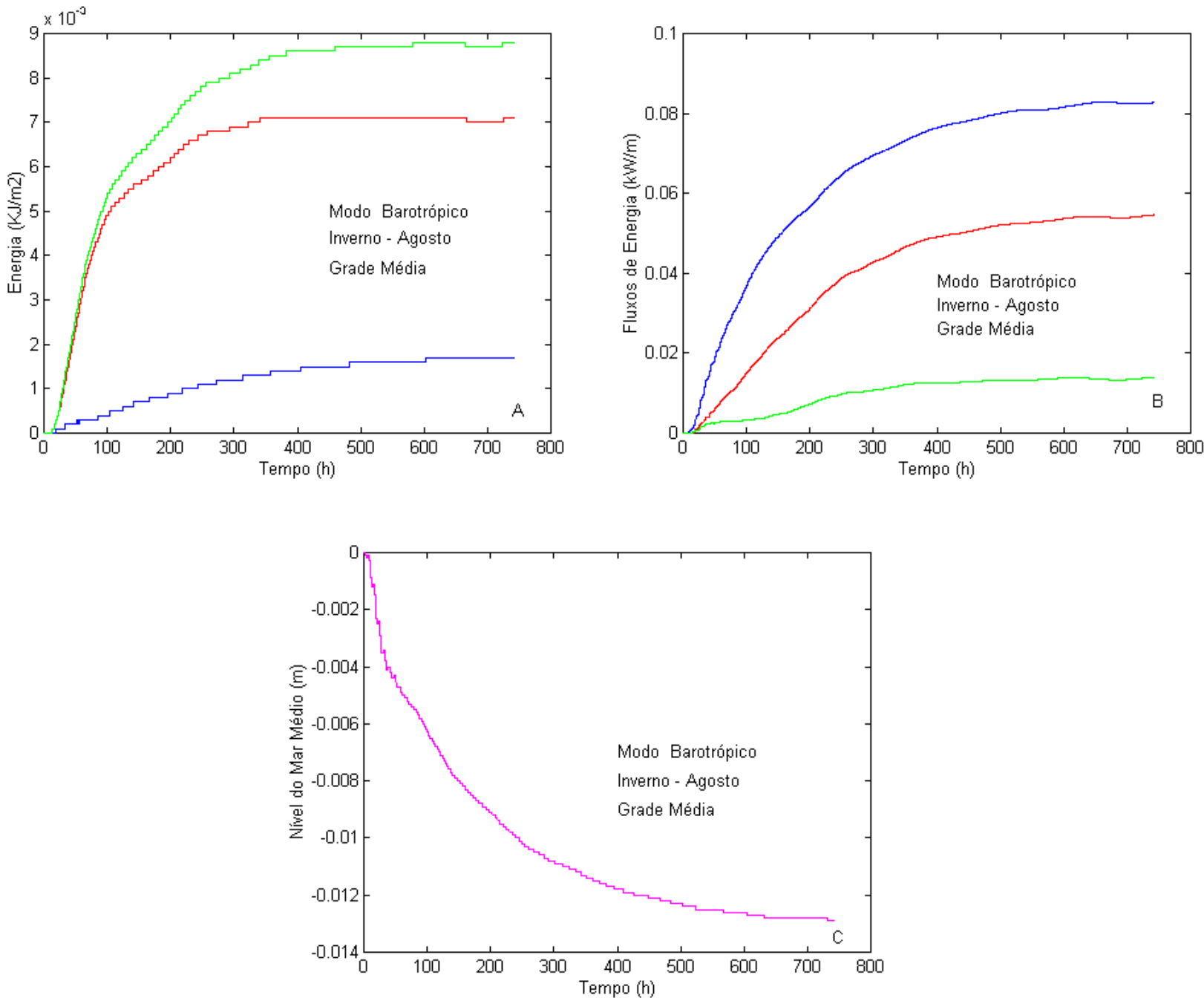

Figura 25: Curvas de energia mecânica (A), fluxos nos contornos (B) e nível do mar médio (C) na PCI, sendo em (A), o verde, a energia mecânica, o vermelho, a energia cinética e o azul, a energia potencial. Em (B), o azul representa o fluxo através do contorno norte, o vermelho, o fluxo através do contorno sul e o verde, o fluxo através do contorno leste. Simulação de inverno - agosto. 

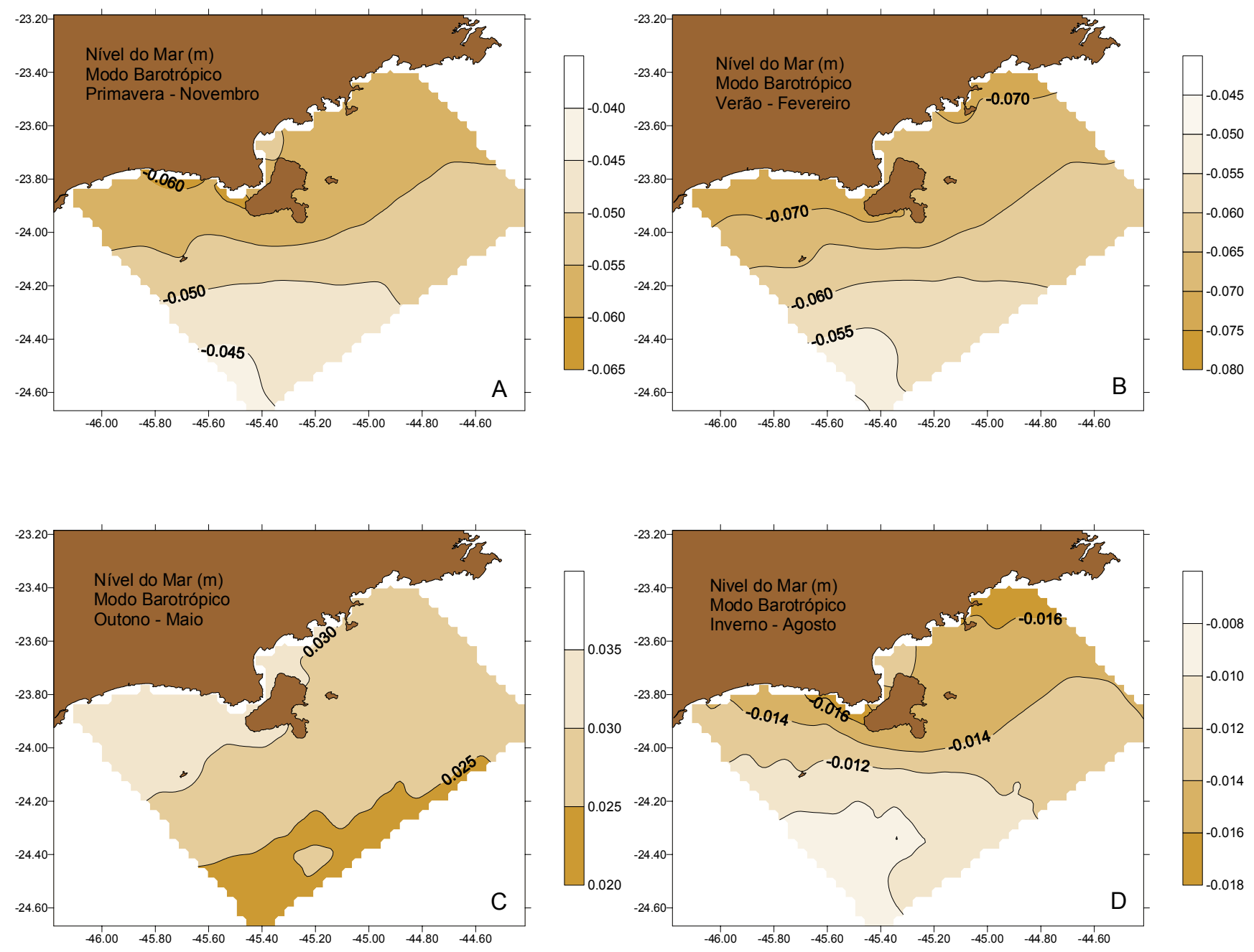

Figura 26: Nível do Mar na PCI obtido em modo barotrópico após 30 dias de integração nas simulações de primavera (A), verão (B), outono (C) e inverno (D). 

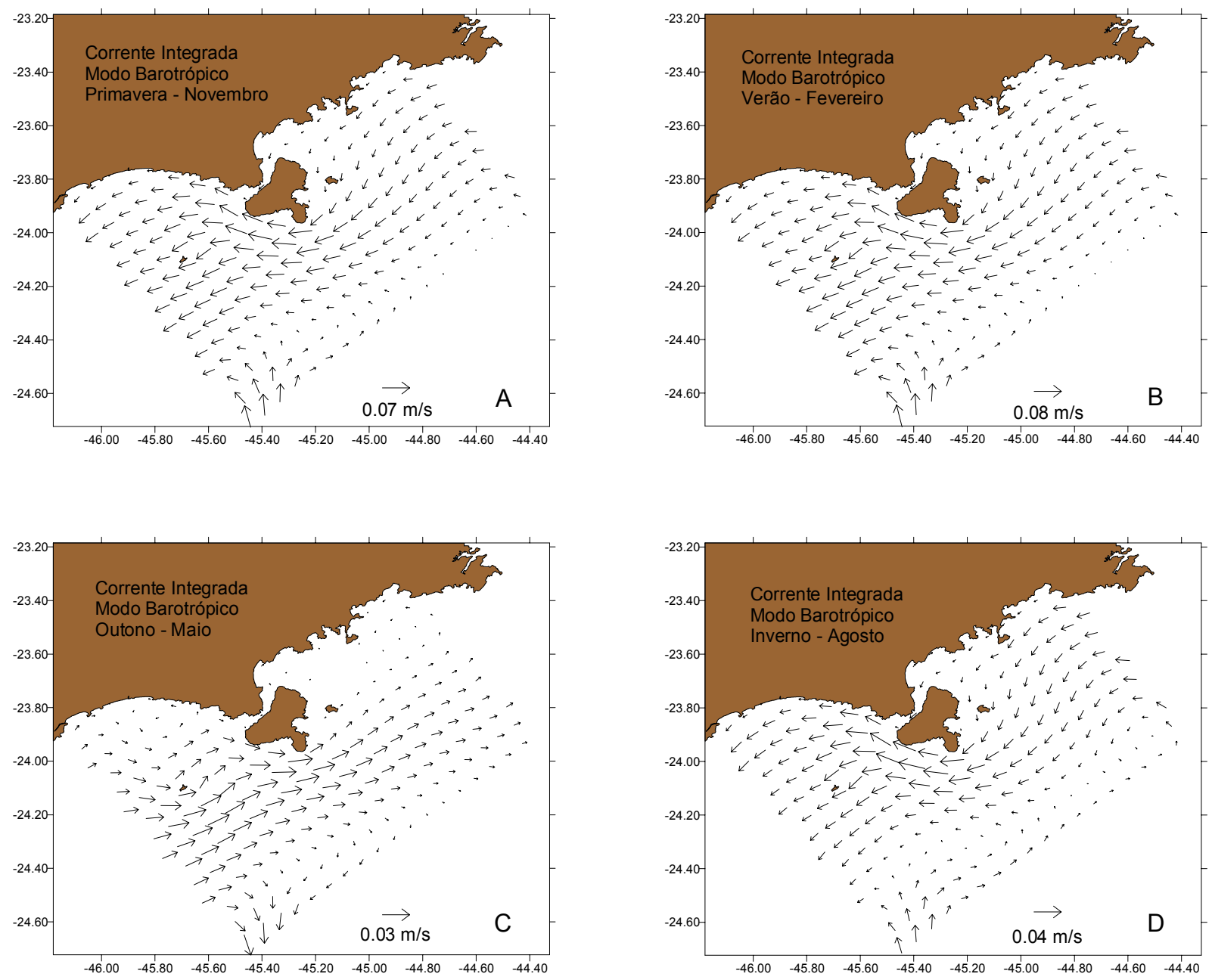

Figura 27: Correntes na PCI obtidas em modo barotrópico após 30 dias de integração nas simulações de primavera (A), verão (B), outono (C) e inverno (D). 


\subsection{O Canal de São Sebastião}

As Figs. 28, 29, 30 e 31 apresentam as curvas de energia mecânica, fluxos nos contornos e nível do mar médio para o CSS nas quatro estações do ano. Estas curvas começam a estabilizar a partir de $300 \mathrm{~h}$ de integração.

Na grade da PCSE, a energia cinética é a maior parte da energia mecânica e na grade da PCI, a energia cinética e a energia potencial colaboram com partes aproximadamente iguais com a energia mecânica; na grade do CSS porém, a energia potencial colabora com mais de $80 \%$ da energia mecânica. Os níveis de energia mecânica na grade do CSS são menores do que aqueles encontrados para a grade da PCI na razão aproximada de $3 / 5$ para a primavera e verão, 4/5 para o outono e $2 / 5$ para o inverno. A energia mecânica, a exemplo das grades da PCSE e PCI, cresce do inverno para a primavera e desta para o verão, decrescendo do verão para o outono e deste para o inverno.

$\mathrm{Na}$ grade do CSS os maiores níveis de fluxo de energia através dos contornos são os do contorno leste, seguido do fluxo de energia através do contorno sul, nas quatro estações. Em relação às estações, os níveis de fluxo de energia aumentam do outono para o verão, diminuindo para o outono voltando a crescer para o inverno. Em relação à grade da PCI, os níveis de fluxos de energia através dos contornos norte e sul são sempre bem menores do que os da grade da PCI, porém os fluxos através do contorno leste tem a mesma magnitude ou são maiores ao daquela grade.

O comportamento do nível do mar médio na grade do CSS é muito similar ao da grade da PCI, em todas as estações, porém, os níveis são levemente menores nas estações de primavera, verão e inverno e ligeiramente maiores na estação de outono.

A Fig. 32 A,B,C,D apresenta o nível do mar no CSS após 30 dias de integração, nas simulações de primavera, verão, outono e inverno respectivamente. $\mathrm{Na}$ primavera, o nível do mar apresenta ligeira inclinação ascendente de sul para o norte, variando entre $-0,06 \mathrm{~m}$ a $-0,058 \mathrm{~m}$ (Fig. 32A); a mesma configuração é encontrada para a estação do verão, porém o nível do mar varia de $-0,074 \mathrm{~m}$ a $-0,070 \mathrm{~m}$. No outono o nível do mar varia entre $0,03 \mathrm{~m}$ e $0,032 \mathrm{~m}$. O nível do mar no inverno se apresenta como na primavera e no verão, porém com gradientes menores. Na região norte do CSS, nas quatro estações, o nível do mar apresenta ligeira inclinação ascendente do leste para o oeste. 
A Fig. 33 A,B,C,D apresenta as correntes no CSS obtidas em modo barotrópico após 30 dias de integração nas simulações de primavera, verão, outono e inverno, respectivamente. O padrão de circulação é bem semelhante nas estações da primavera, verão e inverno com correntes fluindo de nordeste para sudoeste e intensificando-se na região central do CSS. Uma outra característica comum nestas três estações são correntes que fluem do leste para o oeste na entrada sul do CSS. Este campo de correntes no sul do CSS está em acordo com aquele obtido na região da PCI (Fig. 27) onde as correntes se intensificam ao contornarem a ISS fluindo em direção à costa. 

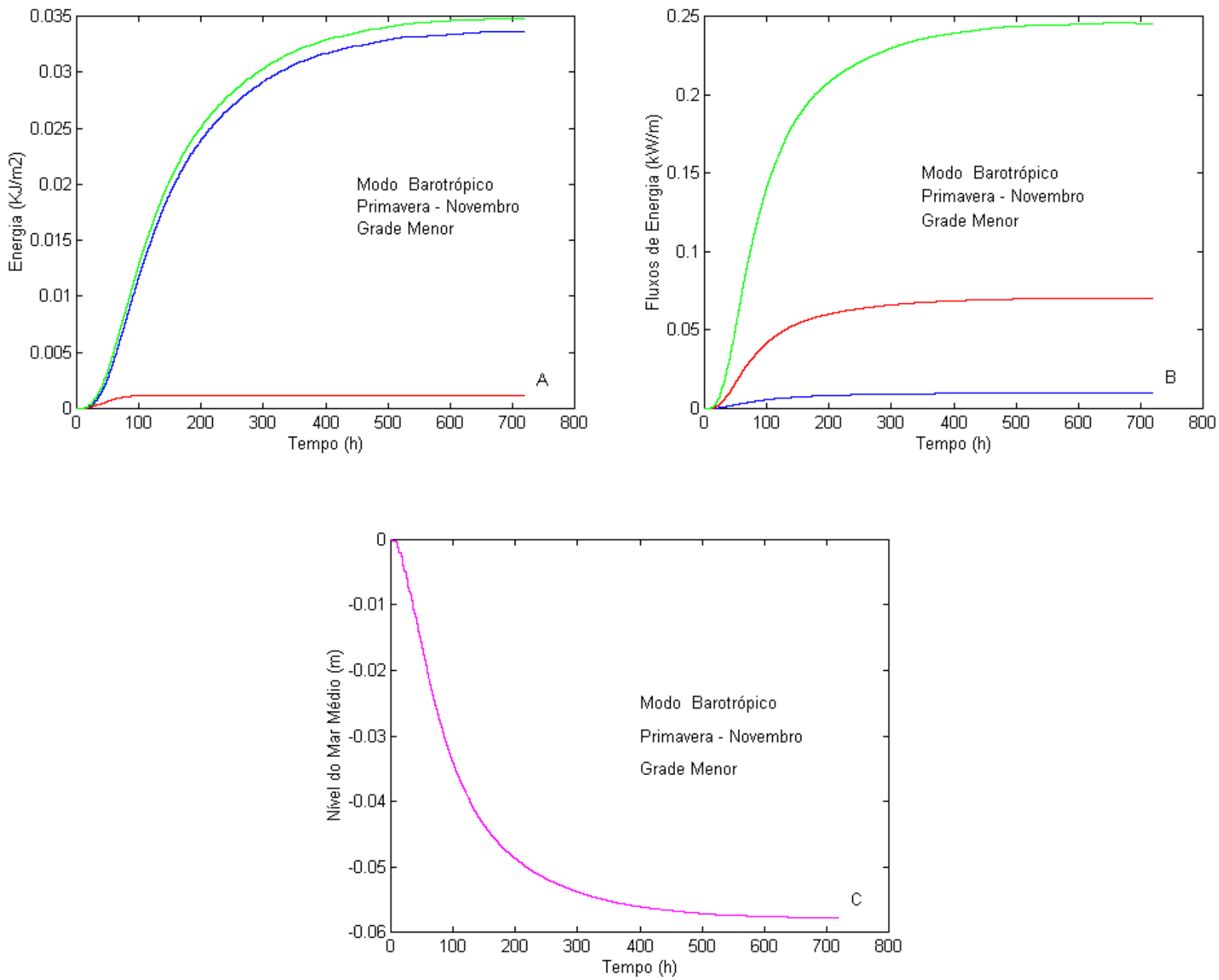

Figura 28: Curvas de energia mecânica (A), fluxos nos contornos (B) e nível do mar médio (C) no CSS, sendo em (A), o verde, a energia mecânica, o vermelho, a energia cinética e o azul, a energia potencial. Em (B), o azul representa o fluxo através do contorno norte, o vermelho, o fluxo através do contorno sul e o verde, o fluxo através do contorno leste. Simulação de primavera - novembro. 

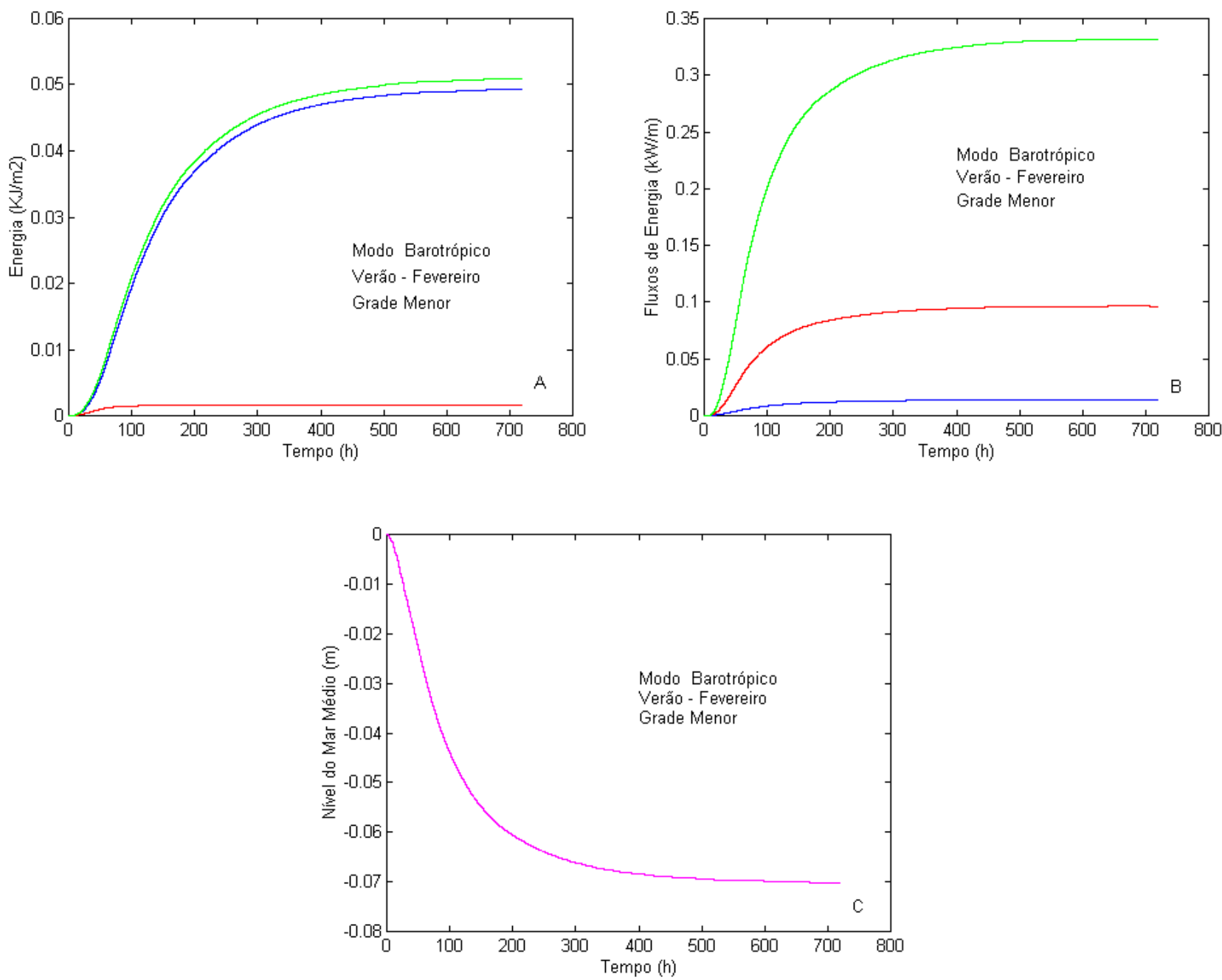

Figura 29: Curvas de energia mecânica (A), fluxos nos contornos (B) e nível do mar médio (C) no CSS, sendo em (A), o verde, a energia mecânica, o vermelho, a energia cinética e o azul, a energia potencial. Em (B), o azul representa o fluxo através do contorno norte, o vermelho, o fluxo através do contorno sul e o verde, o fluxo através do contorno leste. Simulação de verão - fevereiro. 

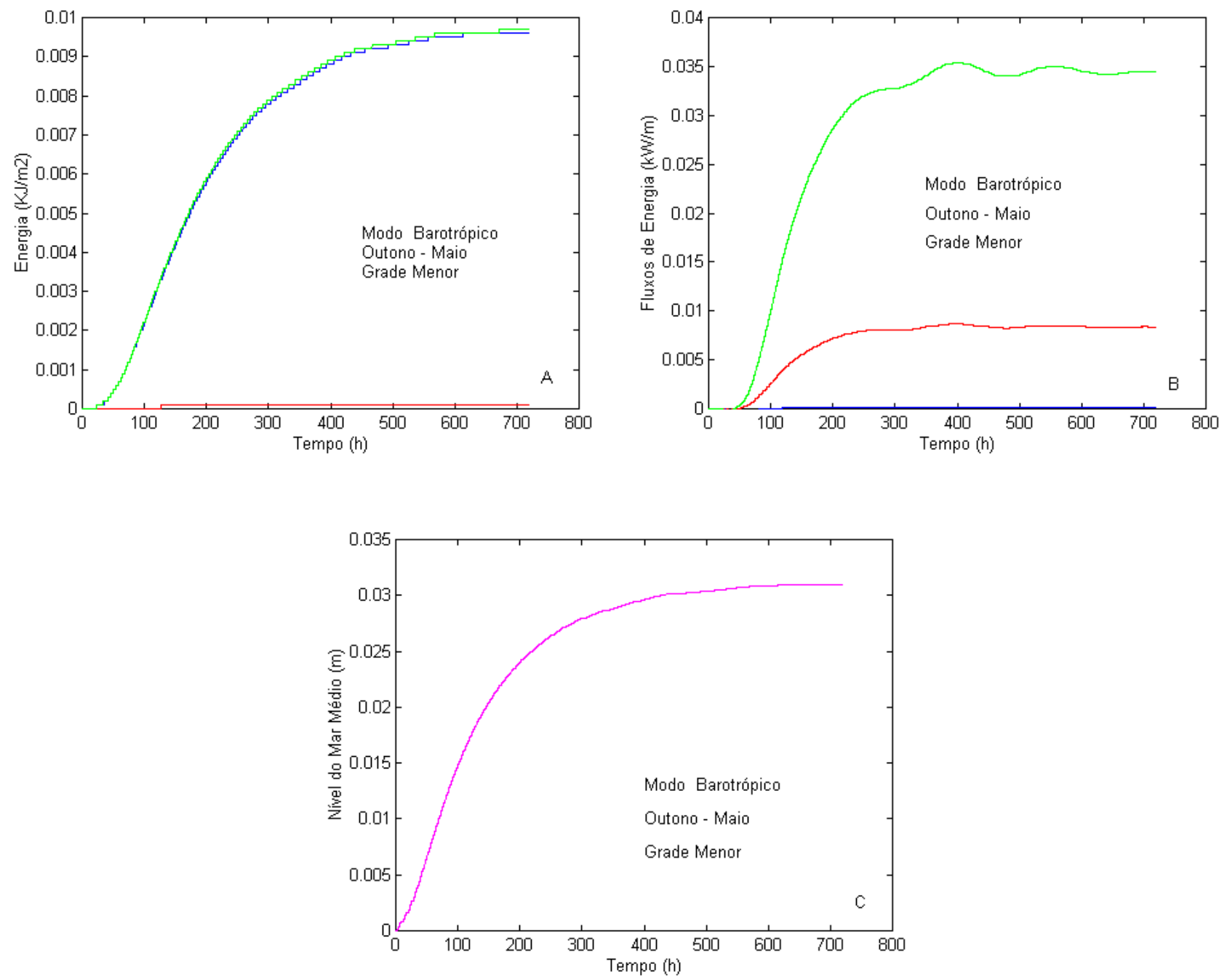

Figura 30: Curvas de energia mecânica (A), fluxos nos contornos (B) e nível do mar médio (C) no CSS, sendo em (A), o verde, a energia mecânica, o vermelho, a energia cinética e o azul, a energia potencial. Em (B), o azul representa o fluxo através do contorno norte, o vermelho, o fluxo através do contorno sul e o verde, o fluxo através do contorno leste. Simulação de outono - maio. 

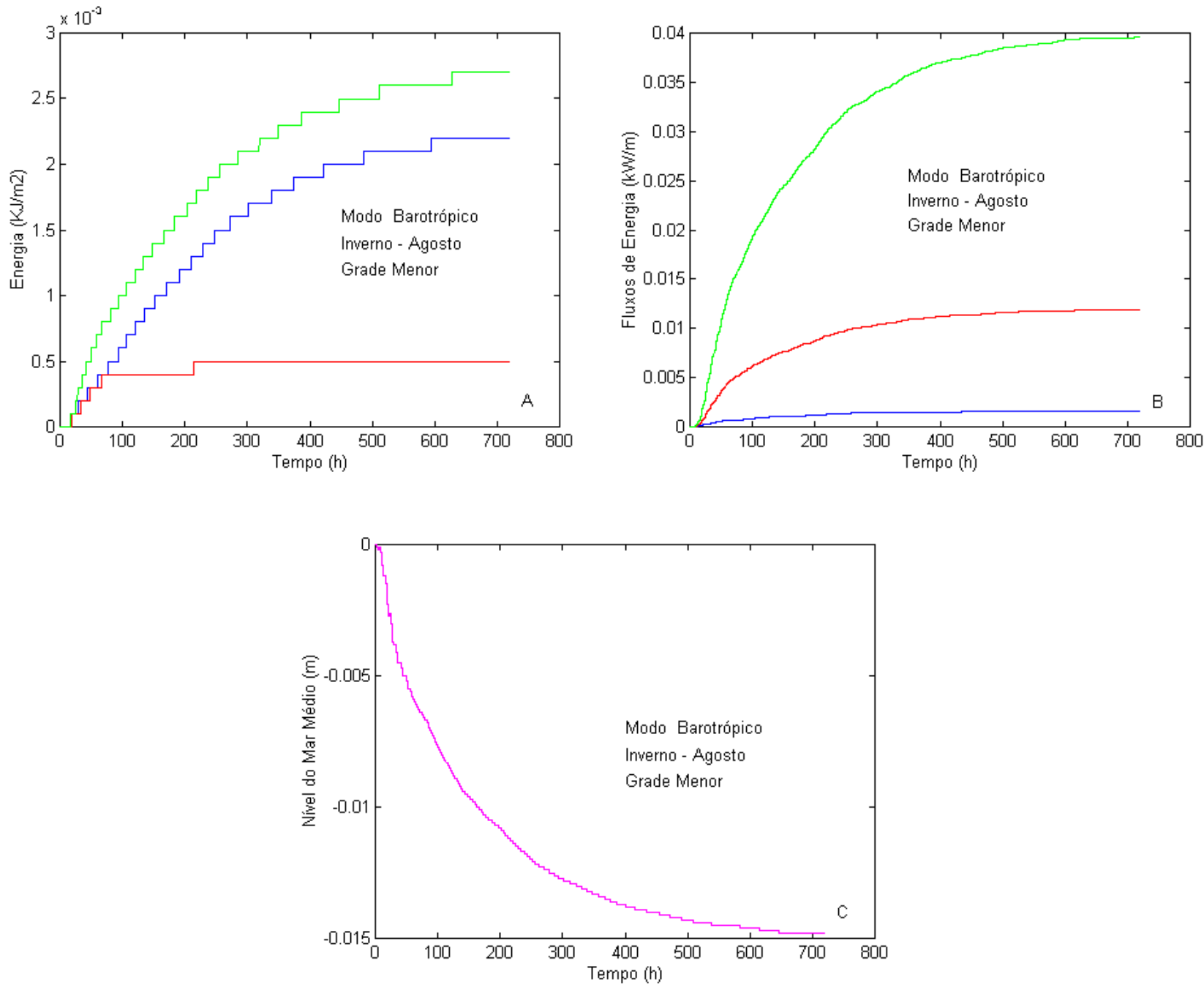

Figura 31: Curvas de energia mecânica (A), fluxos nos contornos (B) e nível do mar médio (C) no CSS, sendo em (A), o verde, a energia mecânica, o vermelho, a energia cinética e o azul, a energia potencial. Em (B), o azul representa o fluxo através do contorno norte, o vermelho, o fluxo através do contorno sul e o verde, o fluxo através do contorno leste. Simulação de inverno - agosto. 

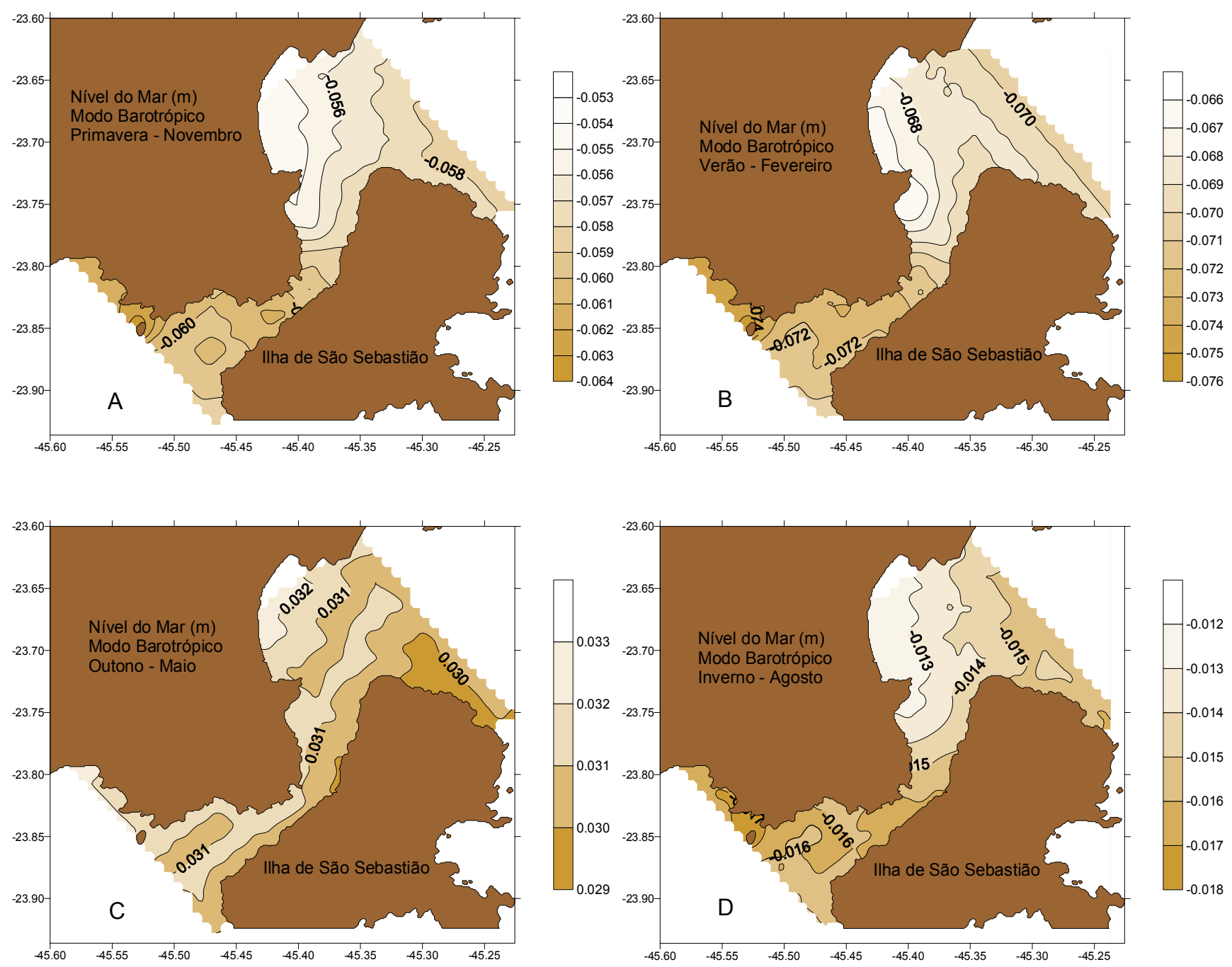

Figura 32: Nível do Mar no Canal de São Sebastião obtido em modo barotrópico após 30 dias de integração nas simulações de primavera (A), verão (B), outono (C) e inverno (D). 

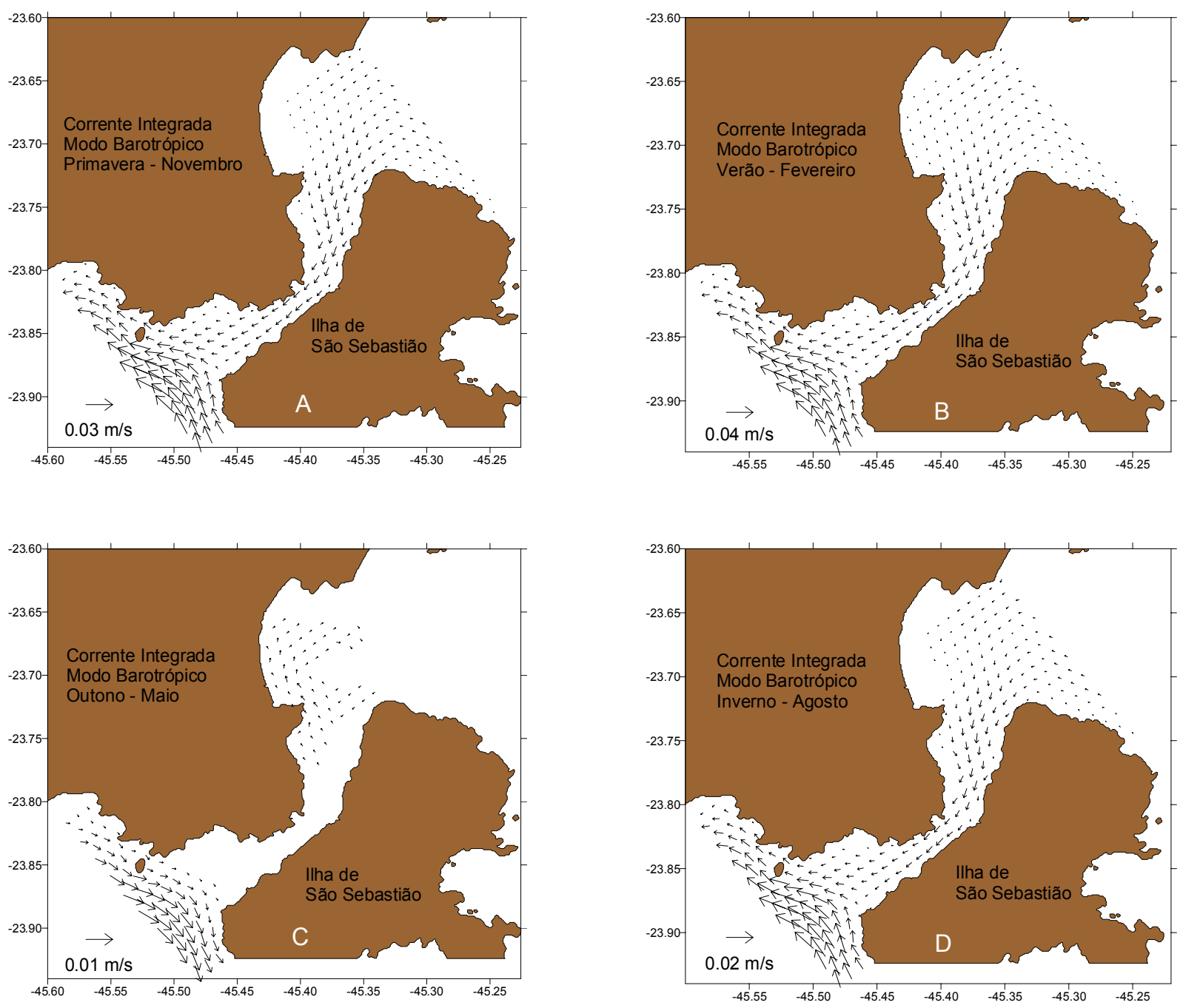

Figura 33: Correntes no Canal de São Sebastião obtidas após 30 dias de integração em modo barotrópico nas simulações de primavera (A), verão (B), outono (C) e inverno (D). 


\section{Capítulo 4}

\section{Resultados do Modo Baroclínico}

\subsection{A Primavera}

\subsubsection{A Plataforma Continental Sudeste}

As curvas de energia mecânica, de fluxos de energia nos contornos e do nível do mar médio encontram-se na Fig. 34 A,B,C. Os níveis de energia e de fluxos de energia, em modo prognóstico, são bem maiores do que em modo barotrópico em decorrência dos gradientes de densidade. A colaboração da energia potencial para a energia mecânica é relativamente baixa, predominando a energia cinética. $O$ fluxo através do contorno norte é maior que o através dos outros contornos e tem sinal negativo (para dentro do domínio). O fluxo através do contorno sul é relativamente pequeno. O nível médio do mar, que oscila no início da integração tende a $-0,04 \mathrm{~m}, \mathrm{o}$ dobro do que aquele encontrado em modo barotrópico.

A configuração das isolinhas de nível do mar (Fig. 35A) é semelhante, dentro da plataforma continental, àquela vista para o modo barotrópico (Fig. $20 \mathrm{~A}$ ), porém os níveis são bem mais acentuados, observando-se nas proximidades da costa, ao norte, valores de - $0,20 \mathrm{~m}$, com inclinação ascendente para o largo. O nível do mar na costa, ao sul do domínio é mais alto, com níveis de $-0,15 \mathrm{~m}$. Os maiores gradientes do nível do mar encontram-se aproximadamente na região da quebra da plataforma continental.. $\mathrm{Na}$ região central encontramos níveis de até $0,10 \mathrm{~m}$.

As correntes superficiais podem ser vistas na Fig. 35B. Elas são bem mais intensas do que aquelas em modo barotrópico e chegam a intensidades de até $0,95 \mathrm{~m} / \mathrm{s}$. A direção preponderante é de nordeste e existe uma intensificação delas na quebra da plataforma, onde encontramos também um forte gradiente do nível do mar. Estas correntes tem feições da Corrente do Brasil.

As distribuições horizontais superficiais de temperatura, salinidade e densidade encontram-se nas Figs. 36A, 36B e 36C respectivamente. Percebemos que existem 
fortes gradientes dessas três propriedades na quebra da plataforma; estes gradientes estão associados a temperaturas maiores do que $20^{\circ} \mathrm{C}$ e a salinidades maiores do que 36 , característicos da Água Tropical, transportada pela Corrente do Brasil. As menores temperaturas encontram-se entre a Ilha Grande e a Baía de Guanabara $\left(18^{\circ} \mathrm{C}\right)$; este mínimo parece ser advectado para SO na forma de uma língua de baixa temperatura $\left(20^{\circ} \mathrm{C}\right)$ até o sul da ISS. Este fato é observado em um grande número de cruzeiros oceanográficos, entre os quais os analisados por Miranda (1982), Matsuura (1986) e Miranda \& Katsuragawa (1991). As maiores temperaturas $\left(25^{\circ} \mathrm{C}\right)$ encontram-se no norte, mais ao largo. A configuração das isohalinas é semelhante 'a das isotermas na região norte, onde ao núcleo de alta temperatura $\left(25^{\circ} \mathrm{C}\right)$ está associado um núcleo de alta salinidade $(37,0)$. No sul do domínio encontram-se fortes gradientes de salinidade com um mínimo na costa de 34,8 e um máximo ao largo de 36,8. O mínimo de densidade $\left(24 \mathrm{~kg} / \mathrm{m}^{3}\right)$ localiza-se na costa, ao sul, associado às baixas salinidades encontradas no local; as maiores densidades encontram-se ao largo, associadas às maiores salinidades lá existentes, e na costa norte da PCSE, em decorrência das menores temperaturas observadas na região. A configuração das isopicnais na costa, ao sul, é determinada pela salinidade, ao passo que na costa, ao norte, a temperatura é fator determinante para a densidade. As correntes superficiais intensas na região da quebra da plataforma estão associadas aos fortes gradientes de temperatura e salinidade ao norte, e ao sul associam-se apenas aos fortes gradientes de salinidade.

A distribuição horizontal superficial dos percentuais de massas de água podem ser vistas na Fig. 37. Percebemos que a Água Costeira encontra-se na costa a partir das proximidades do Canal de São Sebastião (CSS), avolumando-se em direção ao sul. Encontram-se vestígios da Água Central do Atlântico Sul (ACAS) a partir do norte do CSS até o limite norte do domínio. A Água Tropical (AT) encontra-se a partir destas duas massas de água em direção ao largo, sendo que a isolinha de 50\% encontra-se sempre nas imediações da quebra da plataforma continental.

Para representar a simulação das propriedades hidrográficas em seções transversais, foi escolhida a radial que se estende ao largo, a partir do sul do CSS, cujos resultados são apresentados na Fig. 38 A,B,C. Isotermas e isohalinas, centradas nos valores $22^{\circ} \mathrm{C}$ e 36,3 , interceptam a superfície na região da borda da plataforma continental, indicando a formação de frentes térmica e halina. A configuração de isotermas e isohalinas, na camada superficial da plataforma continental, evidencia a 
influência dos altos valores de temperatura e salinidade observados nessa frente. Por sua vez, o fundo da plataforma continental é ocupado por águas relativamente frias $\left(\mathrm{T}=18^{\circ} \mathrm{C}\right)$ associadas a salinidades de 36,0 .

Nas camadas mais profundas e na borda da plataforma continental, isotermas, isohalinas e isopicnais mostram inclinações ascendentes em direção ao talude continental, caracterizando o efeito baroclínico da Corrente do Brasil em seu movimento para SO (Figs. 38 A,B,C).

A Fig. 39 A,B,C apresenta os perfis verticais dos percentuais de massas de água. Os maiores percentuais de contribuição da AC encontram-se nas proximidades da costa. A AT é predominante na camada superficial e ao largo da frente térmica e halina, contribuindo para a formação da massa de água da camada superficial da plataforma continental; esta massa de água pronuncia-se como uma língua para dentro da plataforma até um ponto onde a distância da costa é cerca de $125 \mathrm{~km}$. A ACAS está sob a AT, abaixo de $250 \mathrm{~m}$, ao largo, e no fundo da plataforma continental.

A Fig. 40 apresenta perfis verticais das componentes de velocidade paralela (v) e perpendicular $(\mathrm{u})$ à costa. Os valores mais intensos da componente v ocorrem no talude continental $(-0,60 \mathrm{~m} / \mathrm{s})$ e confirmam o movimento da Corrente do Brasil para SO. Ao largo a intensidade da CB se anula e aparece um contra corrente com intensidade de $0,1 \mathrm{~m} / \mathrm{s}$. A ocorrência de contra correntes à CB já foi observada com a aplicação de modelo geostrófico (Signorini et al., 1989). A intensidade da componente v também decresce sobre a plataforma continental em direção à costa, invertendo seu sentido na costa, fluindo para norte. Ela também diminui sua intensidade com a profundidade, sendo que perto de $700 \mathrm{~m}$ de profundidade seu valor é de $-0,10 \mathrm{~m} / \mathrm{s}$, caracterizando o limite inferior da CB logo abaixo desta profundidade. Em uma figura não publicada verifica-se que ao largo da ISS, na profundidade de $800 \mathrm{~m}$ as correntes fluem para norte, sugerindo fluxos da AIA (Água Intermediária Antártica). À componente v fluindo para sul, associa-se na quebra da plataforma a componente $\mathrm{u}$, apontando para leste, sendo o núcleo de $\mathrm{u}(0,4 \mathrm{~m} / \mathrm{s})$ acompanhado do núcleo de $\mathrm{v}$; na região mais interna da plataforma ocorre uma inversão de sentido de v, acompanhada de uma inversão de u; o mesmo acontece ao largo. 

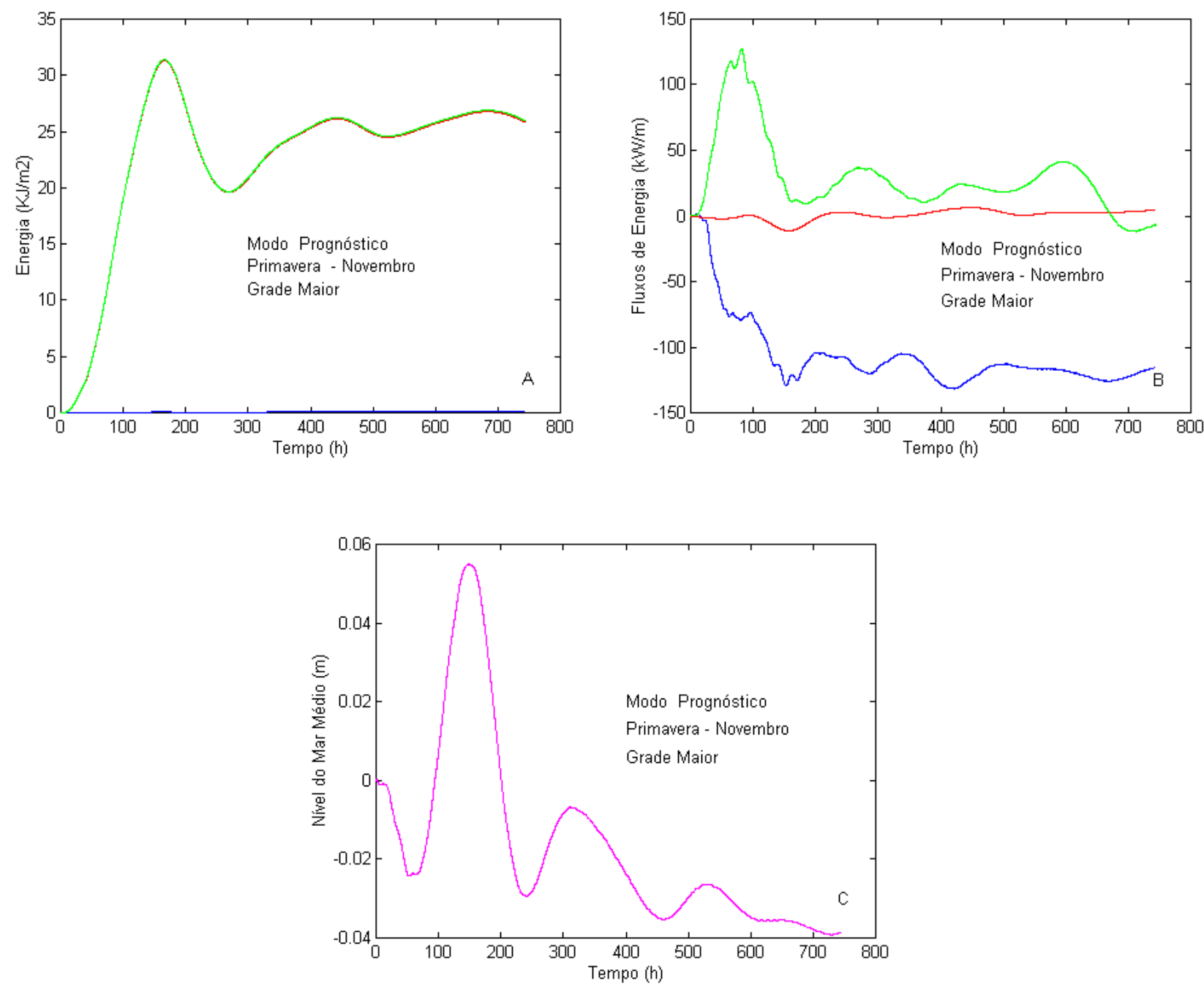

Figura 34: Curvas de energia mecânica (A), fluxos nos contornos (B) e nível do mar médio (C) na grade maior, sendo em (A), o verde, a energia mecânica, o vermelho, a energia cinética e o azul, a energia potencial. Em (B), o azul representa o fluxo através do contorno norte, o vermelho, o fluxo através do contorno sul e o verde, o fluxo através do contorno leste. Simulação de primavera - novembro. 

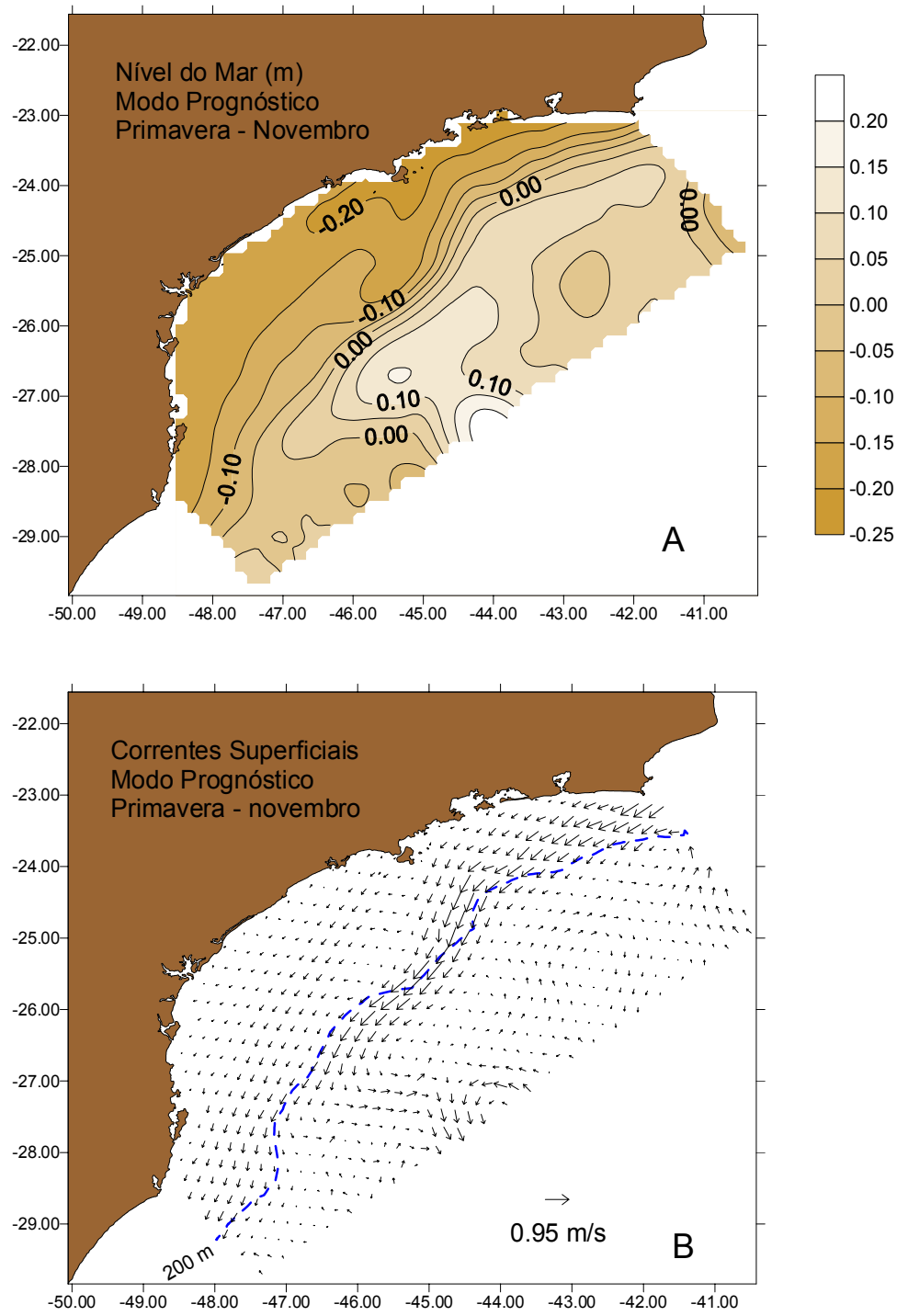

Figura 35: Nível do Mar (A) e Correntes Superficiais (B) na Plataforma Continental Sudeste. Simulação de primavera - novembro. 

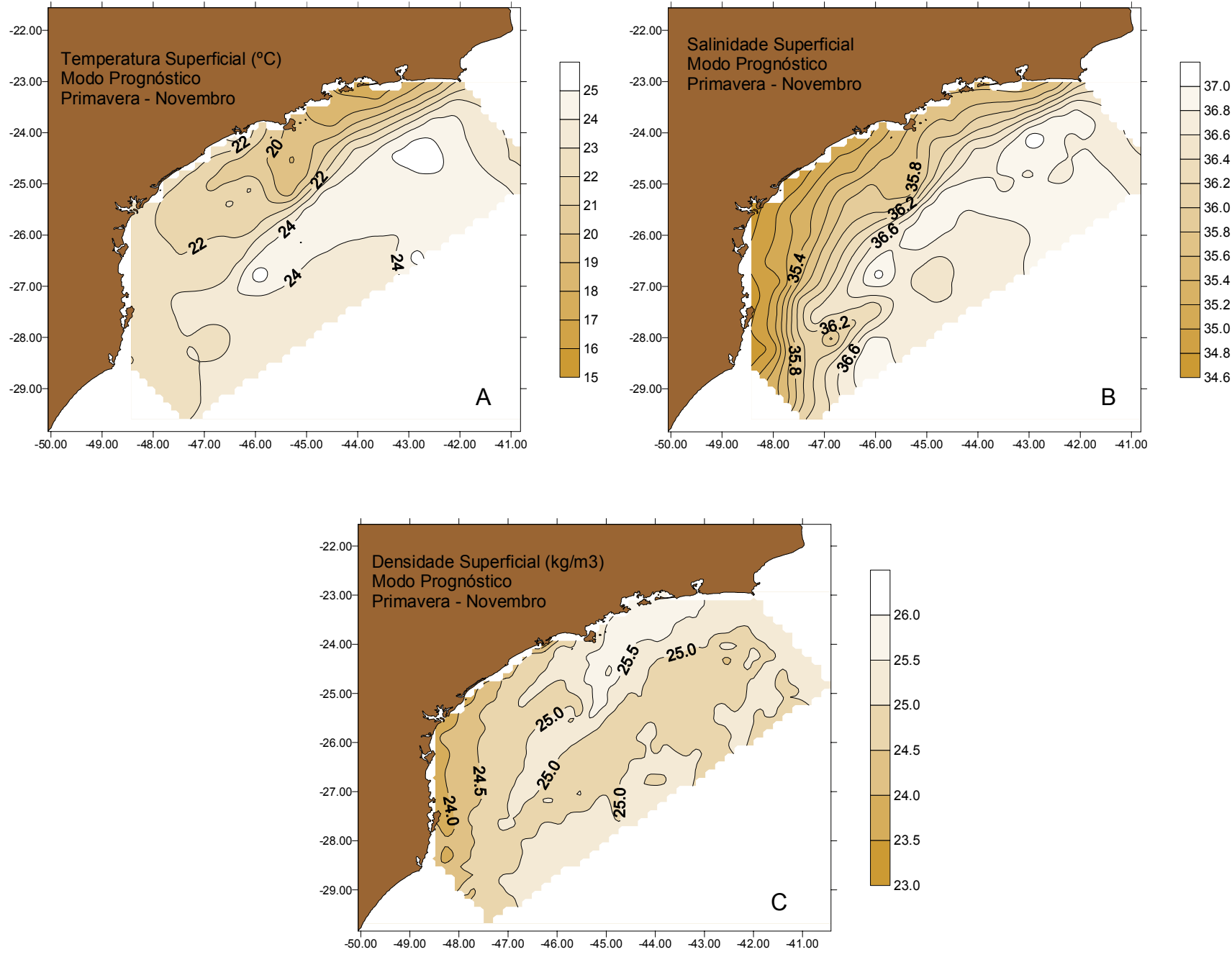

Figura 36: Distribuição horizontal da temperatura (A), da salinidade (B) e da densidade convencional (C) na Plataforma Continental Sudeste. Simulação de primavera - novembro. 

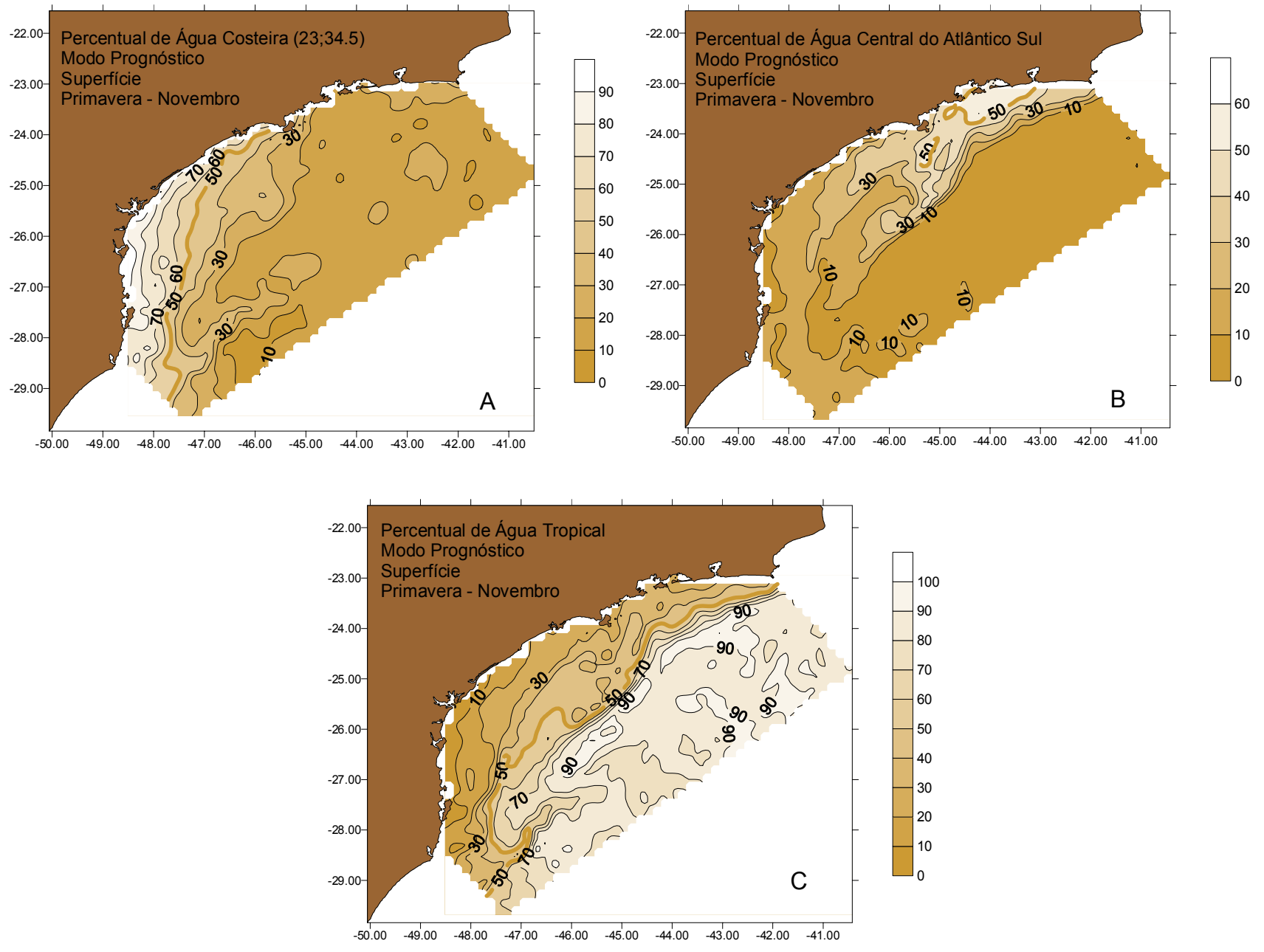

Figura 37: Distribuição horizontal dos percentuais das massas de Água Costeira (A), Água Central do Atlântico Sul (B) e da Água Tropical (C) na Plataforma Continental Sudeste. Simulação de primavera - novembro. 

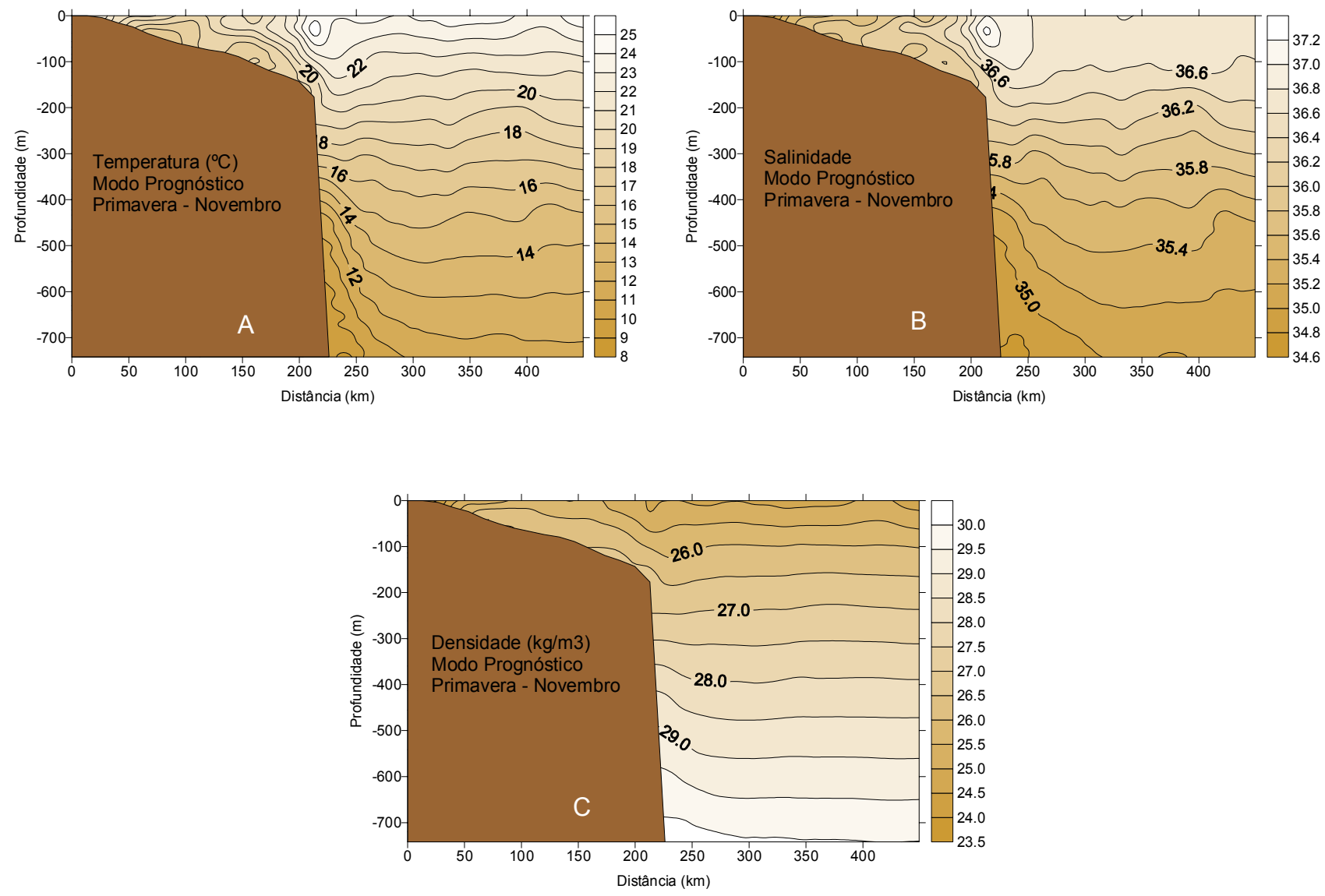

Figura 38: Distribuição vertical da temperatura (A), da salinidade (B) e da densidade convencional (C) na Plataforma Continental Sudeste ao sul do Canal de São Sebastião. Simulação de primavera - novembro. 

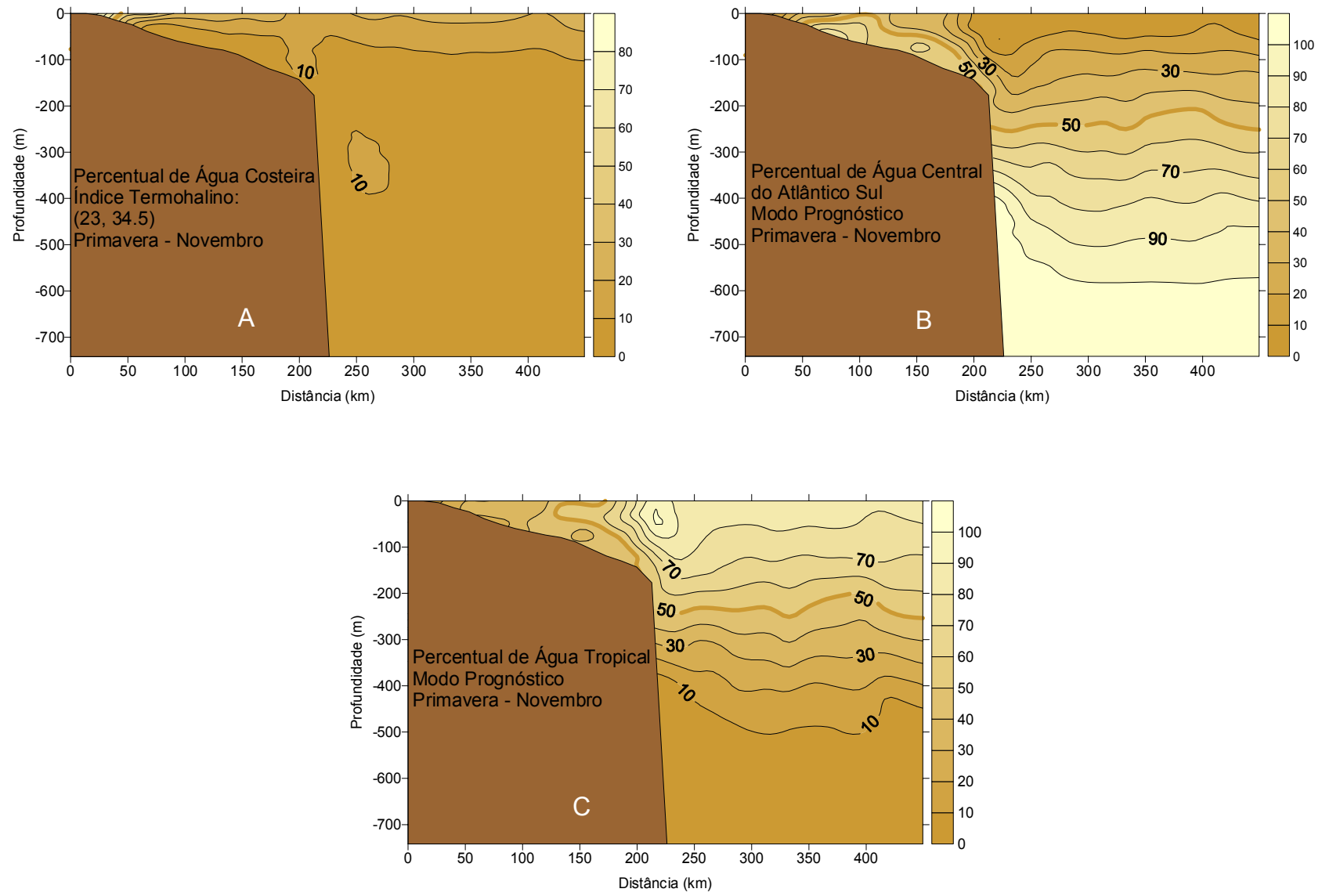

Figura 39: Distribuição vertical dos percentuais das massas de Água Costeira (A), da Água Central do Atlântico Sul (B) e da Água Tropical (C) na Plataforma Continental Sudeste ao sul do Canal de São Sebastião. Simulação de primavera - novembro. 

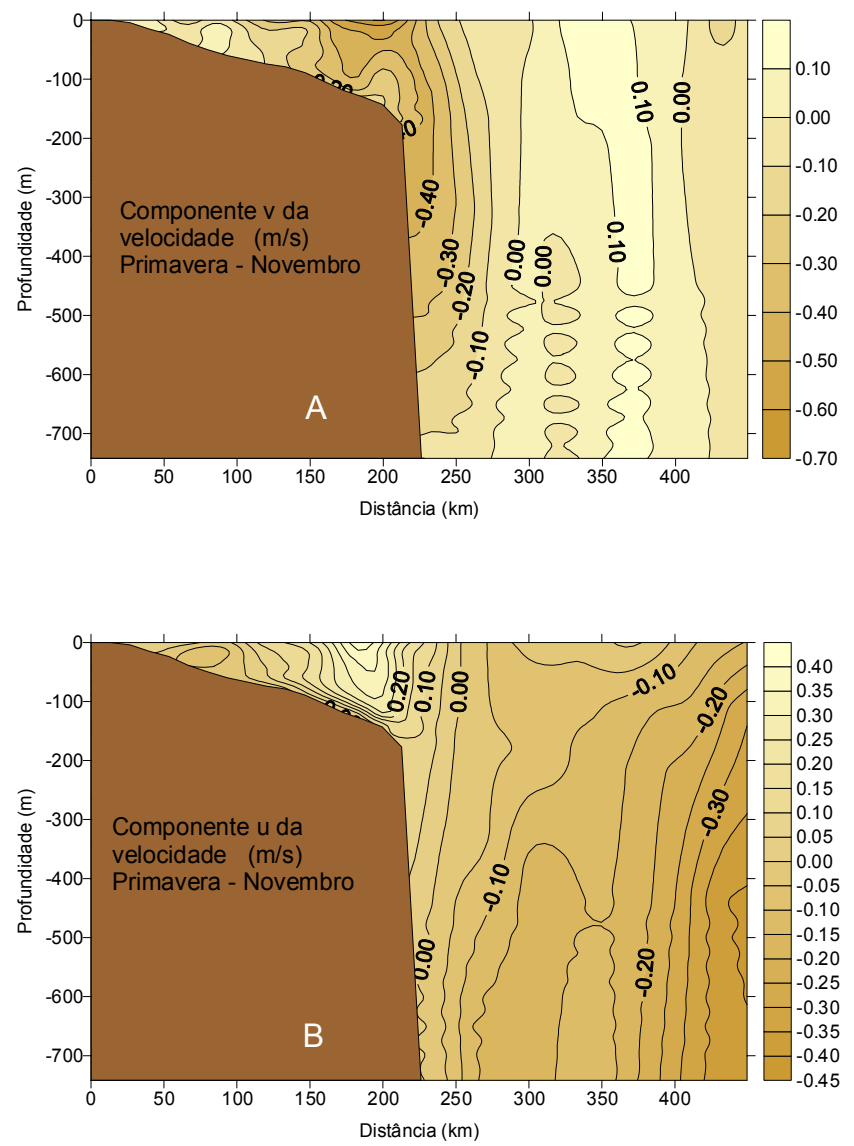

Figura 40: Distribuição vertical dos componentes de velocidade paralelo (A) e transversal (B) à costa na Plataforma Continental Sudeste ao sul do Canal de São Sebastião. Simulação de primavera - novembro. 


\subsubsection{A Plataforma Continental Interna}

A Fig. 41 A,B,C apresenta as curvas de energia mecânica, de fluxos de energia nos contornos e do nível do mar médio. Os níveis de energia mecânica em modo prognóstico são bem maiores do que aqueles encontrados em modo barotrópico e em relação às grades, estes são muito menores do que aqueles obtidos na grade da PCSE. A energia potencial e a energia cinética colaboram igualmente para a energia mecânica. Os fluxos de energia através dos contornos são todos positivos, isto é, fluindo para fora do domínio pelo contorno norte, para dentro do domínio através do contorno sul e para fora do domínio através do contorno leste. O fluxo através do contorno sul tem a maior parte do tempo maior intensidade do que aqueles através dos outros contornos. O nível do mar médio na PCI fica em -0,02 m após 720 horas de integração, metade do valor encontrado para a PCSE.

O nível do mar ao norte (Fig. 42A) varia entre $-0,22 \mathrm{~m}$ na costa e $-0,15 \mathrm{~m}$ ao largo. Ao sul da ISS tem-se gradientes mais acentuados com $-0,21 \mathrm{~m}$ na costa e $-0,15 \mathrm{~m}$ ao largo. Percebemos continuidade hidrodinâmica entre as grades se compararmos esta figura com a correspondente na PCSE (Fig. 35A).

A Fig. 42B apresenta as correntes superficiais. As correntes se intensificam quando contornam o leste da Ilha de São Sebastião (ISS) ocorrendo também uma intensificação no norte do domínio. As correntes são preponderantemente para sudoeste e fluem ao longo das isolinhas de nível do mar. Percebe-se também uma região de sombra a sudoeste da ISS.

Os perfis horizontais superficiais de temperatura, salinidade e densidade encontram-se na Fig. 43 A,B,C. As temperaturas na PCI (Fig. $43 \mathrm{~A}$ ) variam entre $17^{\circ} \mathrm{C}$ no norte até $22,5^{\circ} \mathrm{C}$ ao sul. Uma forte variação de temperatura se estabelece ao sul da ISS paralelamente à costa acompanhada de forte variação de salinidade (Fig. 43B). O mesmo se observa ao examinarmos a distribuição horizontal superficial de densidade (Fig. 43C). As salinidades na PCI variam entre 35,5 na costa até 36,0 mais ao largo. O máximo de densidade encontra-se ao norte $\left(26 \mathrm{~kg} / \mathrm{m}^{3}\right)$, associado ao mínimo de temperatura e, o mínimo de densidade $\left(24,6 \mathrm{~kg} / \mathrm{m}^{3}\right)$, associado ao máximo de temperatura, está ao largo. 
A distribuição horizontal superficial de percentuais de massas de água (Fig. 44 $\mathrm{A}, \mathrm{B}, \mathrm{C})$ mostra que a superfície é praticamente toda tomada pela $\mathrm{AC}$ a não ser por uma região pequena no norte onde encontramos vestígios da ACAS. Nenhum sinal da AT é encontrado.

Observam-se os perfis verticais de temperatura, salinidade e densidade na Fig. 45 A,B,C. Uma frente térmica é observada a aproximadamente $40 \mathrm{~km}$ da costa e as isotermas menores do que $18^{\circ} \mathrm{C}$ tem inclinação ascendente para a superfície. Fica sugerido pela comparação desta figura com a Fig. 10A (a qual apresenta o campo inicial de temperatura para esta estação do ano), a ação do vento através do transporte de Ekman. A mesma observação faz-se para o perfil vertical de salinidade (Fig. 45B). Uma frente halina também é observada no local onde é identificada a frente térmica e ao largo desta um núcleo de salinidades maiores de 36 se apresenta em $40 \mathrm{~m}$ de profundidade a $75 \mathrm{~km}$ aproximadamente. Frentes halinas e núcleos de salinidade maiores de 36 em sub-superfície foram apresentadas por Castro (1996) analisando dados hidrográficos coletados ao norte da ISS. O campo de densidade tem configuração bastante semelhante ao da temperatura apresentando um mínimo na superfície e ao largo de $24,8 \mathrm{~kg} / \mathrm{m}^{3}$ e um máximo no fundo $\left(26,8 \mathrm{~kg} / \mathrm{m}^{3}\right)$ o qual está associado ao mínimo de temperatura lá localizado $\left(14^{\circ} \mathrm{C}\right)$.

Os perfis verticais dos percentuais de massas de água (Fig. 46 A,B,C) mostram que a AC ocupa os primeiros metros da coluna de água até uns $20 \mathrm{~km}$ da costa aprofundando-se para o largo. Nesses primeiros $20 \mathrm{~km}$ da costa a AC delimita-se com a ACAS no fundo. Ao núcleo de alta salinidade observada na Fig. 45B está associado o percentual de $35 \%$ de AT.

Nos perfis verticais das componentes de velocidade paralela (v) e perpendicular $(\mathrm{u})$ à costa (Fig. $47 \mathrm{~A}, \mathrm{~B})$ confirma-se a intensificação das correntes ao redor da ISS onde percebemos que nas proximidades do lado leste da ISS as correntes fluem para sul e para oeste. As correntes fluem para norte abaixo de $10 \mathrm{~m}$ de profundidade a leste da ISS assim como na região mais costeira. 

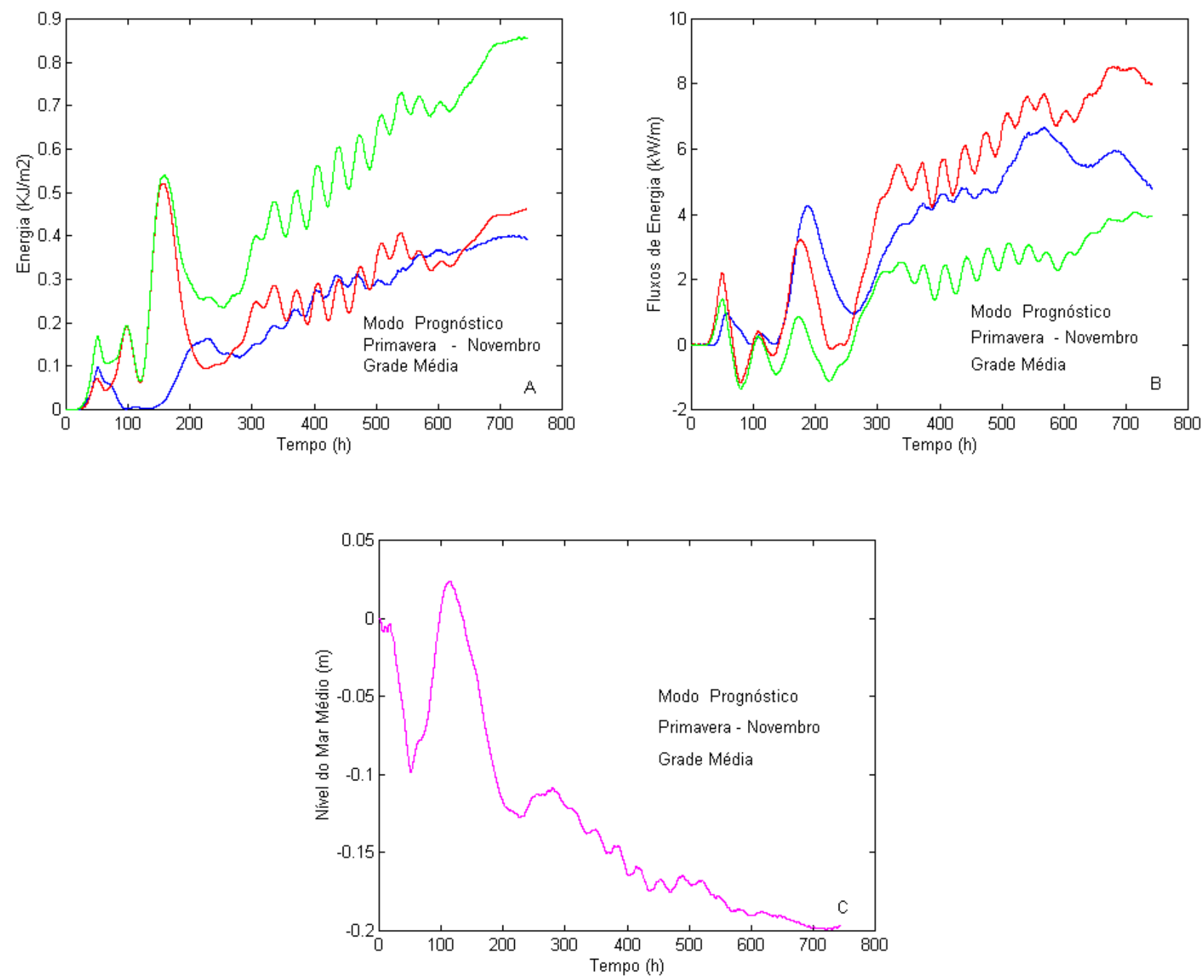

Figura 41: Curvas de energia mecânica (A), fluxos nos contornos (B) e nível do mar médio (C) na PCI , sendo em (A), o verde, a energia mecânica, o vermelho, a energia cinética e o azul, a energia potencial. Em (B), o azul representa o fluxo através do contorno norte, o vermelho, o fluxo através do contorno sul e o verde, o fluxo através do contorno leste. Simulação de primavera - novembro. 

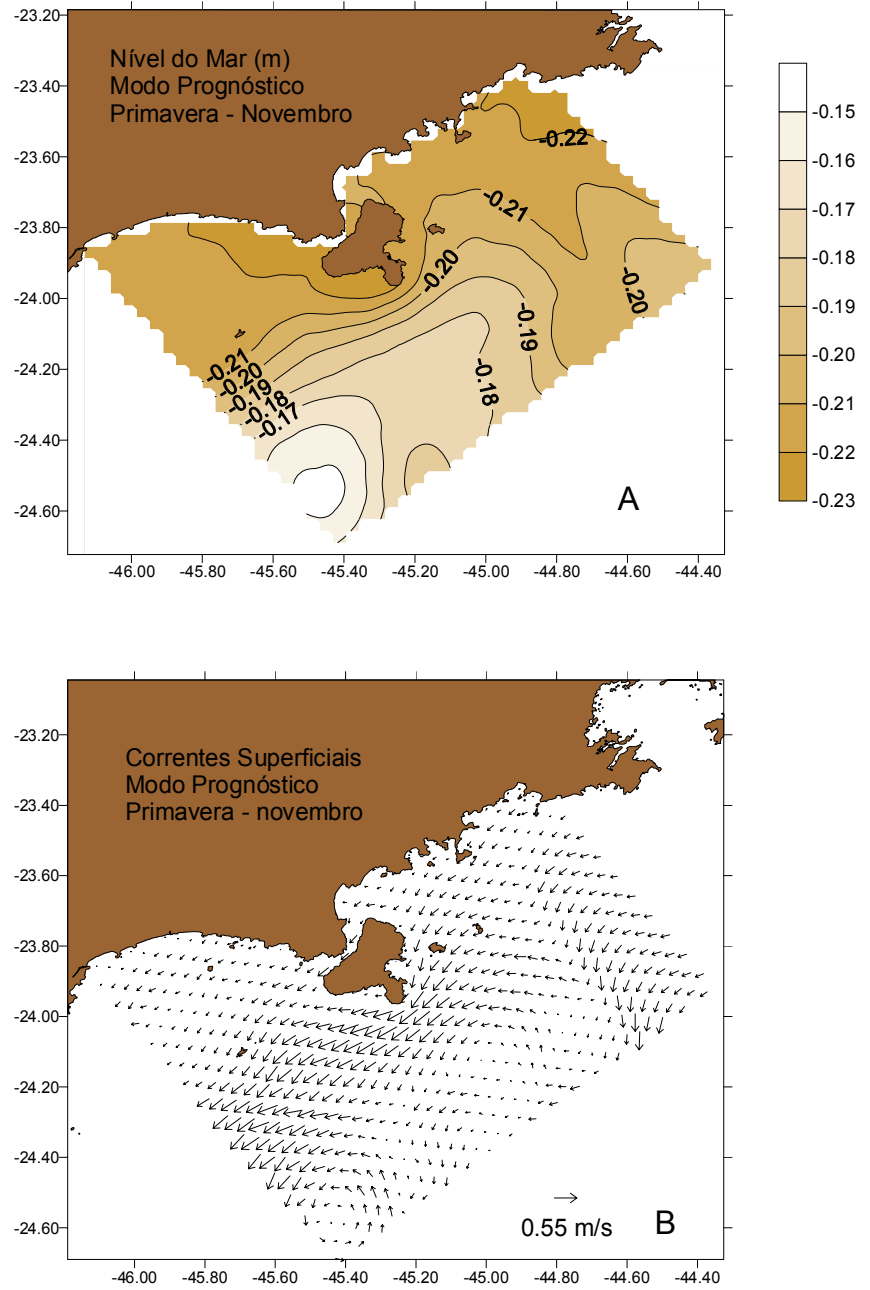

Figura 42: Nível do Mar (A) e Correntes superficiais (B) na PCI. Simulação de primavera - novembro. 

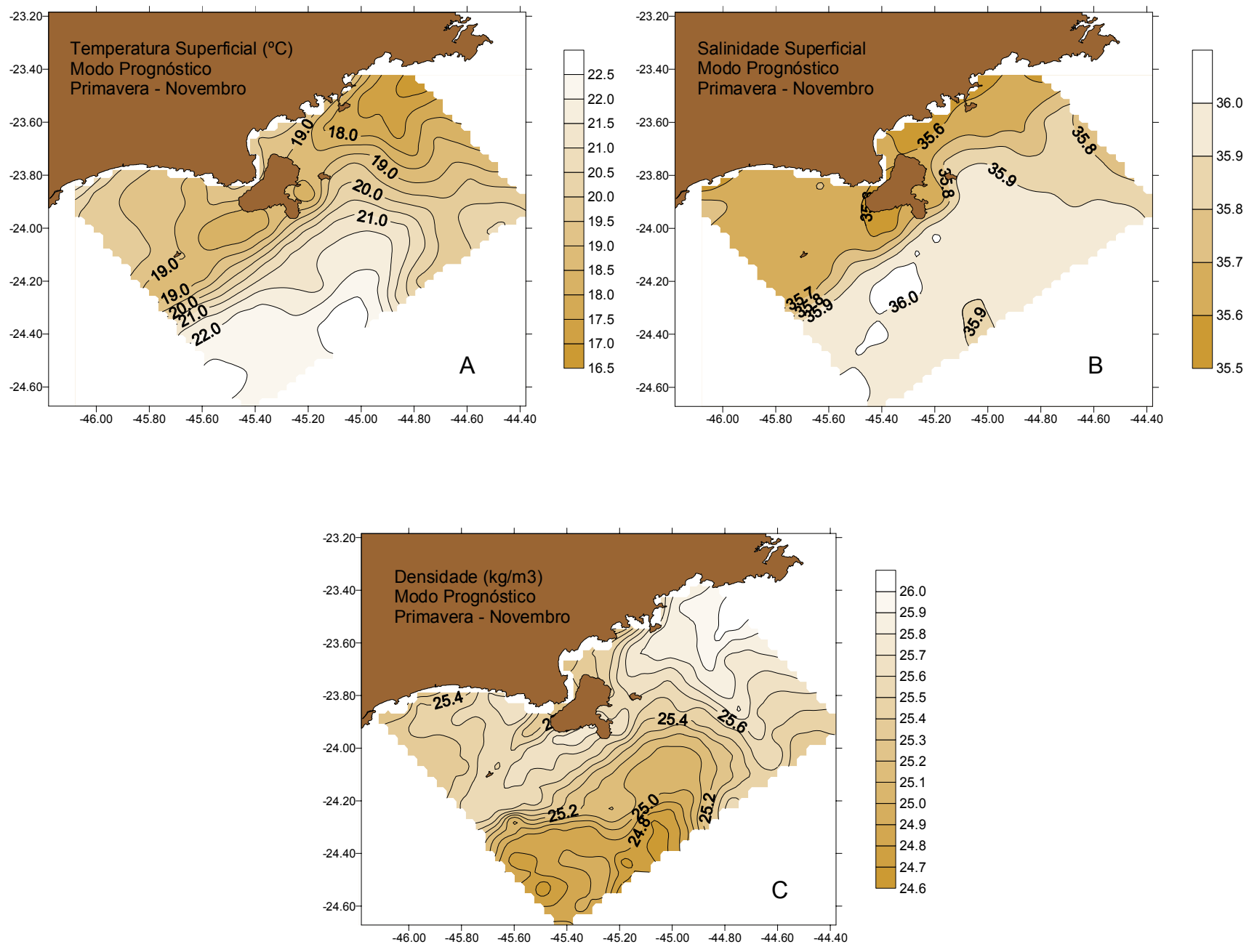

Figura 43: Distribuição horizontal superficial da temperatura (A), da salinidade (B) e da densidade convencional (C) na PCI. Simulação de primavera - novembro. 

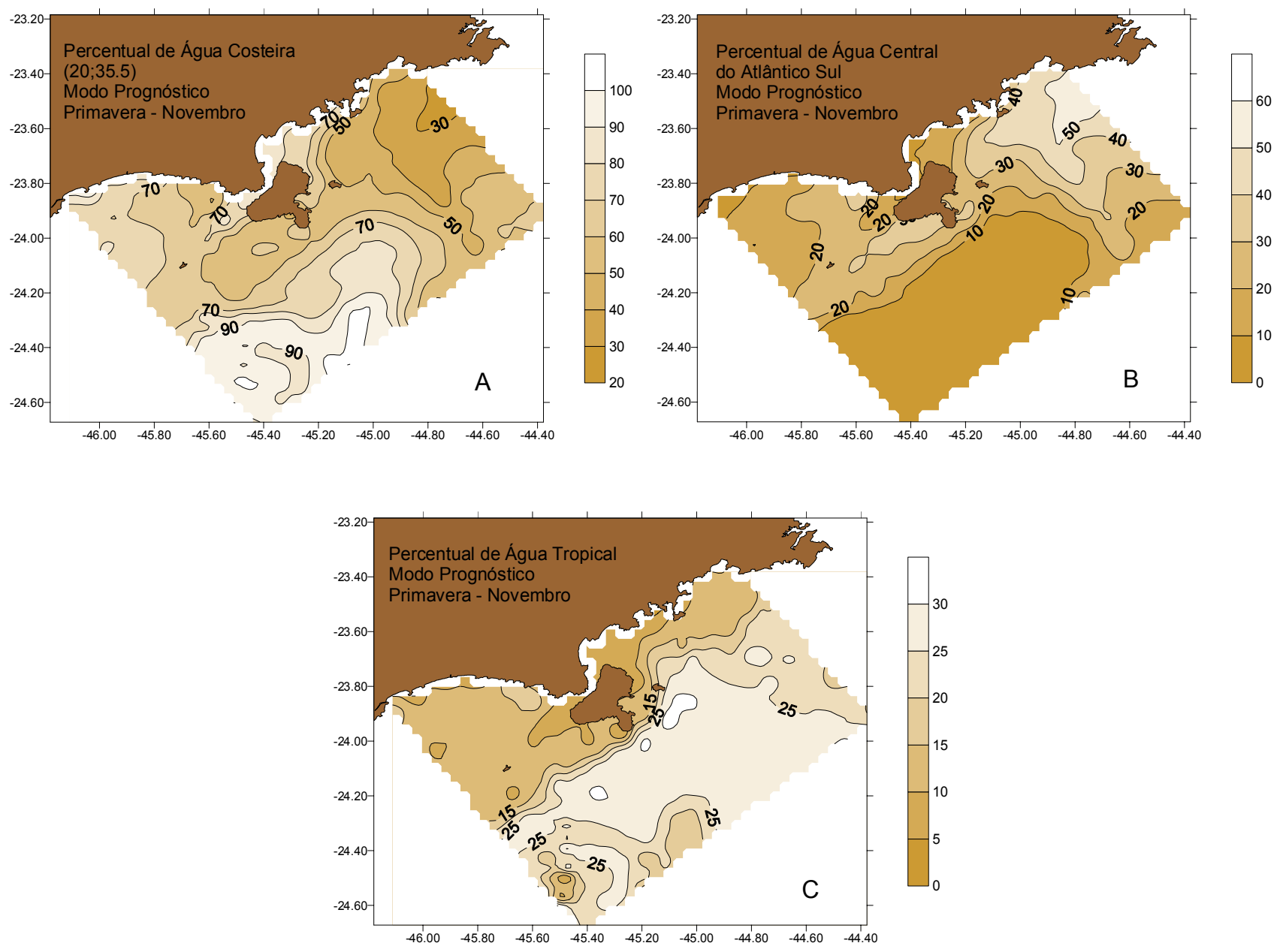

Figura 44: Distribuição horizontal superficial dos percentuais das massas de Água Costeira (A), Água Central do Atlântico Sul e da Água Tropical na PCI. Simulação de primavera novembro. 

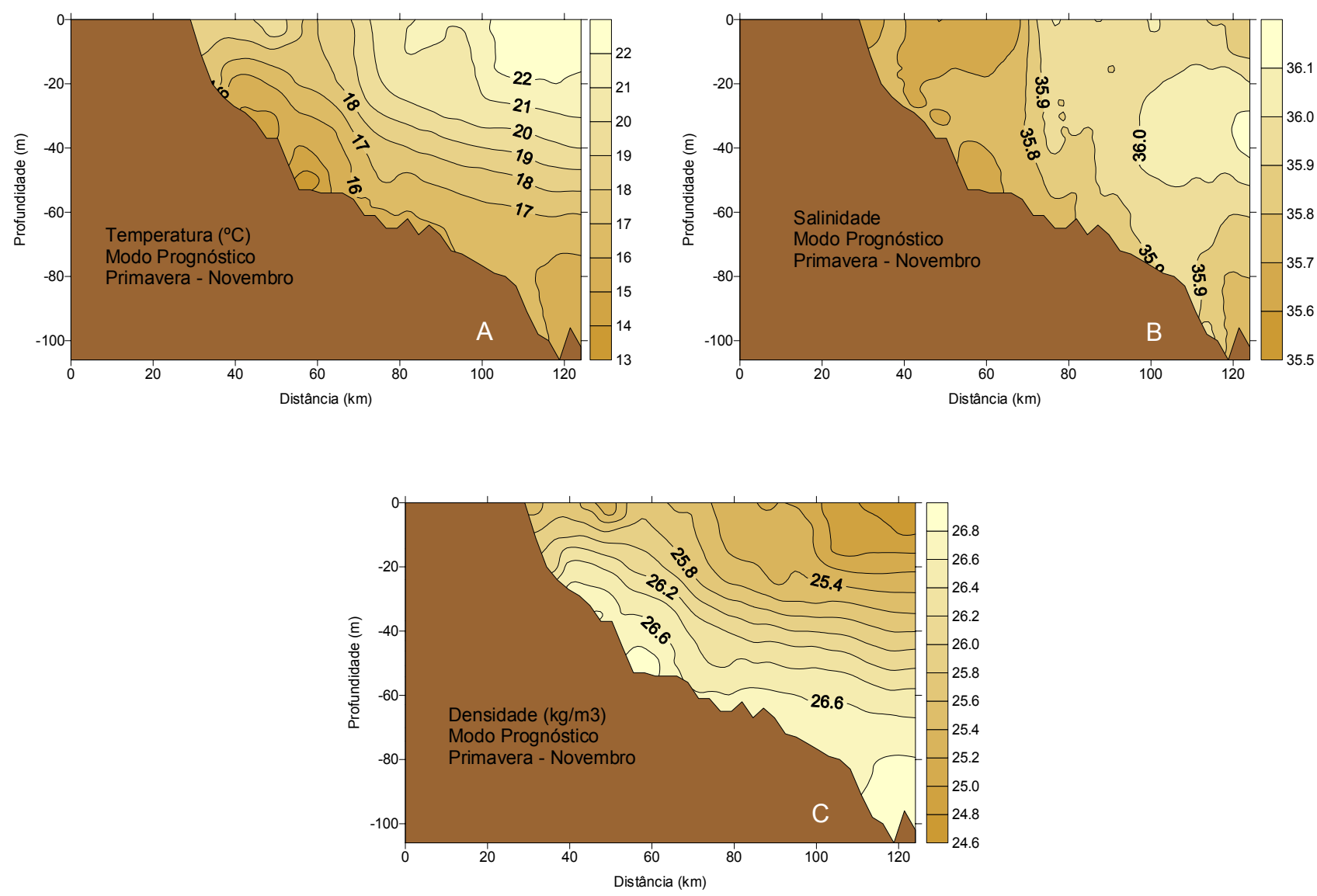

Figura 45: Distribuição vertical da temperatura (A), da salinidade (B) e da densidade convencional na PCI ao sul do Canal de São Sebastião. Simulação de primavera - novembro. 

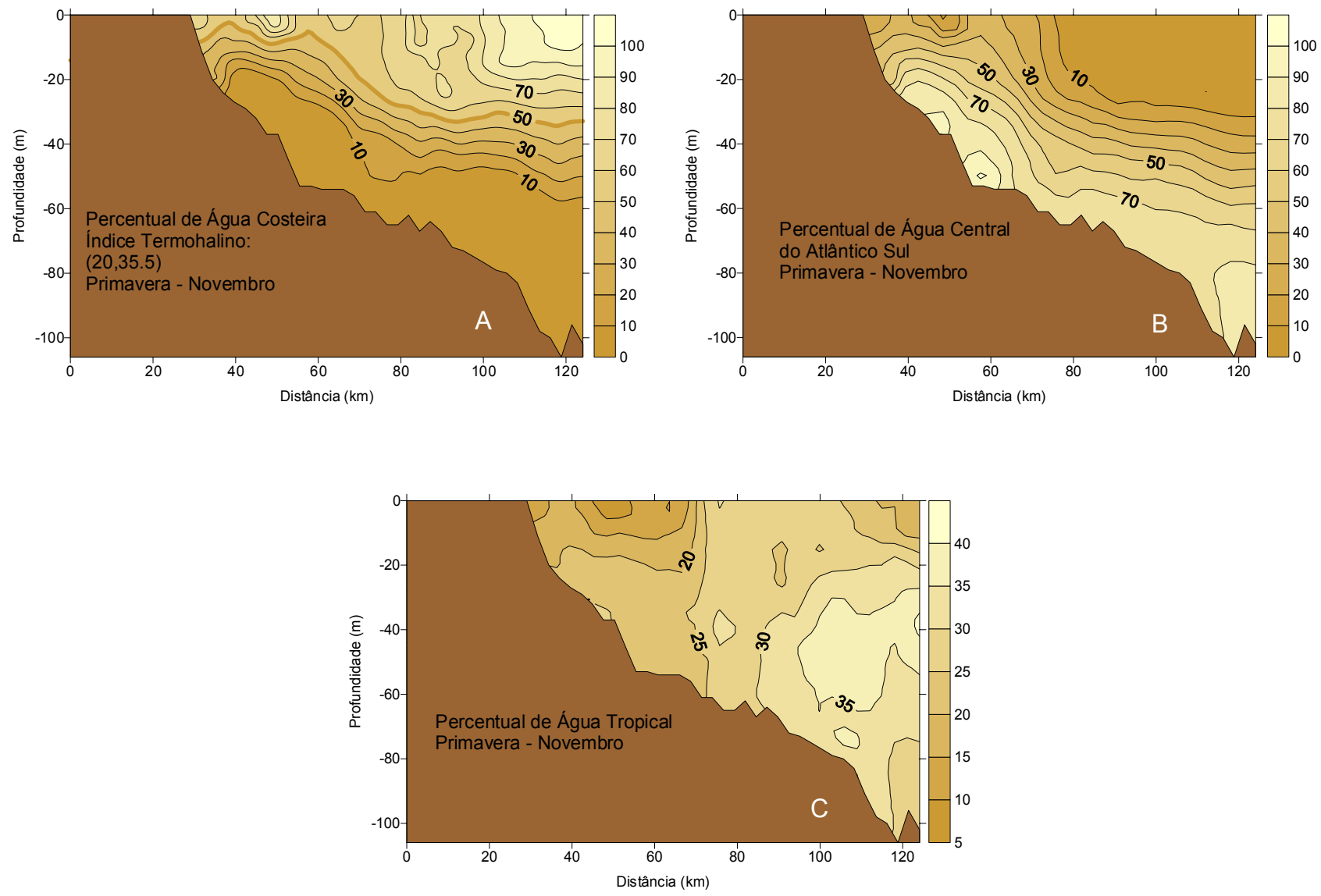

Figura 46: Distribuição vertical dos percentuais das massas de Água Costeira (A), da Água Central do Atlântico Sul (B) e da Água Tropical (C) na PCI ao sul do Canal de São Sebastião. 

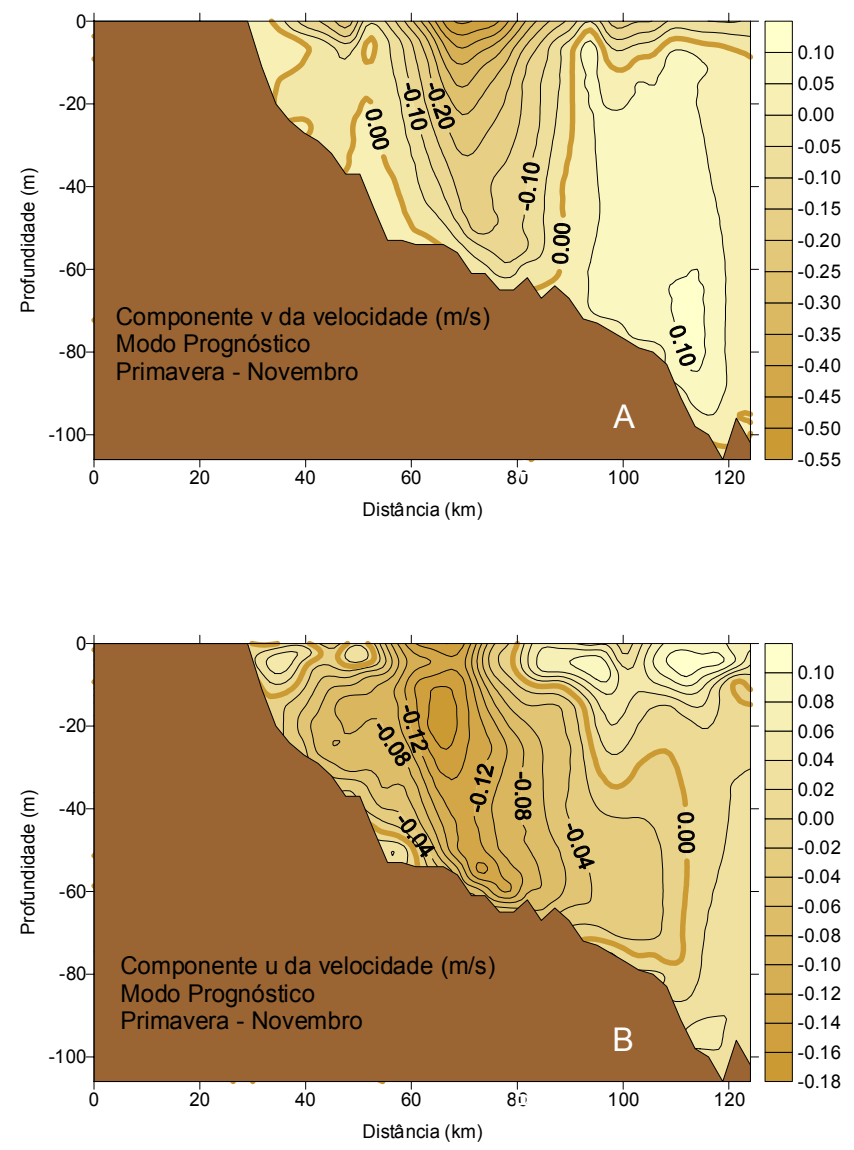

Figura 47: Distribuição vertical das componentes paralela $(\mathrm{A})$ e transversal $(\mathrm{B})$ à costa na PCI ao sul do Canal de São Sebastião. Simulação de primavera - novembro. 


\subsubsection{O Canal de São Sebastião}

A Fig. 48 A,B,C apresenta as curvas de energia mecânica, fluxos de energia nos contornos e nível do mar médio. Os níveis de energia mecânica são menores do que os da PCI, porém a energia potencial contribui mais para a energia mecânica do que a energia cinética. O nível do fluxo de energia através do contorno leste é maior do que os dos outros contornos e o nível do mar médio após 720 h de integração é de $-0,23 \mathrm{~m}$ aproximadamente. Interessante observar a semelhança da configuração desta curva com sua análoga para a grade da PCI. As duas curvas em fase indicam um aninhamento efetivo entre as grades numéricas.

O nível do mar no CSS (Fig. 49A), varia entre - 0,219 m no norte, lado oeste, e $-0,232$ no sul, também do lado oeste. O nível do mar mais alto no norte do lado do continente também foi observado em modo barotrópico. Percebe-se também com relação a este perfil horizontal do nível do mar, comparando-o com o seu análogo para a PCI, a continuidade hidrodinâmica que o aninhamento estabelece.

As correntes superficiais (Fig. 49B) fluem para sudoeste com intensificação no estreito do canal, sendo que as velocidades chegam a $0,45 \mathrm{~m} / \mathrm{s}$. Em modo barotrópico, embora as correntes fluam também neste sentido, elas tem intensidades bem menores (máximo de $0,03 \mathrm{~m} / \mathrm{s}$ ).

As temperaturas superficiais (Fig. $50 \mathrm{~A}$ ) variam entre $17^{\circ} \mathrm{C}$ e $21^{\circ} \mathrm{C}$, sendo as maiores encontradas no norte do canal, do lado oeste e as menores estão no sul, também do lado oeste. O mínimo de temperatura superficial na entrada sul do canal no lado oeste foi encontrado em diversos cruzeiros de primavera e verão (Coelho, 1997; Silva, 1995a), e confirmado na climatologia de Leandro (1999). As salinidades (Fig. 50B) variam entre 35,3 e 35,6. As maiores salinidades estão no sul do CSS, no lado oeste e as menores estão no norte do domínio, do lado oeste. Nos locais onde ocorrem as menores temperaturas e as menores salinidades, encontram-se os maiores gradientes de densidade (Fig. 50C). As densidades variam entre 24,6 e $25,8 \mathrm{~kg} / \mathrm{m}^{3}$.

O perfil vertical da temperatura nas seções A, B, C e D pode ser visto na Fig. 51. As temperaturas variam de $19,5^{\circ} \mathrm{C}$ na superfície até $13,5^{\circ} \mathrm{C}$ no fundo, junto à seção A. A temperatura se eleva tanto em superfície como no fundo entre a seção A até D, conforme o que se observa junto à distribuição horizontal desta propriedade. Podemos observar na Fig. 52, os perfis verticais de salinidade junto às seções A, B, C e D. As 
salinidades variam de 35,55 na superfície até 35,7 no fundo, junto à seção A. Esses valores não se alteram muito nas outras seções, contudo observamos que da seção A até a seção D tanto salinidades superficiais como de fundo diminuem ligeiramente. Os perfis verticais da densidade convencional (sigma-stp) podem ser observados na Fig. 53. As maiores densidades encontram-se no fundo da seção A, do lado da ISS e as menores densidades são observadas na superfície em todas as seções.

A Fig. 54 A,B,C mostra como varia longitudinalmente a temperatura, a salinidade e a densidade no CSS. Os maiores gradientes destas propriedades são observados no sul (Fig. 54A), onde encontramos temperaturas menores do que $15^{\circ} \mathrm{C}$ na forma de uma frente térmica. Neste mesmo local, encontram-se as maiores salinidades $(35,65)$. As salinidades diminuem dos extremos para o centro do canal e aumentam da superfície para o fundo. A configuração das isopicnais é muito aproximada à das isotermas, estando seu máximo no fundo da entrada sul do canal $\left(27 \mathrm{~kg} / \mathrm{m}^{3}\right)$ e o mínimo na superfície $\left(25,2 \mathrm{~kg} / \mathrm{m}^{3}\right)$. A análise percentual de massas de água (Fig. $55 \mathrm{~A}, \mathrm{~B}, \mathrm{C}$ ) mostra que a $\mathrm{AC}$ se encontra na superfície até profundidades de $5 \mathrm{~m}$, ao sul, até $15 \mathrm{~m}$, ao norte. A ACAS encontra-se logo abaixo, sendo que percentuais de $90 \%$ encontramse no fundo, no sul do CSS. Não há vestígios da AT no canal, porém as isolinhas dos percentuais desta massa de água com máximo de $20 \%$, em muito se assemelha ao campo de salinidades.

A Fig. 56 A,B,C,D apresenta perfis verticais das componentes de velocidade paralela (v) e perpendicular (u) ao canal. As Figs. 56A e 56B mostram perfis em seções transversais ao passo que as Figs. 56C e 56D mostram perfis em seções longitudinais ao canal. Junto à seção $\mathrm{A}$ percebemos que na superfície e em todo lado oeste as correntes fluem para sudoeste sendo para nordeste no lado leste, contudo, as correntes superficiais para sudoeste são bem mais intensas do que aquelas para nordeste. Na superfície obtêm-se valores de $-0,30 \mathrm{~m} / \mathrm{s}$ para a componente v. A componente u tem valores máximos de $-0,15 \mathrm{~m} / \mathrm{s}$ e estão associados ao máximo positivo da componente $\mathrm{v}$, indicando que as águas que entram no CSS pelo fundo, fluem de leste. Nos cortes longitudinais vemos que a componente $\mathrm{v}$ (para sudoeste) se intensifica a partir da região central do canal em decorrência do estreitamento que aí ocorre. Percebemos que no sul e abaixo de $10 \mathrm{~m}$ de profundidade as correntes fluem para nordeste aprofundando-se em seu percurso. A componente u mostra que no sul do canal as correntes fluem para oeste. 

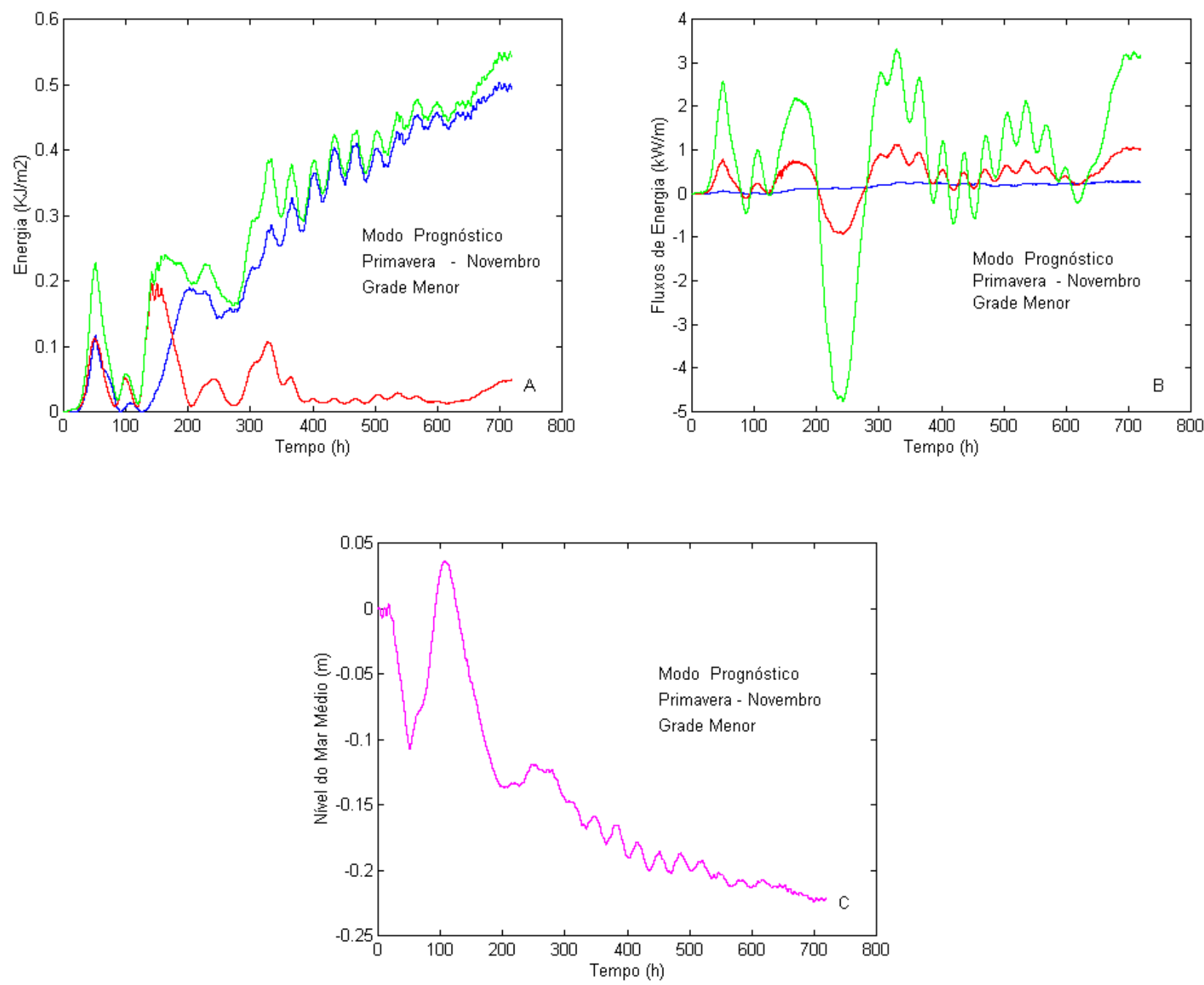

Figura 48: Curvas de energia mecânica (A), fluxos nos contornos (B) e nível do mar médio (C) no CSS, sendo em (A), o verde, a energia mecânica, o vermelho, a energia cinética e o azul, a energia potencial. Em (B), o azul representa o fluxo através do contorno norte, o vermelho, o fluxo através do contorno sul e o verde, o fluxo através do contorno leste. Modo Prognóstico. Simulação de primavera - novembro. 

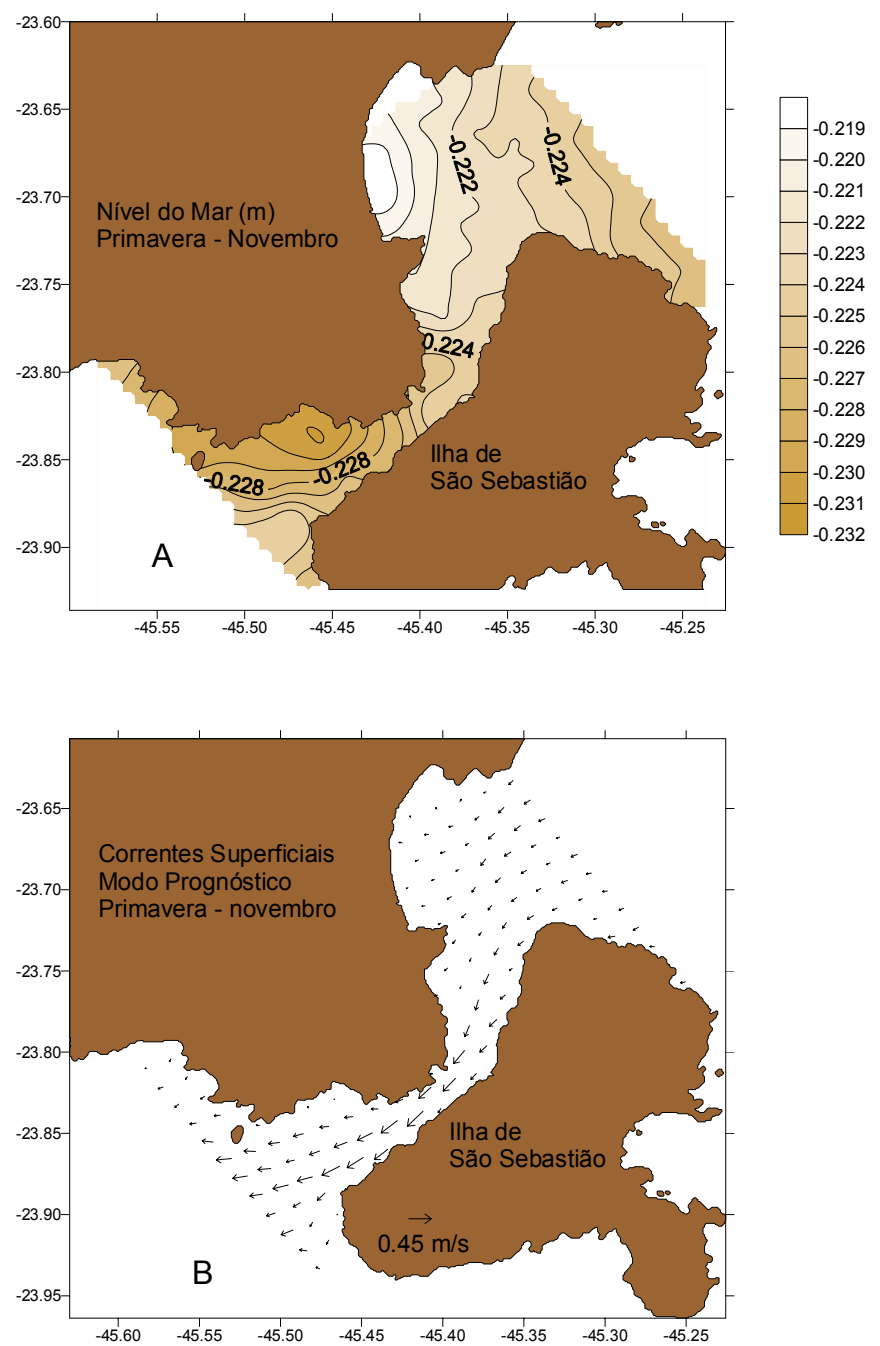

Figura 49: Nível do mar (A) e Correntes superficiais (B) no Canal de São Sebastião. Simulação de primavera - novembro. 

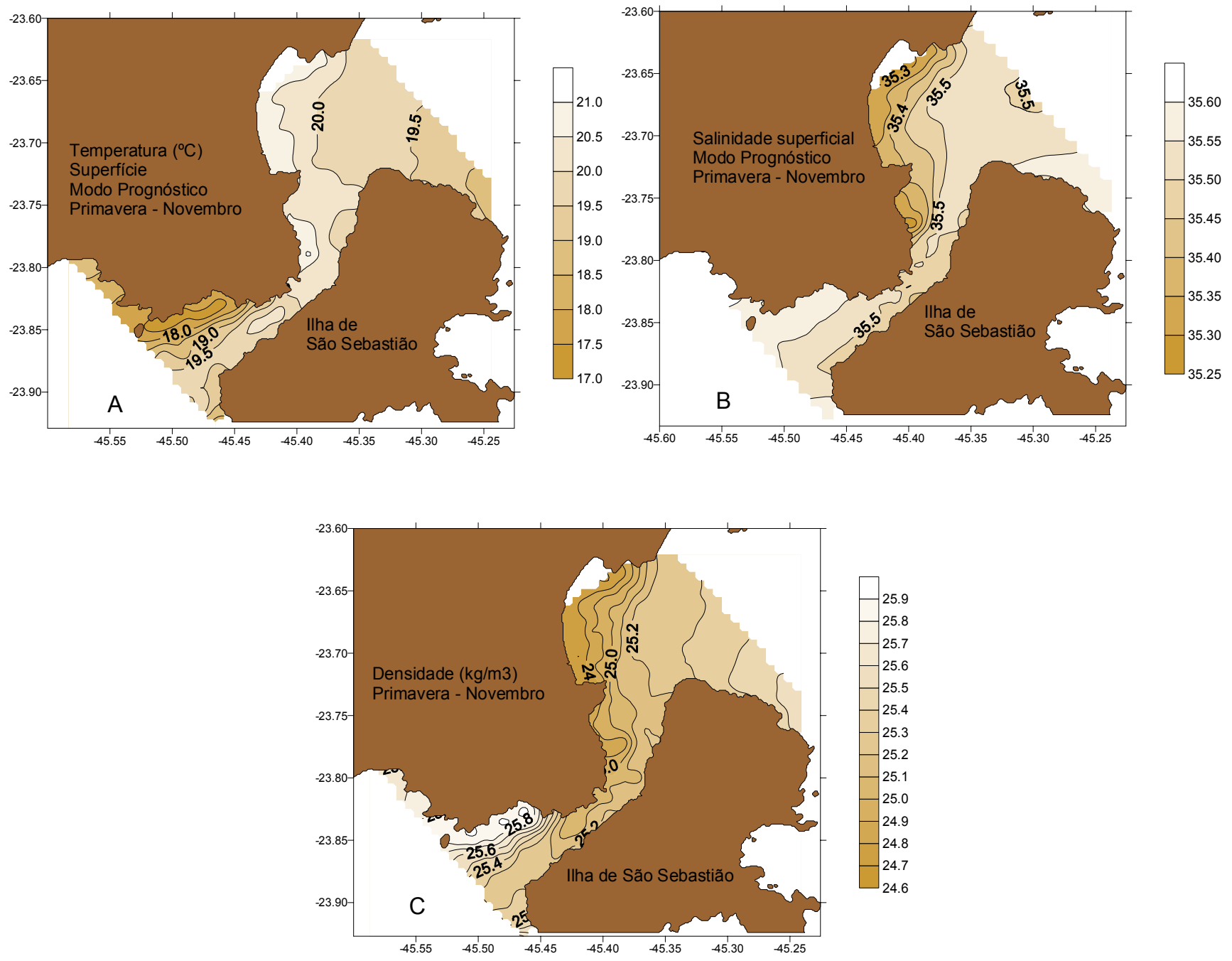

Figura 50: Distribuição horizontal superficial da temperatura (A), da salinidade (B) e da densidade convencional (C) no Canal de São Sebastião. Simulação de primavera - novembro. 

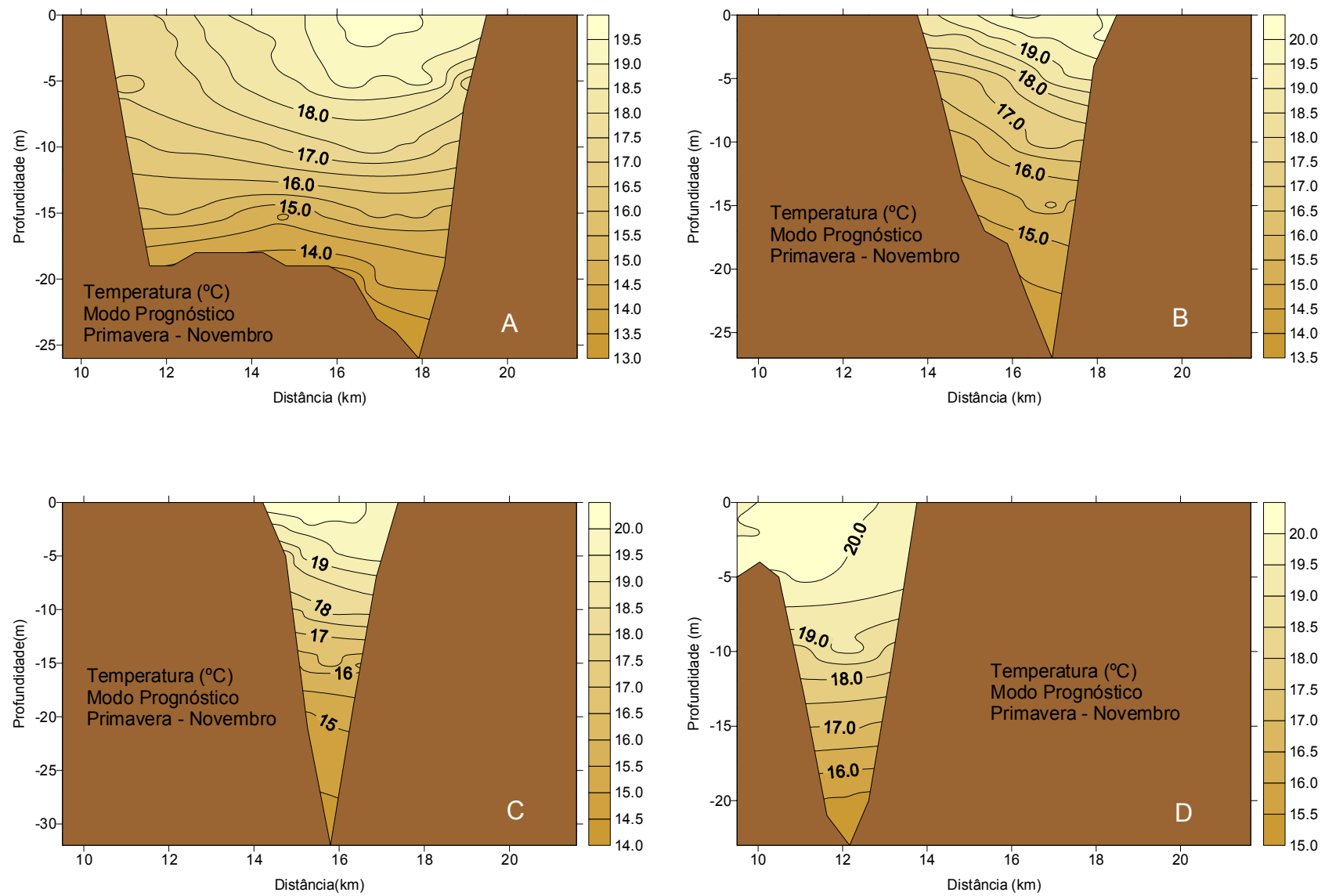

Figura 51: Distribuição vertical de temperatura nas seções A, B, C e D, localizadas na região interna do Canal de São Sebastião. Simulação de primavera - novembro. 

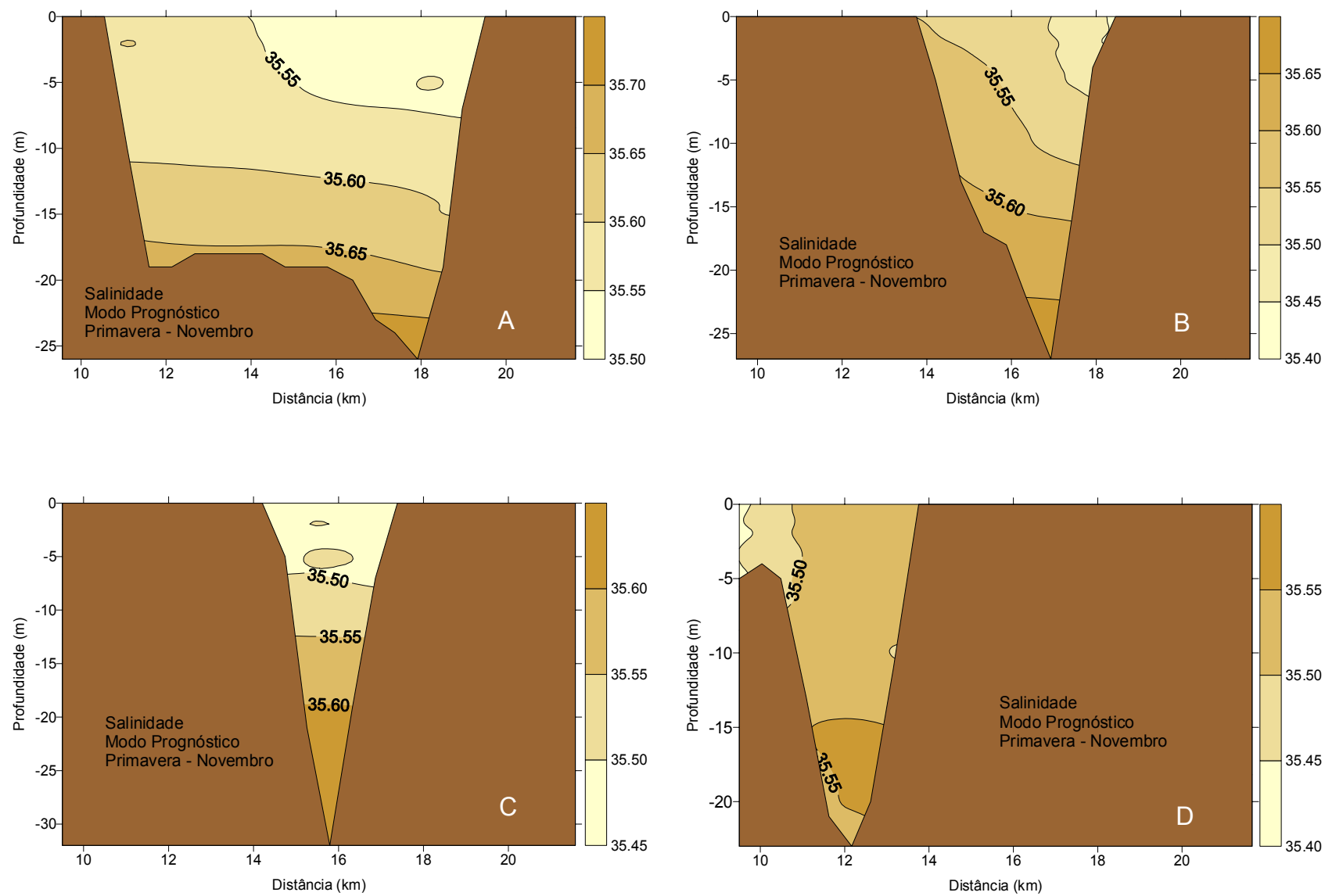

Figura 52: Distribuição vertical de salinidade nas seções A, B, C e D, localizadas na região interna do Canal de São Sebastião. Simulação de primavera - novembro. 

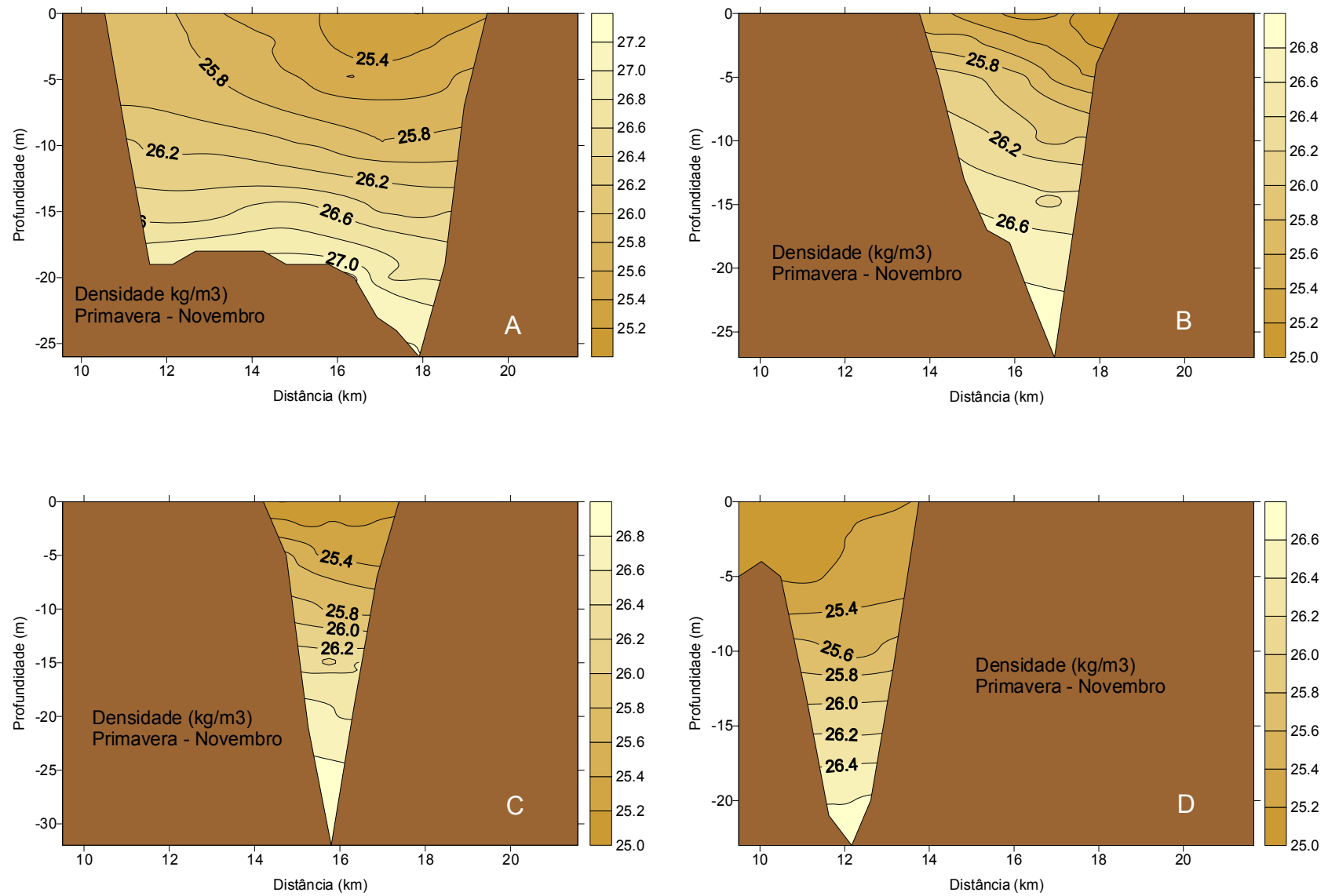

Figura 53: Distribuição vertical da densidade convencional nas seções A, B, C e D, localizadas na região interna do Canal de São Sebastião. Simulação de primavera - novembro. 

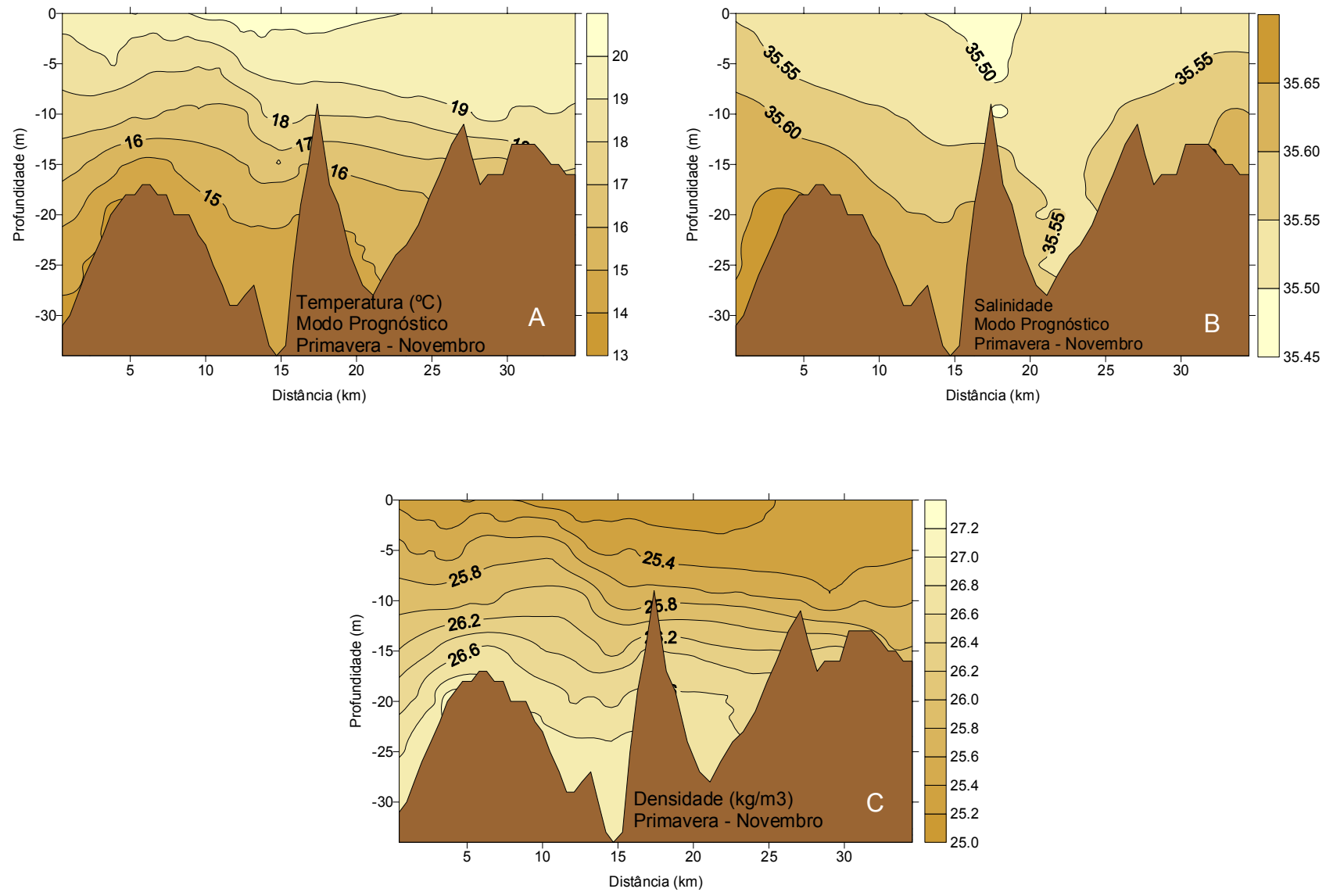

Figura 54: Distribuição vertical ao longo do Canal de São Sebastião das propriedades temperatura (A), salinidade (B) e densidade convencional (C). Simulação de primavera novembro. 

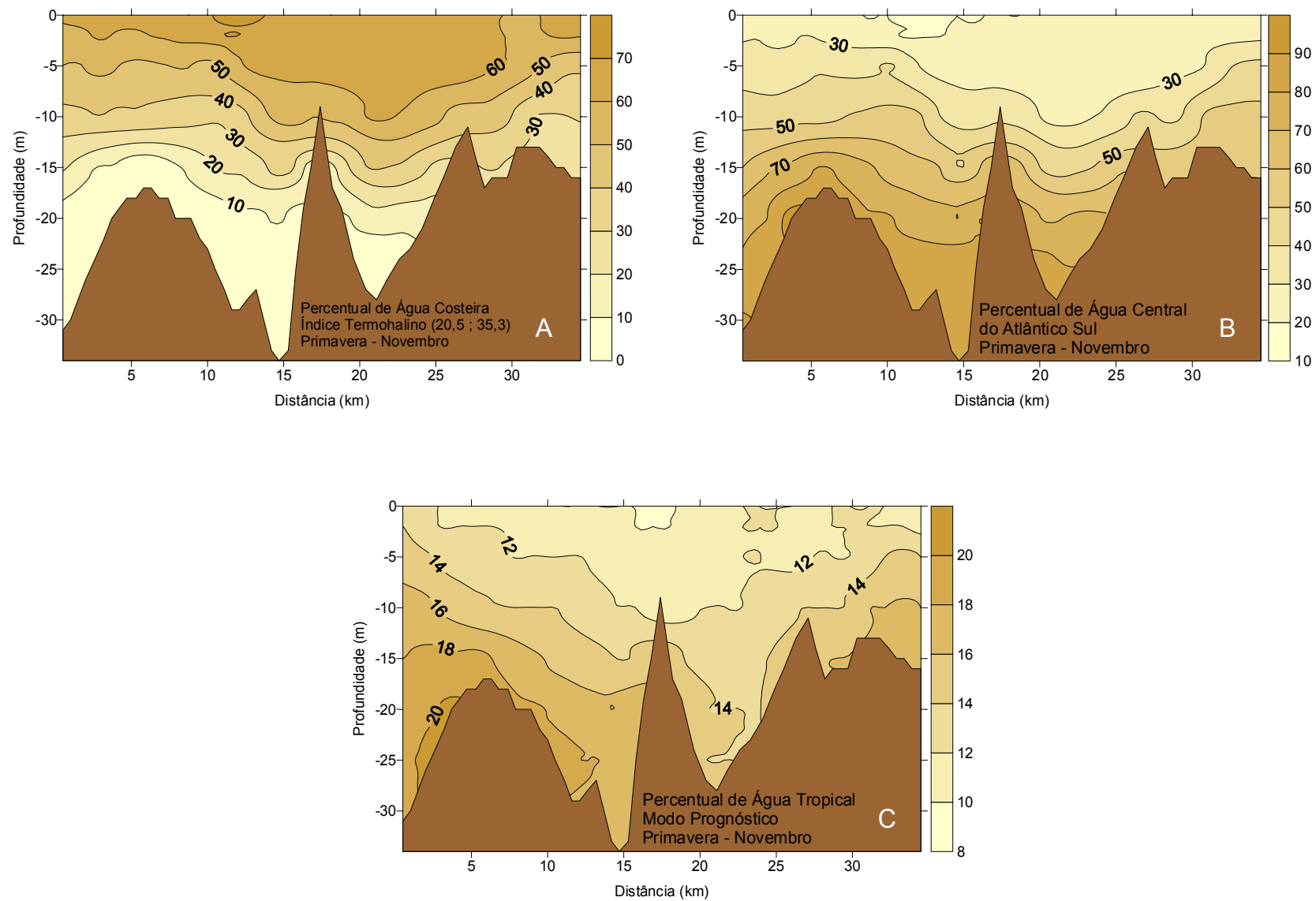

Figura 55: Distribuição vertical ao longo do Canal de São Sebastião dos percentuais das massas de Água Costeira (A), Água Central do Atlântico Sul (B) e Água Tropical (C). Simulação de primavera - novembro. 

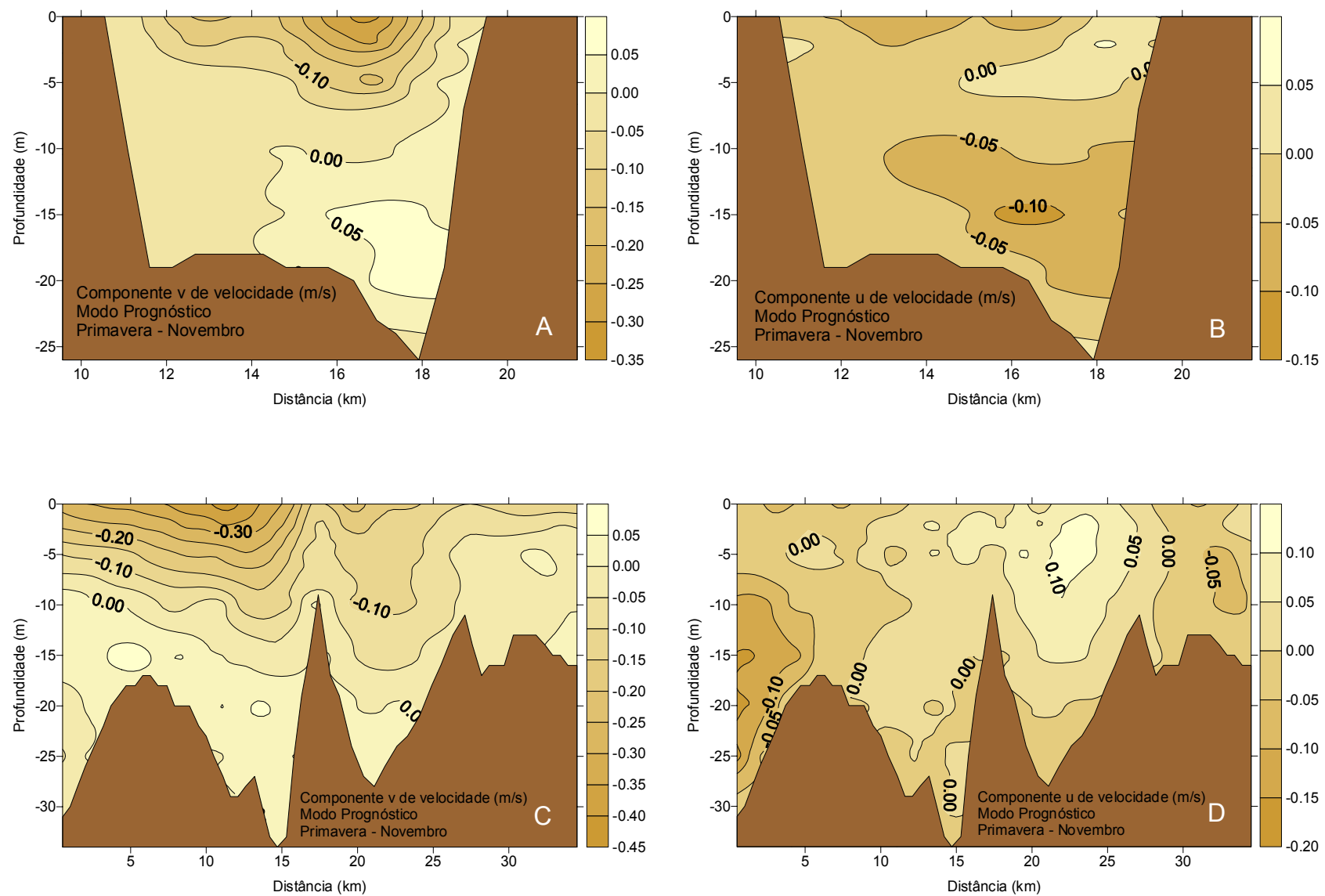

Figura 56: Distribuição vertical das componentes de velocidade normal (A) e paralela (B) à seção A. Distribuição vertical das componentes de velocidade normal (C) e paralela (D) às seções ao longo do Canal de São Sebastião. Simulação de primavera - novembro. 


\subsection{O Verão}

\subsubsection{A Plataforma Continental Sudeste}

A Fig. 57 A,B,C traz as curvas de energia mecânica, fluxos de energia nos contornos e nível do mar médio. Observamos que a configuração das curvas em muito se assemelha àquela observada para a primavera, porém, os níveis no verão são maiores, principalmente com relação aos fluxos de energia nos contornos. O nível do mar médio no verão também é maior em módulo do que aquele encontrado para a primavera.

O nível do mar (Fig. 58A) varia entre $-0,25 \mathrm{~m}$ na costa e no limite norte do domínio e $0,15 \mathrm{~m}$ ao largo. Os maiores gradientes estão na quebra da plataforma, principalmente ao norte, justamente na região onde os ventos estão mais alinhados à costa. Observamos também que as isolinhas desta propriedade na região da plataforma continental são aproximadamente paralelas à costa como no modo barotrópico e que também são muito semelhantes em configuração às encontradas na primavera em modo baroclínico. As correntes superficiais (Fig. 58B) são predominantemente para sudoeste na região da plataforma com intensificação na quebra e na região costeira mais a sul. Estas correntes, com características da $\mathrm{CB}$, fluem preferencialmente onde os gradientes do nível do mar são maiores com intensidades máximas próximas a 1,0 m/s.

As distribuições horizontais superficiais de temperatura, salinidade e densidade encontram-se nas Figs. 59A, 59B e 59C respectivamente. Assim como na primavera, existem fortes gradientes destas propriedades na quebra da plataforma continental, associados a temperaturas maiores do que $24^{\circ} \mathrm{C}$ e salinidades maiores do que 36 , característicos da Água Tropical, transportada pela Corrente do Brasil. O mínimo de temperatura encontra-se entre a Ilha Grande e a Baía de Guanabara $\left(22^{\circ} \mathrm{C}\right)$; este mínimo projeta-se para SO na forma de uma língua até o sul da ISS. As maiores temperaturas superficiais $\left(30^{\circ} \mathrm{C}\right)$ encontram-se ao sul da região e ao largo da quebra da plataforma. Os fortes gradientes de salinidade estendem-se ao longo de toda quebra da plataforma com valores que variam entre 35,4 e 36,4 . O mínimo $(34,8)$ se apresenta na costa, ao sul, e o máximo, ao largo $(36,6)$. Como conseqüência desses campos, as densidades superficiais (Fig. 59C) variam entre $22,5 \mathrm{~kg} / \mathrm{m}^{3}$ na costa, na mesma região onde é encontrado o mínimo de salinidade e $24,5 \mathrm{~kg} / \mathrm{m}^{3}$ também na costa mas agora na região onde encontra-se o mínimo de temperatura. 
Os perfis horizontais superficiais de percentuais de massas de água encontramse na Fig. 60 A,B,C. Conforme observa-se nesta figura, a AC ocupa toda a plataforma com sinais da ACAS (40\%) somente na costa ao largo da Baía da Guanabara. A AT ocupa toda região ao largo da quebra da plataforma continental.

Analisando os perfis verticais de temperatura, salinidade e densidade (Fig. 61 $\mathrm{A}, \mathrm{B}, \mathrm{C})$, vemos que as temperaturas sobre a plataforma são ligeiramente superiores àquelas encontradas na primavera e as salinidades ao contrário, são ligeiramente inferiores. Caracteriza-se na quebra da plataforma uma frente térmica com temperaturas variando entre $24^{\circ} \mathrm{C}$ e $28^{\circ} \mathrm{C}$ na superfície associada a uma frente halina na forma de dois núcleos, sendo que o mais externo com uma salinidade central de 37 e o interno com 36,5. Os gradientes verticais de densidade na superfície são mais acentuados no verão do que na primavera.

Nesta mesma seção, analisando os perfis verticais de percentuais de massas de água (Fig. 62 A,B,C) constata-se uma maior intrusão da ACAS sobre a plataforma no fundo, atingindo valores de $70 \%$ na região da quebra; na primavera os níveis são de 50\% aproximadamente. Em contrapartida, verifica-se o avanço da AC na superfície nesta estação em relação à primavera, acompanhado do recuo da $\mathrm{AT}$, que se afasta de $125 \mathrm{~km}$ da costa, na primavera, para cerca de $160 \mathrm{~km}$. Estes fatos são confirmados quando examinamos os perfis horizontais superficiais da Fig. 60.

A Fig. 63 apresenta perfis verticais das componentes de velocidade paralela (v) e perpendicular $(\mathrm{u})$ à costa. Os valores mais intensos da componente v ocorrem sobre a quebra da plataforma continental $(-0,40 \mathrm{~m} / \mathrm{s})$ e confirmam o movimento da Corrente do Brasil para SO. A intensidade da componente $\mathrm{v}$ decresce sobre a plataforma continental em direção a oeste, invertendo seu sentido na costa, onde flui para norte. No talude, ela diminui sua intensidade com a profundidade, sendo que se anula perto de $400 \mathrm{~m}$ de profundidade, caracterizando o limite inferior da $\mathrm{CB}$; abaixo desta profundidade, as correntes fluem para norte com máximo de $0,30 \mathrm{~m} / \mathrm{s}$. A componente u de velocidade é positiva na metade externa da plataforma com máximo de $0,40 \mathrm{~m} / \mathrm{s}$, o qual está associado ao máximo de v. Na metade interna da plataforma, a componente u é negativa e parece estar associada a regiões onde a componente v é positiva. 

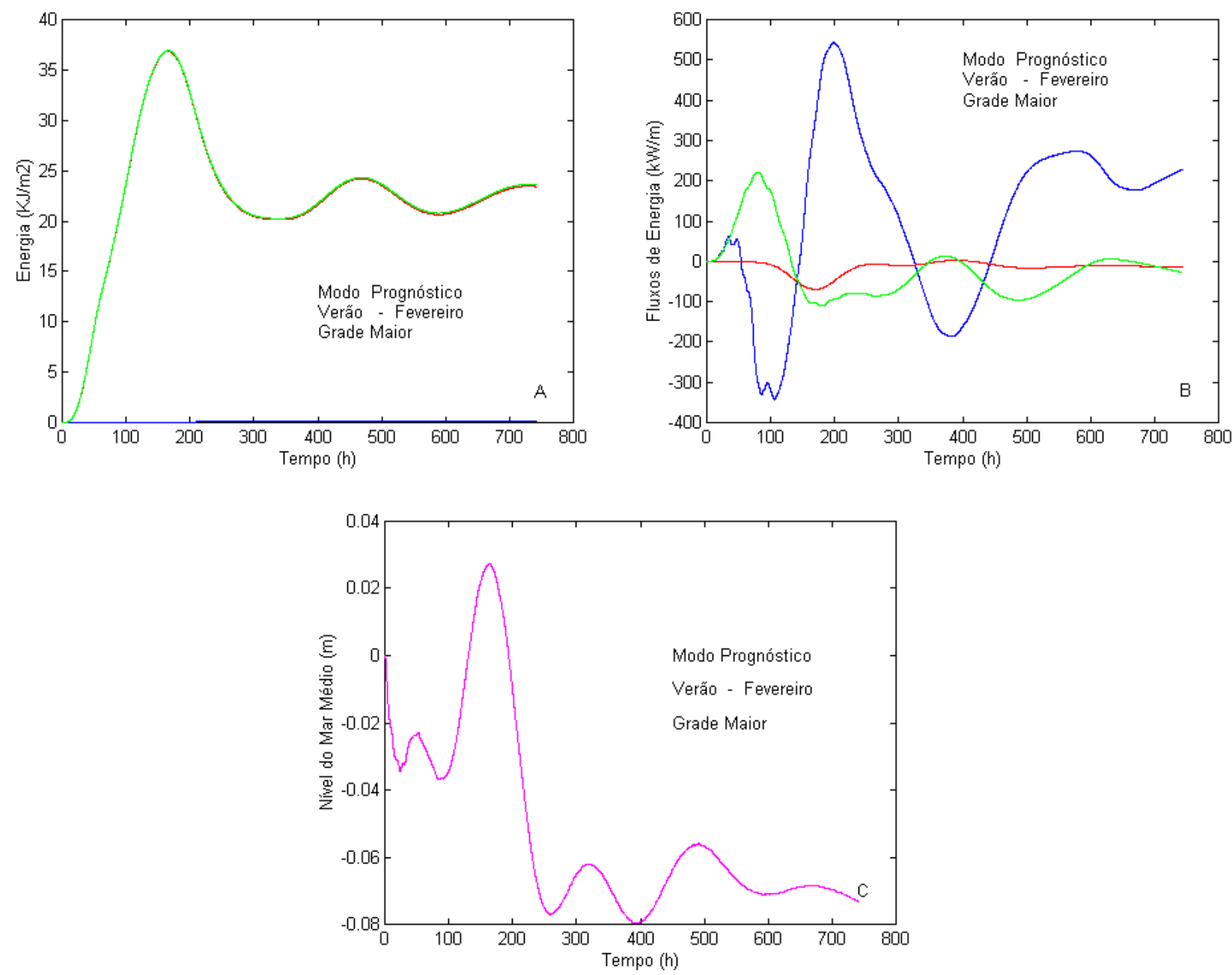

Figura 57: Curvas de energia mecânica (A), fluxos nos contornos (B) e nível do mar médio (C) na PCSE, sendo em (A), o verde, a energia mecânica, o vermelho, a energia cinética e o azul, a energia potencial. Em (B), o azul representa o fluxo através do contorno norte, o vermelho, o fluxo através do contorno sul e o verde, o fluxo através do contorno leste. Simulação de verão - fevereiro. 

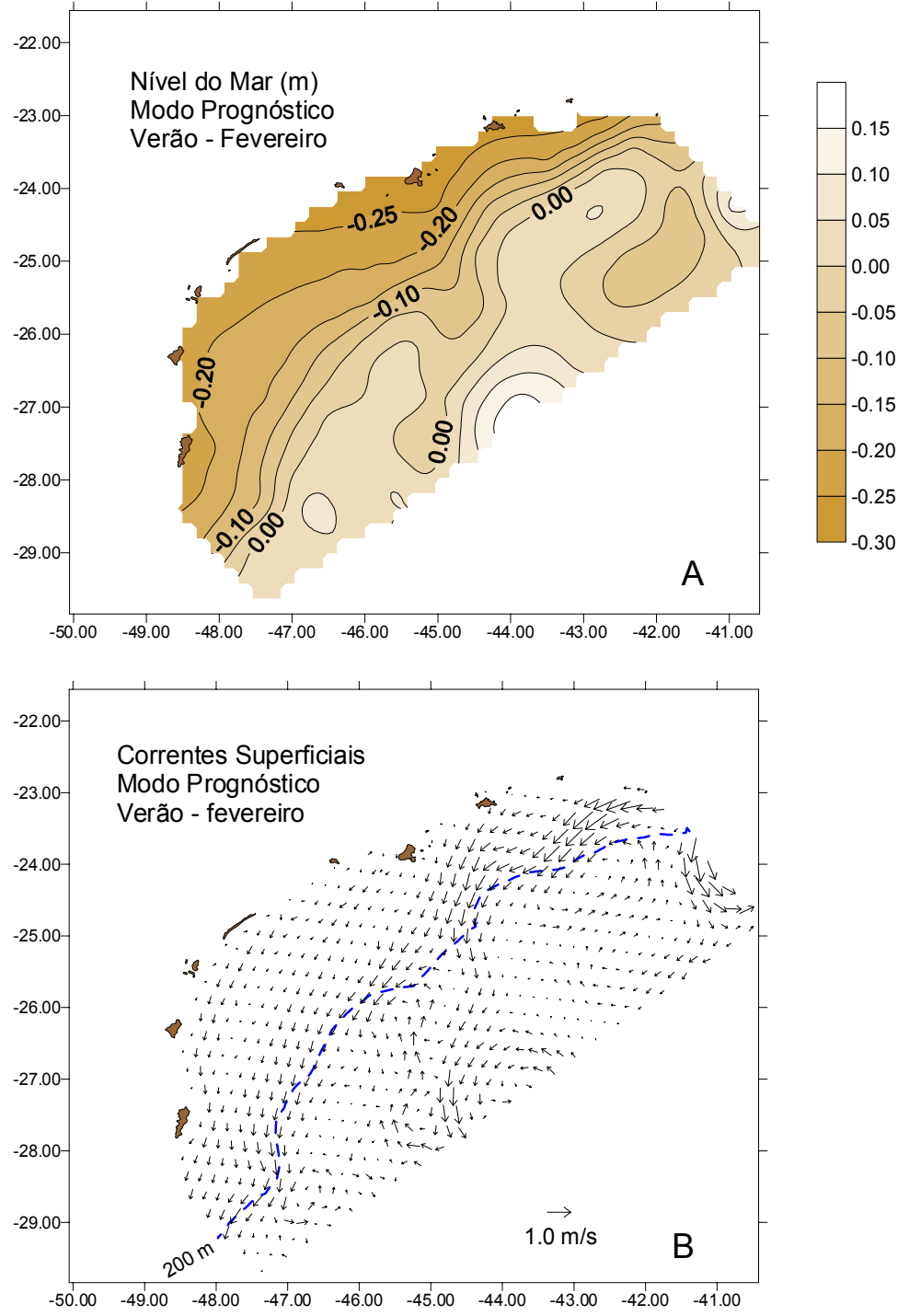

Figura 58: Nível do Mar (A) e Correntes Superficiais (B) na Plataforma Continental Sudeste. Simulação de verão - fevereiro. 

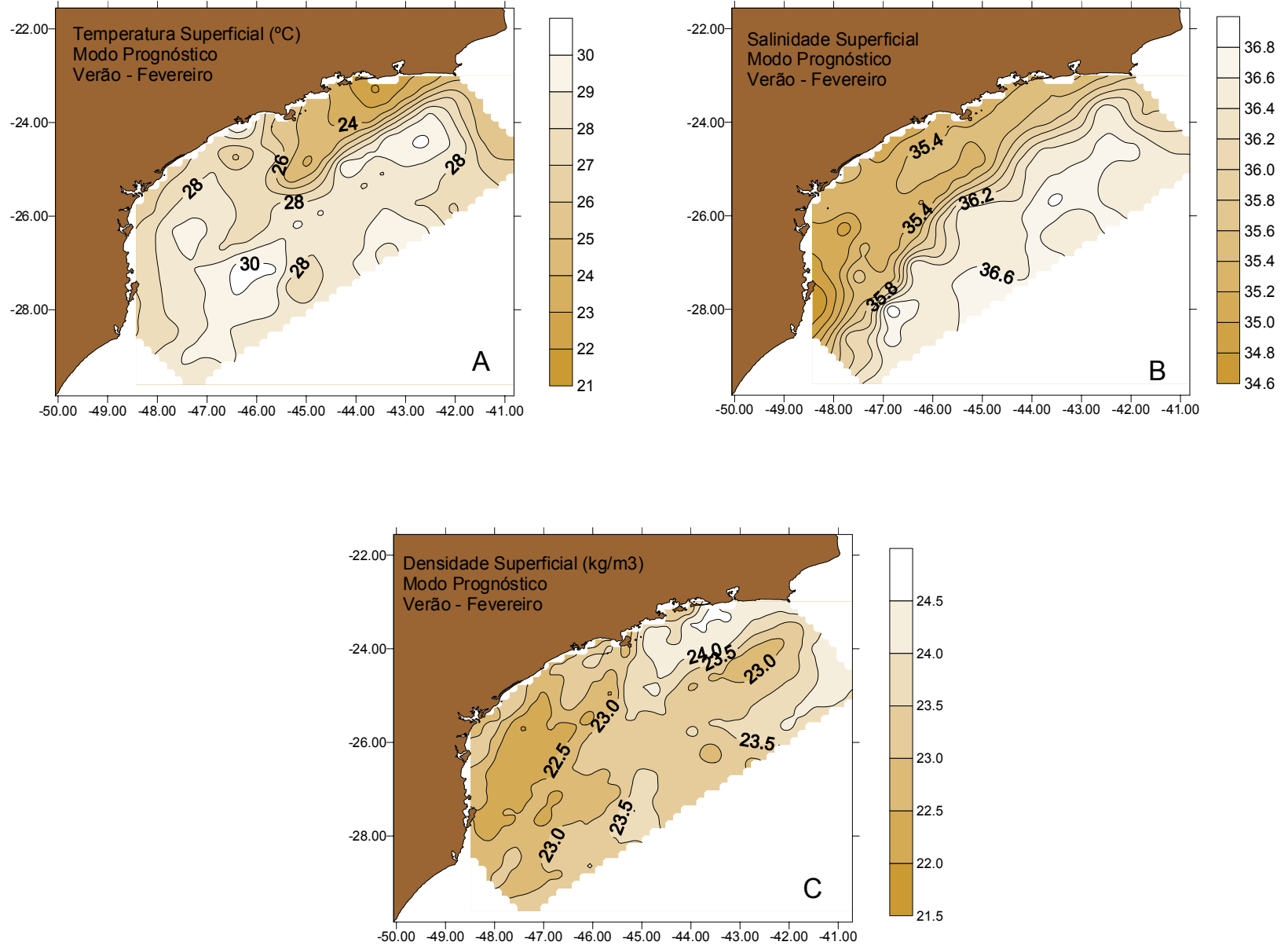

Figura 59: Distribuição horizontal superficial da temperatura (A), da salinidade (B) e da densidade convencional (C) na Plataforma Continental Sudeste. Simulação de verão fevereiro. 

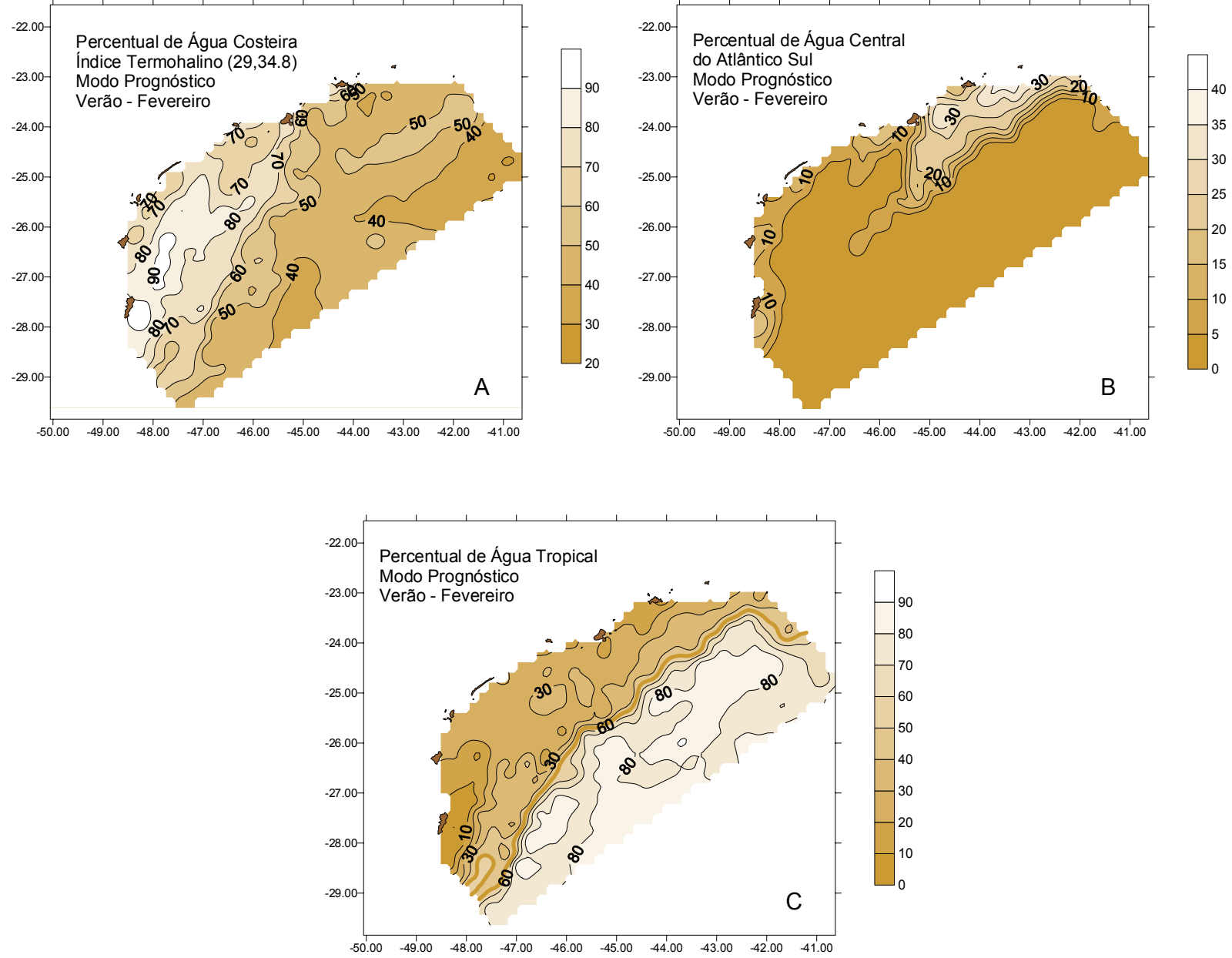

Figura 60: Distribuição horizontal dos percentuais de massas de Água Costeira (A), Água Central do Atlântico Sul (B) e de Água Tropical (C) na Plataforma Continental Sudeste. Simulação de verão - fevereiro. 

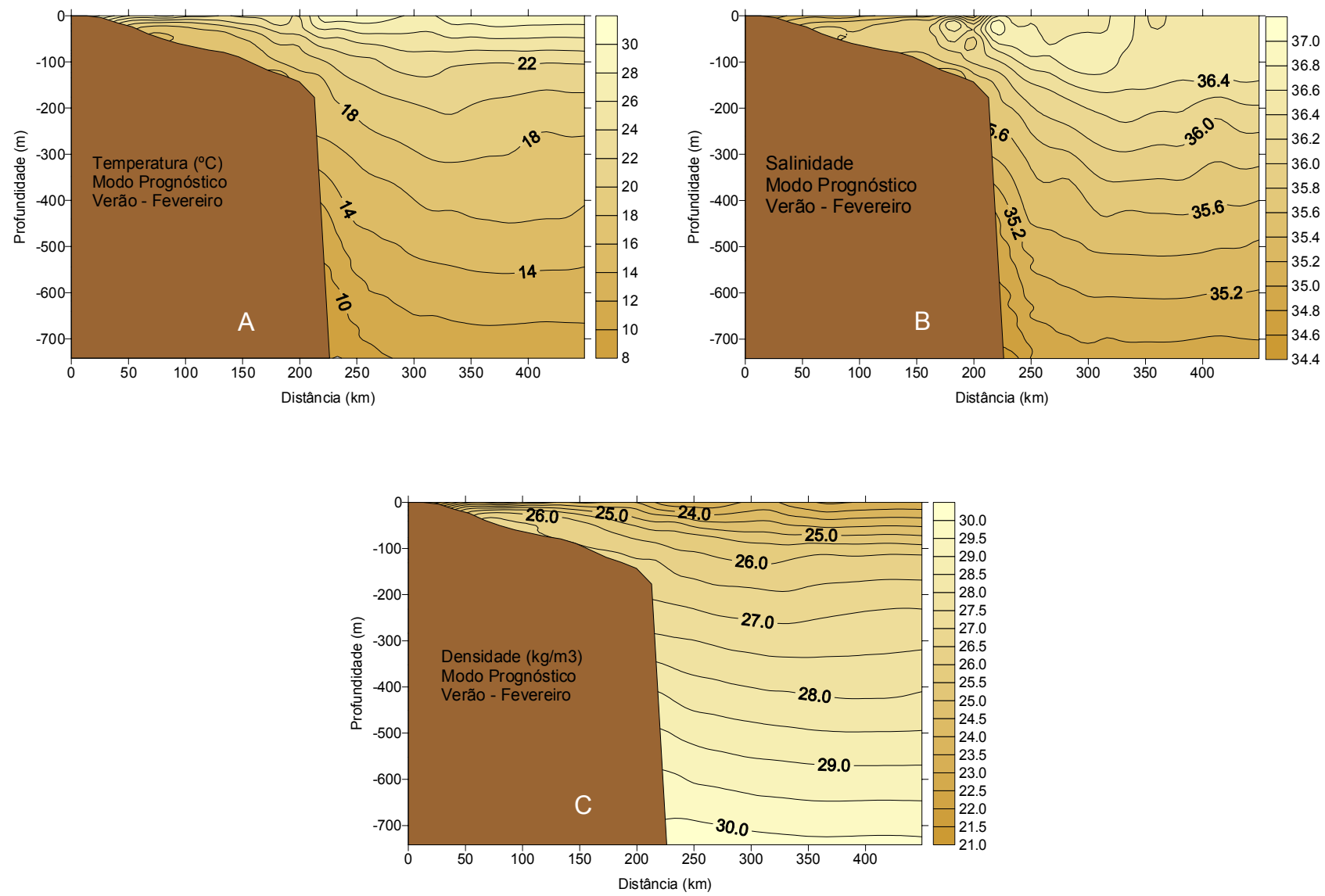

Figura 61: Distribuição vertical da temperatura (A), da salinidade (B) e da densidade convencional (C) na Plataforma Continental Sudeste ao sul do Canal de São Sebastião. Simulação de verão - fevereiro. 

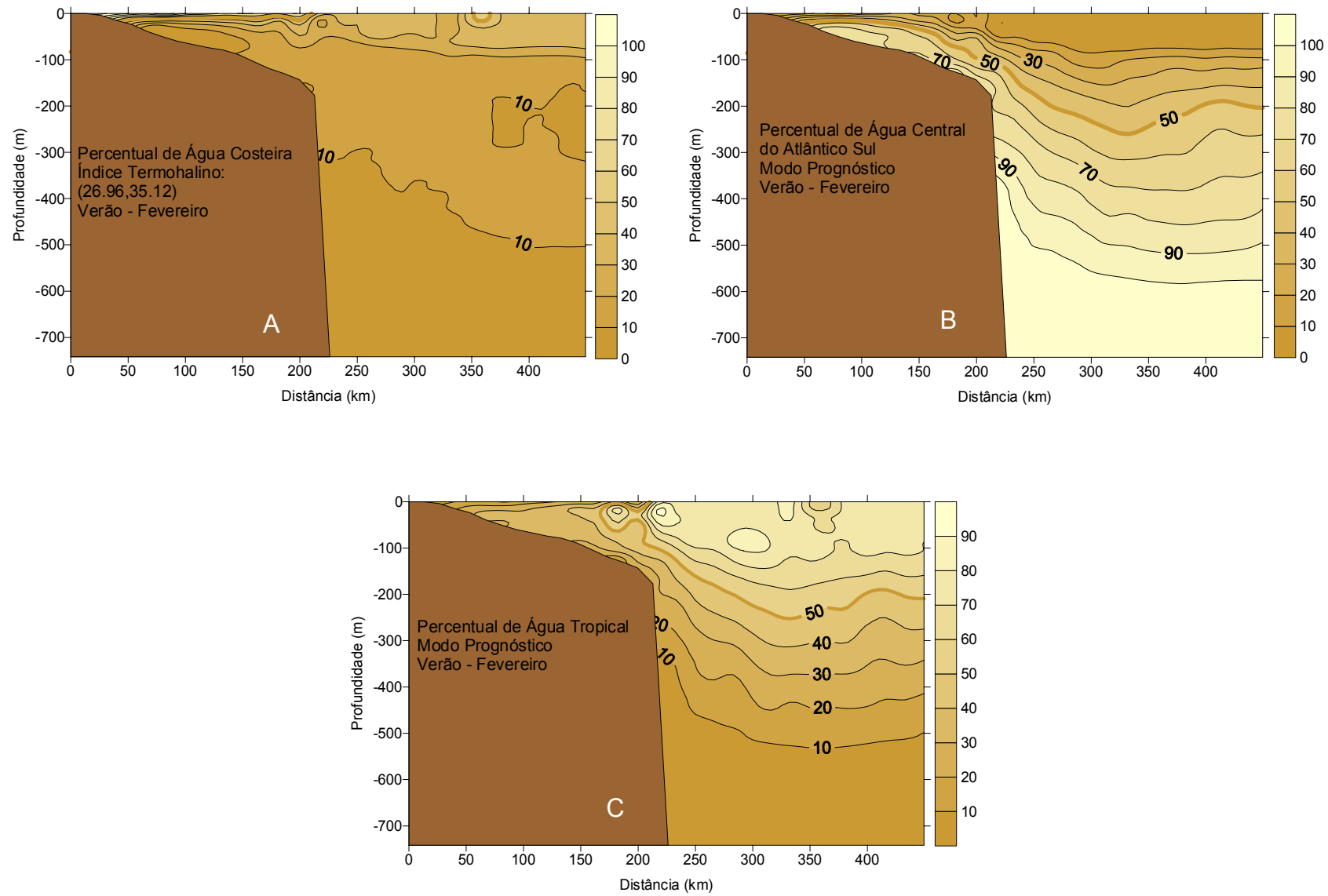

Figura 62: Distribuição vertical dos percentuais de massas de água Costeira (A), Água Central do Atlântico Sul (B) e da Água Tropical (C) na Plataforma Continental Sudeste ao sul do Canal de São Sebastião. Simulação de verão - fevereiro. 

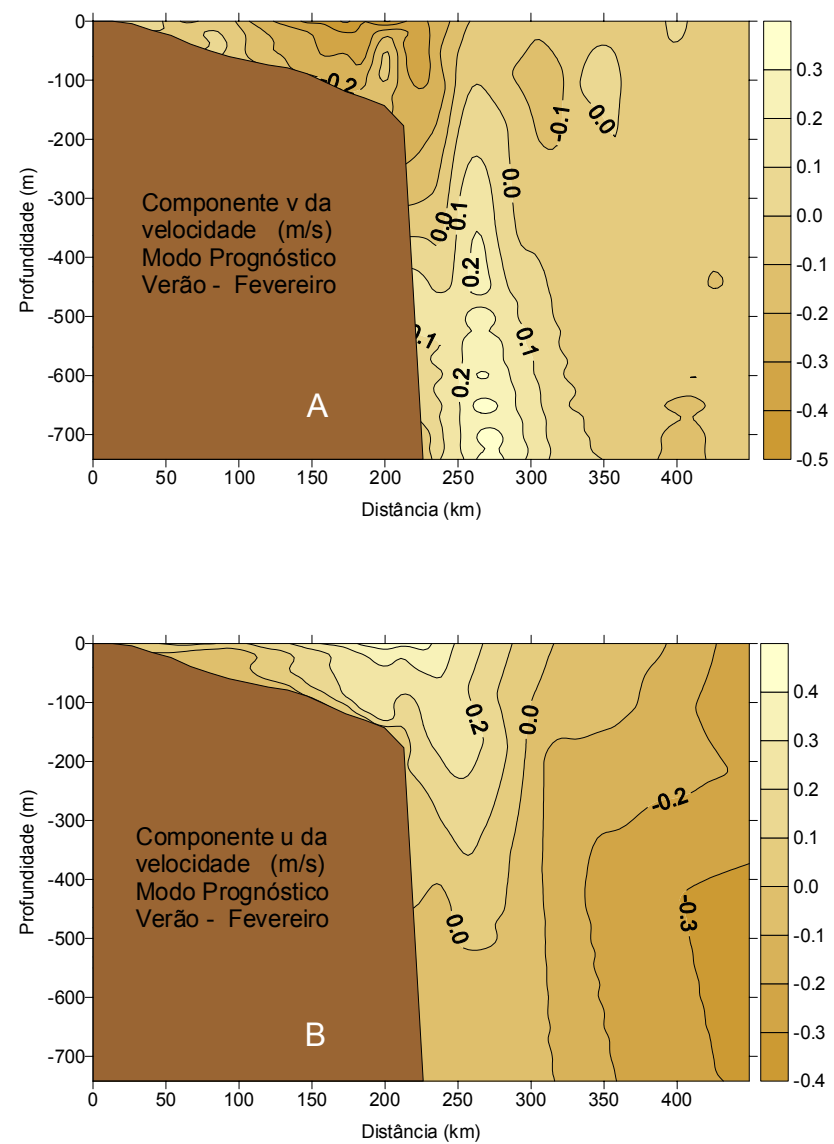

Figura 63: Distribuição vertical dos componentes de velocidade paralelo (A) e perpendicular (B) à costa na Plataforma Continental Sudeste ao sul do Canal de São Sebastião. Simulação de verão - fevereiro. 


\subsubsection{A Plataforma Continental Interna}

As curvas de energia mecânica, fluxos de energia nos contornos e nível do mar médio (Fig. 64) tem configurações semelhantes às correspondentes na primavera, sendo porém, os níveis de energia e fluxos de energia no verão, ligeiramente maiores. O nível do mar médio após $720 \mathrm{~h}$ de integração atinge $-0,25 \mathrm{~m}$, enquanto que na primavera chegou a $-0,20 \mathrm{~m}$.

O nível do mar (Fig. 65A), que tem total continuidade com o nível do mar na PCSE (Fig. 58A), varia entre $-0,18 \mathrm{~m} / \mathrm{s}$ na região sul, ao largo, até $-0,28 \mathrm{~m} / \mathrm{s}$, na costa. A estrutura concêntrica das isolinhas do nível do mar na borda oceânica da região, deve-se a fortes gradientes topográficos $(8,5 \mathrm{~m} / \mathrm{km})$ localizados entre os dois núcleos de nível do mar. As correntes superficiais (Fig. 65B), fluem preponderantemente para sudoeste ao longo das isolinhas de nível do mar sendo mais intensas onde os gradientes desta propriedade são maiores com destaque para o contorno SE da ISS. Vórtices anticliclônicos surgem em torno das depressões do nível do mar sendo mais intenso aquele encontrado ao sul.

Analisando-se os perfis horizontais, na superfície, de temperatura, salinidade e densidade (Fig. 66 A,B,C), percebe-se um mínimo de temperatura $\left(20^{\circ} \mathrm{C}\right)$ a $\mathrm{NE}$ da ISS, o qual projeta-se através de uma língua de baixas temperaturas para SO; esta estrutura térmica também foi observada na região da PCSE. Uma forte frente térmica se observa no sul do domínio. Esta frente fica caracterizada também quando observamos as isopicnais (Fig. 66C) e ela também foi observada na mesma região na primavera (Fig. 43). As menores salinidades (Fig. 66B) se encontram ao norte $(35,4)$ e as maiores salinidades $(35,7)$ encontramos a sudeste da ISS. O meandramento de isotermas e isopicnais na borda da região associa-se ao das isolinhas de nível do mar. Meandramento de isotermas, isohalinas e isopicnais também foi encontrado por Coelho (1997) em diversos cruzeiros oceanográficos na mesma região e sobre a mesma isóbata, sendo que no cruzeiro de 12/12/92, estes núcleos de temperatura e salinidade tinham gradientes positivos em direção ao centro.

Os perfis horizontais de percentuais de massas de água (Fig. 67 A,B,C) na superfícies mostram que a AC domina toda superfície, com exceção do extremo norte da região onde há sinais da ACAS. 
Os perfis verticais das propriedades temperatura, salinidade e densidade convencional (Fig. 68 A,B,C) confirmam a frente a cerca de $55 \mathrm{~km}$ da costa. Um núcleo de alta salinidade é observado em sub-superfície (cerca de $30 \mathrm{~m}$ de profundidade). Fica clara nesta figura uma frente térmica no fundo, onde a temperatura varia entre $16^{\circ} \mathrm{C}$ no fundo e $22^{\circ} \mathrm{C}$, na superfície. Esta frente, resfriando as águas superficiais na costa, geram os gradientes horizontais fortes observados na Fig. 66 A. Uma frente halina destaca-se em sub-superfície através de um núcleo com salinidade maior do que 36,0. A configuração das isopicnais caracteriza a frente térmica no fundo como também a frente halina em sub-superfície mais ao largo.

Os perfis verticais dos percentuais de massas de água encontram-se na Fig. 69 A,B,C. Pela análise desta figura percebe-se que a AC encontra-se na superfície até a profundidade de $20 \mathrm{~m}$ aproximadamente e logo abaixo encontra-se a ACAS. Associado ao núcleo de salinidade máxima (Fig. 68 C), tem-se os maiores níveis de AT em subsuperfície.

A Fig. 70 A,B apresenta os perfis verticais das componentes de velocidade $u$ e v em uma seção transversal onde visualiza-se a entrada sul do CSS. Na maior parte da superfície as correntes fluem para sul com valores máximos de $-0,45 \mathrm{~m} / \mathrm{s}$ para a componente $\mathrm{v}$, nas proximidades do contorno leste da ISS, onde normalmente ocorre intensificação, diminuindo em módulo para o fundo e para o largo, onde ocorrem contra correntes para o norte, da superfície até o fundo, com núcleo em $60 \mathrm{~m}$ de profundidade de $0,10 \mathrm{~m} / \mathrm{s}$. Nas proximidades do contorno leste da ISS, a componente u tem um máximo de $-0,25 \mathrm{~m} / \mathrm{s}$, indicando que as correntes contornam a ISS, fluindo para a costa. A componente u diminui em módulo para o largo, onde também inverte seu sentido, indicando que neste local ocorre um vórtice anticiclônico que se corresponde àquele visto em superfície (Fig. 65B). Na entrada sul do CSS, percebe-se movimento em duas camadas, onde na superfície a componente v é negativa (correntes para sul) com valor máximo de $-0,30 \mathrm{~m} / \mathrm{s}$ e no fundo a componente $\mathrm{v}$ é positiva (correntes para norte) com valores baixos $(<0,05 \mathrm{~m} / \mathrm{s})$. A componente u negativa no fundo do CSS, indica que as correntes penetram o canal através de fluxos de leste para oeste ao contornarem a ISS. $\mathrm{Na}$ camada superior do canal, onde a componente v é para sul, a componente u é para leste. 

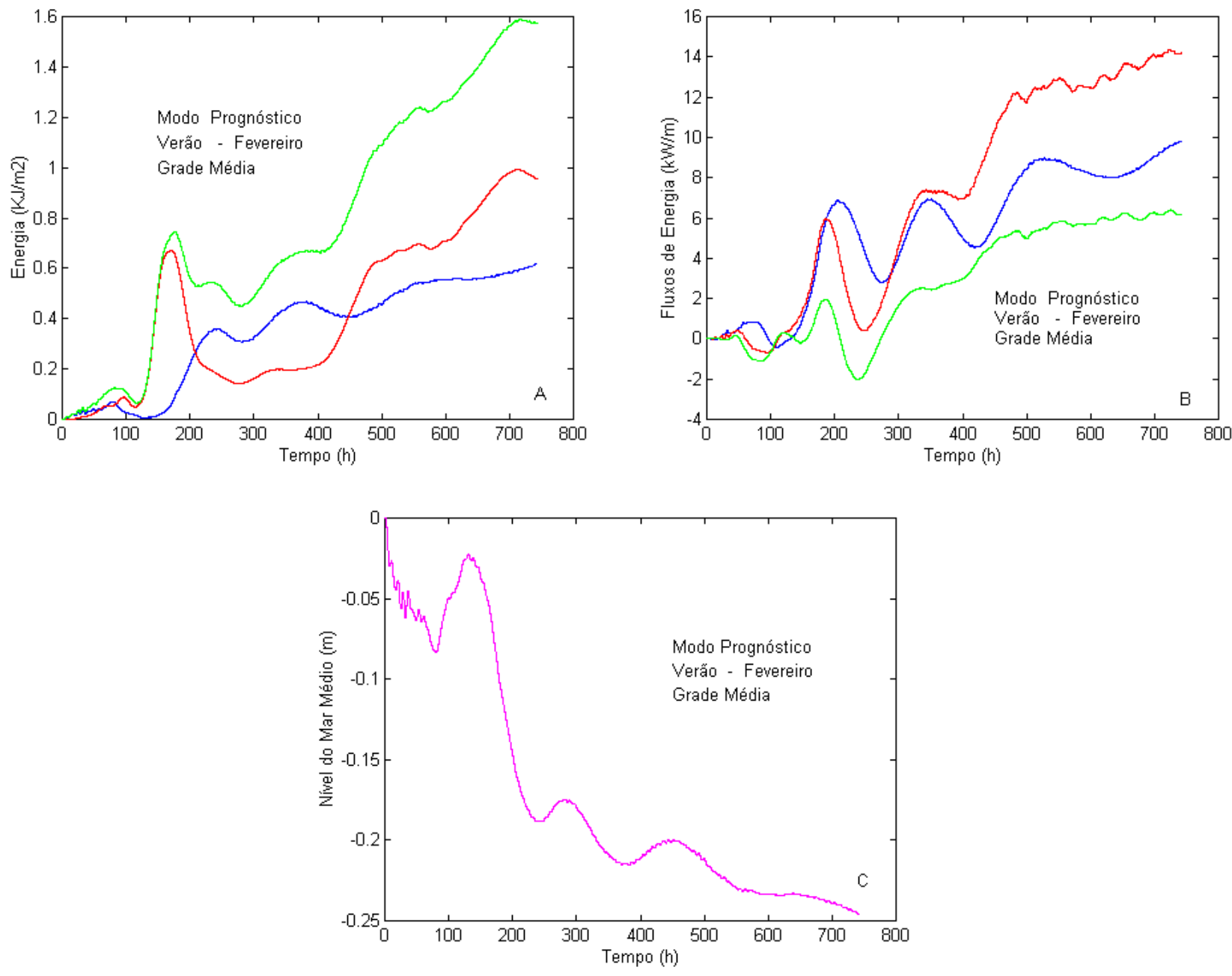

Figura 64: Curvas de energia mecânica (A), fluxos nos contornos (B) e nível do mar médio (C) na PCI, sendo em (A), o verde, a energia mecânica, o vermelho, a energia cinética e o azul, a energia potencial. Em (B), o azul representa o fluxo através do contorno norte, o vermelho, o fluxo através do contorno sul e o verde, o fluxo através do contorno leste. Simulação de verão - fevereiro. 

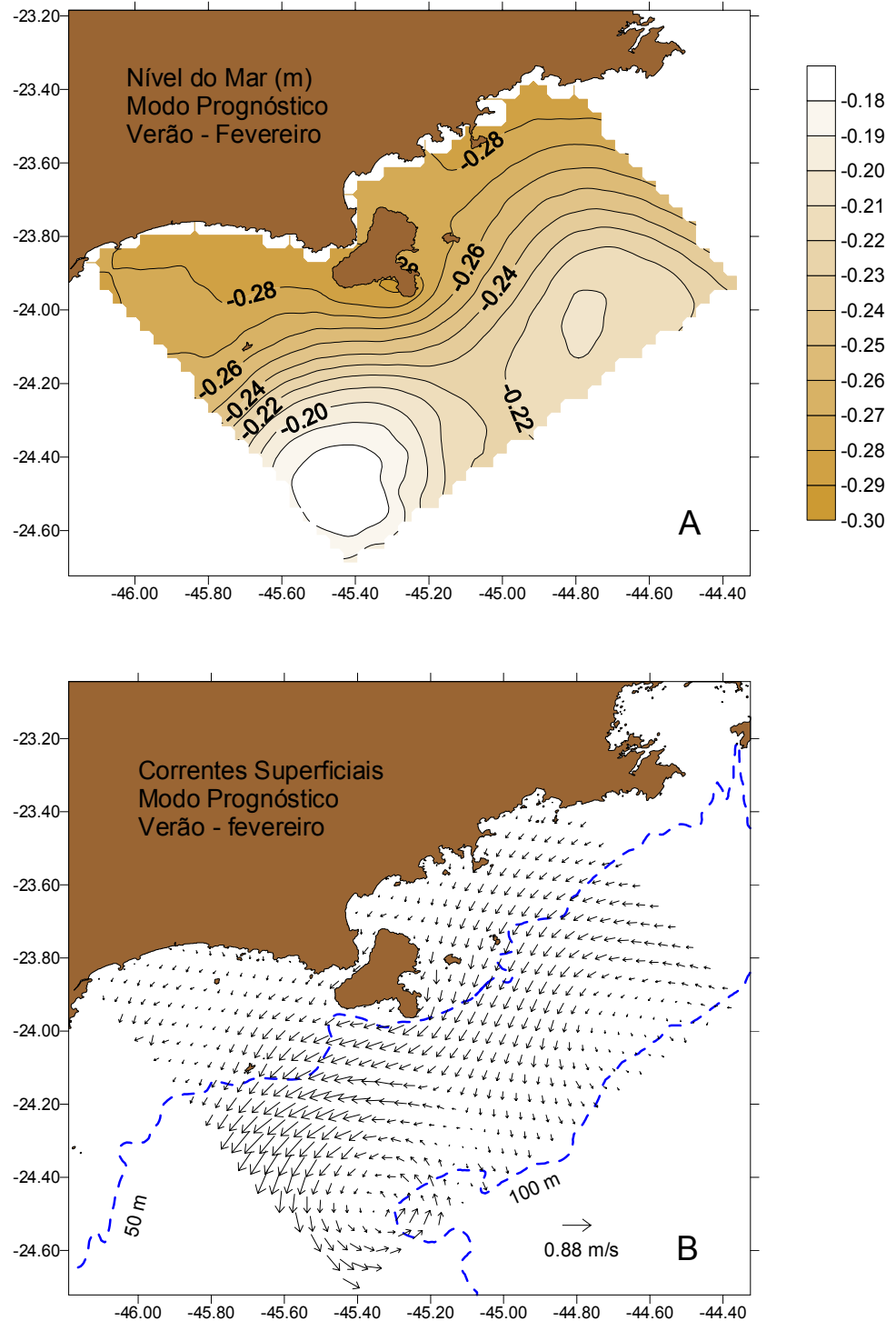

Figura 65: Nível do Mar (A) e Correntes Superficiais (B) na PCI. Simulação de verão - fevereiro. 

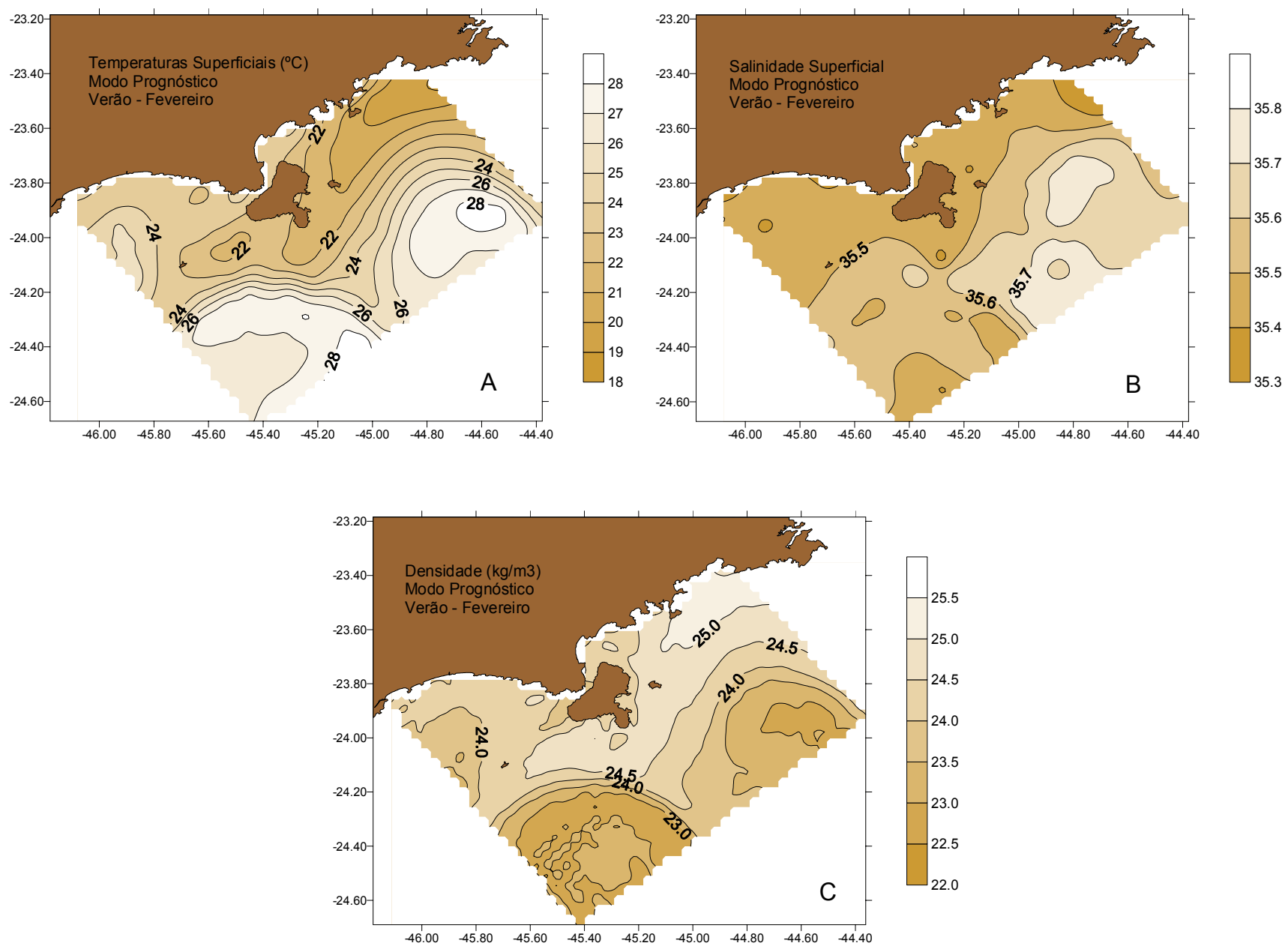

Figura 66: Distribuição horizontal superficial da temperatura (A), da salinidade (B) e da densidade convencional (C) na PCI. Simulação de verão - fevereiro. 

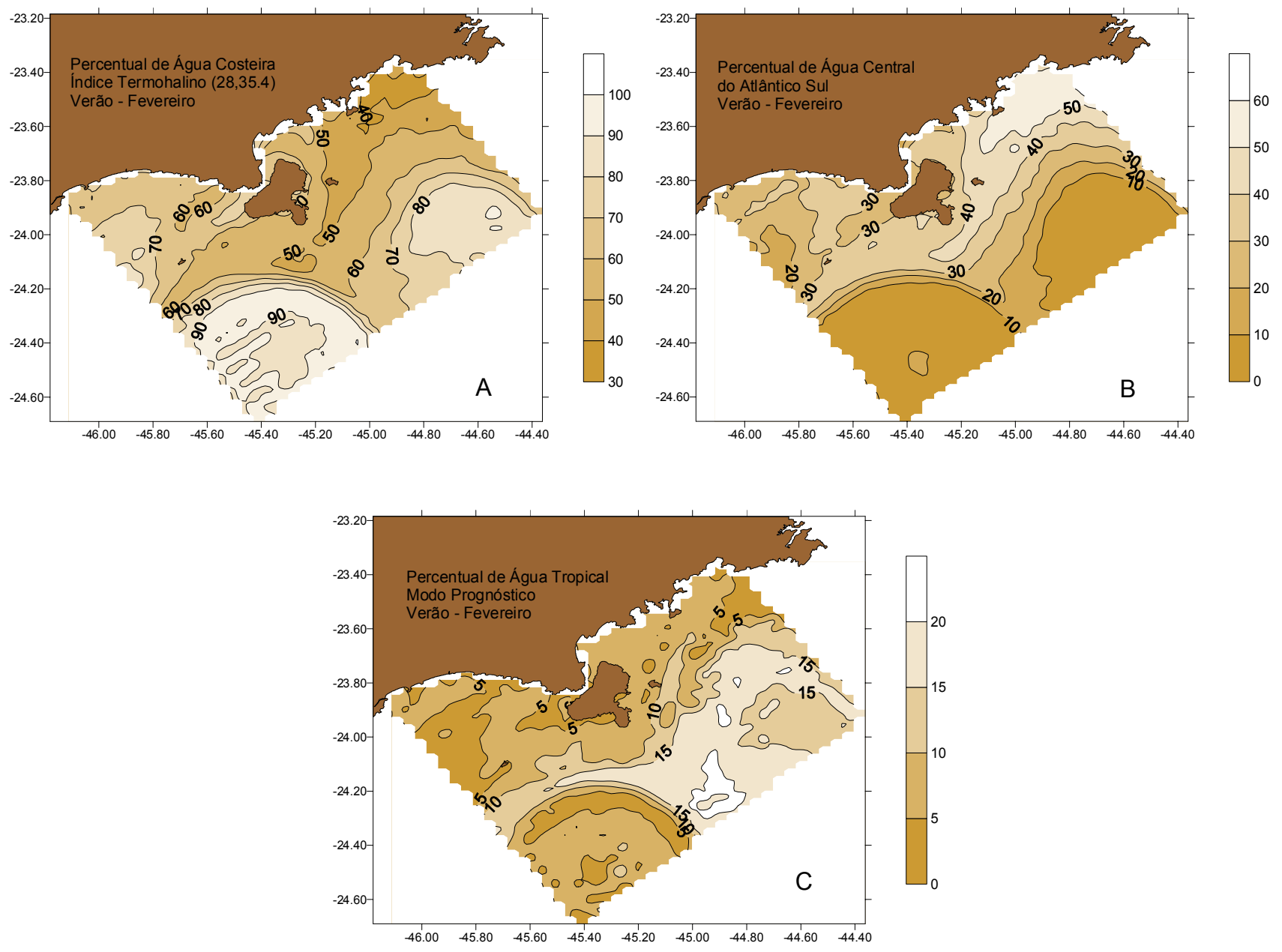

Figura 67: Distribuição horizontal dos percentuais das massas de Água Costeira (A), Água Central do Atlântico Sul (B) e da Água Tropical (C) na PCI. Simulação de verão - fevereiro. 

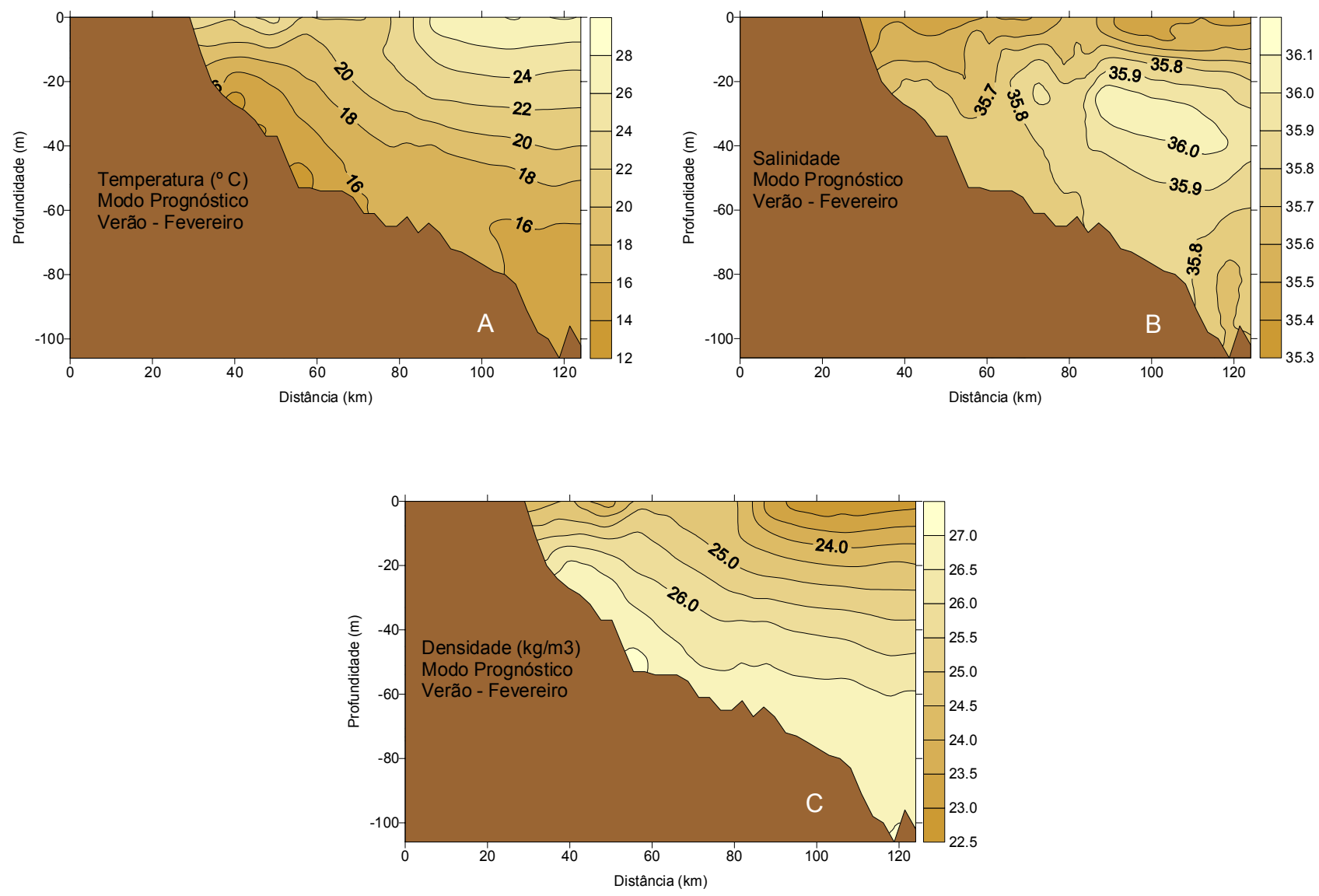

Figura 68: Distribuição vertical da temperatura (A), da salinidade (B) e da densidade convencional (C) na PCI ao sul do Canal de São Sebastião. Simulação de verão - fevereiro. 

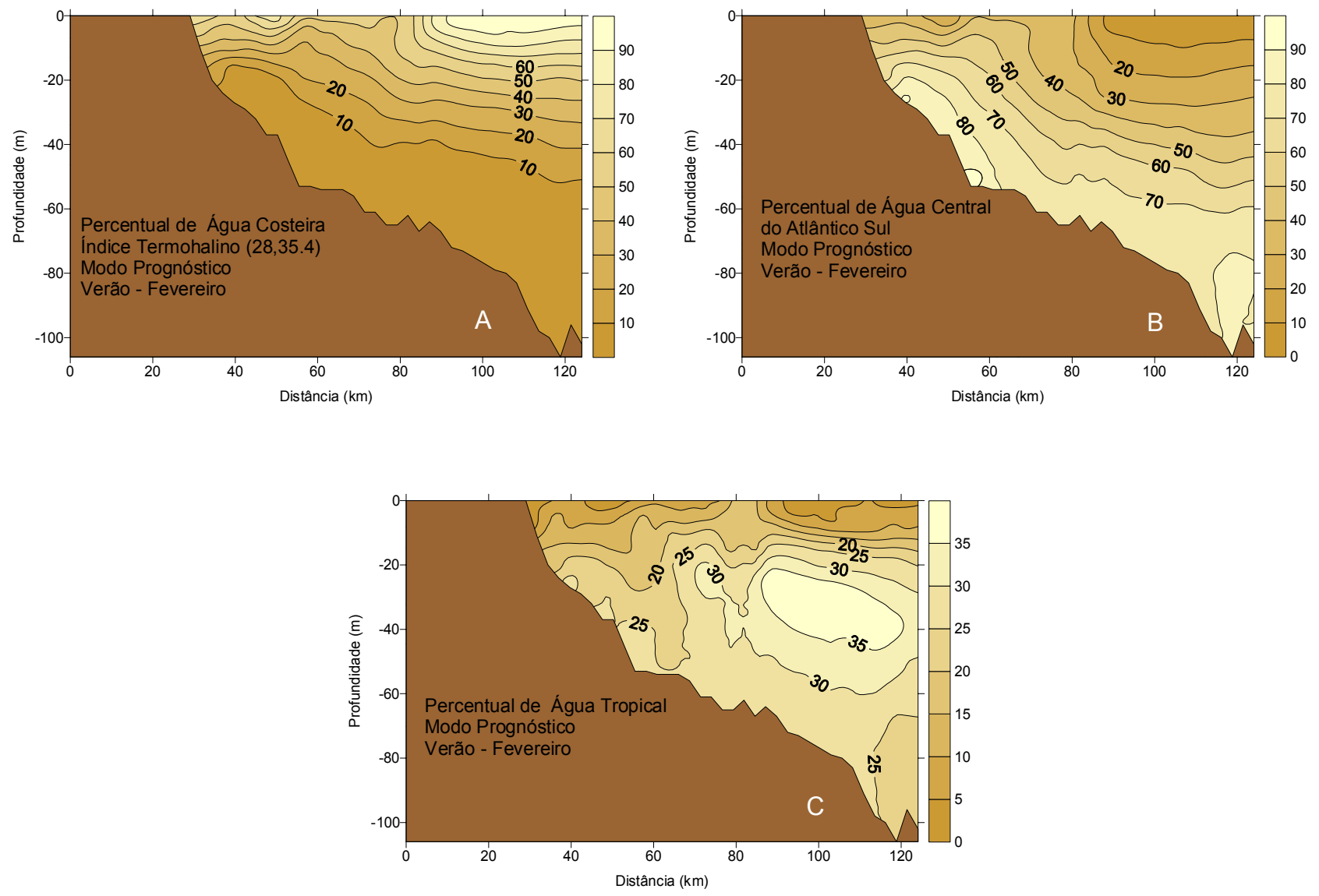

Figura 69: Distribuição vertical dos percentuais das massas de Água Costeira (A), Água Central do Atlântico Sul (B) e da Água Tropical (C) na PCI ao sul do Canal de São Sebastião. Simulação de verão - fevereiro. 

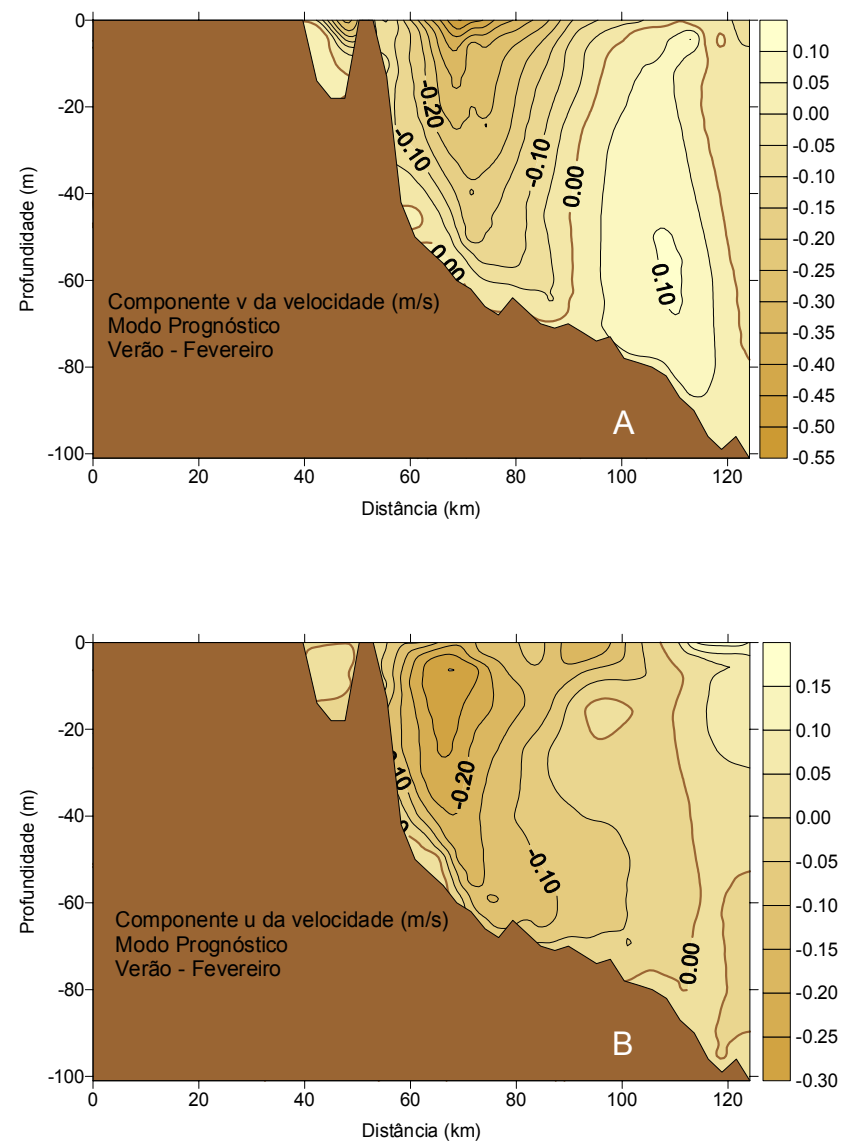

Figura 70:. Distribuição vertical das componentes de velocidade paralela (A) e perpendicular (B) à costa na PCI ao sul do Canal de São Sebastião. Simulação de verão fevereiro. 


\subsubsection{O Canal de São Sebastião}

A Fig. 71 A,B,C apresenta as curvas de energia mecânica, fluxos de energia nos contornos e nível do mar médio. Os níveis de energia mecânica são menores do que os da PCI e, como na primavera, a energia potencial contribui mais para a energia mecânica do que a energia cinética. O nível do fluxo de energia através do contorno leste é maior do que os dos outros contornos e o nível do mar médio após 720 h de integração é de $-0,30 \mathrm{~m}$ aproximadamente. Os níveis de energia mecânica e de fluxo de energia nos contornos são maiores no verão do que na primavera e o nível do mar médio no verão é mais baixo do que o da primavera.

O nível do mar (Fig. 72A) no CSS após 30 dias de integração, como na primavera, resultou em uma diferença mínima entre os extremos, cerca de $0,02 \mathrm{~m}$. O nível mais baixo está no sul, do lado oeste, com -0,30 m. As correntes superficiais (Fig. 72B) fluem para sul com intensificação no estreito do canal. Valores máximos estão ao redor de $0,55 \mathrm{~m} / \mathrm{s}$, ligeiramente maiores do que aqueles encontrados para a primavera $(0,45 \mathrm{~m} / \mathrm{s})$.

As distribuições horizontais superficiais das propriedades temperatura, salinidade e densidade convencional (sigma-stp) podem ser vistas na Fig. 73 A,B,C. O máximo de temperatura $\left(27^{\circ} \mathrm{C}\right)$ encontra-se ao norte, na costa continental, em uma faixa que se estende até a região central do CSS; desta região, a temperatura diminui para o norte, para o leste e para o sul, onde encontra-se o mínimo de $21^{\circ} \mathrm{C}$. As salinidades variam entre 35,3 e 35,45, sendo que o mínimo é encontrado na região central do canal, do lado continental, no mesmo ponto onde foi encontrado as maiores temperaturas. As maiores salinidades encontram-se nas entradas norte e sul, diminuindo em direção ao centro e às regiões mais rasas. As densidades variam desde $23,0 \mathrm{~kg} / \mathrm{m}^{3}$, na região central do canal, até $24,5 \mathrm{~kg} / \mathrm{m}^{3}$, ao sul e ao norte do canal. O comportamento da densidade é análogo ao da salinidade: maiores densidades nas entradas norte e sul diminuindo em direção à região central e em direção aos locais mais rasos.

A distribuição horizontal dos percentuais de massas de água (Fig. 74 A,B,C) indica que na superfície encontramos AC em todo o canal, com os maiores percentuais na região central e os menores nas entradas norte e sul. Percentual da $\mathrm{AC}$ decrescendo da região central do canal para as extremidades, na superfície, foi encontrado por Coelho (1997) em vários cruzeiros oceanográficos de verão. Os percentuais da ACAS 
complementam os da AC, posto que os percentuais da AT são muito baixos; assim, os maiores percentuais da ACAS localizam-se nos extremos do canal, não ultrapassando, porém, 50\%; os menores percentuais encontram-se na região central.

A distribuição longitudinal das propriedades hidrográficas no CSS são apresentadas na Fig. 75 A,B,C. No sul do canal as temperaturas (Fig. 75A) variam de $23^{\circ} \mathrm{C}$ na superfície até cerca de $12^{\circ} \mathrm{C}$ no fundo, ao passo que no norte elas variam de $22^{\circ} \mathrm{C}$ na superfície até cerca de $19^{\circ} \mathrm{C}$ no fundo. As maiores temperaturas $\left(24^{\circ} \mathrm{C}\right)$ encontram-se na região central, na superfície. As salinidades (Fig. 75B) têm seu mínimo na forma de um núcleo em sub-superfície $(35,4)$ aumentando para os extremos e para o fundo do canal onde encontra-se o máximo de 35,7. As densidades (Fig. 75C), que variam entre 23,5 e $27,5 \mathrm{~kg} / \mathrm{m}^{3}$, têm seu máximo no fundo da entrada sul do canal sendo que o mínimo está na superfície, no centro da região. Percebe-se que densidades maiores do que $25 \mathrm{~kg} / \mathrm{m}^{3}$ se aprofundam em direção norte, não chegando naquela extremidade do canal. Nestas figuras, pode-se observar o ajuste das isolinhas das propriedades à topografia de fundo, característica de um modelo de coordenadas sigma.

Analisando-se os percentuais de massas de água nesta seção (Fig. 76 A,B,C), evidenciamos a presença da AC acima de $7 \mathrm{~m}$, abaixo da qual encontra-se a ACAS, estando o percentual de $90 \%$ na região sul, no fundo. Não há vestígios da AT no canal, nesta estação.

As componentes v e u de velocidade são apresentadas nas seções transversais e longitudinais (Fig. 77 A,B,C,D), observando-se que a configuração das isolinhas de velocidade são semelhantes às correspondentes da primavera (Fig. 56 A,B,C,D), mas as intensidades nesta época do ano são maiores. O máximo valor em superfície da componente longitudinal, indicando movimentos para o sul, foi igual a $-0,30 \mathrm{~m} / \mathrm{s}$, enquanto que o máximo da componente transversal, $u$, tem $-0,15 \mathrm{~m} / \mathrm{s}$. Assim como na primavera, percebemos que existem duas regiões distintas com relação às correntes: uma região em que as correntes fluem para sul, compreendendo a superfície e a porção oeste do canal até o fundo e uma outra região em que as correntes fluem para norte, com velocidades menores, máximo de $0,10 \mathrm{~m} / \mathrm{s}$, compreendendo a porção leste do canal abaixo da superfície. O núcleo desta corrente está na profundidade de $15 \mathrm{~m}$ aproximadamente. Na simulação de primavera o núcleo também está nesta profundidade. No corte longitudinal (Figs. 77 C,D), observa-se a intensificação das correntes na região mais estreita do canal e a profundidade de movimento nulo, 
variando entre 5 e $15 \mathrm{~m}$ de profundidade, de sul para o norte, delimitando os movimentos em sentido oposto (para o norte). Observando-se a componente u positiva (para leste), percebe-se que este se intensifica na superfície na região central do canal. Já a componente de u negativa (para oeste) se intensifica na entrada sul do canal. Em outras palavras, as correntes penetram o CSS em sua entrada norte contornando a ISS (componente u positiva), intensificando-se no centro do canal e a partir deste ponto deslocam-se para a costa. O mesmo se observa na primavera.

As distribuições de temperaturas, salinidades e densidades no CSS também podem ser visualizadas através dos perfis verticais junto às seções transversais $A, B, C$ e D das Figs. 78, 79 e 80, respectivamente.

A Fig. 81 A,B,C apresenta os perfis verticais dos percentuais de massas de água junto à seção $\mathrm{A}$, no CSS. A AC ocupa a superfície até a profundidade aproximada de $7 \mathrm{~m}$ do lado leste e a ACAS ocupa a coluna de água logo abaixo. Na superfície do lado oeste há uma região de mistura entre essas duas massas de água. Os maiores percentuais de AT (20\%) encontram-se no fundo, do lado insular. Os maiores percentuais de AC estão na superfície (60\%) do lado leste ao passo que os maiores percentuais de ACAS (95\%) se encontram do mesmo lado, no fundo. Nestes mesmos locais, Coelho (1997) encontrou, em um cruzeiro de primavera (dez/93) e outro de verão (fev/92), os maiores índices de AC e ACAS. O autor também obteve a profundidade de $5 \mathrm{~m}$ a $7 \mathrm{~m}$ como limite entre essas massas de água nas duas ocasiões. 

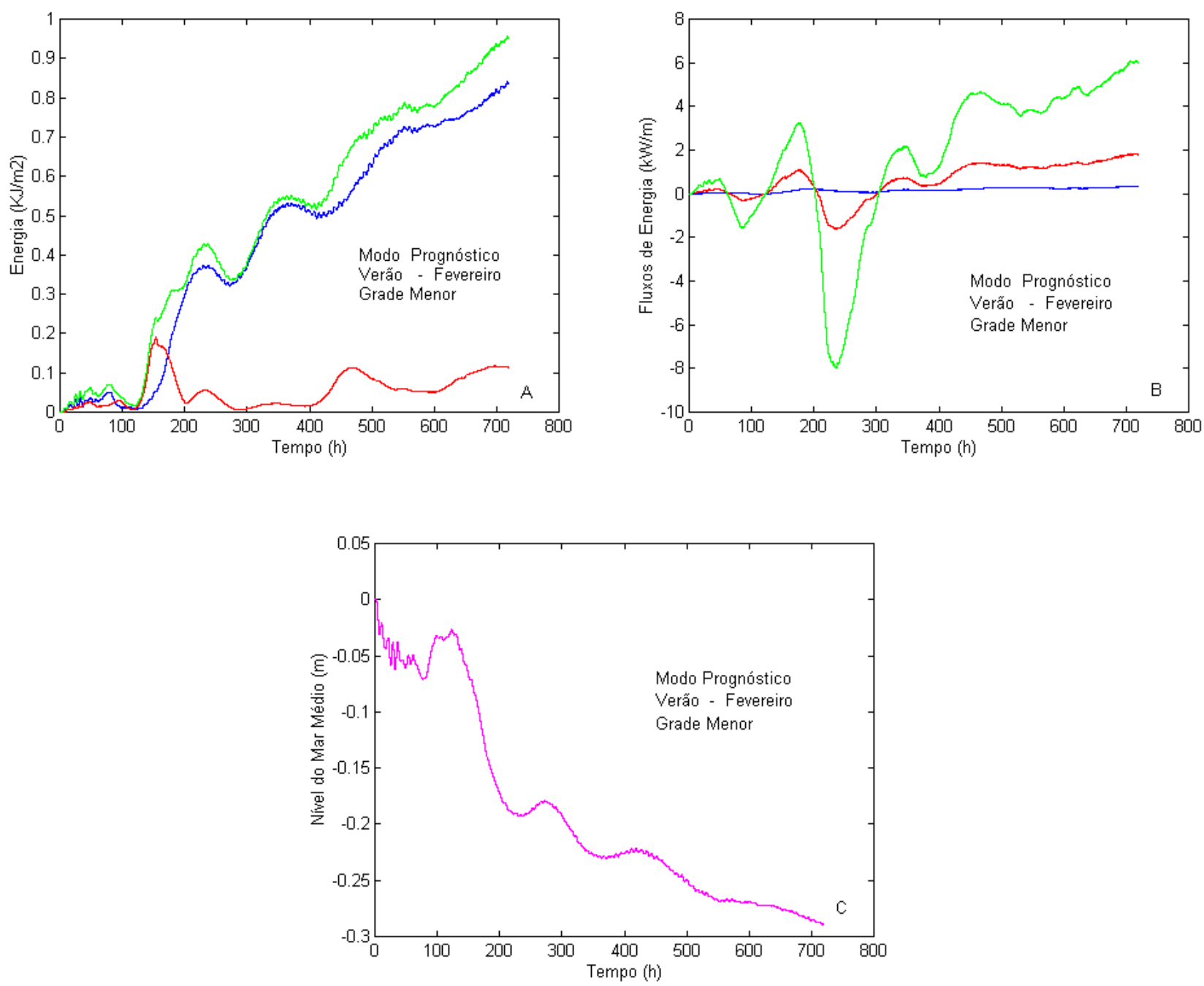

Figura 71: Curvas de energia mecânica (A), fluxos nos contornos (B) e nível do mar médio (C) no CSS, sendo em (A), o verde, a energia mecânica, o vermelho, a energia cinética e o azul, a energia potencial. Em (B), o azul representa o fluxo através do contorno norte, o vermelho, o fluxo através do contorno sul e o verde, o fluxo através do contorno leste. Simulação de verão - fevereiro. 

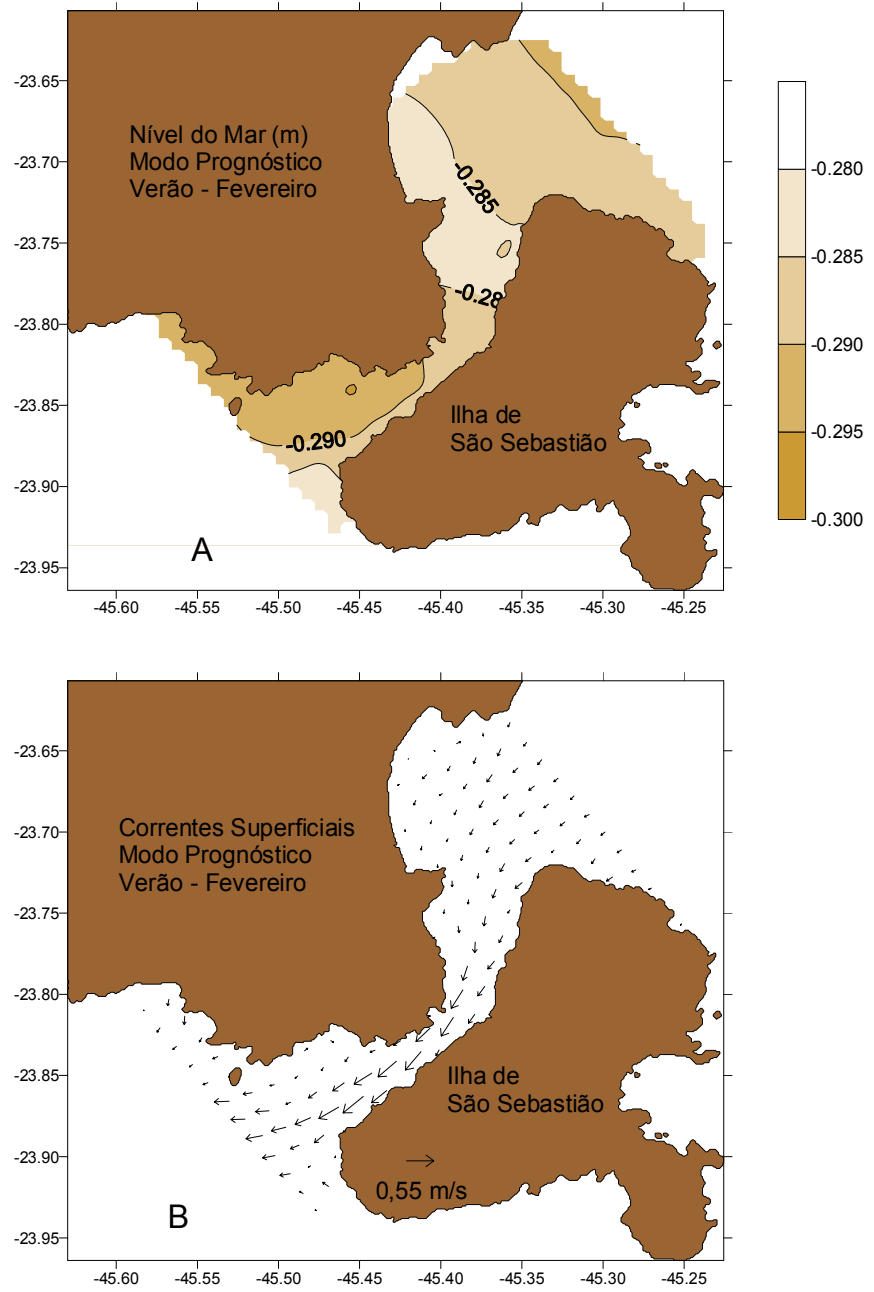

Figura 72: Nível do Mar (A). Correntes Superficiais (B). Simulação de verão fevereiro. 

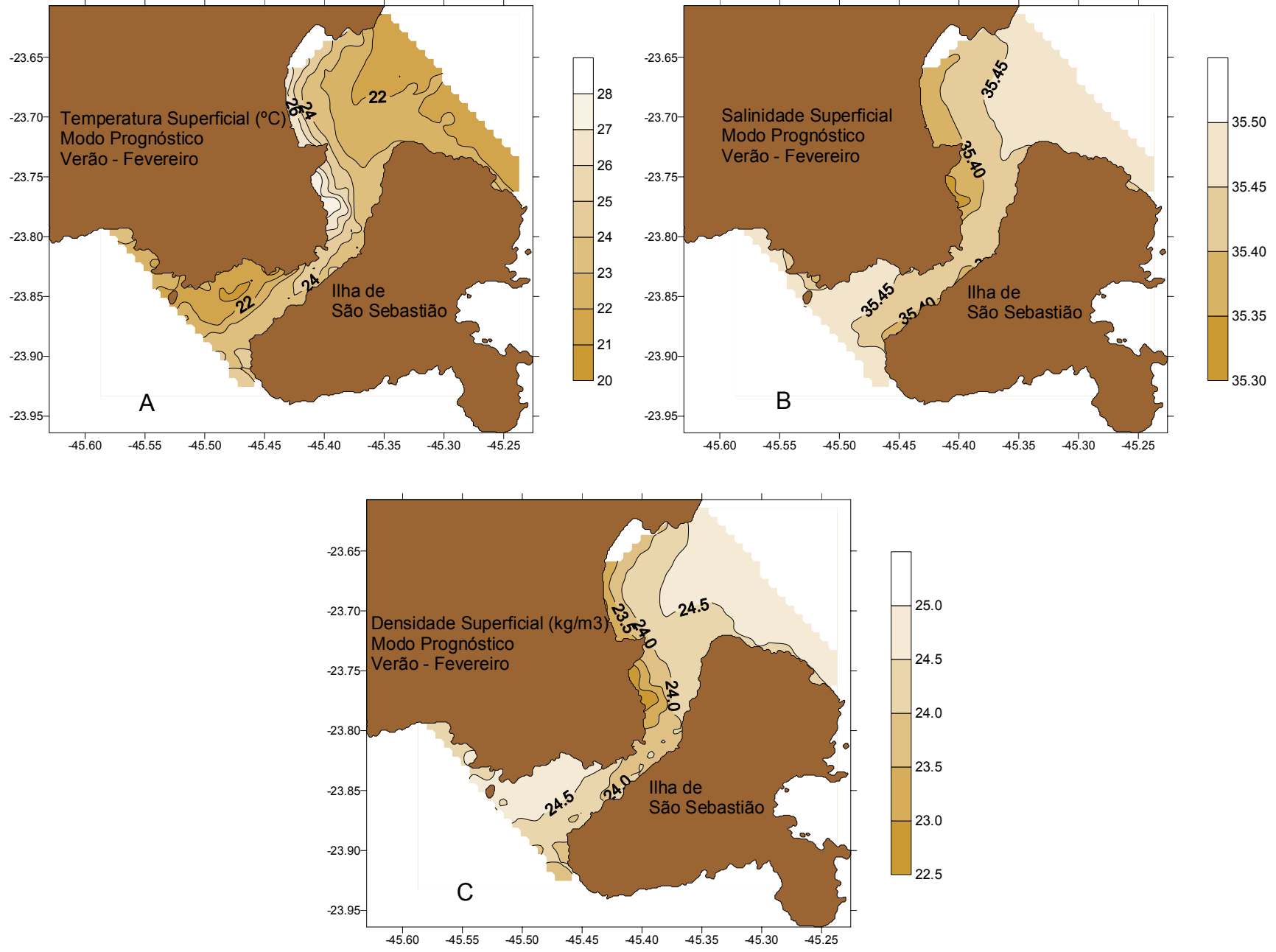

Figura 73: Distribuição horizontal superficial da temperatura (A), salinidade (B) e da densidade convencional (C) no Canal de São Sebastião. Simulação de verão - fevereiro. 

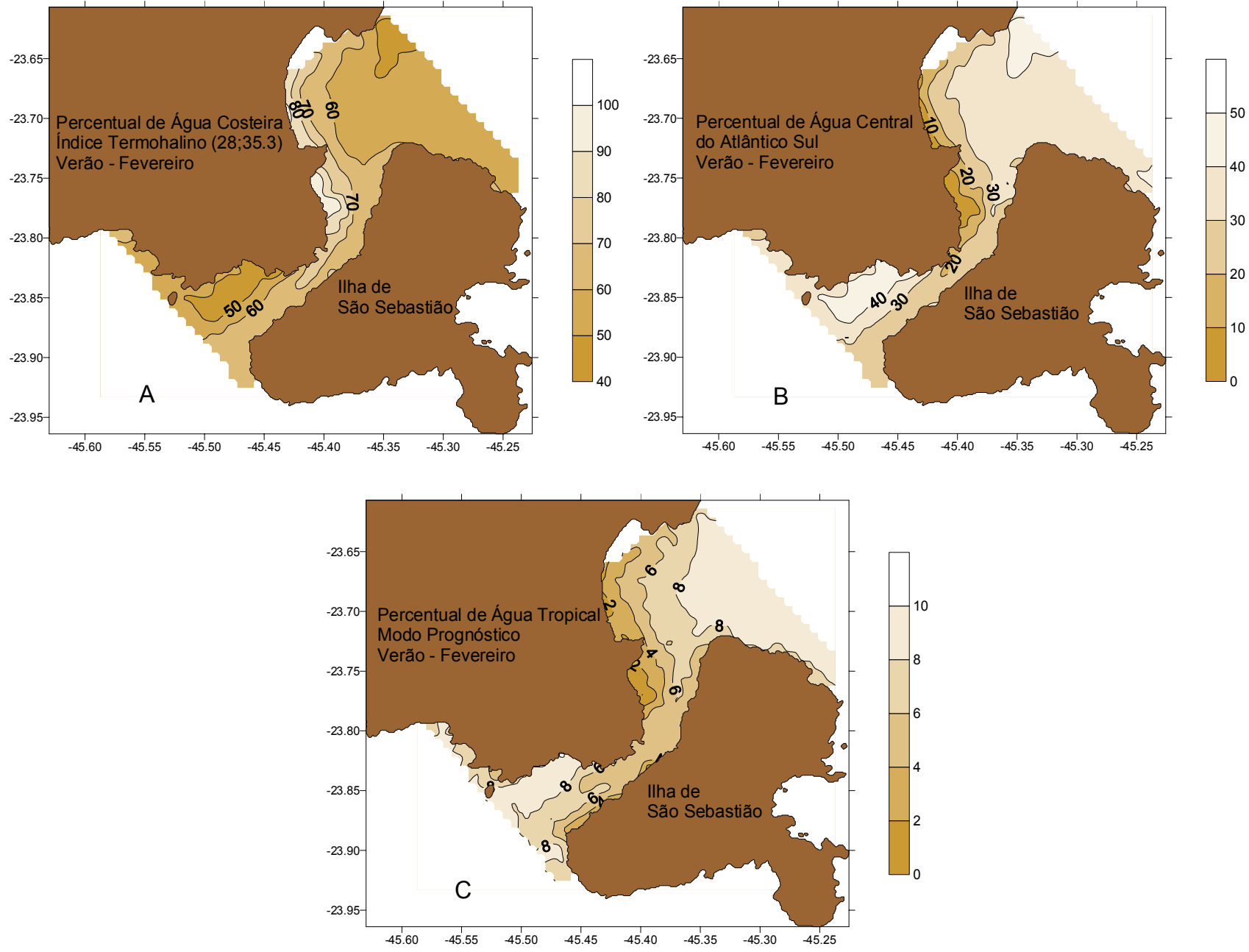

Figura 74: Distribuição horizontal dos percentuais de massas de Água Costeira (A), Água Central do Atlântico Sul (B) e Água Tropical (C) no Canal de São Sebastião. Simulação de verão - fevereiro. 

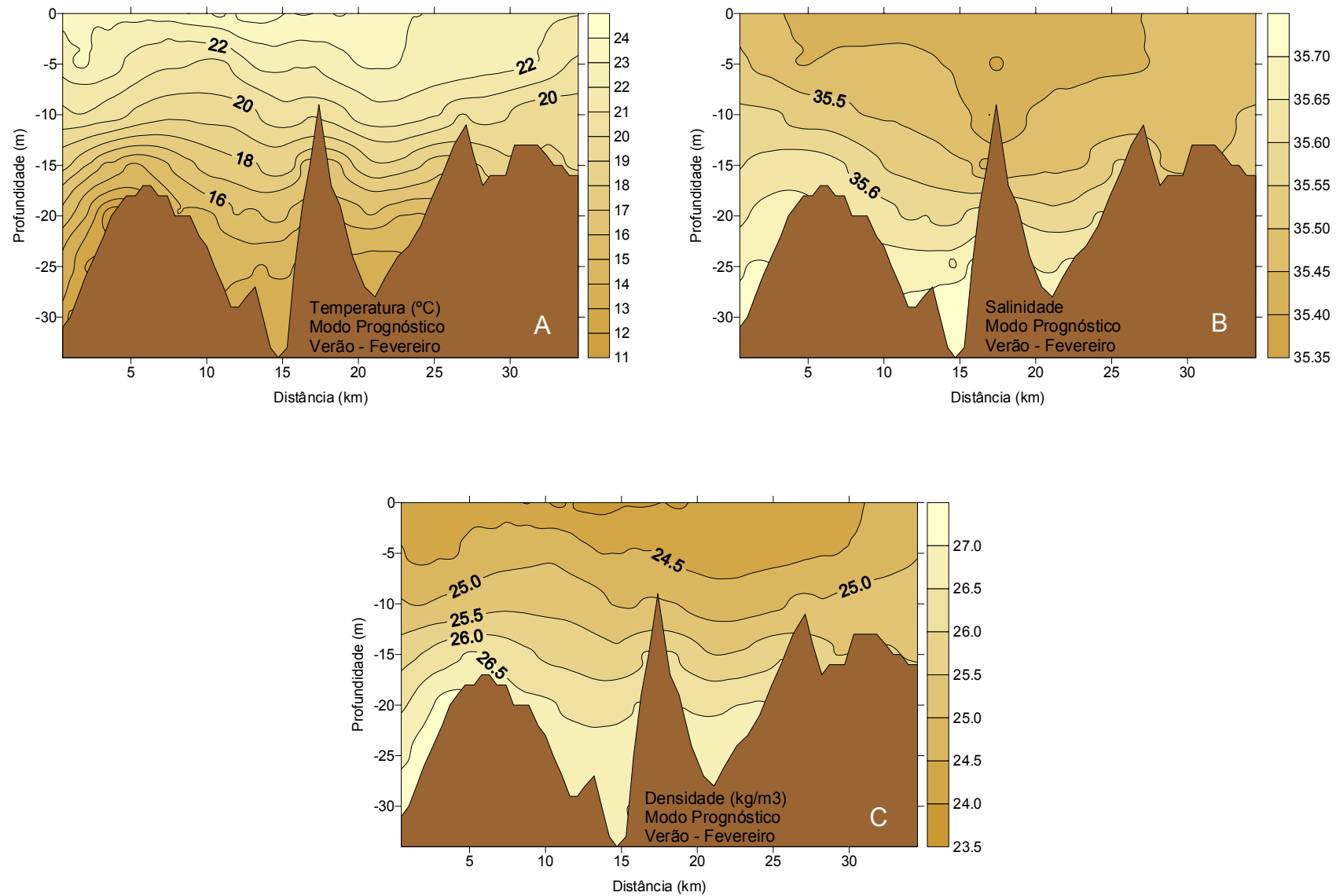

Figura 75: Distribuição vertical em uma seção ao longo do Canal de São Sebastião da temperatura (A), salinidade (B) e da densidade convencional (C). Simulação de verão fevereiro. 

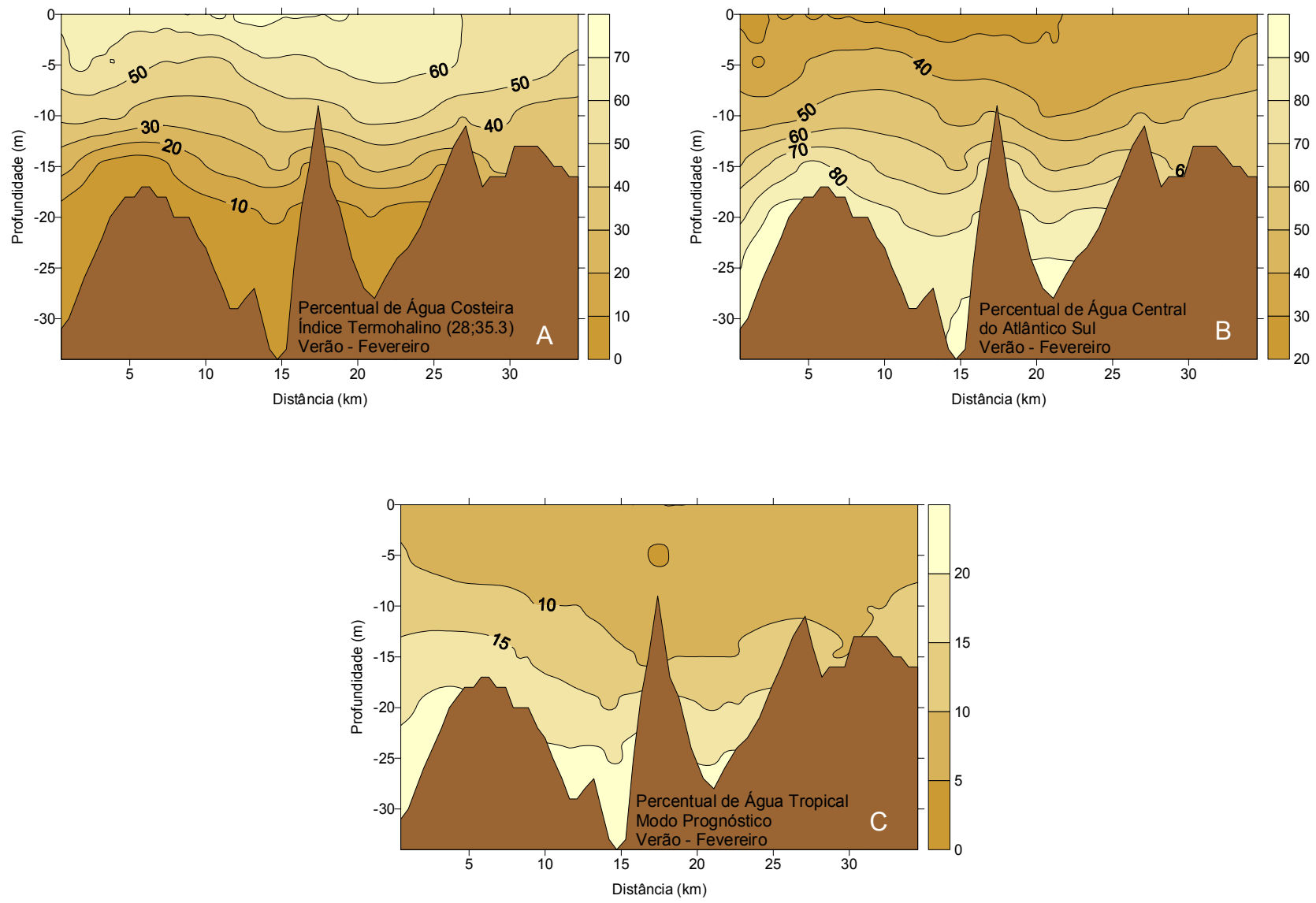

Figura 76: Distribuição vertical ao longo do Canal de São Sebastião dos percentuais das massas de Água Costeira (A), Água Central do Atlântico Sul (B) e Água Tropical (C). Simulação de verão - fevereiro. 

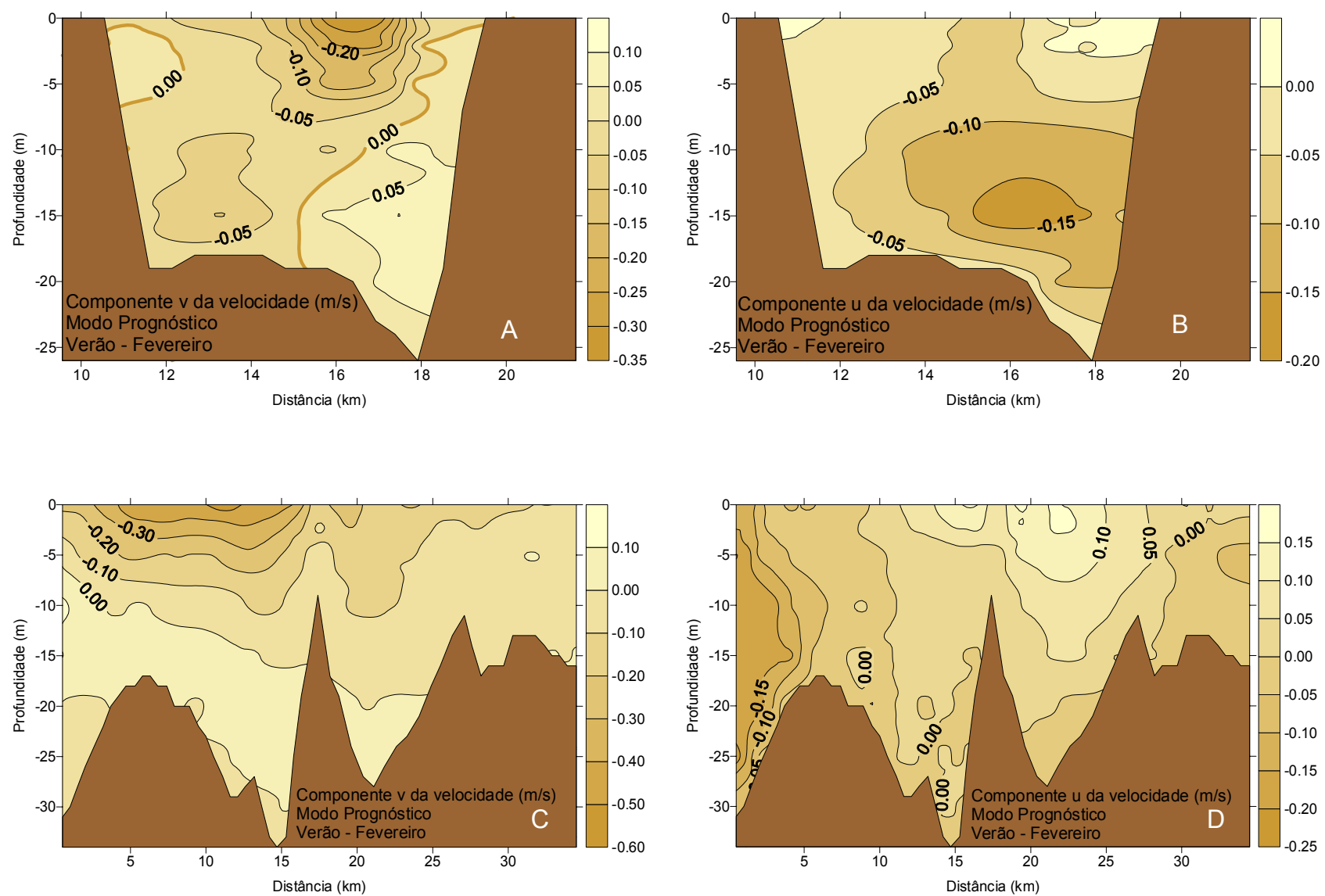

Figura 77: Distribuição vertical dos componentes de velocidade normal (A) e paralelo (B) à seção A . Distribuição vertical ao longo do Canal de São Sebastião dos componentes de velocidade normal $(\mathrm{C})$ e paralelo $(\mathrm{D})$ às seções. Simulação de verão - fevereiro. 

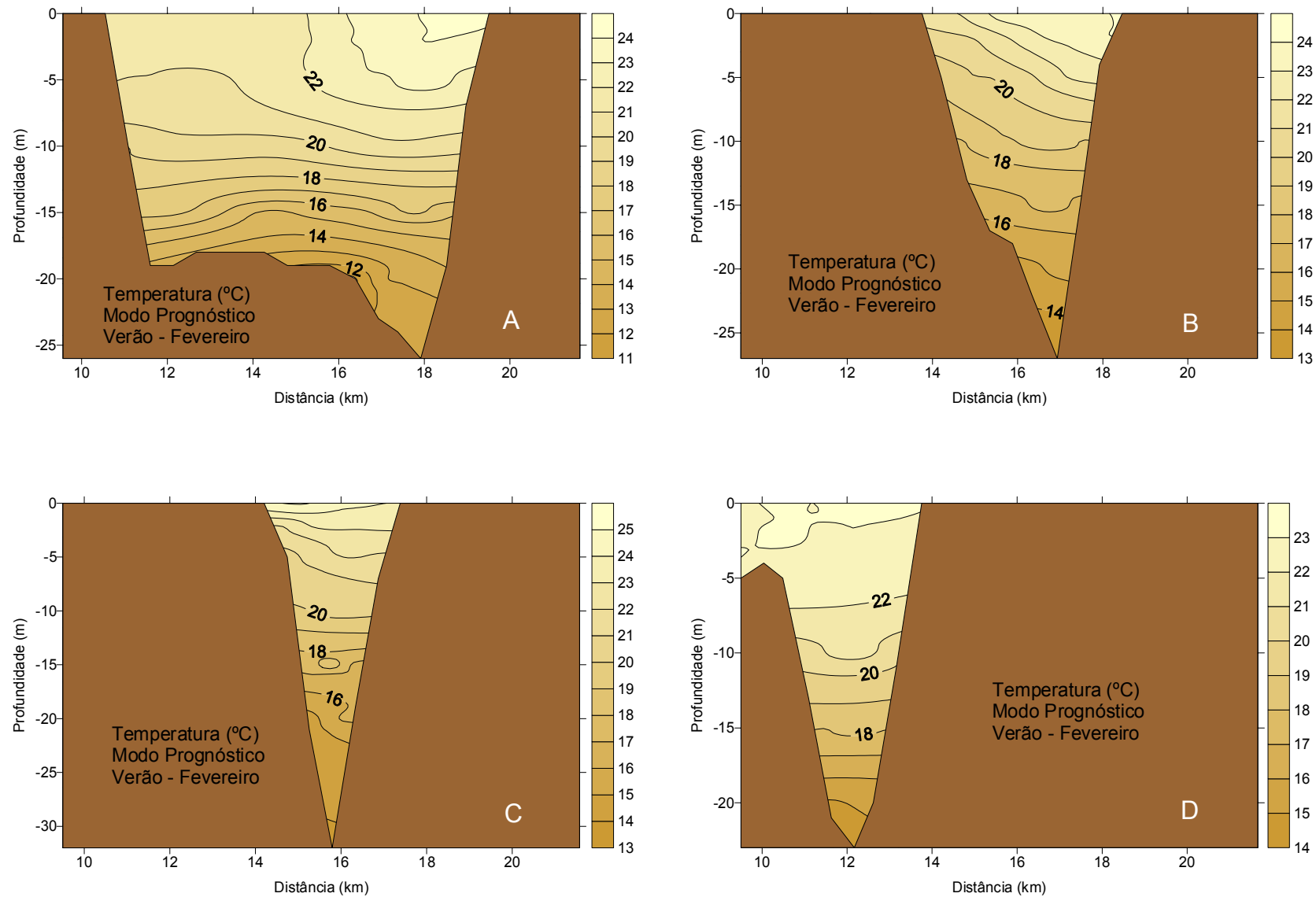

Figura 78: Distribuição vertical de temperatura nas seções A, B, C e D, localizadas na região interna do Canal de São Sebastião. Simulação de verão - fevereiro. 

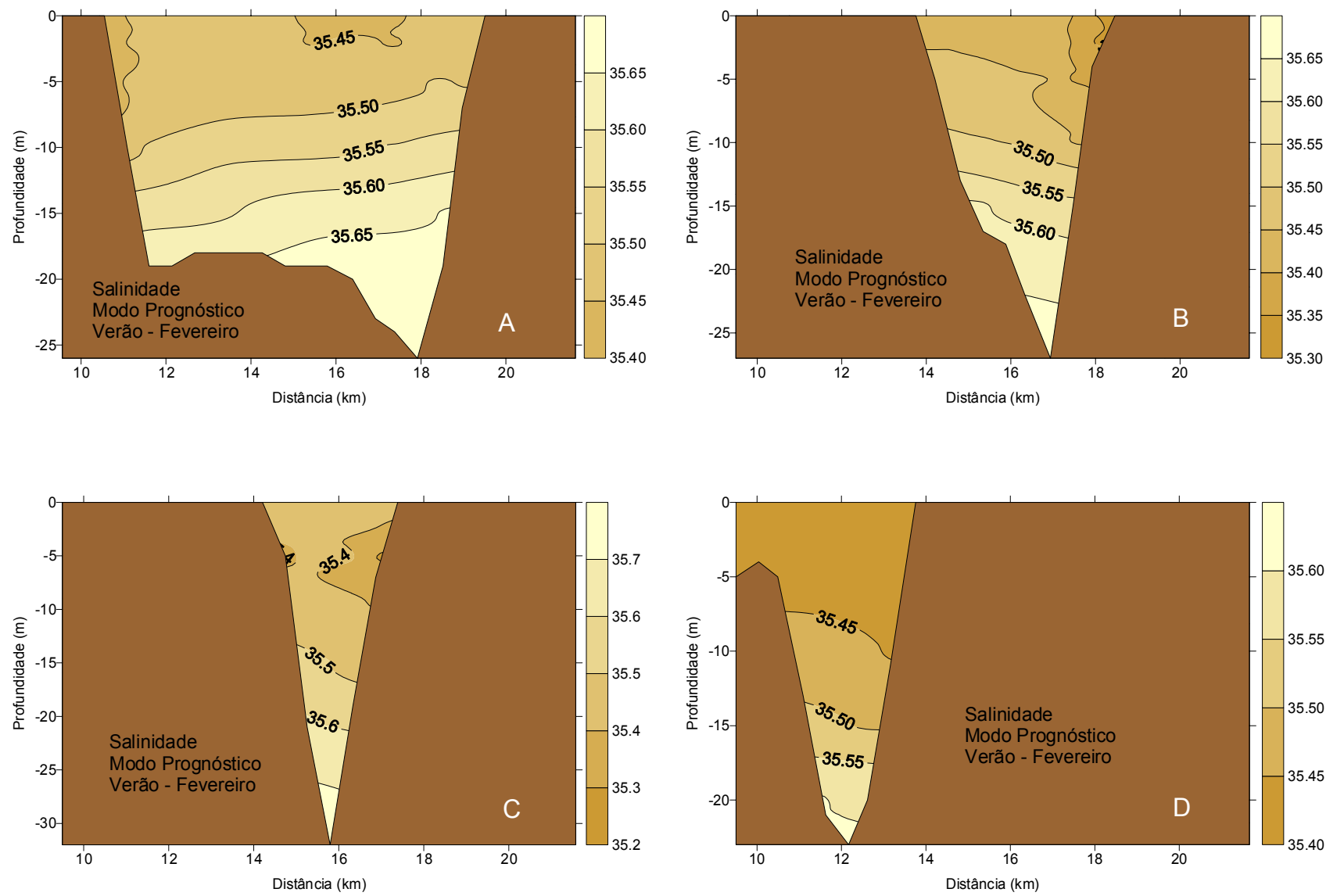

Figura 79: Distribuição vertical de salinidade nas seções A, B, C e D, localizadas na região interna do Canal de São Sebastião. Simulação de verão - fevereiro. 

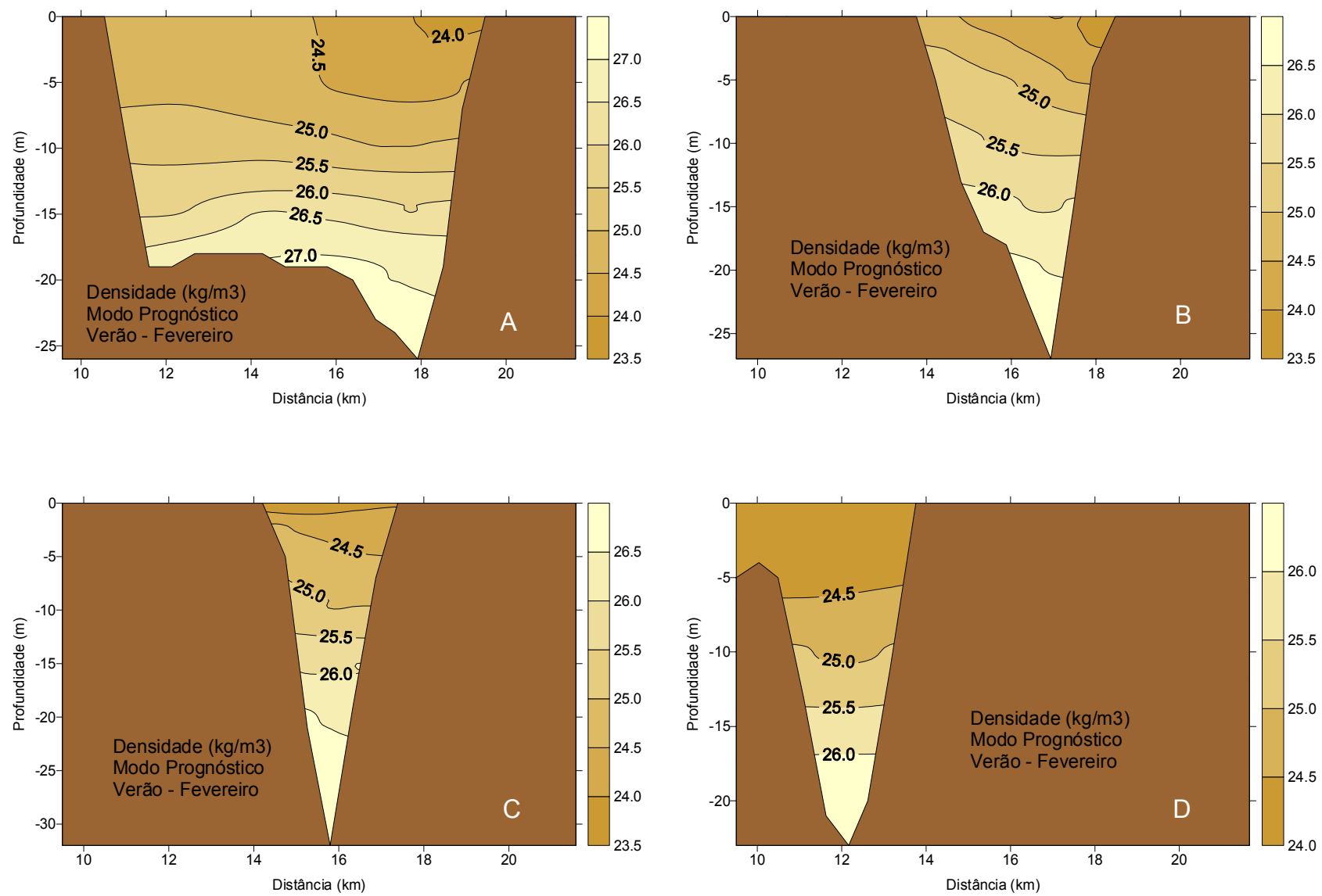

Figura 80: Distribuição vertical da densidade convencional nas seções $A, B, C$ e D, localizadas na região interna do Canal de São Sebastião. Simulação de verão - fevereiro. 

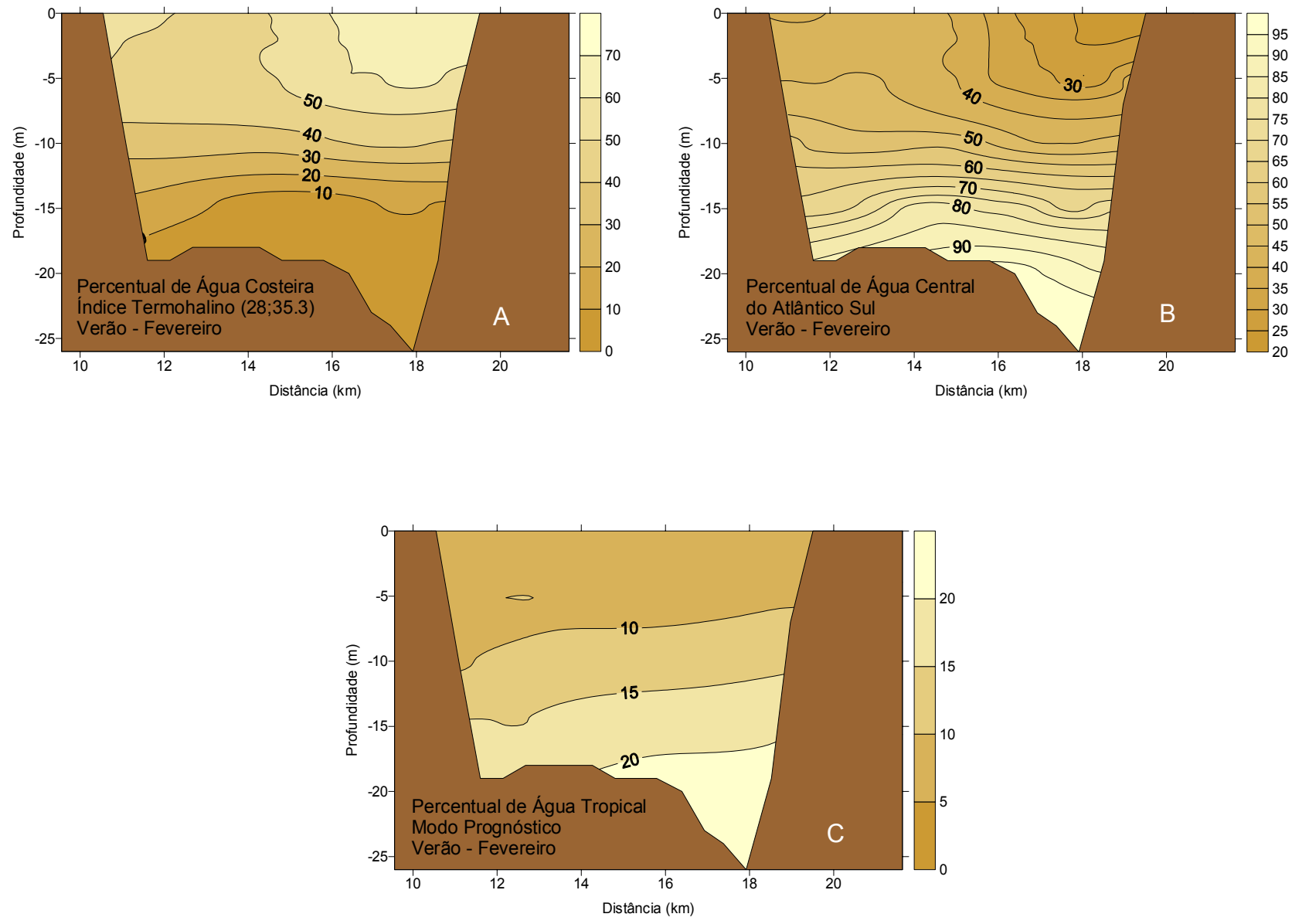

Figura 81: Distribuição vertical dos percentuais de massas de Água Costeira (A), Água Central do Atlântico Sul (B) e da Água Tropical (C) na seção A, localizada na região interna do Canal de São Sebastião. Simulação de verão - fevereiro. 


\subsection{Outono}

\subsubsection{A Plataforma Continental Sudeste}

As curvas de energia mecânica, de fluxos de energia nos contornos e do nível do mar médio encontram-se na Fig. 82 A,B,C. Os níveis de energia mecânica que haviam aumentado da primavera para o verão, diminuem nesta estação, sendo menores do que os da primavera. O fluxo de energia através do contorno norte é oscilante e o mais significativo; o fluxo através do contorno sul mantém-se baixo durante todo o período de integração. A curva do nível do mar médio oscila em torno de valores positivos, em decorrência de que nesta estação, os ventos não são de nordeste.

O nível do mar (Fig.83A) é mais alto na costa $(0,10 \mathrm{~m})$, declinando para o largo, onde encontram-se níveis de $-0,15 \mathrm{~m}$ na região central. Sobre a plataforma, as isolinhas desta propriedade são aproximadamente paralelas às isóbatas. O padrão de circulação superficial (Fig. 83B) muda em relação à primavera e ao verão, com correntes fluindo para nordeste na costa, para sudoeste na região da quebra da plataforma e para nordeste novamente mais ao largo. As velocidades das correntes são bem menores nesta estação, com valores máximos de $0,55 \mathrm{~m} / \mathrm{s}$.

As distribuições horizontais superficiais de temperatura, salinidade e densidade convencional podem ser examinadas na Fig. 84 A,B,C. As temperaturas superficiais que haviam aumentado da primavera para o verão, tornam a diminuir, com valores entre 22 e $24,5^{\circ} \mathrm{C}$ sobre a plataforma, chegando a $27,5^{\circ}$ em alguns pontos mais ao largo. Os fortes gradientes de temperatura ao largo da Baía de Guanabara que caracterizaram as estações da primavera e verão, desaparecem nesta estação, diminuindo a intensidade das correntes da quebra da plataforma (CB). As salinidades variam entre 34,4, na costa, região sul do domínio, até 37,0, na região central, externo à plataforma. Os máximos e mínimos de salinidades nestas três estações examinadas até o momento são aproximadamente os mesmos e suas configurações também, com um gradiente mais acentuado na quebra da plataforma. As densidades variam de $23,6 \mathrm{~kg} / \mathrm{m}^{3}$ na costa até $24,8 \mathrm{~kg} / \mathrm{m}^{3}$ ao largo.

Quando analisamos os percentuais de massas de água na superfície (Fig.85 $\mathrm{A}, \mathrm{B}, \mathrm{C})$, percebemos que a $\mathrm{AC}$ ocupa toda a costa, porém recuada em relação ao verão. Da primavera para o verão ela havia se estendido da costa para o largo e do sul 
para o norte. Os sinais da ACAS (40\%) ao norte, no verão, desfazem-se, porém a AT que havia recuado para o largo da primavera para o verão, volta a se aproximar da costa a uma distância, em média, ligeiramente menor do que aquela na primavera. Percebemos ainda um núcleo destacado da AT ao leste da Baía de Santos. A região de estudo tem nesta estação uma presença mais marcante da AT do que nas outras estações.

Os perfis verticais das propriedades temperatura, salinidade e densidade em uma seção transversal ao sul do CSS encontram-se na Fig. 86 A,B,C. As temperaturas no fundo da plataforma tornam a se elevar, posto que haviam diminuído da primavera para o verão, como podemos perceber ao visualizarmos a isoterma de $18^{\circ} \mathrm{C}$. Ela praticamente volta à mesma profundidade que estava na primavera. No verão esta isoterma 'invade' a plataforma efetivamente. O campo de salinidade não se modifica muito com relação ao do verão a não ser por uma leve diminuição de seus valores. A salinidade sobre a plataforma não ultrapassa 36,6 . Os gradientes de densidade sobre a plataforma diminuem e a isopicnal de $26 \mathrm{~kg} / \mathrm{m}^{3}$ recua para o largo. As densidades variam, sobre a plataforma, entre $22,5 \mathrm{~kg} / \mathrm{m}^{3}$ e $26,5 \mathrm{~kg} / \mathrm{m}^{3}$.

Pela análise da Fig. 87 A,B,C percebemos que a AC recua para a costa em relação ao verão e que a ACAS se afasta da costa e se aprofunda sobre a plataforma. A AT que estava nos limites de $160 \mathrm{~km}$ da costa agora se encontra a cerca de $130 \mathrm{~km}$ da costa.

Analisando-se os perfis verticais das componentes de velocidade (Fig. 88 A,B), vemos que as correntes sobre a plataforma fluem para norte com os maiores valores ao redor de $0,20 \mathrm{~m} / \mathrm{s}$ até cerca de $130 \mathrm{~km}$ da costa, a partir de onde fluem para sul com máximo de $-0,10 \mathrm{~m} / \mathrm{s}$. Da quebra da plataforma até cerca de $370 \mathrm{~km}$ da costa, as correntes fluem para norte com núcleo na profundidade de $400 \mathrm{~m}$ e máximo de 0,40 $\mathrm{m} / \mathrm{s}$. A componente u sobre a plataforma é positiva com máximo na superfície de 0,10 $\mathrm{m} / \mathrm{s}$, indicando que na costa as correntes fluem para nordeste; na quebra da plataforma, esta componente (u) é negativa. Na quebra da plataforma, as correntes fluem aproximadamente para sudoeste embora menos intensas do que na primavera e verão e ao largo destas, há fortes contra - correntes em algumas regiões. Ao longo de toda a costa, as correntes fluem para nordeste. 

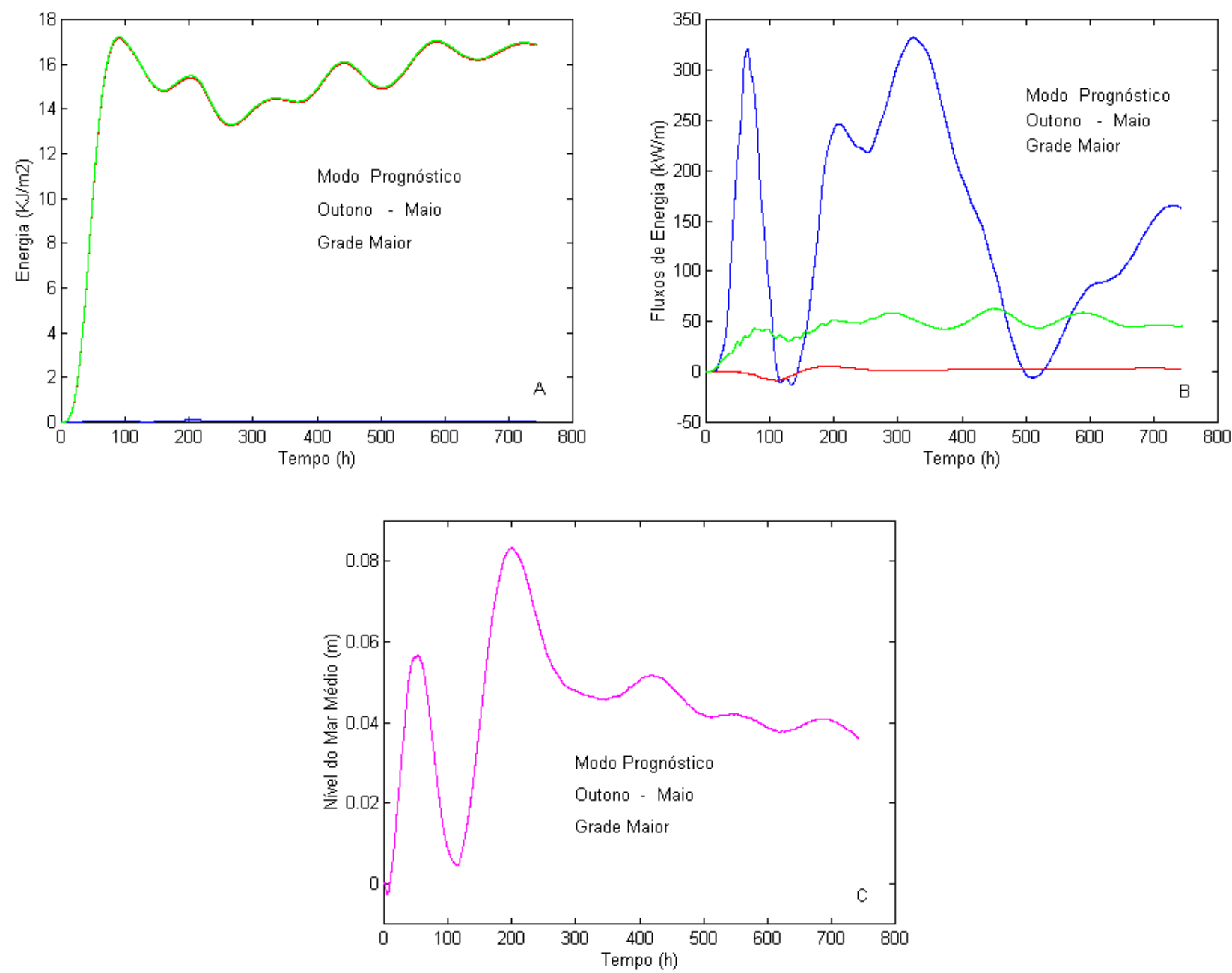

Figura 82: Curvas de energia mecânica (A), fluxos nos contornos (B) e nível do mar médio (C) na PCSE, sendo em (A), o verde, a energia mecânica, o vermelho, a energia cinética e o azul, a energia potencial. Em (B), o azul representa o fluxo através do contorno norte, o vermelho, o fluxo através do contorno sul e o verde, o fluxo através do contorno leste. Simulação de outono - maio. 

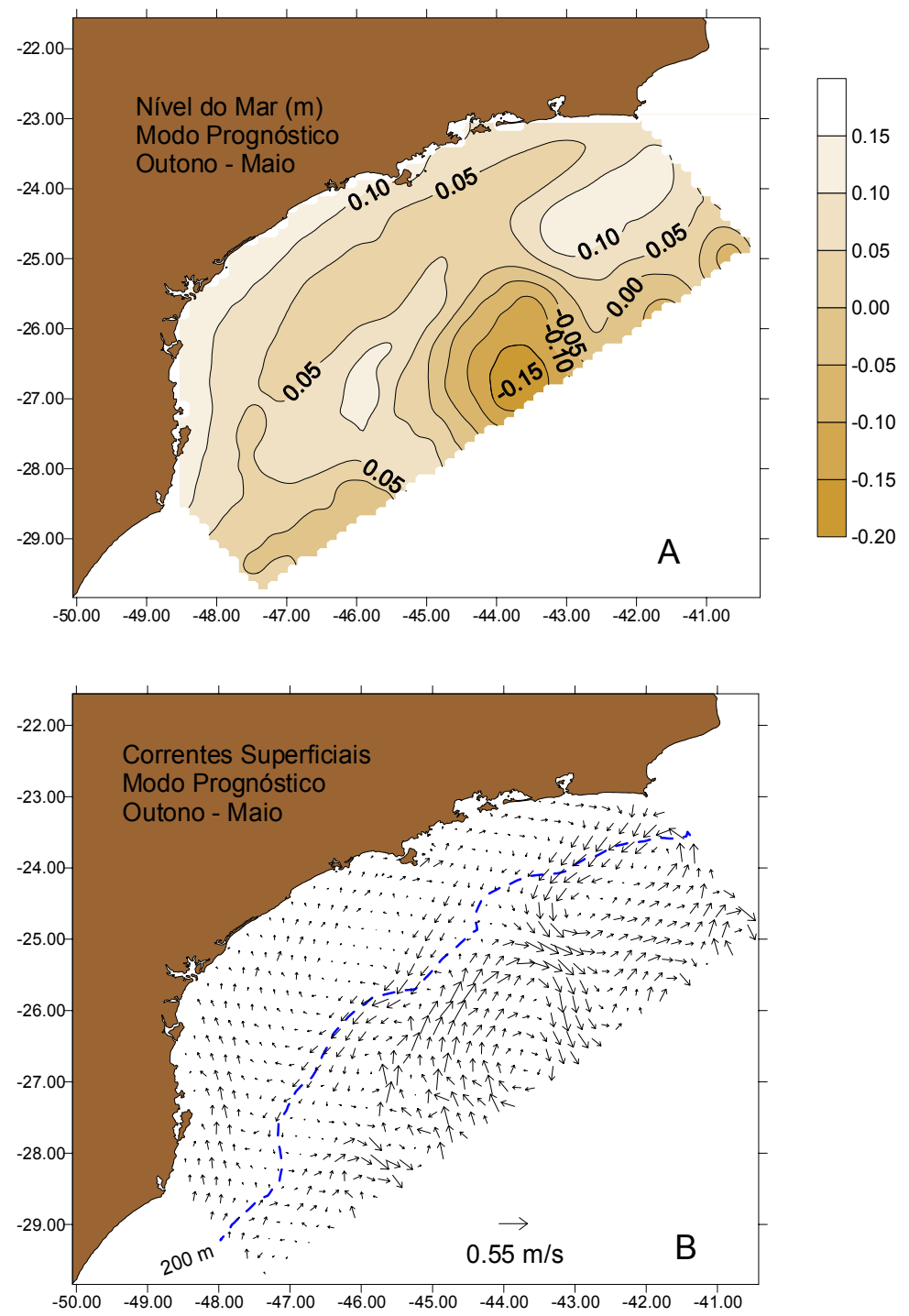

Figura 83: Nível do Mar (A) e Correntes Superficiais (B) na Plataforma Continental Sudeste. Simulação de outono - maio. 

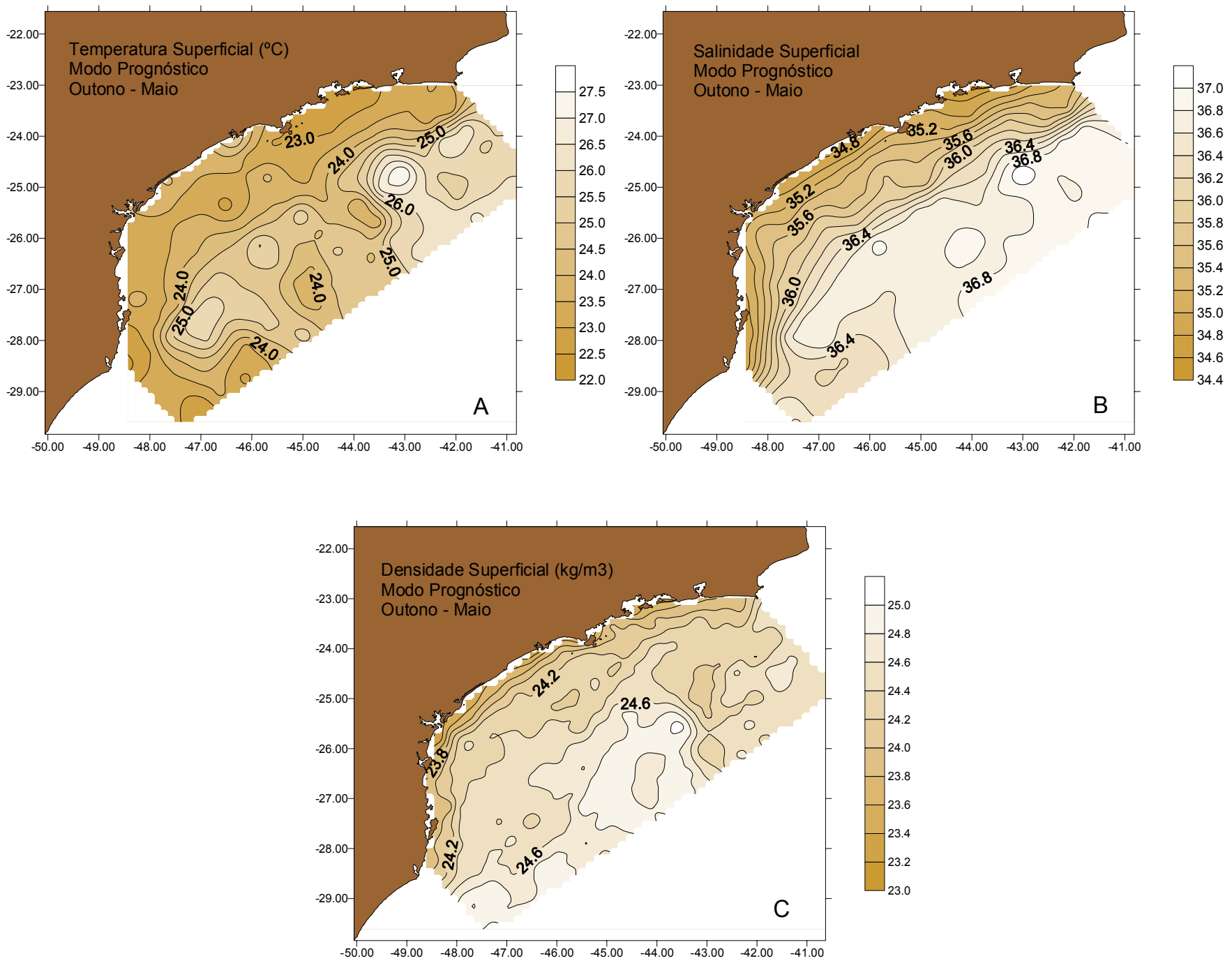

Figura 84: Distribuição horizontal superficial da temperatura (A), da salinidade (B) e da densidade convencional (C) na Plataforma Continental Sudeste. Simulação de outono - maio. 

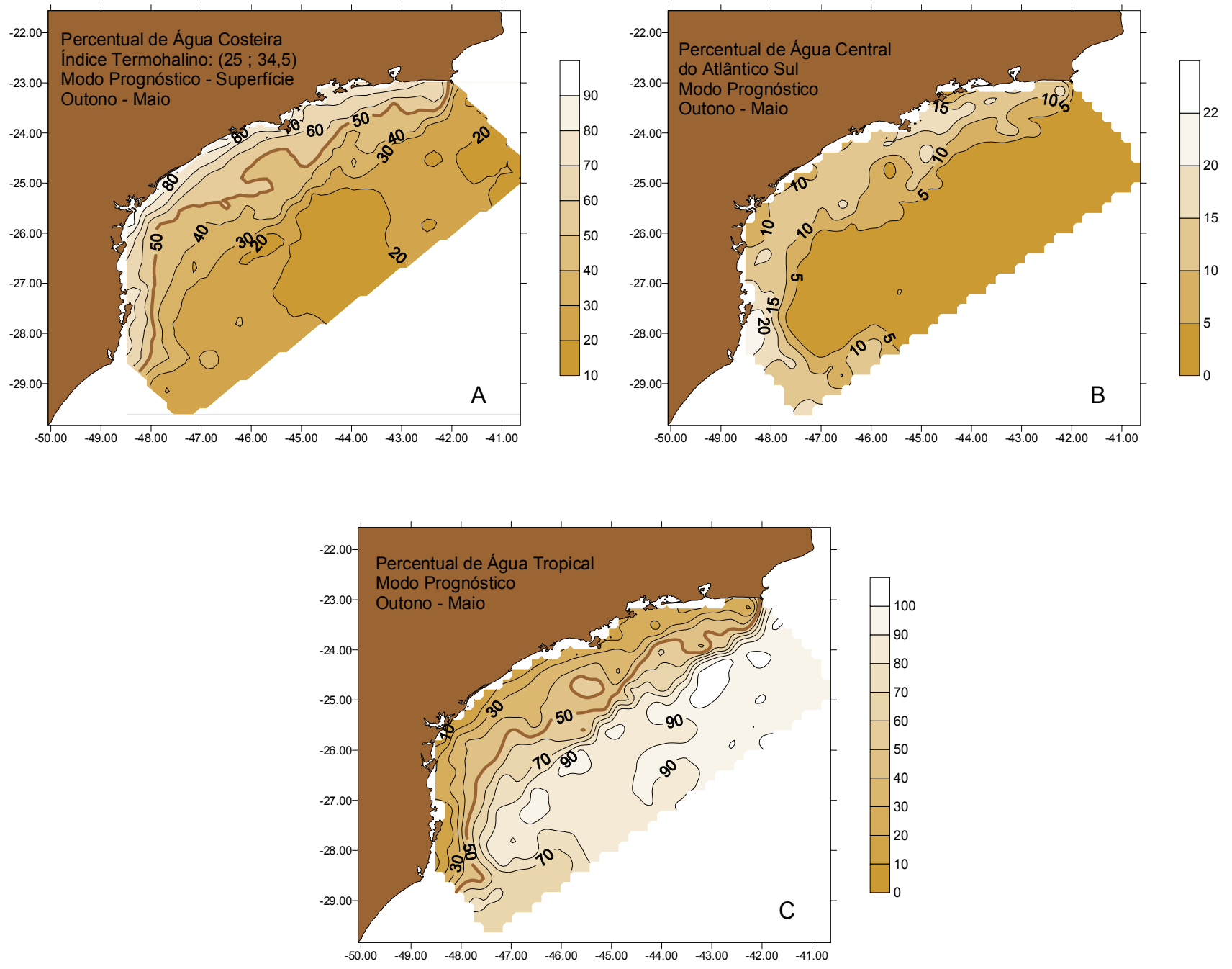

Figura 85: Distribuição horizontal superficial dos percentuais de massas de Água Costeira (A), Água Central do Atlântico Sul (B) e Água Tropical (C) na Plataforma Continental Sudeste. Simulação de outono - maio. 

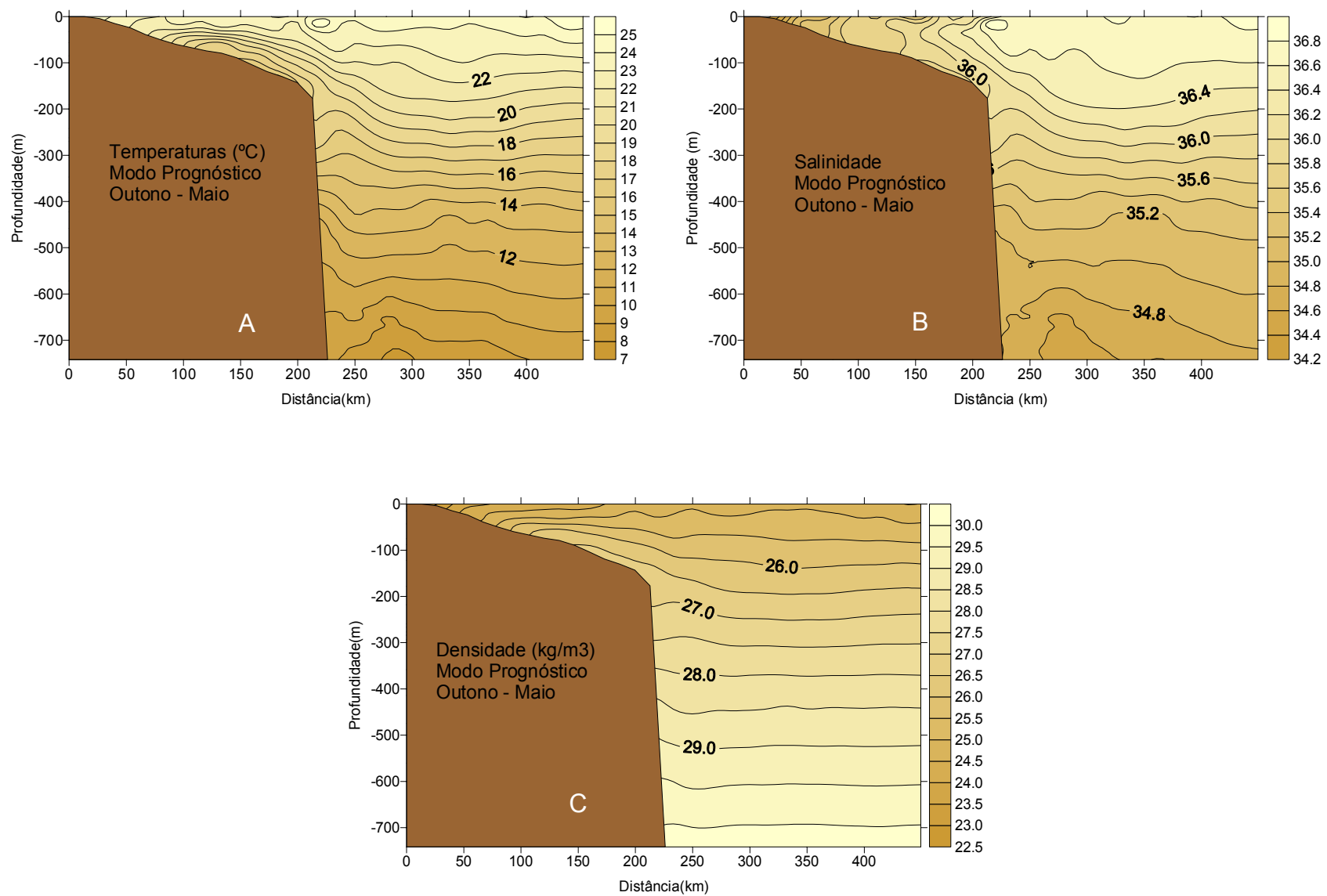

Figura 86: Distribuição vertical da temperatura (A), da salinidade (B) e da densidade convencional (C) na Plataforma Continental Sudeste ao sul do Canal de São Sebastião. Simulação de outono - maio. 

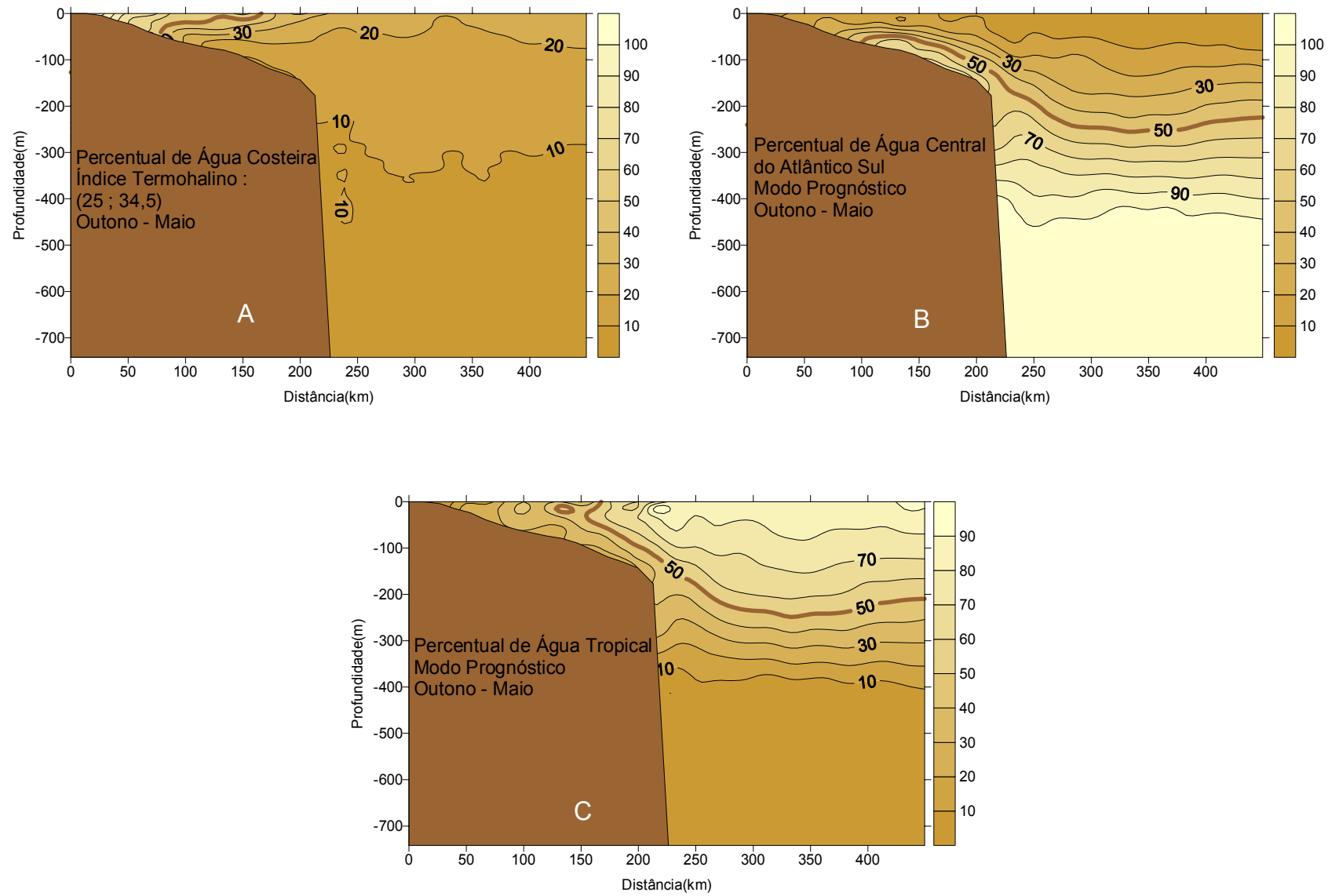

Figura 87: Distribuição vertical dos percentuais das massas de Água Costeira (A), Água Central do Atlântico Sul (B) e da Água Tropical (C) na Plataforma Continental Sudeste ao sul do Canal de São Sebastião. Simulação de outono - maio. 

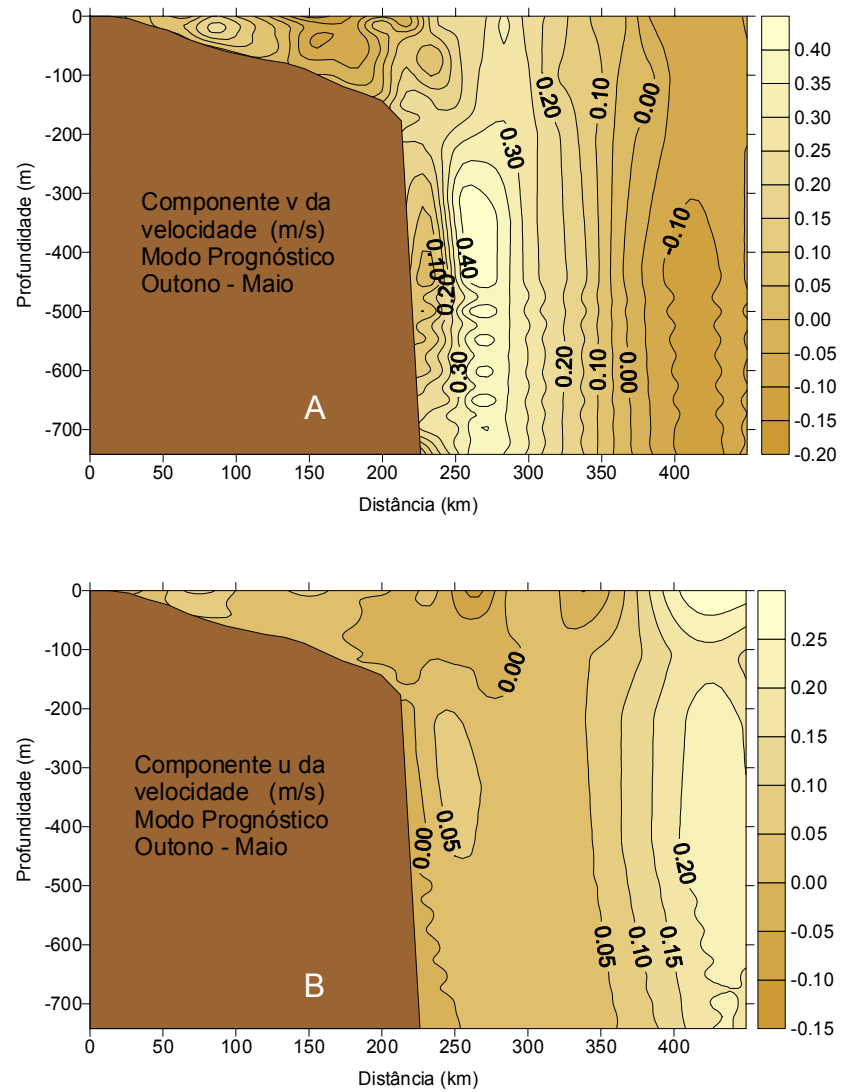

Figura 88: Distribuição vertical das componentes de velocidade paralela (A) e perpendicular (B) à costa na Plataforma Continental Sudeste ao sul do Canal de São Sebastião. Simulação de outono - maio. 


\subsubsection{A Plataforma Continental Interna}

A Fig.89 A,B,C apresenta os níveis de energia mecânica, fluxos de energia nos contornos e o nível do mar médio. Observa-se que estes níveis são mais baixos do que aqueles encontrados na PCSE e do que aqueles encontrados na mesma região nas estações de primavera e verão. A energia cinética contribui mais para a energia mecânica do que a potencial e o fluxo de energia pelo contorno sul é o mais significativo. Percebe-se que o caráter ondulatório encontrado nas três figuras (A,B,C) cessa em 200 h de integração. O nível do mar médio tem valores positivos tal como na PCSE, atingindo o nível de $0,08 \mathrm{~m}$ após 720 h de integração.

O nível do mar na costa (Fig.90A) é de 0,10 m com inclinação descendente para o largo, onde encontra-se $0,05 \mathrm{~m}$. O nível de $0,10 \mathrm{~m}$ na costa também foi obtido na PCSE (Fig.83 A) onde também é encontrado o nível de 0,05 $\mathrm{m}$ a leste da ISS. As correntes superficiais na PCI se apresentam na Fig. 90B. Elas fluem preferencialmente ao longo das isolinhas de nível do mar, deixando níveis mais altos à esquerda. Elas contornam a ISS com sentido nordeste intensificando-se na região onde há os maiores gradientes do nível do mar. Em decorrência de uma depressão a nordeste da ISS aparecem contra correntes fluindo para sudoeste neste local. Esta figura sugere, por continuação, que o nível do mar adquire inclinação positiva ao largo, explicando as contra correntes existentes no local. O nível do mar na PCSE (Fig.83 A) confirma que há inclinação ascendente na borda da PCI. As correntes na PCI tem máximo de 0,30 $\mathrm{m} / \mathrm{s}$.

A distribuição horizontal superficial de temperatura, salinidade e densidade é apresentada na Fig. 91 A,B,C. As menores temperaturas (ao redor de 23,0 ${ }^{\circ} \mathrm{C}$ ) são encontradas no sul e no leste da ISS, enquanto que as maiores $\left(23,6^{\circ} \mathrm{C}\right)$ também encontram-se a leste da ISS. A proximidade destes extremos de temperatura a leste da ISS gera um forte gradiente horizontal desta propriedade. O mínimo de salinidade encontra-se bem junto à costa, ao norte $(35,0)$, enquanto que o máximo de salinidade $(35,7)$ localiza-se no sul da ISS. Em decorrência deste máximo de salinidade, temos neste local o máximo de densidade $\left(24,3 \mathrm{~kg} / \mathrm{m}^{3}\right)$. O mínimo encontra-se no mesmo local onde foi encontrado o máximo de temperatura $\left(23,9 \mathrm{~kg} / \mathrm{m}^{3}\right)$. As propriedades mostradas nestas figuras guardam continuidade com aquelas vistas para a PCSE (Fig. 84). 
Os perfis verticais destas mesmas propriedades se encontram na Fig. 92 A,B,C. Examinando-se as temperaturas e comparando-as às da Fig. 68, percebemos que as águas mais frias no fundo recuam para o largo aprofundando-se. A isoterma de $16^{\circ} \mathrm{C}$ que se estendia de 20 a $40 \mathrm{~m}$ de profundidade no verão, encontra-se no outono em profundidades abaixo de $100 \mathrm{~m}$. Mais ao largo porém, há um resfriamento das águas superficiais. Com relação às salinidades percebemos que junto à costa, na superfície, as salinidades são mais baixas, sendo que a isohalina de 35,6 intercepta o fundo na profundidade de $60 \mathrm{~m}$ quando no verão o interceptava em $20 \mathrm{~m}$ de profundidade. A configuração das isopicnais é semelhante à das isotermas com o mínimo na superfície $\left(23,8 \mathrm{~kg} / \mathrm{m}^{3}\right)$ junto à costa e o máximo $\left(26,4 \mathrm{~kg} / \mathrm{m}^{3}\right)$ no fundo, ao largo. A configuração e níveis obtidos para estas propriedades nesta seção transversal são muito semelhantes aos obtidos por Coelho (1997) em um cruzeiro oceanográfico de maio/92 na PCI em uma seção transversal próxima a esta.

A Fig. 93 A,B,C apresenta os perfis verticais dos percentuais de massas de água para esta estação do ano. A AC que no verão ocupava somente os primeiros metros da superfície (Fig. 67A), no outono, se aprofunda para $60 \mathrm{~m}$. A ACAS se aprofunda para abaixo de $60 \mathrm{~m}$ limitando-se com a AC acima (Fig. 93B). Os percentuais de AT não ultrapassam $40 \%$.

As componentes de velocidade $\mathrm{v}$ e u em um perfil vertical ao sul do CSS podem ser examinadas na Fig. 94 A,B. As correntes nesta seção transversal tem a forma de um jato com núcleo na profundidade de $6 \mathrm{~m}$ aproximadamente. Este jato tem sentido nordeste e sua intensidade diminui conforme afasta-se do centro, sendo que há inversão de sentido no fundo e ao largo. A componente $\mathrm{v}$ atinge valores de até $0,17 \mathrm{~m} / \mathrm{s}$ em seu centro e na região em que a corrente flui para sudoeste chega a $-0,19 \mathrm{~m} / \mathrm{s}$. A componente $\mathrm{u}$ aponta para leste em toda a seção com exceção da região no fundo, ao largo. Seu máximo é de $0,21 \mathrm{~m} / \mathrm{s}$. 

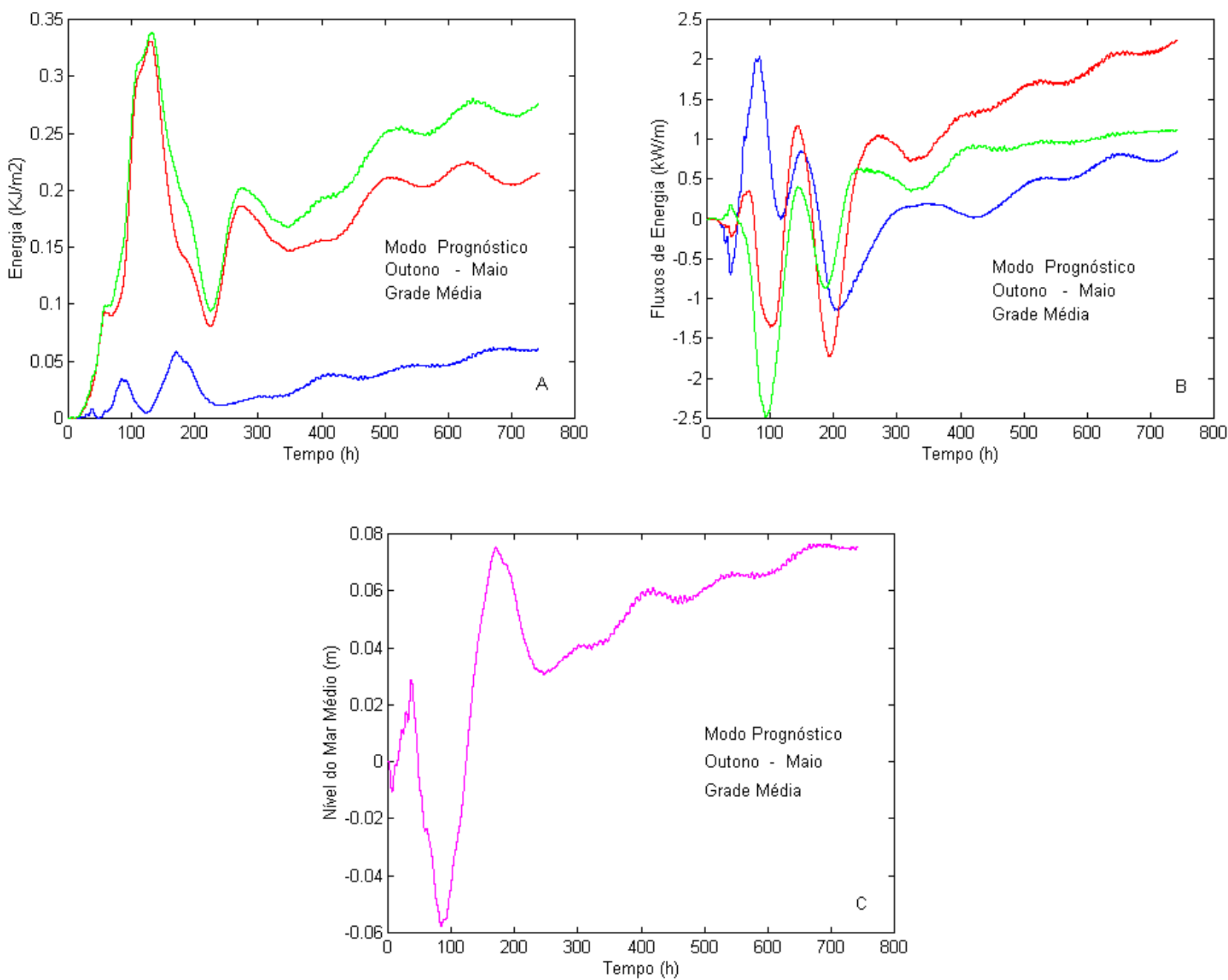

Figura 89: Curvas de energia mecânica (A), fluxos nos contornos (B) e nível do mar médio (C) na PCI, sendo em (A), o verde, a energia mecânica, o vermelho, a energia cinética e o azul, a energia potencial. Em (B), o azul representa o fluxo através do contorno norte, o vermelho, o fluxo através do contorno sul e o verde, o fluxo através do contorno leste. Simulação de outono - maio. 

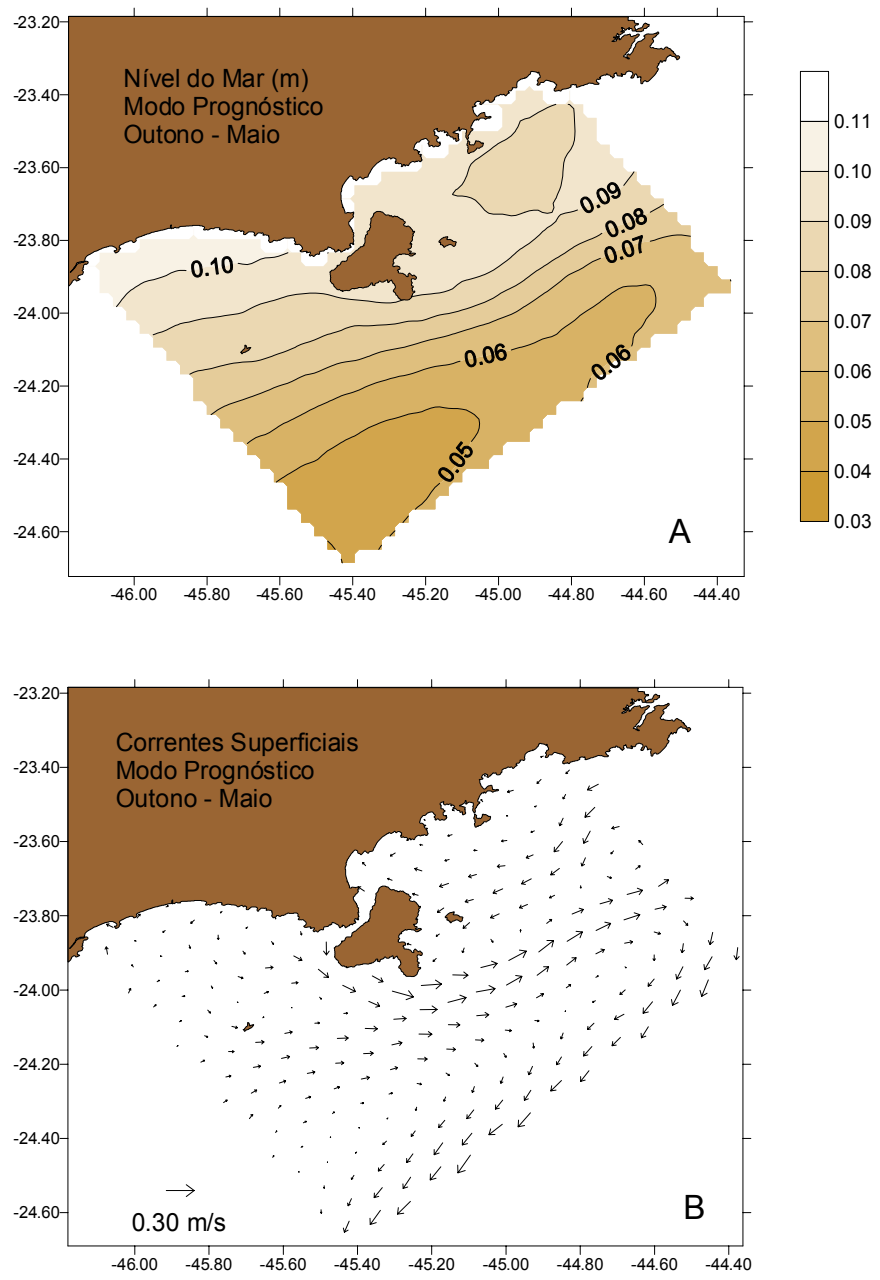

Figura 90: Nível do Mar (A) e Correntes Superficiais (B) na PCI. Simulação de outono maio. 

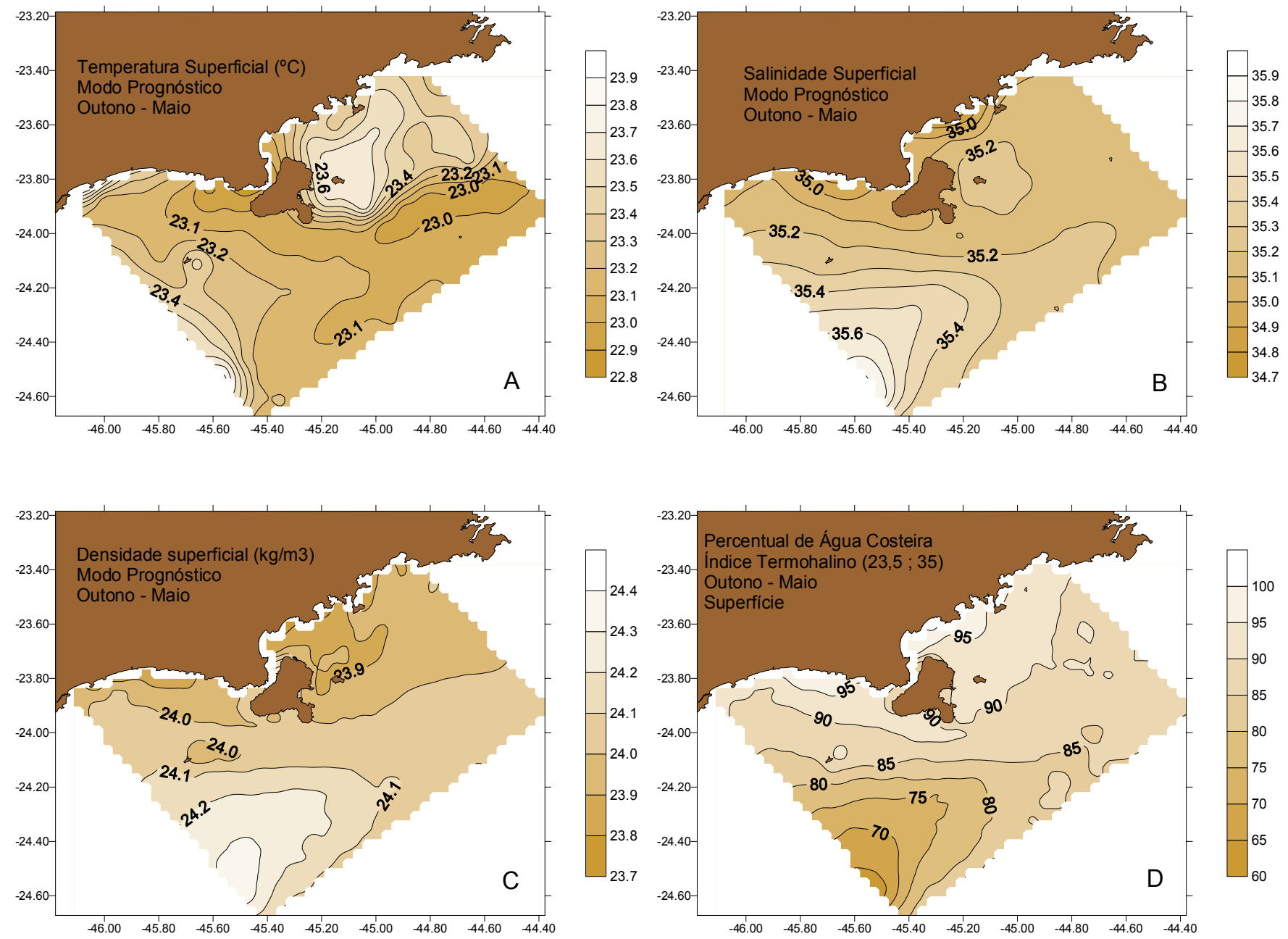

Figura 91: Distribuição horizontal superficial da temperatura (A), da salinidade (B), da densidade convencional (C) e do percentual da massa de Água Costeira (D) na PCI. Simulação de outono - maio. 

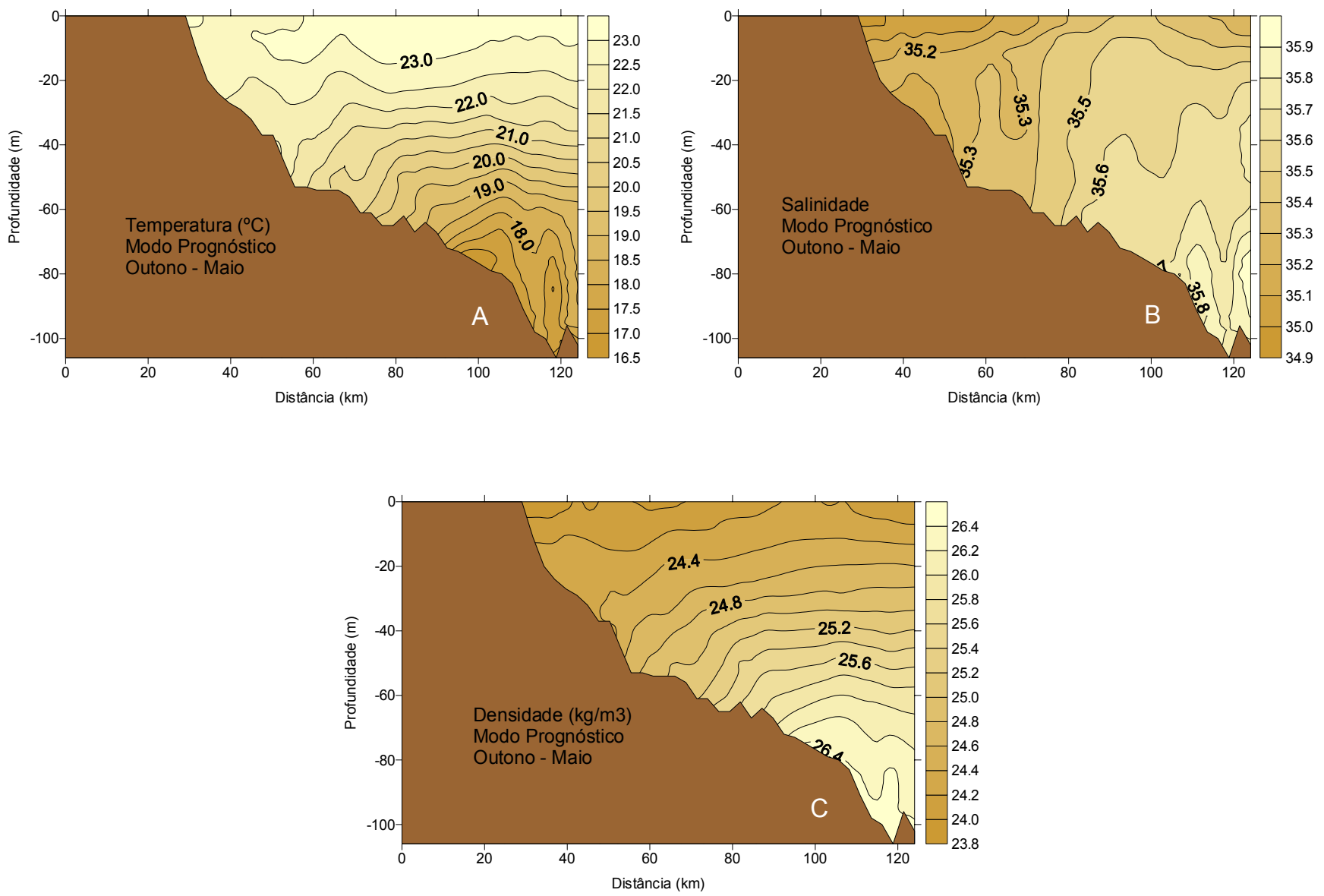

Figura 92: Distribuição vertical da temperatura (A), da salinidade (B) e da densidade convencional (C) na PCI ao sul do Canal de São Sebastião. Simulação de outono - maio. 

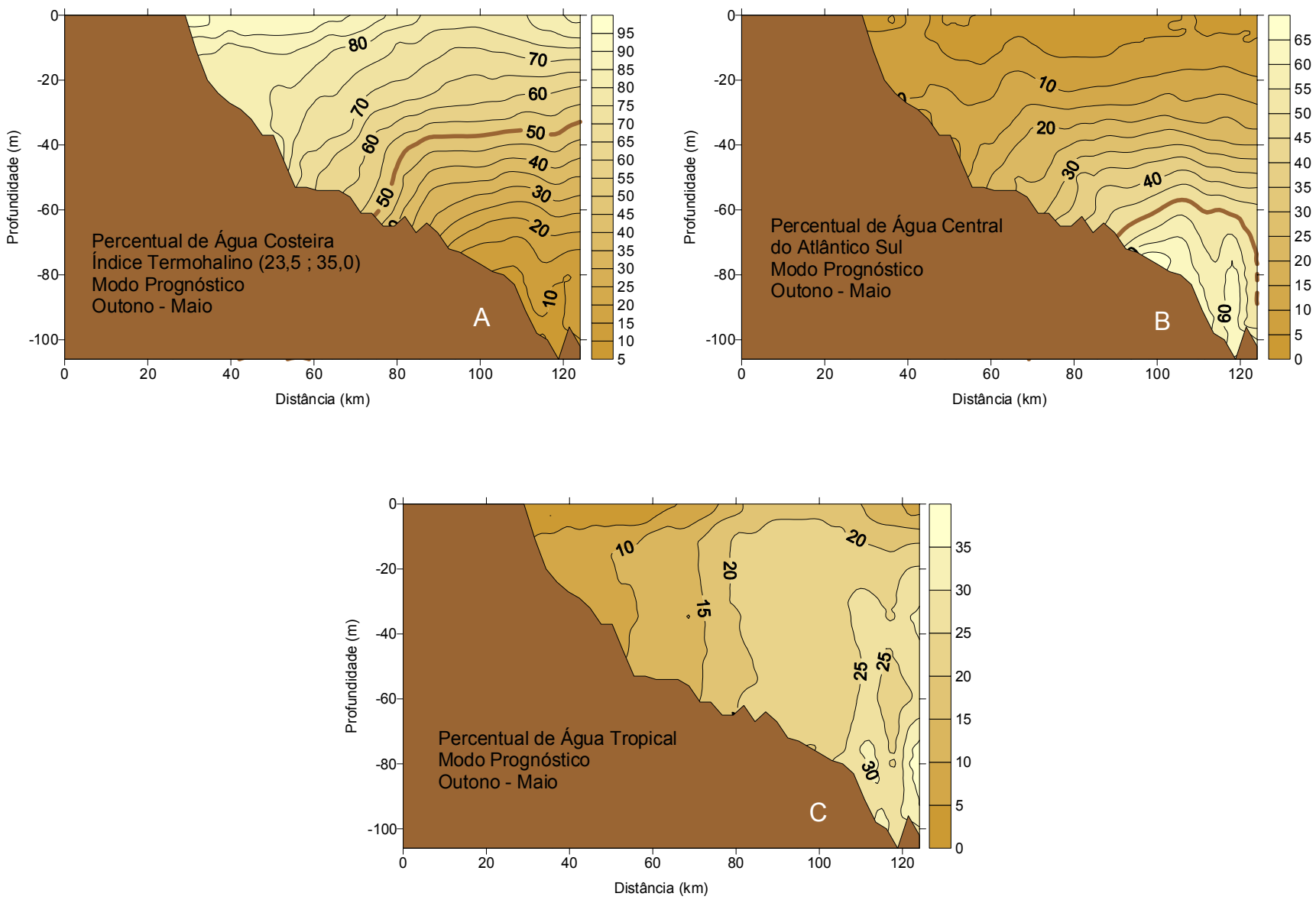

Figura 93: Distribuição vertical dos percentuais de massas de Água Costeira (A), Água Central do Atlântico Sul (B) e da Água Tropical (C) na PCI ao sul do Canal de São Sebastião. Simulação de outono - maio. 

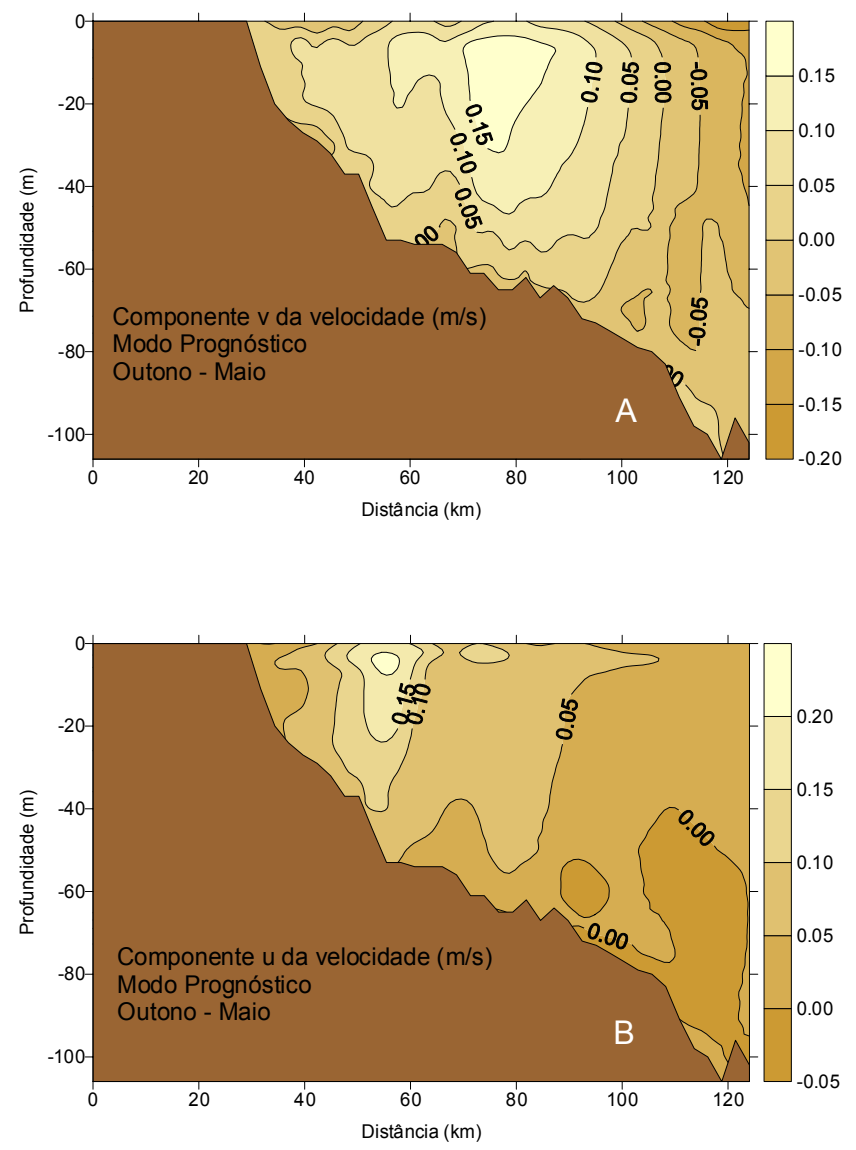

Figura 94: Distribuição vertical das componentes de velocidade paralela (A) e perpendicular (B) à costa na PCI ao sul do Canal de São Sebastião. Simulação de outono - maio. 


\subsubsection{O Canal de São Sebastião}

As curvas de energia mecânica, fluxos de energia nos contornos e nível do mar médio podem ser vistas na Fig. 95 A,B,C. Podemos observar a semelhança da configuração destas curvas com suas correspondentes de primavera e verão, como por exemplo o mínimo ao redor de $220 \mathrm{~h}$ de integração na curva de fluxos de energia nos contornos e o maior fluxo no contorno leste nas três estações analisadas. Os níveis no CSS são normalmente menores do que aqueles para a PCI, porém, a energia potencial é maior do que a energia cinética e o fluxo de energia no contorno leste é no CSS, maior do que o da PCI. O nível do mar médio, com configuração praticamente idêntica àquela da PCI, é ligeiramente maior, a maior parte do tempo, na grade do CSS, em relação à PCI.

As diferenças de nível do mar no CSS (Fig. 96A) são da ordem de 0,01 m, sendo o mínimo encontrado no sul, ao lado da ISS, e o máximo, como nas outras estações, ao norte, do lado do continente. O nível do mar é positivo em todo o canal.

As correntes superficiais (Fig. 96B) fluem de maneira geral para sudoeste, intensificando-se na região central. Junto à entrada sul, as correntes fluem perpendicularmente à costa, em direção ao largo; valores máximos chegam a $0,35 \mathrm{~m} / \mathrm{s}$. Nas estações da primavera e verão, as correntes além de mais intensas em todo o canal, fluem do largo para a costa junto à entrada sul.

As temperaturas superficiais (Fig. 97A) variam entre $22,8^{\circ} \mathrm{C}$ (sul do canal, do lado do continente) e $23,9^{\circ} \mathrm{C}$ (norte do canal, do lado do continente). Nas outras estações, primavera e verão, os extremos também foram encontrados nesses pontos, contudo, nesta estação, os valores de temperaturas estão entre os da primavera e os de verão. As salinidades superficiais (Fig. 97B) são menores do que as encontradas para a primavera e para o verão, estando o mínimo de 34,6 no norte, do lado do continente, e o máximo de 35,0 , no sul. As densidades variam entre $23,4 \mathrm{~kg} / \mathrm{m}^{3}$, no norte, do lado do continente, e $24,0 \mathrm{~kg} / \mathrm{m}^{3}$, no sul, do lado do continente.

As Figs. 98, 99 e 100 mostram os perfis verticais de temperatura, salinidade e densidade, respectivamente, junto às seções transversais A, B, C e D. Os gradientes verticais de temperatura são bem menores do que aqueles encontrados para a primavera e para o verão. Os gradientes horizontais de temperatura na superfície são pequenos, 
$\operatorname{com} 23,0^{\circ} \mathrm{C}$ junto à seção $\mathrm{A}$ e $\mathrm{B}, 23,2^{\circ} \mathrm{C}$ junto à seção $\mathrm{C}$ e $23,6^{\circ} \mathrm{C}$ junto à seção $\mathrm{D}$. No fundo, os gradientes horizontais também são pequenos, com $22^{\circ} \mathrm{C}$ na entrada sul e $22,4^{\circ} \mathrm{C}$ na entrada norte. Os maiores gradientes verticais são encontrados no fundo, na entrada sul do canal. Os gradientes verticais de salinidade (Fig.99 A,B,C,D) junto à seção A são menores do que nas outras seções do canal. Comparando estes valores com os das outras estações (primavera e verão) percebemos que as salinidades no outono são bem menores. As salinidades diminuem na superfície, do sul em direção ao norte e aumentam no mesmo sentido no fundo. Os perfis verticais de densidade conservam as características dos de temperatura e salinidade com o mínimo junto à seção $\mathrm{A}$ e $\mathrm{B}$, na superfície, de $23,9 \mathrm{~kg} / \mathrm{m}^{3}$ e o máximo no fundo das seções B e C, de $24,7 \mathrm{~kg} / \mathrm{m}^{3}$.

Pela análise da Fig. 101 A,B,C,D, percebe-se que o Canal de São Sebastião está preenchido pela $\mathrm{AC}$, estando os maiores percentuais na superfície, junto à seção $\mathrm{D}$ e os menores percentuais, no fundo, na seção B.

A Fig. 102 A,B,C apresenta perfis verticais de temperatura, salinidade e densidade, junto a uma seção longitudinal ao CSS. Nesta figura percebe-se a homogeneização das águas do CSS em relação à estação do verão e os resultados obtidos confirmam aqueles obtidos junto às seções transversais.

A Fig. 103 A,B,C apresenta os perfis verticais dos percentuais de massas de água junto a mesma seção. A Fig. 103 A confirma que os maiores percentuais da AC (80\%) encontram-se mesmo ao norte e os menores percentuais estão na região mais profunda do canal (45\%). Os percentuais de ACAS tem seus extremos nos mesmos locais, porém em oposição, isto é, mínimo ao norte, na superfície e máximo no fundo, no mesmo local onde está o mínimo de AC. O máximo da AT (40\%) está no fundo, aproximadamente entre as estações $\mathrm{C}$ e D.

A Fig. 104 A,B,C,D apresenta perfis verticais das componentes de velocidade paralela (v) e perpendicular (u) ao canal. As Figs. 104A e 104B mostram perfis em seções transversais ao passo que as Figs. 104C e 104D mostram perfis em seções longitudinais ao canal. As correntes superficiais nesta estação fluem para sul (Fig. 104C), porém, com intensidades bem menores do que aquelas encontradas para o verão e para a primavera. O máximo para a componente $\mathrm{v}$ é de $-0,16 \mathrm{~m} / \mathrm{s}$, ocorrendo na entrada sul do CSS ao lado da ISS (Fig.104 A). Abaixo da profundidade de $7 \mathrm{~m}$ aproximadamente, o fluxo é para norte com intensidade máxima de 0,06 m/s. Coelho (1997) analisando dados de um cruzeiro oceanográfico realizado em maio/92 obteve um 
perfil vertical para a componente $\mathrm{v}$ nesta seção, bem semelhante ao encontrado por esta simulação, com correntes superficiais para sul ao lado da ISS e correntes fluindo para norte no resto da seção, com núcleo em $15 \mathrm{~m}$ de profundidade do lado do continente. A entrada de águas no CSS junto à seção A nesta estação não é o lado insular pelo fundo como nas estações de primavera e verão. O núcleo das correntes $(0,06 \mathrm{~m} / \mathrm{s})$ para norte nesta seção está em $10 \mathrm{~m}$ de profundidade ao lado do continente não estando associado à penetração de águas mais frias (ACAS) como evidencia a Fig. 101. As correntes ao sul da seção A do canal fluem para nordeste (Figs. 90B e 94A) contornando a ISS para o largo (Figs. 104B e 104D). Na primavera e no verão, as correntes nesta seção fluem do largo para a costa. Esta corrente para nordeste enfraquece as correntes superficiais para sudoeste no canal. Esta componente u tem um máximo de $0,18 \mathrm{~m} / \mathrm{s}$ no sul. 

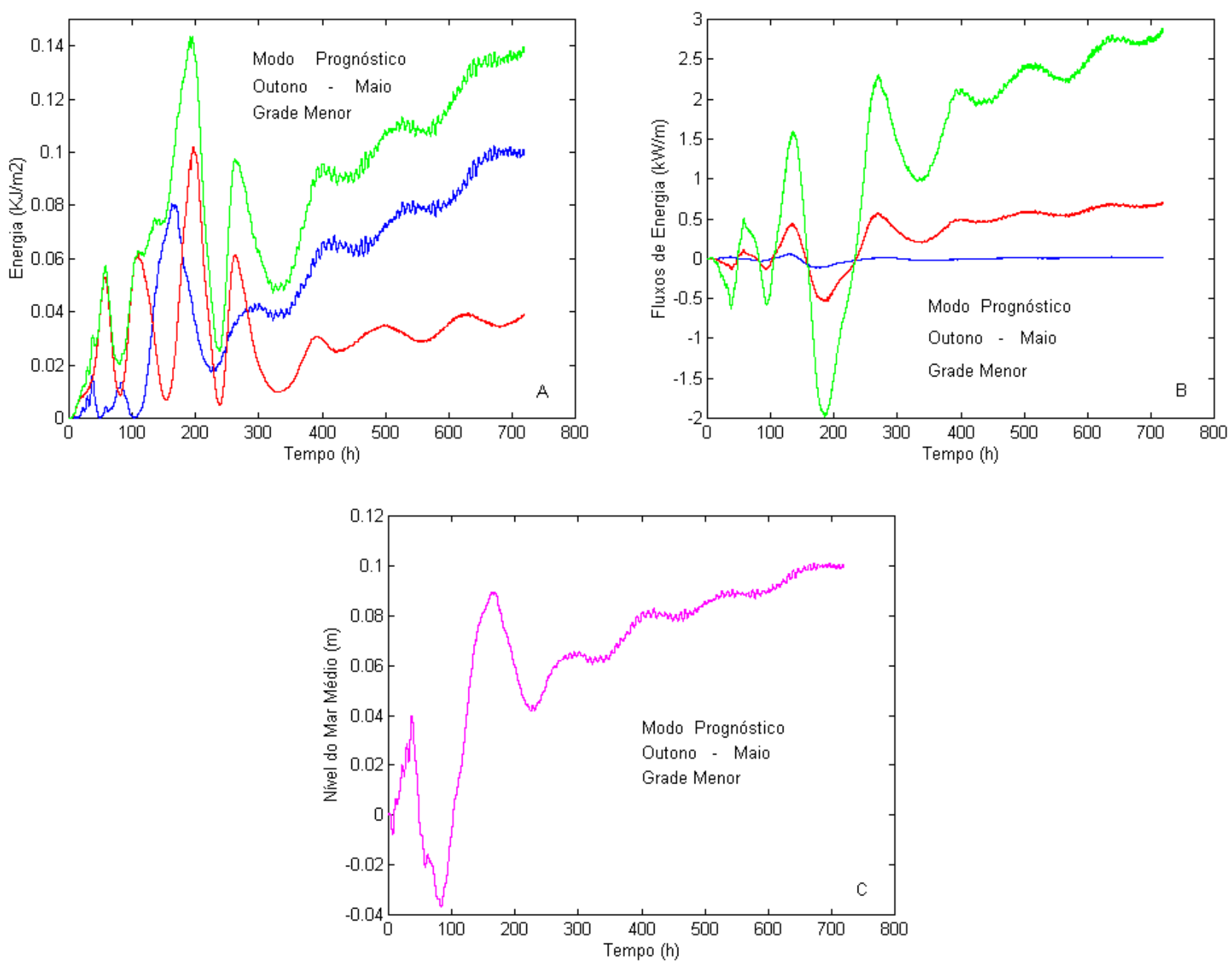

Figura 95: Curvas de energia mecânica (A), fluxos nos contornos (B) e nível do mar médio (C) no CSS, sendo em (A), o verde, a energia mecânica, o vermelho, a energia cinética e o azul, a energia potencial. Em (B), o azul representa o fluxo através do contorno norte, o vermelho, o fluxo através do contorno sul e o verde, o fluxo através do contorno leste. Simulação de outono - maio. 

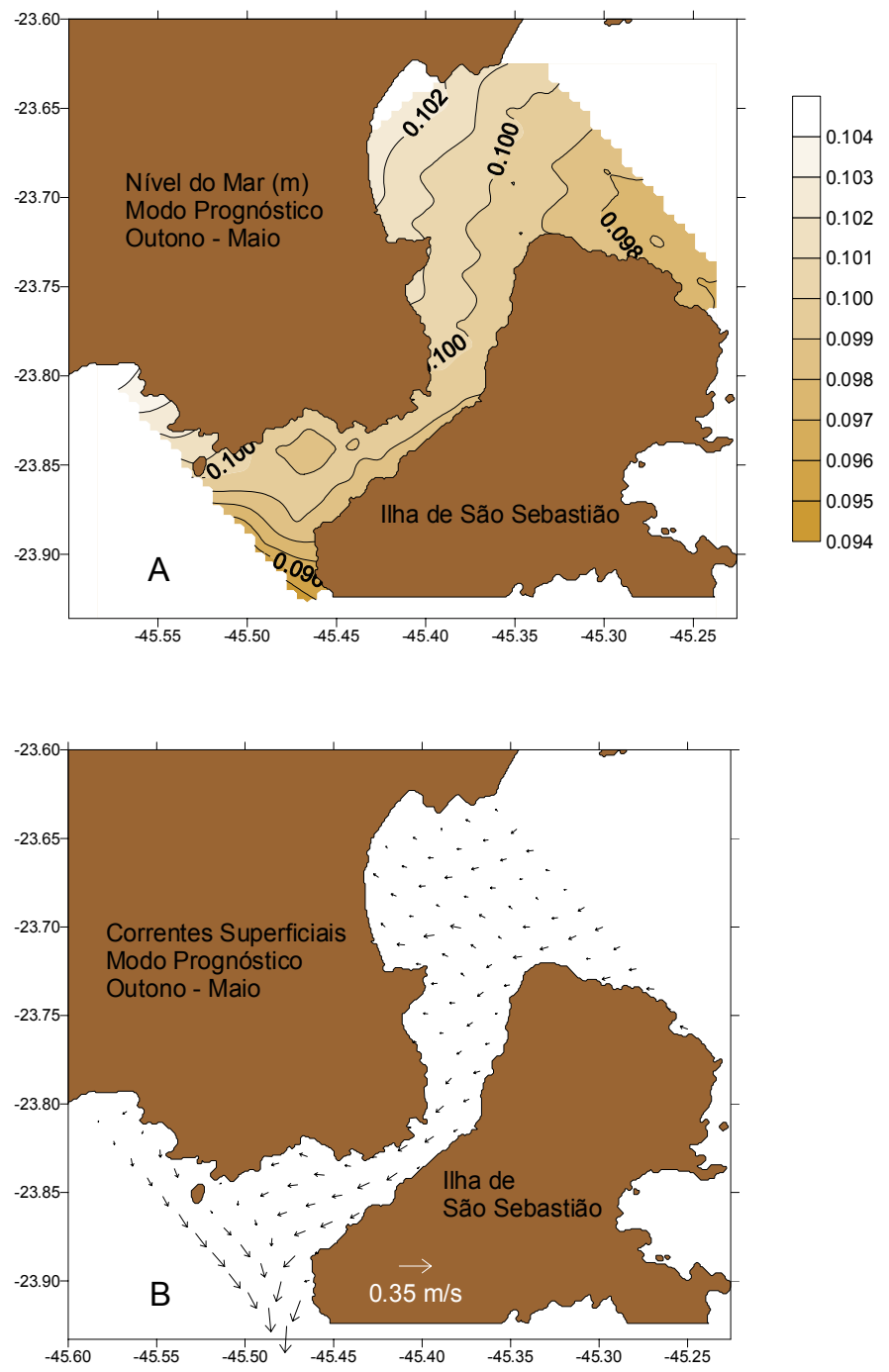

Figura 96: Nível do Mar (A) e Correntes Superficiais (B) no Canal de São Sebastião. Simulação de outono - maio. 

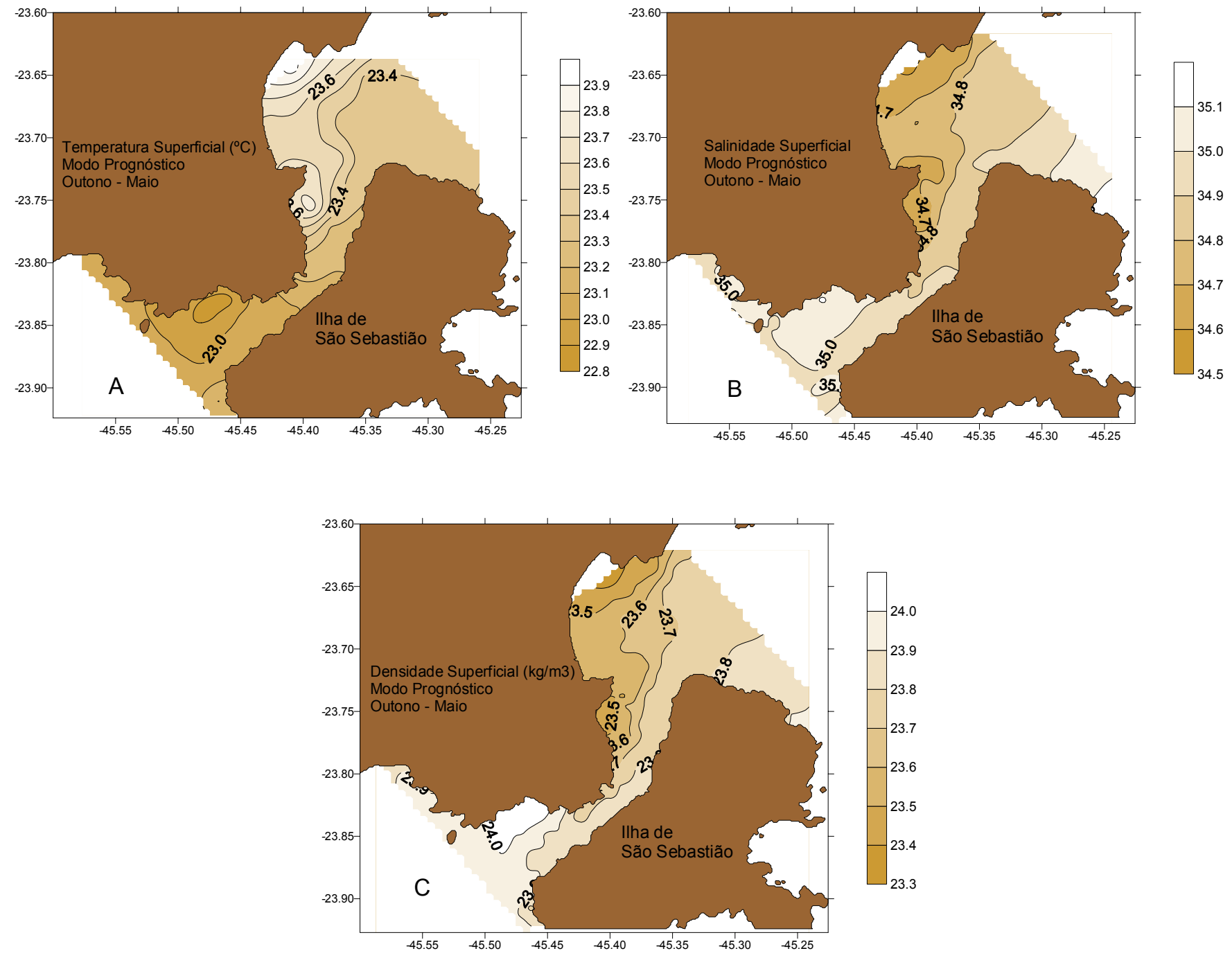

Figura 97: Distribuição horizontal superficial da temperatura (A), da salinidade (B) e da densidade convencional (C) no Canal de São Sebastião. Simulação de outono - maio. 

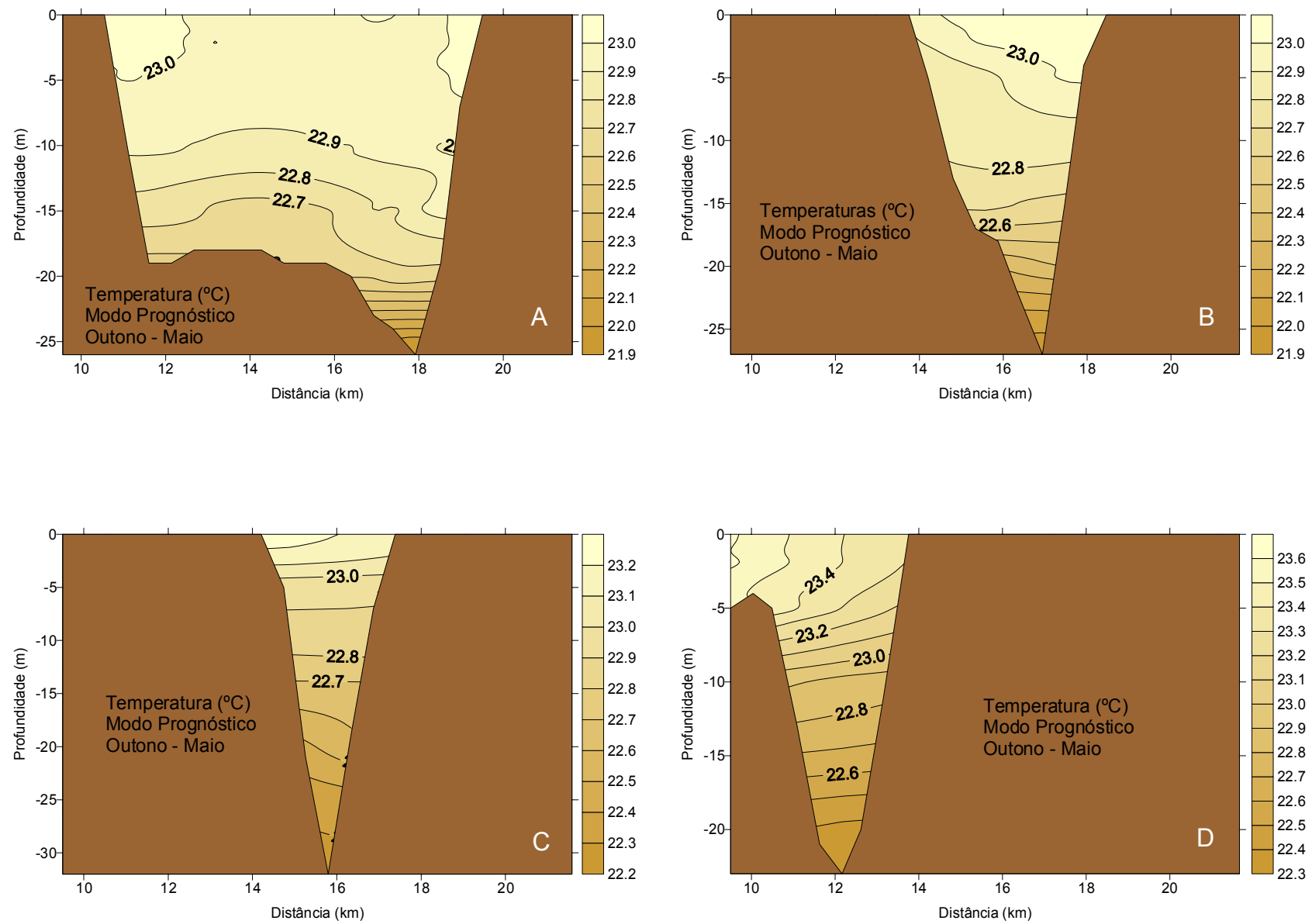

Figura 98: Distribuição vertical de temperatura nas seções A, B, C e D, localizadas na região interna do Canal de São Sebastião. Simulação de outono - maio. 

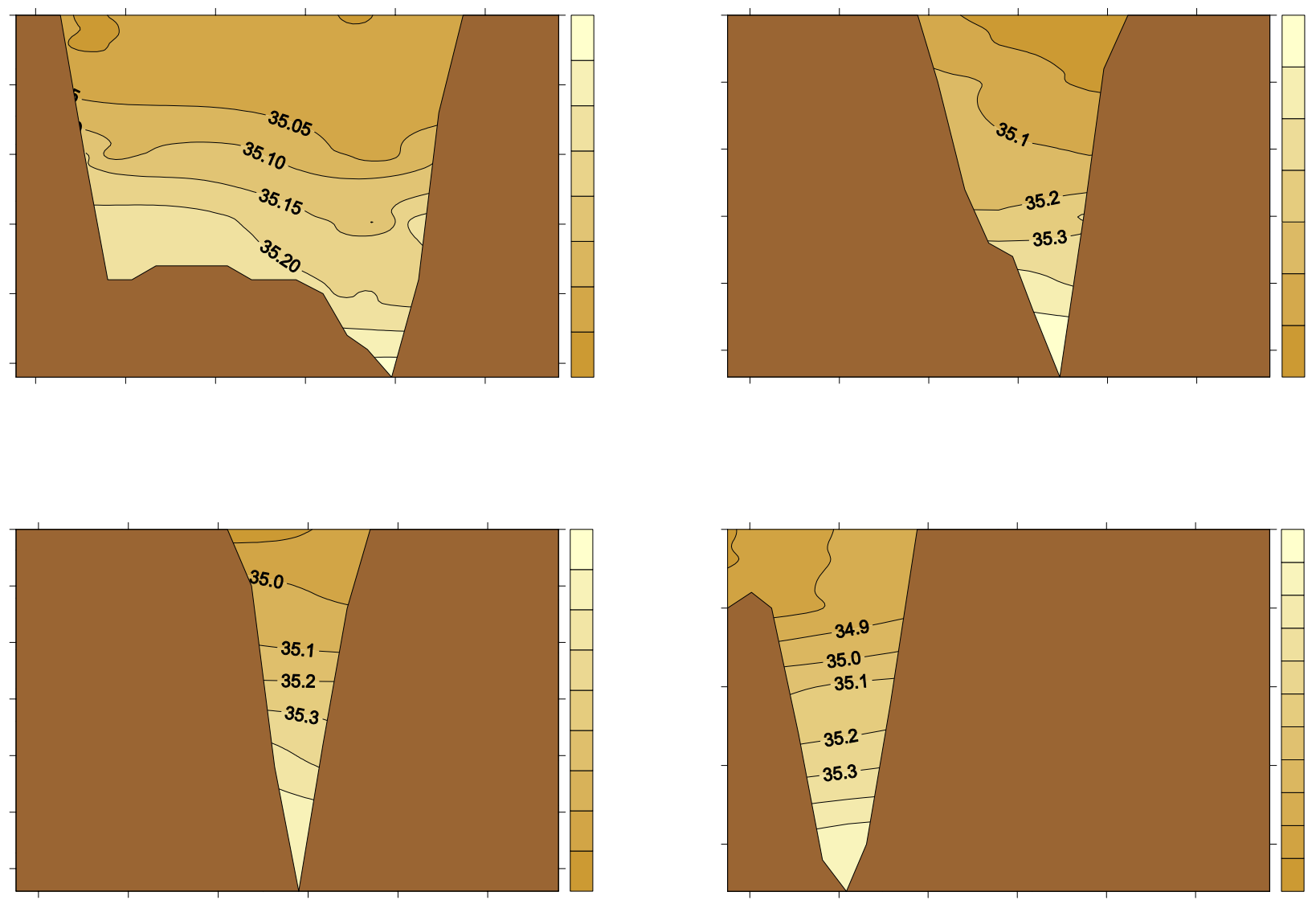

Figura 99: Distribuição vertical da salinidade nas seções A, B, C e D, localizadas na região interna do Canal de São Sebastião. Simulação de outono - maio. 

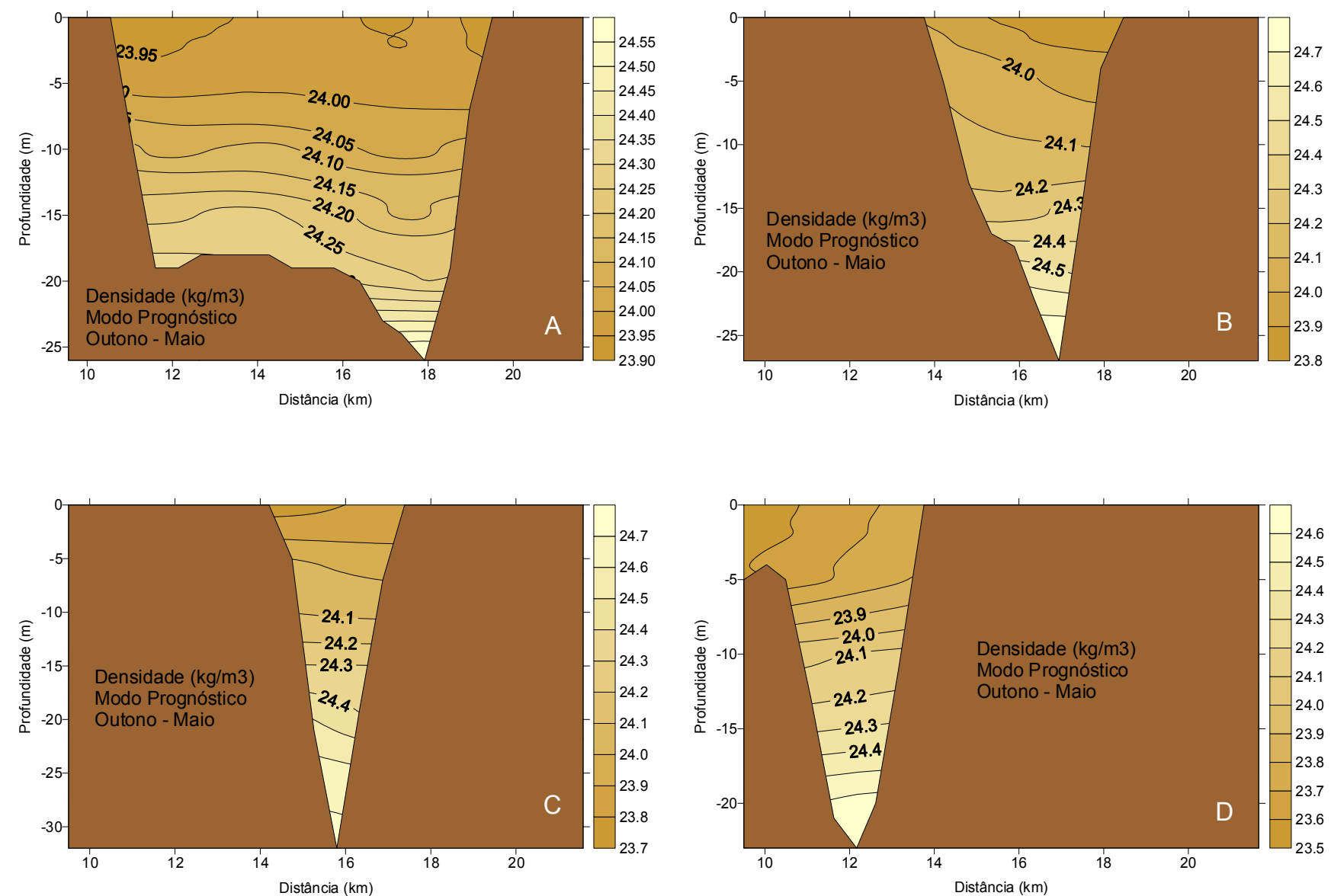

Figura 100: Distribuição vertical da densidade convencional nas seções A, B, C e D, localizadas na região interna do Canal de São Sebastião. Simulação de outono - maio. 

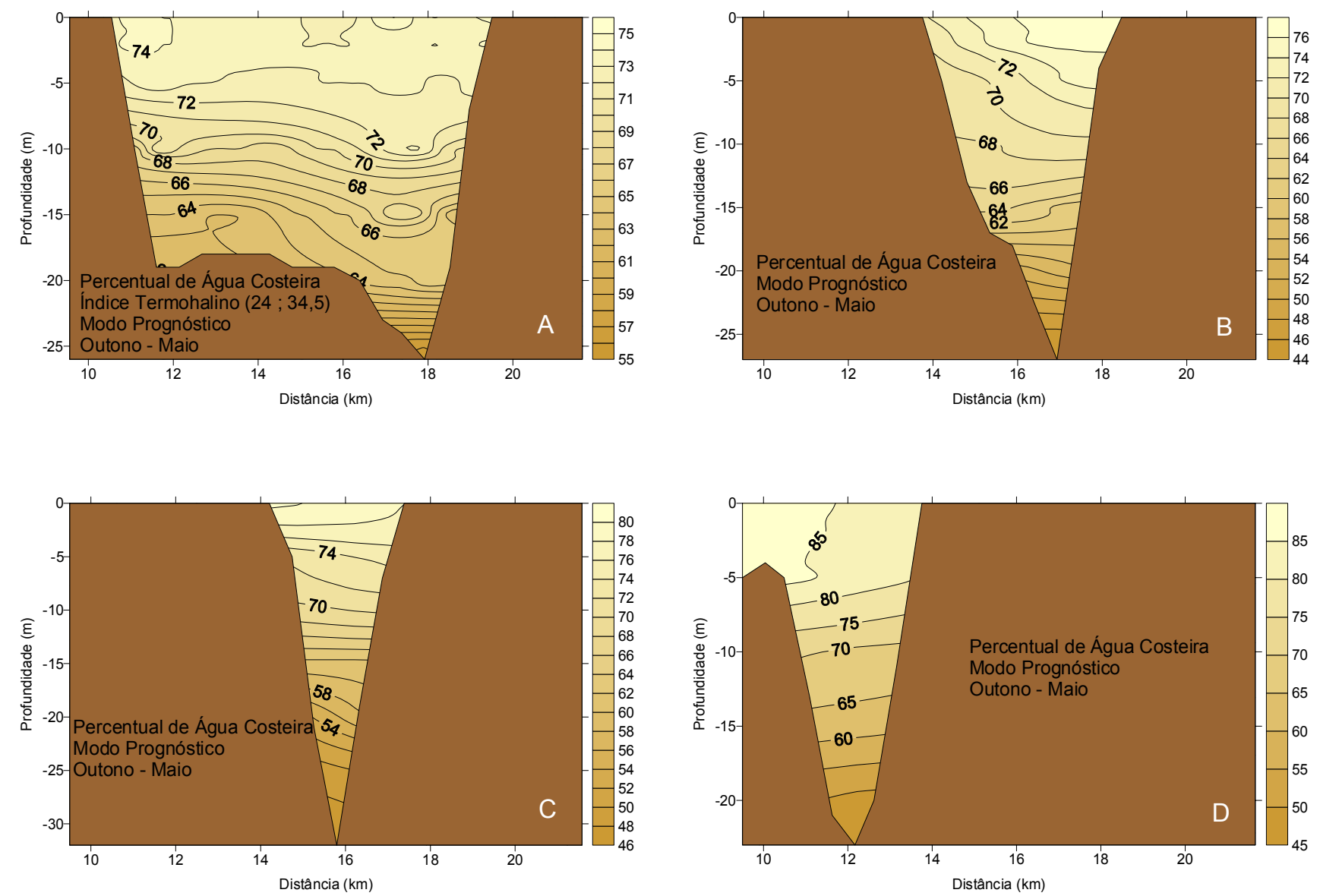

Figura 101: Distribuição vertical do percentual da massa de Água Costeira nas seções A, B, C e D, localizadas na região interna do Canal de São Sebastião. Simulação de outono maio. 

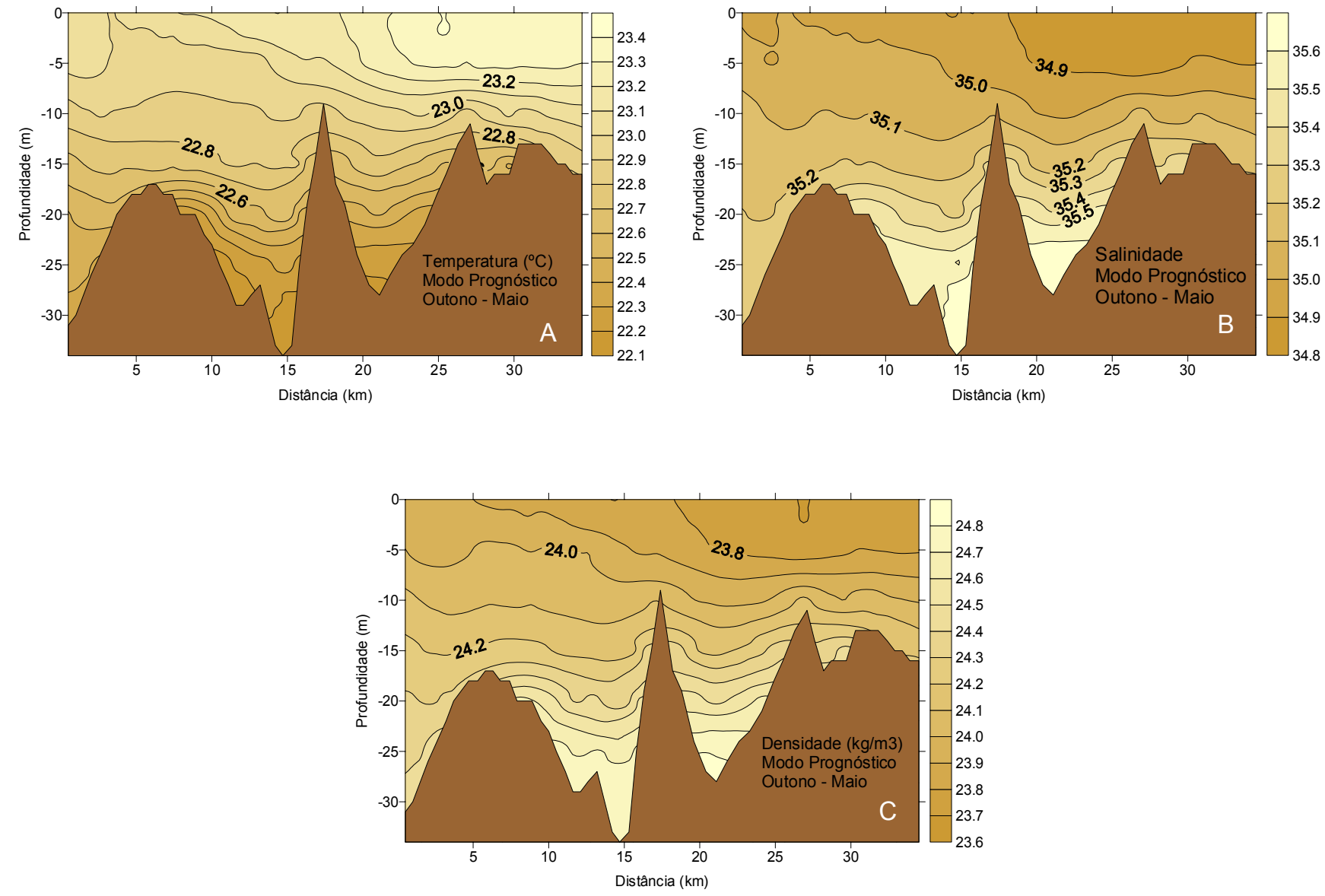

Figura 102: Distribuição vertical ao longo do Canal de São Sebastião das propriedades temperatura (A), salinidade (B) e densidade convencional (C). Simulação de outono - maio. 

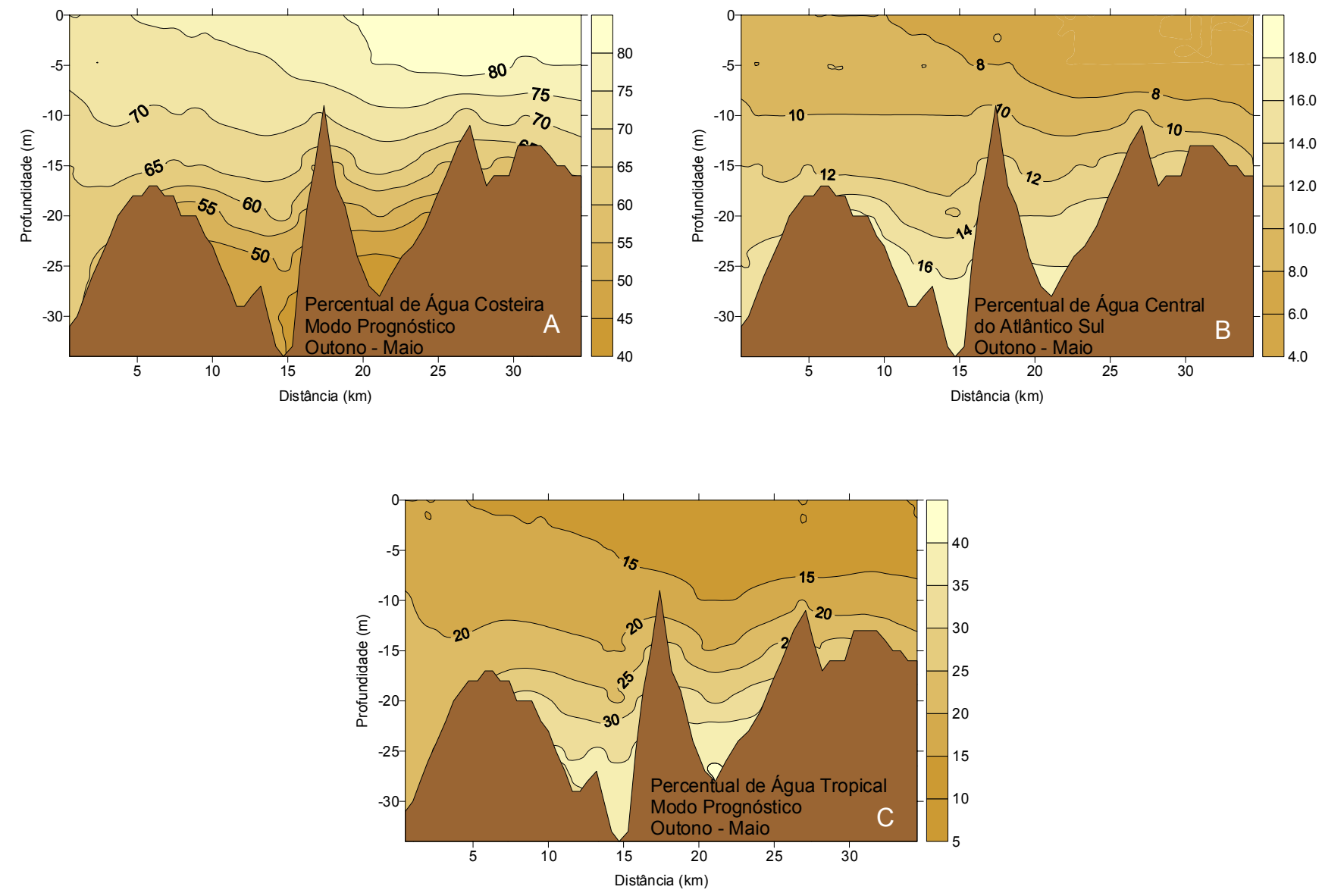

Figura 103: Distribuição vertical em uma seção ao longo do Canal de São Sebastião dos percentuais de massas de Água Costeira (A), Água Central do Atlântico Sul (B) e Água Tropical (C). Simulação de outono - maio. 

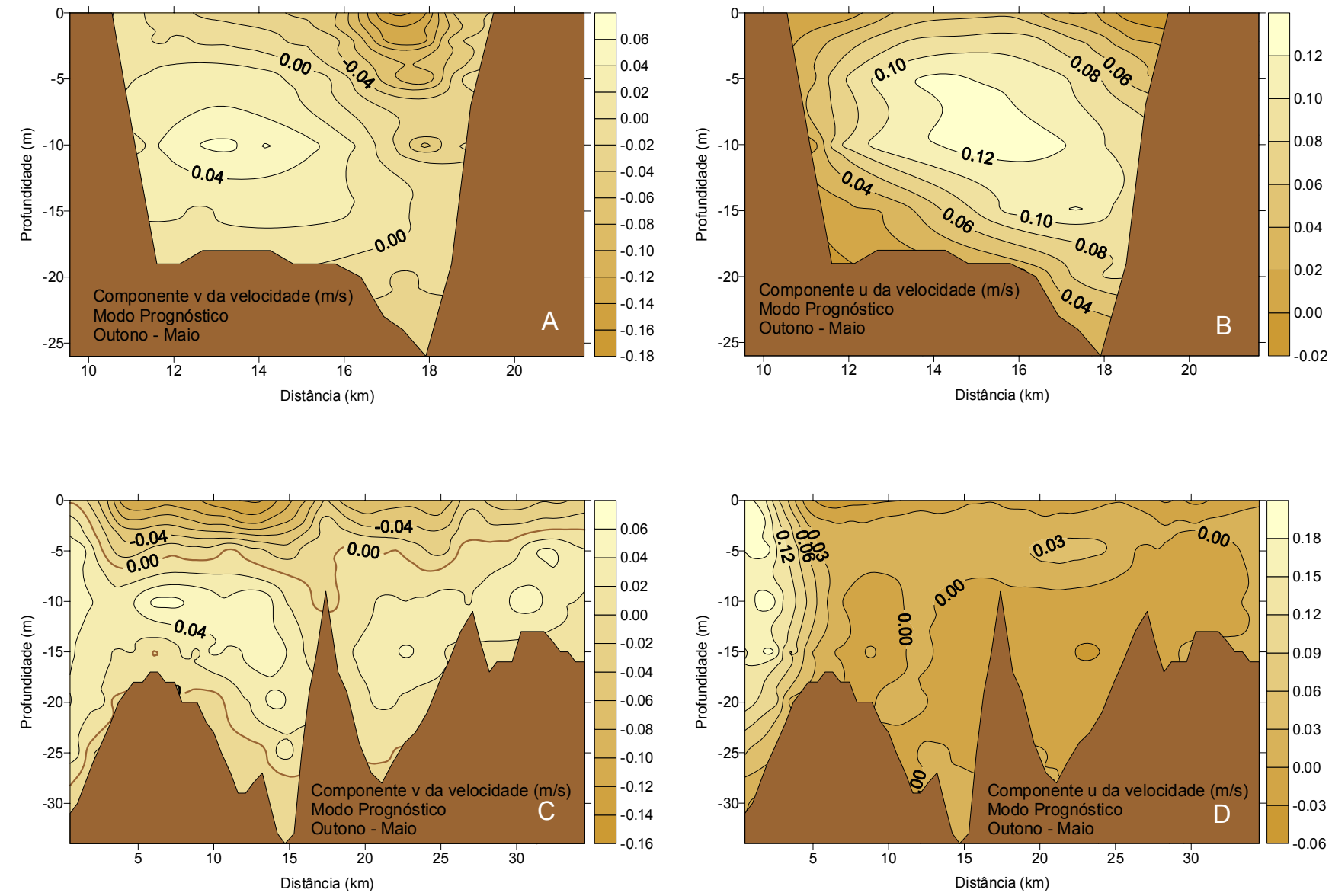

Figura 104: Distribuição vertical da intensidade das componentes de velocidade transversal (A) e paralela (B) à seção A no Canal de São Sebastião. Distribuição vertical ao longo do Canal de São Sebastião das componentes de velocidade transversal (C) e paralela (D) às seções. 


\subsection{Inverno}

\subsubsection{A Plataforma Continental Sudeste}

Analisando as curvas de energia mecânica, de fluxos de energia nos contornos e de nível do mar médio (Fig.105 A,B,C) percebemos que os níveis de energia mecânica são maiores do que os do outono, porém comparáveis aos do verão e primavera. Os níveis de energia potencial são relativamente muito pequenos quando comparados aos de energia cinética, fazendo com que as curvas de energia cinética e mecânica coincidam. O fluxo de energia no contorno norte é normalmente maior do que o fluxo no leste e aponta para dentro do domínio. O fluxo no contorno sul é relativamente pequeno durante todo o tempo de integração. O nível do mar médio oscila em torno de zero amortecendo e tendendo a zero no final da integração.

O nível do mar na costa (Fig. 106A) é da ordem de $-0,02 \mathrm{~m}$. No norte do domínio, mais ao largo há um máximo de $0,16 \mathrm{~m}$. No sul, ocorre um mínimo de $-0,14$ m. Examinando-se os níveis do mar nas estações de primavera, verão e inverno e comparando-os com os campos de tensão de cisalhamento do vento, percebe-se quão efetivo é o vento em dispor as isolinhas de nível do mar ao longo da costa. As correntes superficiais na plataforma (Fig. 106B) fluem de modo geral para sul e são mais intensas na região norte, onde os gradientes do nível do mar também são maiores. A intensificação das correntes na região da quebra da plataforma continental, embora exista, não é tão nítida quanto na primavera e verão. No local onde ocorre o máximo de nível do mar surge um vórtice anticiclônico com correntes ao redor de $0,70 \mathrm{~m} / \mathrm{s}$. Na região onde ocorre o mínimo de nível do mar por outro lado, ocorre um vórtice ciclônico.

Os perfis horizontais superficiais de temperatura, salinidade e densidade encontram-se na Fig. 107 A,B,C. Na maior parte da região, as temperaturas variam entre 20 e $22^{\circ} \mathrm{C}$. $\mathrm{O}$ mínimo se apresenta no sul $\left(17,0^{\circ} \mathrm{C}\right)$ e o máximo, na região da quebra da plataforma é de $24^{\circ} \mathrm{C}$. As isohalinas dentro da plataforma são aproximadamente paralelas à costa e variam de 33,8 na costa, ao sul, até 36,4 . Já fora da plataforma existem alguns núcleos com máximos de 37,0. As isopicnais também se apresentam aproximadamente paralelas à costa, dentro da plataforma, e variam de 24,1 
$\mathrm{kg} / \mathrm{m}^{3}$ ao sul da Ilha de São Vicente até aproximadamente $25,3 \mathrm{~kg} / \mathrm{m}^{3}$. Mais ao largo aparecem núcleos com máximos da ordem de $25,8 \mathrm{~kg} / \mathrm{m}^{3}$.

Perfis horizontais superficiais de percentuais de massas de água são apresentados na Fig. 108 A,B,C. O fato mais marcante que se percebe é que com relação ao outono, a AC e a AT deslocam-se para o largo principalmente ao sul da ISS.

Observando-se os perfis verticais de temperatura, salinidade e densidade (Fig. 109 A,B,C) percebemos que as temperaturas sobre a plataforma são maiores do que $17^{\circ} \mathrm{C}$ sendo que a isoterma de $18^{\circ} \mathrm{C}$ está no fundo, nas proximidades da quebra da plataforma e os gradientes verticais de temperatura são pequenos. As salinidades sobre a plataforma variam entre 34,4 na costa e 36,6 ao largo e os gradientes verticais de densidade são os menores entre as quatro estações, variando sobre a plataforma entre $24,0 \mathrm{~kg} / \mathrm{m}^{3}$ na costa e $26,5 \mathrm{~kg} / \mathrm{m}^{3}$ ao largo.

Embora na Plataforma Continental Sudeste, em média, a AC e AT tenham se afastado da costa em relação ao outono, ao largo da ISS, estas massas de água mantémse aproximadamente na mesma posição (Fig. 110 A,C). O percentual de 50\% de ACAS se afasta da costa e aprofunda-se em relação ao outono. Na verdade, tanto a AC, como a AT avançam para o largo em relação ao outono na região sul da PCSE, permanecendo mais ou menos na mesma posição no resto do domínio.

A distribuição vertical das componentes de velocidade ao longo da costa (v) e perpendicular à costa $(\mathrm{u})$ encontram-se na Fig. 111 A,B. A componente v até cerca de $100 \mathrm{~km}$ da costa tem orientação para norte sendo seu máximo de $0,05 \mathrm{~m} / \mathrm{s}$ e deste ponto para o largo até a quebra da plataforma, $v$ tem sentido sul, alcançando $-0,15 \mathrm{~m} / \mathrm{s}$. A componente u nesta região, entre $100 \mathrm{~km}$ da costa e a quebra da plataforma, tem sentido leste. As correntes mais intensas encontradas na quebra da plataforma continental nas estações da primavera e verão, com características da Corrente do Brasil, perdem intensidade no outono e inverno aproximando-se ligeiramente da costa. Na região do talude continental, a componente v tem orientação para norte até a profundidade de 500 $\mathrm{m}$ enquanto a componente $\mathrm{u}$ tem orientação para a costa. 

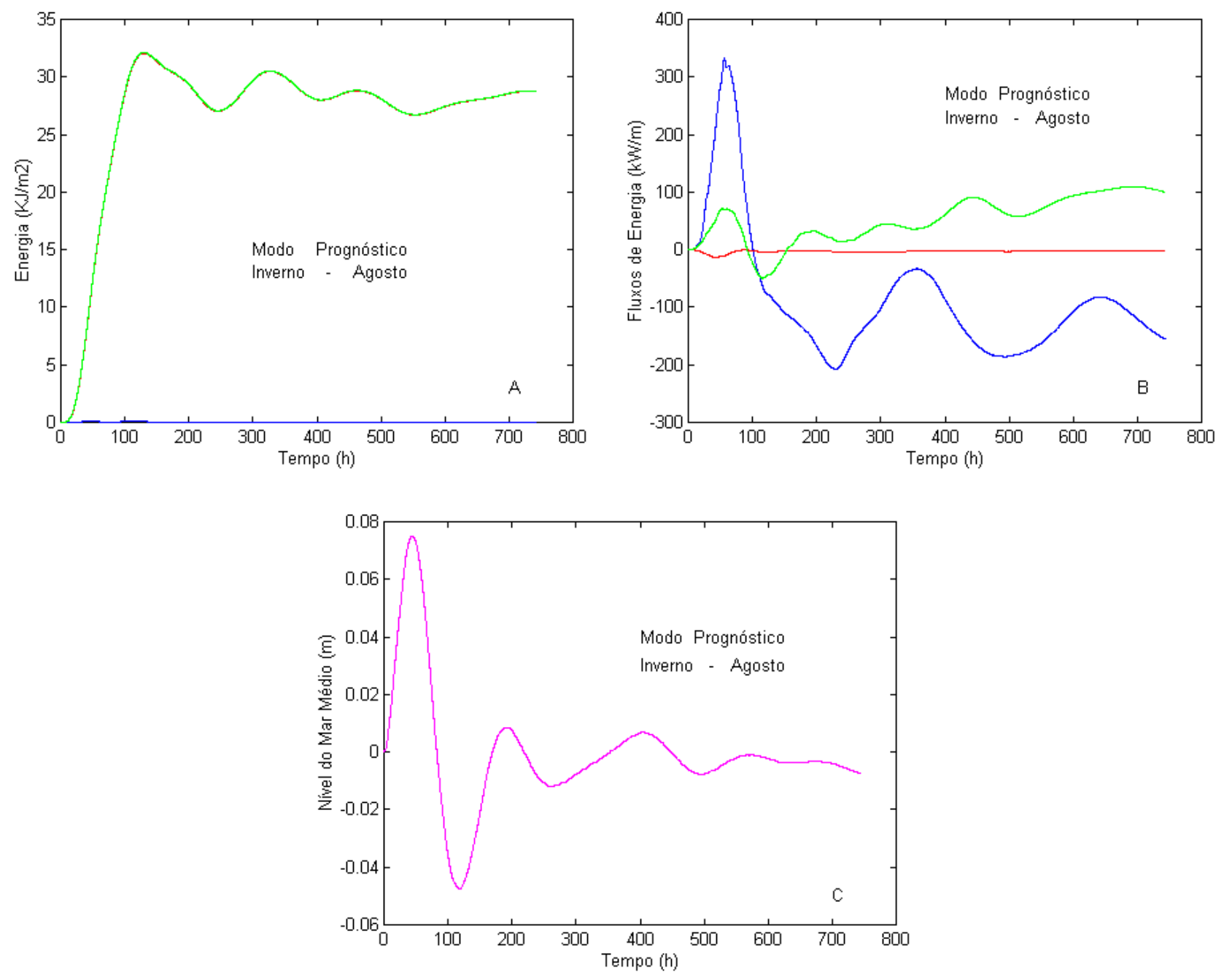

Figura 105: Curvas de energia mecânica (A), fluxos nos contornos (B) e nível médio do mar $(\mathrm{C})$ na PCSE, sendo em (A), o verde, a energia mecânica, o vermelho, a energia cinética e o azul, a energia potencial. Em (B), o azul representa o fluxo através do contorno norte, o vermelho o fluxo através do contorno sul e o verde, o fluxo através do contorno leste. 

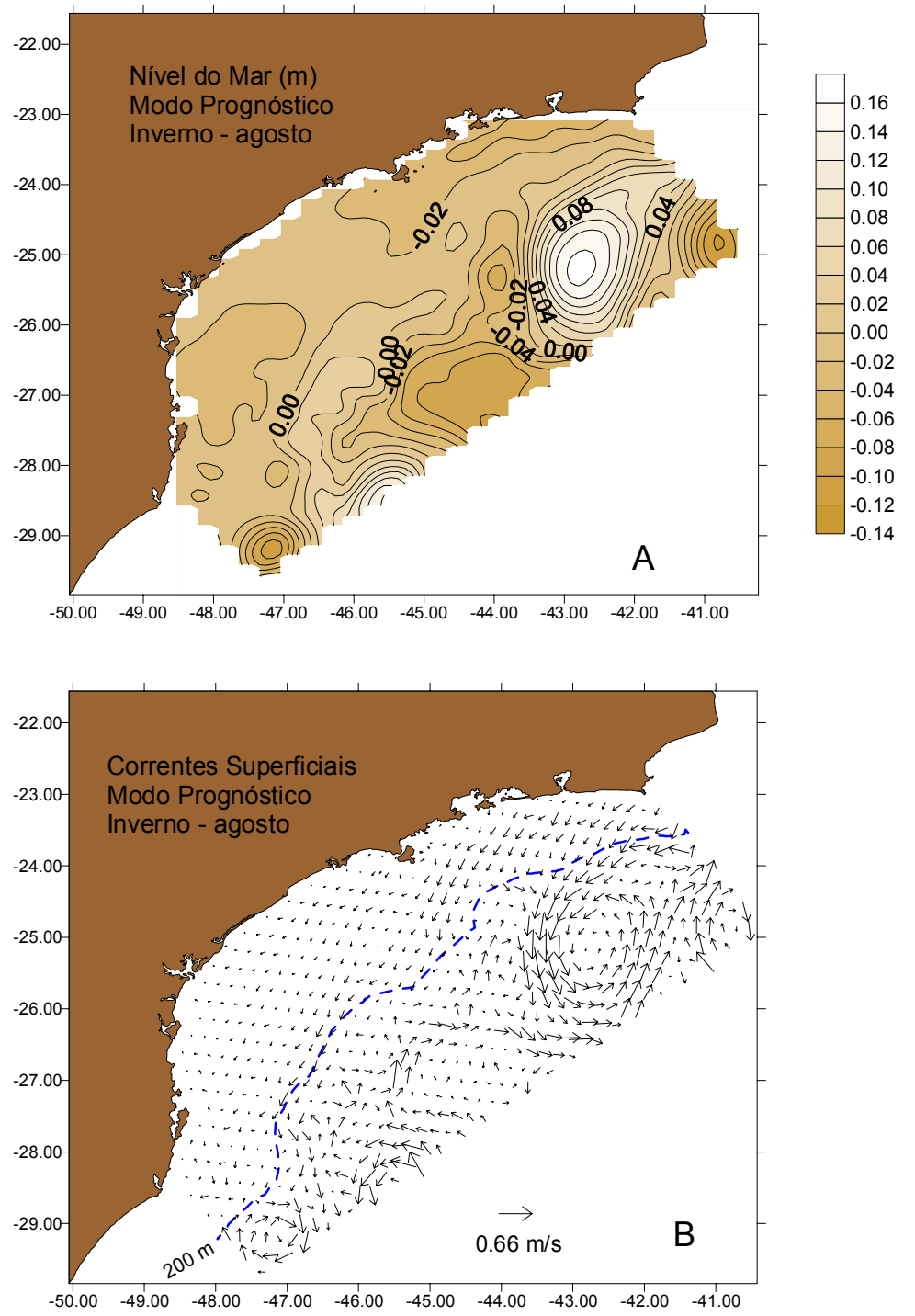

Figura 106: Nível do Mar (A) e Correntes Superficiais (B) na Plataforma Continental Sudeste. Simulação de inverno - agosto. 

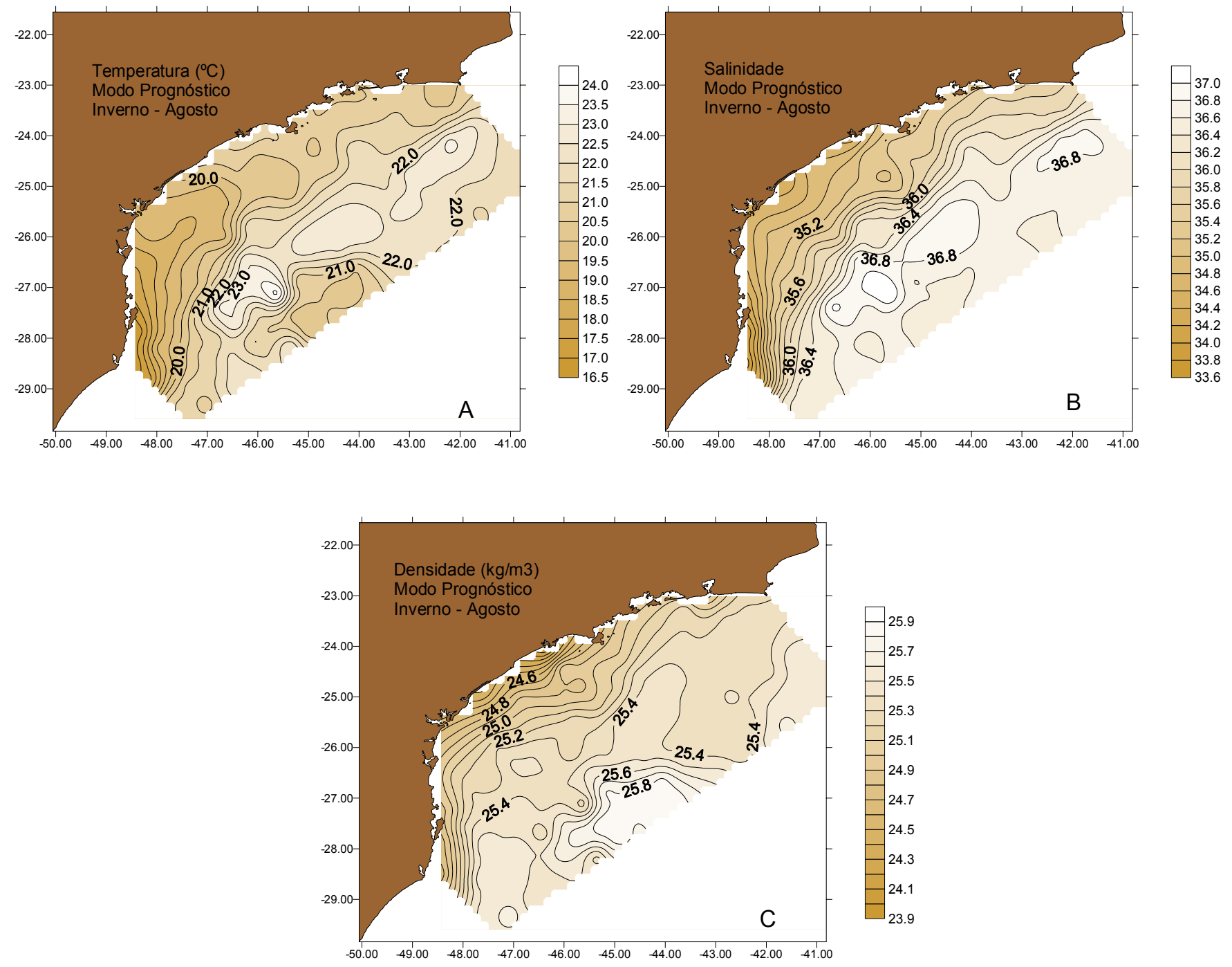

Figura 107: Distribuição horizontal superficial da temperatura (A), salinidade (B) e da densidade convencional (C) na Plataforma Continental Sudeste. Simulação de inverno agosto. 

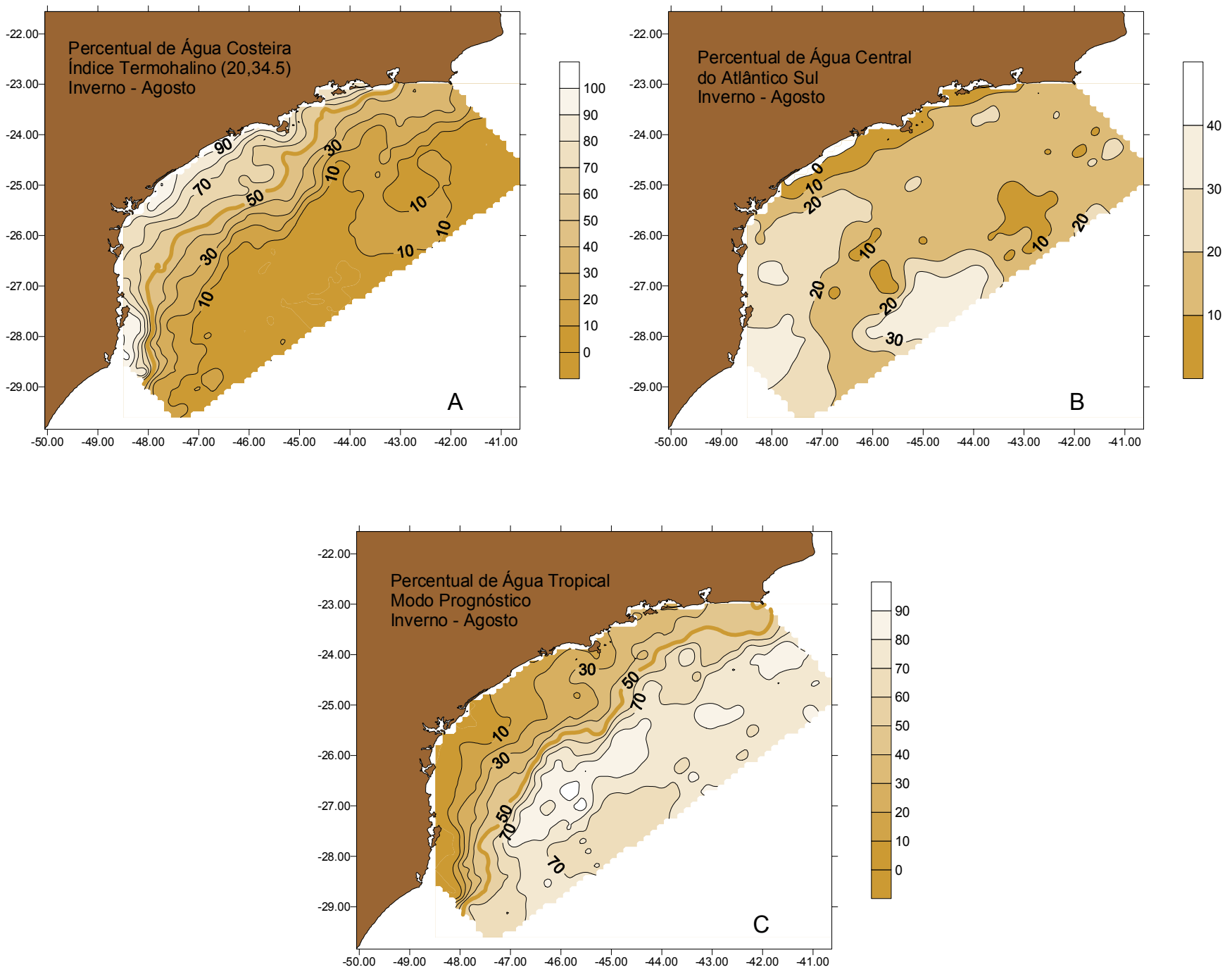

Figura 108: Distribuição horizontal superficial das massas de Água Costeira (A), Água Central do Atlântico Sul (B) e da Água Tropical (C) na Plataforma Continental Sudeste. Simulação de inverno - agosto. 

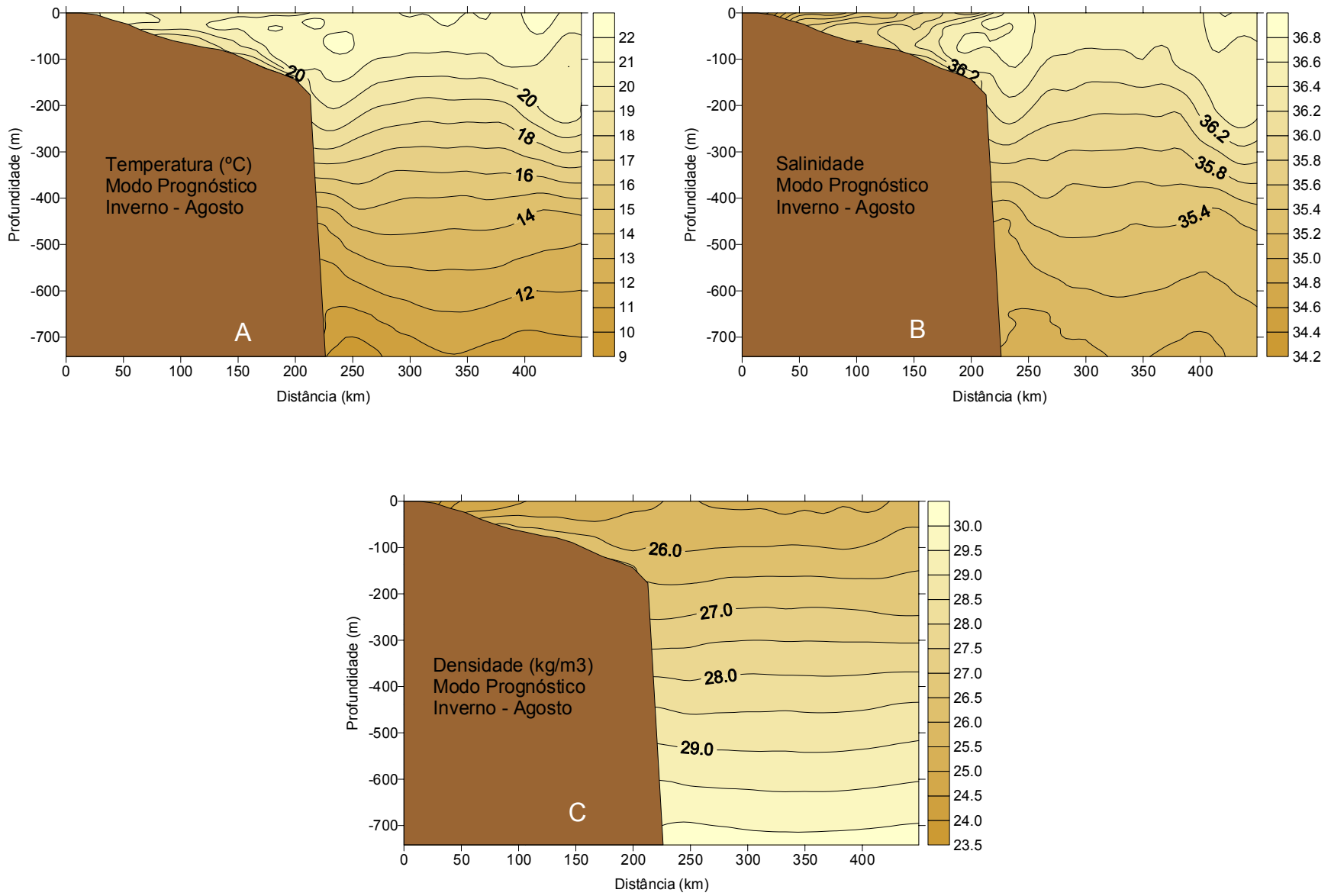

Figura 109: Distribuição vertical da temperatura (A), salinidade (B) e da densidade convencional (C) em uma radial ao sul do CSS. Simulação de inverno - agosto. 

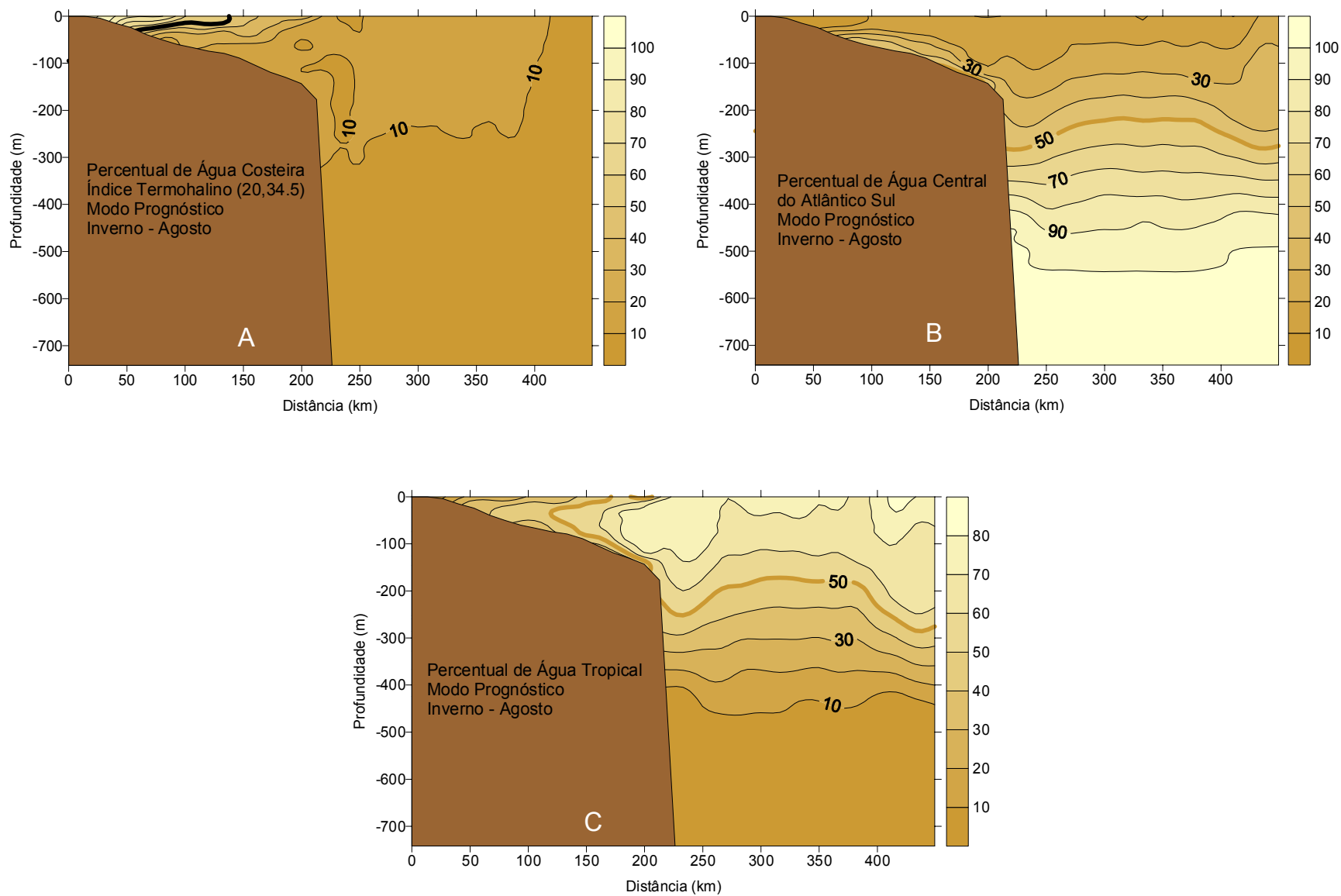

Figura 110: Distribuição vertical dos percentuais de massas de Água Costeira (A), Água Central do Atlântico Sul (B) e da Água Tropical (C) na Plataforma Continental Sudeste ao sul do Canal de São Sebastião. Simulação de inverno - agosto. 

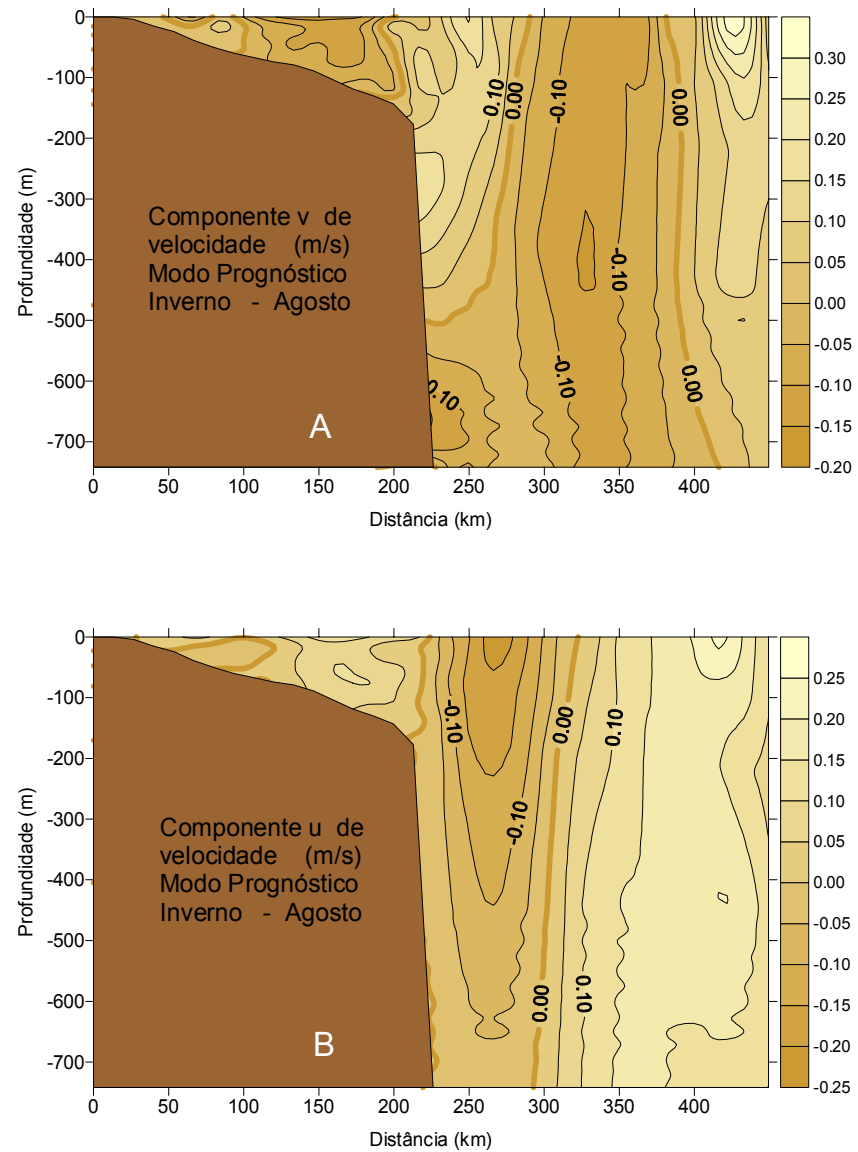

Figura 111: Distribuição vertical das componentes de velocidade paralela (A) e transversal (B) à costa na Plataforma Continental Sudeste em uma seção ao sul do Canal de São Sebastião. Simulação de inverno - agosto. 


\subsubsection{A Plataforma Continental Interna}

As curvas de energia mecânica, fluxos de energia nos contornos e nível do mar médio são apresentadas na Fig.112 A,B,C. Em relação ao outono, estas curvas apresentam níveis mais baixos. Os fluxos de energia nos contornos praticamente tendem a zero e o nível do mar médio oscila em torno de $-0,02 \mathrm{~m}$.

O nível do mar tem baixa amplitude (Fig. 113A) e varia entre -0,01 m e -0,05 m. Os níveis mais baixos encontram-se a NE da ISS e esta propriedade está em perfeita continuidade com os resultados obtidos para a PCSE (Fig.106A). As correntes superficiais (Fig. 113B) fluem preponderantemente para sudoeste, ao longo da costa e intensificam-se a leste da ISS. Valores máximos são da ordem de $0,35 \mathrm{~m} / \mathrm{s}$.

A distribuição horizontal superficial das propriedades temperatura, salinidade e densidade são apresentadas na Fig.114 A,B,C. Assim como no outono, a amplitude de temperatura na região é muito pequena, cerca de $1,5^{\circ} \mathrm{C}$, variando entre $20^{\circ} \mathrm{C}$ ao sul da ISS e $21,4^{\circ} \mathrm{C}$ a oeste da mesma. As salinidades variam entre 35 ao norte e ao leste do CSS e 35,8 ao leste do CSS. Neste local formam-se fortes gradientes horizontais de salinidade. As menores densidades $\left(24,5 \mathrm{~kg} / \mathrm{m}^{3}\right)$ encontram-se ao norte e a oeste do CSS enquanto que o máximo se encontra a leste da Ilha Anchieta $\left(25,2 \mathrm{~kg} / \mathrm{m}^{3}\right)$.

A distribuição horizontal superficial dos percentuais de massas de água (Fig. 115 A,B,C), mostra a AC ocupando toda superfície, com os maiores percentuais (100\%) ao norte e dentro do CSS. Os menores percentuais de AC (50\%) estão ao largo da Ilha Anchieta no mesmo local onde ocorre o máximo de ACAS (20\%). Ainda a leste da Ilha Anchieta encontra-se o máximo de AT (35\%) onde justamente ocorrem os maiores gradientes horizontais de salinidade.

Os perfis verticais de temperatura, salinidade e densidade encontram-se na Fig.116 A,B,C. As temperaturas variam entre $18^{\circ} \mathrm{C}$, encontrada no fundo, na profundidade de $50 \mathrm{~m}$, e $21,5^{\circ} \mathrm{C}$, encontrada na costa e ao largo em sub-superfície. Verifica-se que com relação ao perfil vertical da temperatura inicial (Fig.10), o efeito da simulação de inverno após 30 dias de integração foi a ligeira diminuição da temperatura no fundo e também uma pequena elevação de temperatura na costa. Os efeitos da simulação de verão nesta seção em relação à temperatura inicial foram bem mais 
marcantes. A salinidade varia de 35,1 na superfície, próxima à costa, a 36 , encontrada no fundo, ao largo. Comparando este perfil com o da salinidade inicial, observa-se que as isohalinas interceptam o fundo em profundidades menores após a simulação. Em outras palavras, a isohalina de 35,8 por exemplo, interceptava o fundo em $60 \mathrm{~m}$ de profundidade e após $720 \mathrm{~h}$ de integração, passa a interceptá-lo em $40 \mathrm{~m}$ de profundidade; em decorrência deste mecanismo as salinidades costeiras tornam-se ligeiramente maiores do que as iniciais, passando de 35,0 a 35,3. Os extremos de densidade estão ambos a mesma distância da costa: o mínimo na superfície $\left(24,6 \mathrm{~kg} / \mathrm{m}^{3}\right)$ e o máximo no fundo $\left(26,2 \mathrm{~kg} / \mathrm{m}^{3}\right)$.

Os perfis verticais dos percentuais de massas de água (Fig.117 A,B,C), mostram a AC ocupando os primeiros $30 \mathrm{~m}$ da coluna de água. A ACAS está limitada a uma pequena área na profundidade de $50 \mathrm{~m}$, onde encontramos seu máximo $(55 \%)$. O maior percentual de AT na seção (40\%) é encontrado ao largo, abaixo da profundidade de $30 \mathrm{~m}$.

Os perfis verticais das componentes de velocidade u e v são apresentados na Fig. 118 A,B em uma seção transversal onde visualiza-se a entrada sul do CSS. As componentes v e u mostram que a circulação superficial é para sul. Ao largo da ISS há uma intensificação das correntes em direção sudoeste ao contornarem a ilha, com máximo de $0,25 \mathrm{~m} / \mathrm{s}$ para $\mathrm{v}$, na superfície, e máximo de $0,08 \mathrm{~m} / \mathrm{s}$ para u em subsuperfície. Uma fraca contra corrente com direção nordeste se evidencia ao lado da ISS, sugerindo que correntes superficiais abandonando o CSS contornam o sul da ISS, recirculando. No interior do CSS, desde a superfície até quase o fundo, ao lado da ilha, as correntes fluem para sul com máximo de $0,15 \mathrm{~m} / \mathrm{s}$ para a componente $\mathrm{v}$. No setor esquerdo inferior do CSS as correntes fluem para norte com intensidade que não chega a $0,05 \mathrm{~m} / \mathrm{s}$. A componente u indica que no interior do CSS, na superfície, as correntes fluem para oeste e no resto da seção, as correntes fluem para leste. Este fato sugere que nesta estação, as águas que penetram o CSS, em sua entrada sul, fluem da costa e não do largo, como se verificou no verão (Fig. 70A). 

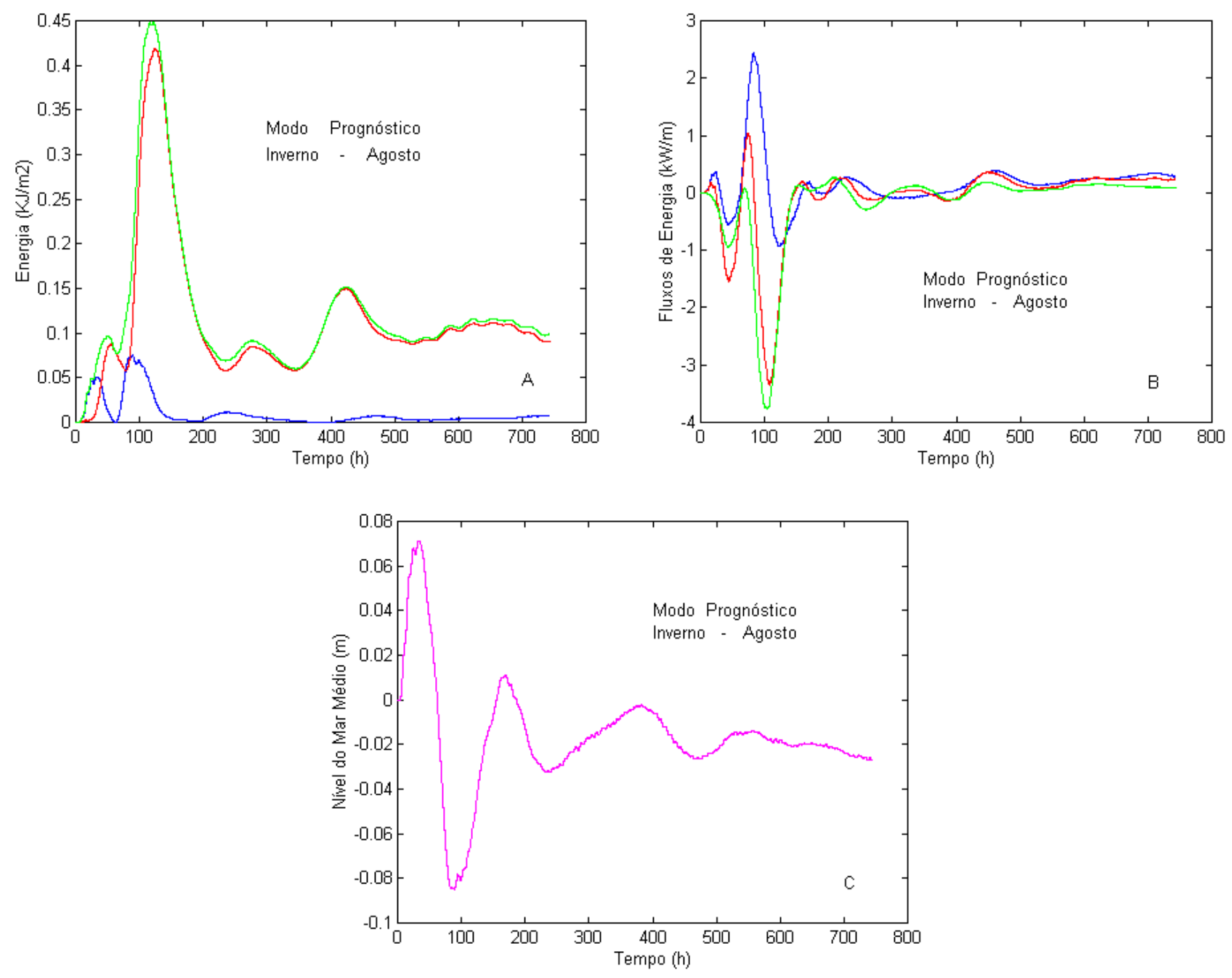

Figura 112: Curvas de energia mecânica (A), fluxos nos contornos (B) e nível médio do mar (C) na PCI, sendo em (A), o verde, a energia mecânica, o vermelho, a energia cinética e o azul, a energia potencial. Em (B), o azul representa o fluxo através do contorno norte, o vermelho o fluxo através do contorno sul e o verde, o fluxo através do contorno leste. Simulação de inverno - agosto. 

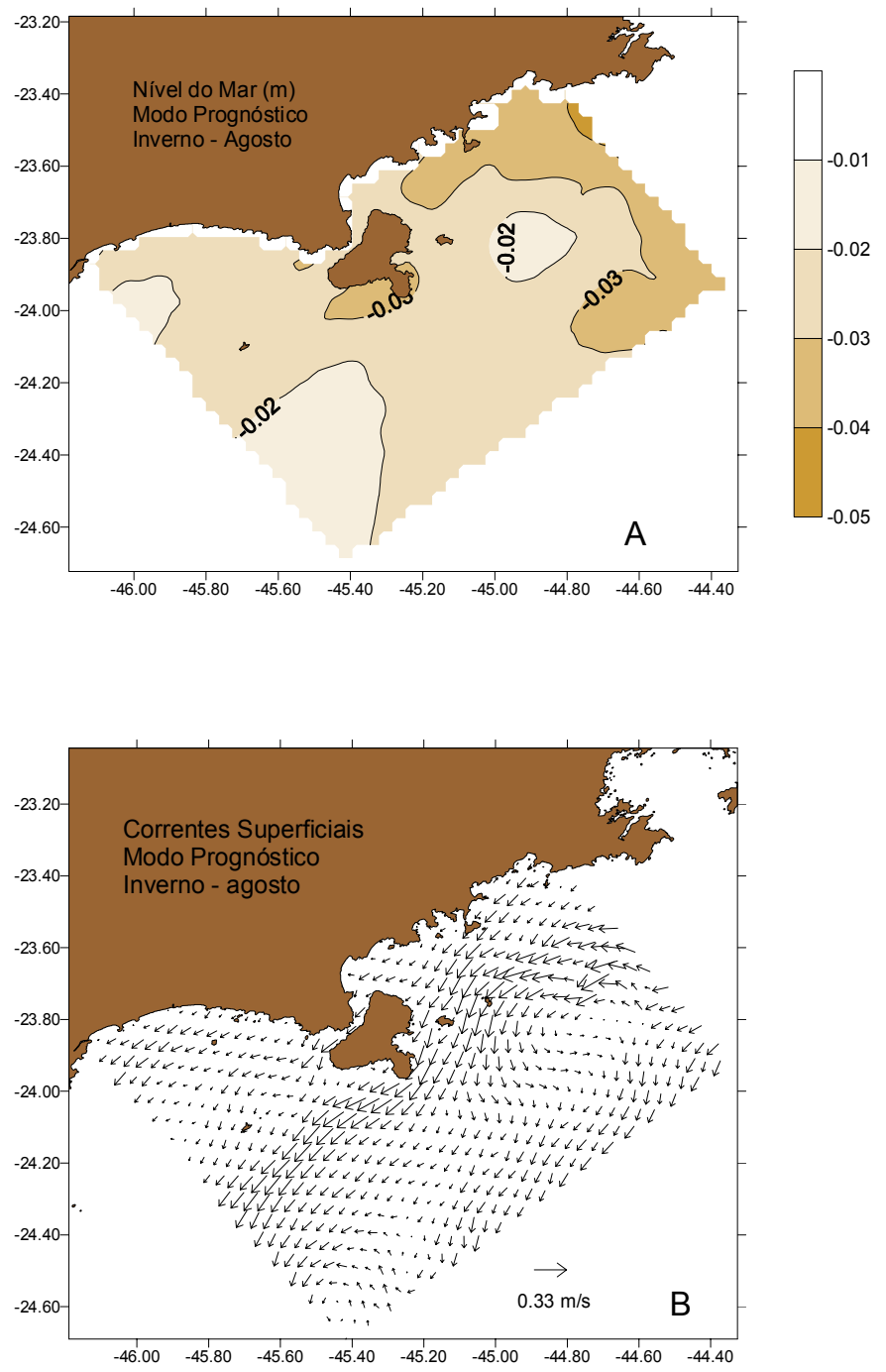

Figura 113: Nível do Mar (A) e Correntes Superficiais (B) na PCI. Simulação de inverno - agosto. 

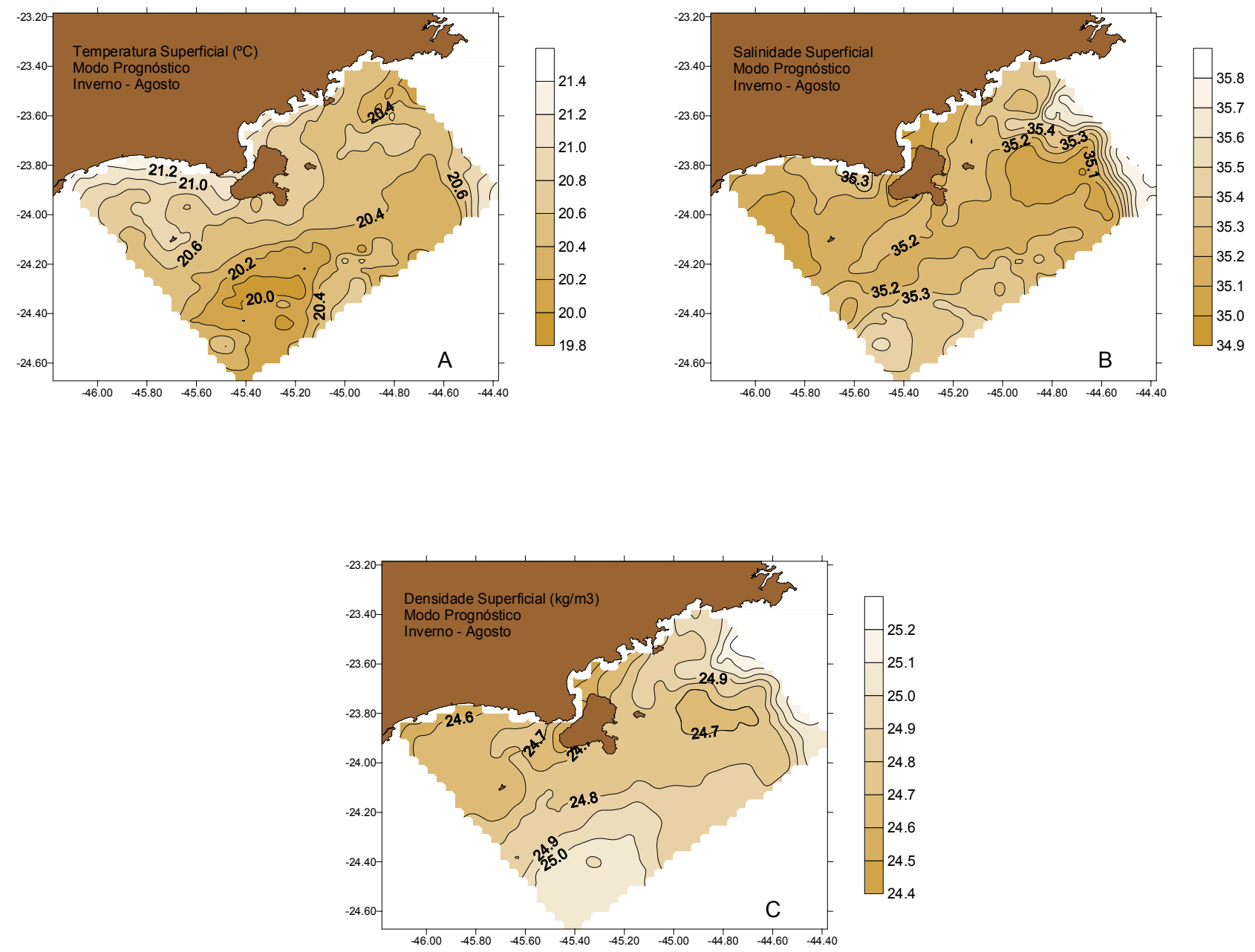

Figura 114: Distribuição horizontal superficial da temperatura (A), salinidade (B) e da densidade convencional (C) na PCI. Simulação de inverno - agosto. 

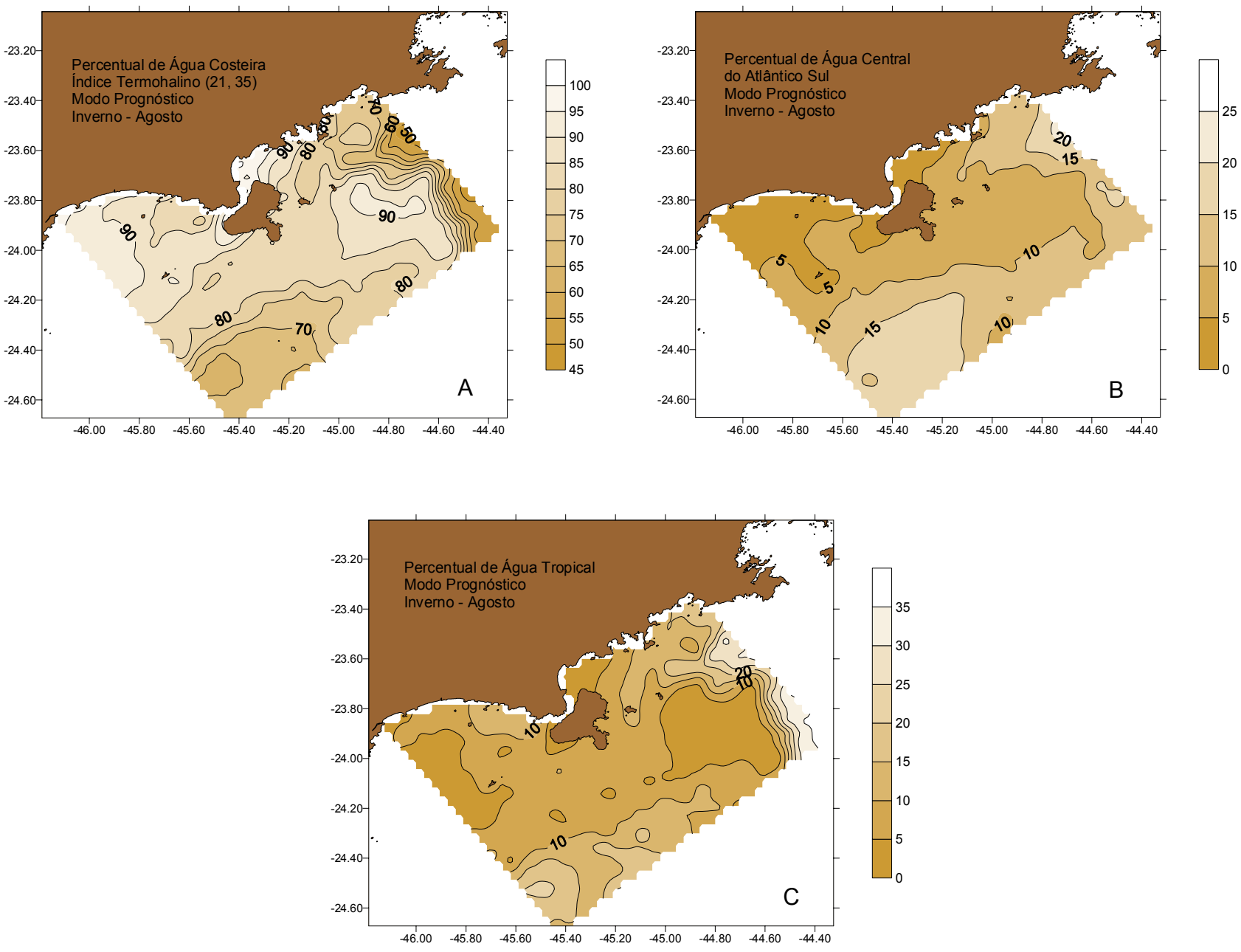

Figura 115: Distribuição horizontal dos percentuais das massas de Água Costeira (A), Água Central do Atlântico Sul (B) e da Água Tropical (C) na PCI. Simulação de inverno - agosto. 

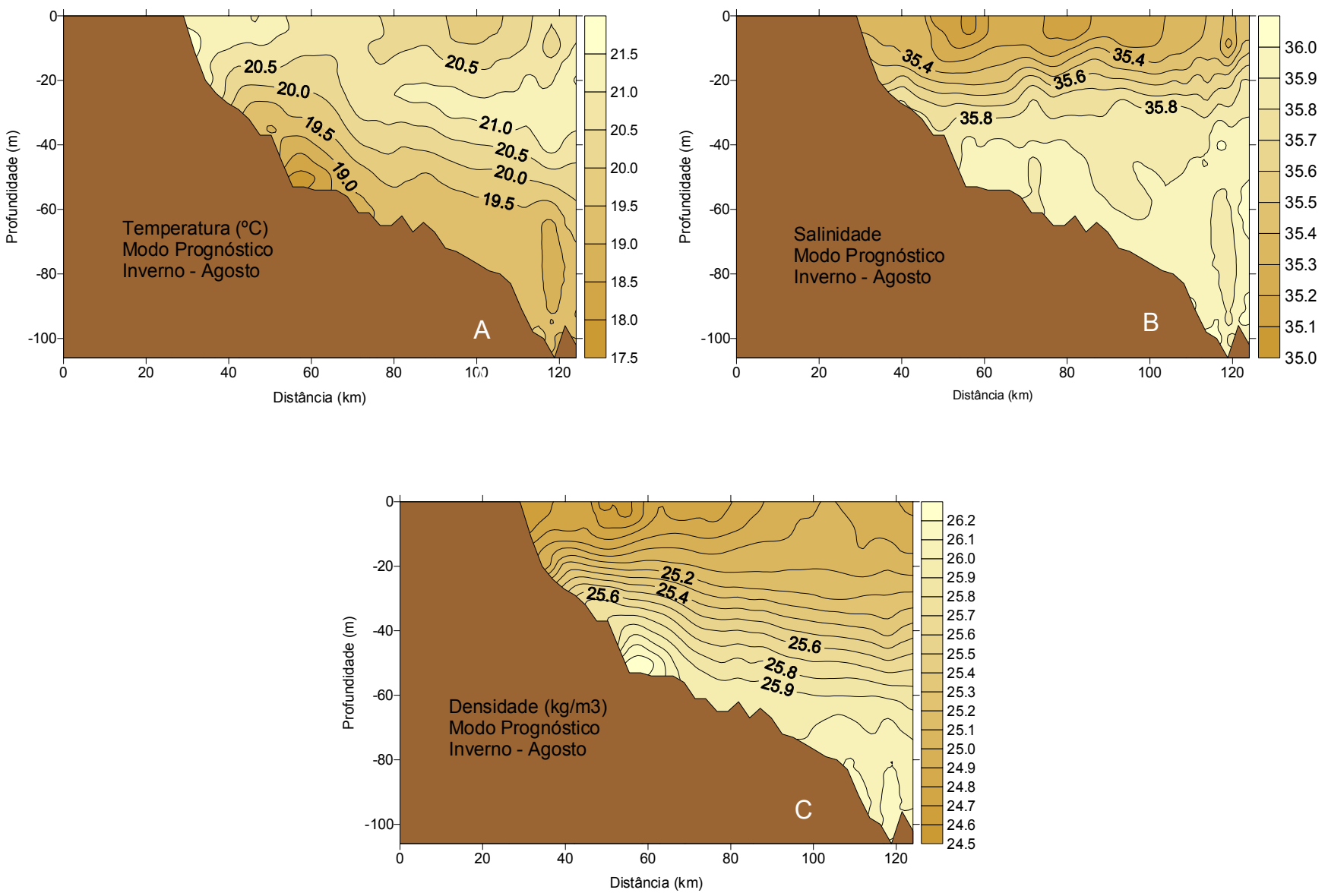

Figura 116: Distribuição vertical da temperatura (A), salinidade (B) e da densidade convencional (C) na PCI ao sul do Canal de São Sebastião. Simulação de inverno - agosto. 

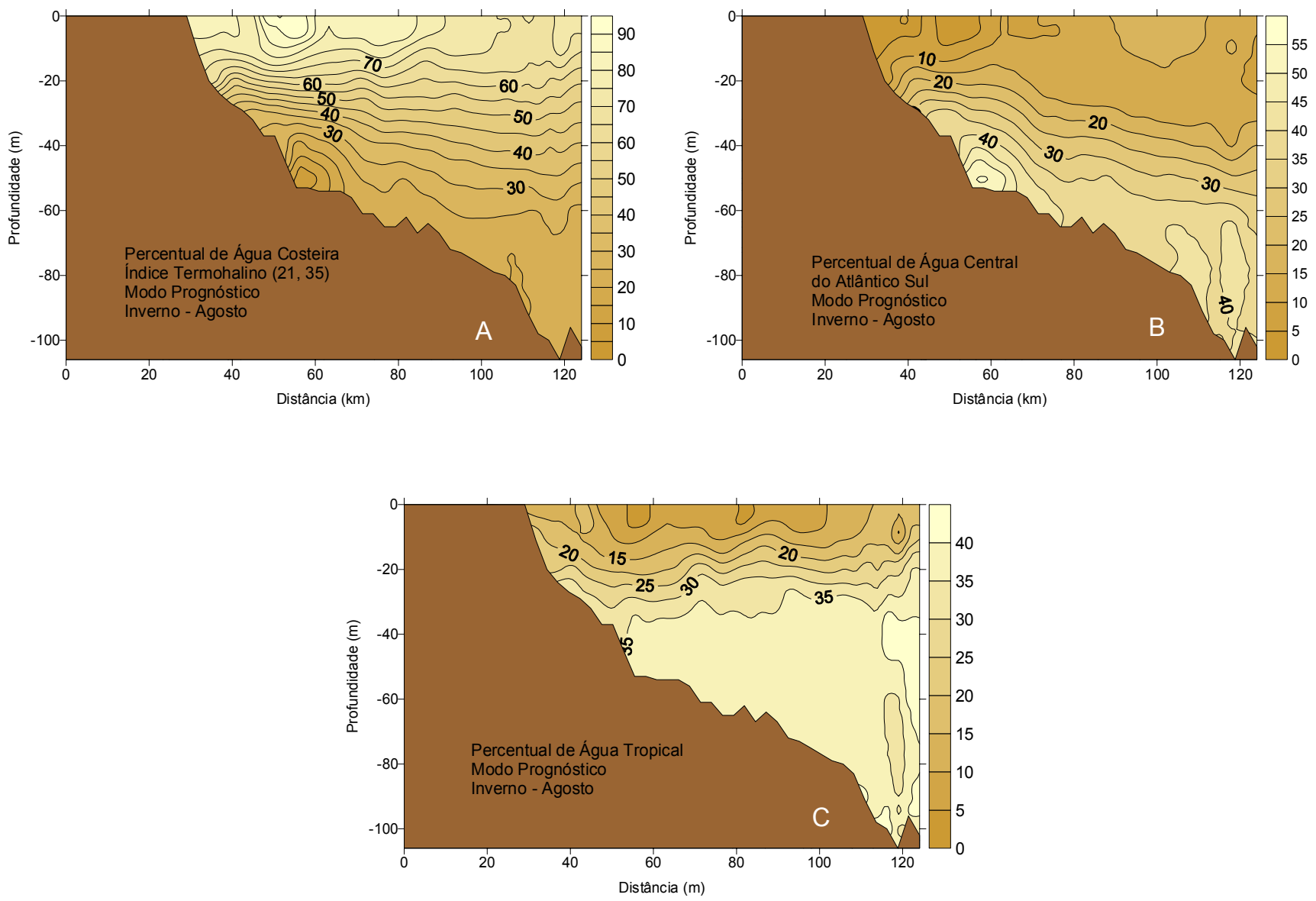

Figura 117: Distribuição vertical dos percentuais das massas de Água Costeira (A), Água Central do Atlântico Sul (B) e Água Tropical (C) na PCI ao sul do Canal de São Sebastião. Simulação de inverno - agosto. 

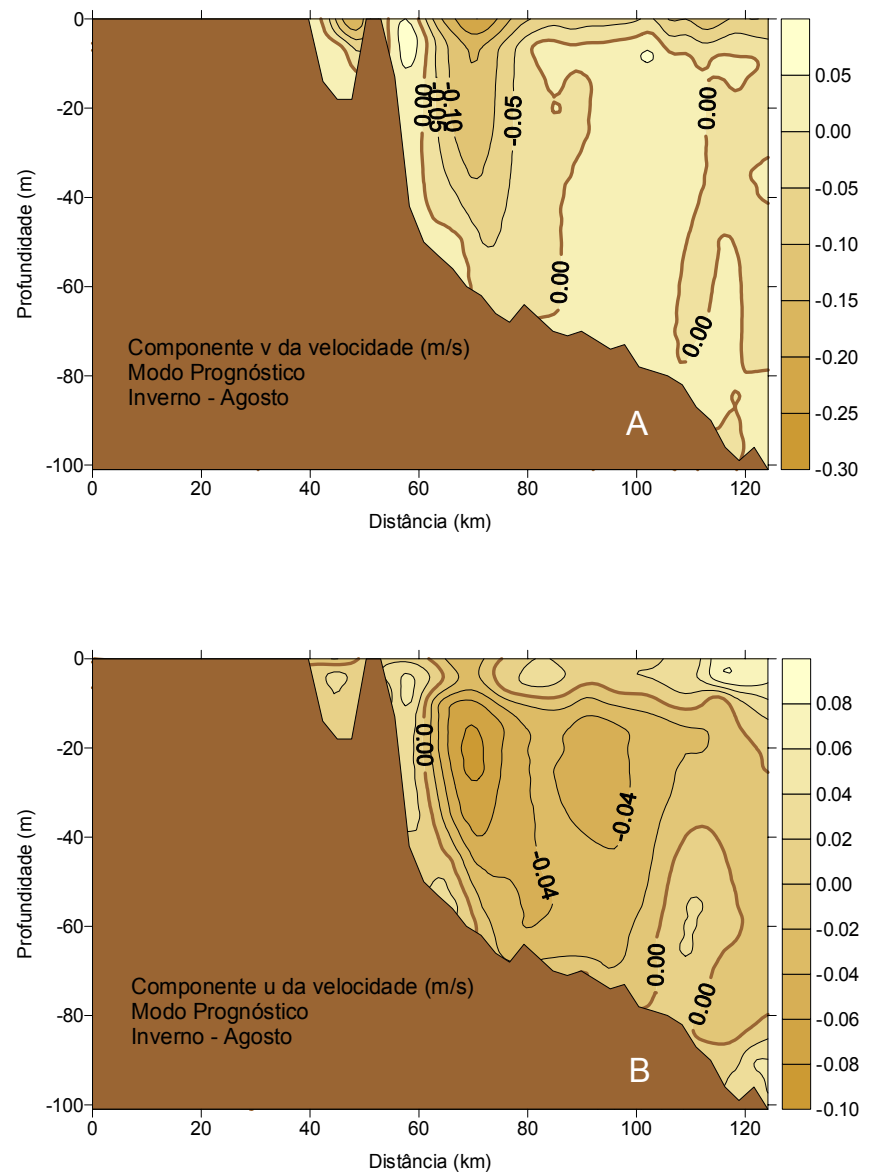

Figura 118: Distribuição vertical das componentes de velocidade paralela (A) e perpendicular (B) à costa na PCI ao sul do Canal de São Sebastião. Simulação de inverno - agosto. 


\subsubsection{O Canal de São Sebastião}

Os níveis de energia mecânica (Fig.119 A) no CSS, analogamente à PCI, após um máximo em $400 \mathrm{~h}$, adquire certa estabilidade, sendo seus níveis bem menores do que aqueles da PCI. Os níveis de fluxos de energia nos contornos (Fig.119 B) após um mínimo em 100 h, oscilam em torno de zero e o nível do mar médio (Fig.119 C) com inclinação descendente bem suave tem é $-0,02 \mathrm{~m}$ após $720 \mathrm{~h}$. Muitos dos máximos e mínimos para as três curvas coincidem no tempo para as três regiões.

Com uma amplitude menor do que 0,01 m, o nível do mar no CSS (Fig. 120A) apresenta um máximo ao norte, do lado do continente e o mínimo localiza-se ao norte da ISS. As correntes superficiais fluem para sudoeste com valores máximos de 0,33 m/s no estreito do canal.

O máximo de $22^{\circ} \mathrm{C}$ para a temperatura (Fig. $121 \mathrm{~A}$ ) encontra-se no mesmo local onde foi encontrado o máximo de nível do mar, estando o mínimo de $20,8^{\circ} \mathrm{C}$ ao norte e ao sul da ISS. Este modelo encontrou para o máximo de temperatura nas quatro estações, o norte do CSS, ao lado do continente e para o mínimo, a região sul do canal. A salinidade na superfície varia entre 34,6 (associado ao máximo de temperatura) e 35,2 no sul. As densidades variam de $24,0 \mathrm{~kg} / \mathrm{m}^{3}$, ao norte, do lado do continente a 24,8 $\mathrm{kg} / \mathrm{m}^{3}$ no sul.

Os perfis horizontais superficiais dos percentuais de massas de água encontram-se na Fig. 122 A,B,C. Os maiores níveis de AC, perto de 99\%, encontram-se ao norte, na mesma região onde foram encontrados os máximos de temperatura e mínimos de salinidade. O mínimo de AC (55\%) encontra-se no sul, associado aos mínimos de temperatura. Os máximos de ACAS e de AT encontram-se no sul, sendo os percentuais de AT (25\%) maiores do que os da ACAS (15\%).

Os perfis verticais de temperatura, salinidade e densidade junto às seções $\mathrm{A}, \mathrm{B}$, C e D encontram-se nas Figs. 123, 124 e 125, respectivamente. A condição é de quase homogeneidade térmica, pois as temperaturas variam entre $19^{\circ} \mathrm{C}$, encontrada no fundo da seção $\mathrm{A}$, e $21,4^{\circ} \mathrm{C}$, encontrada na superfície da seção D. Nas quatro seções, a amplitude de temperatura é de cerca de $1,2^{\circ} \mathrm{C}$. A salinidade em todo o canal varia entre 34,9, encontrada na superfície das seções C e D e 35,7, no fundo da seção A . As salinidades de fundo decrescem da seção A para a seção D; o mesmo acontece com as salinidades superficiais. As densidades, refletindo as condições térmicas e halinas no 
canal, diminuem da seção A $\left(24,6 \mathrm{~kg} / \mathrm{m}^{3}\right)$ para a seção D $\left(24,3 \mathrm{~kg} / \mathrm{m}^{3}\right)$; as densidades de fundo diminuem de $25,6 \mathrm{~kg} / \mathrm{m}^{3}$ na seção A para $24,9 \mathrm{~kg} / \mathrm{m}^{3}$ na seção D.

Os percentuais de massas de água junto à seção A encontram-se na Fig. 126 A,B,C. Os níveis superiores a 50\% da AC encontram-se acima de $10 \mathrm{~m}$ de profundidade e abaixo desta há uma região de mistura, sem domínio de nenhuma das três massas de água. No fundo, os máximos da AC, ACAS e AT são 25\%, 40\% e 30\% , respectivamente. Coelho (1997) encontrou nos dados do cruzeiro de ago/1992 o mínimo de ACAS (58\%) no fundo da entrada sul do canal.

Vemos junto à seção longitudinal ao CSS que as temperaturas (Fig. 127A) aumentam do sul para o norte, sendo o mínimo de $19,2^{\circ} \mathrm{C}$ e o máximo de $21,2^{\circ} \mathrm{C}$. As isotermas dispõem-se de forma concêntrica sob a forma de frente, sendo que o vetor gradiente indica que o fundo do CSS, em sua entrada sul, é o local de entrada da mesma. Esta mesma característica é observada para isohalinas e isopicnais, sendo que a maior salinidade encontra-se no sul, no fundo da entrada sul $(35,7)$ e a menor, na superfície $(35,0)$. O máximo de densidade encontra-se no fundo da entrada sul $(25,7$ $\mathrm{kg} / \mathrm{m}^{3}$ ) e o mínimo de $24,4 \mathrm{~kg} / \mathrm{m}^{3}$, na superfície. A caracterização de frente térmica e halina com origem no fundo do CSS em sua entrada sul também é observada nas estações de primavera e verão e não é verificada no outono sugerindo que o vento de nordeste está associado a esta característica.

Os perfis verticais em seção longitudinal dos percentuais de massas de água (Fig. 128 A,B,C) mostram suas isolinhas dispostas da mesma forma que isotermas, isohalinas e isopicnais revelando sinais de uma frente de ACAS no sul do CSS, no fundo. Não obstante, o domínio é da AC, ocupando todo o CSS, com exclusão do fundo da entrada sul, onde o percentual de ACAS alcança $40 \%$ e o da AT, $35 \%$.

A Fig. 129 A,B,C,D apresenta perfis verticais das componentes de velocidade paralela (v) e perpendicular (u) ao canal. A componente v mostra que as correntes superficiais fluem para sul em todo o canal (máximo de $0,30 \mathrm{~m} / \mathrm{s}$ ) invertendo o sentido abaixo de $10 \mathrm{~m}$ de profundidade (máximo de $0,10 \mathrm{~m} / \mathrm{s}$ ). A componente u mostra que no fundo do CSS, junto à seção A, do lado da ISS, as correntes fluem do largo para a costa, indicando este local como entrada de águas externas ao canal. Esta característica também foi encontrada nas estações de primavera e verão e não foi encontrada no outono. 

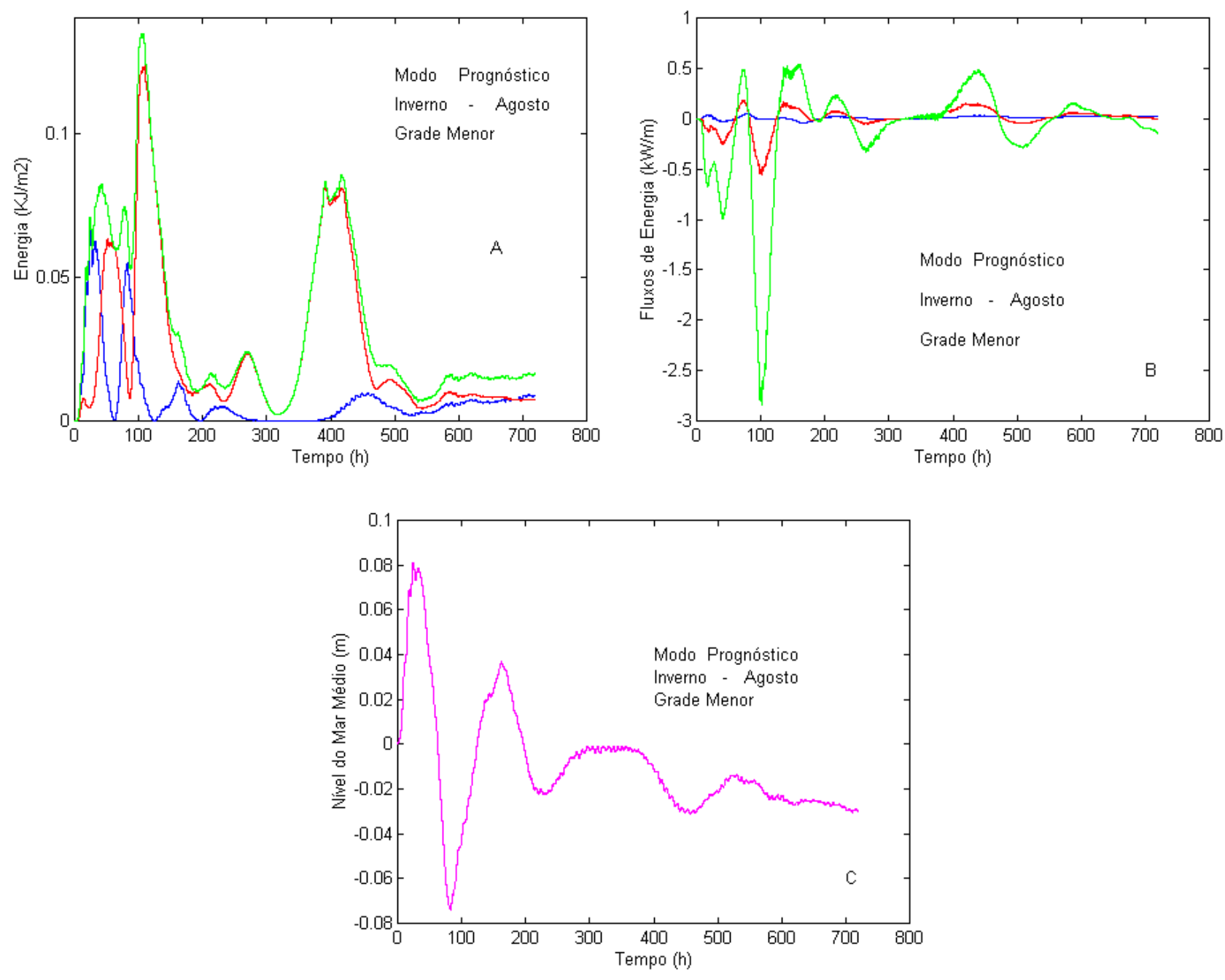

Figura 119: Curvas de energia mecânica (A), fluxos nos contornos (B) e nível médio do mar (C) no CSS, sendo em (A), o verde, a energia mecânica, o vermelho, a energia cinética e o azul, a energia potencial. Em (B), o azul representa o fluxo através do contorno norte, o vermelho, o fluxo através do contorno sul e o verde, o fluxo através do contorno leste. Simulação de inverno - agosto. 

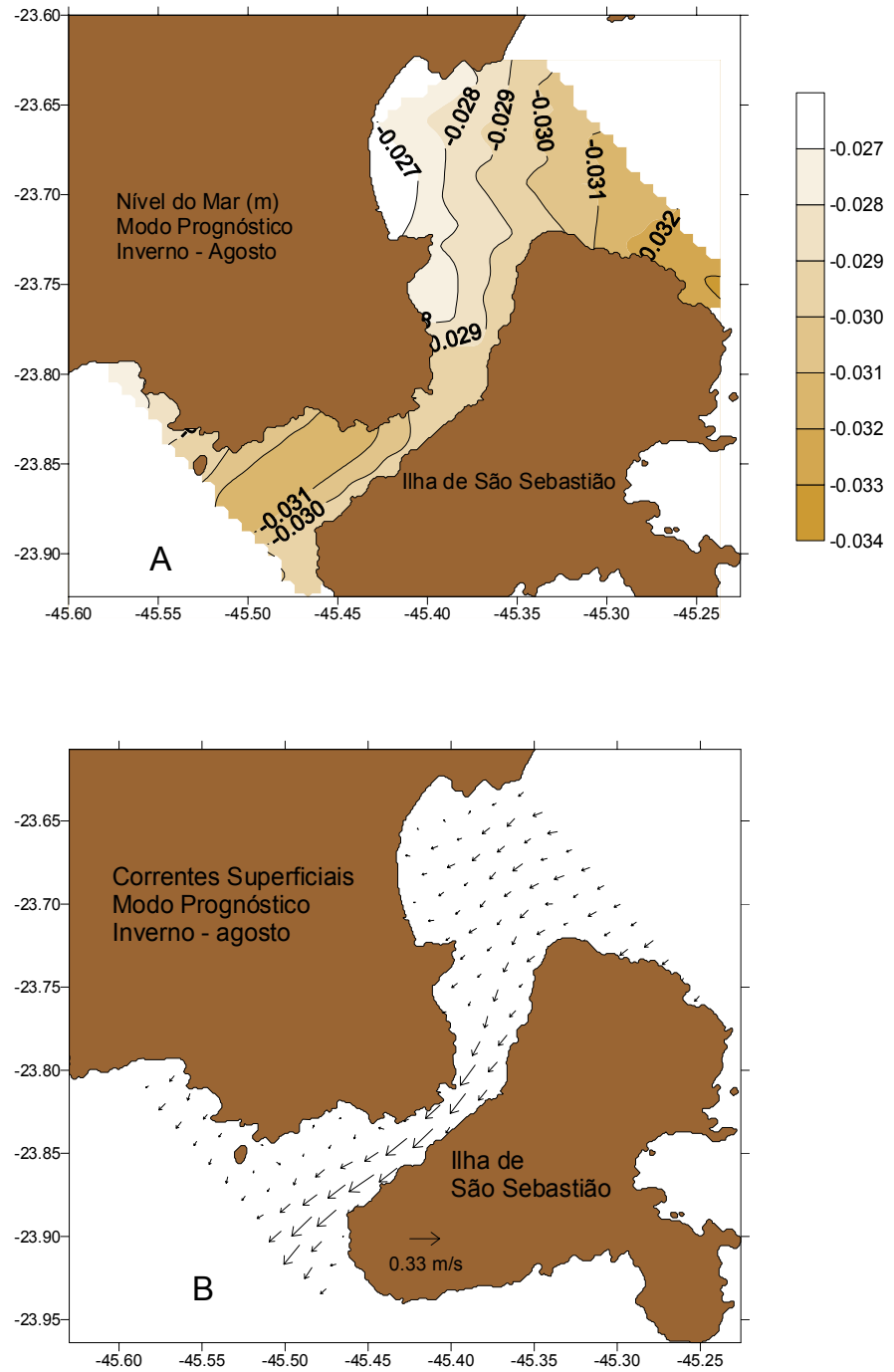

Figura 120: Nível do Mar (A) e Correntes superficiais (B) no Canal de São Sebastião. Simulação de inverno - agosto. 

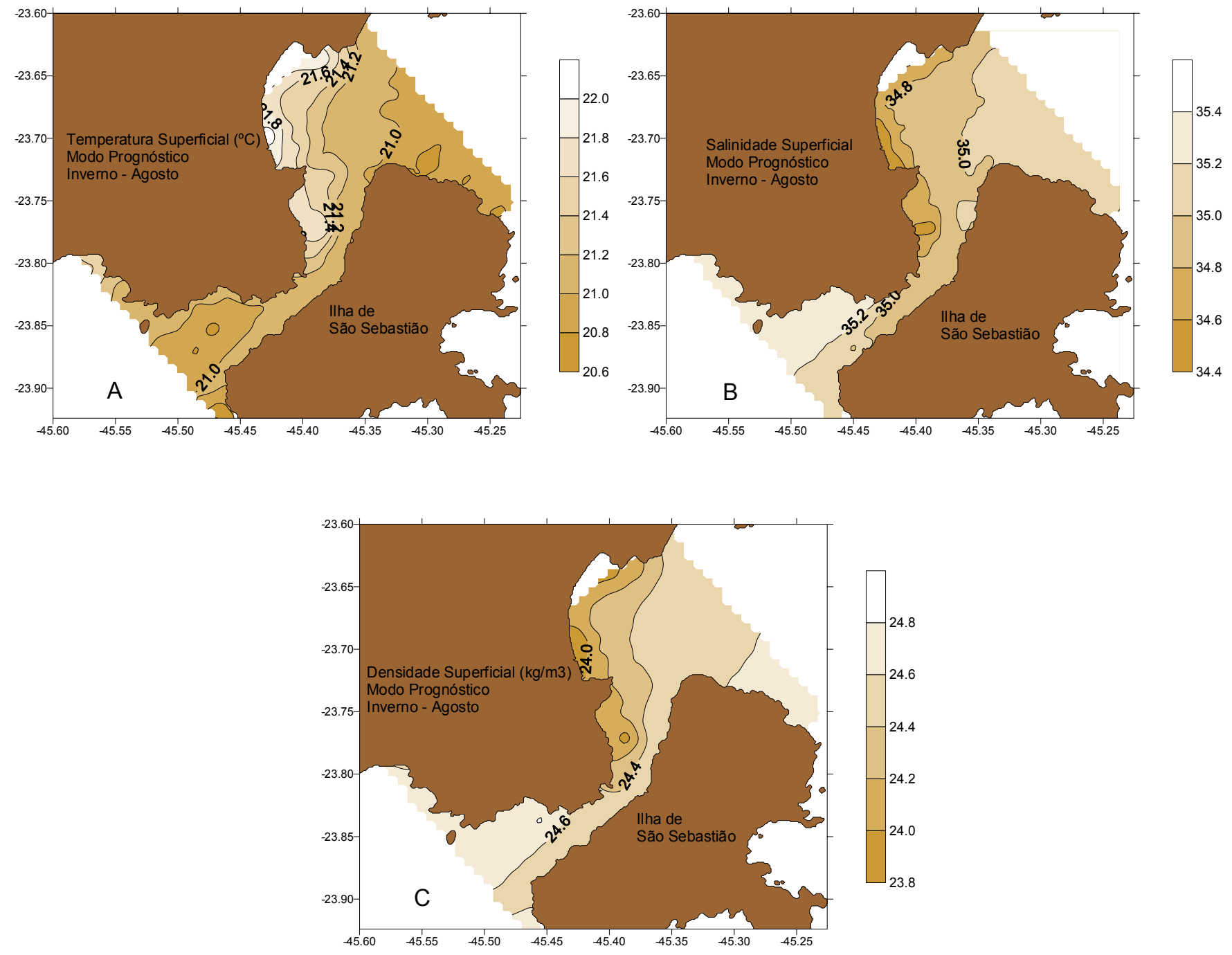

Figura 121: Distribuição horizontal superficial da temperatura (A), da salinidade (B) e da densidade convencional (C) no Canal de São Sebastião. Simulação de inverno - agosto. 

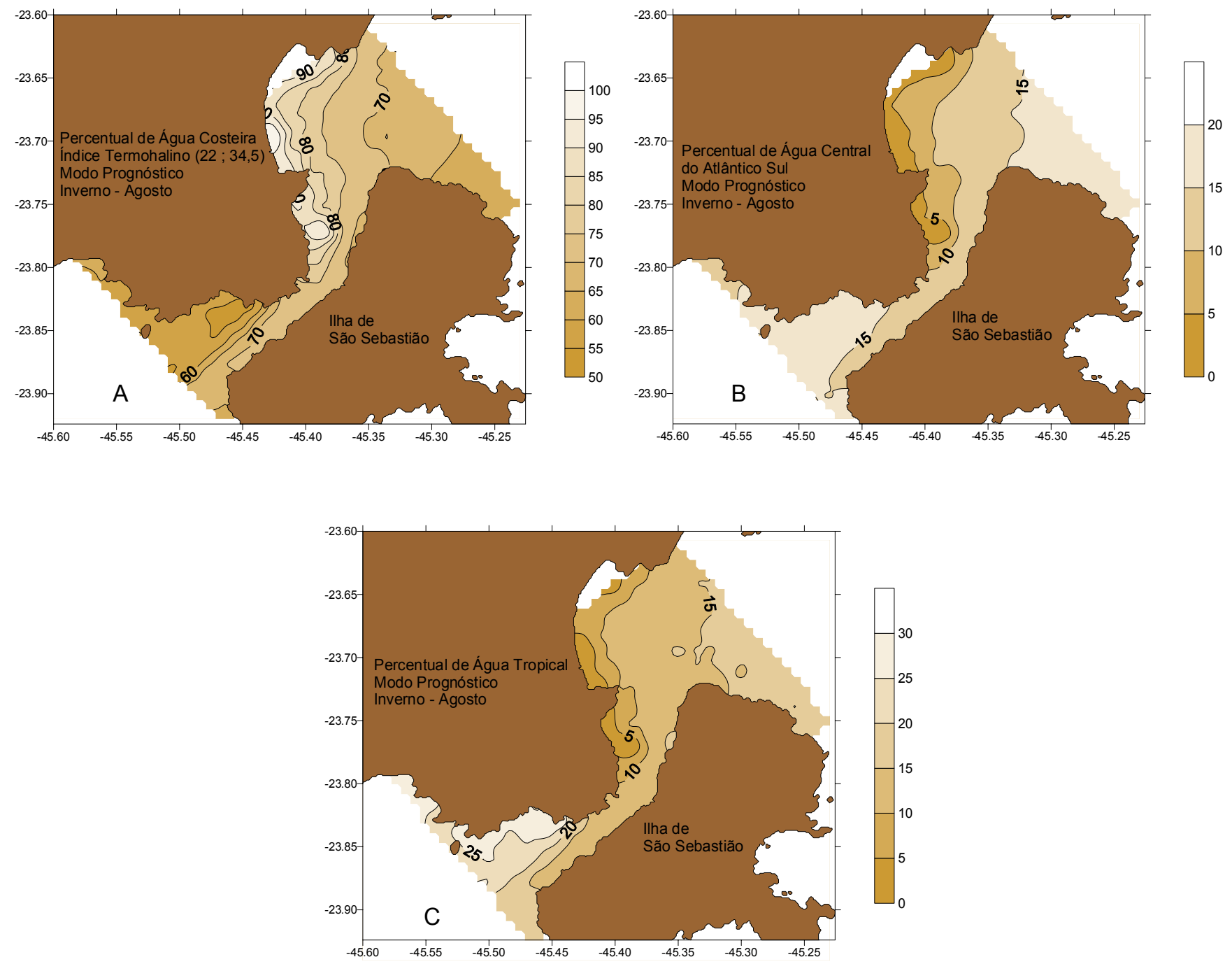

Figura 122: Distribuição horizontal dos percentuais de massas de Água Costeira (A), Água Central do Atlântico Sul (B) e Água Tropical (C) no Canal de São Sebastião. Simulação de inverno - agosto. 

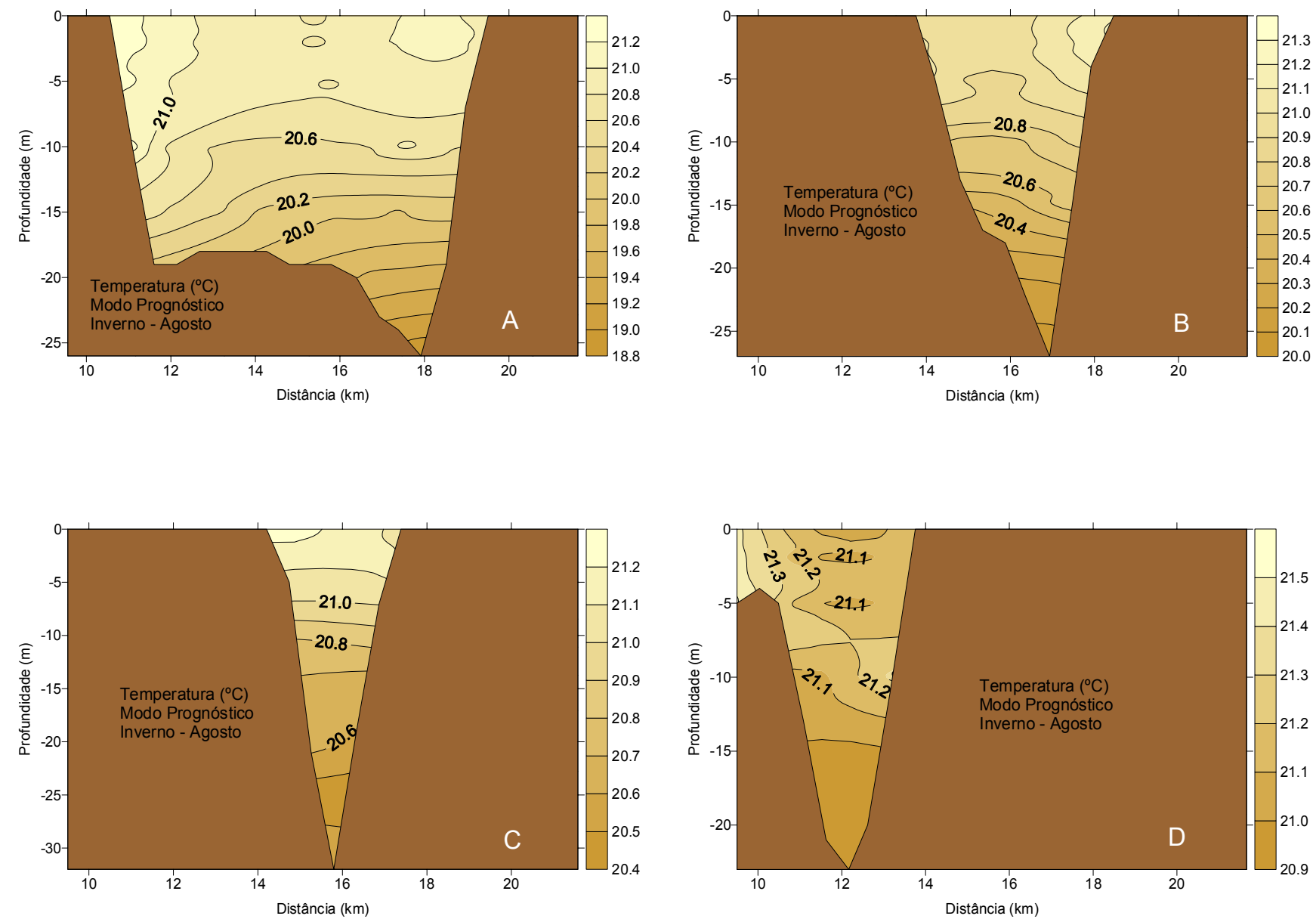

Figura 123: Distribuição vertical de temperatura nas seções $A, B, C$ e D, localizadas na região interna do Canal de São Sebastião. Simulação de inverno - agosto. 

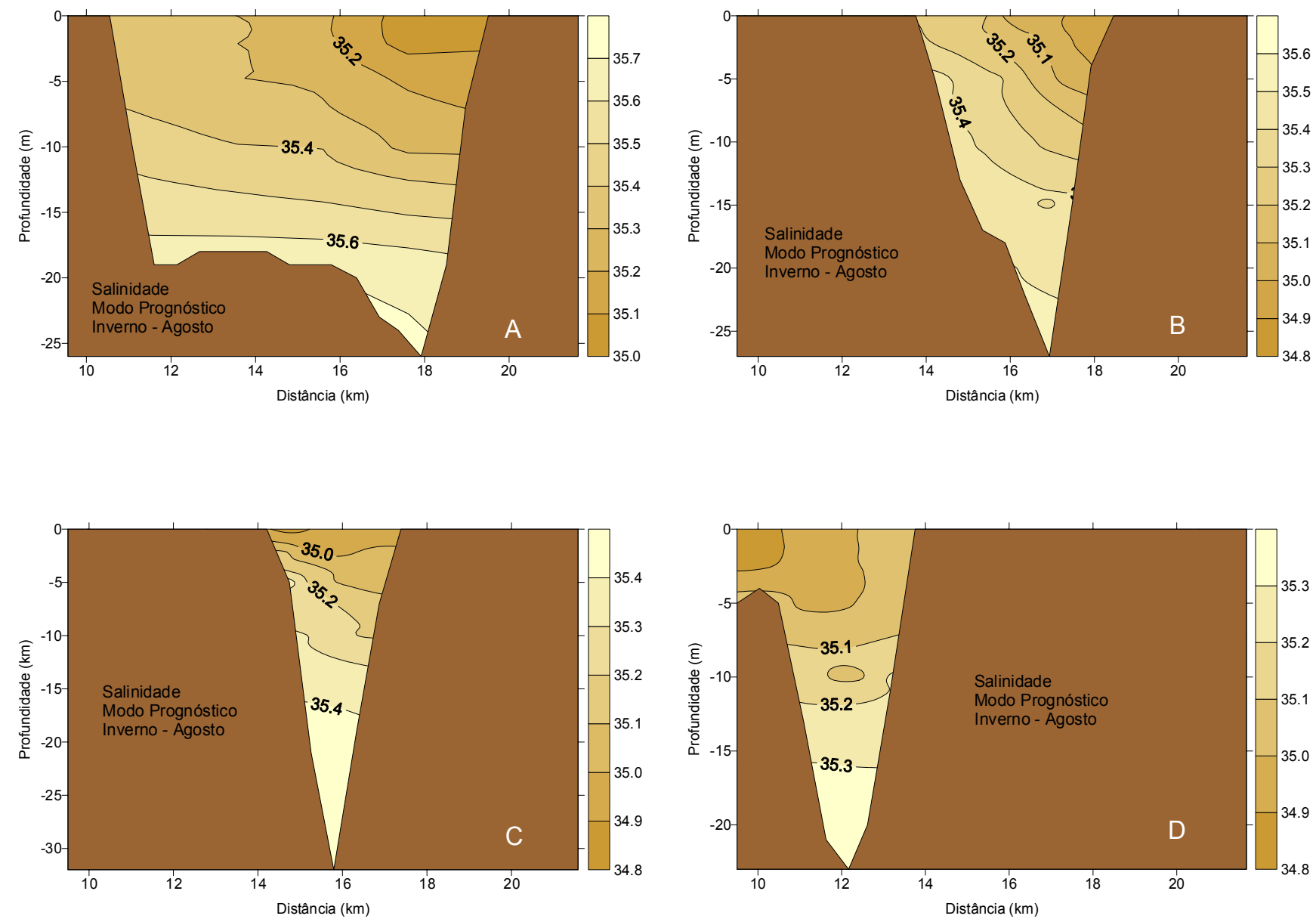

Figura 124: Distribuição vertical de salinidade nas seções $A, B, C$ e D, localizadas na região interna do Canal de São Sebastião. Simulação de inverno - agosto. 

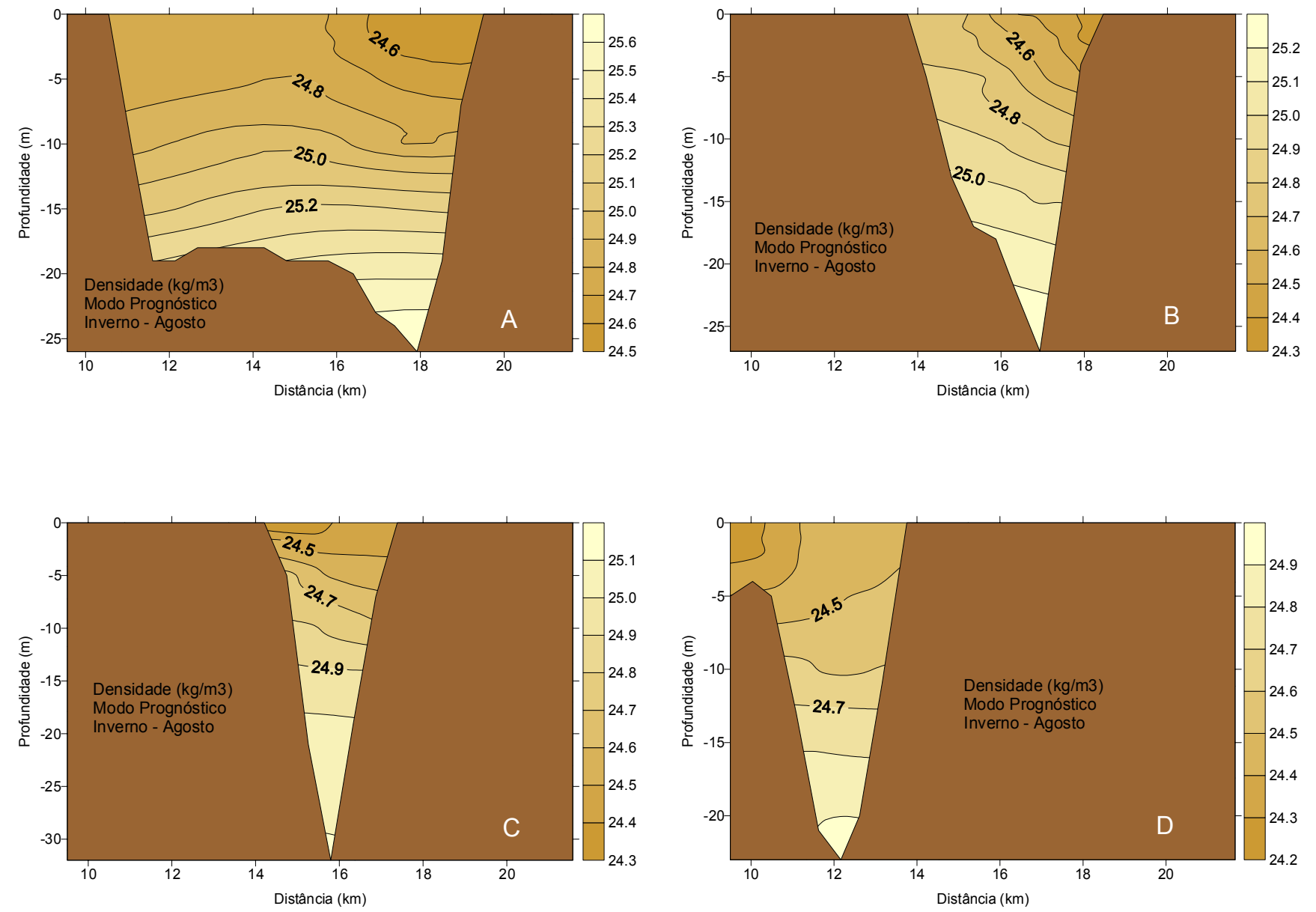

Figura 125: Distribuição vertical da densidade convencional nas seções $A, B, C$ e D, localizadas na região interna do Canal de São Sebastião. Simulação de inverno - agosto. 

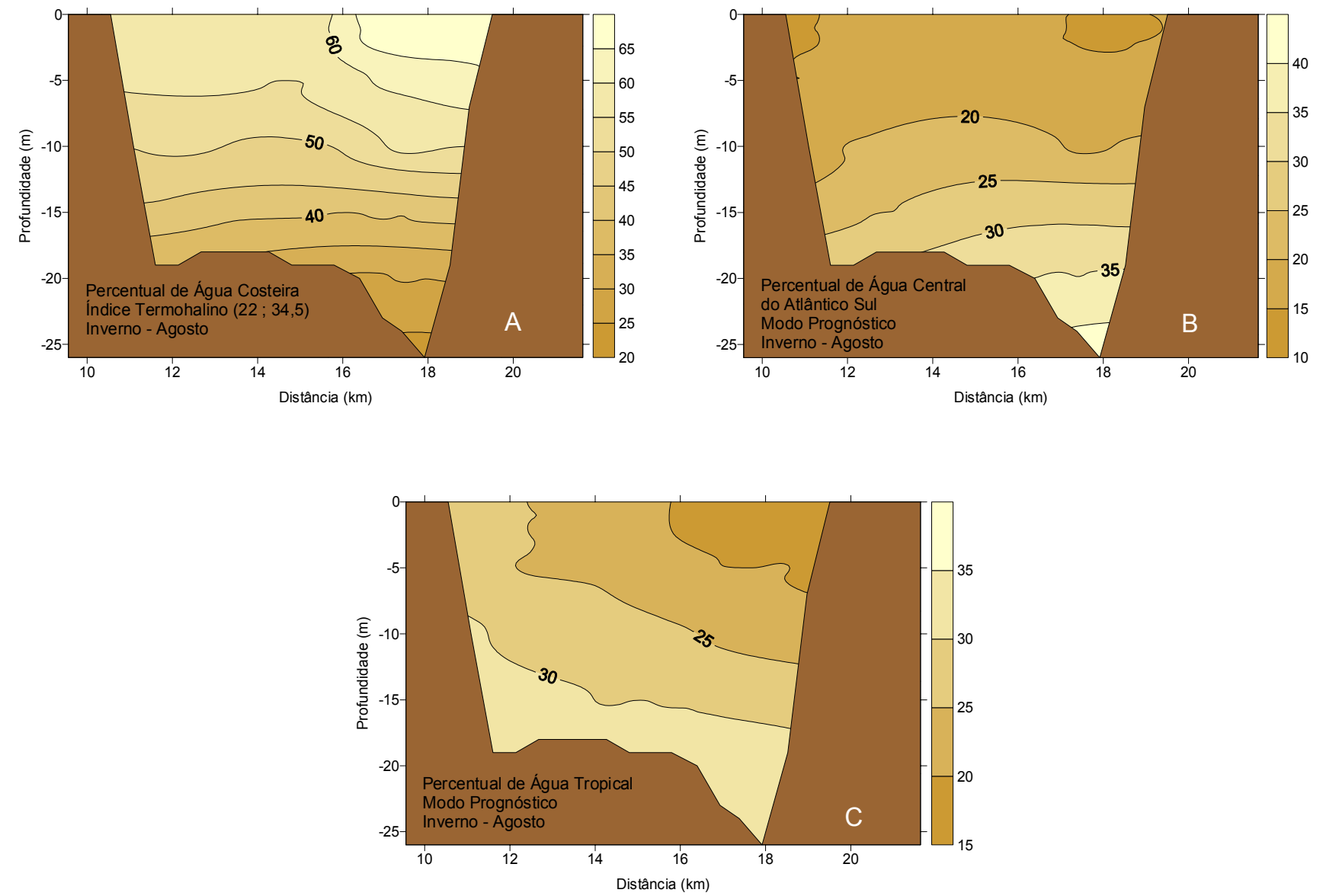

Figura 126: Distribuição vertical dos percentuais das massas de Água Costeira (A), Água Central do Atlântico Sul (B) e da Água Tropical (C) junto à seção A, localizada no Canal de São Sebastião. Simulação de inverno - agosto. 

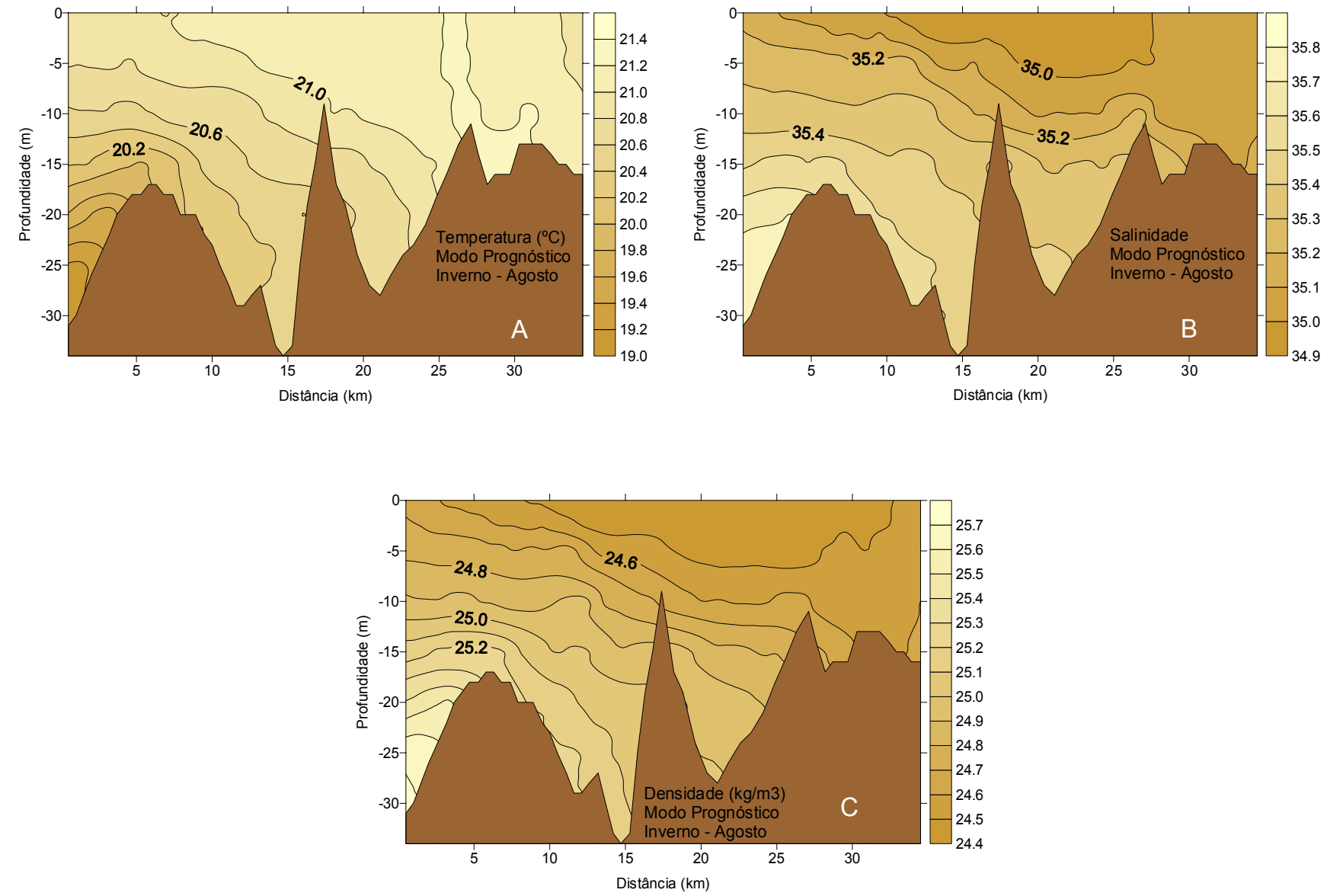

Figura 127: Distribuição vertical ao longo do Canal de São Sebastião da temperatura (A), salinidade (B) e da densidade convencional (C). Simulação de inverno - agosto. 

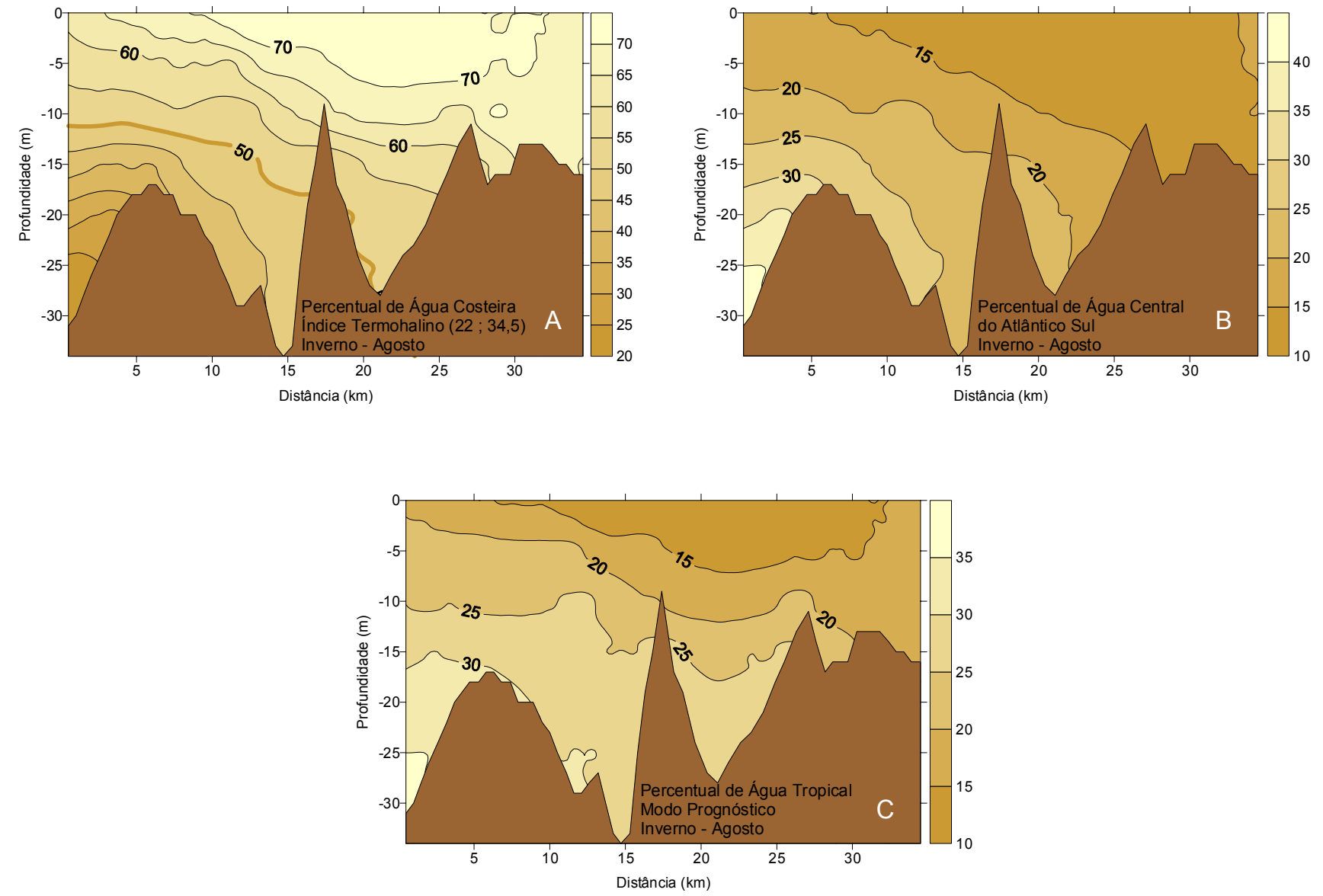

Figura 128: Distribuição vertical ao longo do Canal de São Sebastião dos percentuais de massas de Água Costeira (A), Água Central do Atlântico Sul (B) e da Água Tropical (C). Simulação de inverno - agosto. 

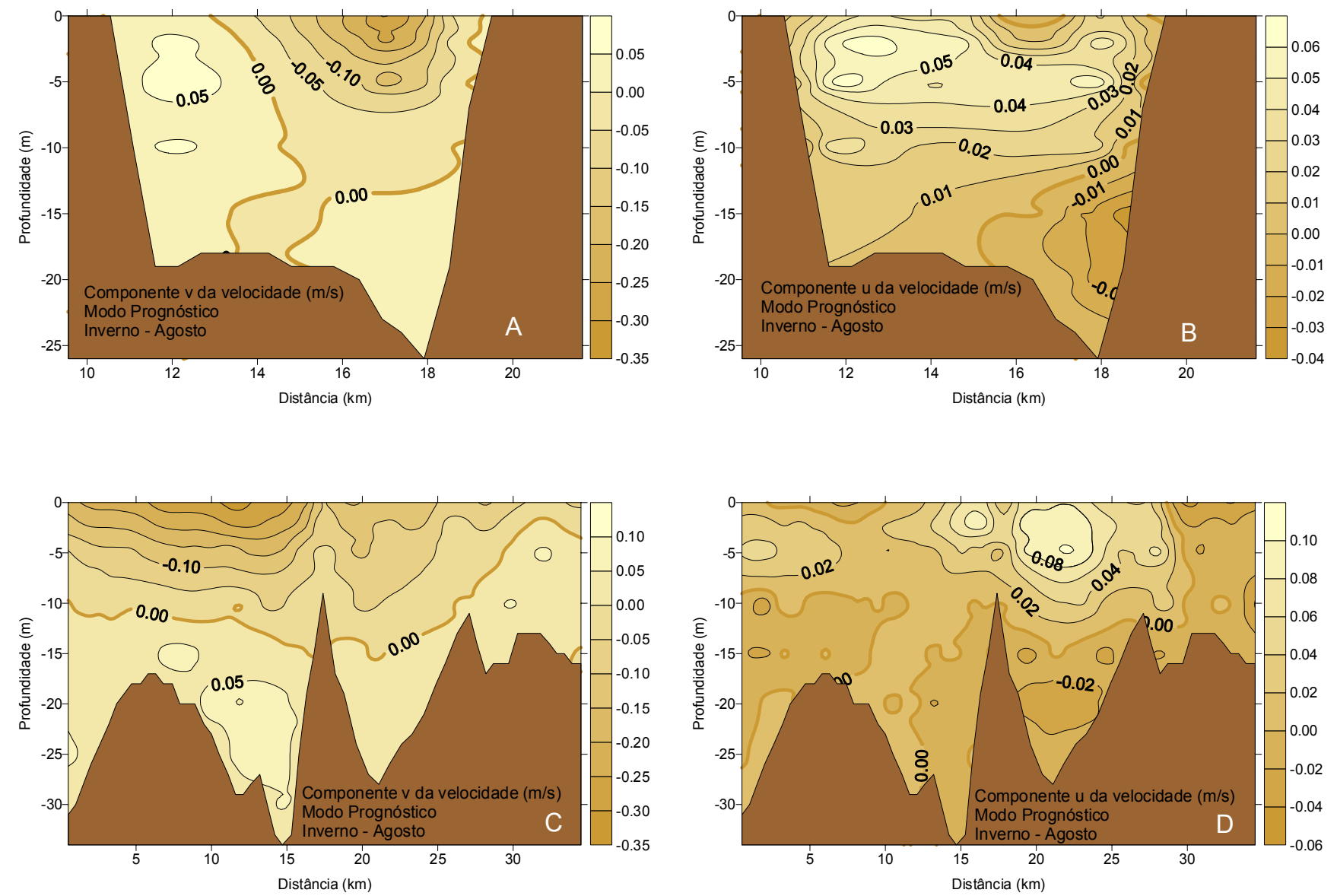

Figura 129: Distribuição vertical das componentes de velocidade normal (A) e paralela (B) à seção A . Distribuição vertical ao longo do Canal de São Sebastião das componentes de velocidade normal (C) e paralela (D) às seções. Simulação de inverno - agosto. 


\subsection{Experimento com vento de sudoeste}

Os experimentos que se seguem usam todos a climatologia de verão. A tensão de cisalhamento do vento utilizada é a gerada pelo vento climatológico do mês de fevereiro, que é um vento praticamente paralelo à costa, porém, com seu sinal invertido. Como os experimentos são fíctícios, utiliza-se de 10 dias de integração.

O nível do mar na PCSE (Fig. 130A) tem seu máximo na costa $(0,15 \mathrm{~m}) \mathrm{em}$ frente à Baía de Paranaguá com inclinação descendente para o largo. As correntes superficiais (Fig. 130B) na plataforma fluem para nordeste ao longo das isóbatas, intensificando-se ao norte da ISS. As temperaturas superficiais se elevam, variando entre 25 e $30,5^{\circ} \mathrm{C}$. A diferença marcante em relação ao experimento de verão são as altas temperaturas na costa (Fig. $130 \mathrm{C})$, no limite norte da região $\left(27^{\circ} \mathrm{C}\right)$, quando neste local, com vento de nordeste, obteve-se $21^{\circ} \mathrm{C}$. As salinidades (Fig. 130D), em decorrência do vento de sudoeste, tornam-se menores na costa, com mínimo de 34,2 ao sul da Ilha de São Vicente, apesar da aproximação do forte gradiente halino encontrado na quebra da plataforma na simulação de verão. Os perfis verticais de temperatura, salinidade e densidade encontram-se na Fig. 131 A,B,C. A isoterma de $18^{\circ} \mathrm{C}$ sobre a plataforma, encontra-se mais profunda e recuada da costa. Verificam-se salinidades mais baixas na costa $(34,8)$ em relação à simulação de verão $(35,2)$ e gradientes mais fortes na plataforma em conseqüência de que as salinidades no talude ficaram aproximadamente invariantes com o vento de sudoeste. Com o recuo da isopicnal de 26 $\mathrm{kg} / \mathrm{m}^{3}$ para o largo, os gradientes verticais de densidade são bem mais fracos na costa (Fig.131C).

O nível do mar na PCI é 0,14 m com inclinação descendente para o largo onde encontramos 0,04 m. As correntes superficiais (Fig.132B) fluindo para nordeste, intensificam-se ao contornarem a ISS, formando uma região de sombra a nordeste da mesma. Os percentuais de AT (Fig.132C) na superfície alcançam 75\% a leste da ISS contra o máximo de $20 \%$ alcançado na simulação de verão, embora o domínio na superfície seja da AC. No local do encontro de AC e AT forma-se uma frente com fortes gradientes horizontais desses percentuais. Os perfis verticais de temperatura, salinidade e densidade encontram-se na Fig. 133 A,B,C. Percebemos que a temperatura junto à costa é bastante elevada $\left(28^{\circ} \mathrm{C}\right)$ e a isoterma de $16^{\circ} \mathrm{C}$ encontra-se em profundidades maiores que $60 \mathrm{~m}$ (Fig. 133A). As salinidades estão mais baixas na costa 
$(34,5)$ e observa-se a formação de uma frente halina (Fig. 133B) a $60 \mathrm{~km}$ da costa. A orientação das isopicnais muda substancialmente em relação ao experimento de verão (Fig. 67C), indicando movimentos para norte. As densidades estão menores na costa (Fig. 133C), com a mínima de $22 \mathrm{~kg} / \mathrm{m}^{3}$; a isopicnal de $26 \mathrm{~kg} / \mathrm{m}^{3}$ recua para o largo, aprofundando-se. Nos perfis verticais dos percentuais de massas de água (Fig.134 A,B,C), verifica-se que os percentuais de $50 \%$ da AC e da ACAS se aprofundam. O percentual de $50 \%$ de AT alcança a PCI principalmente ao norte do CSS, onde encontra-se $60 \%$ desta massa de água.

O nível do mar no CSS varia entre $0,13 \mathrm{~m}$ no sul e $0,15 \mathrm{~m}$ ao norte; as correntes superficiais fluindo para nordeste ao longo da costa em parte penetram o CSS, intensificando-se no estreito do canal e parte contorna a ISS (Fig135 A,B). O contraste com a simulação de verão (vento de sudoeste) é bem nítido nos perfís verticais de temperatura e salinidade (Fig.135 C,D) na seção longitudinal ao canal. A temperatura junto à entrada sul do canal, no fundo é de $25^{\circ} \mathrm{C}$ e a salinidade, 35,1 . Na superfície encontram-se temperaturas de $30^{\circ} \mathrm{C}$ e salinidades de 34,2. Esses resultados também podem ser visualizados nos perfís verticais junto à seção A, na entrada sul, da Fig. 136 A,B,C,D. As temperaturas no fundo, do lado da ISS chegam a $23,5^{\circ} \mathrm{C}$ e nesse mesmo local a salinidade é de 35,0 . A AC ocupa toda a seção com um percentual mínimo de $85 \%$ no fundo da entrada sul, ao lado da ISS. Conforme observa-se na Fig. 136 D, as correntes próximas ao contorno oeste da ISS fluem para sul, sendo que no resto da seção, fluem para norte. No experimento de verão, correntes fluindo para norte, no fundo, ao lado da ISS, estão associadas à penetração de águas mais frias, sendo a componente u negativa, indicando movimento do largo para a costa. Neste experimento em regime de ventos de sudoeste, as correntes na maior parte da seção fluem para norte mas não estão associadas à penetração de águas mais frias do largo, sendo a componente u deste movimento positiva, isto é, correntes fluindo da costa para o largo. 

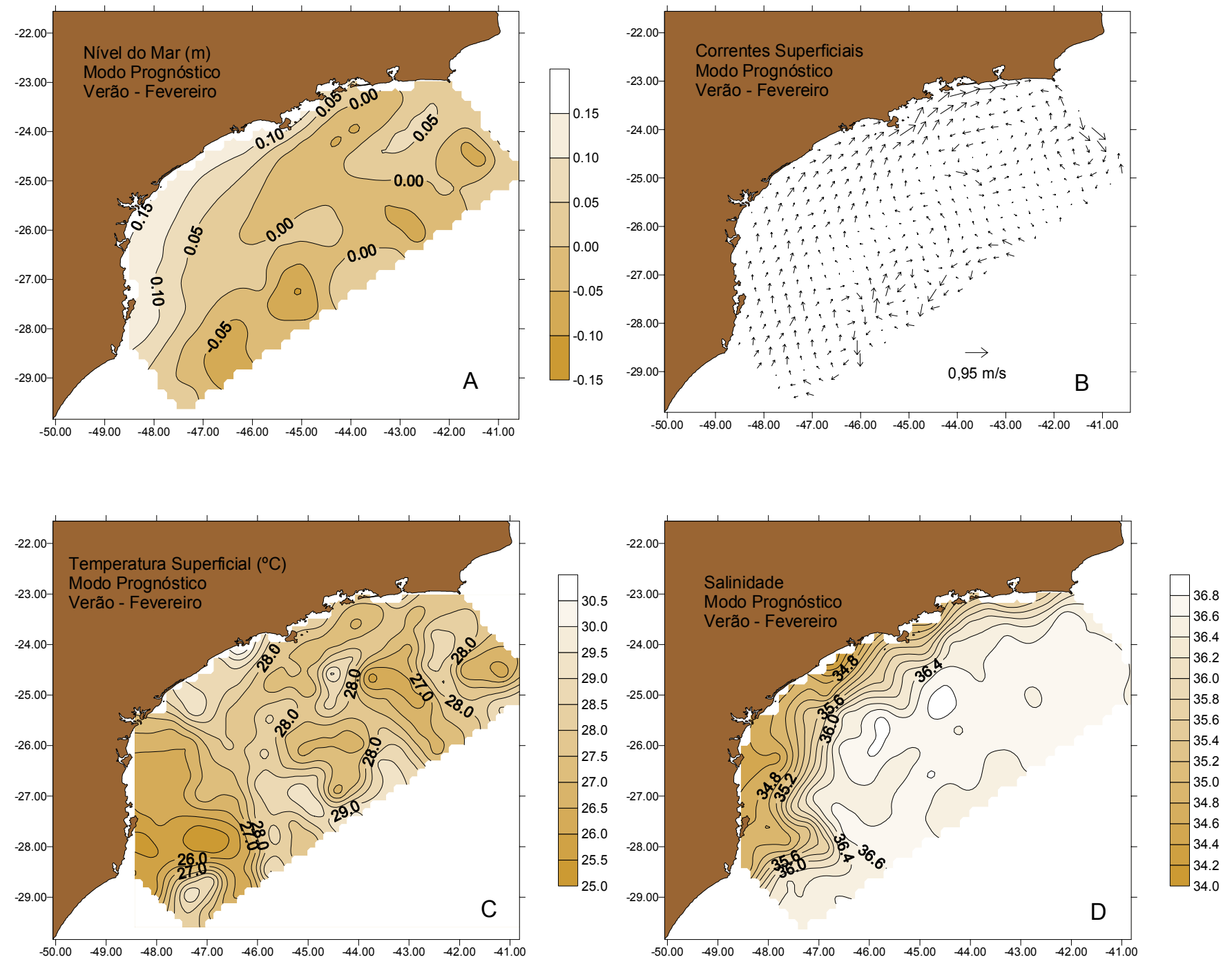

Figura 130: Nível do mar (A). Correntes superficiais (B). Distribuição horizontal superficial da temperatura (C) e da salinidade (D) na Plataforma Continental Sudeste após 10 dias de integração com vento de sudoeste e climatologia de verão - fevereiro. 

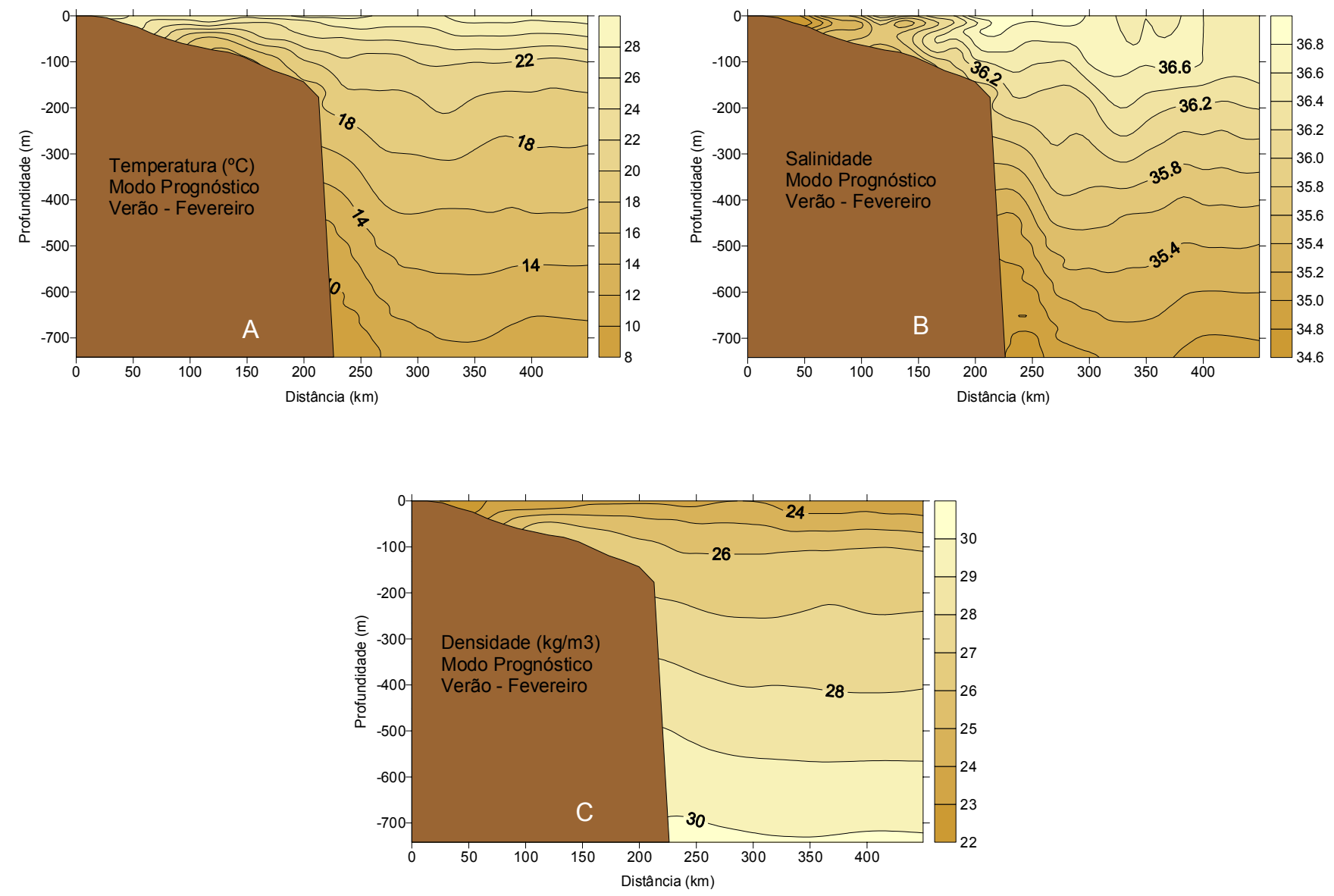

Figura 131: Distribuição vertical da temperatura (A), da salinidade (B) e da densidade convencional (C) na Plataforma Continental Sudeste ao sul do Canal de São Sebastião após 10 dias de integração com vento de sudoeste e climatologia de verão - fevereiro. 

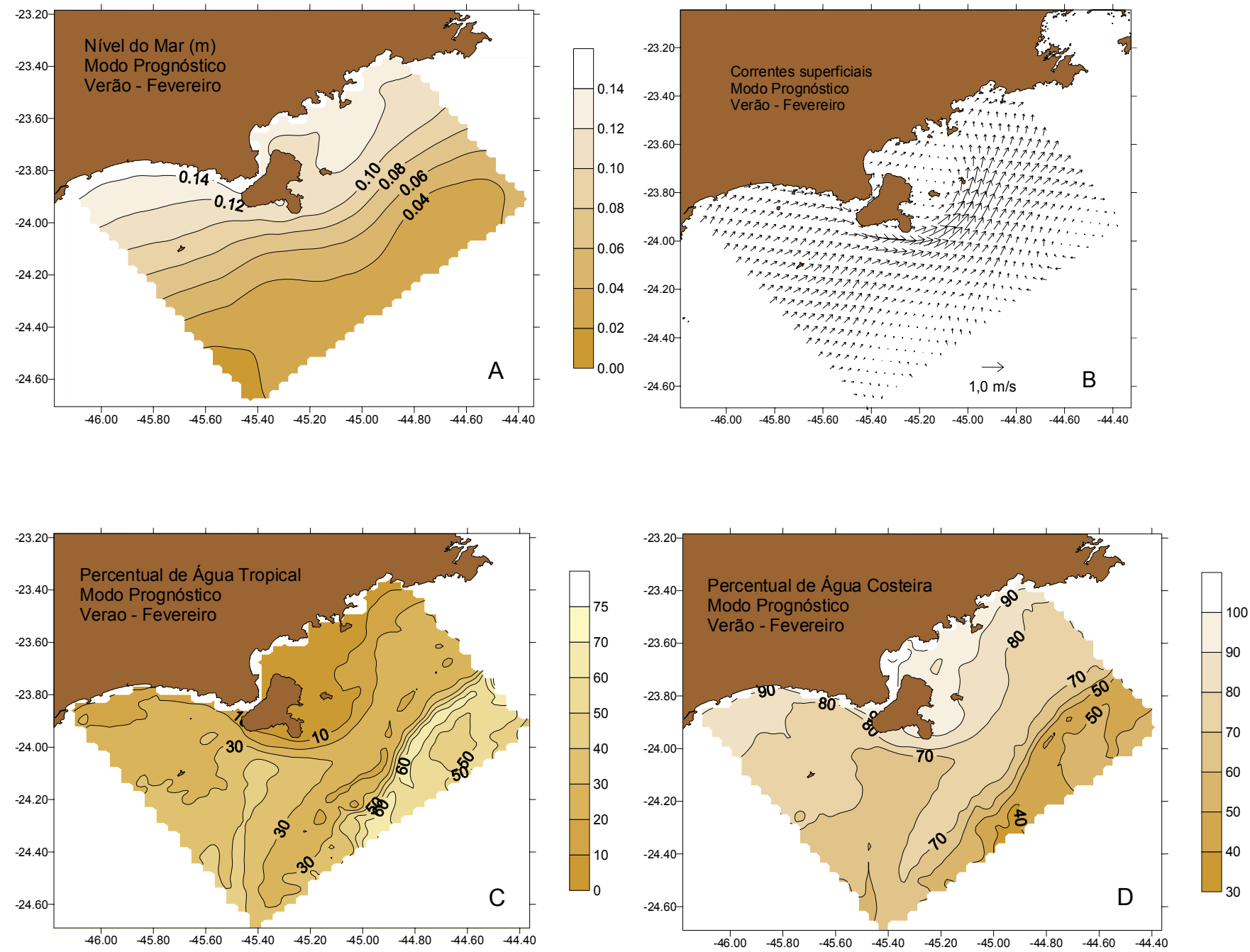

Figura 132: Nível do mar (A), Correntes superficiais (B), Distribuição horizontal superficial dos percentuais das massas de Água Tropical (C) e da Água Costeira (D) na PCI, após 10 dias de integração com vento de sudoeste e climatologia de verão - fevereiro. 

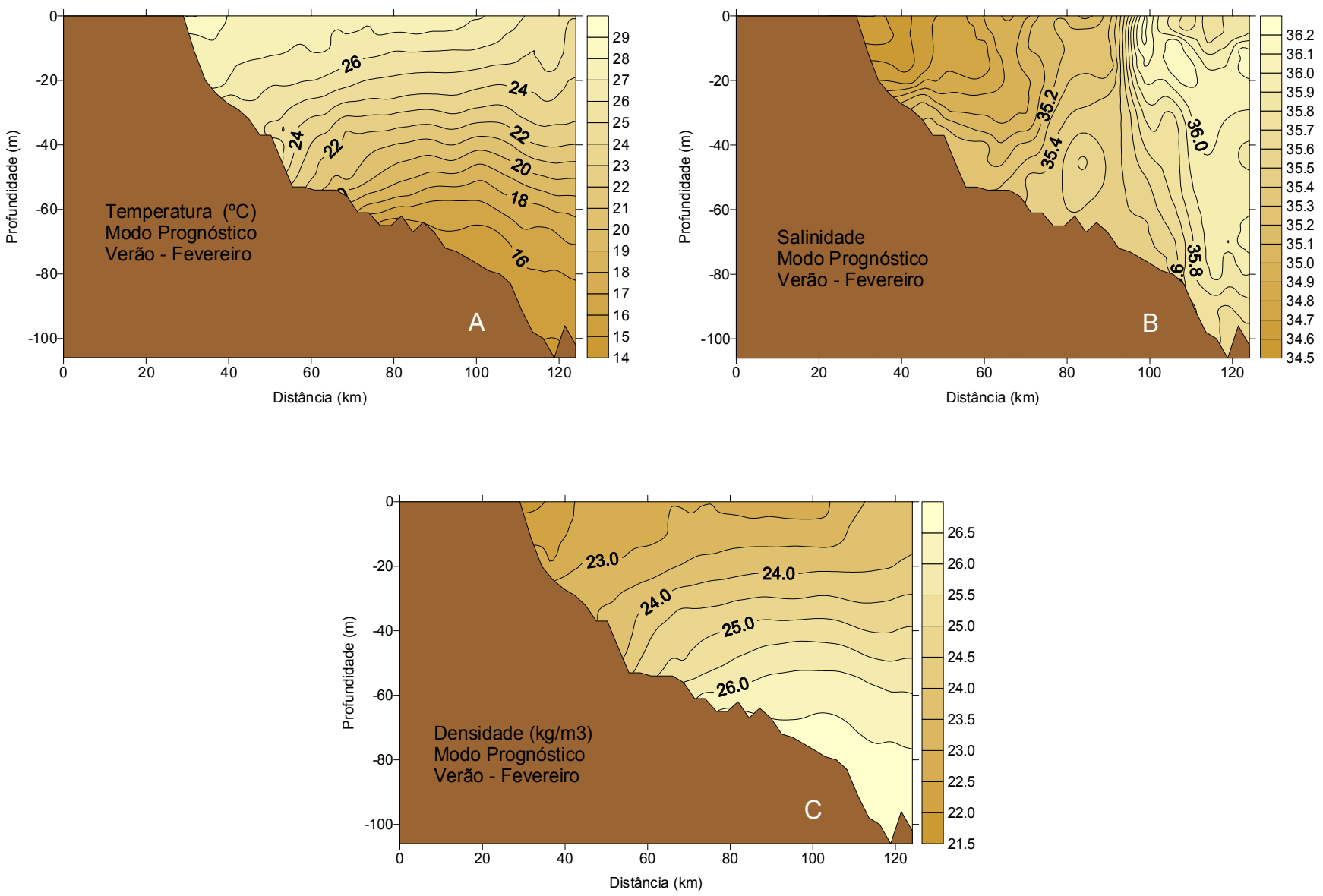

Figura 133: Distribuição vertical da temperatura (A), da salinidade (B) e da densidade convencional (C) na PCI ao sul do Canal de São Sebastião após 10 dias de integração com vento de sudoeste e climatologia de verão - fevereiro. 

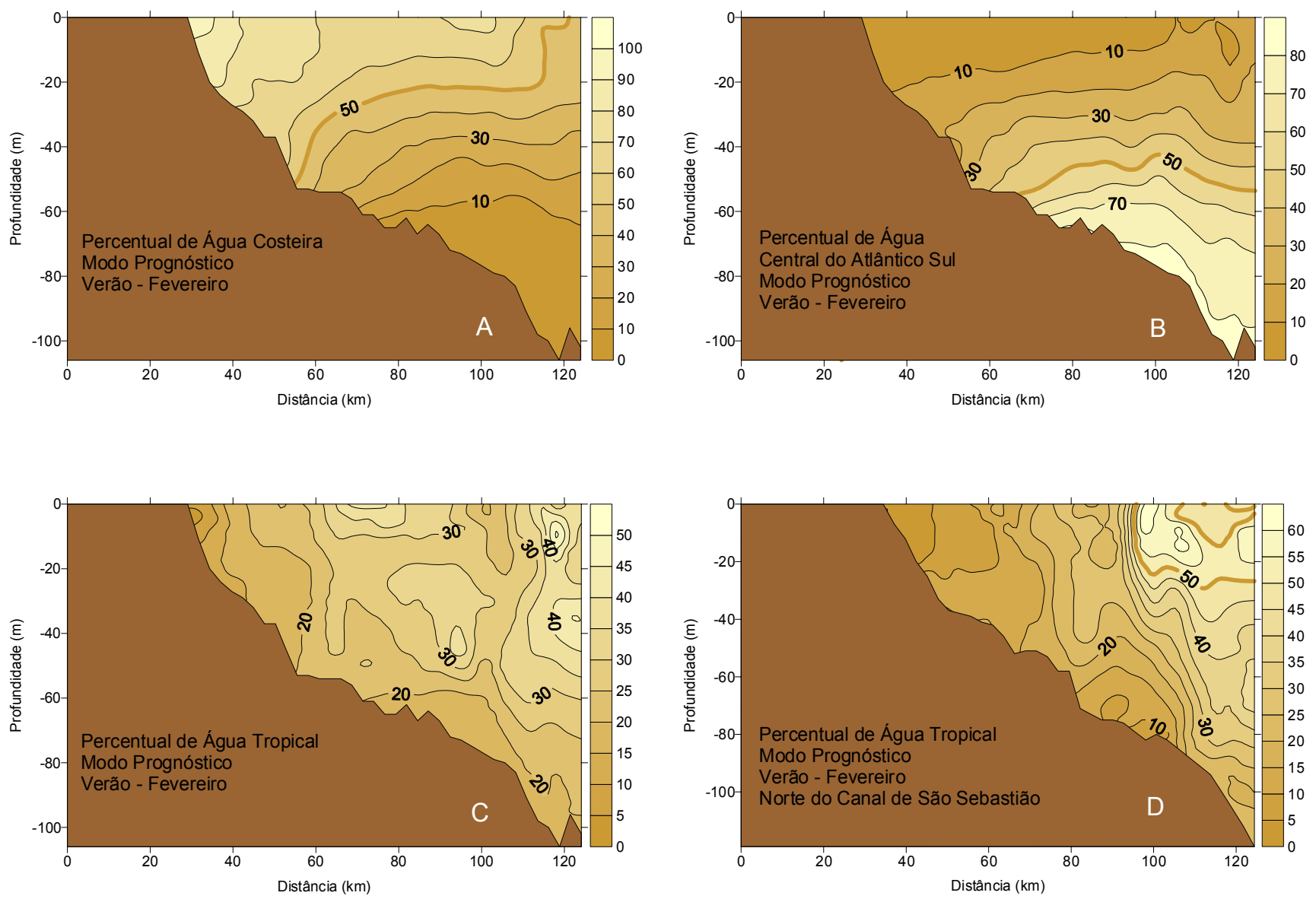

Figura 134: Distribuição vertical dos percentuais das massas de Água Costeira (A), Água Central do Atlântico Sul (B) e Água Tropical (C) na PCI ao sul do Canal de São Sebastião. Distribuição vertical do percentual da massa de Água Tropical (D) na PCI ao norte do Canal de São Sebastião. Simulação com vento de sudoeste após 10 dias de integração e climatologia de verão - fevereiro. 

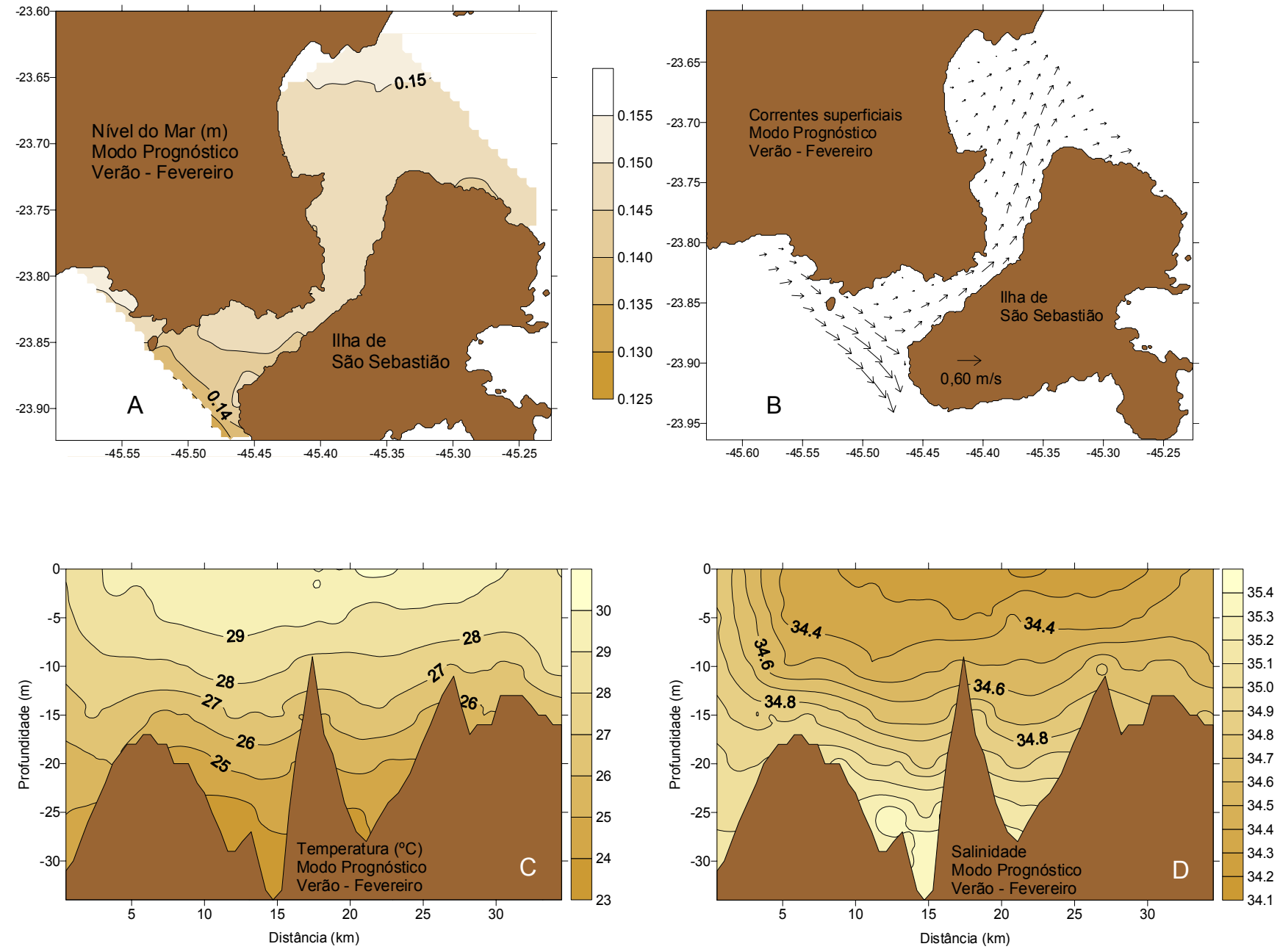

Figura 135: Nível do mar (A). Correntes superficiais (B). Distribuição vertical ao longo do Canal de São Sebastião, da temperatura (C) e da salinidade (D), após 10 dias de integração com vento de sudoeste e climatologia de verão - fevereiro. 

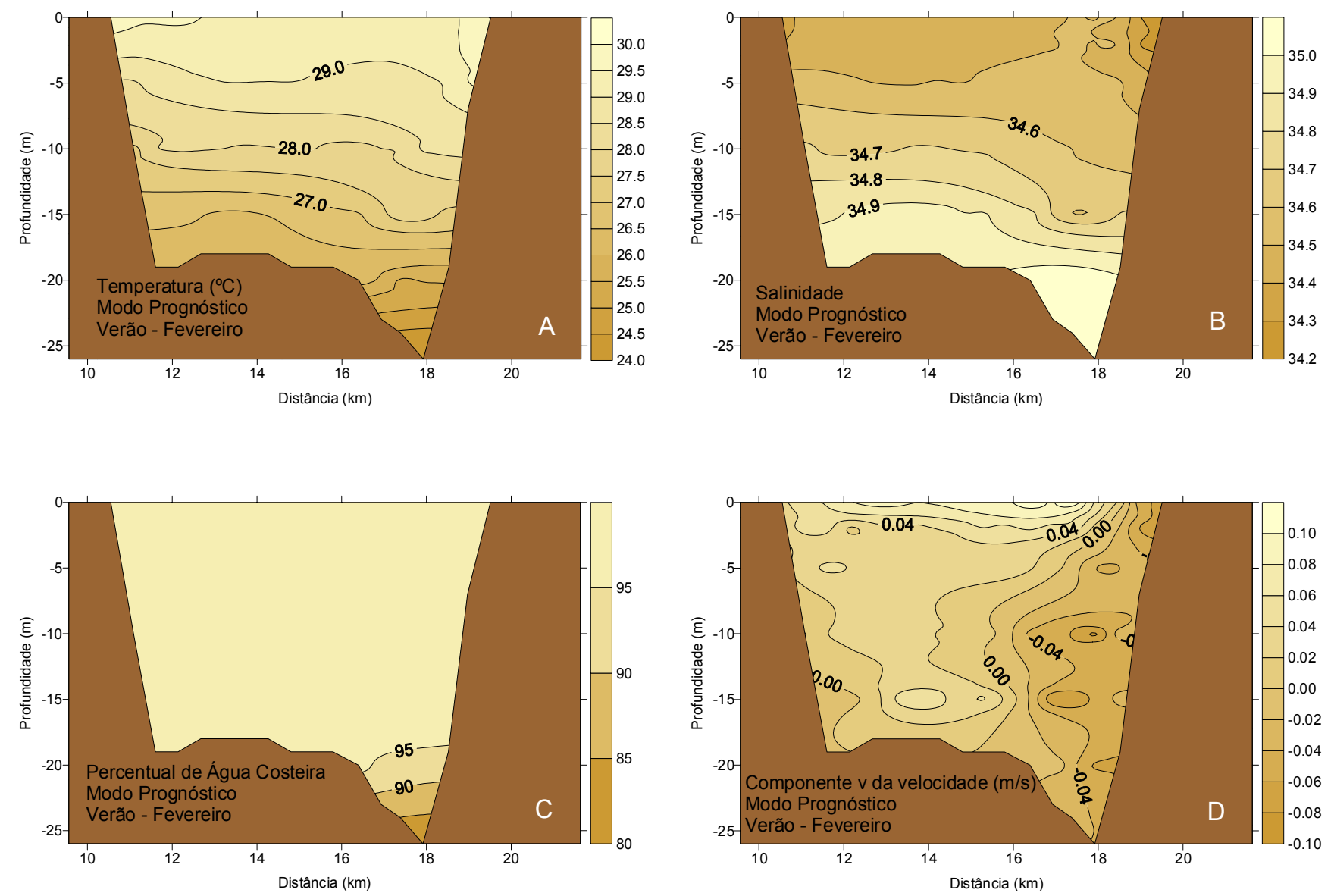

Figura 136: Distribuição vertical da temperatura (A), da salinidade (B), do percentual da massa de Água Costeira $(C)$ e da componente $v$ da velocidade normal à seção $A(D)$ no Canal de São Sebastião após 10 dias de integração com vento de sudoeste e climatologia de verão - fevereiro. 


\subsection{Experimento sem forçante vento}

O nível do mar (Fig.137A) na costa é -0,02 m com inclinação descendente para o largo $(-0,07 \mathrm{~m})$. As isolinhas apresentam-se paralelas às isóbatas e as correntes superficiais (figura não apresentada) fluem para nordeste ao longo das isolinhas do nível do mar, deixando níveis mais altos à esquerda. As isopicnais (Fig.137B) tem configuração assemelhada à das isolinhas do nível do mar com o mínimo na costa, a oeste da ISS, de $21,4 \mathrm{~kg} / \mathrm{m}^{3}$ e o máximo a leste da ISS de $23,0 \mathrm{~kg} / \mathrm{m}^{3}$. Nesta região há gradientes relativamente fortes de densidade, caracterizando uma frente. A Fig.137 C,D , que apresenta os percentuais das massas de AT e AC mostra que esta frente está associada à aproximação da AT da costa, atingindo níveis de 60\%; estes níveis, porém, são menores do que aqueles obtidos com vento de sudoeste.

Os perfis verticais dos percentuais de massas de água (Fig.138 A,B,C) em uma seção ao norte do CSS mostram a AC ocupando os primeiros vinte metros da coluna de água, até uns $40 \mathrm{~km}$ da costa; deste ponto para o largo, temos a AT, que ocupa desde a superfície até a profundidade de $40 \mathrm{~m}$. Abaixo da AC e da AT, encontra-se a ACAS, que se estende até o fundo . Verifica-se na Fig.138C que a frente de AT encontra-se a $25 \mathrm{~km}$ da costa e que seu núcleo está na profundidade de $20 \mathrm{~m}$ aproximadamente. A Fig.139 A,B,C apresenta os mesmos perfis verticais dos percentuais de massas de água, porém, em uma seção ao sul do CSS. Verifica-se nesta figura que em decorrência do núcleo de AT estar mais ao largo e em uma profundidade maior, a AC se estende até ao largo. A análise das Figs. 137C, 138C e 139C mostra que a AT se aproxima da costa pelo norte da ISS.

As correntes superficiais no CSS (figura não apresentada) fluem da costa para o largo junto à entrada sul, separando-se em dois ramos: uma segue contornando a ISS e a outra flui ao longo do canal com sentido nordeste intensificando-se após passar pelo estreito. Essas correntes tem intensidade máxima de 0,45 m/s. A Fig.140 A,B,C apresenta perfis verticais de temperatura, salinidade e densidade em uma seção longitudinal ao CSS. A temperatura no fundo, na entrada sul, é de $22^{\circ} \mathrm{C}$ ao passo que nesse local a salinidade é 35,4 . Na superfície temos temperaturas de $30^{\circ} \mathrm{C}$ e salinidades de 34,4 . As densidades variam entre $21,5 \mathrm{~kg} / \mathrm{m}^{3}$ na superfície e $24,5 \mathrm{~kg} / \mathrm{m}^{3}$, no fundo. Na Fig. 141 percebemos que os níveis de ACAS não ultrapassam 45\% e que o percentual de $50 \%$ de AC encontra-se na profundidade de $18 \mathrm{~m}$ aproximadamente. As 
temperaturas junto à seção $\mathrm{A}(\mathrm{Fig} .142 \mathrm{~A})$ variam de $21^{\circ} \mathrm{C}$ no fundo a $30^{\circ} \mathrm{C}$ na superfície; as salinidades variam de 34,4 (Fig. 142B) na superfície a 35,3 no fundo; as densidades variam de $21,0 \mathrm{~kg} / \mathrm{m}^{3}$ na superfície a $24,5 \mathrm{~kg} / \mathrm{m}^{3}$ no fundo (Fig.142C). Na Fig.143 encontramos os perfis verticais de percentuais de massas de água e verifica-se que o percentual de $50 \%$ de $\mathrm{AC}$ encontra-se na profundidade de $20 \mathrm{~m}$, no fundo, tomando praticamente toda a seção. 

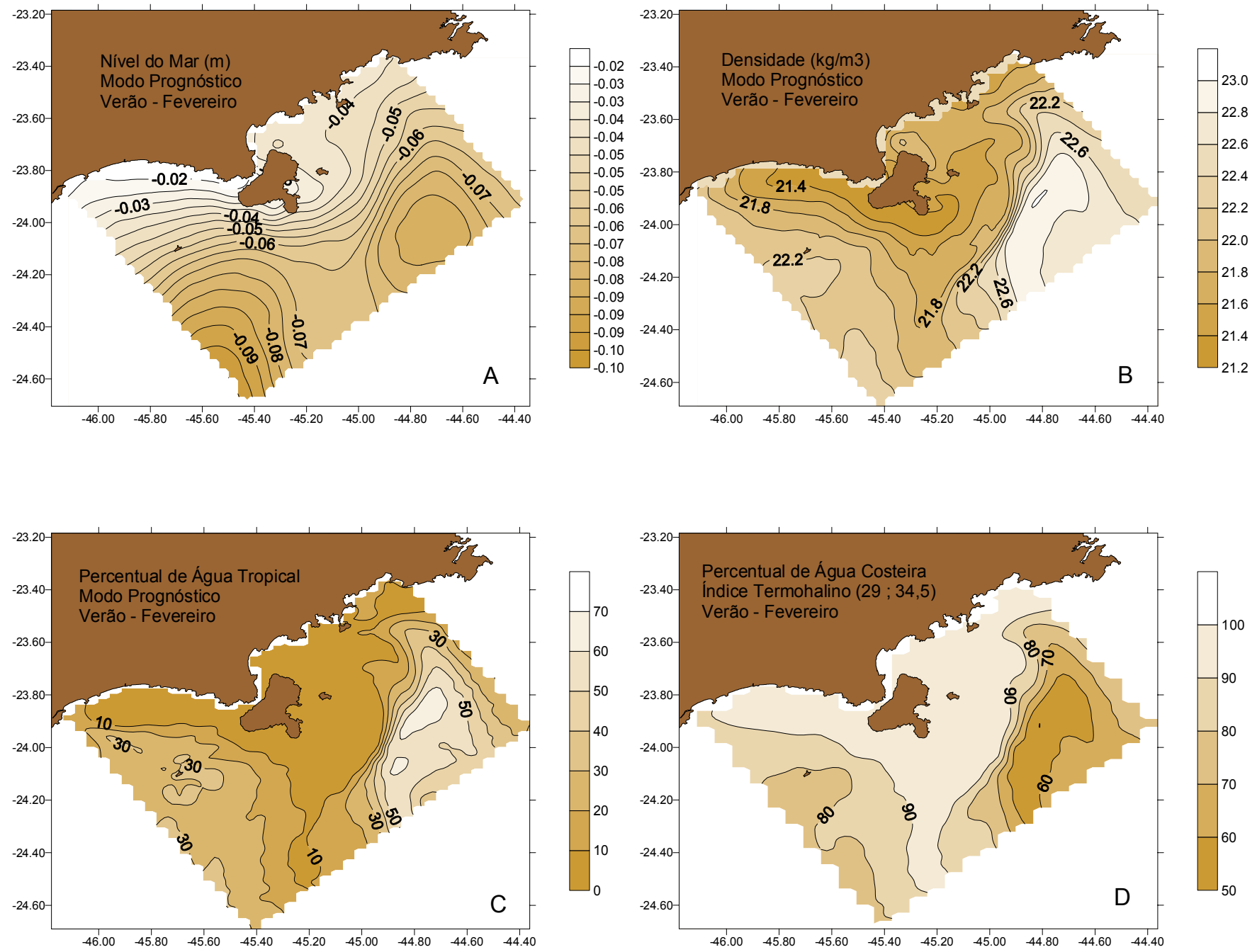

Figura 137: Nível do mar (A). Distribuição horizontal superficial da densidade convencional (B), dos percentuais das massas de Água Tropical (C) e da Água Costeira (D), na PCI, após 10 dias de integração sem forçante vento e com climatologia de verão - fevereiro. 

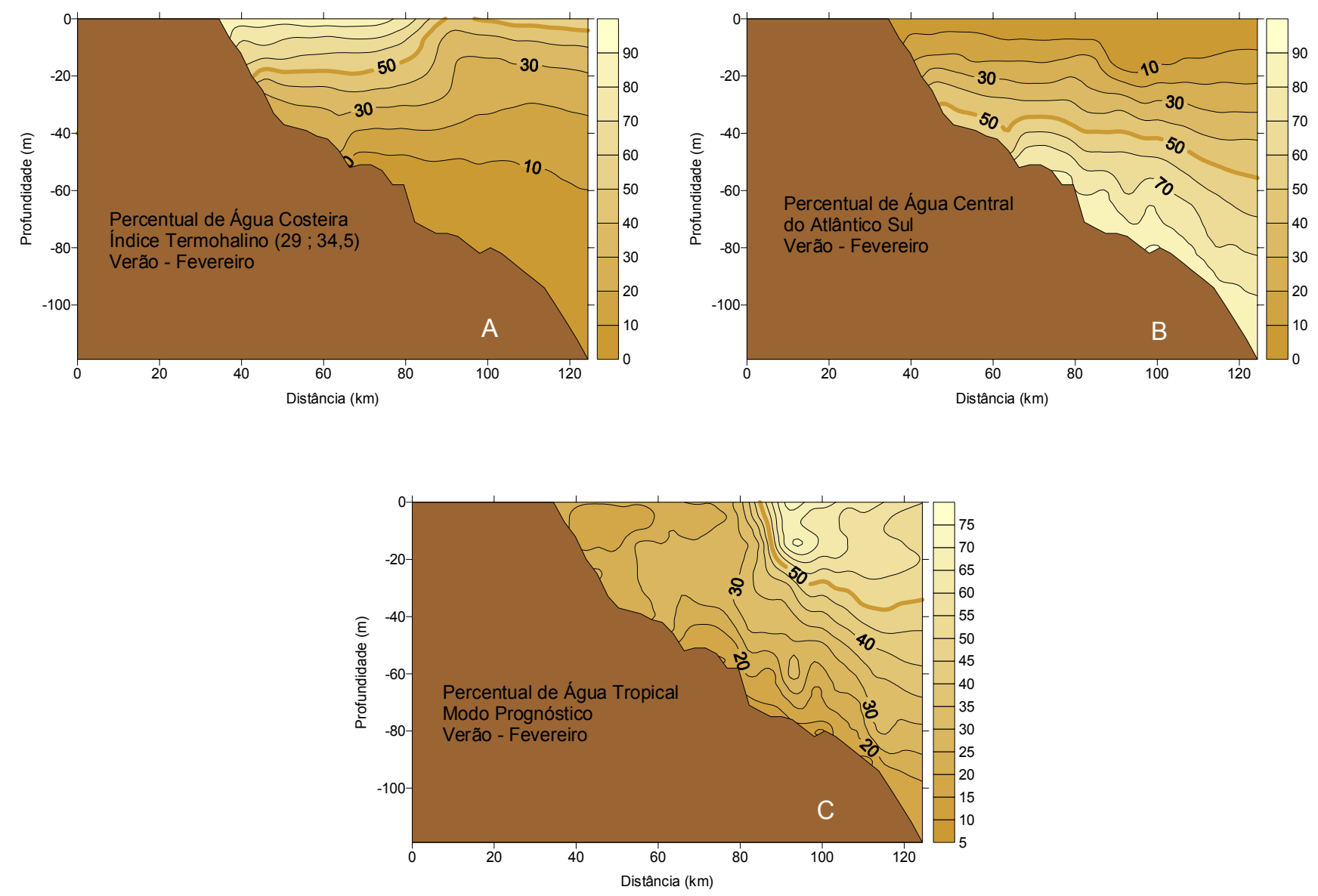

Figura 138: Distribuição vertical dos percentuais das massas de Água Costeira (A), da Água Central do Atlântico Sul (B) e da Água Tropical (C) na PCI ao norte do Canal de São Sebastião após 10 dias de integração sem forçante vento e com climatologia de verão fevereiro. 

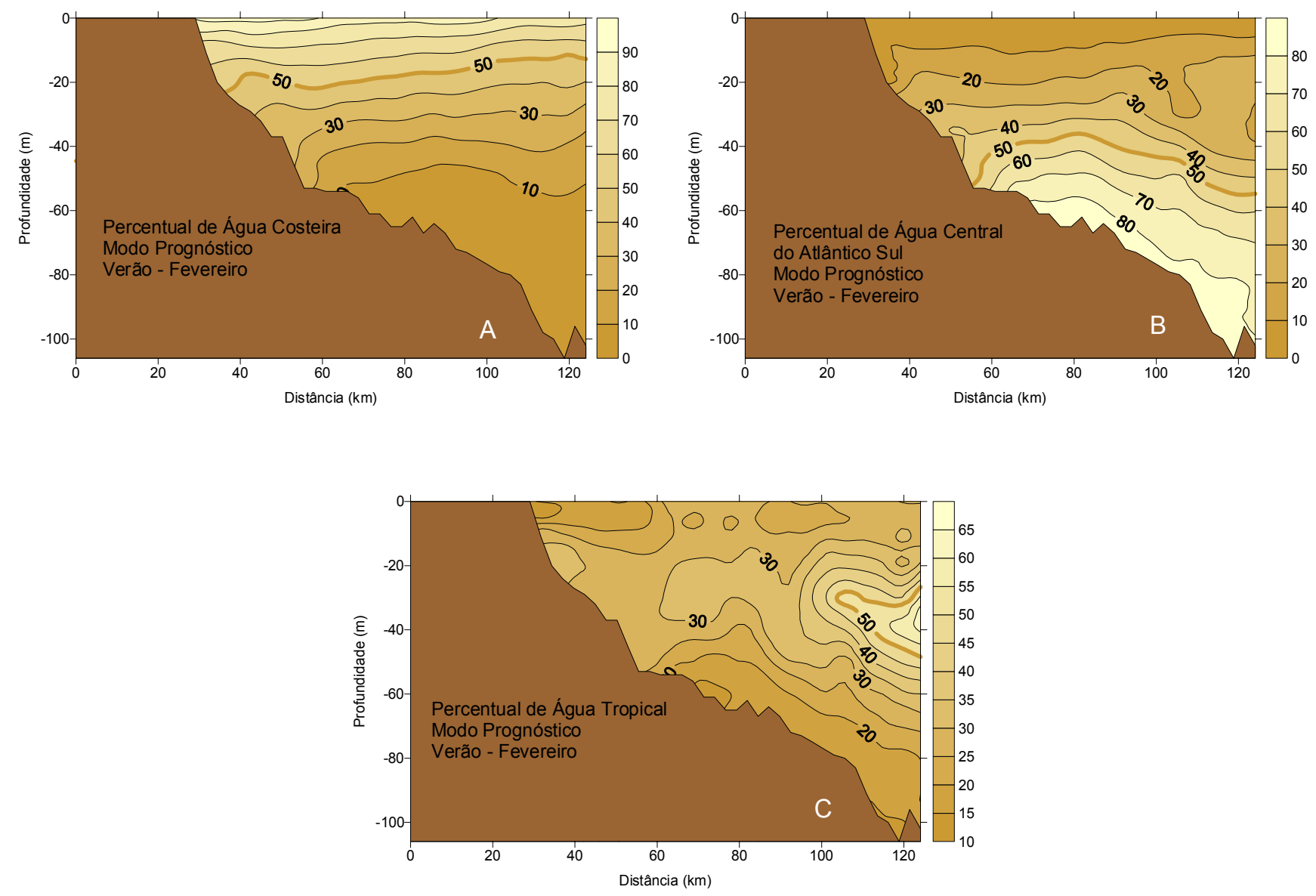

Figura 139: Distribuição vertical dos percentuais das massas de Água Costeira (A), da Água Central do Atlântico Sul (B) e da Água Tropical (C) na PCI ao sul do Canal de São Sebastião após 10 dias de integração sem forçante vento e com climatologia de verão - fevereiro. 

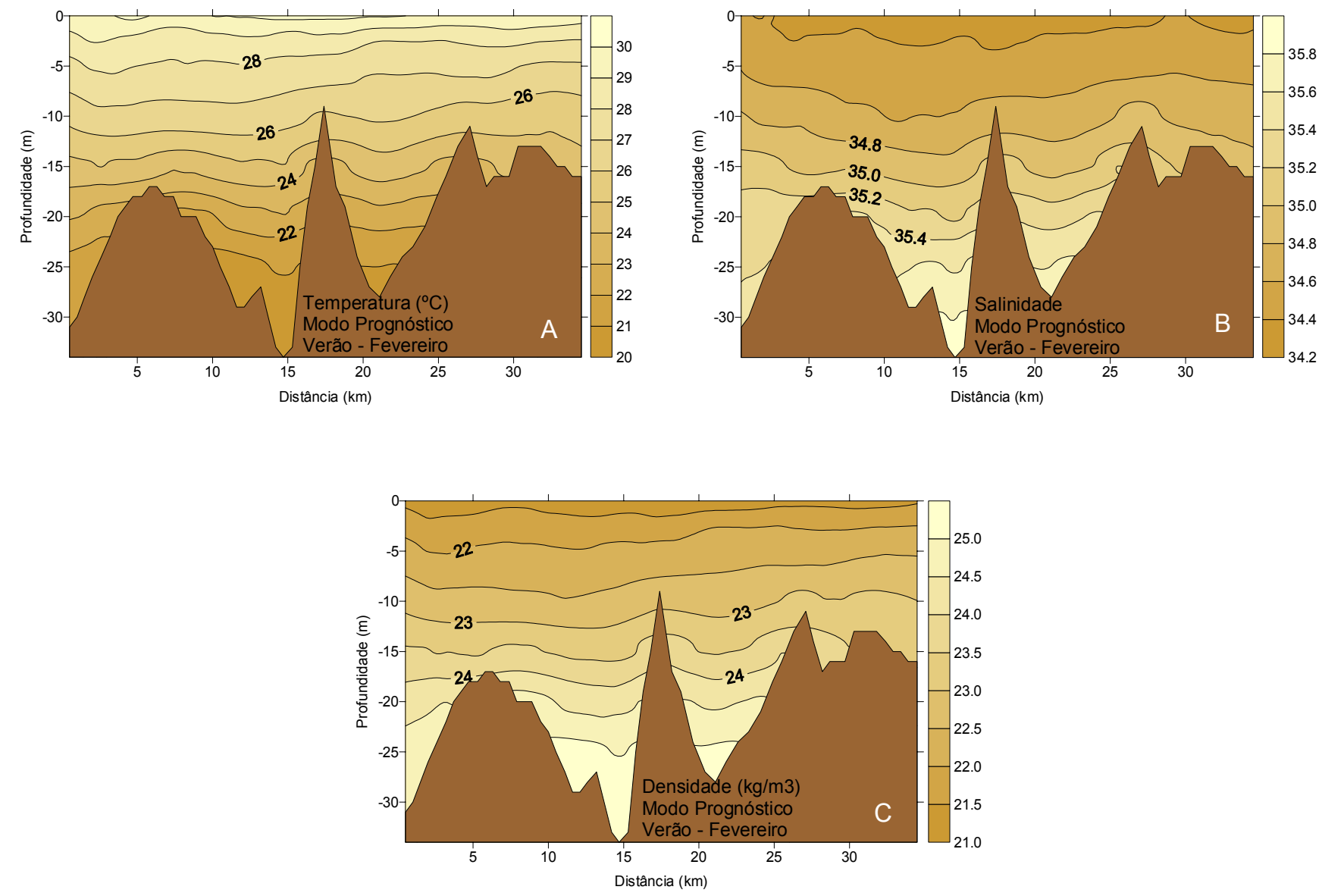

Figura 140: Distribuição vertical ao longo do Canal de São Sebastião, da temperatura (A), da salinidade (B) e da densidade convencional (C) após 10 dias de integração, sem forçante vento e com climatologia de verão - fevereiro. 

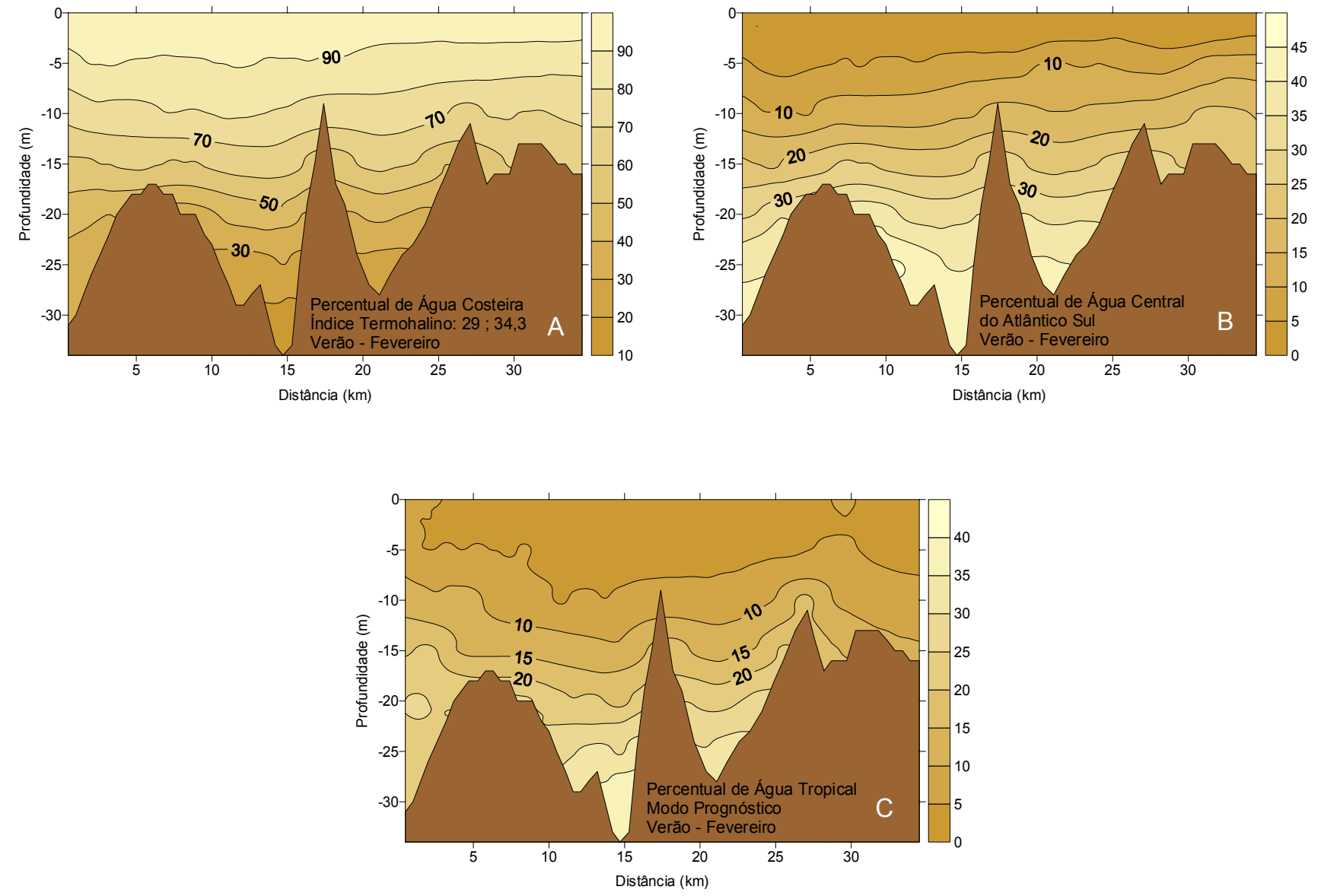

Figura 141: Distribuição vertical ao longo do Canal de São Sebastião, dos percentuais das massas de Água Costeira (A), Água Central do Atlântico Sul (B) e da Água Tropical (C), após 10 dias de integração sem forçante vento e com climatologia de verão - fevereiro. 

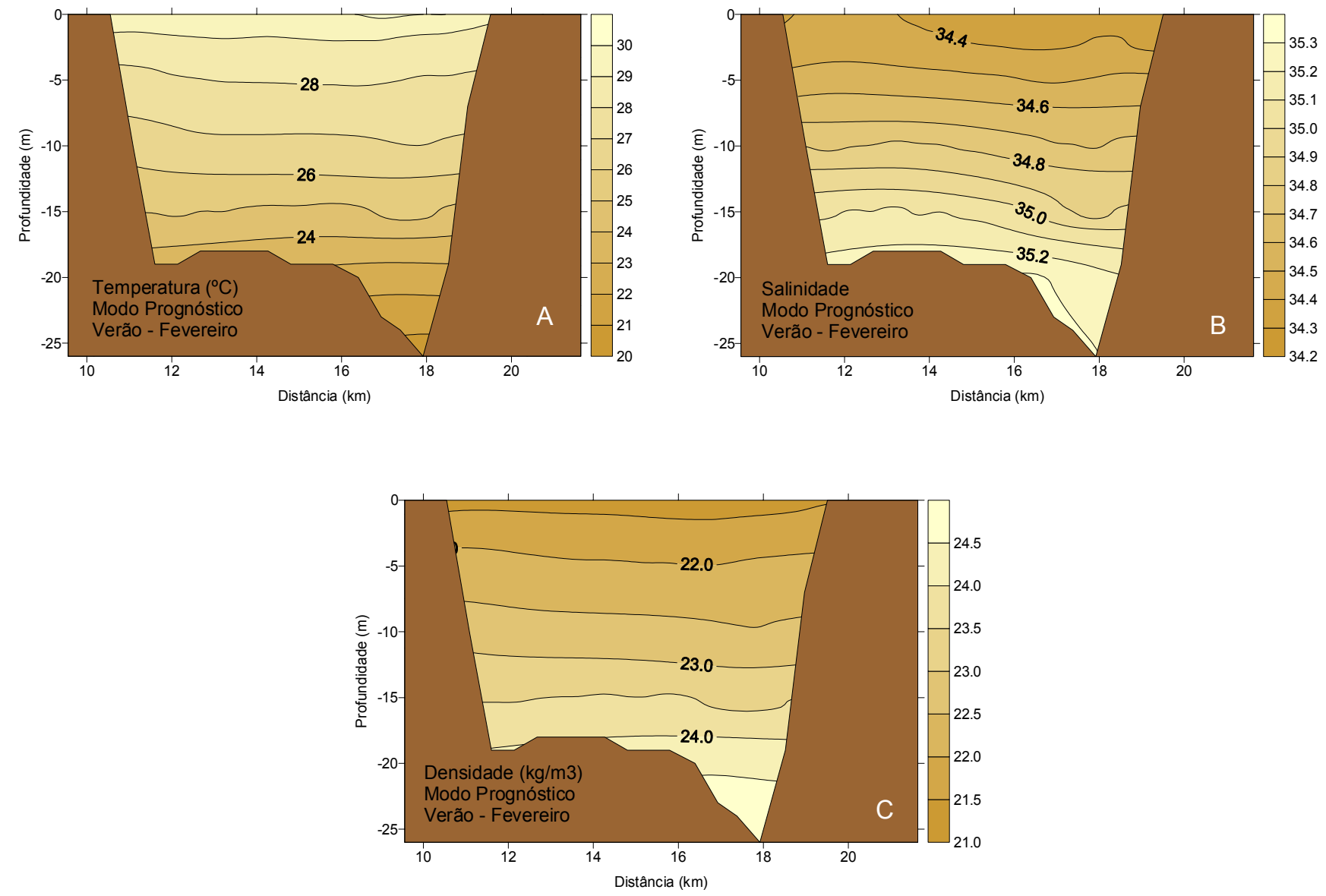

Figura 142: Distribuição vertical da temperatura (A), salinidade (B) e da densidade convencional (C) na seção A ao sul do Canal de Sebastião após 10 dias de integração sem a forçante vento e com climatologia de verão - fevereiro. 

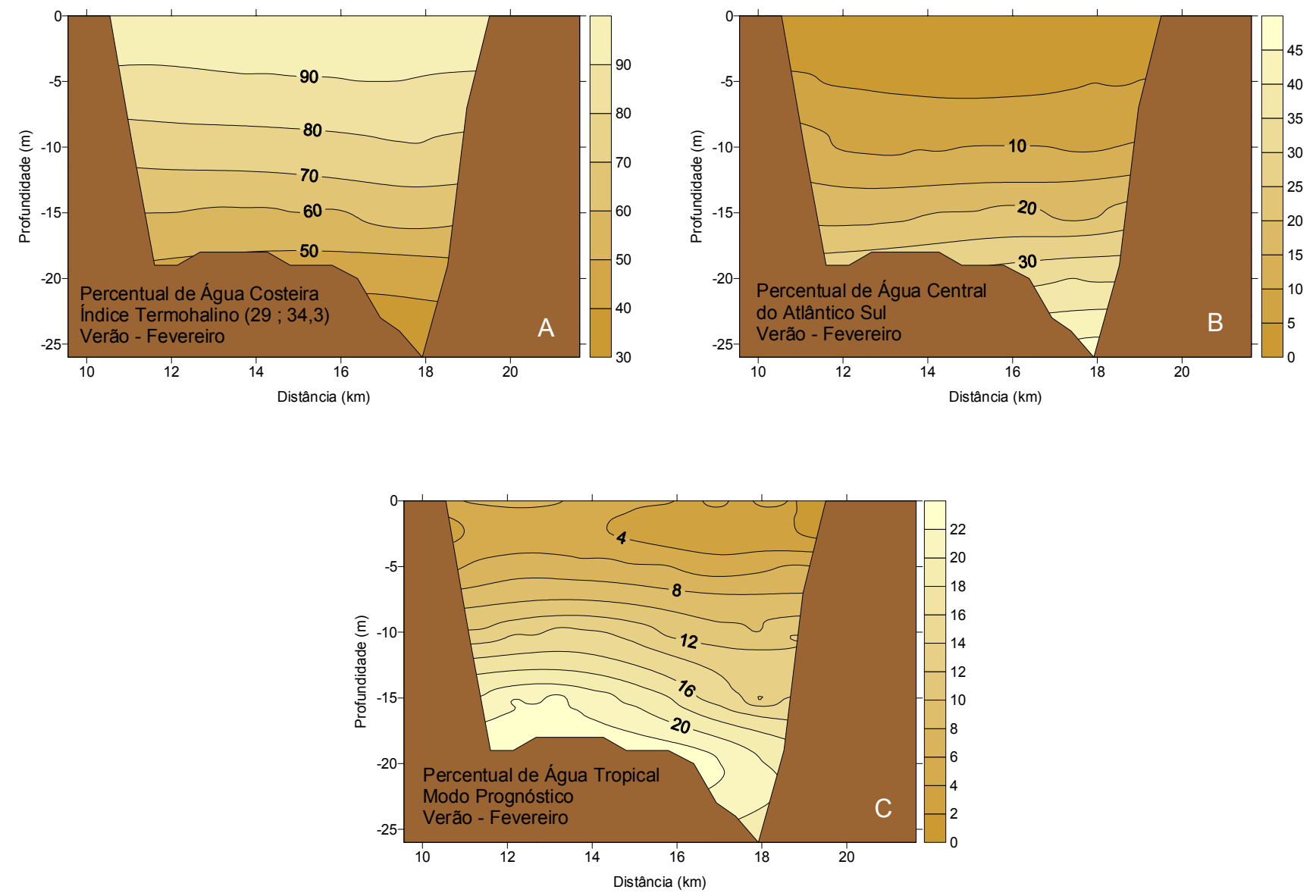

Figura 143: Distribuição vertical dos percentuais das massas de Água Costeira (A), Água Central do Atlântico Sul (B) e Água Tropical (C) na seção A, ao sul do Canal de São Sebastião, após 10 dias de integração, sem forçante vento e com climatologia de verão fevereiro. 


\subsection{Experimento com forçante vento nas regiões da PCSE e PCI e sem forçante vento no CSS}

A Fig. 144 A,B,C e D mostra perfis verticais de temperatura, junto à seção A, no sul do CSS, no $5^{\circ}, 10^{\circ}, 20^{\circ}$ e $30^{\circ}$ dias de integração, respectivamente. Observamos que durante a simulação, as temperaturas superficiais declinam de $28^{\circ} \mathrm{C}$ para $26^{\circ} \mathrm{C}$ aproximadamente. No fundo também observamos um declínio de temperatura, de $17^{\circ} \mathrm{C}$ para $12^{\circ} \mathrm{C}$. No início da integração, as isotermas que se situam acima da profundidade de $15 \mathrm{~m}$ se elevam, ao passo que as isotermas abaixo daquela profundidade se aprofundam; do $10^{\circ}$ dia em diante, porém, todas isotermas se elevam e temperaturas menores surgem no fundo do CSS. Fazem-se as mesmas observações ao analisarmos a Fig. 145 A,B,C e D, porém, em corte longitudinal ao CSS. Nestas figuras observa-se que as isotermas abaixo de $19^{\circ} \mathrm{C}$ aprofundam-se em direção à entrada norte do CSS. Ao compararmos estas figuras às suas correspondentes no experimento de verão com vento nas três grades (Figs. 75 e 79), percebemos que no experimento em que o vento é retirado apenas do CSS, as águas do canal se apresentam ligeiramente mais quentes, da superfície ao fundo, de sul ao norte.

A Fig. 146 A,B,C e D apresenta a distribuição vertical de salinidade junto à seção A, no sul do Canal de São Sebastião, no $5^{\circ}, 10^{\circ}, 20^{\circ}$ e $30^{\circ}$ dia, respectivamente. A salinidade superficial variou de 34,5 a 35,2 no período de integração, enquanto que a salinidade de fundo variou de 35,2 até 35,7. Observa-se com a salinidade fato análogo ao da temperatura no início da integração: as salinidades diminuem ligeiramente no fundo, aumentando após o $10^{\circ}$ dia de integração. De maneira geral, durante o período de integração, temos o aumento da salinidade em todo o canal. É o que também se observa na Fig. 147 A,B,C e D em um corte longitudinal ao CSS, para esta mesma propriedade. Nesta figura percebe-se que para uma mesma profundidade, as salinidades aumentam do centro do canal para os extremos, sendo que os maiores gradientes localizam-se no sul. Comparando-se as Figs. 146 e 147 com as suas correspondentes no experimento com vento no CSS (Figs. 75 e 79), percebe-se que no experimento com vento no CSS, as águas estão ligeiramente mais salinas.

A Fig. 148 A,B,C e D apresenta a distribuição vertical da componente de velocidade normal à seção $\mathrm{A}$, no sul do CSS, no $5^{\circ}, 10^{\circ}, 20^{\circ}$ e $30^{\circ}$ dia, respectivamente. A circulação superficial durante todo o período de integração é para sul, havendo uma 
intensificação do $5^{\circ}$ para o $10^{\circ}$ dia e uma relaxação em seguida. No fundo, do lado da ISS, as correntes fluem para norte no $5^{\circ}$ dia, invertendo deste dia até o $10^{\circ}$ dia, coincidindo com o período em que houve um aumento de temperatura e uma diminuição de salinidade neste local. A partir do $10^{\circ}$ dia as correntes voltam a fluir para norte no fundo do CSS. Analisando-se a distribuição vertical desta propriedade em seção longitudinal ao CSS (Fig. 149 A,B,C,D), percebe-se a ocorrência, ao longo de todo o período de integração, de uma divergência na superfície e no centro do canal, com correntes fluindo para o sul, na metade sul do domínio e correntes fluindo para o norte, na metade norte do domínio. Nesta figura também percebe-se que no $5^{\circ}$ dia de integração, as correntes no fundo, no sul do CSS, fluem para sul, invertendo o sentido no $10^{\circ}$ dia. No $20^{\circ}$ e $30^{\circ}$ dias, as correntes para sul (neste corte), são fracas. Comparando-se as Figs. 148 e 149 com a Fig. 77, percebe-se que o vento no CSS intensificou as correntes superficiais (de $-0,20 \mathrm{~m} / \mathrm{s}$ para $-0,55 \mathrm{~m} / \mathrm{s}$ ). No fundo, ao sul, com a ausência do vento, as correntes que fluíam para norte, confinam-se para o leste, ao largo da ISS. 

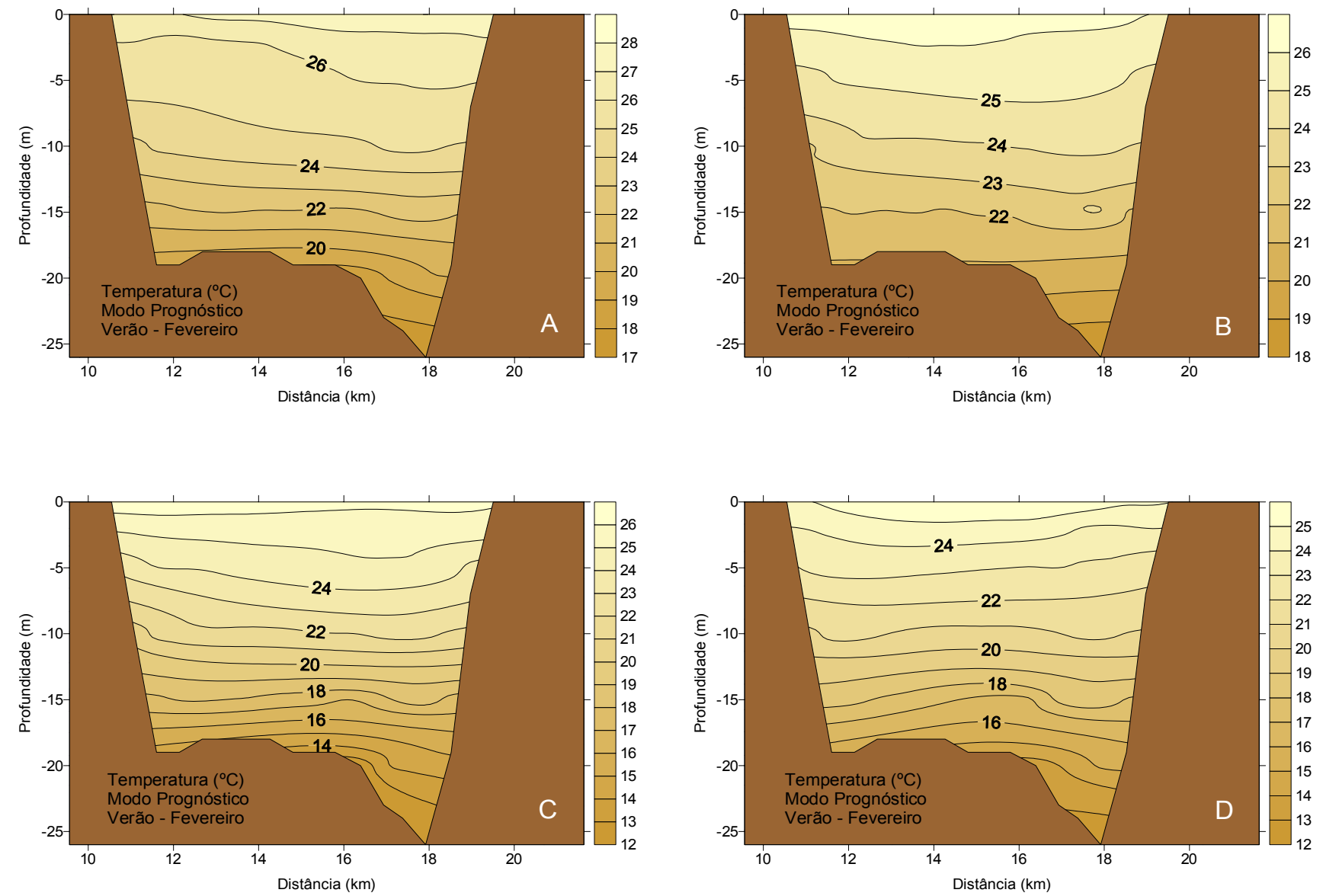

Figura 144: Distribuição vertical de temperatura junto à seção $A$, no sul do Canal de São Sebastião, no $5^{\circ}$ dia (A), $10^{\circ}$ dia (B), $20^{\circ}$ dia (C) e $30^{\circ}$ dia (D) de simulação, com forçante vento na PCSE e PCI e sem forçante vento na grade do CSS. 

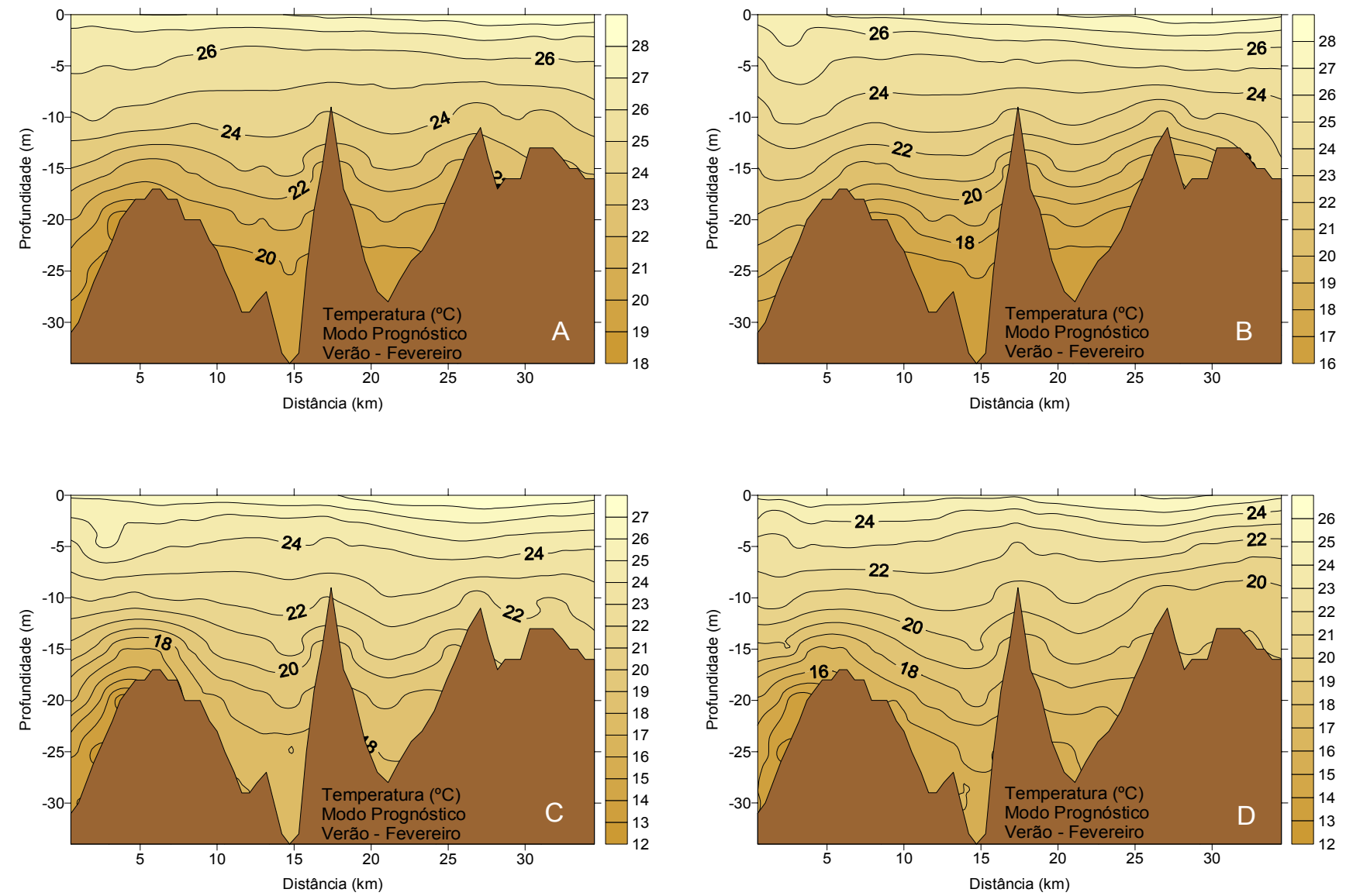

Figura 145: Distribuição vertical da temperatura, ao longo do Canal de São Sebastião, no $5^{\circ}$ dia (A), $10^{\circ}$ dia (B), $20^{\circ}$ dia (C) e $30^{\circ}$ dia (D) de simulação, com forçante vento na PCSE e PCI e sem forçante vento na grade do CSS. 

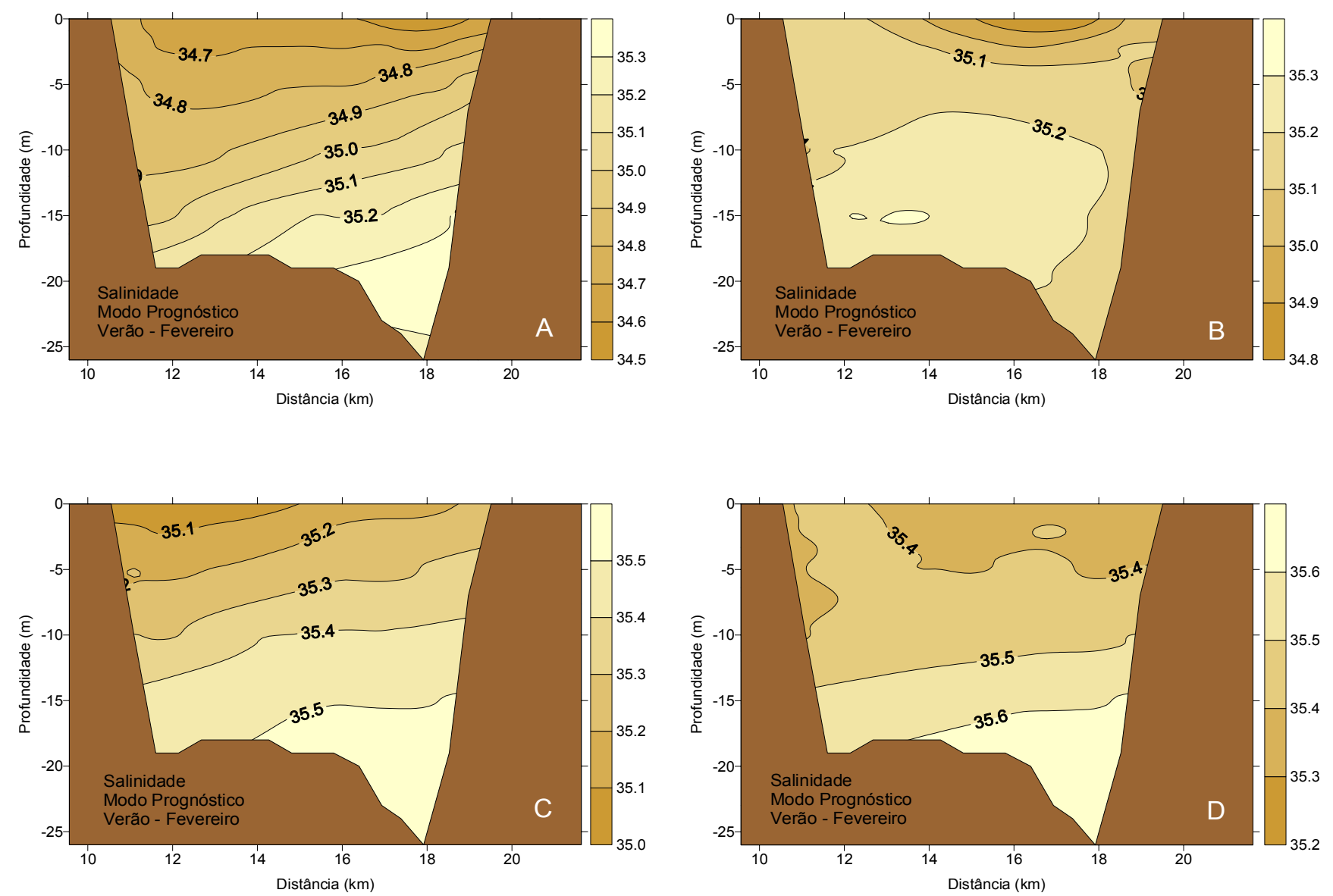

Figura 146: Distribuição vertical de salinidade junto à seção $A$, no sul do Canal de São Sebastião, no $5^{\circ}$ dia (A), $10^{\circ}$ dia (B), $20^{\circ}$ dia (C) e $30^{\circ}$ dia (D) de simulação, com forçante vento na PCSE e PCI e sem forçante vento na grade do CSS. 

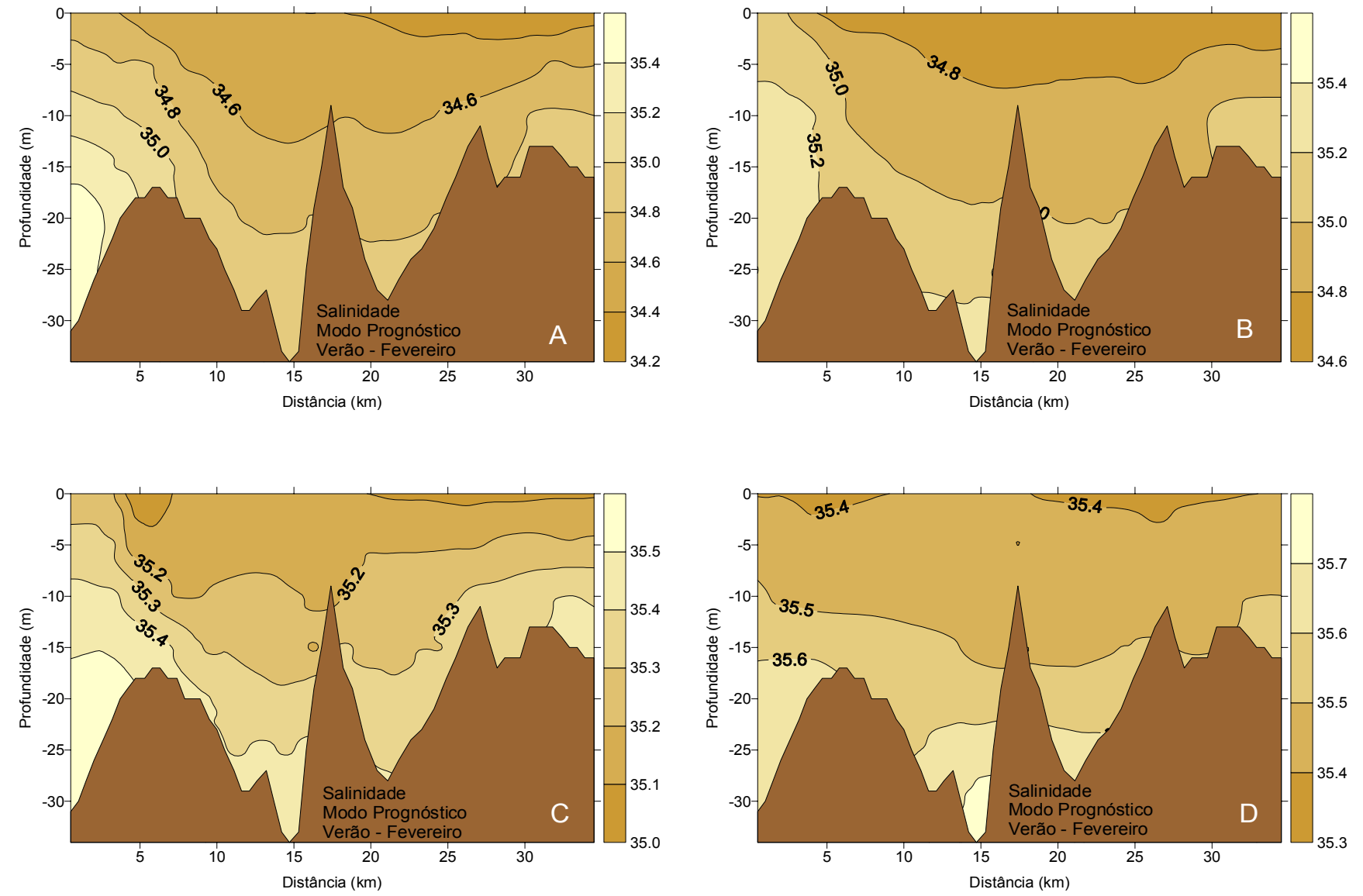

Figura 147: Distribuição vertical da salinidade, ao longo do Canal de São Sebastião, no $5^{\circ}$ dia (A), $10^{\circ}$ dia (B), $20^{\circ}$ dia (C) e $30^{\circ}$ dia (D) de simulação, com forçante vento na PCSE e PCI e sem forçante vento na grade do CSS. 

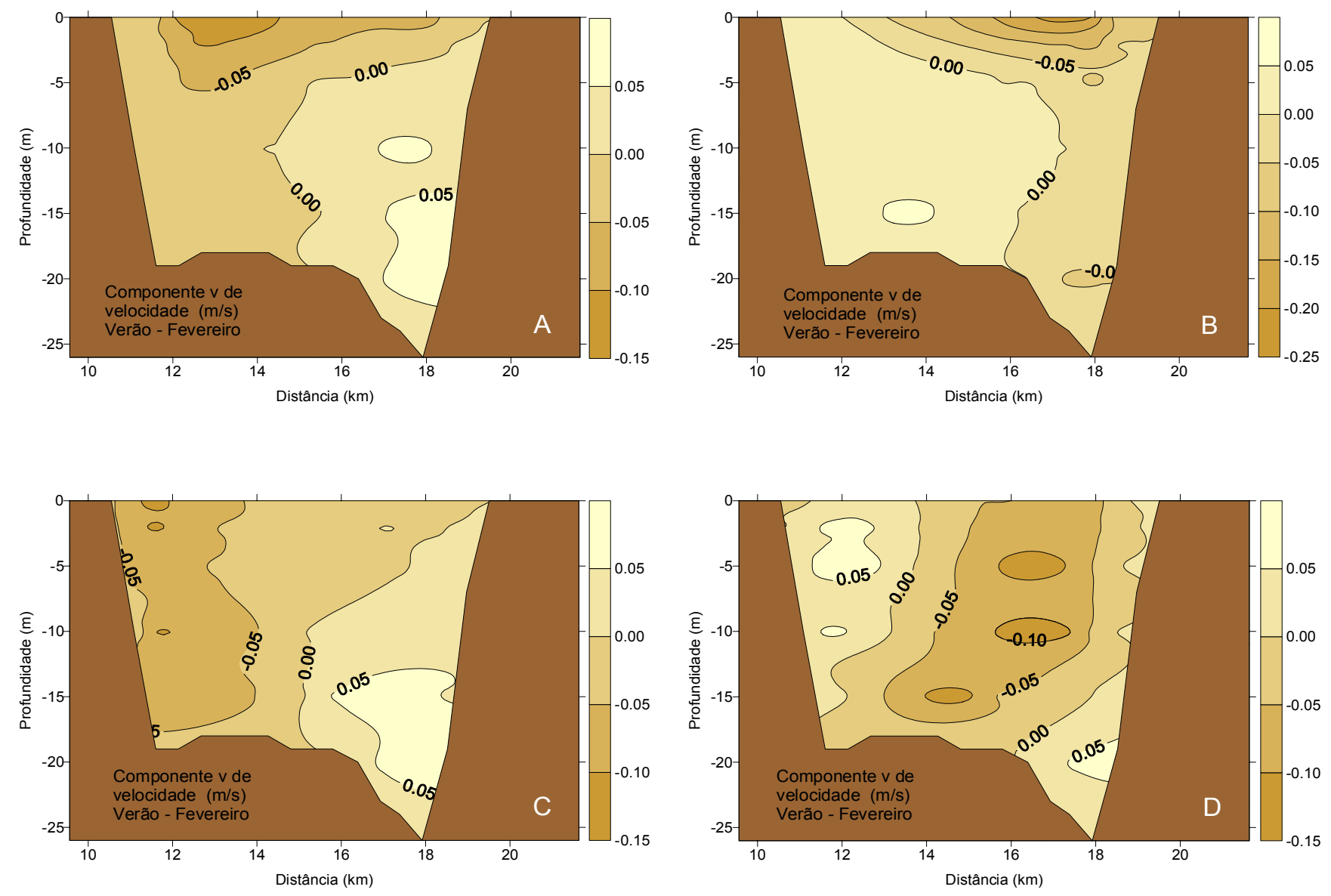

Figura 148: Distribuição vertical da componente de velocidade normal à seção $\mathrm{A}$, no sul do Canal de São Sebastião, no $5^{\circ}$ dia (A), $10^{\circ}$ dia (B), $20^{\circ}$ dia (C) e $30^{\circ}$ dia (D) de simulação, com forçante vento na PCSE e PCI e sem forçante vento na grade do CSS. 

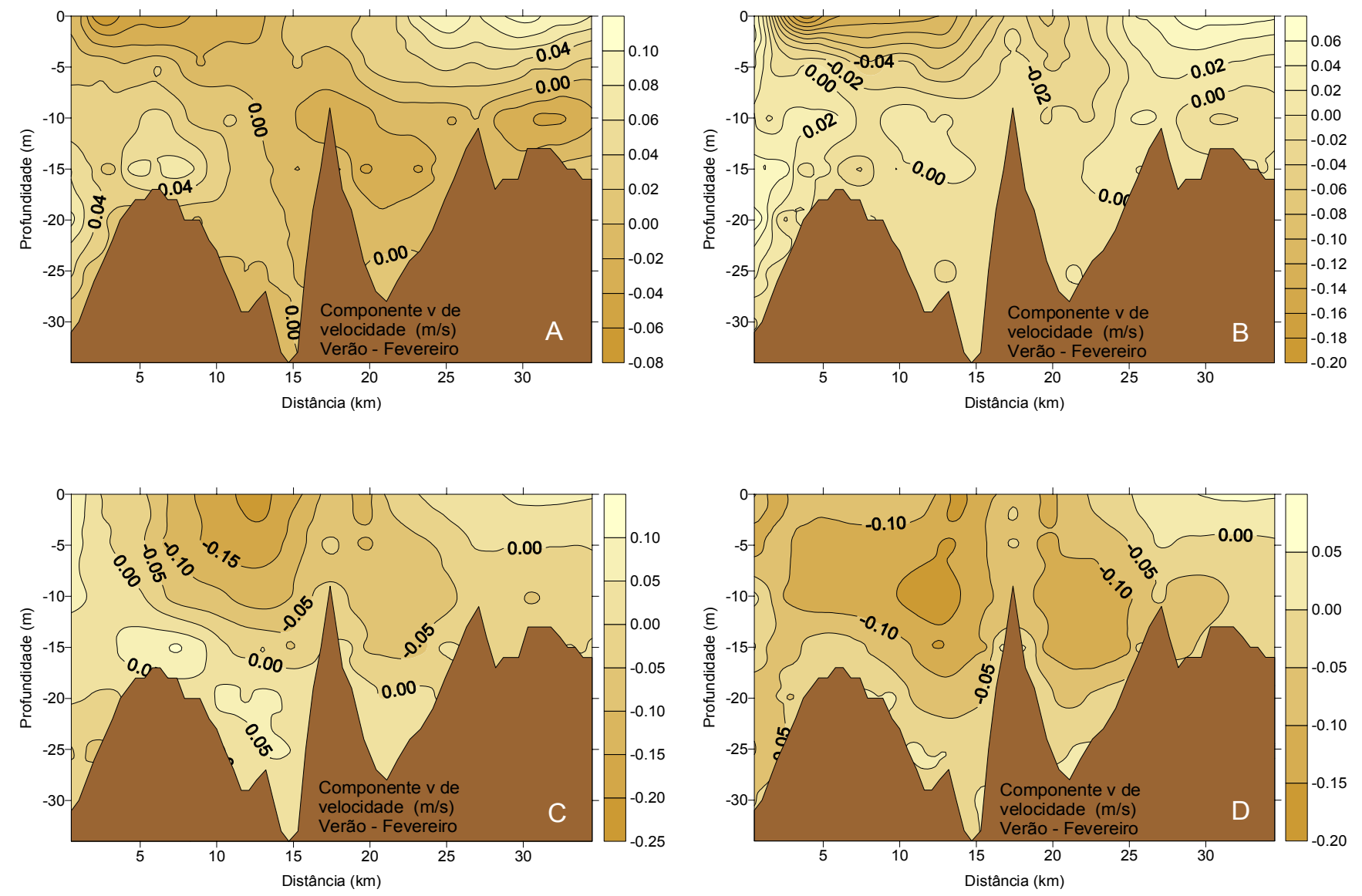

Figura 149: Distribuição vertical da componente de velocidade ao longo do Canal de São Sebastião, no $5^{\circ}$ dia (A), $10^{\circ}$ dia (B), $20^{\circ}$ dia (C) e $30^{\circ}$ dia (D) de simulação, com forçante vento na PCSE e PCI e sem forçante vento na grade do CSS. 


\subsection{Simulação da estrutura térmica do CSS à passagem de uma frente fria}

Um conjunto de dados de velocidade do vento para o período de 21/02/1992 a 05/03/1992 de Fleet Numerical Meteorology and Oceanography Center (FNMOC) foi utilizado para simular uma frente fria na Plataforma Continental Sudeste, com particular interesse no Canal de São Sebastião. Nas Figs. 150, 151, 152 e 153 tem-se a evolução da componente meridional da velocidade do vento no período. Os dados da FNMOC têm resolução de $2,5^{\circ} \times 2,5^{\circ}$ e período de 6 horas. Nossa latitude de referência é $24^{\circ}$ e a longitude $45^{\circ}$ (proximidades do CSS). Podemos observar que o CSS está sob regime de ventos de sudoeste no dia 21/02/92 e que uma frente fria se aproxima do sul. O local é atingido pela frente fria no dia 25/02/92 e pelo que sugerem as figuras ela dirige-se deste local para o leste. Uma nova frente chega dia 28/02/92 e passa totalmente pelo CSS no dia 04/03/92. O modelo é integrado durante vinte dias com vento climatológico de fevereiro e climatologia de verão, isto é, do dia 01/02/92 ao dia 20/02/92. A partir deste dia, o vento é trocado diariamente, tendo sido efetuada uma interpolação linear a cada passo de tempo.

As figuras de 154 a 157 mostram a distribuição vertical da temperatura junto à seção A do Canal de São Sebastião do dia 20/02/92 ao dia 05/03/92. No dia 20/02 as temperaturas superficiais variam entre $23^{\circ} \mathrm{C}$ no oeste, e $27^{\circ} \mathrm{C}$ no leste. Em destaque no centro do canal está a isoterma de $16^{\circ} \mathrm{C}$ e no fundo, temos temperaturas maiores do que $11^{\circ} \mathrm{C}$. O quadro apresentado no dia $21 / 02$ não é muito diferente do dia anterior, a não ser por um leve aquecimento das águas superficiais e ligeiro esfriamento das águas de fundo. No dia 22/02 há um aquecimento geral na seção e a isoterma de $16^{\circ} \mathrm{C}$ se aprofunda aproximadamente $5 \mathrm{~m}$. A isoterma de $12^{\circ} \mathrm{C}$ desaparece no fundo e a de $26^{\circ} \mathrm{C}$ na superfície, antes só no lado leste, ocupa agora o lado oeste. No dia 23/02 as águas na seção continuam aquecendo; a isoterma de $16^{\circ} \mathrm{C}$ no fundo se aprofunda mais $5 \mathrm{~m}$ desaparecendo agora a de $13^{\circ} \mathrm{C}$. Dia $24 / 02$, há um leve aquecimento em todas as profundidades e no dia 25/02, o estado térmico se mantém. Em decorrência do afastamento da frente fria para leste, temos uma diminuição das temperaturas na seção nos dias 26 e $27 / 02$, sendo que a isoterma de $16^{\circ} \mathrm{C}$ se eleva e a de $13^{\circ} \mathrm{C}$ ressurge no fundo. Conforme pode-se observar na Fig. 151, no dia 27/02, enquanto uma frente fria se afasta para o oceano, outra surge no sul da PCSE e alcança o CSS no dia 28/02. As 
isotermas na seção, neste dia, sofrem uma rotação anti-horária com aumento das temperaturas principalmente no lado oeste e no fundo da seção, sendo que neste local, a temperatura se elevou de $13^{\circ} \mathrm{C}$ para $17^{\circ} \mathrm{C}$. As isotermas sofrem rotação horária, alinhando-se com a horizontal no dia seguinte (29/02) e a temperatura no fundo aumentou $1^{\circ} \mathrm{C}$ aproximadamente. Este estado permanece praticamente inalterado no dia $01 / 03$. No dia $02 / 03$ há aumento de temperatura no fundo e a isoterma de $19^{\circ} \mathrm{C}$ desaparece; é bem nítida neste dia a isoterma de $27^{\circ} \mathrm{C}$ na superfície. Embora não surjam novas isotermas no fundo no dia $03 / 03$, todas se elevam, desaparecendo na superfície a de $27^{\circ} \mathrm{C}$. No dia $04 / 03$ há uma diminuição das temperaturas no fundo com o ressurgimento da isoterma de $16^{\circ} \mathrm{C}$ e no dia $05 / 03$ a distribuição vertical de temperatura da seção é praticamente a mesma que a do dia 20/02.

As mesmas observações são feitas, no sul do CSS, ao analisarmos as figuras numeradas de 158 a 161 em seções verticais longitudinais. No norte do CSS durante a passagem da frente fria, ocorre um aumento da temperatura no fundo, porém essa diferença tem amplitude bem menor do que aquela encontrada no sul do canal.

Foram desenvolvidas séries temporais das componentes de velocidade das correntes, de temperatura e de nível do mar em três pontos no CSS, na superfície e no fundo. Estes três pontos estão localizados no sul, no centro e no norte do canal.

As Figs. 162, 163 e 164 mostram séries temporais das componentes de velocidade v e u, no sul, no centro e no norte do CSS, respectivamente. Observa-se que o regime de correntes na superfície é para sul, com exceção do período em que o canal está sob a influência da frente fria, quando as correntes superficiais fluem para norte. As Figs. 162 A, 163 A e 164 A apresentam, cada uma delas, dois máximos da componente $\mathrm{v}$, o da esquerda relativo à passagem da primeira frente fria, de intensidade menor, e o da direita, relativo à passagem da segunda frente fria, de maior intensidade do que a primeira. De maneira geral, a componente u inverte seu sinal durante a passagem da frente. No fundo, observa-se que a circulação é preponderantemente para norte e durante a passagem da frente fria, ela inverte-se para sul. Interessante observar que no fundo da entrada sul do canal, na ausência de frentes frias, a componente $\mathrm{v}$ aponta para norte enquanto que a componente $u$ aponta para oeste, indicando a penetração de água no canal por esse setor. Quando se instala a frente fria, a componente $\mathrm{v}$ no fundo tem orientação para sul ao passo que a componente u também inverte, apontando para leste. 
As Figs. 165, 166 e 167 apresentam séries temporais de temperatura e nível do mar no sul, no centro e no norte do canal, respectivamente e nos mesmos três pontos citados acima, sendo que na Fig. $165 \mathrm{C}$, tem-se a série temporal da componente $\mathrm{v}$ da tensão de cisalhamento do vento para um ponto no sul do CSS. Observa-se nestas figuras que o nível do mar no CSS responde instantaneamente à tensão de cisalhamento do vento, apresentando dois máximos. Estes máximos estão associados às passagens das duas frentes frias, sendo que o nível do mar se eleva em todo o canal, cerca de $0,15 \mathrm{~m}$ a partir da saída da primeira até a chegada da segunda frente. É bem clara a resposta da temperatura de fundo nos três pontos amostrados no CSS, elevando-se quando as frentes se aproximam. 

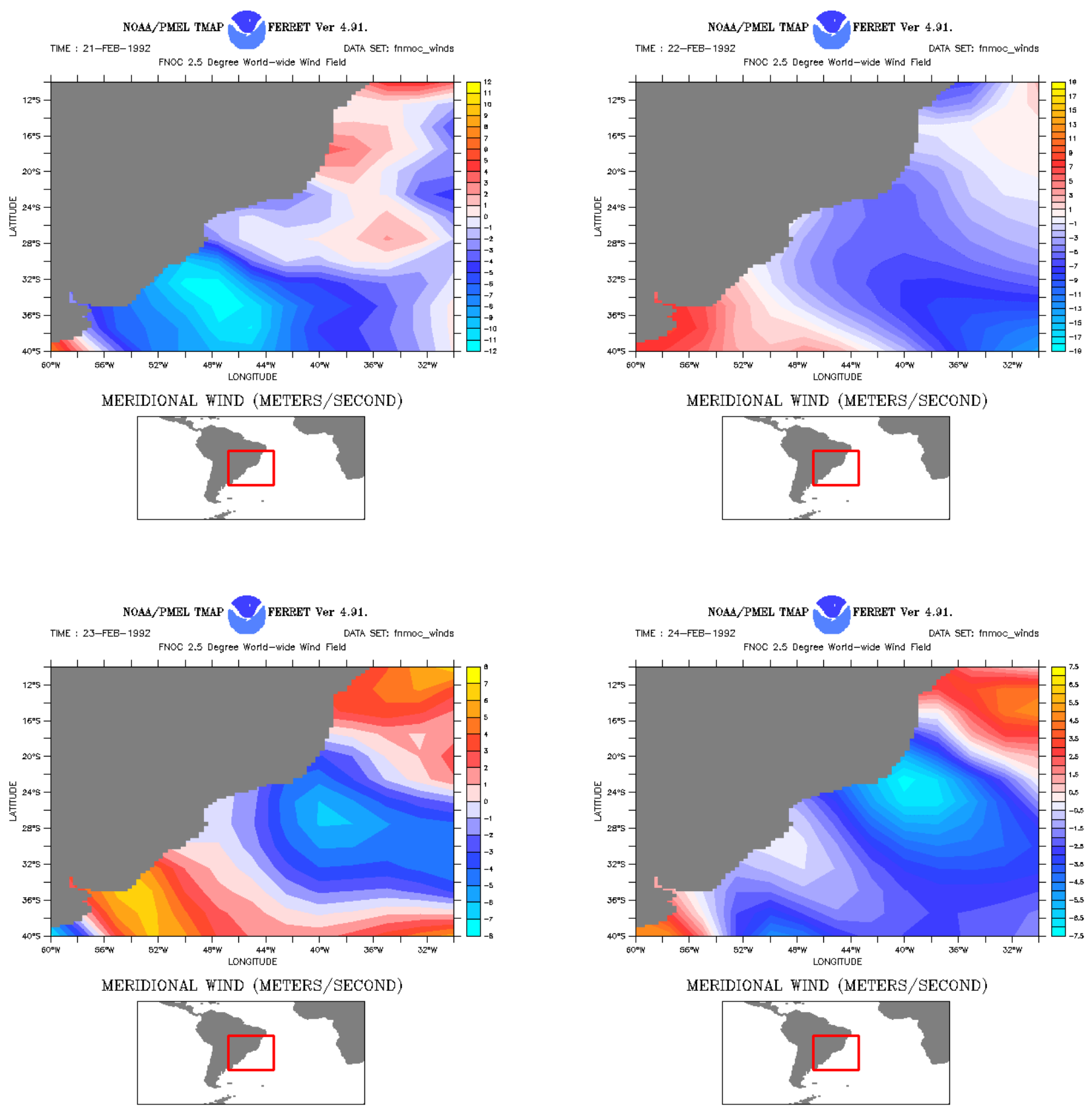

Figura 150: Componente meridional do vento nos dias 21, 22, 23 e 24/02/1992, durante a passagem de uma frente fria na Plataforma Continental Sudeste. Dados extraídos de FNMOC. 

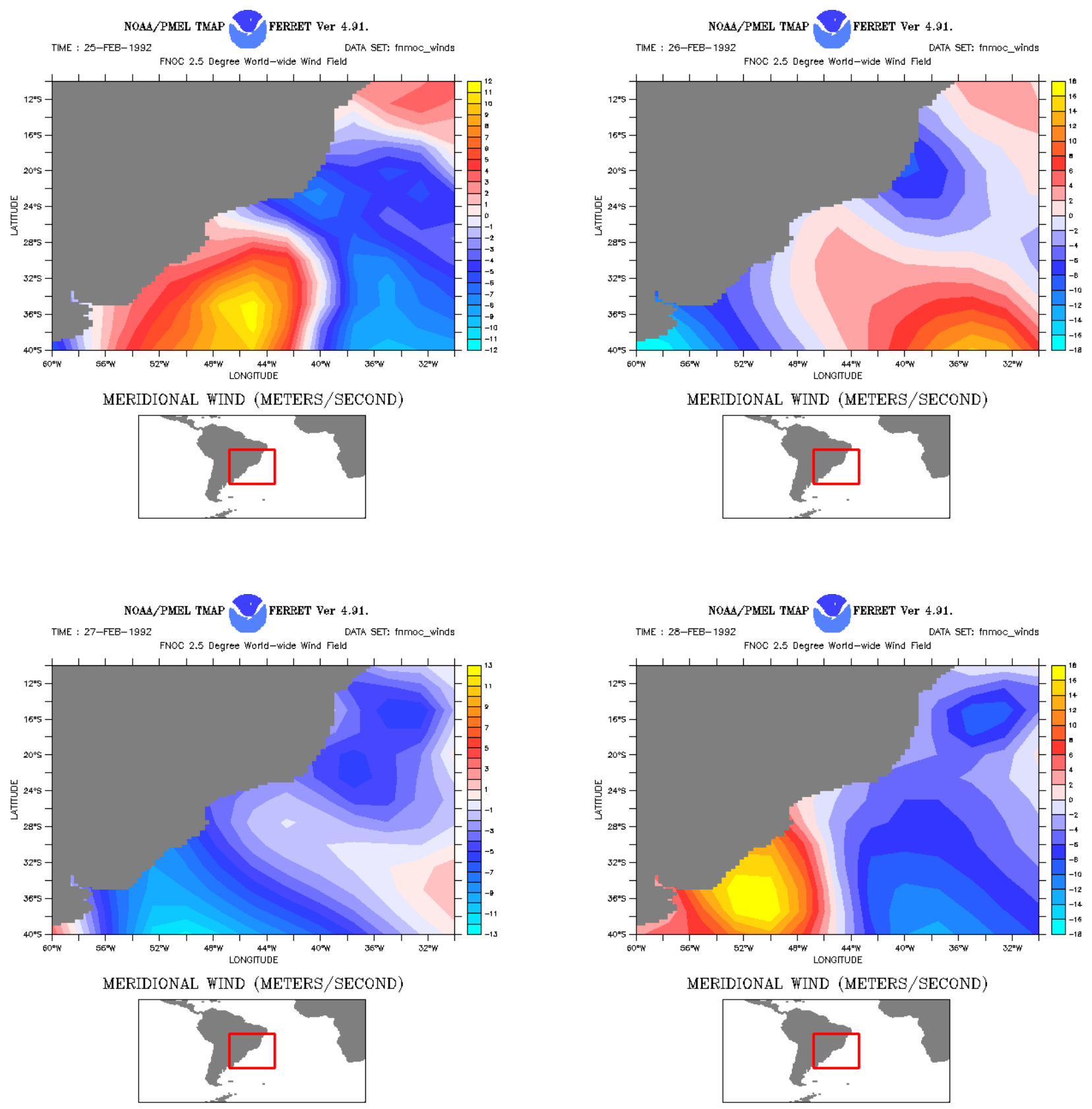

Figura 151: Componente meridional do vento nos dias 25, 26, 27 e 24802/1992, durante a passagem de uma frente fria na Plataforma Continental Sudeste. Dados extraídos de FNMOC. 

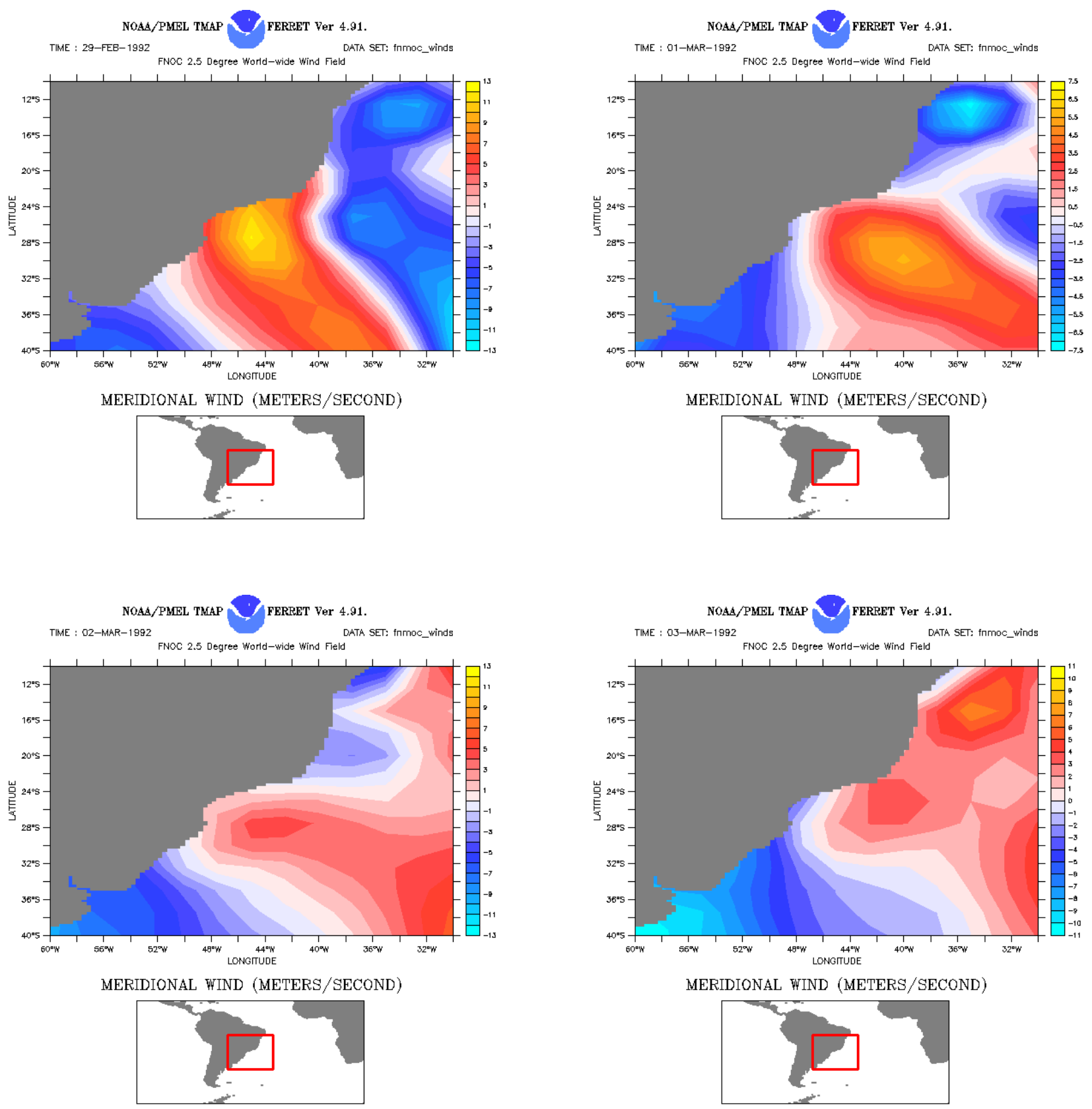

Figura 152: Componente meridional do vento nos dias 29/02/1992 e 01, 02 e 03/03/92, durante a passagem de uma frente fria na Plataforma Continental Sudeste. Dados extraídos de FNMOC. 

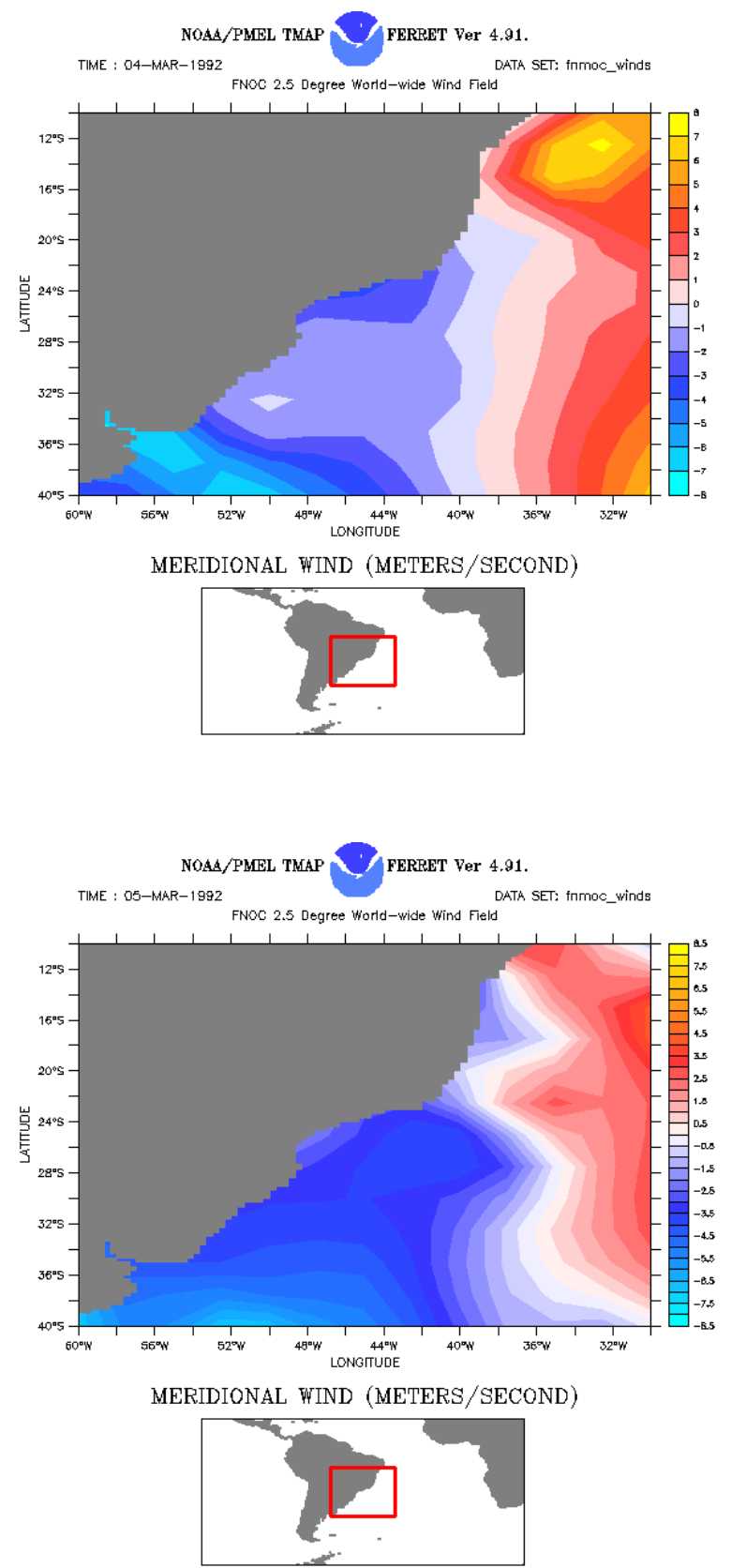

Figura 153: Componente meridional do vento nos dias 04 e 05/03/1992, durante a passagem de uma frente fria na Plataforma Continental Sudeste. Dados extraídos de FNMOC. 

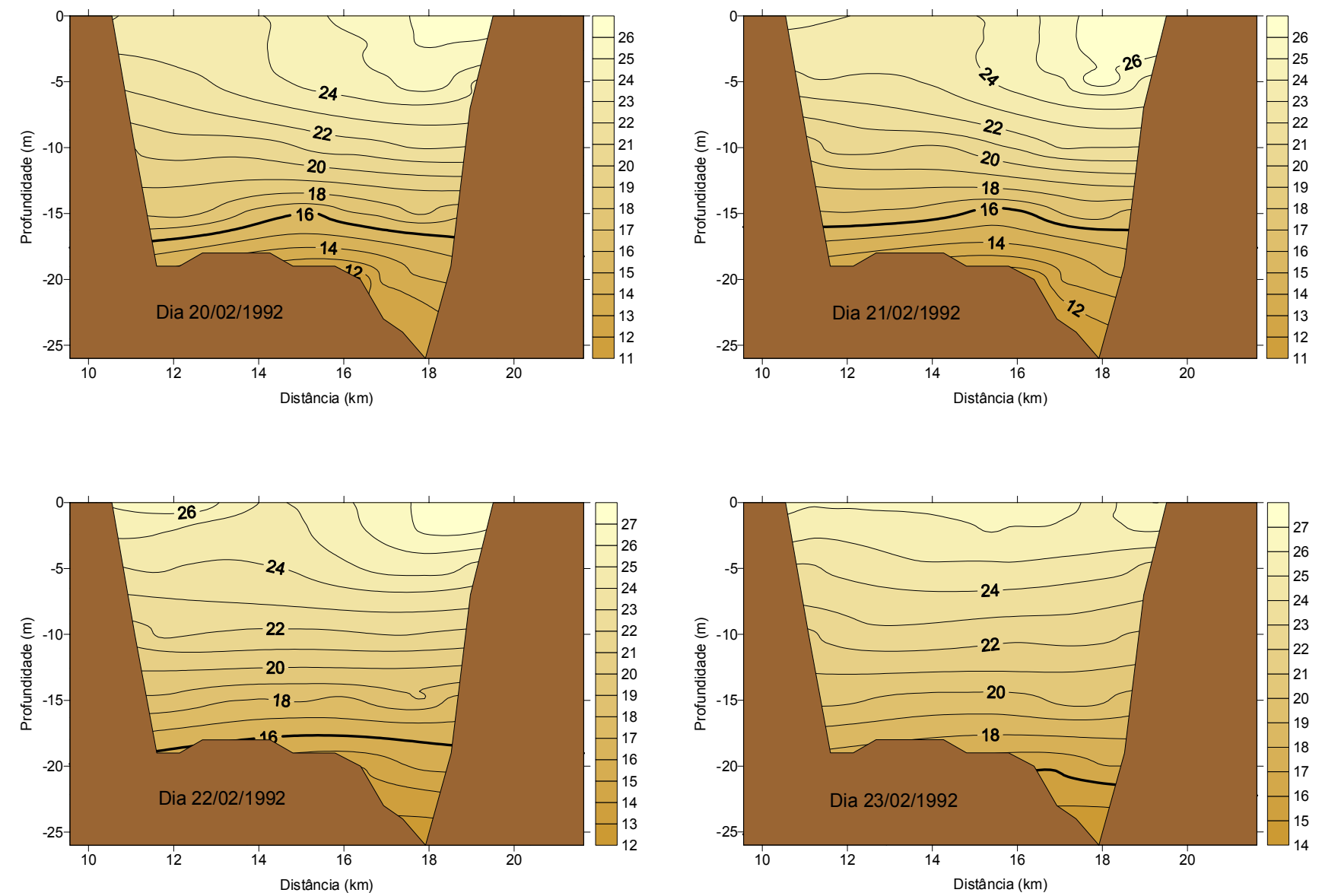

Figura 154: Distribuição vertical de temperatura junto à seção $A$, no sul do Canal de São Sebastião, nos dias 20, 21, 22 e 23/02/1992, durante a simulação numérica da passagem de uma frente fria na Plataforma Continental Sudeste. 

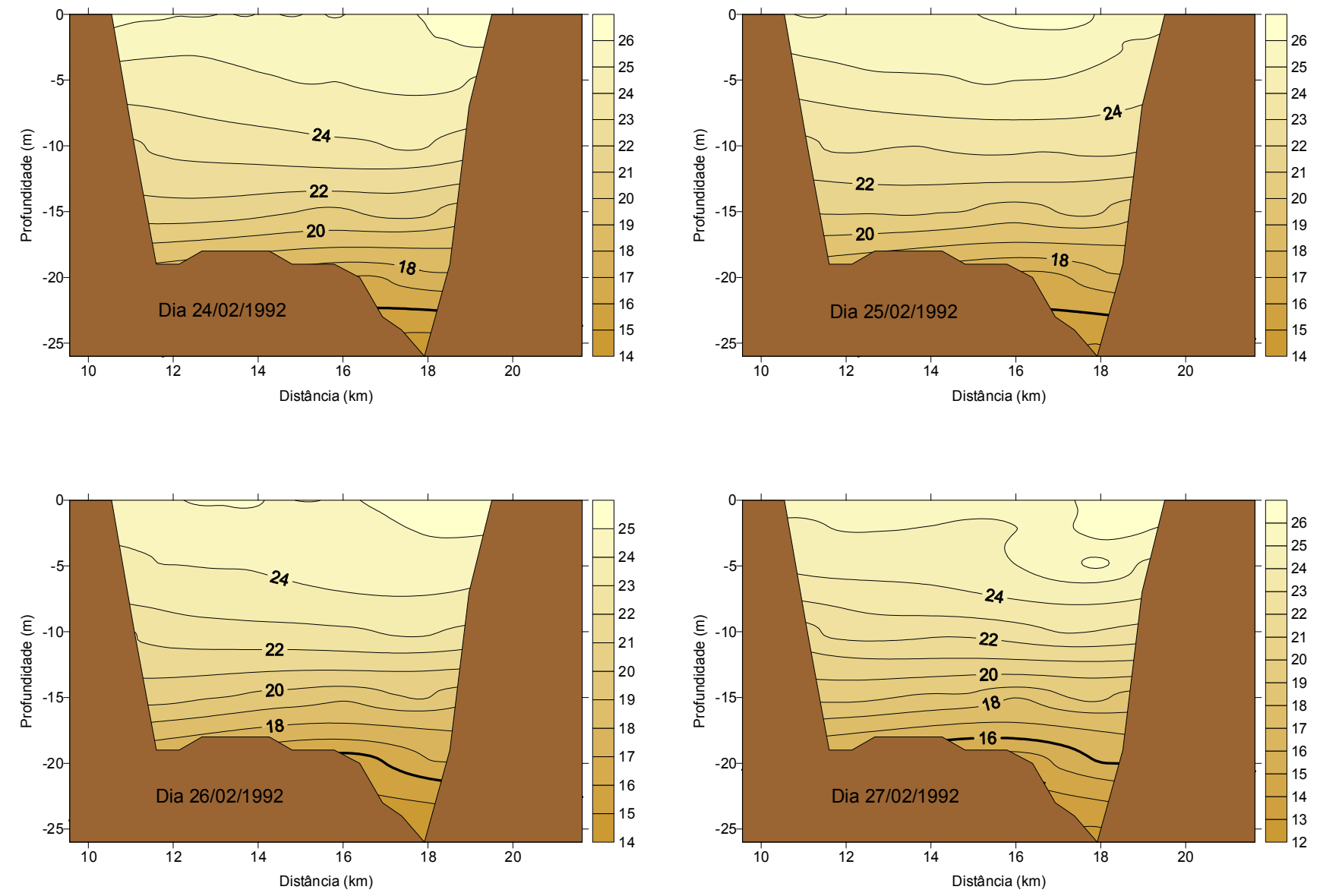

Figura 155: Distribuição vertical de temperatura junto à seção $A$, no sul do Canal de São Sebastião, nos dias 24, 25, 26 e 27/02/1992, durante a simulação numérica da passagem de uma frente fria na Plataforma Continental Sudeste. 

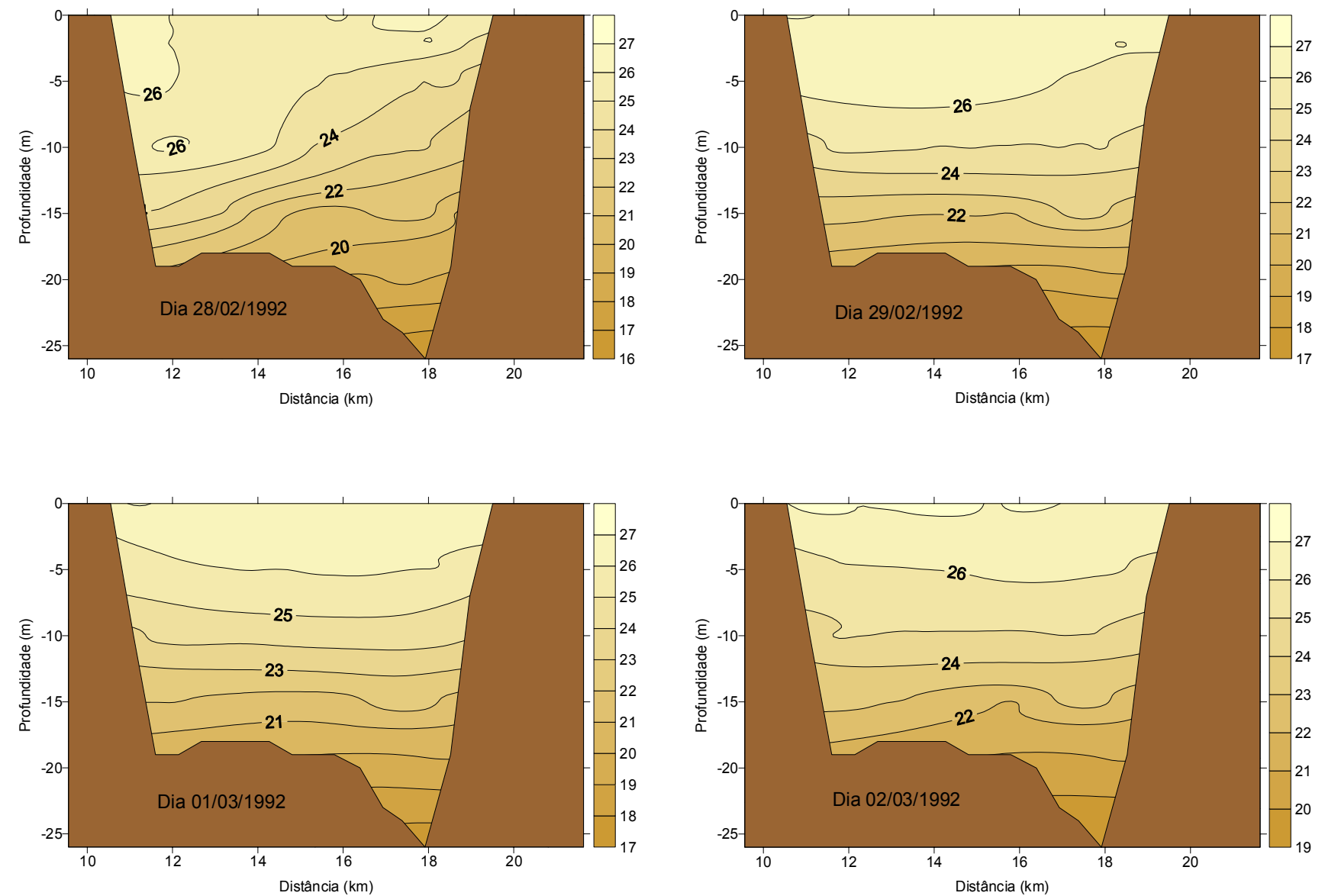

Figura 156: Distribuição vertical de temperatura junto à seção $A$, no sul do Canal de São Sebastião, nos dias 28 e 29/02/1992 e 01 e 02/03/1992, durante a simulação numérica da passagem de uma frente fria na Plataforma Continental Sudeste. 

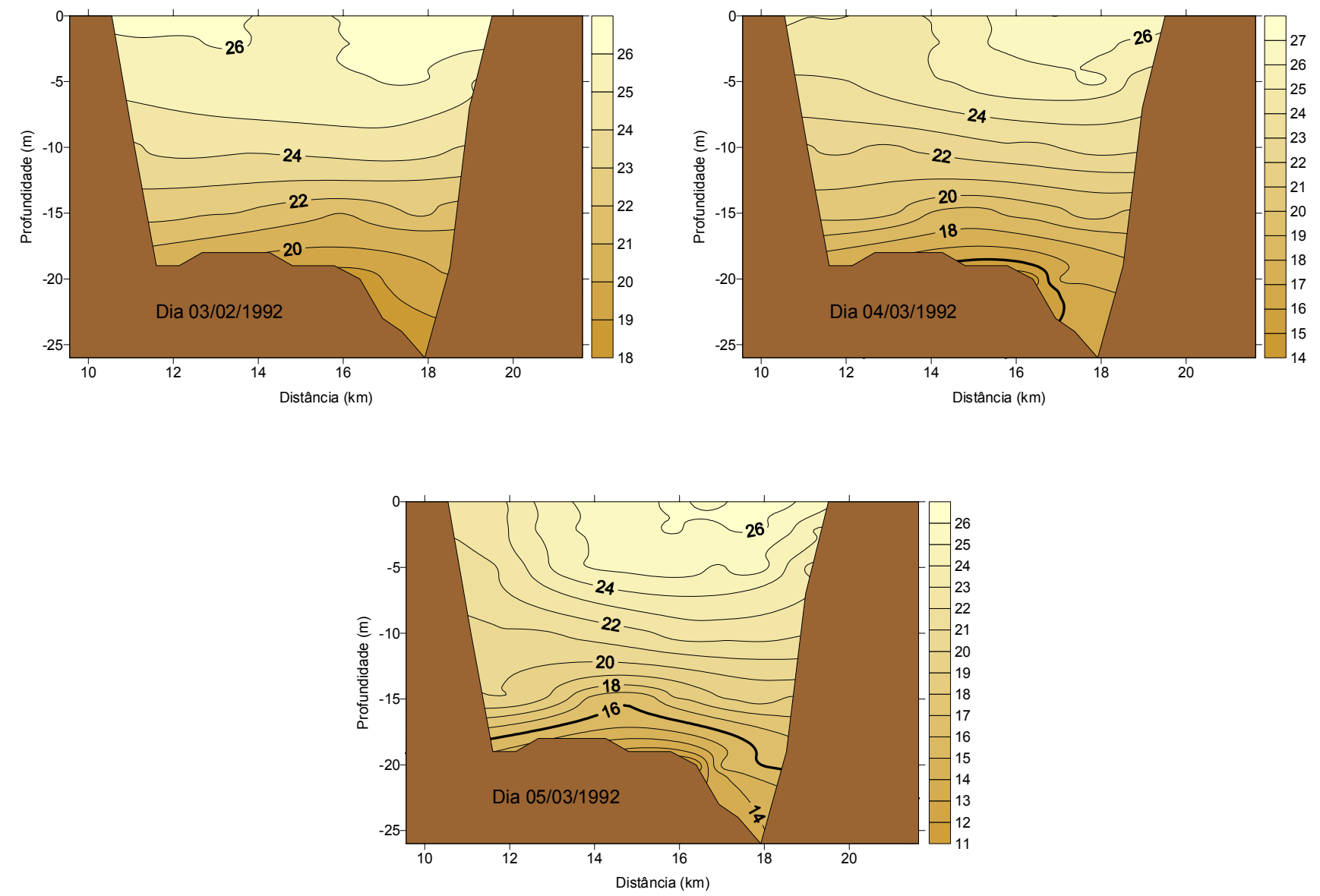

Figura 157: Distribuição vertical de temperatura junto à seção $A$, no sul do Canal de São Sebastião, nos dias 03, 04 e 05/03/1992, durante a simulação numérica da passagem de uma frente fria na Plataforma Continental Sudeste. 

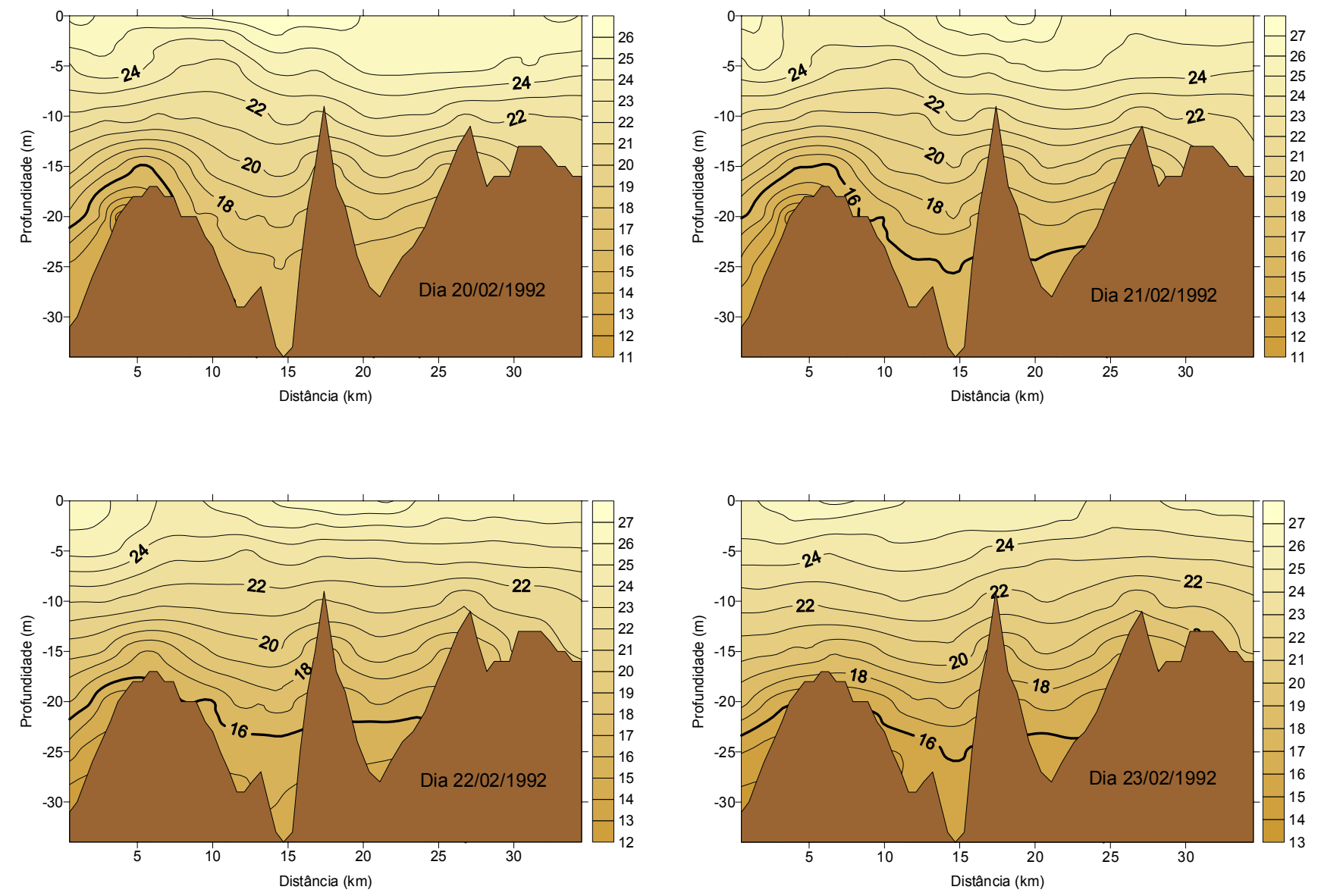

Figura 158: Distribuição vertical de temperatura, ao longo do Canal de São Sebastião, nos dias 20,21, 22 e 23/02/1992, durante a simulação numérica da passagem de uma frente fria na Plataforma Continental Sudeste. 

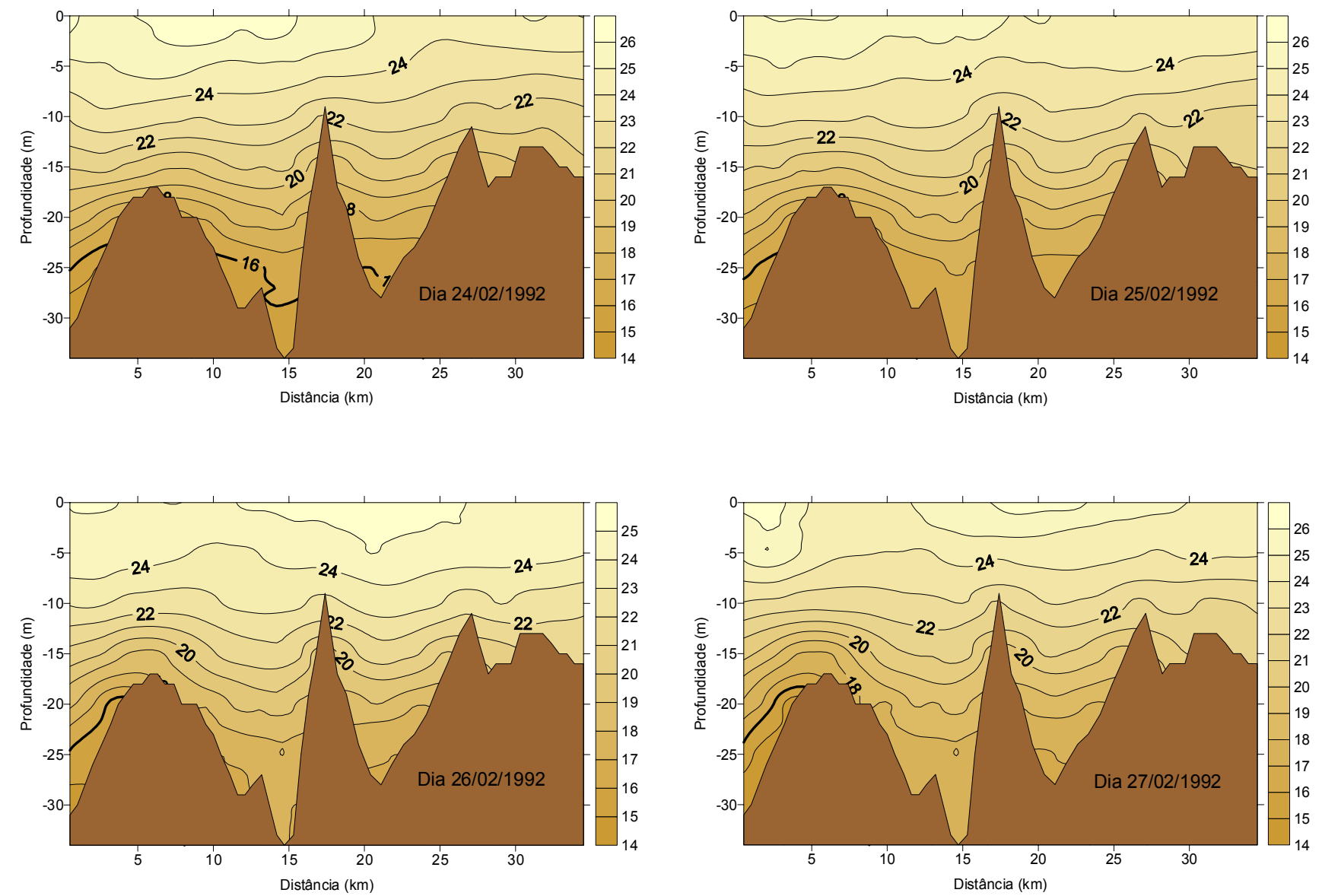

Figura 159: Distribuição vertical de temperatura, ao longo do Canal de São Sebastião, nos dias 24, 25, 26 e 27/02/1992, durante a simulação numérica da passagem de uma frente fria na Plataforma Continental Sudeste. 

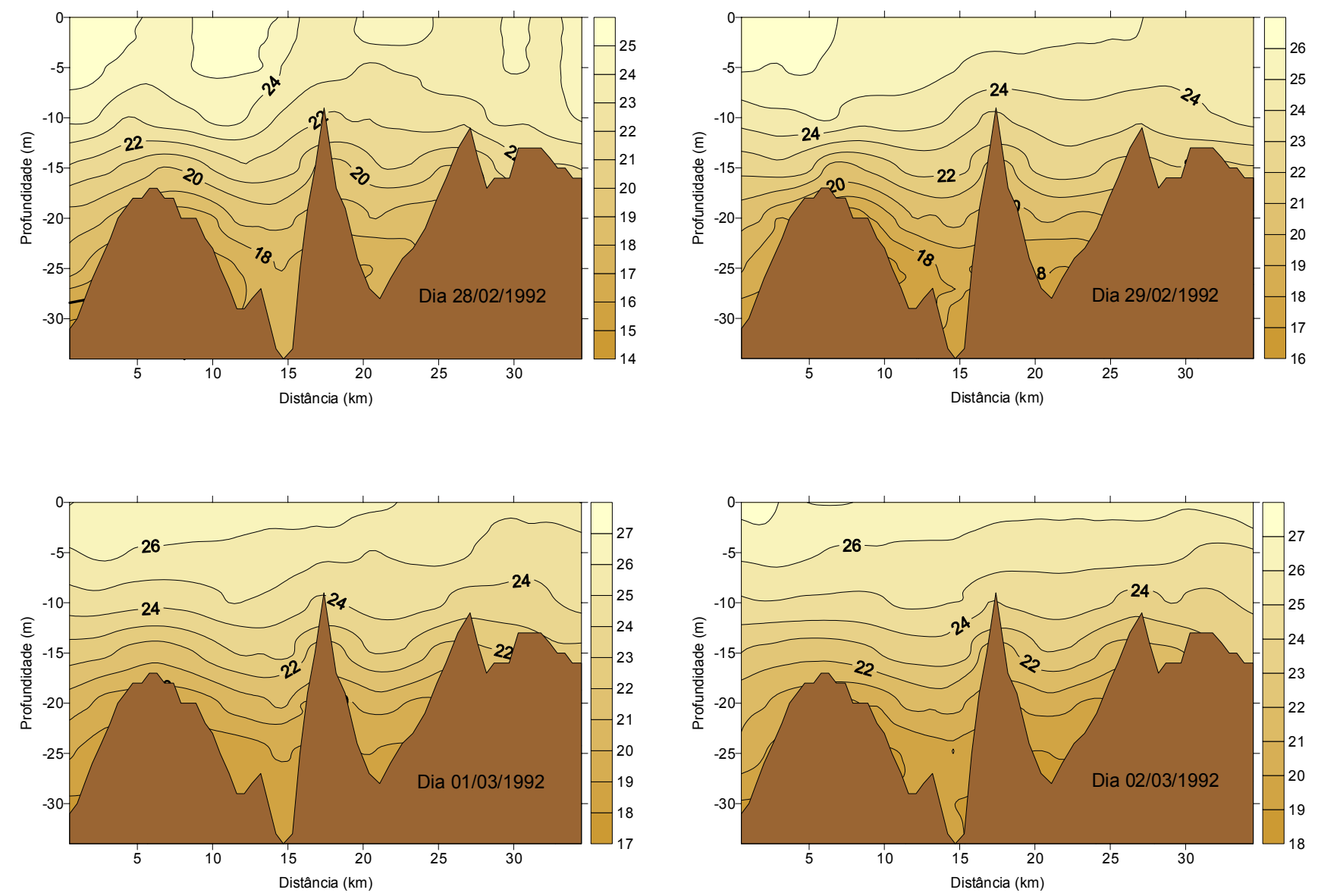

Figura 160: Distribuição vertical de temperatura, ao longo do Canal de São Sebastião, nos dias 28 e 29/02/1992 e 01 e 02/03/1992, durante a simulação numérica da passagem de uma frente fria na Plataforma Continental Sudeste. 

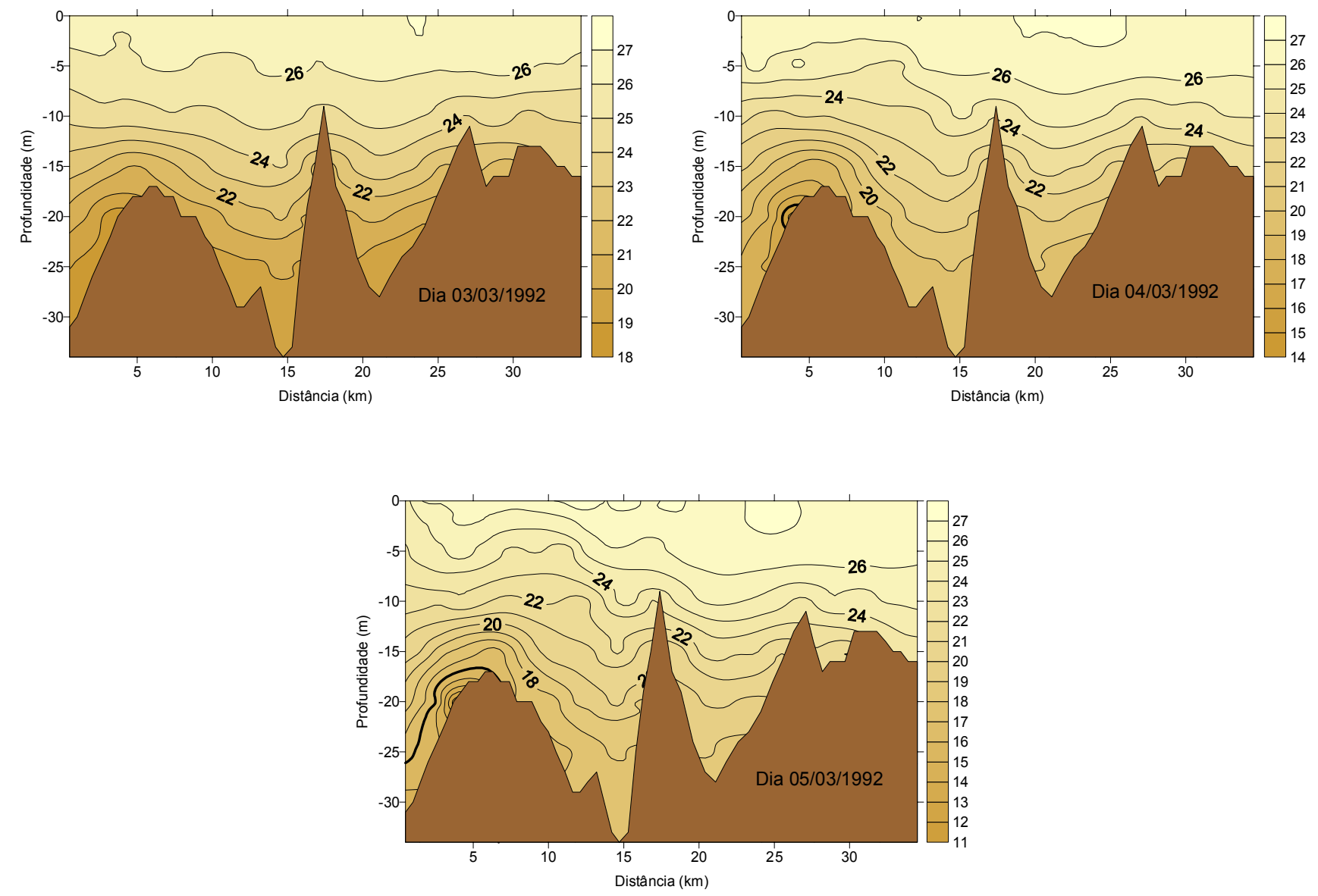

Figura 161: Distribuição vertical de temperatura, ao longo do Canal de São Sebastião, nos dias 03, 04 e 05/03/1992, durante a simulação numérica da passagem de uma frente fria na Plataforma Continental Sudeste. 

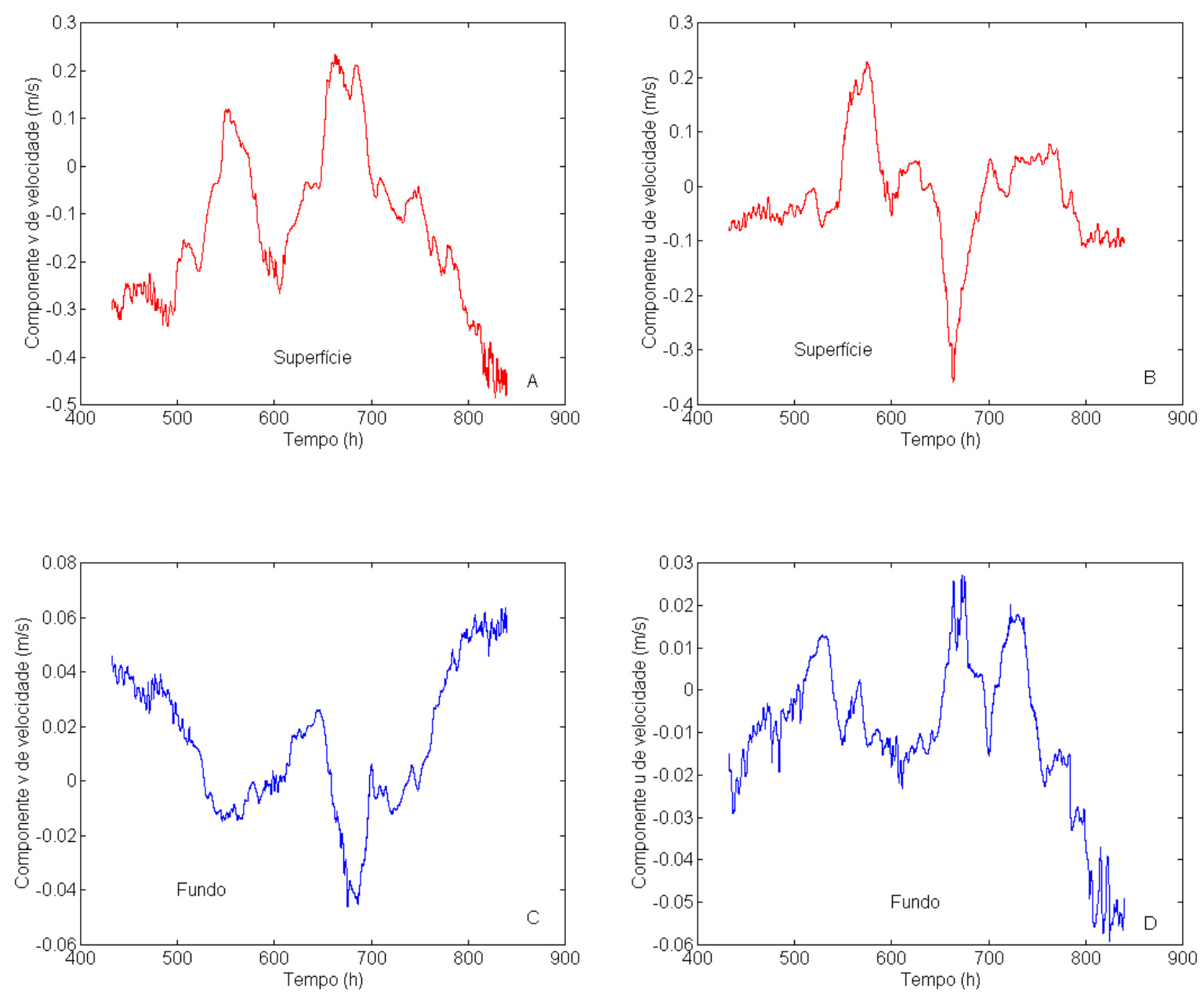

Figura 162: Séries temporais das componentes $\mathrm{v}$ e $\mathrm{u}$ de velocidade para um ponto localizado ao sul do Canal de São Sebastião. 

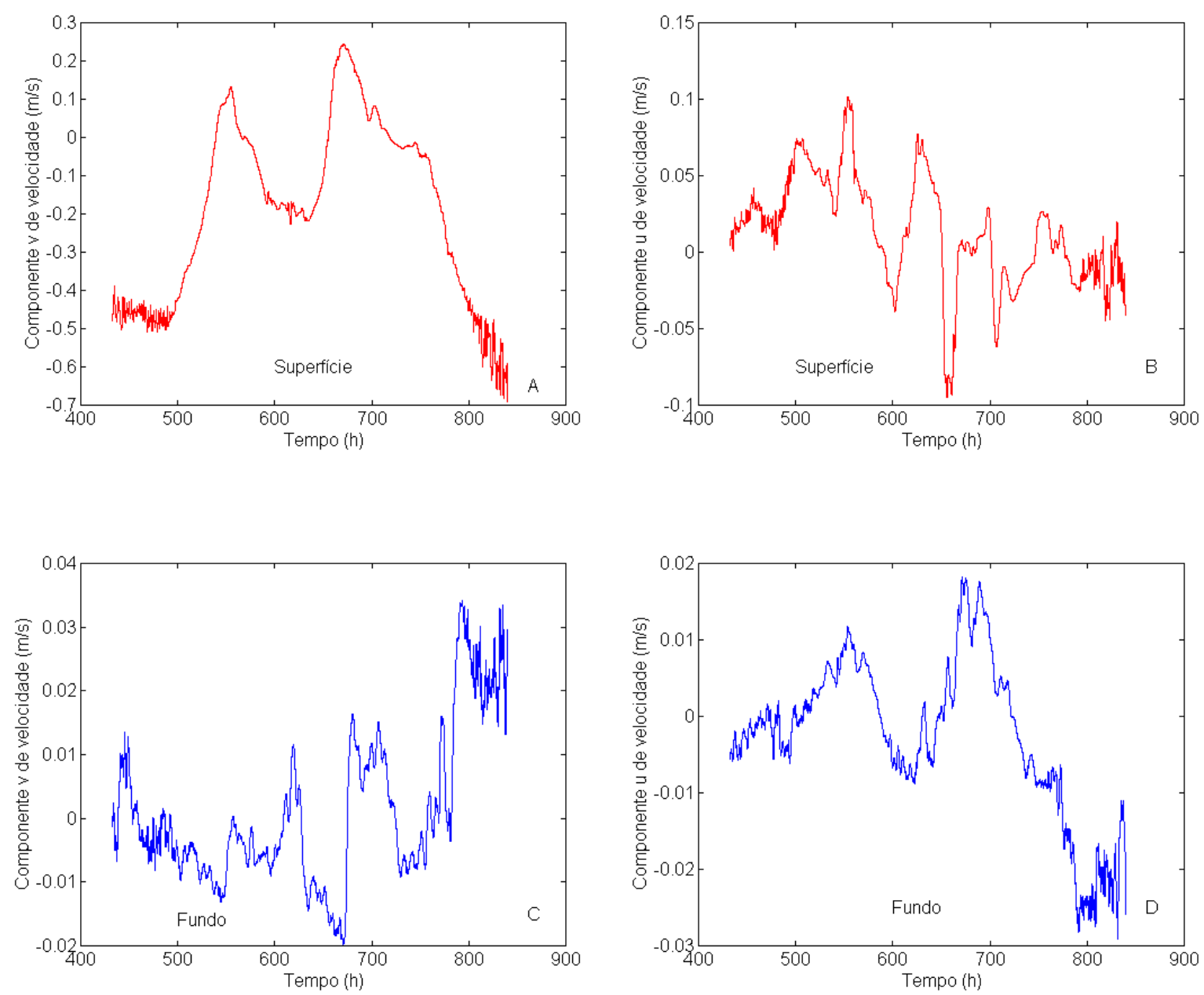

Figura 163: Séries temporais das componentes $\mathrm{v}$ e u de velocidade para um ponto localizado na região central do Canal de São Sebastião. 

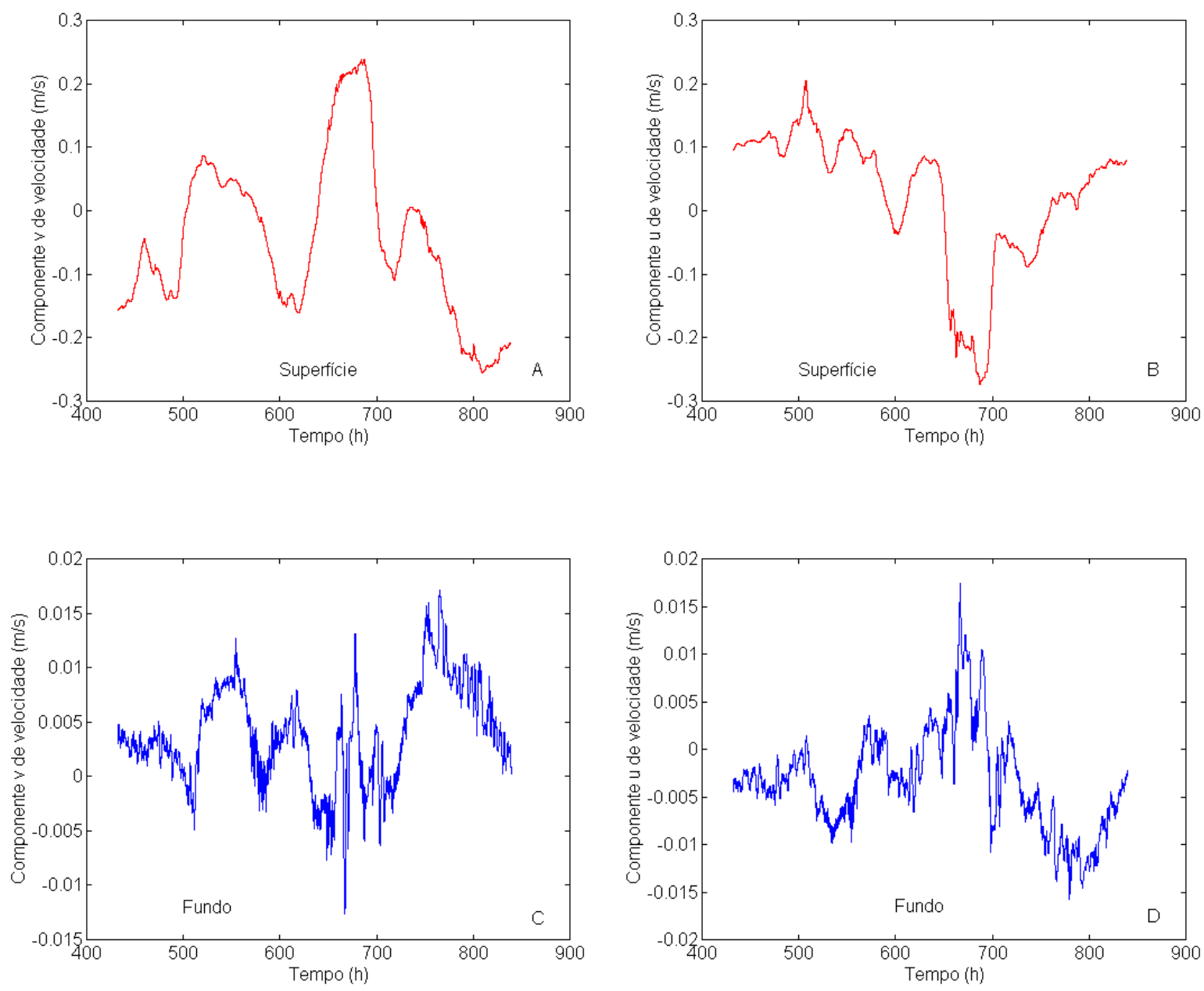

Figura 164: Séries temporais das componentes $\mathrm{v}$ e $\mathrm{u}$ de velocidade para um ponto localizado ao norte do Canal de São Sebastião. 

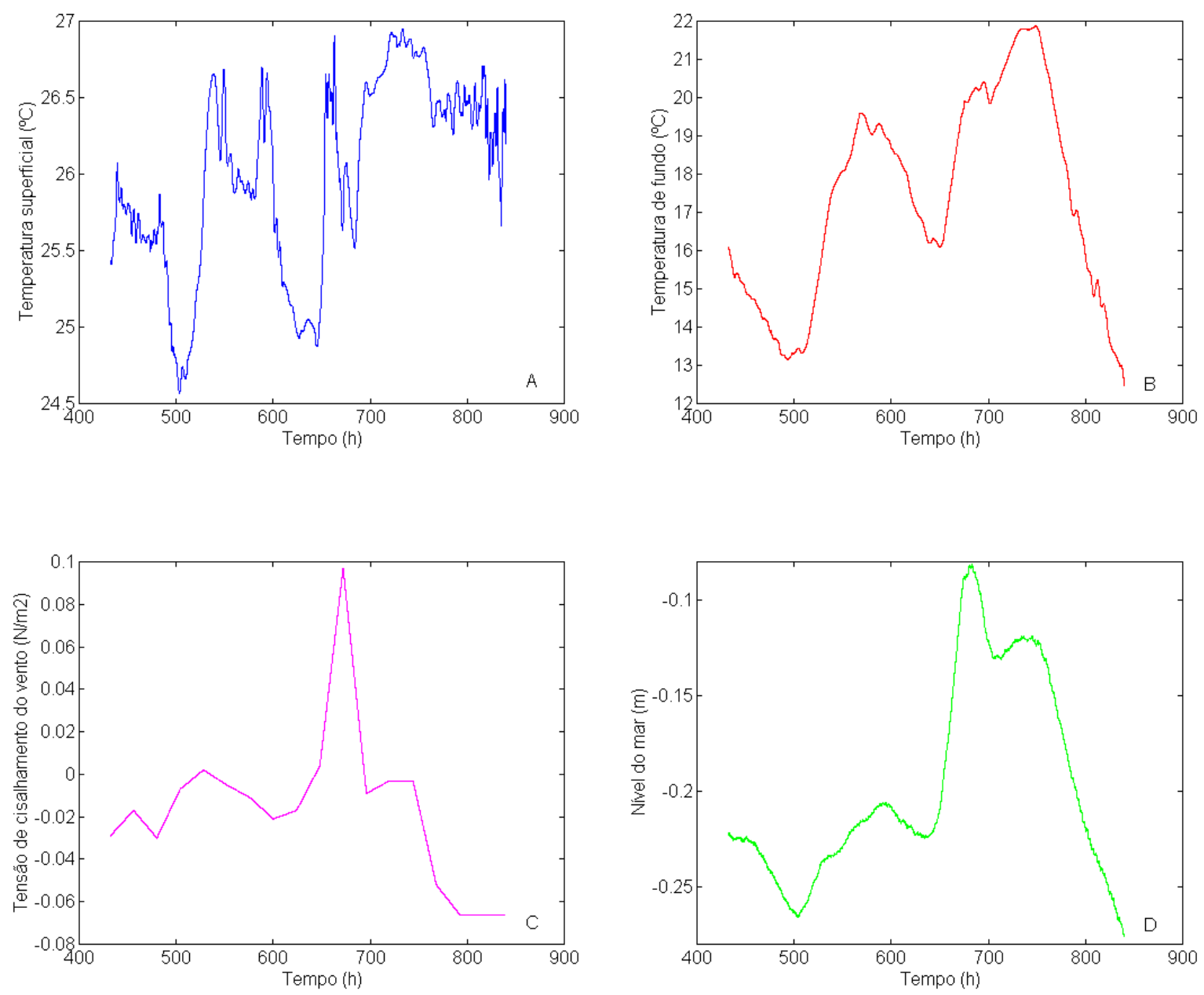

Figura 165: Séries temporais de temperatura $(A, B)$, da componente $v$ de tensão de cisalhamento do vento (C) e de nível do mar (D) para um ponto localizado ao sul do Canal de São Sebastião. 

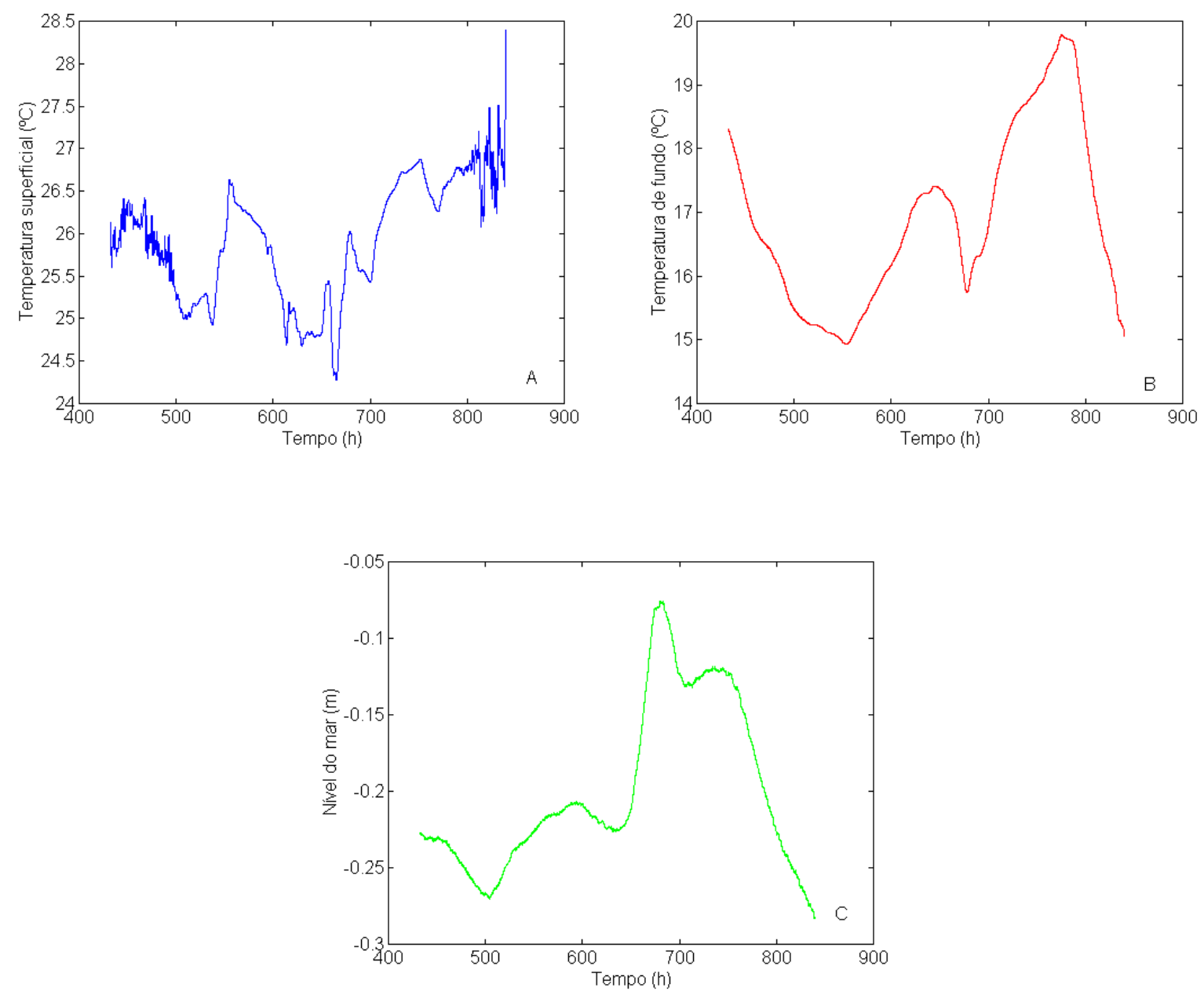

Figura 166: Séries temporais de temperatura (A, B) e de nível do mar (C) para um ponto localizado na região central do Canal de São Sebastião. 

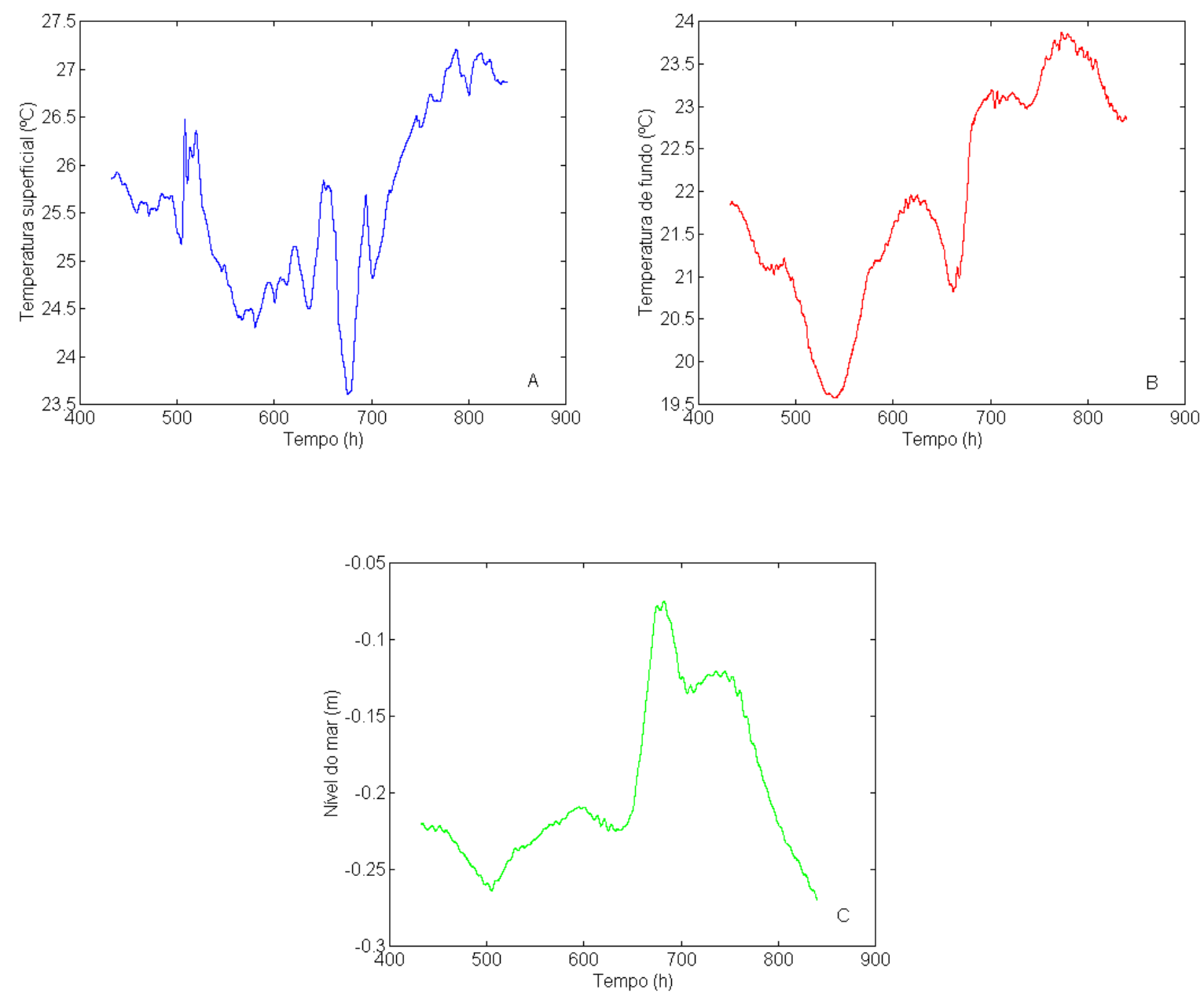

Figura 167: Séries temporais de temperatura $(A, B)$ e de nível do mar $(C)$ para um ponto localizado ao norte do Canal de São Sebastião. 


\section{Capítulo 5}

\section{Discussão dos Resultados}

Oito experimentos foram conduzidos na Plataforma Continental Sudeste: quatro visam simular as condições médias sazonais de primavera, verão, outono e inverno, com base em dados médios históricos de fontes como COADS, HIDROCASS e REVIZEE. Um dos experimentos simula a estrutura térmica do CSS à passagem de uma frente fria, utilizando-se como forçantes, médias diárias de tensão de cisalhamento do vento de FNMOC.

Os outros três experimentos exploram casos extremos e portanto, por um lado improváveis, mas por outro, fornecem elementos de raciocínio para este trabalho e dão uma medida da confiabilidade deste modelo e do Princeton Ocean Model. Estes experimentos seriam então 'didáticos' e simulam (1) uma plataforma sem vento, (2) uma plataforma com vento de sudoeste e (3) vento climatológico nas regiões da PCSE e PCI, porém sem vento no CSS; os dois primeiros simulam 10 dias e o terceiro, 30 dias. O Canal de São Sebastião é o objeto deste trabalho, a PCSE e a PCI foram tomadas como forçantes e nelas buscam-se as causas, não sendo portanto objetos. Alguns resultados destas grades foram mostrados, porém, apenas para apoiar aqueles do CSS. Os resultados de um modelo numérico podem ser credenciados por duas ferramentas: ou por um modelo analítico mais simples ou pela comparação com dados reais. Sempre que possível isto será feito neste capítulo.

\subsection{Primavera}

Após 30 dias de integração, partindo de dados termohalinos históricos e médios para a primavera; forçantes vento, fluxos de calor, de sal e radiação de ondas curtas, provenientes de dados históricos e médios para o mês de novembro, a circulação superficial no CSS apresentou-se para sudoeste enquanto que a de fundo apresentou-se para nordeste. Este fato está completamente de acordo com Leandro (1999), cujo trabalho aponta 6 entre 11 cruzeiros com circulação superficial para sudoeste e 3 entre 11 com circulação de fundo para nordeste, sendo que outros 3 tiveram circulação de fundo para nordeste na metade sul do domínio e para sudoeste na metade norte. A Fig. 
$56 \mathrm{C}$ mostra que na metade sul do domínio, as correntes intensificam-se para sudoeste, divergindo portanto neste local e que na metade norte as correntes superficiais tem menor intensidade para sudoeste e que as de fundo, para nordeste, são muito próximas de zero. Por outro lado, temos que o vento no CSS é o mesmo que atua na plataforma, interpolado apenas para a grade do canal. Através do experimento com vento nas regiões da PCSE e PCI e sem vento no CSS, percebemos que o vento local afeta somente a circulação superficial. A circulação de fundo permaneceu invariante.

As temperaturas no CSS variam nesta estação entre $14^{\circ} \mathrm{C}$ no fundo a $20^{\circ} \mathrm{C}$ na superfície. Leandro (1999) obteve em sua climatologia das águas do Canal de São Sebastião, temperaturas médias para esta estação entre 22,5 e $18,5^{\circ} \mathrm{C}$ junto à entrada sul do canal. Os desvios padrões encontrados pelo autor são ao redor de $1,5^{\circ} \mathrm{C}$ para a superfície e $3,0^{\circ} \mathrm{C}$ para o fundo. De acordo com Coelho (1997) e Leandro (1999), os cruzeiros de início de primavera se assemelham aos de inverno, isto é, as águas do CSS estão bastante homogêneas em relação à temperatura. Já os cruzeiros de final de primavera, em muito se assemelham aos de verão, com baixas temperaturas no fundo e altas temperaturas na superfície. Os resultados deste trabalho chegaram em resultados intermediários, isto é, com baixas temperaturas no fundo, porém, com temperaturas não tão altas na superfície. Faz-se então duas considerações: os dados termohalinos de inicialização do modelo são uma média para os meses de primavera e a forçante tensão de cisalhamento do vento foi a média para os meses de novembro. Os ventos médios de novembro na plataforma estão muito próximos em configuração e em intensidade aos ventos médios de fevereiro, principalmente na região norte da plataforma, com ventos basicamente paralelos à costa, o que favorece o transporte de águas frias para a costa. $\mathrm{O}$ contra exemplo pode ser observado no experimento com vento de sudoeste (confirmado pelo experimento da frente fria): esses ventos não favorecem a intrusão de águas frias na costa. A temperatura inicial de fundo de $17^{\circ} \mathrm{C}$, cai após 30 dias de integração para cerca de $14^{\circ} \mathrm{C}$, provocando um resfriamento das águas superficiais. Tem-se constatado em meses de verão, temperaturas superficiais de $29^{\circ} \mathrm{C}$ no CSS. Porém, quando ocorre a intrusão da ACAS, pelo fundo, no sul do CSS, percebemos que as temperaturas superficiais caem para cerca de $24^{\circ} \mathrm{C}$ (Coelho, 1997). Como as temperaturas superficiais de inicialização do modelo são baixas, pois são a média para toda a primavera, e a forçante vento favorece a penetração de águas frias, tivemos como resultado final, o quadro acima descrito: temperaturas superficiais de cerca de $20^{\circ} \mathrm{C}$ e temperaturas de 
fundo de cerca de $14^{\circ} \mathrm{C}$. Do experimento com forçante vento na PCSE e PCI e sem forçante vento no CSS, concluiu-se que o vento local não modificou o quadro encontrado de quando o vento atuou nas três grades, somente atuando na circulação superficial. O campo termohalino de fundo do CSS é conseqüência do vento que atua em uma escala maior: a da Plataforma Continental Sudeste. Os quadros termohalinos de fundo, obtidos nos cruzeiros oceanográficos realizados no CSS são resultados da atuação dos ventos na plataforma em dias imediatamente anteriores. Como o vento médio na plataforma é de nordeste na primavera, é natural que o CSS tenha temperaturas baixas no fundo; esse quadro só é modificado quando da entrada de uma frente fria na região. Então os resultados de um cruzeiro oceanográfico no CSS vão depender do dia realizado em relação à passagem da frente fria. No caso médio simulado por este modelo, as águas frias estão presentes no fundo do CSS, esfriando as águas superficiais.

O campo de salinidade obtido pelo modelo apresenta salinidades variando entre 35,3, na superfície, e 35,7, no fundo. Este resultado está de acordo com Leandro (1999) se considerarmos os desvios padrões. Na verdade o resultado obtido pelo modelo está dentro da média máxima obtido pelo autor acima citado. Coelho (1997) em um cruzeiro no início de dezembro, obteve salinidades de 35,6 no fundo, na entrada sul do canal. As considerações feitas com relação à temperatura se aplicam também. Os dados iniciais de salinidade ao sul do CSS, tanto na PCSE, como na PCI, variam de 35 a 36 ; aliado a este fato, o vento médio de novembro força o transporte de águas mais salinas do largo para a costa, como contra exemplifica o experimento com vento de sudoeste, que após 10 dias de integração, no verão, trazem salinidades no Canal de São Sebastião entre 34,2 e 35,0 e as temperaturas, entre 24 e $30^{\circ} \mathrm{C}$.

Concluindo, o vento médio de novembro, aliado à estrutura termohalina média, na primavera, na Plataforma Continental Sudeste, leva o Canal de São Sebastião, a ser preenchido, no fundo, pela Água Central do Atlântico Sul. Todos os cruzeiros de primavera analisados por Coelho (1997) em que houve intrusão da ACAS no CSS, ocorreram com vento favorável de nordeste, semelhante àquele utilizado como forçante neste modelo. Especificamente, o cruzeiro de dez/93 (Fig.168) revelou níveis de ACAS superiores a $88 \%$ no fundo, chegando o percentual de $50 \%$ a profundidades de $5 \mathrm{~m}$. A circulação de fundo é para nordeste e a superficial é para sudoeste, sendo que esta pode ser afetada pelo vento local, enquanto aquela é movida por fatores externos ao CSS. 


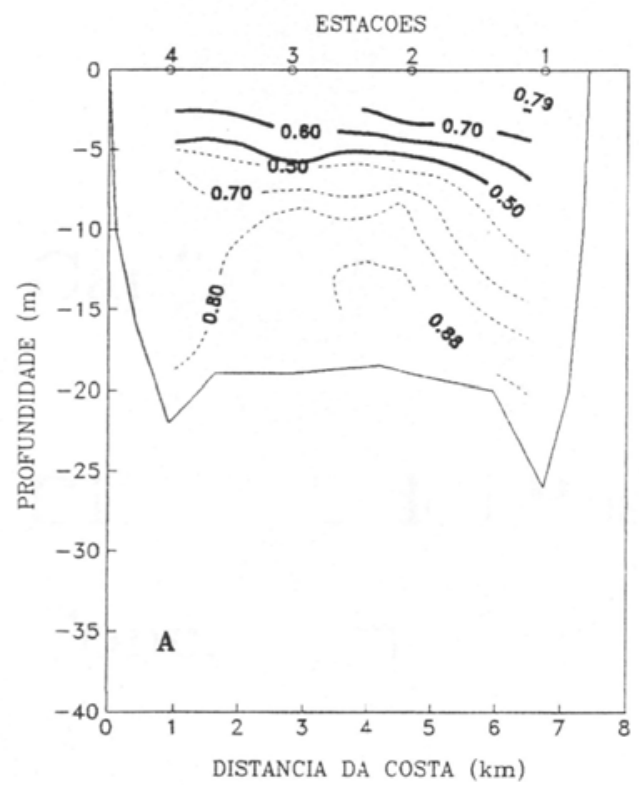

Figura 168: Distribuição vertical dos percentuais de massas de água na seção A do CSS, em dez/93: AC (linha contínua em negrito) e ACAS (linha tracejada). De acordo com Coelho (1997).

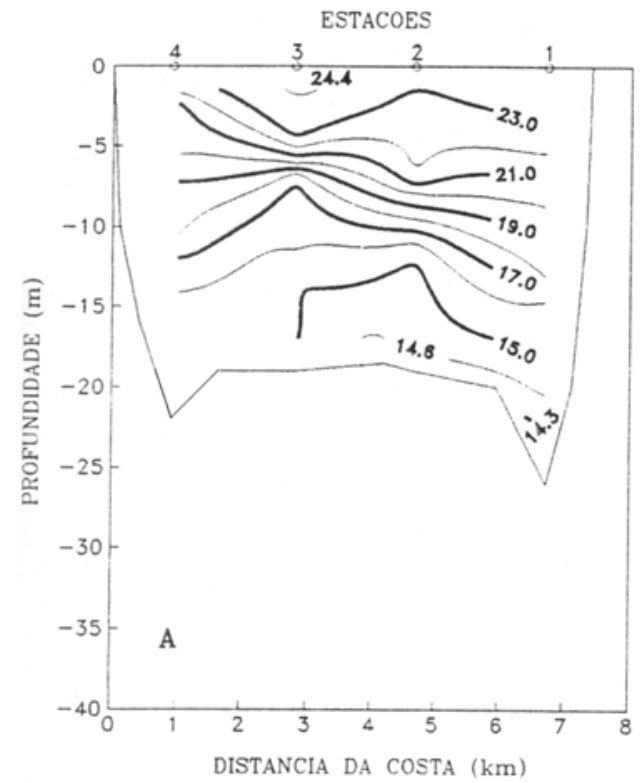

Figura 169: Distribuição vertical de temperatura $\left({ }^{\circ} \mathrm{C}\right)$ na seção $\mathrm{A}$, no CSS, para o cruzeiro de fev/92. De acordo com Coelho (1997). 


\subsection{Verão}

A circulação média obtida nesta estação do ano é em muito semelhante àquela encontrada na primavera. Circulação superficial para sudoeste e no fundo uma circulação menos intensa para nordeste até a região central do canal. Junto à seção A no CSS, do lado oeste, as correntes fluem para sudoeste. Leandro (1999) aponta 3 entre 11 cruzeiros no CSS com correntes superficiais para sudoeste; entre esses três, dois tem correntes de fundo para nordeste, sendo que o terceiro, ocorreu em um dia que uma frente fria havia acabado de deixar a Plataforma Continental Sudeste (FNMOC). Em 5 cruzeiros com correntes superficiais para nordeste, apontados pelo autor acima citado, pelo menos 3 ocorreram durante ou muito próximos da passagem de uma frente fria pela PCSE (FNMOC).

As temperaturas no Canal de São Sebastião variaram entre $12^{\circ} \mathrm{C}$ no fundo e $25^{\circ} \mathrm{C}$ na superfície. Esta situação corresponderia a uma situação média no canal para o mês de fevereiro. Leandro (1999) obteve para a seção A, no CSS, como média, temperaturas variando entre $19^{\circ} \mathrm{C}$ no fundo e $27^{\circ} \mathrm{C}$ na superfície. Porém, o desvio padrão na superfície foi de $2^{\circ} \mathrm{C}$ e no fundo o desvio padrão encontrado foi de $5^{\circ} \mathrm{C}$. Logo os resultados deste modelo estão praticamente dentro da média, considerando-se os desvios padrões. Como dito acima, com relação à circulação, uma boa parte dos cruzeiros de verão analisados pelo autor ocorreram muito próximos de eventos de frentes frias. O cruzeiro de 29/03/94, por exemplo, tem o perfil de temperatura junto à seção A (Fig. 4), bem próximo ao da média obtida por Leandro (1999). Neste dia, uma frente fria estava saindo da Plataforma Continental Sudeste, sendo que no dia anterior, ela estava praticamente toda tomada pela frente (FNMOC). Em contrapartida, o quadro de temperaturas obtido por este modelo numérico é muito semelhante ao obtido por Coelho (1997) em um cruzeiro realizado em 21 de fevereiro de 1992, onde as temperaturas (Fig. 169) no fundo foram da ordem de $14^{\circ} \mathrm{C}$ e as da superfície, $25^{\circ} \mathrm{C}$. Nos dias que precederam este cruzeiro não ocorreram frentes na plataforma. Dias após este cruzeiro, uma frente fria entrou na região, tendo sido modelada neste trabalho. Percebemos que no dia 21/02/92, a temperatura no fundo era cerca de $13^{\circ} \mathrm{C}$ (Fig. 158), no fundo da seção A (sul do CSS) e dia 04/03/92, neste mesmo local, a temperatura era de cerca de $18^{\circ} \mathrm{C}$ (Fig. 161). A situação do dia 21/02/92 volta no dia 05/03/92 quando a frente fria abandona a PCSE. 
As salinidades nesta estação variaram entre 35,3 na superfície e 35,8 no fundo. Considerando-se o campo médio junto à seção A obtido por Leandro (1999), que obteve 33,8 (desvio padrão $=1,2$ ) na superfície e 35,4 (desvio padrão $=0,8$ ) no fundo, concluímos que as salinidades geradas pelo modelo, na superfície, estão levemente acima, mesmo considerando-se o desvio padrão. Alguns fatores podem ser enumerados: 1) os dados de inicialização de salinidade na PCSE e PCI fornecem em geral salinidades maiores do que as correspondentes no CSS (Figs. 9, 11e 13), em decorrência do fato de que as fontes são diferentes; 2) o modelo é eficiente com relação ao transporte de Ekman, conduzindo águas mais frias e salinas de regiões mais profundas ao largo, para regiões mais rasas na costa. Isto também é conseqüência dos ventos favoráveis de fevereiro, pois como vimos, no outono e inverno as salinidades obtidas são bem mais baixas; 3) ausência de fonte de descarga estuarina no modelo, apesar de não haver grandes rios na região.

A Água Central do Atlântico sul está presente no Canal de São Sebastião em profundidades abaixo de $10 \mathrm{~m}$, na situação média imposta pelo modelo, isto é, campo termohalino médio de verão, vento médio de fevereiro. Todos os cruzeiros de verão analisados por Coelho (1997), Silva (1995a) e Leandro (1999) que tiveram por alguns dias consecutivos imediatamente anterior ao cruzeiro, ventos de nordeste, apresentaram a mesma conclusão. Fortuitamente, os cruzeiros de verão no CSS aconteceram em dias de regime de ventos de sudoeste ou logo após a saída da frente fria da região de estudo. $\mathrm{O}$ vento médio de fevereiro (COADS) é favorável à penetração da ACAS no CSS. Esse vento foi substituído pelo de uma outra fonte (Hellerman - Rosenstein wind stress climatology) e os resultados foram semelhantes. $\mathrm{O}$ vento médio de novembro é muito próximo em intensidade e direção ao vento médio de fevereiro. $\mathrm{O}$ de novembro é ligeiramente menos intenso e sua direção um pouco mais voltada contra a costa, principalmente na região sul da plataforma; porém, na região norte e ao norte do CSS, o vento é praticamente idêntico ao de fevereiro, explicando o transporte de Ekman igualmente efetivo. A Fig. 170 mostra os percentuais de ACAS junto à seção A em um cruzeiro realizado em fev/92 (Coelho, 1997). 


\subsection{Outono}

O padrão de circulação obtido no outono é bem diferente daqueles obtidos na primavera e no verão. $\mathrm{Na}$ entrada sul do CSS, as correntes fluem de oeste para leste, sendo que nas estações de primavera e verão, as correntes fluíam de leste para oeste. As correntes superficiais fluindo no canal de norte para sul, unem-se às correntes vindas de oeste na entrada sul do canal para formarem uma só corrente, contornando a ISS, como sugerem as Figs. 90 e 96. Estas correntes possuem intensidades muito pequenas, tendo a componente longitudinal ao canal um máximo de $0,14 \mathrm{~m} / \mathrm{s}$ no centro do canal; na região norte as correntes são ainda menores. Este fato pode ser decorrência dos fracos ventos médios para este mês (maio) e ainda contra a costa, alcançando ambas as entradas do CSS paralelamente. As correntes de fundo são igualmente fracas fluindo de sul para norte. No experimento sem forçante vento no CSS (verão), foi verificado que as correntes superficiais diminuem consideravelmente em relação à presença do vento. Portanto, com correntes superficiais muito baixas, fontes de ventos locais, não considerados neste modelo, tornam-se importantes. Ventos locais de sul, impulsionariam correntes para norte e vice - versa. Dos sete cruzeiros de outono analisados por Leandro (1999), cinco tinham suas correntes (superficiais e de fundo) com sentido nordeste; dois tinham correntes com sentido sudoeste. Entre eles, o cruzeiro de março de 1994, o qual ocorreu com ventos de nordeste (FNMOC), o que explicaria o sentido das correntes, pois estes ventos, impulsionam as correntes superficiais para sudoeste. Apesar do autor acima não ter mencionado, este cruzeiro tem traços de correntes para nordeste no fundo, na entrada sul do canal (Silva, 1995a), fato este que se deve à penetração de águas mais frias pela entrada sul do canal (Fig.4) em decorrência do transporte de Ekman favorecido pelos ventos do quadrante nordeste. Concluindo, as correntes encontradas por este modelo para o outono são basicamente para nordeste com uma fina lâmina superficial de correntes muito fracas para sudoeste, as quais seriam facilmente modificadas sobreponde-se ao vento climatológico da plataforma, o vento local.

As temperaturas variam nesta estação entre $21,9^{\circ} \mathrm{C}$ (no fundo da entrada sul) e $23,6^{\circ} \mathrm{C}$ (na superfície da entrada norte). Leandro (1999) analisando sete cruzeiros de outono, obteve junto à seção $\mathrm{A}$ (entrada sul) um quadro médio que varia entre $25^{\circ} \mathrm{C}$ na 
superfície e $22,6^{\circ} \mathrm{C}$ no fundo. Considerando-se os desvios padrões, os resultados deste modelo estão bastante adequados. As demais seções estão também muito próximas, inclusive em configuração, às obtidas neste modelo (Fig. 171).

As salinidades variam entre 34,8 na superfície e 35,6 no fundo. Leandro (1999) obteve em seu trabalho estatístico para esta estação salinidades variando entre 33,9 e 35,1 com desvios padrões de cerca de 0,7 tanto na superfície como no fundo. Os cruzeiros de maio/92 e maio/93 analisados por Coelho (1997) estão muito próximos com relação à salinidade aos resultados obtidos pelo modelo. Observa-se que nesta estação as salinidades se apresentam menores do que as obtidas na primavera e no verão, em decorrência dos ventos que em maio são bem menos intensos e não são paralelos à costa, não favorecendo portanto o transporte de Ekman.

Apesar da ACAS estar presente abaixo da profundidade de $60 \mathrm{~m}$ nas quatro estações, ela não penetra o CSS no outono, o que demonstra a importância dos ventos de nordeste para a aproximação desta massa de água da costa. Contudo, não se pode afirmar que a ACAS nunca tenha penetrado o CSS em meses de outono; vai depender dos ventos. O vento médio de outono não favorece a entrada da ACAS, porém há registros da aproximação desta massa de água na costa no outono. Um cruzeiro realizado no dia 12/04/2000 ao largo de Santos-SP, no Parque Estadual Marinho da Laje de Santos, Silva (2000) encontrou níveis de 74\% de ACAS numa profundidade de $40 \mathrm{~m}$ (Fig. 172). 


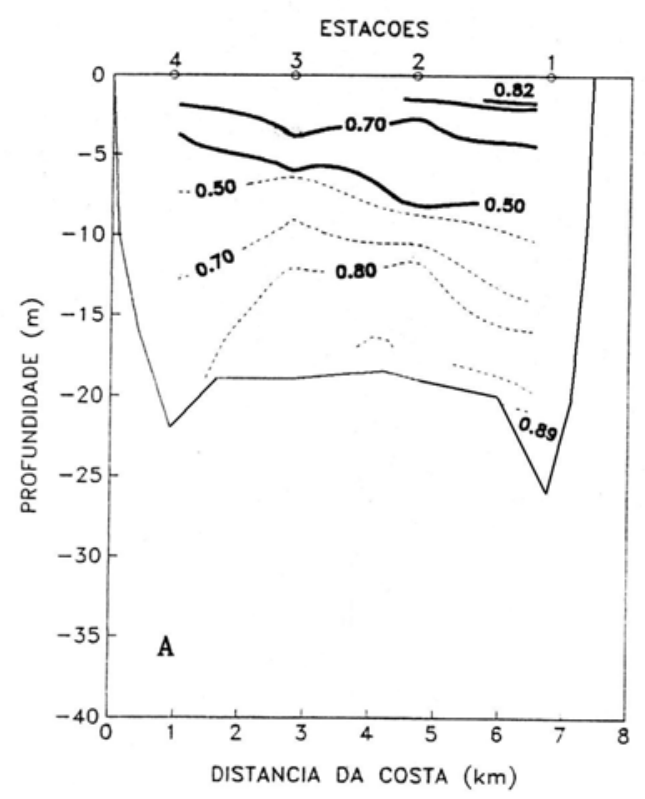

Figura 170: Distribuição vertical dos percentuais de massas de água na seção $A$ do CSS, em fev/92: AC (linha contínua) e ACAS (linha tracejada). De acordo com Coelho (1997).

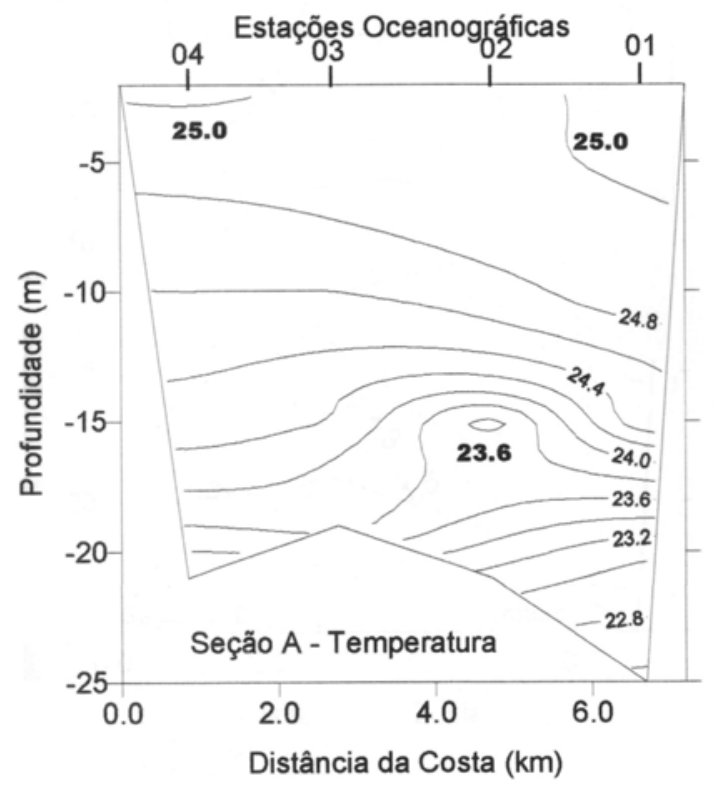

Figura 171: Distribuição vertical das médias dos valores de temperatura no outono, na seção A. De acordo com Leandro (1999). 


\subsection{Inverno}

A circulação nesta estação é basicamente idêntica à do verão e à da primavera porém com intensidades de correntes bem menores. As correntes superficiais fluem para sudoeste enquanto que abaixo de $10 \mathrm{~m}$ de profundidade elas fluem para nordeste. Leandro (1999) aponta sete entre oito cruzeiros analisados com circulação de fundo para nordeste ao passo que todos os oito tem circulação superficial para nordeste, porém os cruzeiros de agosto, neste mesmo trabalho são apontados como aqueles com correntes superficiais baixíssimas (muitos com correntes menores do que $0,10 \mathrm{~m} / \mathrm{s} \mathrm{em}$ todo o canal); concluindo, o vento médio da plataforma gera correntes fracas superficiais para sudoeste e ventos locais podem inverter o sentido da corrente.

As temperaturas no canal de São Sebastião estão compreendidas entre 19,0 e $21,2^{\circ} \mathrm{C}$, sendo que na extremidade norte do canal variam entre 20,9 e $21,5^{\circ} \mathrm{C}$. O perfil médio de temperatura encontrado por Leandro (1999) indica temperaturas variando entre 20,5 e $20,7^{\circ} \mathrm{C}$ com desvios padrões ao redor de $1,4^{\circ} \mathrm{C}$. Apesar dos resultados deste modelo estarem contidos na média obtida pelo autor acima, deve-se ressaltar que os perfis de temperatura entre os cruzeiros ocorridos no mês de julho são aqueles que tem os menores gradientes, por vezes uma única temperatura em todos os $22 \mathrm{~km}$, da superfície ao fundo, do CSS. Já os cruzeiros ocorridos nos meses de junho e agosto apresentam alguma estratificação (Coelho, 1997), como por exemplo o cruzeiro de ago/92 (Fig. 173).

Entre 34,8 e 35,7 estão compreendidas as salinidades no CSS. Este nível de estratificação foi obtido por Coelho (1997) em um cruzeiro de ago92 (Fig. 174), porém com salinidades mais baixas. O campo médio de salinidade encontrado por Leandro (1999) nesta estação varia entre 32,6 e 33,3 com desvios padrões entre 1,6 na superfície e 1,0 no fundo. Constata-se com relação à salinidade, o mesmo que acontece com a temperatura em meses de inverno: pequenos gradientes nos meses de junho e agosto contra praticamente nenhuma estratificação no mês de julho. As salinidades no CSS durante os meses de inverno são muito variáveis; valores muito próximos de 30,0 já foram encontrados assim como valores maiores do que 35,2 (Fig. 175) como no cruzeiro de jun/93 (Coelho, 1997). A Água Central do Atlântico Sul não foi identificada no CSS para as condições médias estabelecidas por este modelo. Contudo os percentuais desta massa de água são maiores do que no outono. 


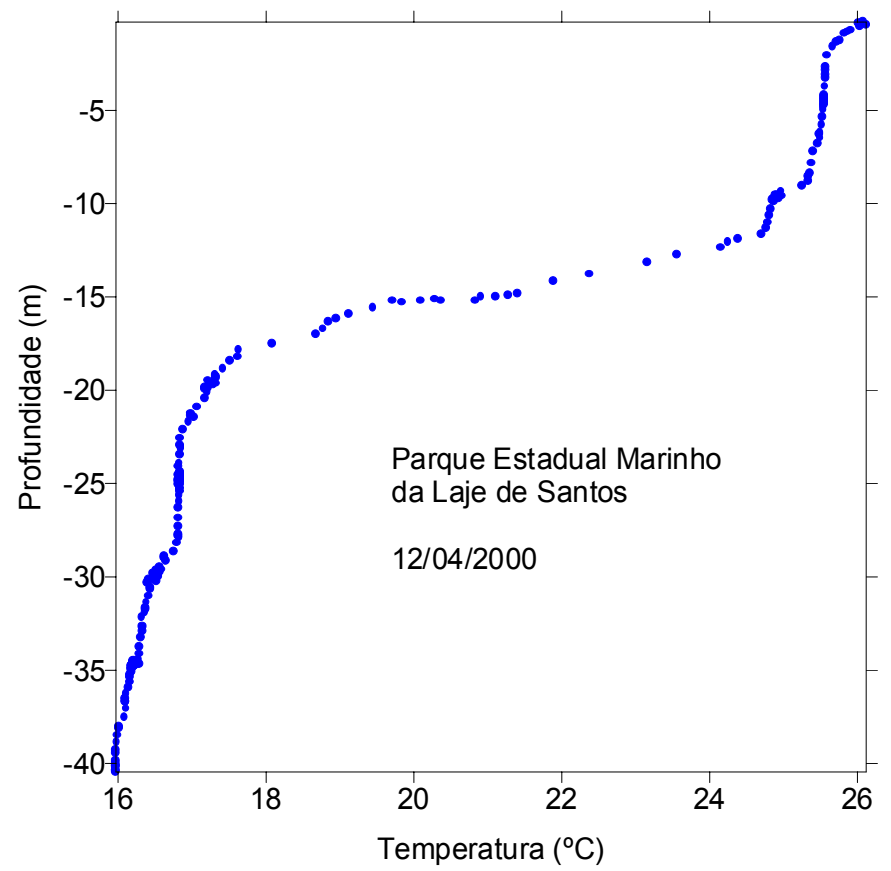

Figura 172: Variação da temperatura com a profundidade obtida em um cruzeiro oceanográfico de outono ao largo da Ilha de São Vicente, no Parque Estadual Marinho da Laje de Santos. De acordo com Silva (2000).

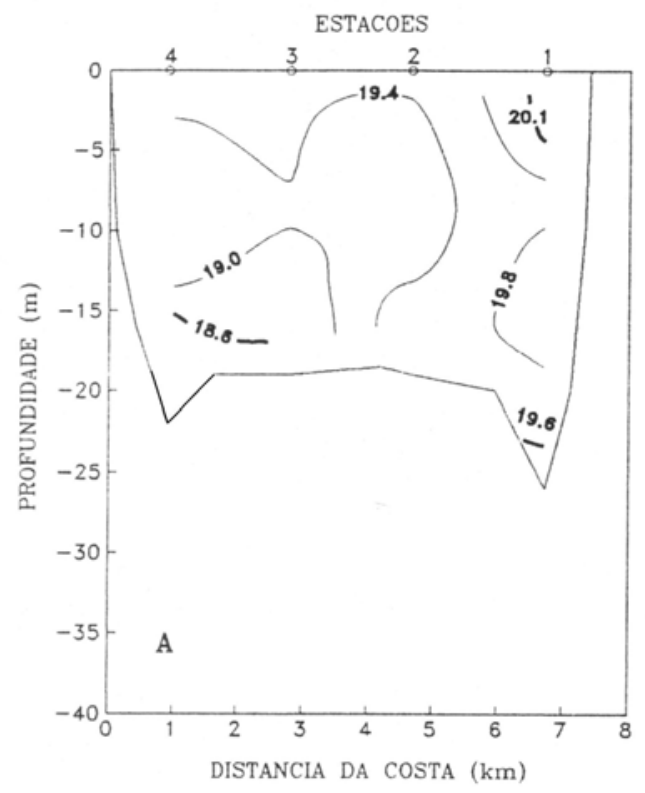

Figura 173: Distribuição vertical de temperatura $\left({ }^{\circ} \mathrm{C}\right)$ junto à seção $\mathrm{A}$ do $\mathrm{CSS}$, em ago/92. De acordo com Coelho (1997). 


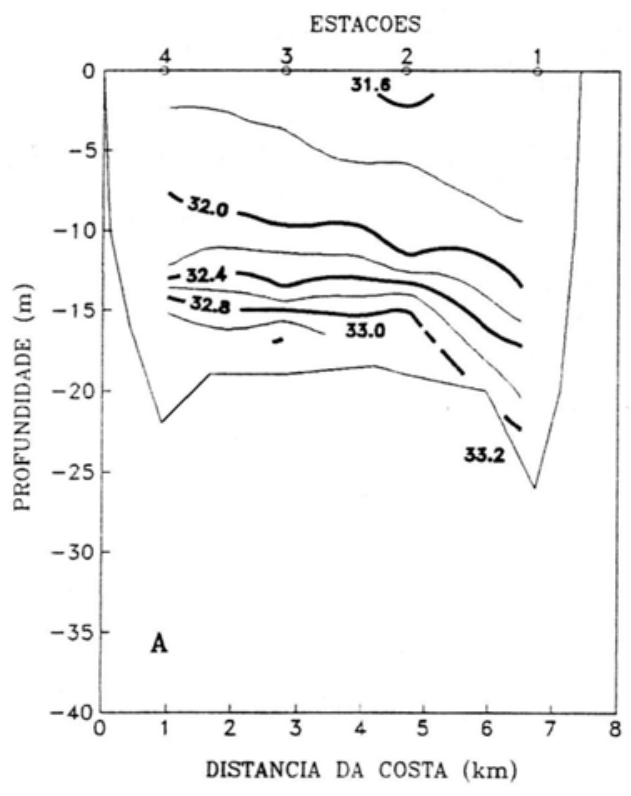

Figura 174: Distribuição vertical de salinidade na seção A do CSS, em ago/92. De acordo com Coelho (1997).

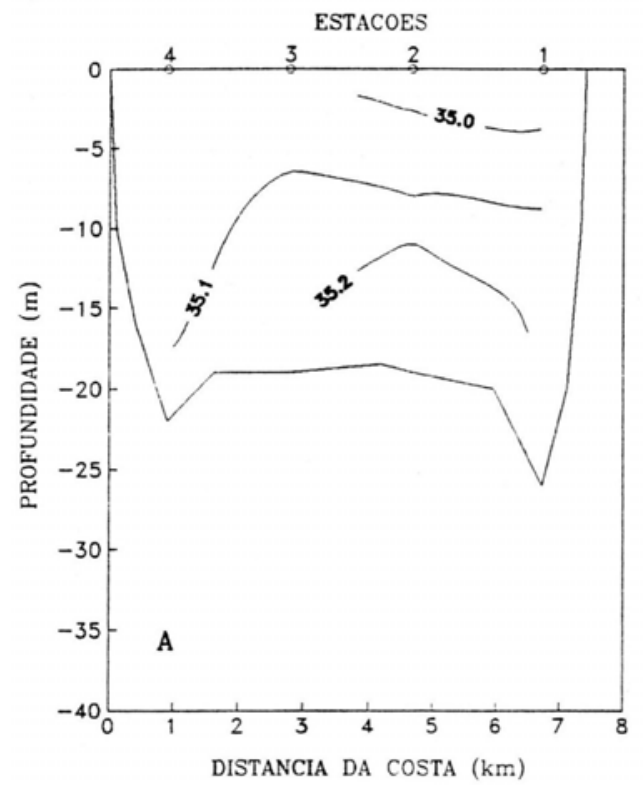

Figura 175: Distribuição vertical de salinidade na seção A do CSS, em jun/93. De acordo com Coelho (1997). 


\subsection{Outros Experimentos}

O experimento com vento de sudoeste evidencia o afastamento da ACAS da costa pelo fundo e a aproximação da AT pela superfície. A Fig.133A mostra que a isoterma de $16^{\circ} \mathrm{C}$ aprofunda-se em relação ao quadro inicial (Fig.10) e mostra também o aparecimento de uma haloclina, anunciando a aproximação da Água Tropical (Figs. 132C e 134D). Estas figuras sugerem que a AT se aproxima pelo norte da ISS. O experimento com forçante vento de sudoeste é o mais efetivo para empilhar a AC na costa, porém o experimento sem forçante vento é mais efetivo para aproximar a AT, chegando esta massa de água a $80 \mathrm{~km}$ da costa ao norte do CSS (Fig. 138C).

O experimento com vento na PCSE e PCI porém sem vento no CSS, mostra que a ausência de vento no CSS não evitou a penetração de águas mais frias no CSS (Figs.144 e 145). Um outro experimento não documentado, retirou também o vento da PCI e os resultados foram praticamente os mesmos. Conclui-se então que os ventos mais distantes na Plataforma Continental Sudeste é que determinam a aproximação ou não da ACAS na costa.

Mas que força faria efetivamente o papel de empurrar a ACAS para dentro do canal? Para entender melhor esse processo, foram analisados os balanços de forças em dois pontos na costa: um ao norte do CSS e outro ao sul do CSS, nas três regiões e em duas estações, o verão e o inverno. Os resultados estão nas figuras numeradas de 176 a 181. A linha vermelha representa as forças difusivas mais as advectivas; a verde, a força de Coriolis; a amarela, a força do gradiente de pressão causada pelo nível do mar; a linha preta, a força do gradiente de pressão gerada pelo efeito baroclínico da densidade; a linha cyan representa a força do gradiente de pressão total; a linha de cor magenta representa a força gerada pelo vento; a azul, a força gerada pelo atrito de fundo; uma outra linha preta, normalmente mais próxima do nível zero representa a soma total das forças. No verão, percebemos que na PCSE, tanto perpendicularmente à costa como ao longo da costa, temos o equilíbrio entre a força de Coriolis e a força do gradiente de pressão. Na PCI, embora haja um equilíbrio entre estas duas forças, percebemos uma importância relativa do vento, principalmente ao longo da costa. Percebemos também que ao sul do CSS, a força do gradiente de pressão é bem mais intensa do que ao norte do CSS no balanço perpendicular à costa. Na grade do CSS, ao sul, o balanço perpendicular à costa é entre a força do gradiente de pressão e a força devida à advecção 
e difusão. No inverno temos aproximadamente o mesmo tipo de resultado na PCSE e na PCI, com a ressalva de que a força devida aos gradientes de densidade tem maior intensidade no verão. Na grade do CSS, com algumas diferenças, temos também o equilíbrio principal entre a força do gradiente de pressão e as forças advectivas e difusivas, porém, estas, são bem menos intensas do que no verão e estas forças também são mais intensas no sul, tanto no verão como no inverno.

A simulação da estrutura térmica do CSS à passagem de uma frente fria mostra a associação existente entre as componentes de velocidade e a temperatura no fundo do CSS, em sua entrada sul ao lado da ISS. Fora dos efeitos da frente fria, as correntes no local fluem para noroeste, indicando que as correntes penetram o canal após contornarem a ISS; as temperaturas locais são baixas, ao redor de $14^{\circ} \mathrm{C}$. Com a aproximação da frente fria, a ACAS se afasta para o largo e as temperaturas se elevam por influência da AC logo acima. As correntes passam a fluir para sudeste, contornando a ISS em sentido oposto àquele inicialmente descrito. $\mathrm{O}$ efeito baroclínico sobre a circulação no CSS então fica claro. A divergência do transporte de Ekman na costa em decorrência de ventos de nordeste na plataforma, aproximam a ACAS da entrada sul do CSS, penetrando o canal após contornar a ISS. A circulação superficial é para sudoeste enquanto que a circulação de fundo é para nordeste. Este quadro é freqüente no final da primavera e no verão. Há uma relaxação desta circulação em duas camadas no inverno, quando os ventos de nordeste são menos intensos e os gradientes de temperatura, menores. Esta relaxação é ainda maior no outono quando os ventos na plataforma além de fracos são contra a costa; a circulação em duas camadas desaparece quando os ventos são de sudoeste, o que normalmente ocorre em regime de frentes frias. 

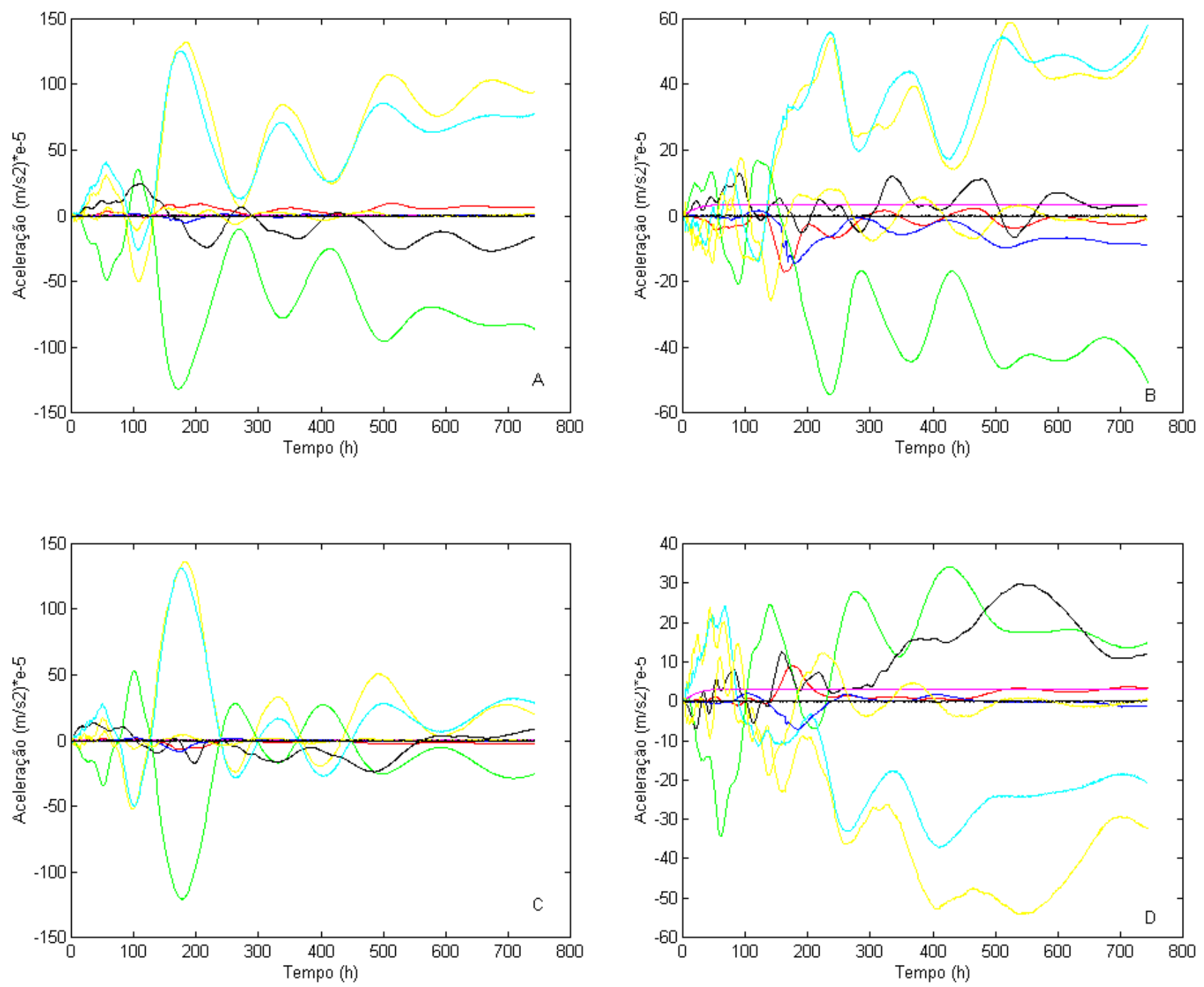

Figura 176: Balanço de forças em dois pontos na Plataforma Continental Sudeste; um em uma radial ao norte do Canal de São Sebastião (A, B) e outro ao sul do Canal de São Sebastião $(\mathrm{C}, \mathrm{D})$. Em $\mathrm{A}$ e $\mathrm{C}$ o balanço é perpendicular à costa e em $\mathrm{B}$ e $\mathrm{D}$, o balanço é ao longo da costa. Simulação de verão - fevereiro. 

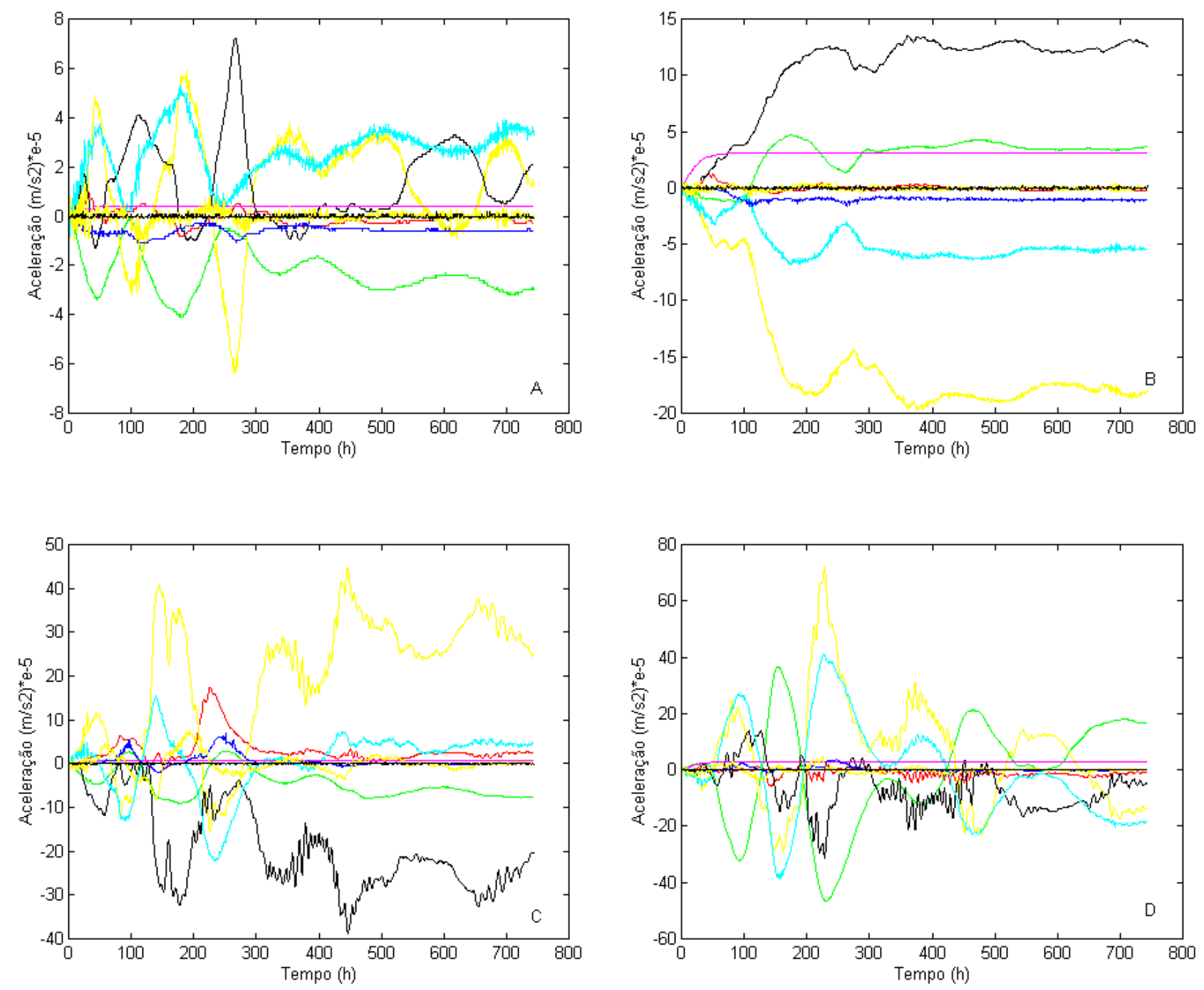

Figura 177: Balanço de forças em dois pontos na PCI; um em uma radial ao norte do Canal de São Sebastião (A, B) e outro ao sul do Canal de São Sebastião (C, D). Em A e C o balanço é perpendicular à costa e em $\mathrm{B}$ e $\mathrm{D}$, o balanço é ao longo da costa. Simulação de verão - fevereiro. 

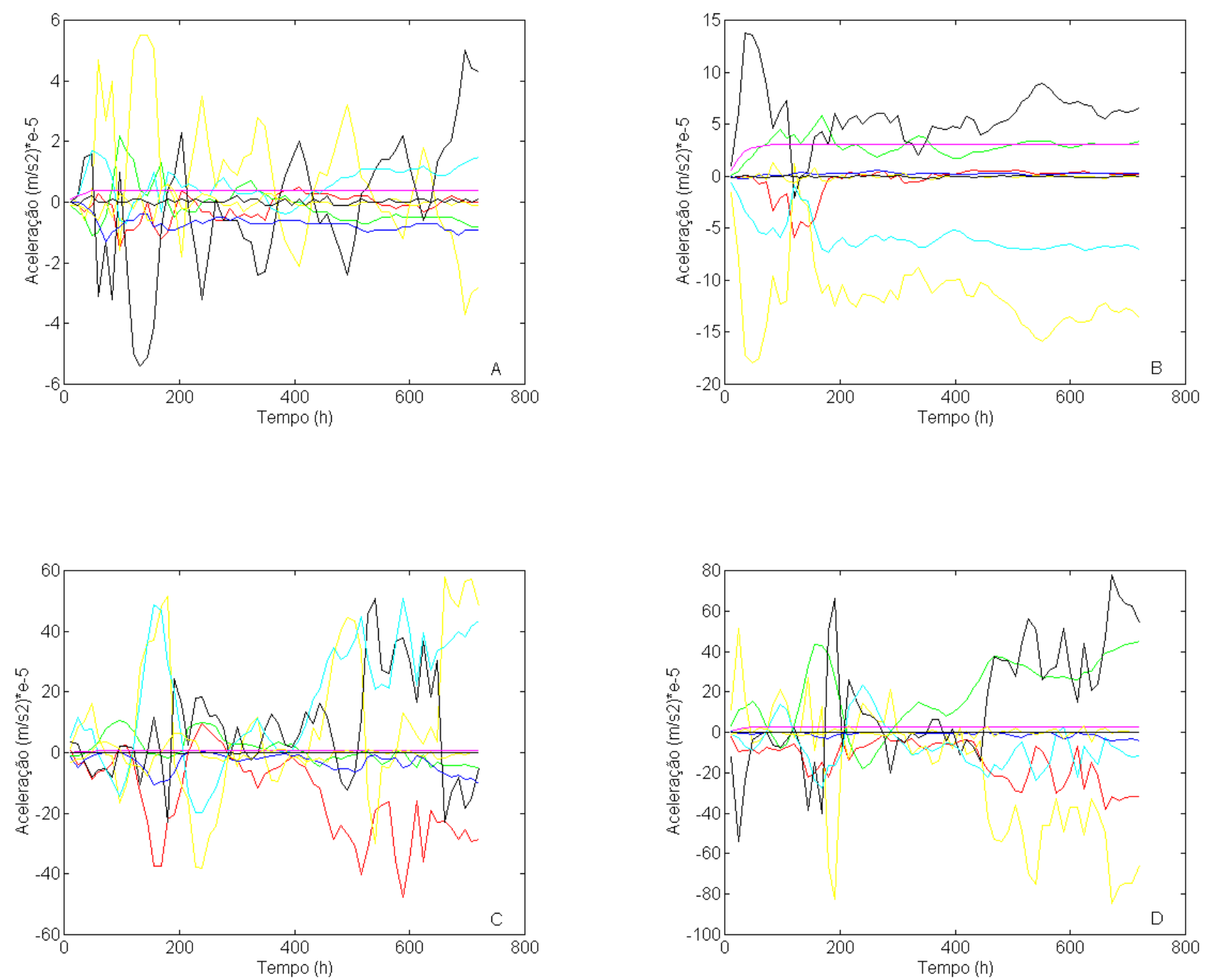

Figura 178: Balanço de forças em dois pontos no Canal de São Sebastião; um ao norte $(\mathrm{A}, \mathrm{B})$ e outro ao sul $(\mathrm{C}, \mathrm{D})$. Em $\mathrm{A}$ e $\mathrm{C}$ o balanço é perpendicular à costa e em $\mathrm{B}$ e $\mathrm{D}, \mathrm{o}$ balanço é ao longo da costa. Simulação de verão - fevereiro. 

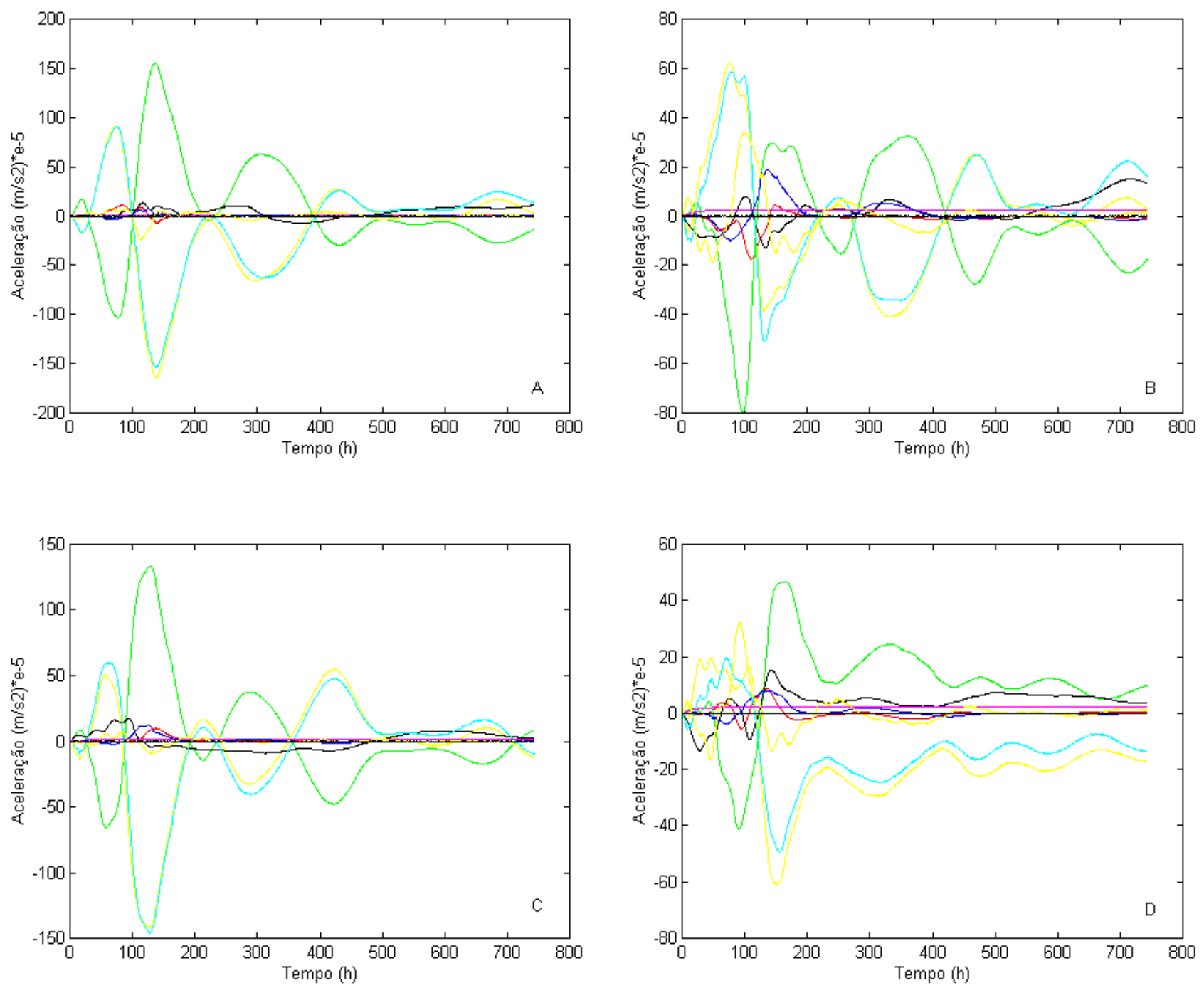

Figura 179: Balanço de forças em dois pontos na Plataforma Continental Sudeste; um em uma radial ao norte do Canal de São Sebastião (A, B) e outro ao sul do Canal de São Sebastião $(C, D)$. Em A e C o balanço é perpendicular à costa e em $\mathrm{B}$ e $\mathrm{D}$, o balanço é ao longo da costa. Simulação de inverno - agosto. 

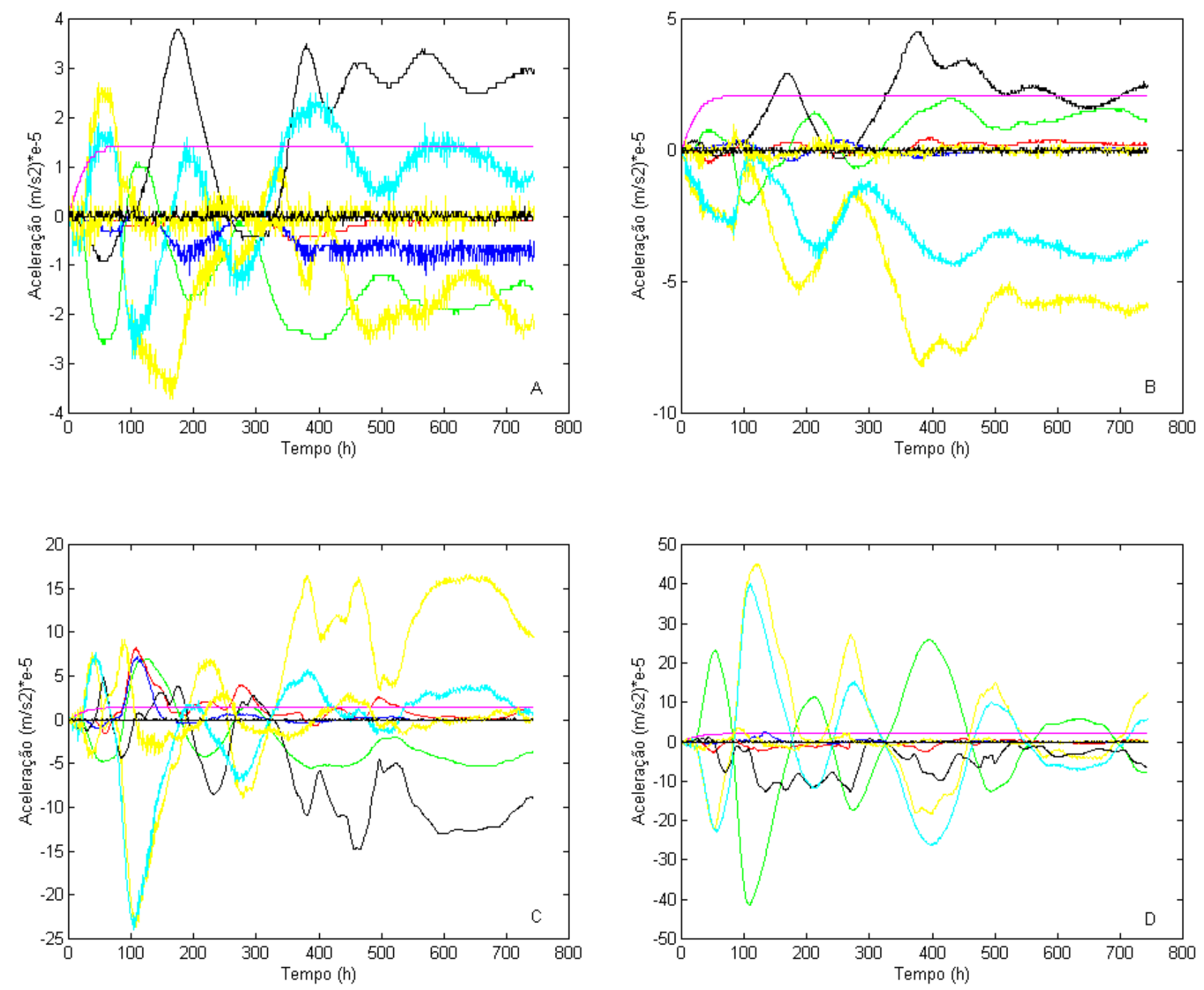

Figura 180: Balanço de forças em dois pontos na PCI; um em uma radial ao norte do Canal de São Sebastião (A, B) e outro ao sul do Canal de São Sebastião (C, D). Em A e C o balanço é perpendicular à costa e em $\mathrm{B}$ e $\mathrm{D}$, o balanço é ao longo da costa. Simulação de inverno - agosto. 

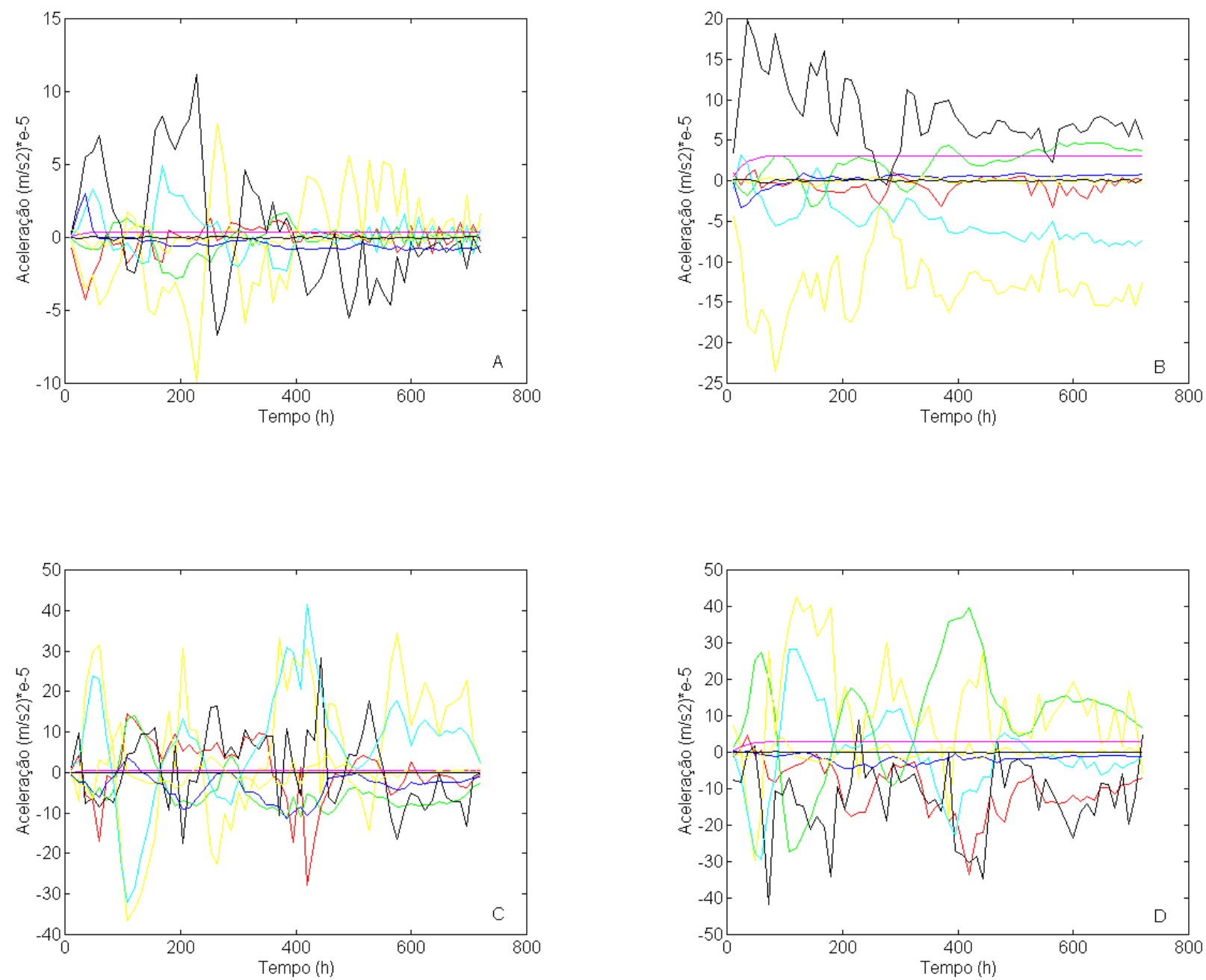

Figura 181: Balanço de forças em dois pontos no Canal de São Sebastião; um ao norte $(\mathrm{A}, \mathrm{B})$ e outro ao sul $(\mathrm{C}, \mathrm{D})$. Em $\mathrm{A}$ e $\mathrm{C}$ o balanço é perpendicular à costa e em $\mathrm{B}$ e $\mathrm{D}, \mathrm{o}$ balanço é ao longo da costa. Simulação de inverno - agosto. 
A maioria dos cruzeiros já analisados no CSS tem suas menores temperaturas na entrada sul do canal, no fundo, do lado leste. As figuras numeradas de 182 a 185 mostram a evolução dos percentuais de ACAS. A isolinha em destaque é a que representa 50\% desta massa de água. Percebemos que após 6 horas ela está na profundidade de $23 \mathrm{~m}$ aproximadamente no sul do CSS. Ao norte temos percentuais de $20 \%$. Após 24 horas temos uma termoclina acentuada no sul com o percentual de $50 \%$ na profundidade de $14 \mathrm{~m}$ e se propagando para norte. Na entrada norte o percentual é ainda de $20 \%$. Conforme observamos nas figuras, o percentual de $50 \%$ de início erguese lentamente mas se propaga mais rapidamente em direção norte. No final de oito dias, no sul, o percentual de 50\% de ACAS se encontra a $10 \mathrm{~m}$ de profundidade e no fundo encontramos percentuais maiores que $90 \%$. Na entrada norte os percentuais de ACAS não chegam a $30 \%$. Os resultados deste experimento confirmam o que já se sabia através dos dados: a ACAS penetra preferencialmente o CSS pelo fundo da entrada sul avançando para o norte. 


\section{Capítulo 6}

\section{Conclusões}

A maior evidência de que este modelo está razoavelmente calibrado são os resultados da análise do cruzeiro de 21/02/1992 realizado no Canal de São Sebastião. Após 20 dias consecutivos de ventos de nordeste na Plataforma Continental Sudeste, tivemos a ACAS preenchendo o canal de sul a norte e abaixo de $5 \mathrm{~m}$ de profundidade. Os ventos médios de fevereiro, segundo COADS, estão muito próximos ao vento do dia 21/02/1992; neste dia os ventos praticamente se alinharam com a costa. Pode-se então concluir que a ACAS está presente em média no fundo do CSS em fevereiro. Os ventos médios de novembro também estão muito próximos dos de fevereiro; o que coloca a ACAS no fundo do CSS também em novembro, porém em percentuais menores. Em maio não houve vestígio de ACAS no canal, tampouco em agosto. Há sinais mais evidentes da ACAS no inverno do que no outono, isto se deve aos ventos de agosto serem de nordeste porém menos intensos que os de fevereiro e bem menos intensos ainda na região sul da PCSE. A estação de outono (maio) foi aquela que mais próxima trouxe a AT da costa. O modelo confirma a entrada sul pelo fundo como entrada preferencial da ACAS no CSS. Os ventos remotos da PCSE é que trazem a ACAS ao CSS e a força do gradiente de pressão, com grande contribuição dos gradientes de densidade, forçam esta massa de água para dentro do canal. Este mecanismo é bem mais intenso no verão do que no inverno e também mais intenso no sul do que no norte do CSS.

A simulação da estrutura térmica do CSS à passagem de uma frente fria pela região em estudo mostrou resposta imediata no canal, com a retirada da ACAS e pronta volta desta massa de água com a saída da frente fria da PCSE. O modelo de circulação no CSS com correntes superficiais para sudoeste e correntes de fundo para nordeste tem seu ápice no verão, desintensifica-se no outono, voltando a intensificar-se na primavera atingindo o ápice novamente no verão. Este mecanismo está claramente associado à penetração da ACAS no CSS, que tem máximo no verão, ausentando-se no outono, voltando na primavera, atingindo novamente o máximo no verão. A seqüência natural deste trabalho seria adotar campos termohalinos de inicialização mensais e não sazonais 
e também seria interessante trabalhar com médias de dez anos para cá, para que tendências mais recentes fossem levadas em consideração.

Apesar das baixas salinidades superficiais no CSS não terem sido obtidas, pelo fato de que elas não estão presentes nos campos iniciais, principalmente com relação à PCI, fontes de descarga estuarina remotas devem ser consideradas em trabalhos futuros. As correntes superficiais para sudoeste e as características termohalinas da camada superficial, no inverno e no outono, teriam sido melhor simuladas com a presença dessas fontes. 

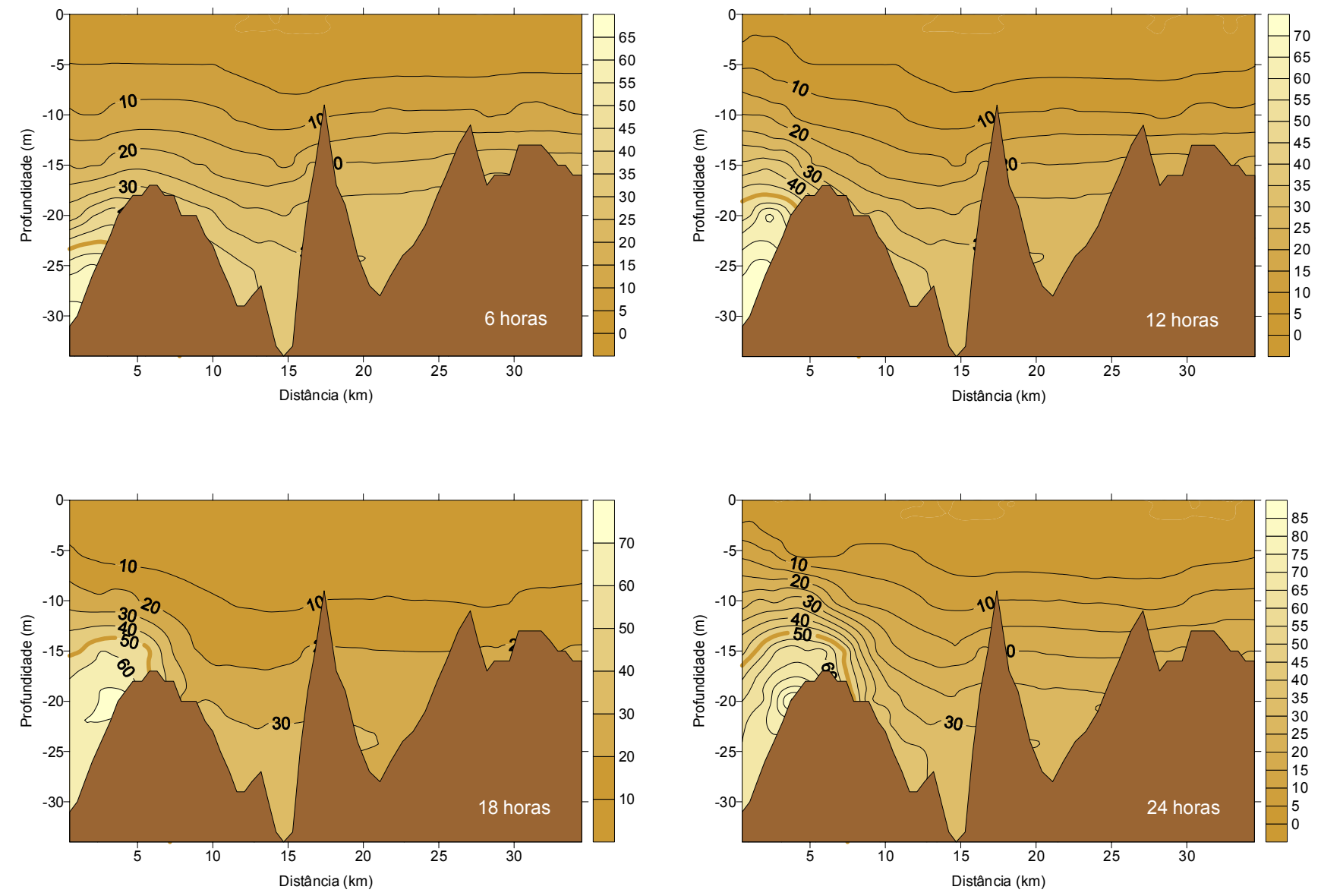

Figura 182: Distribuição vertical longitudinal no Canal de São Sebastião do percentual da Água Central do Atlântico Sul com 6 horas, 12 horas, 18 horas e 24 horas de integração. 

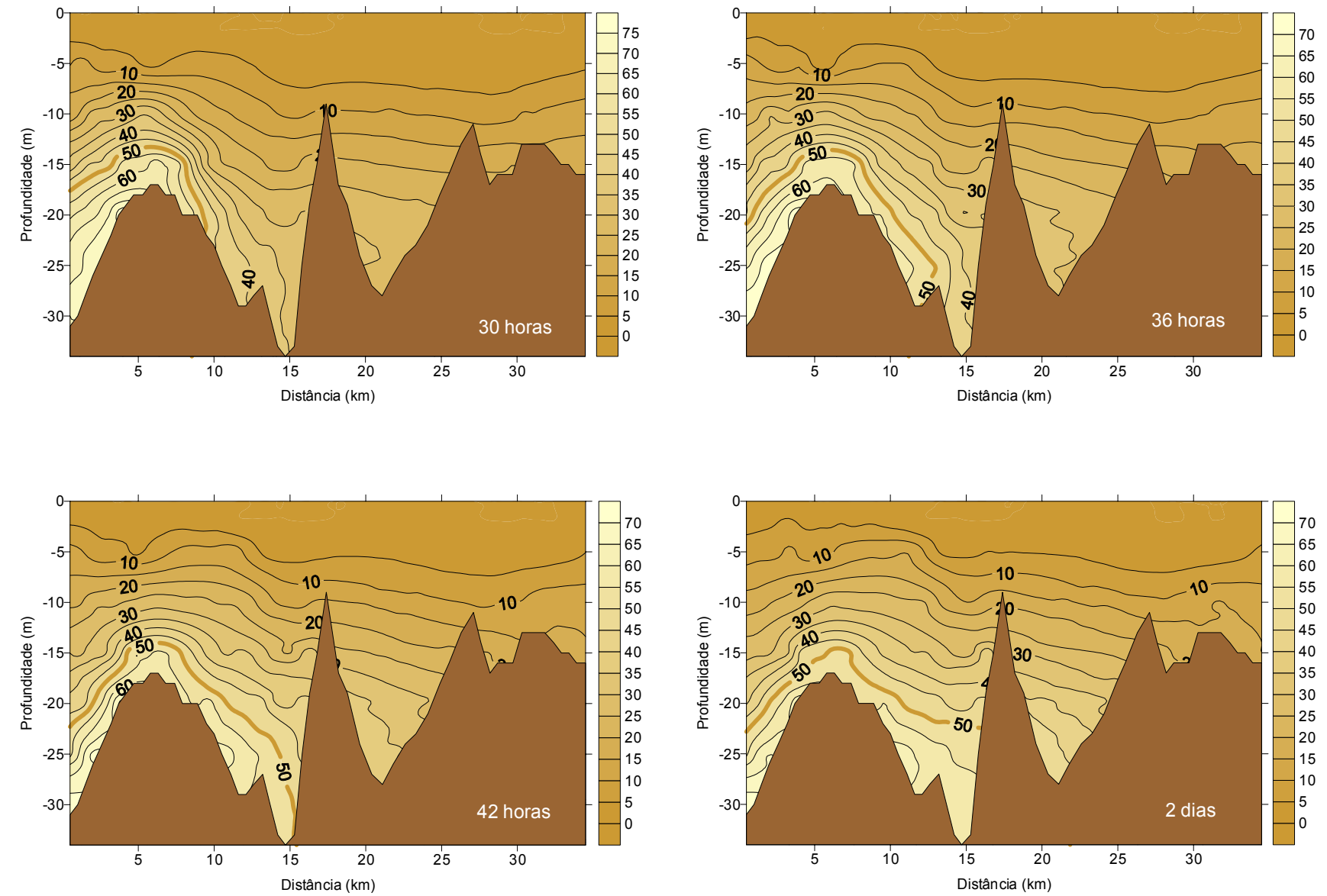

Figura 183: Distribuição vertical longitudinal no Canal de São Sebastião do percentual da Água Central do Atlântico Sul com 30 horas, 36 horas, 42 horas e 2 dias de integração. 

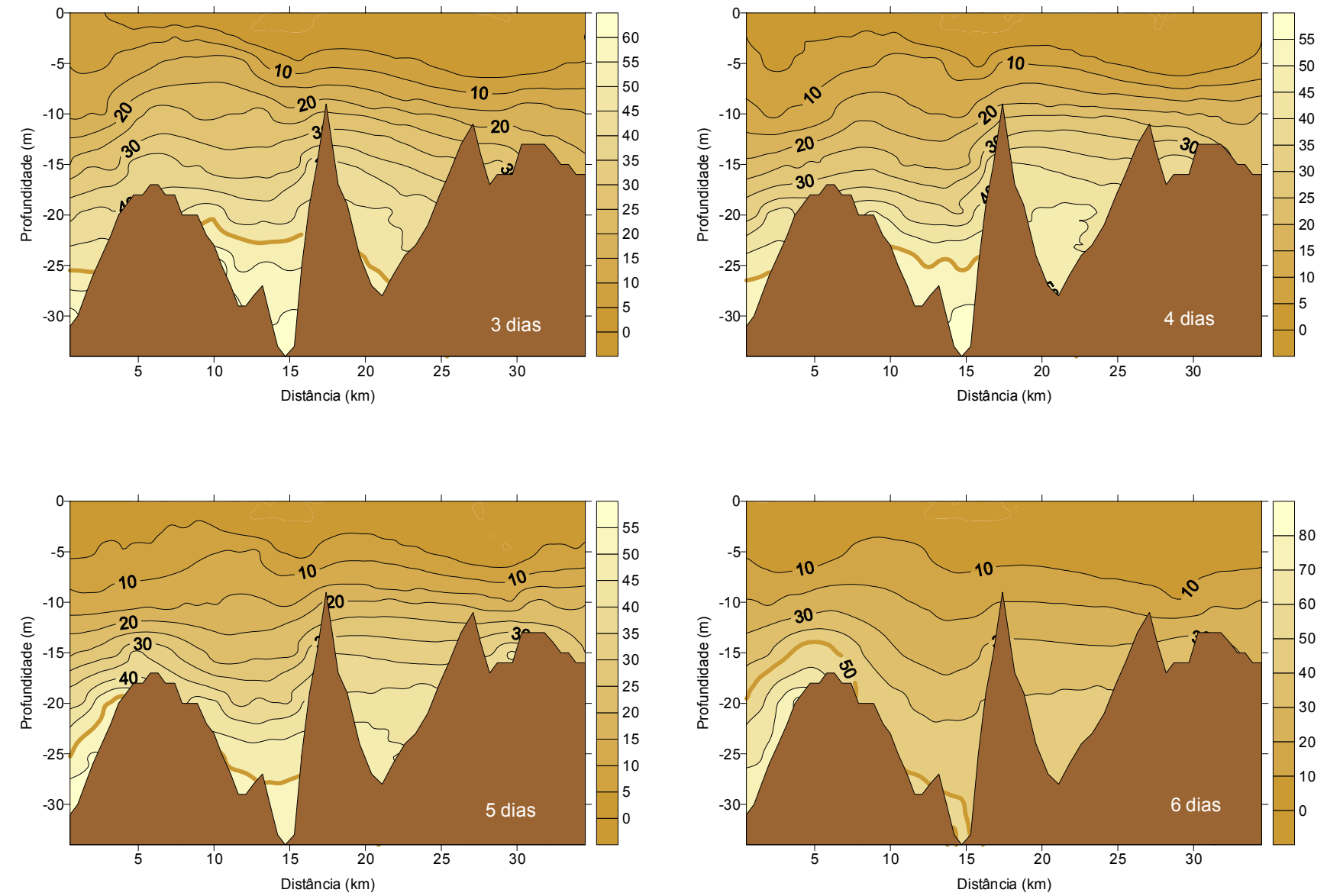

Figura 184: Distribuição vertical longitudinal no Canal de São Sebastião do percentual da Água Central do Atlântico Sul com 3 dias, 4 dias, 5 dias e 6 dias de integração. 

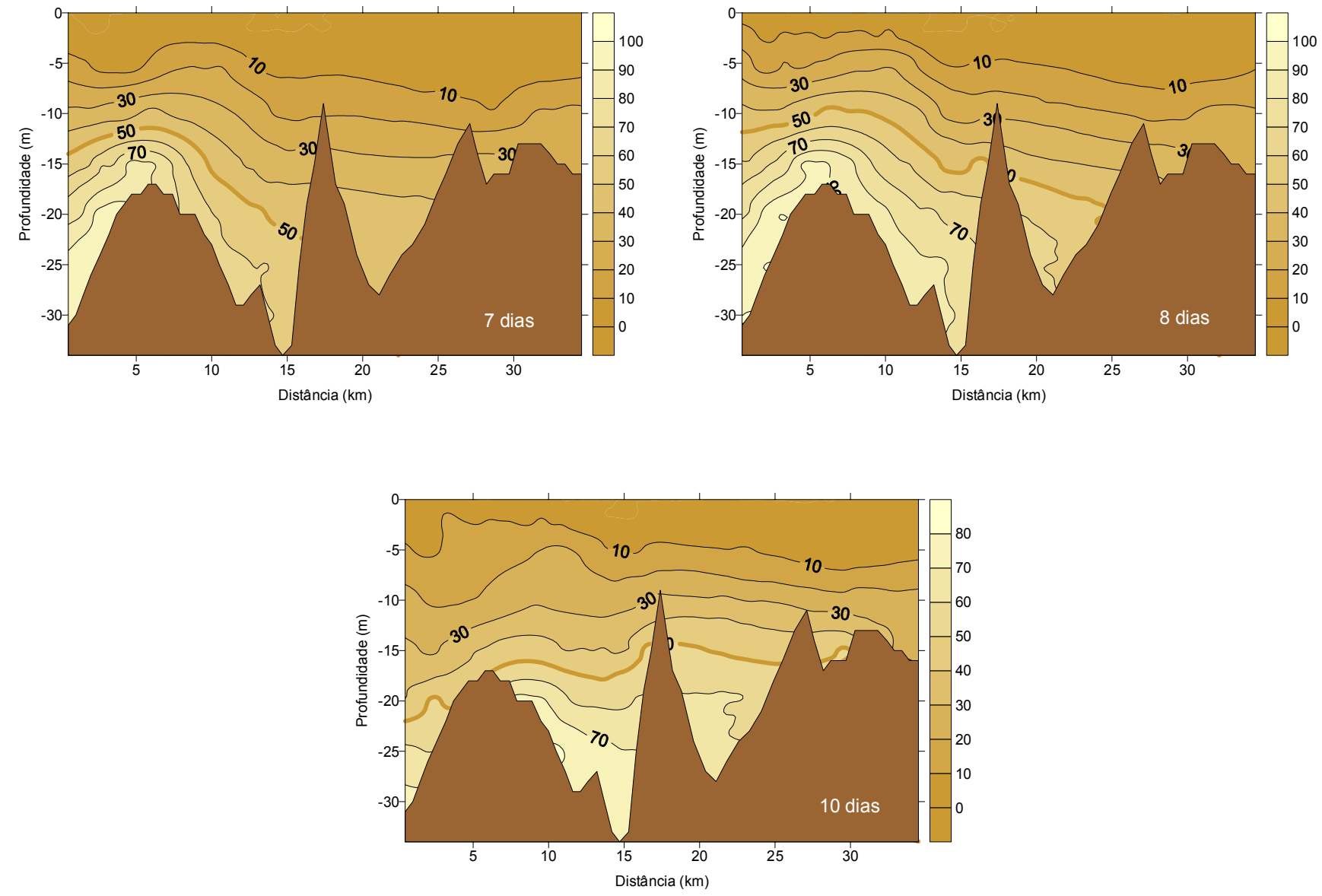

Figura 185: Distribuição vertical longitudinal no Canal de São Sebastião do percentual da Água Central do Atlântico Sul com 7 dias, 8 dias e 10 dias de integração. 


\section{Bibliografia}

Alves, M.A. 1992. Correntes de maré e inerciais na plataforma continental ao largo de Ubatuba. Dissertação de Mestrado. Instituto Oceanográfico da USP, 162 p.

Assad, L. P. de F. 2000. Circulação no Canal de São Sebastião (SP) durante o inverno: Estudos numéricos. Dissertação de Mestrado. Universidade de São Paulo, Instituto Oceanográfico, $138 \mathrm{p}$.

Blumberg, A. F. \& D. M. Goodrich. Modeling of Wind-Induced Destratification in Chesapeake Bay, Estuaries, EUA, No. 13, p. 1236-49, 1990.

Blumberg, A. F. \& G. L. Mellor. A Costal Ocean Numerical Model, In: Mathematical Modeling of Estuarine Physics, Proceedings of na International Symposium, Hamburg, 1978, agosto 24-28. J. Sundermann and K. P. Holz, Eds., SpringerVerlag, Berlin, 1980.

Blumberg, A. F. \& G. L. Mellor. Diagnostic and Prognostic Numerical Circulation Studies of the South Atlantic Bight, J.Geophys.Res., EUA, No. 88, p. 4579-92, 1983.

Blumberg, A. F. \& G. L. Mellor. A Simulation of the Circulation in the Gulf of Mexico, Israel J. of Earth Sciences, Tel-Aviv, No. 34, p.122-44, 1985.

Blumberg, A. F. \& G. L. Mellor. A Description of a Three-Dimensional Coastal Ocean Circulation Model, In: Three-Dimensional Coastal Ocean Models, N. Heaps, Ed., p. 1-16, American Geophys. Union, EUA, 1987.

Blumberg, A. F. ; R. P. Signell \& H. L. Jenter. Modeling Transport Processes in the Coastal Ocean, J. Marine Env. Engg., EUA, No. 1, p. 3-52, 1993.

Campos, E.J.D. ; J. E. Gonçalves \& I. Ikeda. Water mass characteristics and geostrophic circulation in the South Brazil Bight: Summer of 1991. Journal of Geophysical Research, vol.100, No C9, p. 18537 - 18550, 1995. 
Cartwright, D.E.; R. D. Ray \& B.V. Sanchez, Oceanic tide maps and spherical harmonic coefficients from Geosat altimetry. NASA Technical Memorandum 104544, Goddard Space Flight Center, Greenbelt, MD, 75 pp., 1991.

Castro Filho, B. M. de. 1985. Subtidal response to wind forcing in the South Brazil Bight during the winter. PH.D. Dissertation. RSMAS, University of Miami, 211 p. 1990. Wind driven currents in the Channel of São Sebastião: Winter 1979. Bolm. Inst. oceanogr., S Paulo, 38 (2): 111-132.

Castro Filho, B. M. de; L. B. de Miranda \& S. Y. Miyao. 1987. Condições hidrográficas na plataforma continental ao largo de Ubatuba: variações sazonais e em média escala. Bolm Inst. Oceanogr., S Paulo, 35(2):135-151.

Castro Filho, B. M. de. 1996. Correntes e Massas de Água da Plataforma Continental Norte de São Paulo. Tese de Livre-Docência, Instituto Oceanográfico, Universidade de São Paulo, 248 p.

Casulli, V., Semi-Implicite Finite Difference Methods for the twodimensional Shallow Water Equations, J. Comput. Phy., EUA, No. 86, p. 56-74, 1990.

Casulli, V. \& R. T. Cheng. Semi - Implicite Finite Difference Methods for Three Dimensional Shallow Water Flow, Int. J. for Numer. Methods in Fluids, EUA, No. 15, p. 629-48, 1992.

Chapman, D. C., Numerical treatment of cross-shelf open boundaries in a barotropic coastal ocean model. J. Phys. Oceanogr. , 15: 1060-1075, 1985.

Cirano, M. \& E. J. D. Campos. Numerical diagnostic of the circulation in the Santos Bight with Coroas hydrographic data. Rev. Bras.Oceangr., 44(2), p.105-121, 1996.

Coelho, A. L. Massas de água e circulação no Canal de São Sebastião (SP). Dissertação de mestrado. Instituto Oceanográfico, Universidade de São Paulo, São Paulo, SP, 244p. 
Emílsson, I. 1956. Relatório e resultados físico-químicos de três cruzeiros oceanográficos em 1956. Contrçmes. Inst. Oceanogr., Univ. S Paulo, sér Oceanogr. fís., (1):1-70.

1959. Alguns aspectos físicos e químicos das águas marinhas brasileiras. Ciênc. Cult., S Paulo, 11(2):44-54.

1961. The shelf and coastal waters of southern Brazil. Bolm Inst. oceanogr., S Paulo, 11(2):101-112

------- 1962. As correntes marítimas no Canal de São Sebastião. Ciência e Cultura, S Paulo, 14 (4): 269-270.

Fontes, Roberto F. C. 1995. As correntes no Canal de São Sebastião. Dissertação de Mestrado. Instituto Oceanográfico da USP, 159 p.

Furtado, V. V. 1978. Contribuição ao estudo da sedimentação atual no Canal de São Sebastião. Tese de Doutorado. Inst. de Geociências, USP, S.Paulo, 2.V., 110 p. + figs. e tabelas.

J. Gallo \& E. F. Luedemann (in memorian) 1987. Análise do comportamento das correntes através de corpos de deriva no Canal de São Sebastião, São Paulo. Anais do $1^{\circ}$ Congresso ABEQUA, Porto Alegre, pp. 93-102.

Galperin, B.; L. H. Kantha; S. Hassid \& A. Rosati. A Quasi-equilibrium Turbulent Energy Model for Geophysical Flows, J. Atmosph. Sci., EUA, No. 45, p. 55-62, 1988.

Galperin, B. \& G. L. Mellor. A Time - Dependent, Three-Dimentional Model of the Delawere Bay and River System, Estuarine Coastal Shelf Sci., EUA, No. 31, p. 231-81, 1990 a.

Galperin, B. \& G. L. Mellor. Salinity Intrusion and Residual Circulation in Delawere Bay During the Drought of 1984, In: Residual Current and long term transport, R.T.Cheng, Ed., Spring-Verlag, Nova Iorque, No. 38, p. 469-80, 1990 b.

Harari, J. 1984. Representação da circulação na plataforma continental sudeste do Brasil através de modelo numérico tridimensional linear. In: I Semin. Modelagem do Mar, INPE, S. J. dos Campos, Brasil. 
Harari, J. 1985. Desenvolvimento de um modelo numérico hidrodinâmico tridimensional linear, para a simulação e a previsão de circulação na plataforma brasileira, entre $23^{\circ}$ e $26^{\circ} \mathrm{S}$. Bolm Inst. Oceanogr., S Paulo, 33(2):159-191.

Kvinge, Thor. 1967. On the special current and water level variations in the Channel of São Sebastião. Bolm Inst. oceanograf., S Paulo, 16 (1): 23-38.

Leandro, R.P. 1999. Climatologia das Águas do Canal de São Sebastião (SP). Dissertação de Mestrado. Instituto Oceanográfico da USP, 162 p.

Martinsen, E. A. \& H. Engedahl, Implementation and testing of a Lateral Boundary Scheme as na Open Boundary Condition in a Barotropic Ocean Model, Coastal Eng., 11, 603-627, 1987.

Matsuura, Y. 1986. Contribuição ao estudo da estrutura oceanográfica na região sudeste entre Cabo Frio (RJ) e Cabo de Santa Marta Grande (SC). Cienc. \& Cult., S Paulo, 38(8):1439-1450.

Mellor, G. L. \& T. Yamada. Development of a Turbulence Closure Model for Geophysical Fluid Problems, Rev. Geophys. Space Phys., EUA, No. 20, p. 851-875, 1982.

Mesquita A. \& J. Harari. 1987. Harmonic constants of tides and currents of the southern Brazilian shelf. In: Simpósio sobre Ecossistemas da Costa Sul e Sudeste Brasileira: Síntese dos conhecimentos, Cananéia, São Paulo. ACIESP, 2:415422.

----- \& J. Harari. 1988. Vertical profiles of tidal currents in the southern Brazilian shelf. Ciênc. Cult., 40(7):704-705, supl.

Miranda, L.B. de \& Y. Ikeda. 1976. Investigacion preliminar de la variabilidad de temperatura y salinidad superficiales en la region adyacente a Bahia de Isla Grande (RJ): 16/06 a 21/06/1975. Men. I Reun. Lat. Cienc. Tecnol. Ocean. (México) (1):15-48.

----- , Y. Ikeda; N. Pereira Filho \& B. M. de Castro Filho. 1977. Note on the occurrence of saline fronts in the Ilha Grande (RJ) region. Bolm Int. Oceanogr., S Paulo (26):249-256. 
1982. Análise de massas de água da plataforma continental e da região oceânica adjacente: Cabo de São Tomé (RJ) e Ilha de São Sebastião (SP). Tese de LivreDocência. Universidade de São Paulo, Instituto Oceanográfico, 123p. + figs.

------ \& B. M. de Castro Filho. 1995. Variabilidade da circulação e do transporte de volume no Canal de São Sebastião (SP). Publicação esp. Inst. Oceanogr., São Paulo, (11): 1-9.

------\& M. Katsuragawa. 1991. Estrutura térmica na região sudeste do Brasil (outubro/novembro de 1988). Publicação esp. Inst. Oceanogr., S Paulo, (8):1-14.

Oey, L.; G. L. Mellor \& R. I. Hires. Tidal modeling of the Hudson-Raritan Estuary, Estuarine Costal Shelf Sci., EUA, No. 20, p. 511-27, 1985 a.

Oey, L.; G. L. Mellor \& R. I. Hires. A Three - Dimensional Simulation of the Hudson - Raritan Estuary. PartI: Description of the Model and Model Simulations, J. Phys. Oceangr., EUA, No. 15, p. 1676-92, 1985 b.

Oey, L. ; G. L. Mellor \& R. I. Hires. A Three - Dimensional Simulation of the Hudson - Raritan Estuary. Part II : Comparison with Observations, J. Phys. Oceangr., EUA, No. 15, p. 1693-1709, 1985 c.

Oey, L. ; G. L. Mellor \& R. I. Hires. A Three-Dimensional Simulation of the HudsonRaritan Estuary. Part III: Salt Flux Analyses, J. Phys. Oceangr., EUA, No. 15, p. 1711-20, $1985 \mathrm{~d}$.

Orlanski, I. A simple boundary condition for unbounded hyperbolic flows, J. Comput. Phys., 21, 251-269, 1976.

Palma, E. D. \& R. P. Matano, On the implementation of open boundary conditions to a general circulation model: The barotropic mode, J. Geophys. Res., 103, 1319 1341, 1998.

Roache, P. , Computational Fluid Dynamics, Revised printing, Albuquerque, n.e., n.p., 1982.

Signorini, S. R. ; L. B. Miranda; D. L. Evans; M. R. Stevenson \& H. M. Inostroza V. 1989. Corrente do Brasil: estrutura térmica entre $19^{\circ}$ e $25^{\circ} \mathrm{S}$ e circulação geostrófica. Bolm Inst. oceanogr., S Paulo, 37(1):33-49. 
Silva, L. dos S. 1995. Condições Oceanográficas no Canal de São Sebastião: fevereiro de 1994 a março de 1995. Dissertação de Mestrado. Universidade de São Paulo, Instituto Oceanográfico, $130 \mathrm{p}$.

Silva, L. dos S. 2000. Estrutura Termohalina e análise de massas de água no Parque Estadual Marinho da Laje de Santos. Revista Científica do Centro Universitário Monte Serrat.

Silva, M. P. 1995. Caracterização Físico-Química das Massas de Água da Bacia de Santos durante o Projeto COROAS. Verão e inverno de 1993. Dissertação de Mestrado, Universidade de São Paulo, Instituto Oceanográfico, 135 p.

Soares, I.D. 1995. Um Modelo Numérico de Dispersão Oceânica: Aplicações ao Canal de São Sebastião e Adjacências. Dissertação de Mestrado. Universidade de São Paulo, Instituto Oceanográfico, 126 p.

Stech, J.L. \& J. A. Lorenzzeti. 1992. The response of the South Brazil Bight to the passage of wintertime cold fronts. Journal of Geophysical Research, vol.97, $\mathrm{n}^{\mathrm{o}}$ c6, p.9507-9520.

Valente, M. H. M. 1998. Circulação na Plataforma Interna do Litoral Norte do Estado de São Paulo. Dissertação de Mestrado. Universidade de São Paulo, Instituto Oceanográfico, $153 \mathrm{p}$.

Zembruscki, S.G. 1979. Geomorfologia da Margem Continental Sul Brasileira e das Bacias Oceânicas adjacentes (Relatório Final). In: Reconhecimento Global da Margem Continental Brasileira, Ed. Chaves, H.A.F.. PETROBRÁS, p. 129-177. 